SOCIAL, ECONOMIC AND POLITICAL STUDIES OF THE MIDDLE EAST ETUDES SOCIALES, ECONOMIQUES ET POLITIQUES DU MOYEN ORIENT

VOLUME XV

MAXWELL J. FRY

THE AFGHAN ECONOMY

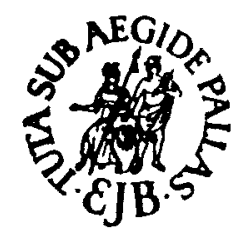

LEIDEN

E. J. BRILL

1974

\section{THE AFGHAN ECONOMY}

MUNEY, FINANCE, ANI THE CRITICAL CONSTRAINTS

TO ECONOMIC DIVVELOPMENT

แบ

MAXWELL, J. FRY
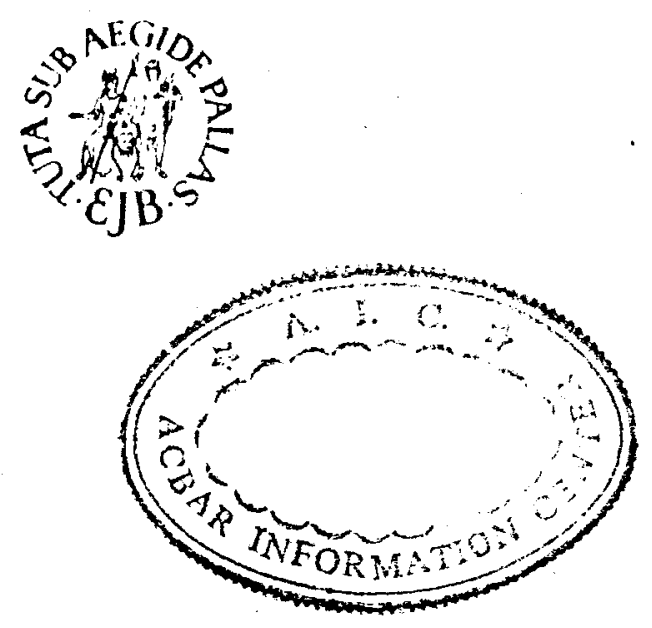

LIEIDIN

E. J. BRILL

1974 


\section{Agrtcelture-O/AID/REP}

LIRRARY

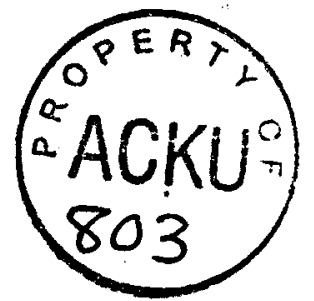

IHI: AFGHAN T:CONOMY 


\section{(ONTI:NTS}

F. Barth (Etnografisk Museum, Oalo), E. Geuner (London School of liconomics), C. Issawi (Columbia University), S. Khalaf (American University of Beirut) M. I. Al-Khatm (Cairo Univeraity), P. Marthelot (Ecole Pratique dés Hautes Ftudies, Piris), S. H. NAsa (Arya-Mehr Uriversity of Technology, Tehrail), M. SoYsal (Ankara University), M. ZGHal (Université de Tunis).

\section{Redacieur-Edlior}

\section{A. O. van NHuwenhumzz}

L.e but de la colloction est de faciliter la communication entre le grand nublic international et les sptcialistes des sciences sociales étudiant le Moyen-Orient, et notamment ceux yui y resident. Les ouvrages seloctionnes porteront sur les phémomicnes et problemes contemporains: sociaux, culturels, écononiques et administratifis. Leurs principales orientations releveront de la théorie génirale, de problématiques plus précises, et de la politologie: amenagement des institutions et administration des affaires publiques.

The series is designed to serve as a link between the international ruading public and social scientists studying the contemporary Middle East, notably those living in the area. Works to be included will be characterized by their relevance to actual phenomena and problems: whether social, cultural, economic, political or administrative. They will be theory-orientod, problem-oriented or policy-oriented.

\section{ISBN 9004039864}

Tables

Figures

Preliace

Notc

I. Introduction

i. Development Potential and Five Critical Constraints

1i. Summary of Subsequent (hapters

Aprendix: Atghanistan in the Adelman-Morris Study

II. The teconomy

i. Introduction

Secial Indicators of change

iii. An Estimate of Gross Nationa! Product . . . . . . . 29

iv. Conclusion . . . . . . . ....... 42

111. A Fragnented Economy. . . . . . . . . . . . . . . . 44

i. Introduction . . . . . . . . . . 4

ii. Government, Modern Sictur and the Bazaar Economy $4 \mathrm{a}$

iii. Econonic Sectors . . . . . . . . . . . . . . . . 49

iv. Geographic Fragmentation. . . . . . . . . . 55

$\checkmark$ Generalisation and Explanation of Fragmentation . 61

Appendix: Batatar Finance. . . . . . . . . . . 64

IV. Resource Mobilisation under the Development Plans . . . 68

i. Financial, Fiscal and Foreign Sectors in Resuurce Mobilisation . . . . .

ii. The Five Year Development Plans . . . . . . . . . 70

iii. Invesiment and Growth during the Three Five Year

Development Plans

iv. The Conmmitment lo and process of Planning. $\cdot \cdot 76$

V. The financial Sector . . . . . . . . . . . . . . . 82

i. Introduction . . . . . . . . . . . . . . . . . 82

ii. Overall View of the Financial System . . . . . . . . 96

iii. The Central Bank. . . . . . . . . . . . . . . . . 109

iv. Moncy Supply. . . . . . . . . . . . . . . . . . 112 5

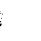
9 9

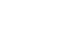

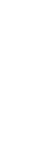

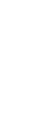

4

8
9
2


v. Bank Millie and Pashtany Tejaraty Bank. . . . . . . 131

vi. Specialised Banks. . . . . . . . . . . . . . . . . 134

vii. Problems of Bank Lending . . . . . . . . . . . . 137

viii. Non-Bank Financial Institutions . . . . . . . . . . 146

ix. Conclusion . . . . . . . . . . . . . . . . . . . 149

VI. Public Finance . . . . . . . . . . . . . . . . . . 151

i. Introduction . . . . . . . . . . . . . . . 151

ii. The Fiscal System. . . . . . . . . . . . . . . . . 157

iii. Domestic Revenue . . . . . . . 169

iv. Fiscal Effort . . . . . . . . . . . . . . . . . 181

v. Deficit Finance............... 189

vi. Expenditure . . . . . . . . . . . . . . . . . . 193

vii. Variance in Rates of Return to Investment . . . . . . 208

viii. Conclusion . . . . . . . . . . . . . . . . . 213

VII. The Foreign Trade Sector . . . . . . . . . . . . . . . 216

i. Introduction . . . . . . . . . . . . . 216

ii. Foreign Trade . . . . . . . . . . . . . . . . . . . 218

iii. Financing Foreign Trade. . . . . . . . . . . . . . 231

iv. Kabul and Kandahar Money Bazaars . . . . . . . . . 234

v. Importance of the Money Bazaars in Foreign Trade. . 241

vi. Conclusion . . . . . . . . . . . . . . . . . . . 253 Appendix A: Foreign Exchange Regulations in Afghanistan.

Decree 2632, 1329 (1951). . . . . . . . . . . . . . . . 255

Appendix B: Afghanistan's Foreign Trade System . . . . 259

Appendix C: Prohibited Trade . . . . . . . . . . . . . . 264

Appendix D: Free Market Dollar and Rupee Exchange

Rates, "Bazaar Rates," 1332-1352 . . . . . . . . . . . 264

VIII. Financial and Fiscal Reform . . . . . . . . . . . . . . 268

i. Introduction . . . . . . . . . . . . . . . . . . . 268

ii. Outline of a Programme of Financial Development . 271

iii. Central Banking for Development . . . . . . . . . 276

iv. An Interest Rate Policy . . . . . . . . . . . . . . . . 284

v. Domestic Resource Mobilisation . . . . . . . . . . 293

vi. Conclusion . . . . . . . . . . . . . . . . . . . . . . . 299

Bibliography. . . . . . . . . . . . . . . . . . . 301

Index. . . . . . . . . . . . . . . . . 317

\section{TABLES}

2.I Population, 1310-1352. . . . . . . .... 13

2.2 Vducation and Health Statistics, 1311-1351 ... . . . . . . 14

2.3 Trinsport and Communicaltions Statistics, 1311-1351 . . . 15

2.4 Various Economic Indicattors Specified in Non-Monetary IInits, 1311-1351

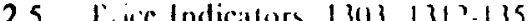

2.6 Exchange Rales. U.S. Wholesale Price Index and Purchasing Power Parity P'rice Index, 1310-1352 . . . . . . . . . 20

2.7 Moditicd Purchasing Power Parily Price Index, 1310-1351

2.8 Aighani/Dollar Exchange Rates Derived from the Silver (ontent of the Afghani and Silver Prices on the Now York Bullion Market, 1303-1320

2.9 Innomic Indicators Specitied in Monetary Units. 1311-1351

2.10 Hcomomic Indicators Specitied in Monetary Units at Constant Prices, $1311-1351$.

2.11 Currency/Moncy Ratios and Velocities in Iran, Pakistan and Turkey, 1962-1970

2.13 Actual and Expected Ratcs of Inflation, 1311-1352 . . . 35

2.14 An Estimate ol Gross Nalional Product, 1314-1352 . . . . 37

2.15 An Estimate of Gross National Pioduct at Constint Prices, $1314-1352$

2.16 Average Annual Percentage Rates of Change in Gross National Product, Government Domestic Revenue and the Money Sluck at Constant Prices, 131+1351 . . . . . . 40

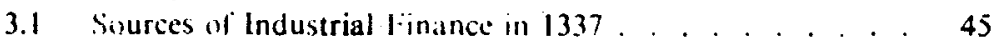

3.2 Wheat Yield in Tons per Hectare, 1335-1351. . . . . . . 52

3.3 Harvest Period Wheat Prices in Eight Provinces, 1303, 1343 1351

4.1 Planned Financing of Development Expenditure, 1335-1355

4.2 Planmed Financing of Development Expenditure at Constant prices, 1335-1355. .

4.3 Actual Financing of Development Expenditure at Constant Prices. 13.36-1.350

4.4 Acwal Financing of Development Expenditure att Constant Prices in Relition to Gross National Product, 1336-1350. 
4.5 Investment and Savings at Constant Prices, 1331-1351. .

4.6 Five Year Average Annual Incremental Capital/Output Rillios, 1331-1351.

5.2 Total Assets of the Financial Institutions in Afghanistan, 1.340-1351.

5.3 Total Assets of the Financial Institutions in Afghanistan at Constant Prices, 1340-1351

5.4 Number of Persons Working in the Financial Institutiuns at lice End of 1351

5.5 Percentage of Total Assets of the Financial Institutions Held by Central and Commercial Banks in 16 Countries in 1963

5.7 Monetary Survey, 1340-1351 . . . . . . . . . . . . .

Monetary Survey at Constant Prices, 1340-1351 . . . . . . 99

5.6 Dumestic Credit, 1330-1351 . . . . . . . . . . . . . . 100

5.9 Dumestic Credit at Constant Prices, 1330-1351 . . . . . . 101

5.10 Yicid on Government Bonds in 22 Countries . . . . . . . . . 103

5.11 Discount Rate in 19 Countries . . . . . . . . . . . . 104

\$.12 Binks, Branches, Assets and Deposits in Afghanistan, Iran, Pakistan and Turkey . . . . . . . . . . . . . . . . . 107

5.13 Assets and Liabilities of Da Afghanistan Bank, 1340-135i . 110

5.14 Three Year Moving Average Percentage Changes in the Money Stock and Modified Purchasing Power Parity Price Index, 1331-1351

5.15 Currency and Money Stock, . . . . . . . . . . . . . . 117

118

5.17 Average Annal Constant Prices, 1310-1351 . . 119 Average Annual Percentage Changes and Standard Devialiuns in Money and Prices in Afghanistan, Iran, Pakistan ind Turkey

5.1K Sources of the Rates of Change in Afghanistan's Moncy Stock, 1338-1351

5.19 Sources of the Rates of Change in the Money Stock in Iran, Pilkistan and Turkey, 1961-1970.

5.20 Annual Changes in Iligh Powered Money and Public Sicitor Debt, 1338-1351 . . . . . . . . . . . . . . . . . . .

5.21 Assets and Liabilities of Bank Millie and Pashtany Tejaritty Bank, 1340-1351 . . . . . . . . . . . . . . .

5.22 Banking Ratios of Bank Millie and Pashtany Tejaraty Bank, 1340-1351.................. 04 107

5.23 Asscts and Liabilities of the Agricultural Development Bank, $1350-1351$.

5.24 Asscts and Liabilities of Ilve Mortgage and Construction Bank, 1334-1350

5.25 (irous Insurance Premiuns, 13 Product in 14 Developed (i)untries, 1971 . . . . . 147

6.1 Government Domestic Revenuc and Expenditure, 1311-1352 152

6.2 Civvermment Domestic Revenue and Expenditure at Constant Prices, 1311-1352.

6.3 Budgetary Position, $1331-1352 \ldots \ldots \ldots$

6.4 Budgetiry Position at Constant Prices, 1331-1352 . . . . 16.

6.5 Ciovernment Revenuc, $1331-1.352 \ldots . . . . . . . .170$

6.6 Ciwernment Revenue at Constant Prices, 1331-1352 . . . 172

6.7 I.1 Revenue Sources in 51 linderdeveloped Countries . . 174

6.8 liaxable Capacity and Tax lilfort in 50) Underdeveloped (iountries

Calculating Afghanistan's Tax Effort, 1346 . . . 184

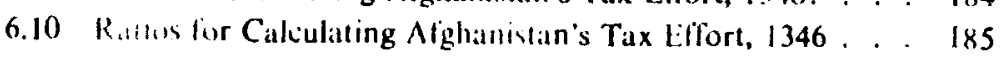

6.11 A Ripresentative Tax Systen Applied to Arghanistan, 1346187

6.12 Pubitic Sector Net Savings as a Percentage of National Income in 15 Underdeveloped Countrics. 1968 ....... 188

6.13 Ciuvernment Expenditure, 1331-1352 . . . . . . . . 194

6.14 Cinvernment Expenditure at Constant Prices, 1331-1352 . . 196

7.1 Agghanistan's Foreign Trade, 1309-1351 . . . . . . 217

7.2 Fiorcign Trade in Relation to Gross National Product, 13141.351 . . . . . . . . . . . . . . . . . . 219

7.3 Direction of Trade, $1331-1350 \ldots \ldots$. . . . . . . . . . . 220

7.4 Composition of Exports, $1331-1.350 \ldots \ldots$. . . . . 22

7.5 Composition of Imports, 1347-1348 . . . . . . . . . . . . 221

7.6 1.xport Distribution of Ten Sclected Commodities, 1345-1348 222

7.7 Import Distribution of Ten Sclccted Commodities, 1345-1348 223

7.8 Mllicial International Reserves, 1335-1351 ....... 224

7.9 Merilge Duties by Sector in 1352 Based on 1348 Imports . 225

7.10 Illictive Export Taxes on coston, Karakul and Wool, $1.355-1350$

Trade Balances, 1335-1350)... 229

7.12 Amulal Turnover of Foreign Fixchange, 1349-1351 . . . . 243

7.13 Frer Market Dollar and Rupee Exchange Rates, "Bazaar Rattes," 1329-1351 . . . . . . . . . . . . . . . . . . 244

35

(1) (a)

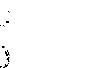

(2)

32

5

7

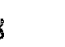
6

9


7.14 Liags between Changes in the Money Stock and the Exchange Rate, 1332-1351, $\Delta \log E R_{t}=a_{0}+a_{1} \Delta \log M_{t \cdot n}$.

7.15 laigs between Changes in the Morey Stock and the Exchange Rate, 1332-1351, $\Delta \log E R_{t}=a_{1} \Delta \log M_{t \cdot n} \ldots \ldots . . .247$

7.16 Commodity and Income Terms of Trade, 1338-1347 . . . . . 248

7.17 Differential between Dollar Cash Selling Rates in the Kabul Mioney Baziar and Da Afghanistan Bank for the Last Tuesday of Each Month, 1344-1350 . . . . . . . . . . . 250

7.18 Aighanistan's Exports by Month, 1344-1350.

7.19 Returns from Seasonal Foreign Exchange Speculation, 1372 1351 . . . . . . . . . . . . . . . . . . .

7.20 Irree Market Dollar Exchange Rates, "Bazaar Rattes," $1332-1352 \ldots \ldots$. . . . . . . . . . . .

7.21 Fre Market Indian Rupee Exchange Rates, "Bazaar Rates,"

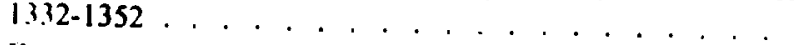

7.22 Free Market Pakistani Rupee Exchange Rates, “Bazialir Rittes," 1332-1352.

8.1 Innual Average Percentage Rates of Change in Real Moncy Stick, Per Capita Gross National Product and Velocitics of Circulation in Six Countries . . . . . . . . .

K.2 Currency/Deposit Ratios and Velocities of Circulation in 45 Underdeveloped Countries, $1969 \ldots \ldots . . . . . . .294$

8.3 Changes in Currency/Money Ratios and Velocities of Circul.1twn in 10 Countries, 1964-1909.

\section{FIGURES}

2.1 An Estimate of Gross National Product at Constant I'rices, 1314-1352 ................. 39

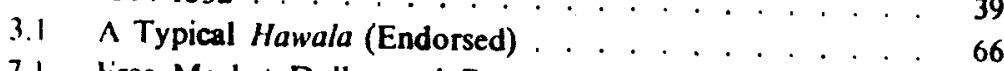

7.1 Free Market Dollar and Rupee Exchange Rates, "Bitzitir Rates," 1332-1352. . . . . . . . . . . . . facing 240

7.2 Monthly Exports and Exchange Rates, 1344-1350 . . . . 252 K.1 Shifting Demand for Money. . . . . . . . . . . . . . . . . 277 Map of Afghanistan . . . . . . . . at the end of thie book

PREFACE

At the end of an eventful eighlecen months in Afghanistan, many pleasant memories vie for predominince: a mountain view from every window; walking holidays in Bamian and Nuristan; skiing in the Hindu Kusl: field trips to all the major twwns in thr country; colourful nomads on the move; the variety of people in lhe bazaars; and the friendly social and working relations with mathy individuals both in and outside the Government. During this periud the vructure and contents of this book took hape. It started with work on the financial system, much of which was presented as working papers to the Financial Development Committoe for which the Minister of Finance asked me to act as Secretary at the beginning of 1973. The first six montlis of this year were spent in this capacity preparing balckground reports. etc., for the Committee. Regretfully, it was one of the calsualties of the July coup. The last six months have, therefore, been devoled cxclusibly to writing this book.

There are many pcople whom I wh to thank for their help in this endeavour. Numerous bankers and civil servants have been most kind in supplying information. For help on the analytical side, I would like to thank Raymond Hooker of the United States Agency for International Devilupment, Sig voll Post. Resident Representative of the International Monctary fund, and Edward Shaw of Stanford University. For conscientious rescarch asvistance throughout the past eighteen months, I am very gratefil 1" Mir Agit Kabiri. Acknowledgement is due to the British Social Sicience Reseilf h Combil. Hic (ity University, l,ondon, and the United Slates Agency for International Development Mission to Afghanistan fir their financial support, without which this study could not hatve been undertiken. Finally, my heartfelt thanks go to my wife, Celia, for typing every word of several provisional drafts as well as the final manuscripl.

Kahul

Diamlw. 1973

Marwell Fry 
In transliteration, the spellings at present in most common use in Afghanistan have been adopted. This may frustrate Persian scholars but is hopefully more convenient for readers familiar with Afghanistan. However, there is still considerable scope for choice in using this criterion. fur example, at present Bank Millie, the oldest commercial hank in the country, itself uses three spellings, namely Bank Millie, Banke Millie and Bank Melli, inferchangeably. In the past, the Bank has used at variety of alternative spellings, as have other authors, one of the nust popular heing Bank-i-Milli. Although the form Bank-e-Melli is probably the closest phonetic transliteration, the spelling Bank Millie has been adopted here since it is used on the Bank's most recent balance sheets and appears on a set of blue signs, one of which is displayed outside cach of its domestic branches. The forerunner of Bank Millie was the Shirkat-iSahami-i-Afghan or the Afghan Joint Stock Company. For some unknown reason, it has frequently been speit in the plural, Shirkatt-i-Ashami-iAfghan. There is a particular problem over the choice of $K$ and $Q$ in certain cases. Thus, earlier reports mention Qandahar while contemporary writings refer to Kandahar. Karakul, similar to and sometimes known as astrakhan or Persian lamh, the skin of very young or unborn lambs from an Asiatic breed of sheep, is perhaps more correctly, though rarely, spelt q:irakul.

Where dates appear, the Afghan Shamsi (solar) date is given first filluwed by the Gregorian date in brackets. Since the Shamsi calcndar is hased on the solar year, i.e. 21 March to 20 March, corresponding Gregorian dates can be either 621 or 622 years greater than the Shamsi date. Find of year figures will show 622 years' difference, while mid-ycar estumates only 621 . Where an entirc year is referred to the 021 year difference is shown.

The alphanumeric code in equare brackets relates to the list of matcrials $i: 1$ the bibliography at the end of the book. Afs I millior - $A f s ~ 1,000,000$; Afs I billion $=$ Afs $1,000,000,000$. Afs is the abbreviation of Afghanis, the monetary unit of Afghanistan. It is subdivided into 100 Pul- $A$ common unit of weight is the seer; one seer equals 7.1 kilograms. All logarithms used in the text are natural logaritlums unless otherwise stated.

\section{INTRUIDIICTION}

\section{i. Drestopment Pof'mtial and Fin' C ritical Comstraints}

This hook analyces some of the lactors which have prevented rapid economic growih in Afghanistan. In particulat, it is concerned with five detcrminants of Aighanistan's development potential. Because this potential is low, thexe are the critical constraints to development. Untess attention is foeused first on them, deschopment effort and expenditure in olher directions cannot be expected to produce significant restils or accelciatc the rate of growth.

Much that is written below is eritical. The purpose of this book, however, is (1) reconstruct the coonomic history of Afghanistan during the Musihihan period, 1308-1352 (1929-1973), and so illuminate past mistithes 14 be avoided in the future. Hopefully, the new Republican Govermment established on 26 Saratian 1352 (17 July 1973) may find such analysis of some use in its attempts to remove the constraints to economic development. The findings of the analysis can be interpreted optimistically. The critical constraints are, in the main, policy variables: they cian be overcome. Indeed, their cemoval is not a question of vast financial outlay but of determination on the part of the nation's leaders.

Thus book has been written in the hope that the analysis will be useful to those planning Aighanistan's divelopment in the future. Therefore, an attemnt has been made to prodace constructive rather than destructive criticism. Positive recommendations have, however, largely heen deferred to the finat chapter since the body of the book is designed to elucidate in detail the "icturs which have constrained economic development to date. This Collows the tenet that too many recomnendations in the past based on misleiding assumptions ant imsullicient data have been presented to the (iovernment by the army of lioreign advisors in Aighanistan. Given the dearth of hard facts, the analysis and conclusions put forward below must still be used with caution. It is hoped, however, that the documentaltion d' data sources throughout will be of value in this regard.

In 190, Adelman and Morris published the results of a comparative study of 73 countries designed to measure development potential [A2]. Using discriminant analysis, the study linds tive indicators of development potential: 
A. The degree of improvement in financial institutions as measured by the growth in private savings flowing through the banking system and the growth in bank lending on medium and long term to the private sector;

B. The degree of improvement in physical overhead ciapital as mealsured by the improvement in transport systems;

C. The degree of improvement in agricultural productivity achieved through the application of "modern" inputs and techniques;

I). The degree of modernisation of outlook measured in part by the extent to which development programmes have gained support of both the rural and urban population;

f: The degree of commitment by the leadership to promoting economic levelopment as measured by the existence of concerted efforts by heads of agencies involved in central guidance of the economy to promote economic growth, by whether the planning effort included serious attempts to alter institutional arrangements which clearly hlicked the achievement of planning goals, and hy the existence "if a national plan or planning agency.

The absence of any improvement in financial institutions, i.e. financial development, is briefly mentioned in the next chapter and is discussed at length in Chapter $V$. There it is shown that financial develupment has not ociurred partly because Government activities and policies have impeded it, partly because the banks themselves have not been interested in change and partly because the external environment has not been conducive to the expansion of banking. It is also shown that the private sector has been squeezed as the Government acquired an increasing share of domestic credit to finance development expenditure.

There is no railway system in Afghanistan. The improvements in the road system, however, are analysed in Chapter III. Despite a sizable invesiment in roads over the past two decades, the total lingth of motorahle roads in 1351 (1972) was only 29 miles per 1,000 square miles [U19, $p$. 9]. The rate of improvement has been greatly reduced since the early 1.340s $(1960 \mathrm{~s})$ when the foreign aid input into road building reached a peik.

The negligible improvement in agricultural productivity is discussed in (halpters III and IV. The development expenditure in the agricultural sector has been predominantly on large scale infrastructure projects rather than on small scale on-farm investment which might have rapidiy increased output. Furthermore, the very limited institutional credit facilitics have prevented firmers from realising modest but highly productive investment opportunitics. Following two years of Arought, the (iovernment realised that priority had 1 ) be given to raising agricultural productivity. To this end, fertiliser imports were substantially increased in 1351 (1972). The Afghan Fertiliser Company, able to obtain fertiliser using a lo:ll from the IInited States Agency for International Development, was established and the Regricultural Development Bank agreed 11 extend credit for fertiliser purchases in 1352 (1973). Unfortunately. these last two developments towh place during a year of exceptional precipitation. This resulted in whealt prices so low that many farmers were deterred from obtaining fertiliser for the next year's crop. In addition, fertiliser prices exploded in the same year. The combination of low wheat and high fertiliser prices hits produced serious problems for the Alghin fertiliser company, ats yet unresolved. P'rojections for future fermliser demand have had to be revised downwards.

As show in Chapters IV and VI, there has been little support for Afghanistan's development programmes and the commitment on the part of the country's leaders to ccinnomic development appears to hive decriased over the past decade. Ilic lack of support has been due to the absenci of any clear henefits to the majority of the population from developmient projects. The lack of commitment to economic development was secn in the unwillingness of Zahir Shah or his Government to make institutioual changes repeatedly shown to be prerequisites for successful developuncint, the demise of the economic plans and the low fiscal effort resulting in 80 per cent of the development expenditure being financed by forcign rid. The necessity on the donor's part to hold out only extremely limitid expectations of results under such circumstances has been expressed as follows:

... achievement of a substantial and cumulative process of development depends essentially on efliorts and conditions in the less-developed country itielf. If locil conditions are untivourable and local efforts are insufficient or misapplied, assistance can make wily limited contributions to economic and social advance, if any. [D6, p. 3]

It is mut, lherefore, surprising to lind Atghanistan classified in the Low Prospect (ifrup in the Adelman and Morris study [A2, p. 262].

A re.1 commitment to planned economic development in Afghanistan canmll be satid to exist until several decisive institutional changes have been madc. The most important of these must consist of measures to improve administration. These are also critical in any programme of finalmial development. Middle and lower level executives need rigorous 
Irainung in simple office procedures and many more Afghans who have received higher education àbroad have to be enticed 10 return home. This requires not only a realistic look at remuneration, e.g. following the Iranian example of the 1950s, in which a special cadre of Iranians were recruiled to form the Plan Organisation at higher salarics than other civil servants [B], Chapter 2], but also the prospect of rewarding joh content in the form of reasonable independence and responsibility. A successtiul start on systematic project preparation and cvaluation will be the indication that the necessary changes are being made at the higher levels. An overhilul of civil service personnel policies and the introduction of Iraining will indicate efforts to inprove middle and lower levels. The latter measures applied within the financial institutions together with the granting of autonomy in personnel policies to the Government banks. will he a major step in the direction of financial development. Further, legal ruform is a sine qua non for rapid expansion of bank lending to the privatc sector. Such measures can all be regarded as indicators of a real cummulment to development. They do not form a comprehensive list of all that needs to be done. They do, however, comprise those for which high priority musi be given.

Recient research conducted by the Development Assistance Dircctorate of the Organisation for Economic Co operation and Development has attempted to measure the stage of development in 82 underdeveloped countries [D6]. The index which is produced places Afghanistan at the sixty-eighth position with a per capita GNP equivalent of $\$ 10)$, compared 11) seventy-third position with a World Bank estimated figure of $\$ 70$. 1) most interest in the Development Assistance Directurate's study is the finding that the volume of investment is not strongly corrclited with the stage of development [D6, p. 113]. Furthermore, other cros country comparisons also show that the relationship between the volume of investment and growth, although positive, is weak [Dh, p 28]. The implication is important in that it suggests that Afghanistan's luw stage of development per se is no impediment to rapid economic growth. In other words, should the factors identified by Adelman and Morris [A2] as critical drterminants of development potential be altered in appropriate respects, a high grou'th rate could oe achieved despite the low stage of Alghanistan's development at the outset. Given that the efficiency of resourcic utivisation is considerably more important than the amount of investment, as shown in Chapter IV, this conclusion is thrt surprising. Only the volume of investment, not its efficiency, is determined by the stage of development.
In sum. Herefore, withous precedent changes in the tive Adetman. Morris indicators, no amount al develupment expendilure is likely to be effeculic in producing rapid comomic growth. Hence, the reason for stres litroughout this book an these tive critical constraints to develop ment. With appropriale actionl to remove these constraints, rapid growt? seem possible despite Afghanistan's low starting position.

ii. Summary of Subrequent Chaprers

The next chapter contains a xelective economic history of Afghanistan over the past firty years. In it, all attempt is made to trace long run and cycllcial monconents in ecommulc activity over this period. The finat sectlom presents estimates of (jross National Product for 1314-1.35: (193.5-197.3). The important pounts which emerge include indicators of the dantage w the embryonic mudern sector sutlered as a result of the Secones World War in which Afghanistan played no part, the protracted perind of remery, and the decelerating ralle of growth despite large inflows af foreign aid from the second hall of the 1.3.31)s (1950s) to the second hall we the 1.341$) \mathrm{s}(1960) \mathrm{s})$.

Chapher III looks al the ecumomy as a heterogeneuts systen with only weat lans beiween its separalle seclors. This approach is pursued at thre: levels. lirst, the Government, the mokern private sector led by the Bank Millic (ir up and the bazalar or tradlitional economy are viewed ass separalc parts within the economy as a whole. Where there has hees. interaciion it is shown to have been anc of antagonism. The ground rules in this struggle hate promoted destrutive rather than productive comprtition. Second. the subsistence agricultural ciconomy and industry are allalysed, the former becaluse at leist 50 per cent of Gross Domestic Prodact arises in this sector, the latter hecause it illustrates the problems of nodernising the conomy. The third view is of geographic fragmentation. Ilere the criticill transport constraint is exannined. The final section of thus chapter presents a generatisation and explanation of the phenomenou of economic liragmentation.

Development plannming has existed in onc form or other throughout the past hour decades. It is, however, only with the plans starting in 1.335 (1956) that Chapter IV is concerned. The important issue taken up here Afghamstan's commitment to conomic development through planning The conclusion is reached that on this critical determinant of developmer potential a low score must he recorded.

The tinancial system is described in detail in Chapter V. A survey of the financial instifutions and central banking is followed by an analysis of 
the prublems of bank lending. The findings show that financial development has not laken place and that the financial sector is a lagging part of the ecunomy. Private financial savings have been small and domestic credit allocated to the private sector has declined in real terms. Thus, the contribution to Afghanistan's low development potential by the total absence of financial development has been strong.

Chapter VI examines public finance. After a description of the fiscal systen and domestic revenue sources, the fiscal effort is meinured. That only a very low effort appears to have been forthcoming suggests not unly a lack of commitment to economic development on the part of the country's leatders (the conclusion also reached in Chapter IV) but also the rejection of Government promoted development activities on the part of a large section of the population. The reason for this is discussed after in analysis of the incidence of the benefits from development expenditures. These appear to have been negligible or even negative Io the vast majority of the community.

Afyhanistan's foreign trade and the role played by the money bazairs is the subject of Chapter VIl. Because future development efrorts must cuncentrate on export promotion activities, the importince of foreign trade cannot be overestimated. After a description of forcign trade developments and of Afghanistan's foreign trade and exchange system, the role of the money bazaars in foreign trade is discussed. The conclusion is reached that not only have the Kabul and Kandahar money bazaars tinanced the major part of foreign trade but that their foreign exchange operatlions produced a highly eflicient market in sharp contrast to inefficiencies observed in Government and modern sector operations. This chapter ends with an analysis of the determinants of both seasonal and year-to-year fluctuations in the free market Afghani/Dollar exchange rate.

The linal chapter presents an outline of a programme of lintincial and liscill refiorm which would need to be pursued concomitantly with an increalsed commitment to economic development, a greatly expinded road building programme and much more effort to raise agricultural productivity, all of which should be designed to raise Afghanistan's development potential. More attention is focused on financial development than on fiscal reform since prescription for the latter is considerably simpler. The penultimate section indicates the possible direct benefits which might be obtained from reform along the lines suggested in these a reas.

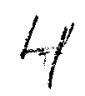

\section{APINIIIX}

Afshomistun in the Adelman-Morrix Study

Adelman and Morris examined data from 73 non-communist underdeveloped countries having first classilied these countries into three groups according to their past records of economic growth. Through discriminant analysis, four out of 29 indicators were selected which together accounted for 97 per cint of the discriminable variance between the llire groups of countries [A2. P. 26.X]. After nurmalising the estimatted equ.lim w that its variance in catch group is unity. the following result is ohlaincel:

$$
\text { I)', } 1271: 65 \mathrm{I}+108 \mathrm{M}+72 \mathrm{~L}
$$

where $F$ is linancial development. $k$ transport improvement, $M$ modernisation in autlook and acceptance of cconomic development on the part of the population at large, and I the commitment of leadership to development [A2, p. 269]. In terms of the overall contribution to the discriminating power of the function, the order of importance of the variables is given by ranking the matgniludes of their coefficients.

Adelman and Morris then omitled all countries which had originally been misclassilied on the batsis of their past econonic growth record accirding to the results of Equation I.I, and re-ran the discriminant analysis. his produced the following result:

$$
D_{2}^{\prime}=95 \mathrm{I}+1.39 \mathrm{M}+88 \mathrm{~L}+70 \mathrm{~A}
$$

where $A$ is improvenent in igricullural productivity [A2, p. 277]. This equation also accounts for over 97 per cent of the overall variance [A2. p. 278 | Furthermore, the separation between the groups is much better and the dispersion within the groups reduced. The probability of Afghanistan, membership in the Low Potential (iroup is 1.00 with a score 10 (2) [A2. Tinble V. p. 279]. The mean scures lior the three groups are 174, 113 and $\$$ for high, intermediate and low potential groups, respectively [A2, pl. 278-60].

An important point to note is that the datta used in this study refer in general to the period 1.3.36-1.341 (1957-1962) when all indicators for Afghanistan must have been near their peaks. There had been rapid develupment in the liclds of hanking and road building. commitment to develupinent was relatively strong among the countrys leaders and the population had not hecome disillusioned with the development programme as it hiut only just started. Neverthelen. Afyhanistan is classified among 
countries that have shown no significant improvement in the ellectiveness of their financial institutions as indicated hy quilitative in. formation on saving and lending activities and, for countries for which the relevant data are available, by either (1) a negligible increase or a decrease in the ratio of the sum of demand and time deposits to GNP /Gross Nitlional Product] or (2) a negligible increase or a decrease in the real value of private domestic liabilities to the banking system. [A1, p. 123]

On the degree of improvement in physical overhead cilpilill, Afghanistun reccives an $A+$ because the annual percentage increase in paved ruads between 1336 (1957) and 1343 (1964) exceeded 15 per cent. Since there were no such roads in 1335 (1956) and the road-building boum took place hetween 13.35-1345 (1956-1966) this result is not surprising even if it is mislealding.

With respect to agricultural productivity, Afghanistan w clatsitied as a country

in which there has been no significant improvement in agricultural profluctivity since 1950. Included in this category are some countries in which substantial increases in total agricultural output have occurrid but in which the increases in output are largely due to additionil inputs of the sime quality as those generally prevailing in 1950. [AI, $p, 108$ ]

On llie degree of modernisation in outlook Arghanisfin is mentioned logethic with other countries

.... in which the outlook of the educated urban sector was partially but not significantly modernized and in which programs of modernization, if they existed, had gained relatively little support among either the urban or rural population. $[\mathrm{Al}$, p. SI]

Finally. Afghanistan appears as one of a number af countries

... . in which some government leaders evidenced a definite commitment to economic development (during the period 1957-62) as indicated by the praclice of some form of national development planning. However, it was typical of the countries in this category that the activities of agencies involved in central guidance of the economy were poorly co-ordinated and that government attempts to alter institutional arrangements unfuvourable 10 econumic growth were infrequent or poorly sustained. [AI, p. 80]

One might simply add that had the data referred to the late 1.3413 (1900) insteat of the early years of that decide, Afghanistan's score would bive heen considerably lower than the 62 achieved in the Adelmatn-Morris study.
(IINIIR TWO

TIII I:CONOMY

i. Intrustinction!

The patucity of quantitative data on Alghanistan makes any attempt to survey cionomic developments over a forty yeatr period difficult and conclusious tenursus. Nevertheless. an atlempt appears warranted if only to disp i commonly held belici, reinforced by the recent classification of Afghanistan as a Least Developed country, that change has been negligible. On severill fronts, changes over the past forty years have taken placic at a pace many limes finler than that with which comparable changes took place in medievall l:urope. Indeed, considerable change had alreildy occurred during the $1.3(0) \mathrm{s}$ (1920s). It is interesting to note a passage in a report writlen in $1316,(192 x)$ in which Afghanistan is described as lollows.

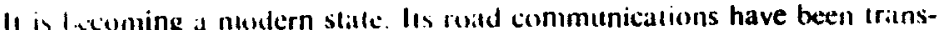
formed. There is a well-trained army. There are excellent schools. The mellic systen was recertly achomed. In the centre of Asia what is almost a new country is in process of birth or, at least, the old country is being nietamorpliosed. [1t10, p. 4kt)]

The improvements recorded must, "il cuurse, be interpreted in relative terms. Neverilieless, it behoves platuners, technical advisors and donor agencies frustrated by resistince 10 new projects, procedures and programmes w compare the present situation in an economy so often labelled stagnant with that of a nere firty years ago.

The Afghan economy at the start of 1311.(1932) was still recovering from the holocaust of $1307(1929)$ and the reign of the bandit, Bachat Salyiw, 1307-130x (1929), during which severe economic disruption, cessiltion of foreign trade, the closure of schools and hospitals and a flight of citpital took place [C15, np. 263-75; G21, p. 424; M21, p. 182]. Condulum during and immedialely after sataito's rule were described as follows in a contemporary repurt:

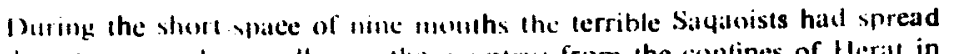
der distuon and ruil all oue the country: from the contines of tlerat in the west right un to the Indian borler in the east, pestilence and famines, lublerey and dacoity were the oriler of the day. There was no order, no liw. silve that might was right. When the present king took Kabul, he leund the whole country in a chato:, tribal wars raging on all sides, trade 
and agriculture badly crippled, people half starving and diseased, and many dressed in rags with their skin showing through the rents ancl imploring for food, villages deserted, houses burnt, thousands of people rendered homeless. schools and colleges entirely closed, some of thein burnt and demolished, the students having taken shelter in far off thein burnt and to avoid the wrath of this ignorant ... The granaries were empty, and the grainfelds had bem as renegades reaping the gruesomere empty, and the grainfields had been neglected for reaping the gruesome harvest of human lives. [AIS, pp. 177-78]

On the accession of Nadir Shah, the country was

.... without an army, police or money in the treustry. I/te souther tribes were in ferment, the northern provinces had virtitally veceded. look almosi Iwo years and an army of 40,000 to pull the count axain. [K12, p. 245]

To he sure, the economy was then as now predominanly an aluricultural, suhsistence economy:

.. there was literally no industry, only fragmentary handiciaft, and scanty trade. While the majority of Arghans tilled the soil or kept the llocks, nearly all the commerce of the couns tilled the soil or kept their carried on by the Kuchis or camel nomads, was ithe exception of that carried on by the Kuchis or camel nomads, was in the hands of Sikh and Hindu merchants. [F9, p. 229]

There were, in fact, a few Government munitions factories in Kabul [SI6, pp. 642-43] but no electricity. Transport and communicillions :vere rudimentary and unreliable. A contemporary report states:

The following roads are fit for motor traffic, except after snow or heavy ritii, but are hadly constructed and mostly unmetalled: Khitibir-Kabul. Kallul-Kandahar, Kabul-Gardez, Kandahar-Chaman, and Kilhul-Bamian. In addition there are some 200 miles of minor roads lit for motor traffic. inustly in the vicinity of Kabul. Merchandise, however, is still (ra) traffic. chicfly on camel or pony back. [S16, p. 64.3]

It did not a dd that travellers were likely to be robbed. The (iovernor of Kandahar, for example, had had to deal sumnarily with highway robbery at this time:

When he arrived at Kandahar the tribesmen were playing tricks on the roall of a rather old-fashioned kind, shooting drivers and robbing motors. The Governor had the criminals hanged in public at the gates of Kandahar. [F20, p. 11]

Ditliculty in obtaining petrol was another problem of motorised transport [E], p. 204]. The poor road conditions impeded foreign trade. It took, for example. two full days for the British Legation's mail lorry to reach Peshauar [B33, pp. 34-39], nevertheless a substantial reduction from the 45 days previously taken by caravans [M1, p. 225]. (iovernment revenue raised mainly from tarilts on forcign trade was "subiect to considerable fluctuations" [S|6, p. 642]. In 1311 (1932), total Government revenue was Als 140 million. There were no banks or paper moncy. Two currencies, the Alghani ind Kabuli, circulated side by side in the form of silver coins [S16, p. 643]. In the field of commercial transactions, another contemporary report states:

Afyhanistan has not responded to the invitation of the league of Nations 10 atcede to various recent conventions concerning cheques and negotiable

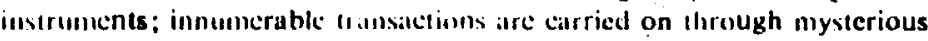
humlis and by word of mourh. ind credit is bascil on persomal note of hand rather than on decuments which represent specitic goods. [S19, p. 722]

Prinary schools had been re-npenced by the heginning of 1311 (1932) but the quality of the education provided was generally low and compulsory elemenl: y education was an unrealistic ideal included in the Constitution of 1310 (1931) [Gi5, pp. 307-30x]. There were only 22 schools, 1.350 pupils, and 105 teachers in the couniry [M13, p. 88]. Eventually, the four secondary schools in Kabul were re-opened but had to be staffed by French, Germans and Indians since no qualified Afghans could be found $[F 9, p .231]$. There were no fitcilities at all for vocational training $[K / 2$. p. 2571 :

Trade look place between $\Lambda$ fghanistan and India as well as between Alghanistan and the U.S.S.R. The total value of Afghanistan's foreign tride in 1311 (1932), of which one-third was with the U.S.S.R., was Afs $2(19$ million [M 12, pp. 101-103]. It is of interest, however, that contemporaly economic reports make little refierence to either the U.S.S.R. or to Hie morthern part of Afghanistan. It was not until the Great North Roud joined the two halves of the colintry that the towns of the north are mentioned. Even then malariat deferred visitors until its irradication witl the help of the United Nations in the 1.330s (1950s).

The Aighan economy of 1.352 (1973) is still basically agricultural. However, assuming on the scantiest ol evidence that population was 6.85 million in 1.310 (1931) and 10 million in 1352 (1973), wheat production. the staple food in Afghanistan, which has increased from 2.0 million tons in 1.332 (1953), the carliest year for which a consistent estimate exists, to 2.4 million tons in 1.351 (1972), shows a small decrease in per capita terms for this period. The production of other grains has increased at at somewhat l.uster rate. Fertiliser use in 1351 (1972) was estimated at 48,000 ) tons |k|l, p. If| compared (1) nil in 13/| (1932). If fertiliser use increases as predicted. Afghanistan maly become self-sullicient in food production durin!t 1lic $1350 \mathrm{~s}(1970 \mathrm{~s})$ 
There is now some industry in Afghanistan. A total equity carpital of Atis 1.5 hillion with a labour force of 30,000 has been estimated for public sectur enterprise and capital of Afs 3 billion with a labour force of 15,000 fior the private sector [G6, p. 2]. Of the latter Afs 1.2 billion, creating $6 .(x)$ jobs, has been invested under the terms of the 1345 billion, creating and I ormestic Private Investment Law.

Two thousand five hundred kilometres of paved road now links north and swuth and east and weat and there is a totil of 17,300) kilometres of motorible roads [M31, p. 89] compared to 2,880 kilometres of barely pilssitble tracks in 1311 (1932) [A15, pp. 221-22].

Government revenue has not increased rapidly if measured at constant prices. In 1340 (1961) prices, domestic sevenue was Afs 1,428 million in 1.311 (1932) and Afs 2,683 million in 1351 (1972), giving a per capita increalse of only 30 per cent over the entire period, or an average annual per cilpita increase of 0.6 per cent. This unsatisfactory development is considereu in detail in Chapter VI.

There are now three commercial banks, one of which is also the central hank, and three specialised banks. Although considerable attention is elevotid later to the inadequacies of the financial system, trans irs can he eflicted and accounts maintained. There is a generally acceptable paper currency in wide circulation, although problems of making commercial transactions have changed little from those existing in 1311 (1932) describcd above. In real terms, the money stock has increased only slightly fister thitn the Government's domestic revenue. Subsequently, it will be argued thist both the fiscal aystem and the financial sectur are in fact underdeveloped even in relation to other secturs of the ecomomy. Nevertheless, the widespread acceptance and use of paper currency is a major change from the bi-metallic specie systcm existing in 1311 (1932).

In 1311 (1932) there were only 22 schools in the whole country. but by 1.351 (1972) there were 3,972 schouls, 21,920 teachers and 760,469 students. In relation to total population, however, education still reaches only a small minority and literacy is very low.

In 1.341 (1961) prices, the total value of foreign trade in 1.311 (1932) of Afs 2.1 .3 .3 million can be compared to a figure of Afs 7,015 million for 1.351 (1972), showing an increase of over 200 per cent or 1 per cent annually. Foreign trade has been a beneficiary of road improvements.

This brief comparison of a few key variables for the years 1.311 (1932) and 1.351 (1972) indicates that changes have occurred, some quite rapid, "thers relatively slow. That Aghanistan still lacks almost all signs of a rapidly expanding modern economy suggests that changes have taken place from an exceddingly low initial position. There is no dispute with the assertion that the country is poor. The lack of main drains and a main water wpply even in the capital, the prevalence of disease, the absence of modern skills generally and of administrative ability within the civil service in particular, and the subsistence standards of living of all but a small minority amply attest to the poverty of the nation. Yet, if only because banditry has been suppressed, violence and cholera, malaria and smallpux epidemics reduced. life expectancy hats increased.

ii. Ecomomic and Social Indicaloris of changes

A. Num-Monetary Indicilurs

Lack of reliable data is perhaps no better illustrated than in the demorraphic field. It 1311 (19.32), pepulittion estimates ranged from six to 1 million, of which nomads comprised one-third [S19, p. 716]. In

$\operatorname{Talh} \cdot 2.1$

Parrukation 1.3/0-135?

(Milliuns)

\begin{tabular}{|c|c|c|c|}
\hline Inuts & Population & Date & Propulation \\
\hline 1310 & 6.85 & 1.333 & 7.80 \\
\hline 1311 & 0.89 & 1334 & 7.88 \\
\hline 1.312 & 6.92 & 1.335 & 7.96 \\
\hline 1313 & 6.96 & 1336 & 8.04 \\
\hline 1314 & 6.99 & 1337 & 8.12 \\
\hline 1315 & 7.03 & 1338 & 8.20 \\
\hline 13116 & 7.06 & 1334 & 8.28 \\
\hline 1317 & 7.10 & 1340 & 8.36 \\
\hline $131 \mathrm{x}$ & 7.13 & 1341 & 8.49 \\
\hline 1319 & 7.17 & 1342 & 8.62 \\
\hline 1.320 & 7.20 & 1343 & 8.75 \\
\hline 1321 & 7.24 & 1344 & $8.8 x$ \\
\hline 1322 & $7.2 x$ & 1345 & 9.01 \\
\hline 1.23 & 7.31 & 1346 & 4.15 \\
\hline 1124 & 7.35 & 1347 & 9.28 \\
\hline 1325 & 7.39 & $134 k$ & 4.42 \\
\hline 1.326 & 7.42 & 1349 & 9.56 \\
\hline 1.327 & 7.46 & 1350 & 4.71 \\
\hline $132 x$ & 7.50 & 1.351 & 9.85 \\
\hline 1.324 & 7.5 .3 & 1.352 & 10.00 \\
\hline 13.30 & 7.57 & & \\
\hline 1331 & 7.65 & Averige Anirual & \\
\hline 1.332 & 7.72 & Percentuge Increase & 0.905 \\
\hline
\end{tabular}

Nork: Population in $1352(1973)$ is assumical to be 10 million. Ammual growth rates assunk'd are 0.5 per cent for the $131(0 \mathrm{~s}$ (1931) 3) and 1320 s (144(h), 1.0 per cent for the 1330 s $(1990$, and 1.5 per cent for the remlameng years. 
1351 (1972), estimates ranged from eight to 17.88 million. the litter being the official estimate [12, p. 40]. Thus, no direct estimates of the rate of thange in the population can be derived. The range in the estimates allows for increasing. decreasing or stable population, although the oficial series shows an annual increase over the 1340s (1960)s) of 2 per cent [1 3, pp. 228-29].

Table 2.2

Education and Healih Statistics /31/-1351

\begin{tabular}{|c|c|c|c|c|c|c|}
\hline Dostr & $\begin{array}{l}\text { Number } \\
\text { of } \\
\text { Schowils }\end{array}$ & $\begin{array}{l}\text { Number } \\
\text { of } \\
\text { Pupils }\end{array}$ & $\begin{array}{c}\text { Number } \\
\text { of } \\
\text { Teachers }\end{array}$ & $\begin{array}{c}\text { Numberer } \\
\text { of } \\
\text { Hluspitals }\end{array}$ & 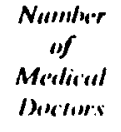 & $\begin{array}{c}\text { Number } \\
\text { of } \\
\text { llospitul } \\
\text { liseds }\end{array}$ \\
\hline 1311 & 22 & 1.350 & 105 & & & 600 \\
\hline 1319 & 42 & 9.275 & 309 & & & 650 \\
\hline 1320 & 3.31 & 64,000 & 2.190 & & 18 & 7.30 \\
\hline 1325 & 359 & 93.544 & 2.677 & & $x x$ & 770 \\
\hline 1330 & $37 x$ & 98.743 & 3,128 & 50 & 167 & \\
\hline 13.35 & 804 & 126.092 & 4.007 & 52 & $1+49$ & 1.380 \\
\hline 1.340 & 1.4 .36 & 235,201 & 5.983 & 54 & 250 & 1,754 \\
\hline 1.4 .5 & $2,29 \mathrm{X}$ & 443,459 & 0,824 & 6.3 & 527 & 2,197 \\
\hline 1351 & 3,972 & 760,469 & 21.420 & 67 & 827 & 3,504 \\
\hline $\begin{array}{l}\text { Averaks } \\
\text { Ammual } \\
\text { Percentige }\end{array}$ & $\therefore$ & & & & & \\
\hline Incre:ass & 13.9 & 17.2 & 14.3 & & & 4.5 \\
\hline
\end{tabular}

Souric: Education-Ministry of Education. Education in Afghumivan (Kabul Ministry of Education. 1956). p. 88: Ministly of Planning. Survel' of ('rogress 196264 (Kabul: Ministry of Planning. 1964). Table A-50. pp. 150-51; Ministy of Planning. Surrey uf Progress 1971-1972 (Kabul: Ministry of Planning, 1972), Table S-32; and Ministry of Planning.

Health Ministry of Planning. Survey of Progress 196/-62 (Kabul: Ministry of Planning. 1963). Part If, Table Health (1). p. 21: Ministry of Plaminimg. Survey of Proxerss 1971-1972 (Kabul: Ministry of Planning. 1972), Table S-41: And Ministries of Planning and Public Health.

Population estimates should be forthcoming from the Alghan Demographic Survey towards the end of 1352 (1974). At the present, however, there is virtually no foundation on which any estimate $a$ in be based. Here, it has been assumed for convenience that the population in 1.352 (1973) is 10 million and that annual growth rates have been 0.5 per cent for the 1.310s (1930s) and 1320s (1940s), 1.0 per cent for the 1.3.30 (1950s) and 1.5 per cent thereafter. Annual estimates are presented in Tithle 2.1. By 1352 (1973), the population growth rate might have reached 2.0 per cent.
Iahli: 2.1

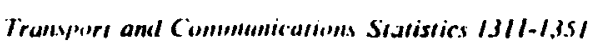

\begin{tabular}{|c|c|c|c|c|c|c|}
\hline Dalle & $\begin{array}{l}\text { Number of } 1 \\
\text { Asphult aud } \\
\text { Concrete }\end{array}$ & $\begin{array}{c}\text { Romeires } \\
\text { Roal }\end{array}$ & Molorahle & $\begin{array}{c}\text { Number of } \\
\text { Mouror } \\
\text { Vehicles }\end{array}$ & $\begin{array}{l}\text { Number of } \\
\text { Telephones }\end{array}$ & $\begin{array}{l}\text { Nunther of } \\
\text { Lellers } \\
\text { (in (knis) }\end{array}$ \\
\hline 1311 & o & 2,880 & $2.5 \times(0)$ & 350 & so & \\
\hline 1315 & 0 & & & & 120 & \\
\hline 1320 & 0 & & & & & \\
\hline 1325 & 0 & & & & & \\
\hline 1330 & 0 & & & & & \\
\hline 1335 & 0 & 6.2000 & $6,2(x)$ & 5.350 & 3.136 & 2.429 \\
\hline 1340 & $+1 \% 4$ & & & 13.802 & 6.238 & $.3,034$ \\
\hline 134.5 & 1.886 & 11,434 & 13,120 & 45,102 & 9.8666 & 4,824 \\
\hline 1351 & $2.5(x)$ & $14, k(x)$ & $17.3(x)$ & 55.076 & $19,9.39$ & $4,9(1) 7$ \\
\hline $\begin{array}{l}\text { Average } \\
\text { Annual } \\
\text { Percentilge } \\
\text { Increasc }\end{array}$ & & 4.2 & 10 & 13.5 & 16.1 & \\
\hline
\end{tabular}

Nole: The number of motor vehicles grven are only those registered in Kabul. In 1.344 (1970). Whis atciounted for 87 per cent of the total. The numibers of letters rocorded for 1319111972 1 alle 1350 (1471) tigures

Somci: Roads - M. Ali. Progresvive A/shanistim (Lahore: Punjab Educational Electili Press, 19.33), nn. 221-22: Ministry of Planning. Survey of Progress 1960 (Kabul: Ministry of Planning, 1960). p. 119: Ministry of Planning. Survey of Progress. 196/-n2 (Kabul: Ministry of Planning. 196,3), p. 24: Ministry of Planning. Surver. of Pruxerin 1966-1967 (Kabul: Ministry of Plamning. 1967). p. 73; Ministry of Planning. Surter of Proxesss 1971.1972 (Kabul: Ministry of Planning. 1972), p. 89.

Velicies - $A$. Ciuha, "The Econoniy of Afghimistan during Amanullah's Reign,

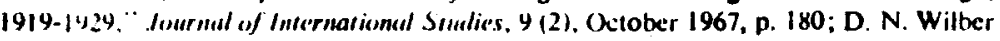
(Ed.). Afkhumivan (New Haven: Iluman Relations Area Files, 1956), p. 251; Ministry of Planning. Surrey of Progress 19n/.6? (Kabul: Ministry of Planning. 1963), p. 25: Ministry of Plaming. Survey "P Pruseress 1971-1972 (Kabul: Ministry of Planning. Mig72) (Kabul: Ministry of Platining. 1,351), lathles 54 and 55, pp. 104-105; and Ministry of Planning

Telephones and Letters -Minisiry of Plamming. Survey of Progress 1960 (Kahul: Ministry of Plamning. 19(x)), pn. 132, 1.14 and 136; Ministry of Planning, Survey of Progress 1961.62 (Kubul: Ministry of 1'tanning. 1963), pp. 21-22; Ministry of Platuning. Surver of l'aceress 1962-04 (Kabul: Mluistry of Planning, 1964), Table A-37, p. 141

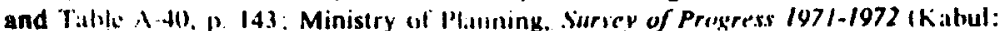
Minisery of Planneng, 19721, Tables $\mathrm{S}-11$ and $\mathrm{S} .44$; and Ministry of Planning.

A number of indicators call be used lo provide some information on changes which have occurred in Alghanistan over the past forty years. However, given that most of them start at negligible levels, rapid-growth does nut necessarily stiggest significant impact on the bulk of the popula- 
tion. Educational statistics, for example, indicate rapid drvelopment. as can be seen in Table 2.2. Nevertheless, the literacy ratc was estimated at only 8 per cent of the population in 1347 (1968) (M5, Table V-I. p. 104].

In the field of health and medicine, changes have also taken place. Figures in Table 2.2 show rapid expansion but again still left much roum for further advances by 1351 (1972), as illustrated for example in the high patient/doctor ratio, whatever population estimate is used. However. in public health, effects have been more wide-reaching with the climiniltion of cholera, malaria and smallpox epidemics.

Pransport and conımunications have shown similar rapml expansion as is shown in Titble 2.3. Again, the numbers of teleplunics and letters

Tahle' 2.4

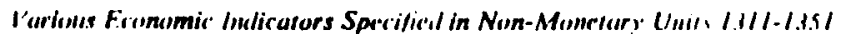

\begin{tabular}{|c|c|c|c|c|c|c|}
\hline lank & $\begin{array}{l}\text { Comcen' } \\
\text { (Thousunds } \\
\text { of Touns) }\end{array}$ & $\begin{array}{c}\text { Electricity } \\
\text { (Millions } \\
\text { of Kilowall } \\
\text { Hours) }\end{array}$ & $\begin{array}{l}\text { Cioul } \\
\text { (Thousunds } \\
\text { of Toons) }\end{array}$ & $\begin{array}{c}\text { Gas } \\
\text { (Millions } \\
\text { of (inbic } \\
\text { Metrex) }\end{array}$ & $\begin{array}{c}\text { Wheut } \\
\text { (7housumels } \\
\text { of limes) }\end{array}$ & $\begin{array}{l}\text { Aarah ul } \\
\text { Export.s } \\
\text { (Ihousamels } \\
\text { (f) Skin.) }\end{array}$ \\
\hline 1311 & 0 & & & 0 & & 906 \\
\hline 1315 & 0 & & & 0 & & 1,715 \\
\hline 1.320 & 0 & 6 & & 0 & & 1.834 \\
\hline 1325 & 0 & 7 & & 0 & & 1,537 \\
\hline 1330 & 0 & 9 & 14 & 0 & & 1,423 \\
\hline 1335 & 0 & 36 & 29 & 0 & 2,2100 & 1,874 \\
\hline 1.740 & 41 & 126 & 69 & 0 & 2.274 & 2,089 \\
\hline 1345 & 177 & .302 & 162 & 0 & $2,0.13$ & 1.373 \\
\hline 1.151 & 91 & 487 & 71 & 2.849 & 2.401 & 1,313 \\
\hline
\end{tabular}

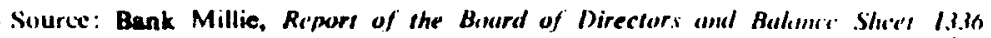
(Kabul: Bank Millic, mimeo, 1337), p. 19; Da Afghanisfan Breshna Mfuas sessu (Kabul: National Defence Press, Sunbula 1349); A. Guha, "The Economy of Afghanistan during A manullah's Reign, 1919-1929," Journal of Internutional Studics, 9 (2). Octoher 1473) 473). m. 34: Ministry of Commerce, A/ghanisfon's Fureign Truht. M.1.15 through 1.142 (K.ahul: Ministry of Commerce, mimeo, 1343), Tahle V. p. 26: Ministry of Commerce. A Sunimary of A/ghanissan's Fureign Trade from 134.3 "1.348 (Kabul: Ministrs of Commerce, mimeo, Qzus (350); Ministry of Planning. Survey of Progress 1960 (Kabul: Ministry of Planning, 1960), Table Agriculture (1); Ministry of Planning. Survev uf Protress 1061-62 (Kabul: Ministry of Planning 1963). Tulle Agriculure 11: Ministry of Prom

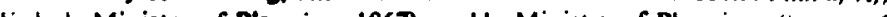
Kabul: Miniatry of Planning. 1967), p. 11; Ministry of Planning. Siuriey" of Progress 1469-1470) (Kabul: Ministry of Planning, 1970), Tables S-22 and S-24; F. Rhein and

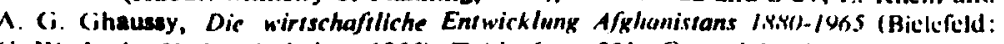
( $\therefore$ W. Leske Verlag Opladen, 1966), Table 6, p. 201; Central Stativics Onlice and Ministries of Commerce and Planning. deliverid were not high in 1351 (1972), despite the rapid increase over the period. Transport developments, on the other hand, have had a significant effect on the inajority of the population. Because transport developments may well hive been the most impurtant single factor causing change for both gind and ill in Afghanistan iver the past four decades, it is taken up again in more detail in the following chapter.

Oblice s.utistics used to compare living standards between countries or wer time include cement and curil p.oduction, electricity and steel consumption, and cultivated lind, protein and calories per capita. Datta aval.thile on some of these indicitors are provided in Table 2.4. Apart from ditlicultural statistics, mignitudes for 1351 (1972) are still so small

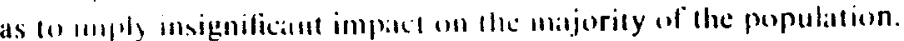

\section{B. Pinc findices}

Before turning (1) indicatoms given in value terns, the lirst problem which must be eximmed is that of meisuring price changes which hate occurred over the peried. Even the wllicial price index for the pist decide is pour. It was the first tash of the Central Statistics Ollice (CSO). establishlicd in 1351 (1972), to prepare a new price index. Hansen and Tourk have also constructed an allernative price index for the 1.340\% $(19(1)$ ) beciluse they found the ollicial index misleading [H2, Table 1-10, p. $|t|$. Given that indicators in vallue terins allow relatively short run comparisons and provide clues to cyclical movements, some attempt at producing a price index for the purpose of deflating vilue figures 10 : constint price batse in necessitry. The price of wheat, the consumer price index and the tlansen-Tourk index firr the 1340s (1960) are presented in Table 2.5. The consumer price index is a cimposite spliced together from live dillerent series used in Willor [W., p. 197], the Tudor Report [T6, p. 157] and Surveys of Progress [M19; M22; M27; M28: M29; M30] and a revised series for the last three years produced by the Central Statistics ontlice as one of its first publicitions [C7]. Its accuracy hats been improved since 1340 (1961) but the revisions for the last three years by the (entral Statistics Oflice suggest that even the data for the 1340) (196(1)) are rough.

Taking the criticisms of the ollicial index, which centre around the over-weight given to food items (llie Hatnsen-Tourk index simply uses different weights un lle sanke price ditta used for the ollicial index), and the impossibility of using wheat pricess as a general deflator on a year-toyear havis, the alternatives appear to be either a backward extension of the ( $\mathrm{SO}$ or the Hansell-Tourk index or a new approach. As price data do 
Tuble 2.5

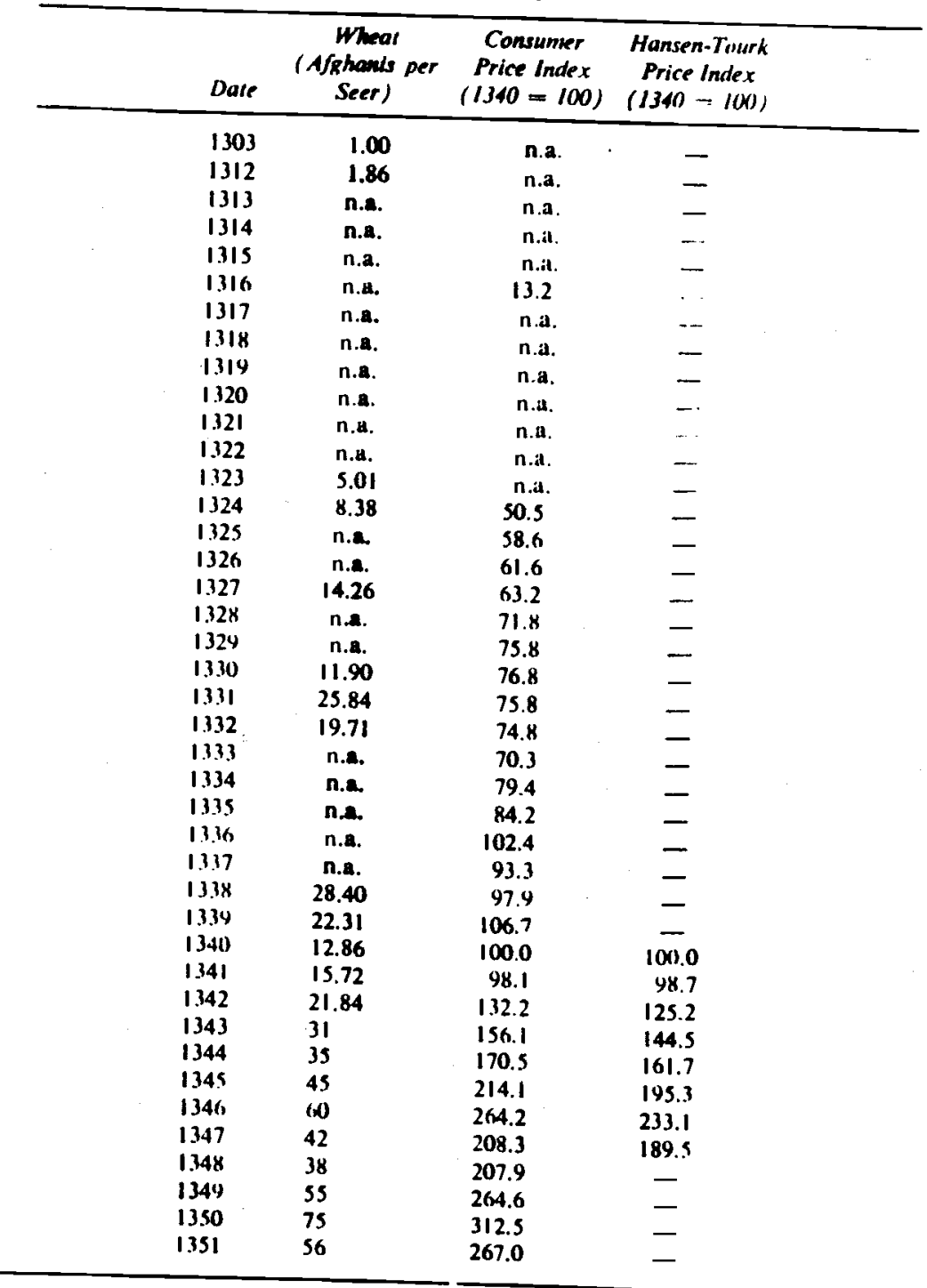

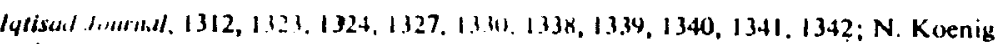

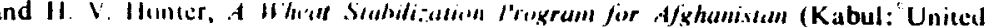

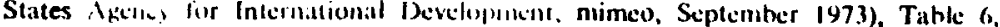
p. 26.

Consumer Pilce Index 1316 from D). N. Willer, (Ed.). Afghanistan (New Haven Hunan Relations Area lailes, 1\$56), p. 197: 1323.1328 from Tudor Engincering

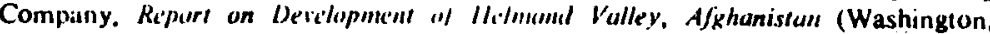
D.C.: Fudor Engineering (ompany. Novemixr 1456). p. 157; 1329-1335 from Ministry of Planning, Survey of Progress 19.5\% (Kiabul: Ministry of Planning. 1958), Volume I, Table 4. p. 5 of Money Section (['al1 III); 1332-1340 from Ministry of Planniny Surve' i/ Progeress 196/-h2 (Kabul: Minisiris of Planning. 1963). Table 9, p. 78: 1340

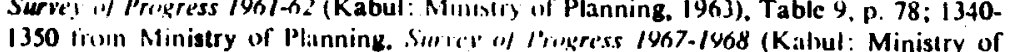

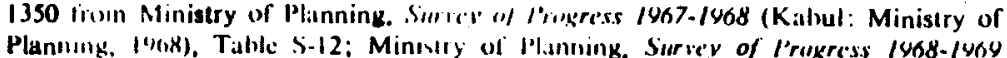
(Kabul: Monistry af Plauning 196\%) Lable S-13: Minisery of Planning Survey of

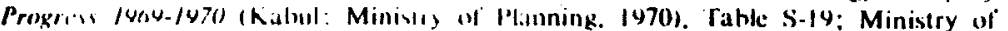

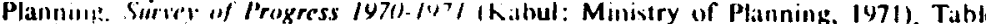

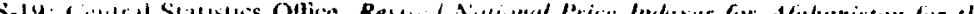

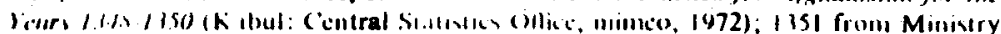
of Plamolint.

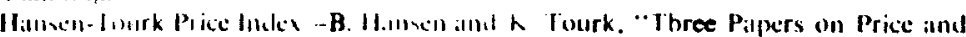

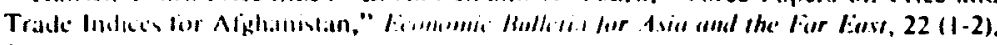
Juate Sifleminer 1971, fable 1-11, D. I6.

not exint fo enable the former allermative to be wied, a llew approach, nancly the combruclion of a purdatsing power parity price index. has been intopled.

Recint work by Gilliot [Cil] shows that over relatively long periods the purchassing power parity theory is valid even under fixed exchange ritte systems. Using it. the following relationship is found

$$
\text { (Relative inflation in Alghanistan). } \begin{aligned}
& E R^{0}{ }_{A t s / s} \\
& E R^{t}-1
\end{aligned}
$$

where $1: R_{A f s}$ is the exchange rate in Afghanis (the monetary unit in Afglumistan) per (Inited Stites Dollar. The superscripts denote the base yeur " $0 "$ and the current year ". $"$ ". The relative inflation in Afghanislan is meatsured by

$$
\begin{gathered}
\text { WPI', WPI } \\
\text { WPI! } \\
\text { WPIOA }
\end{gathered}
$$

where WPI is the wholesale price index. Taking WPIO, -- 100, it is possible to express the remaining unhnown variable, $W P{ }_{A}$, as follows

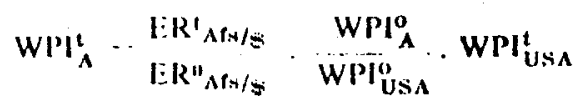


Table 2.5

Price Indicators, 1303, 1312-1351

\begin{tabular}{|c|c|c|c|}
\hline Date & $\begin{array}{c}\text { Whear } \\
\text { (Afgheols per } \\
\text { Seer) }\end{array}$ & $\begin{array}{c}\text { Consumer } \\
\text { Price Index } \\
(1340=100)\end{array}$ & $\begin{array}{c}\text { Hansen-Tourk } \\
\text { Price Index } \\
(13 \$ 0=100)\end{array}$ \\
\hline 1303 & 1.00 & n.a. & $\rightarrow$ \\
\hline 1312 & 1.86 & n.a. & - \\
\hline 1313 & n.a. & n.a. & - \\
\hline 1314 & n.a. & $\mathbf{n} . \mathbf{a}$. & - \\
\hline 1315 & n.a. & n.a. & - \\
\hline 1316 & n.a. & 13.2 & $\cdots$ \\
\hline 1317 & n.a. & n.a. & - \\
\hline 1318 & n.a. & n.a. & - \\
\hline 1319 & n.a. & n.a. & - \\
\hline 1320 & n.a. & n.a. & - \\
\hline 1321 & n.a. & n.a. & - \\
\hline 1322 & n.a. & n.a. & - \\
\hline 1.323 & 5.01 & n.a. & - \\
\hline 1324 & 8.38 & so.s & - \\
\hline 1325 & n.a. & 58.6 & - \\
\hline 1326 & n.a. & 61.6 & - \\
\hline 1327 & 14.26 & 63.2 & - \\
\hline 1328 & nas. & 71.8 & - \\
\hline 1329 & n.a. & 75.8 & - \\
\hline 13.30 & 11.90 & 76.8 & - \\
\hline 1331 & 25.84 & 75.8 & - \\
\hline 1332 & 19.71 & 74.8 & - \\
\hline 1333 & n.m. & 70.3 & - \\
\hline 1334 & $n=$ & 79.4 & - \\
\hline 1.335 & nas. & 84.2 & - \\
\hline 13.36 & n.a. & 102.4 & - \\
\hline 1337 & n.a. & 93.3 & - \\
\hline 1338 & 28.40 & 97.9 & - \\
\hline 13.39 & 22.31 & 106.7 & - \\
\hline 1340 & 12.86 & 100.0 & 100.0 \\
\hline 1341 & 15.72 & 98.1 & 98.7 \\
\hline 1342 & 21.84 & 132.2 & 125.2 \\
\hline 1343 & 31 & 156.1 & 144.5 \\
\hline 1344 & 35 & 170.5 & 161.7 \\
\hline 1345 & 45 & 214.1 & 195.3 \\
\hline 1346 & 10 & 264.2 & 233.1 \\
\hline 1347 & 42 & 208.3 & 189.5 \\
\hline 1348 & 38 & 207.9 & - \\
\hline 1349 & 35 & 264.6 & - \\
\hline 1350 & 75 & 312,3 & - \\
\hline 1351 & 56 & 267.0 & - \\
\hline
\end{tabular}

Note: Simple averages of all wheat prices recorded during the year have then calculated.

Source: Wheal prices-A. Guhn, "The Economy of Afghanistan during Amanullah's

Reign. 1919-1929," Journat of Internoniumal Studies, 9 (2), October 1967, p. 167;

I4tisuil.Jurrt.al, 1312, 1323, 1324, 1327, 13311. 1338, 1339, 1340, 1341, 1342; N. Koenig and H. V. Humter, $A$ Wheut Siahilization I'regram for Afikhanistun (Kabul: United States Agchly for International Develonment, mimeo, September 1973), Table 6, p. 26

Consumer Price Index - 1316 from D. N. Wilher, (Ed.), Afghanistan (New Haven: Human Relutions Area Files, 1956), p. 197; 1323-1328 from Tudor Engineering Company, Repurt on Development of H/s/mant Valley, "Afghanisfan (Washington, D.C.: Tudor Engineering Company. Noveruther 1956), p. 157; 1329-1 335 from Ministry of Planning, Survey of Progress 1958 (Katul: Ministry of Planning. 1958), Volume I. Table 4, p. 5 of Money Soction (1'all III); 1332-1340 from Ministry of Planning. Survey "f Prugress 1961-62 (Kabul: Ministiy of Planning, 1963). Table 9, p. 78: 1340 1350 from Miniatry of Planning, Siu'vey of l'rupress 1967-1968 (Kabul: Ministry of Plannmg. 1968). Table s-12; Ministry of l'tanning. Surrey of P'rogress 1968-1965 (Kahul: Ministry of Planning, 1964). Tathle S-13: Ministry of Planning, Survey sof Progeres 1964-1970) (Kahul: Ministrs of Pllonning. 1970). Table S-19: Ministry of Plannonk, Survey of Progress 197(1)-107/ (kathul: Ministry of Planning. 1971), Table

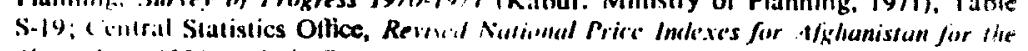
liours 1.1.'i-1.150 (K:Ibul: Central Si.tliwics (Mlice, nimeo, 1972); 1.151 from Ministry of Planning.

Hanxill-fisurk Price Index-B. llathen and h Tourk. "Three Papers on Price and

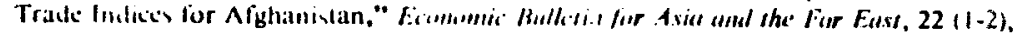
June, Sinfeinler 1971, Iithle 1-10, b. 16.

not exint (1) enable the former alternative to he used, a new approach, nanuly the construction of a purclatsing power parity price index, has been idopted.

Recent work by Galliot [G]] shows that over relatively long periods the purchasing power parity theory is valid even under fixed exchange rate systems. Using it, the following relationship is found

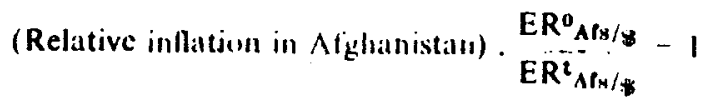

where $I: R_{A f H / S}$ is the exchange late in Afghanis (the monetary unit in Alghmistan) per United States Dollar. The superscripts denote the baise year " 0 " and the current year " $t$ ". The relative inflation in Afghanislan is meitsured by

$$
\underset{\text { WPI ISA }}{\text { WIA }} \underset{\text { WPIOAA }}{\text { WPIOA }}
$$

where WPl is the wholesale price index. Taking WPI $_{\Lambda}^{0}=100$, it is possible to express the remaining unh nown variable. WPIt, as follows

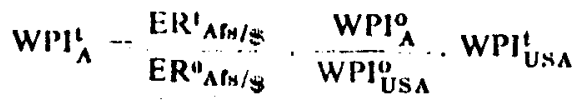


Table 2.6

Exchange Raves, U.S. Wholesale Price Index and Purchusing Power Partily Price Index 1310-135I

\begin{tabular}{|c|c|c|c|c|}
\hline & Date & $\begin{array}{c}\text { Afghand/Dollar } \\
\text { Exctiange } \\
\text { Rate }\end{array}$ & $\begin{array}{l}\text { U.S. Wholesale } \\
\text { Price Index }\end{array}$ & $\begin{array}{l}\text { Purchasing } \\
\text { Power Purity } \\
\text { Price Index }\end{array}$ \\
\hline & 1310 & 9.92 & 39.79 & 9.1 \\
\hline & 1311 & 12.06 & 35.34 & 9.8 \\
\hline & 1312 & 9.42 & 35.93 & $7 . x$ \\
\hline & 1313 & 10.04 & 40.88 & 9.4 \\
\hline & 1314 & 9.99 & 43.63 & 10.0 \\
\hline & 1315 & 9.73 & 44.07 & 9.9 \\
\hline & 1316 & 9.72 & 47,09 & 10.5 \\
\hline & 1317 & 11.24 & 42.89 & 11.1 \\
\hline & 1318 & 12.02 & 42.05 & 11.6 \\
\hline & 1319 & 13.05 & 42.89 & 12.9 \\
\hline & 1320 & 13.05 & 47.68 & 14.3 \\
\hline & 1321 & 13.05 & 53.89 & 16.2 \\
\hline & 1322 & 13.05 & 56.24 & 16.9 \\
\hline & 1323 & 13.05 & 56.74 & 17.0 \\
\hline & 1324 & 13.05 & 57.75 & 17.3 \\
\hline & 1325 & 13.7 & 66.06 & 20.8 \\
\hline & 1326 & 17.2 & 80.92 & 32.0 \\
\hline & 1327 & 27.0 & 87.6 & 54.4 \\
\hline & 1328 & 33.0 & 8.3 & 63.2 \\
\hline & 1324 & 39.0 & 86.5 & 77.6 \\
\hline & 1330 & 35.0 & 96.4 & 77.6 \\
\hline & 1331 & 37.0 & 93.7 & 79.7 \\
\hline & 1332 & 37.1 & 92.4 & 78.8 \\
\hline & 1333 & 42.1 & 92.6 & 89.6 \\
\hline & 1334 & 45.2 & 92.9 & 96.5 \\
\hline & 1335 & 53.8 & 95.9 & 118.6 \\
\hline & 1336 & 54.1 & 98.7 & 122.8 \\
\hline & 1337 & 54.7 & 100.1 & 125.4 \\
\hline & 1338 & 46.6 & 100.3 & 107.4 \\
\hline & 1339 & 40.8 & 100.4 & 94.2 \\
\hline & 1340 & 43.5 & 100.0 & 100.0 \\
\hline & 1341 & 52.8 & 100.3 & 121.7 \\
\hline & 1342 & 51.3 & 100.0 & 117.9 \\
\hline & 1343 & 63.6 & 100.2 & 146.5 \\
\hline & 1344 & 75.3 & 102.2 & 176.4 \\
\hline & 1345 & 76.4 & 105.6 & 185.5 \\
\hline & 1346 & 76.4 & 105.8 & 185.8 \\
\hline & 1347 & 74.8 & 108.4 & 186.4 \\
\hline & 1348 & 75.4 & 112.7 & 195.3 \\
\hline & 1349 & 84.8 & 116.8 & 227.7 \\
\hline & $\begin{array}{l}1350 \\
1351\end{array}$ & $\begin{array}{l}84.6 \\
79.4\end{array}$ & $\begin{array}{l}120.6 \\
126.0\end{array}$ & $\begin{array}{l}234.5 \\
230.0\end{array}$ \\
\hline \multicolumn{2}{|c|}{$\begin{array}{l}\text { Average Annual } \\
\text { Purcentage Increase }\end{array}$} & 5.20 & 2.85 & 8.20 \\
\hline
\end{tabular}

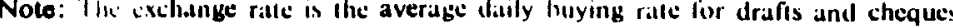

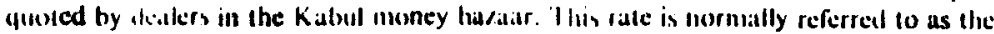
bacalar ralc.

Source: Alghiani/Dollar Exchange Kate -..1310-1.324 from /4tisckl Journal, 1310-1324; 1124-1327 from A. 11. Kayoumy. "Momopoly l'ricing of Afghan Karakul in Inter-

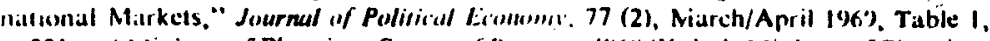

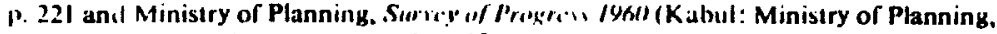
19(x)), p. IRt; 1328 is the arerilge of the 1327 and 1.329 lales; 1324-1351 from Research Departnxul, Da Afglanistan Bjank.

United Stalles Wholesale Price Index thmled Staks Hurcau of the Census, Historical Statistics of in' United States, Cultumiol time's "1" 1957 (Washington, D.C.: United

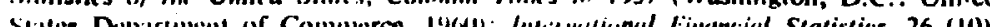

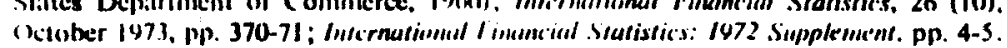

The United States wholesale price index and the free market Afghani/ Dollar exchange rate are conbined in this way to produce a purchasing power parity price index for Alghanistan which is given in Table 2.6.

The purcllasing power parity price index can give an indication of short run price movements in a country such as Alghanistan whose exchange rate floalls. However, the disruplion to international trade caused by the Second World War reduces the reliathility of the index during the 1320s (1940s) I. the point where an alternative hats to be used. Scattered information oll consumer prices which hass bicll used for the consumer price index in Table 2.5 does exist. If the purclasing power parity index for the period $1321-1328$ (1942-1949) hats been distorted by wartime disruptions, an alternative can be provided in the following manner. $1 \mathrm{t}$ is assumed that the price level did increatse from 13.2 in 1.316 (1937) to 79.4 in 1334 (1955) as in Table 2.5. The price increase given by the consumer price index in 'Table 2.5 between 1316 (1937) and 1324 (1945) is 283 per cent. The purchasing power parity price index consistent with this increase is 39.66 for 1324 (1945). Assuming prices ruse by equal percentage steps over the period 1321-1324 (1942-1945), the intermediale figures can be calculated. This gives annual percentage price increases of 29.05 per cent. From 1325-1328 (1946-1949) price increases are issumed to have taken place in proportiun to those of the consumer price index recorded in Table 2.5 . However, the total rise in prices between 1324 (1945) and 1329 (1950) using the revised purchasing power parity index is 95.54 per cent compared to 50 per cint shown in Table 2.5. Thus, each annual price increase shown in this table is appropriately inflated 1 , whtain the 95.54 per cent price rise over the entire period. In this manner, the moditied purchasing power parity price index which is used herealicr hals heen constructed and is presented in its entirety in Table 2.7. 
Table 2.7

Mfoclified Purchasing Powier Parity Price Imdex 1310-1.151 (Base $1340=100)$

\begin{tabular}{|c|c|c|c|}
\hline Dare & Index & Dare & Inclex \\
\hline 1310 & 9.1 & 1333 & 89.6 \\
\hline 1311 & 9.8 & 1334 & 96.5 \\
\hline 1312 & 7.8 & 1335 & 118.6 \\
\hline 313 & 9.4 & 1336 & 122.8 \\
\hline 1314 & 10.0 & 13.17 & 125.4 \\
\hline 1315 & 9.9 & 1338 & 107.4 \\
\hline 1316 & 10.5 & $1.3,39$ & 14.2 \\
\hline 1317 & 11.1 & 1.140 & I(x).0 \\
\hline 1318 & 11.6 & 1341 & 121.7 \\
\hline 1319 & 12.9 & 1342 & 117.9 \\
\hline 1320 & 14.3 & 1343 & 1.46 .5 \\
\hline 1321 & 18.5 & 1344 & 176.9 \\
\hline 1322 & 23.8 & 1345 & $1 \times 5.5$ \\
\hline 1323 & 30.7 & 1346 & $1 \times 5.8$ \\
\hline 1324 & 39.7 & 1347 & 186.4 \\
\hline 1325 & $5 t .8$ & 1348 & 195.3 \\
\hline 1326 & 56.3 & 1349 & 227.7 \\
\hline 1327 & 58.6 & 1350 & $\therefore 4.5$ \\
\hline 1328 & 71.5 & 1351 & 230.0 \\
\hline 1329 & 77.6 & $\cdot$ & \\
\hline 1330 & 77.6 & Average Annuil & \\
\hline 1331 & 79.7 & Percentage & \\
\hline 1332 & 78.8 & Increase & 820 \\
\hline
\end{tabular}

Nolc: Figures for $1321-1328$ derived as described in the text.

Source: Same as Tables 2.5 and 2.6 .

Thic exchange rate data are accurate for the period $|329-135|$ (19501972). the figures given being the averages of buying rates for dralts and cheques collected daily by Da Afghanistan Bank from Seray Shorda, the Kabul money bizaar. The data for 1310-1328 (1931-1949) are probably not as accurate as those for the later years. Furthermore, controls instituled by Bank Millie in 1315 (1936) and the disruptions created by the Second World War throw serious doubts on the utility of the index in this period for short run purposes. A few checks, however, can be made on the reliability of the index over the long run. The first springs from the fact that in 1310 (1931) the currency in Afghanistan was silver. A Lonparison can, therefore, be made between an exchange rate based on world silver prices combined with the silver content of the currency, on the one hand, and the recorded exchange rate, on the other. Assuming one silver Kabuli contained nine grams of silver in 1303 and 1304 (1924 and 1925) and thereafter one silver Afghani also contained nine grams, notwithstanding the official conversion of 11 Kabulis to 10 Afghanis, implicit exchange rates can be culculated using silver prices quoted on the Nex. York Bullion Market [A21, Chart 77]. Two year moving average prices have been used, e.g. for the 1310 (i9.31) exchange rate the average silve: price in New York for 1930 and 1931 is adopted. The results are presented in Tible 2.8 .

$$
7(1) / 4 \cdot 2.8
$$

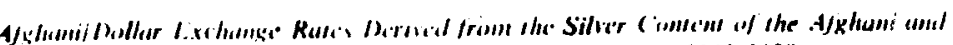

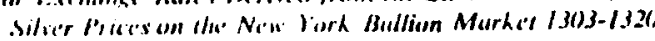

\begin{tabular}{|c|c|c|c|}
\hline surt. & $\begin{array}{c}\text { A/shoni/Do/lur } \\
\text { lixchange } \\
\text { Rate }\end{array}$ & Dute & $\begin{array}{c}\text { Ajikhuni/Du/hur } \\
\text { Exchastgc } \\
\text { Rate }\end{array}$ \\
\hline 1.303 & 4.73 & 1312 & 11.04 \\
\hline 1,3114 & 4.56 & 1313 & 8.36 \\
\hline 1305 & 5.25 & 1314 & 6.16 \\
\hline 1306 & 5.83 & 1319 & 6.32 \\
\hline 1307 & 6.03 & 1316 & 7.68 \\
\hline 1308 & 6.22 & 1317 & 7.85 \\
\hline 1309 & 7.58 & $131 \%$ & 8.40 \\
\hline 1310 & 10.34 & 1319 & 9.36 \\
\hline 1311 & 12.21 & 1320 & 9.94 \\
\hline
\end{tabular}

Note: Exchinge rates calculated by methud described in the text.

Notc: Exchinge rales calculated by method described in 1976 (Sill) Francisco: American Internaticnal Invesinient Corporation, 1970; Chart 77.

Fur the years 1304-1312(1925-1933) the implicit exchange rates appear reilivic, with the rates for $1310-1312(1931-1933)$ very close to the recorded rates shown in Table 2.6. The fall in the implicit exchange rate after 1311 (19.32) resulting from the upturn in world silver prices was no: in fitct. reflected by a significant downturn in the recorded exchange rate for the simple reason that debasement of the currency occurred continuously from the introduction of the Arghani in 1305 (1926) [B29, p. 433; G22, p. 173].

The second check on the purchasing power parity price index for long run trends lies in a comparison with other prices and price indices. The consumer price index produces roughly the same picture as the index in Table 2.7. The wheat price data given in Table 2.5 also follow the same broid trends as the modified purchasing power parity price index. Furthermore, the change in buth price indices, 2,911 per cent for wheat 
Table 2.9

Eronomic Indiculors Specified in Monetary Unifr 1.311-1351 (Millions of Afyhanis)

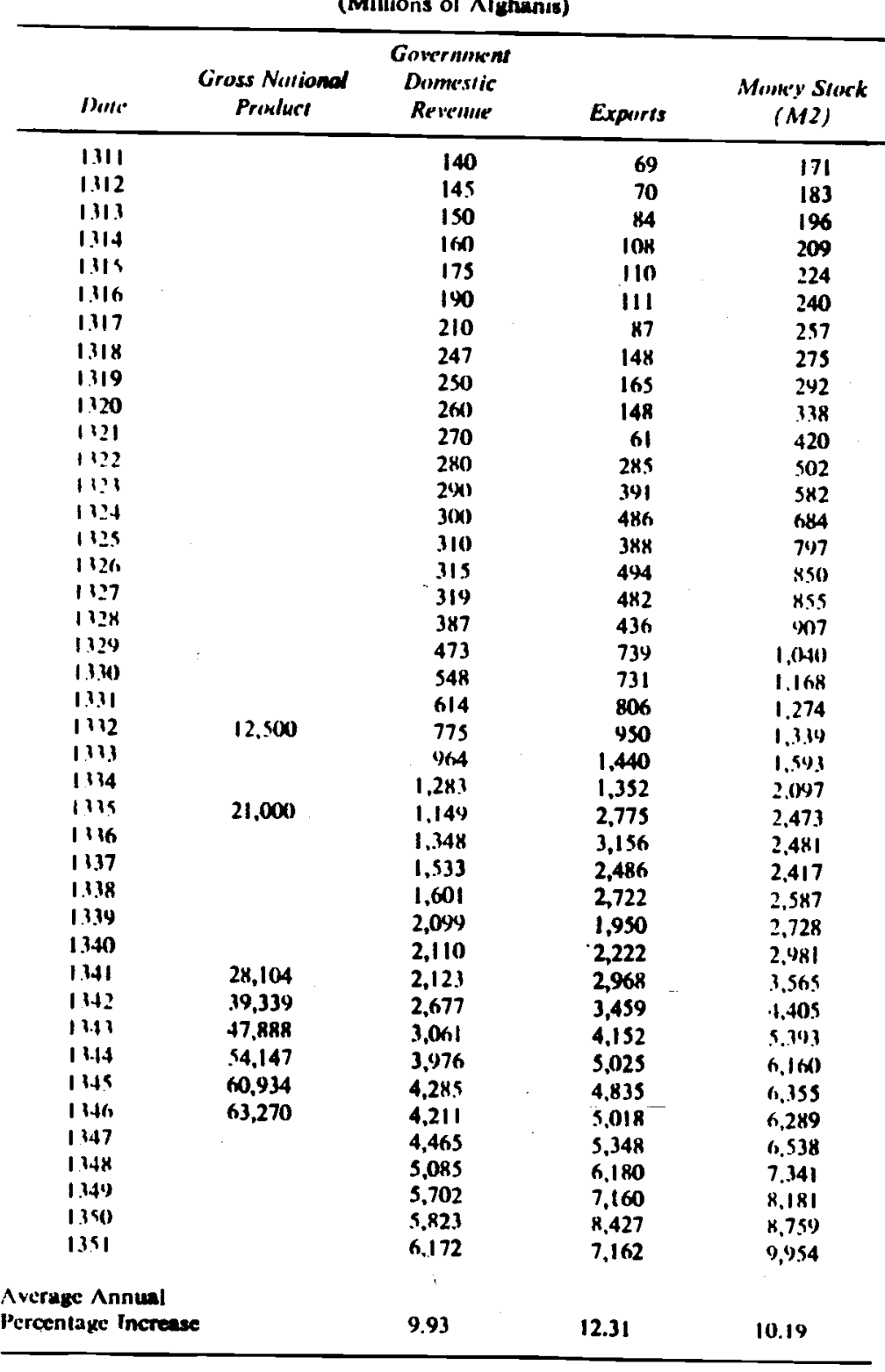

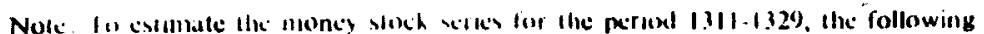
aenumpuous hate been miade: 1) Ais 16,5 million in specic was in circulation at the end of $1310(1932) ; 2)$ The money stexih incivitsed steudily leitween 1310 (1932) and $1319(1 \%+1)$. (13y 1315 (1936) it comistel of specic, banknotes and bank deposits): 3) A cillstitnt currency/money ratio of $0 . k$ wiss maintained between the end of 1319 (1941) and 1.329 (1951). (Currency notes in circulation have heen recorded since 13 !5 (14371). 1) All specie was withdrawn by 1318 (1940). The moncy stock data are the averats of tresinning and end of year tigures thus providing a mid-year estimale.

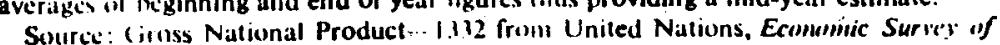
Sourcic: Cimss National Product...11.12 from United Nations, Ecomemic Survey if

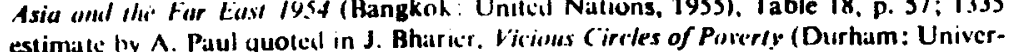
estimate by $A$. Paul quoted in J. Bharicr. Vicions (irrles of Poverly (Durham: University of Durham, 1 Repartment of Fconomlics, 15 pescript. 1972). Table

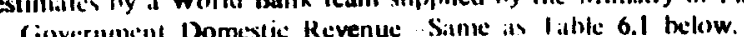

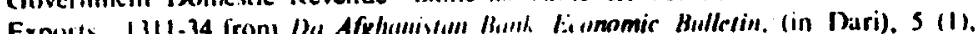
August 1\%1. Table 18: 1335-42 from Mlinstly of Comnerce. A/ghumistumis Forreign

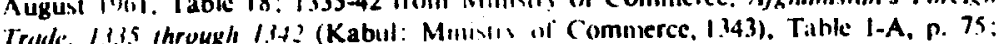

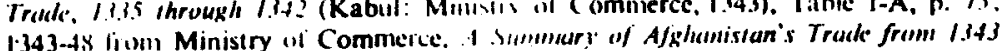
1.343-4s fiom Ministry of Commerce. I Stemmury of Afghmistan s Trade from 1.143

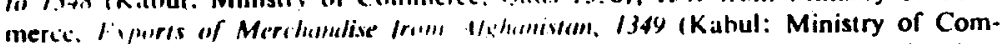

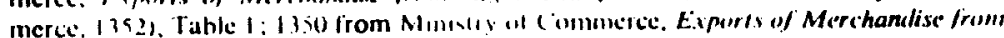

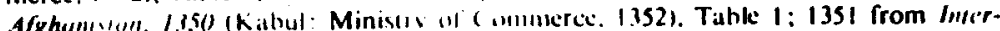

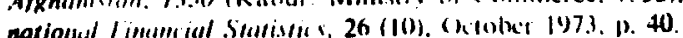

Money Siock (M?) 1315.18 from A1 II. K. Zia, "lrom Brokerage to National

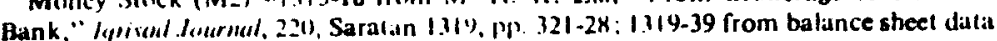

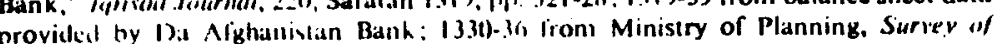
Progrin 1058 ikithul: Atinistry of Plannioge. 1958), Volume II. Tahle Money 7-30: Ministey of Planning. Surreg of Proxerss 19.59 (Kabul: Ministry of Planning. 1959), Volumk IV 7able 47, p. I 86; Ministry of Planming, Survey of Progress 1962-64 (Kabul:

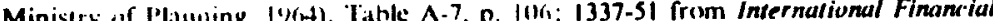

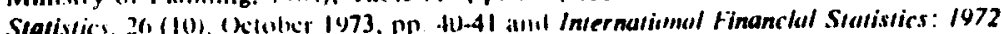
Supplicmetil, pr. 22x-29.

and 2.54 per cent for the muditicd purchasing power parity price index hetwich $1312(1933)$ and 1351 (1972) is virtually identical.

Wage rates also provide sume indication of the long run movement in prices. In 1311 (1932), the British Legation paid between Afs 30 and Afs 45 per month "1" "Afghan inleriur servants" [B33, Standing Order No. 1.11 In 1334 (1955) domevic servants received about Afs 600 per momh |P15, p. 41 ; W3, p. 2071. In 1351 (1972), wages for the silme type of employment were around $A l$ s $1 . K(K)$ per month. The rise in wages of 1,23.3 1 , 1.90) per cent between 1311 (19.32) and 1.334 (1955) can be compared wilh a rise in prices of 885 per cont, the rise of 200 per cent between $1334(1955)$ and 1351 (1972) with the 138 per cent increase in prices. Thus, real wages over the furty years have increased by between 70 and 156 per cent "Ir. .3 to 2.4 per cent annuilly, ligures which appear reasonable in their awn right and eonsistent with the rate of growth in the Gross National Product estinated bclow. 
Table 2.10

Iicomumuic Indicutors Spectind in Monetary Units at Constumt Price. 1311-135 (Millions of Afghanis, 1340 Prices)

\begin{tabular}{|c|c|c|c|c|}
\hline Date & $\begin{array}{l}\text { Gross Nartional } \\
\text { Product }\end{array}$ & $\begin{array}{c}\text { Government } \\
\text { Domestic Revenue }\end{array}$ & Exporis & $\begin{array}{l}\text { Money Sturk } \\
\text { (M2) }\end{array}$ \\
\hline 1311 & & 1.428 & 704 & 1,745 \\
\hline 1312 & & 1,859 & 897 & 2,346 \\
\hline 1313 & & 1.596 & 894 & $2,0 \times 5$ \\
\hline 1314 & & 1.600 & 1.080 & $2,0 \% 0$ \\
\hline 1.315 & & 1.768 & 1.111 & 2.26 .3 \\
\hline $1.11 \mathrm{~h}$ & & 1.810 & 1,057 & 2.286 \\
\hline 1317 & & 1,892 & 784 & 2.315 \\
\hline 1.318 & & 2.129 & 1,276 & 2.371 \\
\hline 1319 & & 1.938 & 1.279 & 2.264 \\
\hline 1.320 & & 1.818 & 1,035 & 2.364 \\
\hline 1321 & & 1,459 & 330 & 2.270 \\
\hline 1,32 & & 1,176 & 1.197 & 2.109 \\
\hline 132. & & 945 & 1.274 & 1.896 \\
\hline 1.324 & & 756 & 1,224 & 1,723 \\
\hline 1325 & & 598 & 749 & 1,539 \\
\hline 1326 & & $S(x)$ & 877 & 1.510 \\
\hline 1.127 & & 544 & 823 & 1.459 \\
\hline 1328 & & 541 & 610 & 1.269 \\
\hline 1.329 & & 610 & 952 & 1.340 \\
\hline 13.10 & & 706 & 942 & 1.505 \\
\hline 1331 & & 770 & 1,011 & $1,59 \mathrm{~B}$ \\
\hline 1332 & 15,863 & 983 & 1,206 & 1.694 \\
\hline 1.3 .33 & & 1.076 & 1,607 & 1.778 \\
\hline 1.174 & & 1.330 & 1.401 & 2.173 \\
\hline 1335 & 17,707 & 969 & 2.340 & $2.0 \times 5$ \\
\hline 1136 & & 1,098 & 2,570 & 2.020 \\
\hline 1337 & & 1,218 & 1,975 & 1.920 \\
\hline 1138 & & 1.491 & 2.534 & $2.4(Y)$ \\
\hline 1339 & & 2.228 & 2,070 & 2,896 \\
\hline 1.240 & & 2,110 & 2.222 & 2.981 \\
\hline 1341 & 23,093 & 1,744 & 2,439 & 2,929 \\
\hline 1342 & 33,366 & 2,270 & 2,934 & 3,736 \\
\hline 1.41 & $32,68 \mathrm{~K}$ & 2,089 & 2,834 & 3,681 \\
\hline 1344 & 30,604 & 2,248 & 2,841 & $3,4 \times 2$ \\
\hline 1.345 & 32,849 & 2,310 & 2,606 & 3,426 \\
\hline 1.346 & 34,053 & 2.266 & 2,701 & 3,385 \\
\hline 1.347 & 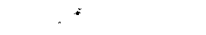 & 2,395 & 2,869 & 3,508 \\
\hline 1348 & & 2,604 & 3,164 & 3,759 \\
\hline 18.19 & & 2.504 & 3,144 & 3,593 \\
\hline 1350 & & 2.483 & 3,594 & 3.735 \\
\hline 1.351 & & 2,683 & 3,114 & 4,328 \\
\hline \multicolumn{2}{|c|}{$\begin{array}{l}\text { Averagc Annual } \\
\text { Peroentage Increase }\end{array}$} & 1.59 & 3.79 & 1.83 \\
\hline
\end{tabular}

Sourte: Figurea in Table 2.9 have been deflated hy the modified nurchasing power parity price index in rable 2.7.
C. Molteliary Indicitors

Having constructed a price index, it is now possible to examinc if available economic statistics given in value terms and to deflate then for comparative purposes to a constant price base. The data now discussec include Gross National Product (GNP), Government revenue, exports and the money stock. Figures in current prices are presented in Table 2.9 and deflated by the modified purcluasing power parity price index in Table 2.10 .

The reliability of the datta is low. The (iNP estimates atre considered so inaccurate that they are no longer referred to in official publications. Government revenue figures are more aceurate for the last two decades than for the first two. In general. the public finance data logether with the exchange ralc and money stock figures are the only aggregate economic series unlihely to be misleading. lioreign trade statistics are known to seriously understate Afghanivian's lioreign trade. Throughout the period. smetggling has prohably accounted fir at least one-third of actual foreign tracte Obviously, no reliable information on the extent of smuggling avaltahle. Nevertheless, accounts lior the earlier years estimate smuggling at about ane-third, while for the later period a proportion of one-fifth hats been quuted [R'. p. 95:S13, pp. 328-29]. In Chapter VII it is suggested that the latter figure is an underestimate. Despite these drawbacks, the trend in the recorded foreign trade statistics probably gives an accurate indicition of overall trade movements. Considerable growth is recorde in ill deciades except the 1.22(3) (1941) . In the 1310s (1930s) the Govern nowl actively encouraged exports In shice of the seatistics clatly show a steady increase in kerill ceromising evports and imports. Giovernment lends a helping hund nicrchants and enterprisers by supplying them with large sums of money without interest. [A15, p. 220]

Such concouragement has nol taken place in the last two decades.

liintly, the moncy stoch series. defined to include private demand, atims and time deposits, are much less accurate for earlier years that for 111.1340 (1960) . The alvailability of any monetary statistics at all is in liage part due to issistance provided by the International Monetary Fund. A resident representative of the Fund hals worked in Da Afghanistan Bank, the central bank, for a number of years providing assistance or tan Batnk. The central bank, for a number of years providing assistanded a statistical as well as other matlers. lor a time, the Fund also provided a
statistician. Even now, however, inacicuracies exist. For example, deposits 
in the commercial banks' provincial branches are excluded irom money stock calculations. An improved series will be appearing soon. Despite these cureats, the fact that the main component of the moncy stock is currency in circulation, a relatively easy statistic to measurc, makes serious error unlikely. Thus, in order of reliability one might list exchange rate data first, followed by money stock and public finance figurcs. The foreign trade data consistently underestimate actual values and GNP estimates are of extremely doubtful utility.

The general picture presented by all the indicators so litr discussed is of one decade of rapid recovery and expansion, the 1330.s (1950)s, one of recession, the 1.320 s (1940s), and two of inoderate growth, the 1310 s (19.31)s and 1340s (1960s). Of interest in Table 2.10 is the litct that Government domestic revenue failed to increase as fast as the rcall values of exports and the money stock, primarily because of the mucli greater decrease in the real magnitude of the former during the 1320 s (1940s).

The disruption caused by the Second World War was considerable and

recovery slow. One contemporary report presents the following analysis:

The capital accumulation process, well launched by 1939, wils set back by the war and the attendant uncertainty in world markets, the cultingoff of capital equipment deliveries from Central Europe, and a severe husiness dislocation. Some shirkats fell apart, others became mere facades for proprietary business activities, promotion schemes, and outright profiteering. Government control over prices and essential supntics of food and cloth were not effective enough to curb black markets.

To halt the growing disintegration of the country's business organization and the ensuing inflation, Banke Millie curtailed business newcomers, induced traders with idle funds to invest them in sound nrojects, and assumed more control over the remaining shirkats through inojects, and and joint management boards. By the end of 1947 the new policy had largely succeeded, and today most industrial, utility and service enterprises, as well as the bulk of foreign trade, are again in the hands of wellorgillized shirkats. [FIS, p. 432]

The developments during the 1310s (1930s). mainly in the first hall' of the decade, were due to Nadir Shah's serious commitment to a rational programme of economic development. The latter was prepared by Abdul Majid Zabuli, the founder of the first bank, Bank Millic [B7]. Set against the backcloth of the Great Depression, developments in Afghanistan in the fields of education, health and industry were impress. ve during this decade [G15. Chapters 11 and 13]. Of significance is the fact that little external finance was solicited for them. The development progranmes of the post-war period, on the other hand, relied heavily on the inflow of forcign aid. Hefore discussing the development strategy, however, an altempt is made to construct an alternative GNP series.

iii. An Lssimate of Ciross National Proshuct

It is noteworthy that most economic reports on Afghanistan start with in analysis of public finance almost as if such analysis could stand in lieu of a study of developments in the economy as a whole. The explanation for this tendency to equate an analysis of public finance with a broader economic appraisal simply lies in the fact that data are easily avail:thle for the former but now for the latter. For certain economies. extrapolation from public sector developments to the economy as a whole for short run analysis may not lead to serious error, since movements in one sector are paralieled elsewhere. For the Afghan economy, this practice can and does mislead. Thus, the regressive changes in the fiscal incounts over the past ten years have led to the conclusion that the economy has been stagnant, while indicators from the private sector point to sone cionomic growth over the same decade. The figures in Tables 2.9 and 2.10 also support this.

There are two basic reasuns for the independence of movements in public linance from changes in uther sectors of the economy. The first is the fict that the Afghan economy is highly fragmented; few links exist betweell one sector and the other. The second is that the public sector is small in relation to any GNP estinates. Therefore, it is neither a strong leading seclor nor a large component in the total. Thus, extrapolation is inpussible.

Having suggested that the commonly adopted approach to aggregative unalysic of the Afghan economy is misteading. an alternative is now put forward, namely monetary estimales of GNP. Both Friedman and Duyitir have suggested and tested such a procedure with good results [F21; D8]. The theoretical underpinning behind this method lies in a simple economic model from which a reduced form equation relating GNP tw llic money stock and the expected rate of inflation can be derived. The fundamental empirical prerequisite is a stable functional relationship between these three variables or. looked at in a slightly different way, a stable velocity function.

In liact, Park finds higher coeflicients of variation for velocity in underdeviloped than in developed economies [P2]. However, Brunner and Meliser find that the quantity theory, based on the assump:ion of a stable velocity function, as a short run theory performs significantly 
better in econometric lests than any of the alternative hypotheses tested [B.36]. For an excellent discussion of alternative approitches to monetary model building, the interested reader is referred to Park's recent contribution [P3].

Velocity of circulation is customarily measured by dividing a country's GNP ty the money stock. The figure so obtained is designed to indicate how many times, on average, money circulates during the course of a year for the purchase of final goods and services, i.e. for those transactions constituting GNP.

In an economy like Afghanistan's, a large proportion of GNP consists of grods and services for which money transactions are not made, e.g. agrieultural products consumed by those who grow them. the value of owner nocupied housing. etc. Provided that the proportion of such items, for which imputed values are given when GNP estimates are derived, in the total GNP remains constant over time, ineissured velocity will. arcris paribus, remain constant. On the other hand, if the process commonly known as monetisation is taking place in the economy an increasing proportion of GNP will take the form of goods and services for which money payments are made. This process can be expected to occur in underdeveloped economies as they develop: firming gradually switches from subsistenco to commercial agriculture, urbanisation increases and modern sectors of the economy expand. Under such circumstances, measured velocity will, ceteris paribus, decline. A numerical example may be useful in illustrating why this is so.

In the base year, it is assumed that GNP is composed of $\$ 100$ million of linal goods and services for which money transactions are made and $\$ 100$ million of final goods and services for which there are no such transactions. Thus, 50 per cent of GNP is imputed. If it is firther assumed that the money stock a veraged $\$ 40$ million over the year, the velocity of circulation can be calculated as 5 . The $\$ \mathbf{4 0}$ million has in fict been used to purchase only $\$ 100$ million of final goods and services over the ycar and has therefore only circulated on average $2 \$$ times for the payment of such ilems.

Assuming everything else remains unchanged, e.g. the proportion of imputed value in GNP, institutional payments arrangements, per capita income, expected rates of inflation and interest, tastes and preferences, etc., a GNP in the following year of $\$ \mathbf{4 0 0}$ million would only be possible if the money supply averaged $\$ 80$ million over the year. Velocity would again be measured as 5. However, had the composition of the $\$ 400$ million GNP not remained the same, but consisted of $\$ 300$ million of final goods and services for which money payments were made an $\$ 1(0)$ million for which no money transictions took place, the mones needed to finance the $\$ 300$ million component would he $\$ 120$ million othe original assumption that money circulates on average $2 \frac{1}{2}$ times a yea for the purchase of final goods and services. Calculated velocity no: falls to 3.33 .

Another reason for expecting velocity to fall as development take place is that the income elasticity of demand for money is greater the onc. In other words, as real per capita income increases, the demand to money increases more than proportionately. For example,

$$
\left(\begin{array}{c}
M \\
\ddot{p}
\end{array}\right)=a\left(\begin{array}{l}
Y \\
p
\end{array}\right) "
$$

where $h$ in the elasticity of dentand, $a$ is a constant. (M/P) is demand money in real termis and $(Y / P)$ is real income. With a 0.001 and $b$ an increase in real fer capiti income from $\$ 200$ to $\$ 400$ will increase re.

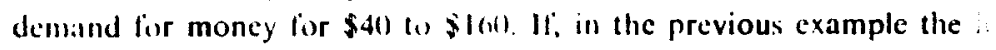
crease in GNP from $\$ 2(x)$ million $10 \$ 400$ million doubled per caps? income, i.c. assuming no population growth, calculated velocity wou. c'teris paribus fall from 5 to $2 !$.

Irom the above, it is evident that a relationship between velocity an dermand for money exists. The higher demand for money at a given lous of income, the lower velocity. It is therefore possible to analyse veloc: by examining the demand for money function; this approach is no. filluwed. The demand for money linction chosen takes the form:

$$
\left(\begin{array}{l}
M \\
p^{3}
\end{array}\right) \quad a_{11}\left(\begin{array}{l}
Y \\
P
\end{array}\right)^{n_{1}} c^{n_{1} / v}
$$

in which $(M / P)$ is per capitil demand for real money balances, $(Y / P)$ : per cupita real income and $i^{*}$ is the expected rate of inflation expressed $a$ a proportion rather than a percentage. If the constants $a_{u}, a_{2}$ and as ar: known, a unique velocity consistent with given values for any two of $t$ ? three variables $(\mathrm{M} / \mathrm{P}),(\mathrm{Y} / \mathrm{P})$ and $\mathrm{i}^{*}$ can be derived. $A$ priori, it can gene rally be assumed that $0<a_{0}<1, a_{1}>1$ and $a_{2}<0$. Two predictions can be based on these assumptions, namcly, that a rise in per capita income wil. cause a fall in velocity, and il rise in the expected rate of inflation wil: conversely increase it.

$I t$ is usual to include the interest rate in a demand for money function. Unlintunatcly, no data exist for either interest rates or per capiti real 
income. However, the effect of rising per capita income, which can reasonably confidently be assumed to have occurred during the past two decades in Afghanistan, on velocity will have tended to offset the effect of the reported upward movement of interest rates. Income and interest clasticities of demand for money are usually found to be of the same order of magnitude with reverse signs [E7; P12]. For example, a 10 per cent increase in per capita income produces a 14 per cent increase in the demand for money. A 10 per cent increase in the rate of interest causes a 4 per cent decrease in demand for money. The net effect of the combined thanges in income and interest rate is a 10 per cent increase in the demand for money which, of course. resulis in a constint velocity. It will therefore be assumed that the combination of changes in the level of per capita income and changes in the rate of interest will, over the 40 year span under analysis, cancel one another and thus produce no overall effect on velocity. In fact, both per capita income and interest rates are assumed to have risen on average annually by 0.4 per cent with elasticities of 1.4 and - 0.4 , respectively. The combined effects of these assumptions ciln be incorporated in Equation 2.5 by making at -1

Table 2.1I

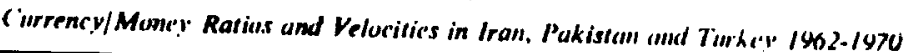

\begin{tabular}{|c|c|c|c|c|c|c|}
\hline \multirow[b]{2}{*}{ Date } & \multicolumn{2}{|c|}{ Iran } & \multicolumn{2}{|c|}{ Pak/stun } & \multicolumn{2}{|c|}{ Timhary } \\
\hline & $\bar{C} / \bar{M}$ & $v$ & $\vec{C} \bar{M}$ & $i$ & $\overline{C / M}$ & $i$ \\
\hline 1962 & 0.28 & 5.7 & 0.48 & $4 . \%$ & 0.38 & 5.2 \\
\hline 1963 & 0.27 & 5.1 & 0.45 & 4.4 & 0.37 & 5.4 \\
\hline 1964 & 0.25 & 4.8 & 0.43 & 4.1 & 0.38 & 5.2 \\
\hline 1965 & 0.24 & 4.7 & 0.40 & 4.0 & 0.36 & 4.7 \\
\hline $\mid y(x)$ & 0.22 & 4.4 & 0.40 & 4.0 & 0.33 & 4.1. \\
\hline 1967 & 0.21 & 4.2 & 0.37 & 3.9 & 0.32 & 4.3 \\
\hline 1968 & 0.19 & 3.9 & 0.35 & 3.9 & 0.30 & 4.1 \\
\hline 1969 & 0.18 & 3.8 & 0.35 & 3.8 & 0.27 & 4.0 \\
\hline 1970 & 0.17 & 3.6 & 0.34 & 3.6 & 0.27 & 4.0 \\
\hline
\end{tabular}

Nole: C-Currency: M-Money Slock: V-Velucity.

Currencu and nwney sluck data are centred annual averages,

Source: Iran-Money stock data from Bank Markazi Iran Bullesins. 1-10, 1962-1971; Hank Markazi Iran, 1971). Table 2. Annual Report amd Bulance Siluete, 1971 (T'thran: Pakislan lran, 1971). Table 2, p. 116.

of Pakistan. Money stock and GNP data from Central Statistical Ollice. Government Turkey, Monthly Siatistical Bulletins, 1962-1971.

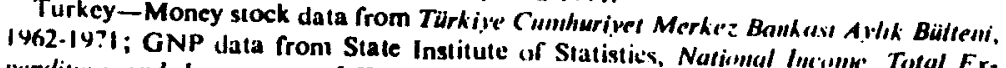

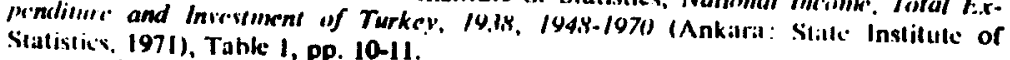

Fortunately, there is a further independent indicator to support these somewhat heroic assumptions. A significant trend in velocity is usually accompanied by a trend in the same direction in currency/money ratios [G27; $k$ 10]. Table 2.11 provides examples of this phenomenon for Iran, Pakistan and Turkey. In Afghanistan, the currency/money ratio in 1331 (1952) was 0.753 and in 1351 (1972) 0.752 as is shown in rable 2.12. The absence of any change in this rattio over the long run would not normally be associated with any distinct trend in velocity.

$$
\text { Tolble? ?12 }
$$

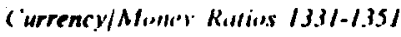

(Milliow of Arghanis)

\begin{tabular}{|c|c|c|c|}
\hline Date & $\begin{array}{l}\text { Currency in } \\
\text { Circulatioun }\end{array}$ & $\begin{array}{l}\text { Money Stock } \\
\text { (M2) }\end{array}$ & $\begin{array}{l}\text { Currency/ } \\
\text { Mourel Ratio }\end{array}$ \\
\hline 1331 & 959 & 1,274 & 0.753 \\
\hline 1332 & 984 & 1.339 & 0.734 \\
\hline 1333 & $1,09 \mid$ & 1,593 & 0.685 \\
\hline 1334 & 1,334 & 2,097 & 0.6 .36 \\
\hline 1335 & 1,617 & $2,47.3$ & 0.654 \\
\hline 1336 & 1,825 & 2.481 & 0.736 \\
\hline 1337 & 1.869 & 2,417 & 0.766 \\
\hline 1338 & 1.86 .5 & 2.587 & 0.721 \\
\hline 13.39 & 2.018 & 2,728 & 0.740 \\
\hline 1.341 & 2,381 & 2,981 & 0.799 \\
\hline 1.341 & $2,8 \times .1$ & 3,565 & 0.809 \\
\hline 1342 & 3.521 & 4,405 & 0.799 \\
\hline 1343 & $4,30 \mathrm{~J}$ & 5.393 & 0.798 \\
\hline 1344 & 4,683 & 6,160 & 0.760 \\
\hline 1345 & 4.634 & 6.355 & 0.729 \\
\hline 1346 & 4.714 & 6,289 & 0.149 \\
\hline 1.347 & 5,021 & $6,53 \mathrm{~K}$ & 0.768 \\
\hline 1348 & $5,\left(6^{4}\right)$ & 7,341 & 0.775 \\
\hline 1349 & $6,3.36$ & 8,181 & 0.775 \\
\hline 1350 & 6.659 & 8,759 & 0.760 \\
\hline 1351 & 7.483 & 9.954 & 0.752 \\
\hline & & \multicolumn{2}{|c|}{ Average 0.748} \\
\hline
\end{tabular}

Source: Same as Tabli: 2.9 .

The effect of changes in the money stock on the nominal level of GNP takes place with a lag. An exhaustive study on this lagged relationship for the Turkish cconomy indicated that the lag lay in the region of twelve months [F25, pp. 103-106]. The siniplest way of incorporating this lag is to deline vetocity as

$$
V_{1} \cdots Y_{1}
$$


where $V_{t}$ is velocity in year " $t$ ", $Y_{t}$ is GNP in year " $l$ " and $M_{t-1}$ is the money stock in year " $t-l$ ". Taking Equation 2.5 in which $a_{1}=1$, it is now possible to divide both sides by $\mathrm{Y} / \mathrm{P}$ :

$$
\left(\begin{array}{c}
M \\
P
\end{array}\right) /\left(\frac{Y}{P}\right)=a_{0} e^{m_{1} 1}
$$

However,

$$
\left(\begin{array}{l}
\mathbf{M} \\
\mathbf{P}
\end{array}\right) /\left(\begin{array}{l}
\mathbf{Y} \\
\mathbf{P}
\end{array}\right)=\frac{\mathbf{M}}{\dot{Y}} \frac{\mathbf{V}}{\mathbf{V}}
$$

where $V$ is velocity. Taking logarithms

$$
-\log V \quad \log a_{0} \quad \mid \quad a_{8} i^{*}
$$

or

$$
\log V-m_{0}+m_{1} i^{*}
$$

where $m_{0}=-\log a_{n}$ and $m_{1}=-$ an. Thus, given values for the two constints $m_{0}$ and $m_{1}$ and the expected rate of inflation $i^{*}$. velocity can be calculated from Equation 2.10.

In a recent study, the expected rate of inflation, $i^{*}$ or $\left(\begin{array}{c}\Delta P \\ P\end{array}\right)^{e}$, was calculated using the Almon lag technique in the relationship

$$
\left(\frac{\Delta P}{P}\right)_{t}^{0}=\sum_{i=0}^{n} w_{1}\left(\begin{array}{c}
\Delta P \\
P
\end{array}\right)_{t-1} \quad w_{n}-0
$$

The average lag between a given rate of inflation and its effect on the nominal interest rate using Canadian data was found to be $1 \frac{1}{2}$ to 2 years for the short term rate of interest and $2 \mid$ to 3 years for the long term rate [CS, p. 593].

For the relationship between inflation and the medium term interest rate [CS, Table I, p. 59I], the expected rate of inflation, adjusted here for annual rather than quarterly observations, is

$$
\begin{gathered}
\left(\begin{array}{c}
\Delta \mathrm{P} \\
\mathrm{P}
\end{array}\right)_{t}-0.249\left(\frac{\Delta \mathrm{P}}{\mathrm{P}}\right)_{t}+0.317\left(\frac{\Delta \mathrm{P}}{\mathrm{P}}\right)_{t-1}+0.278\left(\begin{array}{c}
\Delta \mathrm{P} \\
\mathrm{P}
\end{array}\right)_{t-2} \\
+0.137\left(\frac{\Delta \mathrm{P}}{\mathrm{P}}\right)_{1}
\end{gathered}
$$

\begin{tabular}{|c|c|c|}
\hline Dat! & $\begin{array}{c}\text { Acrual Anmioul } \\
\text { Inflarion! }\end{array}$ & $\begin{array}{c}\text { Expecied } \\
\text { Inflution }\left(100 i^{*}\right)\end{array}$ \\
\hline 1311 & 7.19 & \\
\hline 1312 & -20.41 & \\
\hline 1313 & 20.51 & \\
\hline 1314 & 6.38 & 3.47 \\
\hline 1315 & $1 .(x)$ & 4.68 \\
\hline 1316 & (..06) & $5.7 \mathrm{x}$ \\
\hline 1317 & 5.71 & 3.94 \\
\hline $131 x$ & 4.50 & $4.4 x$ \\
\hline 1319 & 11.21 & 6.tot \\
\hline 1320 & $10 \times 5$ & K.29 \\
\hline 1321 & 24.37 & 14.49 \\
\hline 1322 & $2 \times 65$ & 21.00 \\
\hline 1323 & $2 x . w$ & 25.45 \\
\hline 1324 & 24.32 & 28.48 \\
\hline 1325 & $30.4 x$ & 28.87 \\
\hline 1326 & $8 .(6)$ & 23.95 \\
\hline 1327 & $4.0 y$ & 16.26 \\
\hline 1328 & 22.01 & 13.37 \\
\hline 1329 & 7.83 & 11.25 \\
\hline 1330 & 0.00 & 9.16 \\
\hline 1331 & 2.71 & 5.87 \\
\hline 1332 & -1.13 & 1.65 \\
\hline 1333 & 13.71 & 3.81 \\
\hline 1334 & 7.70 & 6.32 \\
\hline 1335 & 22.40 & 11.80 \\
\hline 13.36 & 3.54 & .12 .16 \\
\hline 1337 & 2.52 & 9.17 \\
\hline 1.338 & 14.69 & 1.26 \\
\hline 13.19 & 12.24 & 6.53 \\
\hline $13+40$ & 0.16 & -6.10 \\
\hline 1341 & 21.70 & 1.93 \\
\hline 1342 & 3.12 & 6.13 \\
\hline 1343 & 24.26 & 11.93 \\
\hline 1344 & 20.75 & 14.96 \\
\hline 1345 & 4.80 & 14.10 \\
\hline 1346 & 0.16 & 10.67 \\
\hline 1347 & 0.32 & 4.32 \\
\hline $134 \mathrm{~K}$ & 4.77 & 2.00 \\
\hline 1344 & 16.59 & 5.75 \\
\hline 1350 & 2.99 & 7.37 \\
\hline 1351 & 1.42 & 5.74 \\
\hline 1352 & 0.00 & 2.50 \\
\hline Average & x.65 & 9.15 \\
\hline Standard Deviation & 12.21 & 8.21 \\
\hline
\end{tabular}

Table 2.13

Aciwal and Expecied Rati"s if Inflation 1311-1352 (Percentuges) 

Note: Expected inflation rates derived as described in the text. Actual inflation for
1352 has been acumed nil. Source: Figures in Table 2.7 have been used to calculate actuai innual rates of
infation.

Using this relationship to calculate expected rates of inflation in Afghanistan, the figures in Table 2.13 have been produced.

Because there has been a large subsistence component in GNP throughout the period, which has not been affected by inflation, the wartime decline in foreign trade, etc., an attempt has been made to derive estimates for this component separately from the monetiry estimates. Ideally precipitation would have been used as a variahle, as it has been the main determinant of short run changes in this sector. but data are only avirilable for the past 15 years. It has, therefore, simply been assumed that in $13 / 4$ (1935), 60 per cent of GNP originated in the subsistence sector and that tnis sector has grown at the same rate as population.

For the money economy component. a value of $m_{11}-1.6094$ in Equation 2.10 has been assumed. This gives a velocity of 5 in the absence of any expected change in the price level. Assigning a value for $m_{1}$ is somewhilt more difficult since considerable variation has been fi ind in empirical tests. Nevertheless, a value of $m_{1}=0.5$ could he accepted taking comparative studies (e.g. [H3]) and the relatively modest expected rate of inflation in Afghanistan over this period. Having calculated $V$ in this manner, the following transformation was made to Equation 2.6 .

$$
Y_{i}^{*}=V_{t} M_{t-1}
$$

where $Y_{i}$ is the non-subsistence component of GNP. The estimates are shown in Tables 2.14 and 2.15 and Figure 2.1 below.

There are three simple methods of assessing the validity of the monetary GNP estimates. All are approximate in the extreme but nevertheless can allow a modicum of confidonce to be placed in the monetiry estimates where they indicate a reasonable degree of positive correlation. The first mecond method the estimates with other economic indicators. The second method uses the impressionistic assessments of the rate of econoThe third is based on experts visiting Afghanistin on regular inissions. The third is based on recent work on fluctuations in currency/money

The GNP estimates are consistent with the indicators presented in growth, the 1320 s (1940s) in the 1330s (1950s) show the must rapid growth, the 1320s (1940s) indicate recession and the 13.40s (1960s)
Tulse 2.14

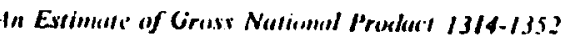
(Milliens of Alghtunis)

\begin{tabular}{|c|c|c|c|c|c|c|c|}
\hline Dure & 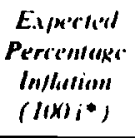 & Veluscily & $\begin{array}{l}\text { Momy } \\
\text { Stock } \\
\text { (M2) }\end{array}$ & 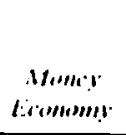 & $\begin{array}{c}\text { Subsistence } \\
\text { Ecunomy } \\
\text { "II } 1314 \\
\text { Prices }\end{array}$ & $\begin{array}{c}\text { Subsistence } \\
\text { Ecomomy } \\
\text { at Current } \\
\text { Prices }\end{array}$ & $\begin{array}{c}\text { Grosss } \\
\text { National } \\
\text { Product }\end{array}$ \\
\hline 1313 & & & 196 & & & & \\
\hline 1314 & 3.47 & 5.09 & 200 & y97 & 1.496 & 1,496 & $2,49.3$ \\
\hline 1315 & 4.1 .8 & 5.12 & 224 & 1.071 & 1,503 & 1,488 & 2,558 \\
\hline 1316 & 5.78 & 3.15 & 240 & 1.153 & 1,511 & 1,587 & 2.740 \\
\hline 1.317 & 11 & 5.10 & 257 & 1.224 & 1,518 & 1,685 & 2,900 \\
\hline 1318 & 4.15 & 5.11 & 275 & 1,314 & 1.526 & 1,770 & $3,0 \times 4$ \\
\hline 1319 & h n.t. & 5.17 & 292 & 1,421 & 1.533 & 1.978 & $3.394)$ \\
\hline 1320 & X.24 & 5.21 & 338 & 1.522 & 1.541 & 2,204 & 3.726 \\
\hline 1321 & 14.44 & 5.38 & 420 & 1.817 & 1,549 & $2.86 h$ & 4.683 \\
\hline 1322 & $21 .(0)$ & 5.55 & 502 & 2.332 & 1.557 & 3.706 & 6,038 \\
\hline 1323 & 25.95 & 5.69 & 582 & $2.85 \mathrm{x}$ & 1.564 & 4.801 & 7,659 \\
\hline 1324 & 28.48 & 5.77 & 684 & 3.355 & 1.572 & 6,241 & 9,596 \\
\hline 1325 & 28.87 & 5.78 & 797 & 3.951 & 1.580 & 8.184 & 12.135 \\
\hline 1326 & 23.95 & 5.64 & 350 & $\left.4.4^{1}\right) 2$ & 1.588 & 8.940 & 13,432 \\
\hline 1327 & 16.26 & 5.42 & 855 & 4.610 & 1.596 & 9,353 & 13,963 \\
\hline 1,328 & 13.37 & 5.35 & 907 & 4,571 & 1.604 & 11,464 & 16,040 \\
\hline 1329 & 11.25 & 5.29 & 1,040 & 4.747 & 1,612 & 12.509 & 17,306 \\
\hline 1,330 & 9.16 & 5.23 & $1,16 x$ & $5.4+4$ & 1.620 & 12.571 & 18,015 \\
\hline |3.31 & $5 \times 7$ & 5.15 & 1.274 & 6.014 & 1.636 & 13,039 & 14,053 \\
\hline 1,332 & 10,4 & .04 & $1,3.319$ & 6.42 .3 & 1.653 & 13,026 & 19.449 \\
\hline 1333 & $|x|$ & $\$ .10$ & 1.593 & 6.824 & 1,669 & 14.954 & 21,778 \\
\hline 1334 & 6.12 & 5.16 & 2,097 & 8.221 & 1,686 & 16,270 & 24,491 \\
\hline 1335 & 11.80 & 5.30 & 2,473 & 11.122 & 1,703 & 20.198 & 31,320 \\
\hline 1336 & 12.16 & 5.31 & $2.4 \times 1$ & 13,140 & 1,720 & 21.122 & 34,262 \\
\hline 1337 & 4.17 & 5.23 & 2,417 & 12,987 & 1.737 & 21.869 & 34,856 \\
\hline | 338 & $12 n$ & 5.0 .3 & 2,587 & $|2.16|$ & 1.754 & $18,83 \times$ & 30,949 \\
\hline 1339 & 1.5 .1 & 4.84 & 2,728 & $12.511)$ & 1.772 & 16.692 & 29,211 \\
\hline 1340 & 6.10 & 4.85 & 2,981 & 13.230 & 1.789 & 17,890 & 31,120 \\
\hline 1341 & 1.93 & 5.05 & 3,565 & 15.050 & 1,816 & 22,101 & 37,151 \\
\hline 1342 & h.1. & 5.16 & 4.405 & $18.3 \times 0$ & 1,844 & 21.741 & 40,121 \\
\hline 1.343 & 11.93 & 5.31 & 5.393 & 23.374 & 1,871 & 27,410 & 50,789 \\
\hline 1344 & 14.186 & 5.19 & 6.160 & 29.1159 & 1,899 & 33.593 & 62.652 \\
\hline 1345 & 14110 & 5.37 & 6.355 & 33,050 & 1,928 & 35.764 & 68,814 \\
\hline 1.346 & $11) .67$ & 5.27 & 6,289 & 33.516 & 1.957 & 36,361 & 69,877 \\
\hline 1.347 & 4.32 & 5.11 & 6,538 & $32,1,32$ & 1,986 & 37.019 & 69,151 \\
\hline $1.34 B$ & $2 .(101)$ & 5,05 & 7,341 & 33,019 & 2.016 & 39.372 & 72,391 \\
\hline 1349 & $\$ .75$ & 5.15 & 8,181 & 37.776 & 2.046 & 46.587 & 84,363 \\
\hline 1.350 & 7.37 & 5.19 & 8,759 & 42,440 & 2.077 & 48,706 & 91.146 \\
\hline 1351 & 5.74 & 5.15 & 9,954 & 45,070 & $2.10 x$ & 48.484 & 93.554 \\
\hline 1352 & 2.50 & 5.06 & & 50,346 & 2,140 & 49,220 & 99,616 \\
\hline
\end{tabular}

Vote: The moncy stock data are the averages of beginning and end of year figures, thus providing a mid-year estimate. Velocity is issumed to equal $Y_{i} / M_{2}, \ldots$. Therefore, velocity is multiplied by the moncy stock ligure of the preceding year to obtain estimates for $\mathrm{Y}_{i}$, tlue non-subsistence component of Gross National Product.

Source: Ixpected inllation datu are lathen from Tablo 2.11. Money wlix:k dulu are laken frou. Tuble 2.\%. Velowily is calculated in the manner slexcribeal in the text. 
Table 2.15

1" Entumate of Gross National Prodiuct at Constant Prices, 1.1/4-1.152 (Millions of Afghanis, 1340 Prices)

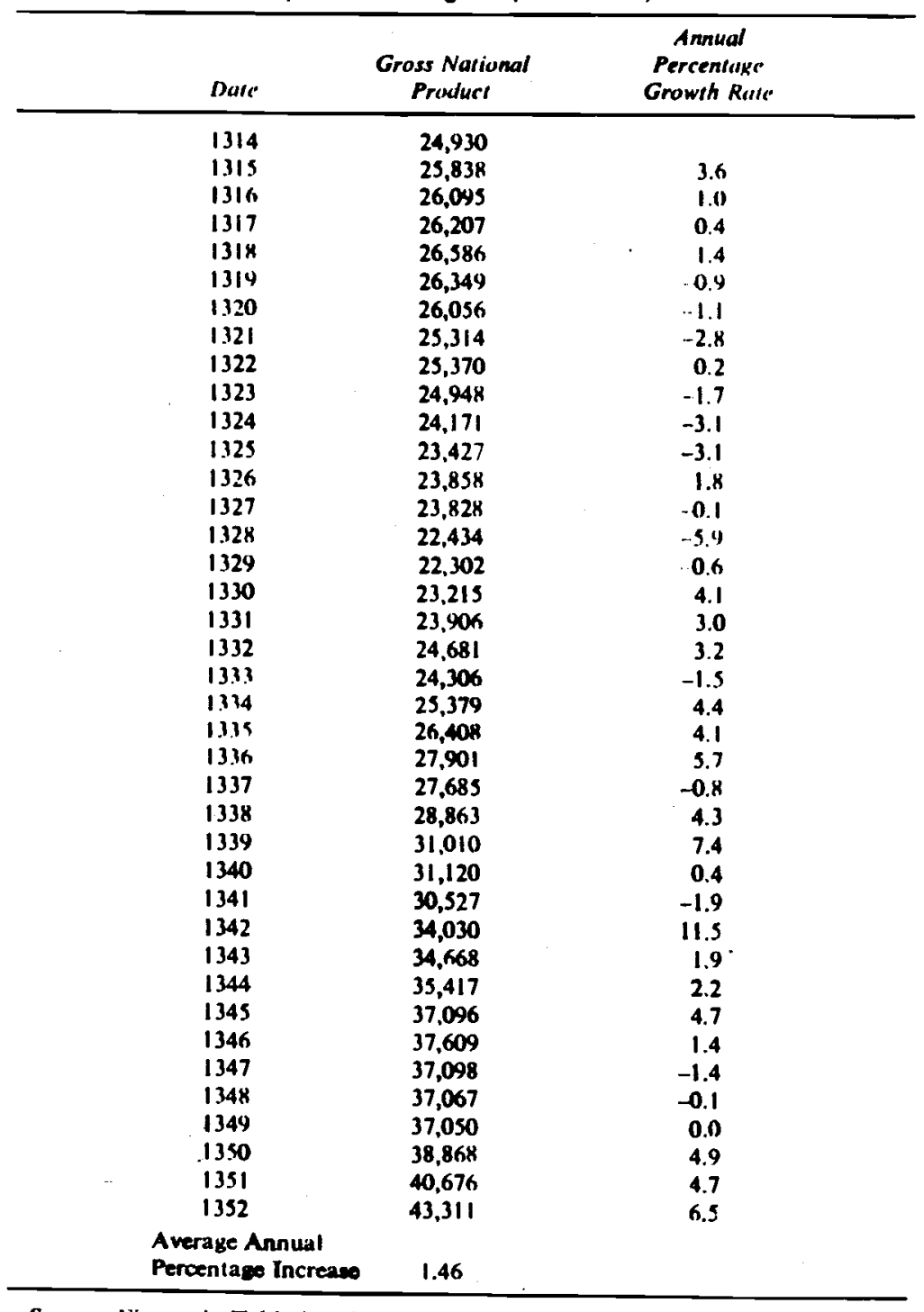

Source: Figurea in Table 2.14 have been deflated by the modified purchasing power parity price index in Table 2.7 . The average annual growth rate is the annurlly communded rale of erowth in GNP in real lerma.

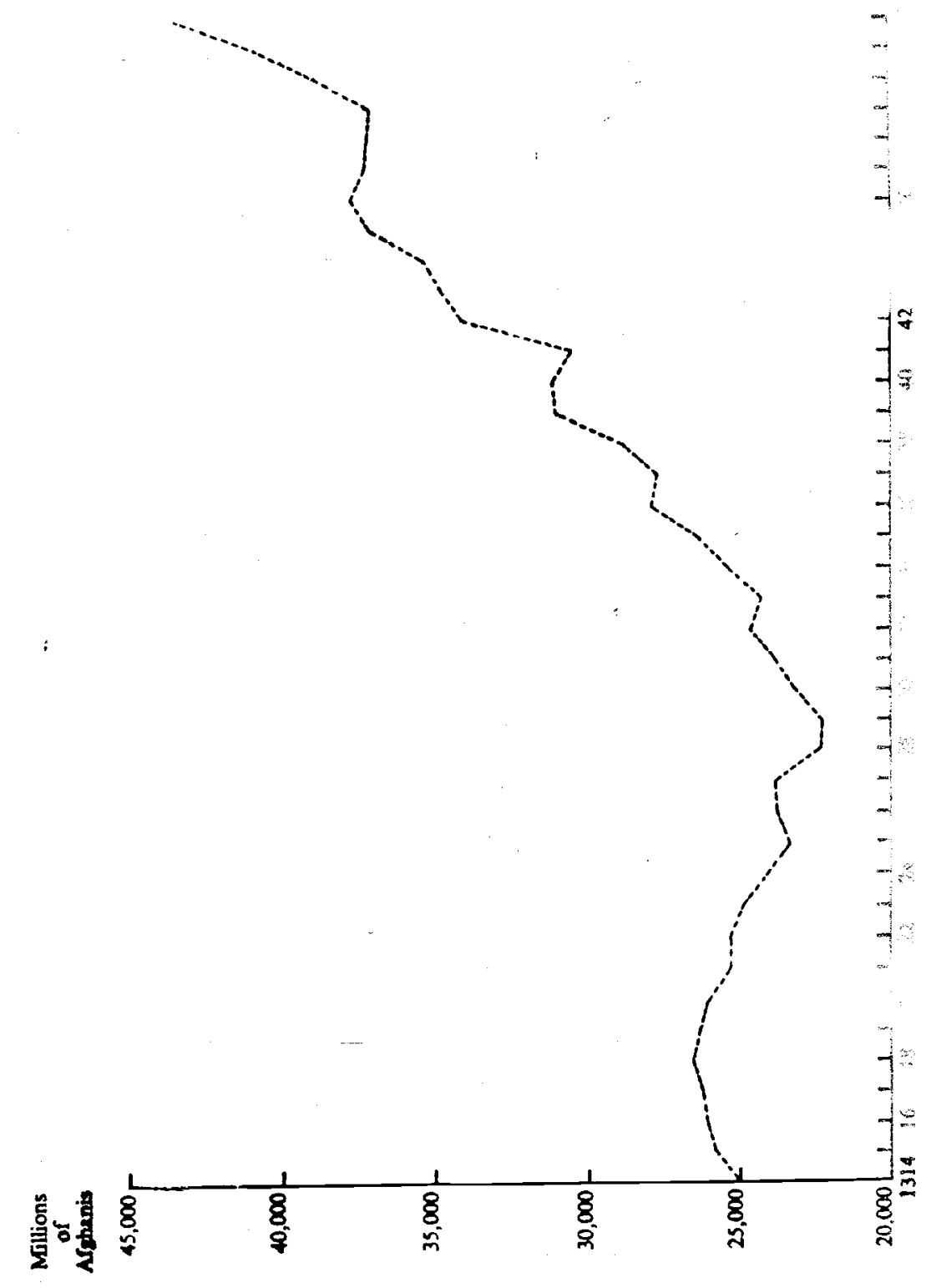


moderalte growth. A more detailed comparison is given in Table 2.16 . Over the entire period, Government domestic revenue has increased at a slightly faster rate than GNP which is consistent with expectations based on a detailed evaluation of fiscal developments in Chapter VI. Exports have increased considerably more rapidly than GNP, also a reasonable expectation given the substantial improvement in transport facilities over the past four decades.

Table 2.16

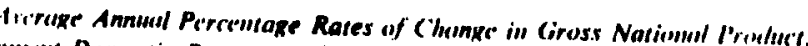

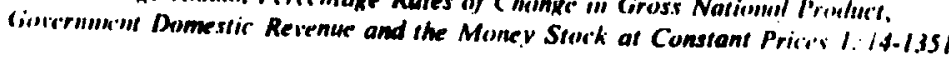
(Percentayes)

\begin{tabular}{|c|c|c|c|c|}
\hline Dull. & $\begin{array}{l}\text { Aieruge Annual } \\
\text { Percentage } \\
\text { Change in GNP }\end{array}$ & $\begin{array}{l}\text { Average Annual } \\
\text { Arrcentage } \\
\text { Change in } \\
\text { Government } \\
\text { Reirenue }\end{array}$ & $\begin{array}{l}\text { Avruxe Annwal } \\
\text { P(rrentage } \\
\text { Chunge in the } \\
\text { Money Stock }\end{array}$ & 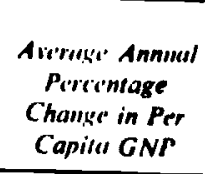 \\
\hline $1314-1351$ & 1.3 & 1.4 & 2.0 & 0.4 \\
\hline $1314-1329$ & -0.7 & -6.2 & -2.9 & 1.2 \\
\hline 1329.1351 & 2.8 & 7.0 & 5.5 & 1.5 \\
\hline 1329.1335 & 2.9 & 8.0 & 7.6 & 1.9 \\
\hline $1335-1340$ & 3.3 & 16.8 & 7.4 & 2.3 \\
\hline $1340-1345$ & 3.6 & 1.8 & 2.8 & 2.0 \\
\hline $1,345-1350$ & 0.9 & 1.5 & 1.7 & 0.6 \\
\hline
\end{tabular}

Source: Figures in Tables 2.1, 2.10 and 2.15 have been used to compule average annually compounded annual rates of change.

The effects of the Second World War, most pronounced on Ciovernment revenuc, caused a fall in GNP over these years. A report written in 1319 (1940) indicates that they were, in part, anticipated:

It is probable that the present war will cause a serious curtailment of the progratll for the develonment of Afghan resources. Europe will no longer be interested in buying karakul skins, which have been the most valuable article of export. When we left Kabul the Government was carefully considering which items of the program were least essential and might the first abandoned. Public works and industrial projects are almost sure to sufier as funds are diverted to a military use. In times like these the demands of national defense come first. [H11, p. 122]

The results of the decline in GNP from a level barely above subsis'ence are vividly described in Akhramovich's history of the post-war period [A13, pp. 8-28].

On a cyclical basis, the movements in Government domestic revenue and GNP are also consistent with one another. Thus, the recessions of
1318-1321 11939-1942). 1339-1341 (19601-1962), and 1346-1349 (1967-1970) are matched by declines in Governınent revenue as is the rapid decline from 1321 (1942) to 1.326 (1949). The booms of 1329-1332 (1950-1953), $1337-1339$ (1958-1960) and 13+1-1342 (1962-1963) also correspond to significant increases in Government domestic revenue at constant prices.

Regular visits of foreign experts to Afghanistan have taken place since 1.335 (1956); the first pronouncements on economic growth were apparently made in 1341 (1962). In that year, the conclusion was reached that there had not been much growth wver the past six years. Given the absence of statistics, six years is a long time span over which to draw comparisons. One would in fiut expect such an assessment to be biased loward greater emphasis on the neiter events and less emphasis on developunents acurring in the earlier pitrt of the period. On this assumption, the munetary estimates are confirmed. Real growth was significantly negative in 1341 (1962) and stagnant in 1.340 (1961).

The stagnation reported at this time was attributed to excessive levels of deficit finance. Using data from International Financial Statistics [12, pp. $4(1)-41 ; 13$, pp. 228-29)], it kivuld appear that this phenomenon occurred in the last three years of this period and was considerable only by 1341 (1962). This again supports the monetary estimates if deficit finance did in lact retard growth.

At the tinc; the fiscal and forcign exchange reforms at the beginning of 1342 (1963) were thought to have stimulated agricultural production and ranced the rate of growth. The monctary estimates indicate rapid growth during this yciar. The less salisfactory performance reported in the followiaf ycir, attribuled to the increase in infationary pressures, is again indciatcd. Improvement reported in the following few years is also consistint with the munetary estimalte. Finally, a recession from the latier patt of $1345(1960)$ to $1347(196 x)$ was reported by a mission in $1348(19(19)$

In comclusion. Huctuations in the ratc of growth during the 1340s (1960s) repurted by teams of forcign experts have all been forecast by the monetiry eitmates, thus providing considerable support to their validity.

The llurd method is based on recent evidence on the cyclical behaviour if the currency/money ratio provided by Hess:

In the cully part of a business expansion income rises, increasing the demand for demand deposits. However, since currency is related to consumption expenditures which in turn are dependent on permanent incume. and perimanent incume has a muted response to changes in measured incume, the demand for currency rises little if at all. Hence, the currency 
ralio initially falls. As the expansion proceods. the demand for currency the ellier faster than tho demand for demand deposits in response to of eurler increasea in incomo. This is because the cumulative response incom is larger than that of demand deposits demand deposits to interest rates, which further depreases response of demand deposits to relative to responses take effect Hence, midway through the expansion the lagged responses take effect and currency rises relative to demand deposits. This is reinforced as economic activity moves past its peak. After the peak, the demand for currency falls less than for demand deposits, the peak, the currency ratio to continue to rise. However, as during the causing the delayed responses of currency to consumption and consume expansion, the and demand deposits to inconstion and consumption to income relative demates results in an eventual fall in the relative demand for currenes. The currency ratio starts to fall midway through the contraction whbh continsues past the trough when the cyclical process repeats itself. In summary. the cyclical pattern of the currency ratio is effectively explained in terms of the cyclical pattern of the ratio of consumption to income in conjunction with interest-induced changes in the velocity of demand deposits. [H8, p. 673]

From the currency/money ratios for the period 1331-1351 (19.52-1972) given in Table 2.12, business cycle upswings should have occurred in $1335(1956)$ and 1.345 (1966) and downswings in 1341 (1962) and 1349 (1970). From Table 2.15 and Figure 2.1, it can be seen that the expected movements in GNP at constant prices have taken place in these years according to the monetary estimates.

\section{iv. Conclusion}

The consistency of the monetary estimates of GNP with other ecinomic indicators reinforces the assumption made at the outset that there has been no significant decline in velocity over the past four decarles. Average velocity for $1314-1316(1935-1937)$ was 11.6 and for 1349-1351 (1970 1972). 10.0. The significance of this lies in the fact that velocity can be used to measure financial development. As shown in Chapter 1 , the latter Was found to be the most important economic determinant of grewth
[A2: M7].

The inverse of velocity measures the proportion of income held on average in the form of money. Thus, any decrease in velocity is an increase in this proportion, i.e. is an increase in the demand for money per unit of income. In a country like Afghanistan, where muncy is the only importint financial claim, an increase in the demand for moncy per unit of income increases financial savings and results in a relative expansion of the financial sector which provides such financial claims.
The citusal links between financial development and economic growth are twolild: lirst, an increase in savings is a concomitant of financial development: second, a higher proportion of savings is held in financial form. In turn, these have two effects on investment: first, investment increases; second, its productivity riscs. The increase in savings occurring with financial development frees additional resources for investment. The increase in the proportion of savings held in financial form means that a greatter portion of those savings can be allocated to the most productive investment opportunities by the financial system, thus reducing fragmentation in the capital market. Since the real interest rate is the critical variable in linancial development, it positive relationship exists between it and both the quantity and quality of investment. As shown in Chapter $V$, institutional interest rates have generally fluctuated around zero in real terms. The financial constraint is discussed at length in this chapter. Interest rate policy within the context of tinancial development is the subject matter of a large part of Chapter VIII.

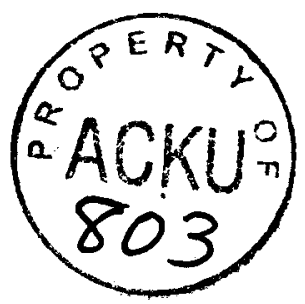




\section{CHAPTER THREE}

\section{A FRAGMENTED ECONOMY}

\section{i. Introduction}

Dubious though data used elsewhere in this book to support the analysis ire. at least some information is available. In this chapter, however, the propositions put forward have almost no statistical support. Nevertheless. because of its importance in the minds of a number of ecunomists in Afghanistian to an understanding of the economy, the idea of a fragmented economy is considered here. The central hypothesis is that the economy has consisted of distinct segments which have been only very loosely linked to one another. This fragmentation has occurred in three ways. The first is the separateness of the public sector from both the modern private seclor and the bazaar economy. The second is the lack of cohesion between economic sectors, particularly agriculture, construction, industry and foreign trade, and the isolation of the subsistence economy. The third is the separation by distance of Afghanistan from the rest of the world and of regions within the country itself.

Had it not been for the recent appearance of a book contilining arguments in a theoretical context along the same lines as those pursued here [M7], the importance of this phenomenon to economic development would have been underestimated. However, in many ways it is intimately related (1) all the critical constraints to economic development discussed in Chitpter $l$ in circular relationships.

ii. Govermment, Modern Sector and the Bazaar Economy

A comparison of developments in Goverment, modern and the bazalar sectors of the economy reveals strong countervailing forces at work throughout the past forty years. As soon as Bank Millie, the only private commercial bank, rose to prominence in the 1310 s (1930s) as the leader of the modern private sector, it turned to restrict the bazaar economy with the weapons of exchange control and monopoly concession. In the 1330 s (1950s), a sirong Government restricted bnth the Bank Millie Group and the bazaar in its single-minded attempt to pursue an étatist cconomic policy. During the 1340 s $(1960$ s), increased liberalism witnessed a boom in the bazaar economy, a near collapse of the publie sector, and a consolidation and retraction of Bank Millie.
Details of the relationship between Bank Millie and the Government are presented in Chapter V. Here it suflices to point out that the Bank was establishicd with equity participation of the Government. The Bank and the Gusernment cuoperated in various ways until after the Second Worid War. In the early 1330, (1950s) the l3ank wils torn apart by Abdul Malik. the Minister of Finance, in his étatist purge. Pank Millie has not flourished since then, despite the absence of "nen antagonism between it and the Government during the past decade.

Other puint-war industrial development in the private sector has also suffered all the covernment's hands. In general, since the early 133 hs (1950s) the Government has not supported and in many instances has actually decerred private industry:

The Afylatn policy known as "guided ecomomy" may in fact be instrument. al in urceluding so larke an antumt of achievernent rewards for the econo. mically active segment of the population as to have a serious dampening etlict an economic development. Praginatically. "guidance" can be and nure ofien is a toot for obstructing thatn facilitating econumic activity. [N.?. [N. $5-6$ ] ]

The "mixed guided economy" philosophy has meant in practice participation and involvement in private sector atcivities as well as a programme

$$
\text { Table .1. I }
$$

Sarieces of Industrial limunce in 1337 (Millions of Aighanis)

\begin{tabular}{|c|c|c|c|c|}
\hline Vime & 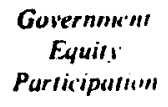 & $\begin{array}{c}\text { Privale } \\
\text { Equity } \\
\text { Purricipariunt }\end{array}$ & Loans & $\begin{array}{l}\text { Toral } \\
\text { Funds }\end{array}$ \\
\hline (iovernnemi I) Inot & 211 & 0 & 600 & 811 \\
\hline Afghan Texule Cumpany & 12 & 624 & 68 & 704 \\
\hline Electricily ('onpany & 365 & 139 & 102 & $60 \mathrm{n}$ \\
\hline Cotton Company & 107 & 81 & 74 & 262 \\
\hline Transport (umpiany & 82 & 0 & 8 & 90 \\
\hline Governnent Monopslies & 41 & $\mathbf{0}$ & 40 & 81 \\
\hline Siaughter House & 30 & 0 & 5 & 35 \\
\hline Cuvernment Printing Press & 30 & 0 & $\mathbf{0}$ & 30 \\
\hline Medicine Depot & 29 & 0 & 0 & 29 \\
\hline Governnenll Cooperalives & 16 & 5 & 51 & 72 \\
\hline Hotel Conmany & 0 & 14 & 0 & 14 \\
\hline Ariana Airline Company & 5 & 5 & 0 & 10 \\
\hline Pruic company & 4 & 1 & 1 & 6 \\
\hline Kolnu Counpany & 2 & 1 & 0 & 3 \\
\hline De Hoto (onjpany & 2 & $\mathbf{0}$ & $\mathbf{3}$ & 5 \\
\hline
\end{tabular}

Source: Minivery of Planning. A Surue of Progeress 145., (Kabul: Ministry of :Planning. liskis. Volutme II, Table Induslly (6). 
of public enterprise, as illustrated in Table 3.1. The latter has been unsuccessful and was not greatly expanded after 1342 (1963). Although resulting in the establishment of unprofitable enterprises, this did no great harm to other sectors of the economy. Interference in the private sector, on the other hand, has had an extremely damaging effect not only by making legitimate profit hard to earn but also by increasing uncertainty in what was already an uncertain environment:

A nother problem the privato noctor has always encountered relates to the lack of satisfactory commuaication with the Government con to the varied industrial policies in of such a policy and husiness decision the Government is prone to intervene in industrial and husiness decisiona without having an adequate basis for determining the effects of such intervention. [N3, pp. 144 and 156]

Under such circumstances, it is hardly surprising that the private sector has not exhibited much enterprise. Further, the absorption of domestic credit by the public sector to the point where institutional credit extended to the private sector actually declined in real terms greally inhibited what initiatives there were. A distinct picture of the economy as a battlefield

During the 1330s (1950s), the embryonic entrepreneurial class within the modern private sector began to express grave doubts as to the viability of the Government's development strategy and, in particular, the country's increasing dependence on the U.S.S.R.:

In its opposition to the new fordign policy alimment, the business group has predicted disastrous economic consequences of the commitment of so many Afghan resources to the repayment of Sovict loans .... [F18, p. 13]

As shown in Chapters IV and VI these fears were far from groundless.

The distance between the Government and other sections if the community is not confined to Bank Millie and the modern private sector. In fact. one of the critical constraints to development in Afghanistan in that it has caused low potential for development is the lack of identification of the public with the Government's development programme: economic development which would rom policies designed to achieve the Afghan people (an officially accepted objective) are not heard and have relatively little influence on the course objective) are not heard and remain largely unafiected by the course of events. Their lot tends to Government of Afghanistant the development efforts of the RGA [Royal objective of optimum growth and such efforts are rarely directed to the income lowing from such dovalopment efforts 5-ycar plans. this sense of particination by a significant number of people in the variuts regions of the country is notably lacking. This is particularly distressing when the (iovernment should be asking for increased contributions from the people to support a continuing program. [N3, pp. 4 and 56]

Perhaps because it is further removed from the Government, the bazaar economy, i.c. traditional, small scalc entrepreneurial activities; has not been so adversely affected by the Government as the modern private sector. Where it has been involved in areals of Government interest, e.g. foreign exchange and trade, intervention has occurred. Apart from the 1310 (1910) when Bank Millic persuaded the Government to curb the Kabul forcign exchange market and to institute foreign exchange controls, intervention also took place during the 1330s (1950s) as the exchange system became increasingly complex and non-market oriented and again in 1352 (1973). Further details of the history of the foreign exchange markets is given in Chapter VII.

Little infiormation on other sections of the bazaar economy is available. It was therefiore one of the first tasks of this study to conduct a small survey in 1351 (1972). What is now reported is largely drawn from that survey. It must be emphasised at the outset that the sample was not randomly cisted. The author and his assistant simply walked round sections of all the major towns in Afghanistan and picked what was hoped to he a reasonably representative sample. Some altempt was made to evaluale the accuracy of information obtained through cross-check yuestions and intuitive assessment on the part of the interviewers. It was found, for example, that respondents who had been on the haj, i.e. pilgrimage (1) Mecca, were far less willing to discuss prevailing rates of interest than others. There is also no doubt that sales figuris collected were grossly underestimated and questions on the respondents' own credit arrangements biased heavily in favour of interest free loans both given and received. Nevertheless, most of these same respondents seemed well aware of the prevailing rates of interest. There was almost unanimous agreement on a number of issues, particularly on the upward movement of interest rates over the past ${ }^{-}$decade, and some interesting regional dilferences emerged. A strong degree of optimism regarding business conditions and standards of living was encouncered throughout the field trip which conflicled strongly with accepted views on Afghanistan's economic stagnation.

The impression ubtained from intervicws and observations during this survey wis that cconomic conditions in the Alghan bazaar have improved considerably over the past ten years. Making a regional comparison, the 
northern part of the country seemed to have experienced the most rapid development as a result of the new asphalt roads and increased trade with the U.S.S.R. The only town visited on this survey which both appeared less prosiperous than reported in the past and whose inhabitants indicated thill husiness conditions had deteriorated was Faizabad. The droughts in 1349 (1970) and 1350 (1971), distance from the asphalt road, and dectining handicraft industries, the consequence of competition from the importation of cheap manufactured goods and used clothes, all appear to have contributed to this situation. In the south, Lashkir Gahl seemed 11, have experienced, not surprisingly, the greatest boom, while husiness in Herill, Jalalabad and Kandahar has seen reasonable expansion.

Kabul has attracted the major part of Afghanistan's embryonic industrial sector, the availability of cheap electricity, a locial market, labour force and credit facilities, as well as Kabul's position as the capital city, all acting as magnets. There is hardly any need to record that most respondents in Kabul thought that business conditions and the general standaral of living had improved considerably over the past len yeirs.

Despite the impression of increased prosperity, not all have benefited from the economic boom. The asphalt roads have had enurmous impact in the towns through which they pass. However, by providing a comparalive advantage for many forms of economic activity in these locations, enterprise has been attracted away from other areas such as Chakcharan. liaizabad and Mainana. A predictable concomitant of modernisition is the decline of traditional forms of economic activity. The fict that people engaged in handicrafts, such as thoes, kitchen utensils, etc., and traditional forms of trade reported that their economic position hatd deteriorated over the past decade lends support to the veracity of statements by the majority of respondent on the improvement in business conditions. Carpet making has not been affected in the same way as other handicrafts since carpets are still an important export. Interestingly, in a study of the hatzatar cconomy in lran, Thaiss found that it was here that "some of the nure dynamic (traumatic) changes are occurring" [T2, pp. 210-11]. One of the less fivourable findings of the survey was that respondents frequently felt that income distribution was becoming less equal; standards of living at the bottom end of the scale had declined. The rich had become richer, the poor poorer.

The survey findings documented here as well as in the Appendix to this chapter and in Chapters V and VII are consistent both with one another and with basic economic principles. They present a picture of an cconomic boom. a new awareness of economic opportunities and the growth of an entreprencurial cadre in the bazaar. The concomitants of these have been increasing incquality in the distribution of income, al decline in traditional forms of economic activity and higher costs of horrowed funds.

The prosperity of the bazaar economy'stands in sharp contrast to developments in both the modern and the Government sectors. Between 1339 (1960) and 1351 (1972) Government domestic revenue did not grow at all on a per capita basis at constant prices, while capital and reserves of Bank Millic actually declined. Increased liberalisation of foreign tract and reduction of Government control have in part been responsible the economic boom in the bazalar. The contrast is also another indicat. of the fritgmented econumy.

iii. Economic Sictors

The agricultural sector is thought 110 cumbribute atwout 50 per cent of the total value of Gross Domestic Prinduct. in this respect and even more in that about 80 per cent of the labuur force works in it, the predominant position of agriculture in the Alghan economy cannot be neglected. Despite the concentration of development expenditure in the agriculturat sector, meithe output nor productivity his risen substantially. Indeed, domestic wheat production has generally heen barely sufficient to feed the population. Prior to the Second World War, bad harvests resulted in famine. In 1326 (1947), 1331 (1952) and 1332 (1953), wheat was imported commercially [F|8, p. 17]. Since 13.5 (1956) wheat importation through commodity aid programmes has greatly alleviated the effects of bad harvests. This sector has for a number of reasons remained largely at subsistence economy with strong barriers between it and the money economy.

Price controls on bread have not encoulraged wheat production, again illustrating the unfavourable effects of (iovernment intervention. Cornparing the alverage price of wheat for 1312 (1933), 1330-1332 (1951-1953) and 1347-1.349 (1968-1970) with the averige modified purchasing power parity price index for the same years, the following results emerge. Average wheat prices were $A f s$ 1.00, Als 14.15 and $A$ fs 45.00 per seer and the price index 7.8, 78.7 and 203.1. Thus, between 1312 (1933) and 1330-1332 (1951-195.3) wheat prices increased slightly faster than the rise in the modified purchasing power parity price index. Thereafter, they did not increase as rapidly as the index. In other words, price controls may have heen effective. To the extent they were, wheat production was deterred. At the same tume, Commodity $A$ ssistance itsell by increasing supply also contributed to keeping prices down and so to deterring donestic production. 
The experience of 1352 (1973) provides another example of Government actions which were not likely to provide incentive for future cash crop production. An increase in fertiliser use combined with a more importint factor, above average and well distributed precipitation, led to a bumper wheat crop and the cancellation of Commodity Assistance in the form of wheat. A price support programme was announced early in the year. This was soon abandoned and at harvest time farmers in many areas were receiving prices so low that neither could they afford to buy fertiliser for the next year's crop nor was there incentive to do so. The (iovernment's granaries, the only commercial storage facilities since the Anti-llıarding Law prohibits private storage, remained untilled.

In general, farmers have not been given great incentive to move from subsistence to caslı crop farming. Farmers in the North have at various times heen obliged to grow cotton by the Government because the price differential between it and wheat has generally failed to provide economic incentive for cotton production. This has had unfortunate results. As early as 1325 (1946) a failure of the wheat harvest forced the Government to allow farmers to grow wheat instead of cotton and sugar bect. Consequently. "the textile factory was starved and the sugar factory had to close down" [S1S, p. 12]. During the first half of the 1340s (1900s), the failure of the Government to raise cotton prices greatly deterred productiun as the cotton/wheat price ratio was halved over a five year period [113, pp. 29-30]. Government intervention in 1.335 (1956) resulted in it han, later lifted, on privately owned cotton gins and the establisht : ant of conditions of virttual monopsony. Although this ban was purportediy for the henclit of farmers, cotton prices have never been raised by the (iovernment to sufficient levels to encourage more farmers to transfer resources into cotton production, except in 1352 (1973). The increase is this year. combined with low wheat prices, began to increase production again, thwig'. still not to the levels of the early 1340s (1960s). This has been unfortunate in that cotton exports have been an importint foreign exchange earner and domestic textile manufacturers have consistently bei:n unable to operate at full cipacity due to shortages of raw cotton.

Apart from unfavourable Government action which has also included the surrender requirements at below frec inarket rates on foreign exchange caried from cotton, karakul and wool exports. high transport costs from firm to market have also deterred cash crop production. This is considered in some more detail later. The incentive to remilin isolated has recently heen expressed as follows:
In ellect, as long as the farmer has no webts and is producing crops for self-consumption his own living conditions are preserved at a relatively high level eompared with conditions in other Asian countries. As far as the economy as a whole is concerined. the real problem is to encourage the farmers to produce a mithetible surplus to feed that part of the population which lives in towns "rr doe's not own land. In this, the country's agricultural policy has failed. Indeed, the more interference. from the government in the agricultural sector, the more the Afghan farmer seems to retreat into the shell of self-consiumption or barter. [B26, p. V/22]

Involvensent with the money economy by way of trade with the nomads has also re.ulled in unsalisfactory expericilces for the farmer:

The result of this trade is clear: the llazilas are sinking deeper and deeper into deht, and even if they wish (1) try 10 get straight economically they are seldom able to do so, heing as it were compelled by their earlier financial engagements to continte dritling with the nomads, a vicious circle. A setlement of an unredeemed weht the nomasts take over sheen. cows and, in the last resort, land. [1:3, 1. 132]

Indeed, contact with hoth the Guternment and the bazaar conomy has not provided much incentive for tirmers 11 improve agricultural productivity so as to produce a marketabl. surplus. In 1348 (1969), one observer opined that in any Government initiative l, improve agricultural productivity

the obstacles appear alnust insturmountable: if the Government cannot even eollect the land taxes on the books, how ean it hope to make the necessary concirted efforts to engage the farmers in a nationwide campaign to attain self-sulficiency in foudstufls in so short a period fi.c. by the end of $1.351(1972)]$ ? (1)y, p. 277)

Productivity has not risen significantly and, in the words of a report written in 1311 (1932). "it will he long before the Afghitn peasant pays much heed to the advice of experts" [T.3, p. 11].

The failuce of agricultural productivity to rise, as shown in Table 3.2, is another result of economic fragmentation in both capital and product markets. The underlying cause is again an inadequate information systen. In some areats where ellorts have been concentrated on demonstrating uew inputs and techniques and on providing the necessary credit lincilities for the farmers to follow suit, the results have heen striking. Only becaluse the cutchment arcas for demonstration projects are so small and eredil sol limited have these not been rellected in a general upward trend in overall agriculturat productivity. A greatly increased effort is needed under such comditions lo affect signiticantly the total 
Table 3.2

Wheat Yleld in Tons per Hectare 1.3.35-1.15I

\begin{tabular}{cccc}
\hline Date & $\begin{array}{c}\text { Ourpur } \\
\text { (Thowsands } \\
\text { of Tons) }\end{array}$ & $\begin{array}{c}\text { Hectares } \\
\text { Sown } \\
\text { (Thousands) }\end{array}$ & $\begin{array}{c}\text { Yield } \\
\text { per } \\
\text { Hectare }\end{array}$ \\
\hline 1335 & 2,200 & 2,200 & 1.00 \\
1336 & 1,983 & 2,204 & 0.90 \\
1337 & 2.234 & 2,212 & 1.01 \\
1338 & 2,240 & 2,218 & 1.01 \\
1339 & 2,279 & 2,230 & 1.02 \\
1340 & 2,279 & 2,230 & 1.02 \\
1341 & 2,279 & 2,341 & 0.97 \\
1342 & 1.947 & 2,341 & 0.83 \\
1343 & 2,250 & 2,343 & 0.96 \\
1344 & 2,282 & 2,346 & 0.97 \\
1345 & 2,033 & 2,346 & 0.87 \\
1346 & 2,280 & 2,030 & 1.12 \\
1347 & 2,354 & 2,036 & 1.16 \\
1348 & 2,454 & 2,070 & 1.14 \\
1344 & 2,081 & 2,176 & 0.96 \\
1350 & 1.915 & 2,350 & 0.81 \\
1351 & 2,401 & 2,897 & 0.83 \\
\hline
\end{tabular}

Source: Ministry of Planning. Survey of Progress 1962-64 (Kabul: Ministry of Planning. 1964) Tables A-26 and A-27, pp. 132-33; Ministry of Planning. Survey of Pregress $1968-1969$ (Kabul: Ministry of Planning. 1969). Table S-20; Ministry of Planning. Survey of Prugress 1971-1972 (Kabul: Ministry of Planning. 1972), Table S-27: and Miniary of Planning.

picture. This is doubly important not only because self-sufficiency in gratin produc.ion is a sensible goal from an economic viewpoint but also hecause rising agricultural productivity is one of the Adelman-Morris indiciators of development potential. Its failure to rise in Afghanistan thus acts as a critical constraint to econumic development.

Industry has already been mentioned in the discussion of the modern privale sechor's conllicts with the Government. However, as an economic scuor it comprises hoth public and private sector enterprises. The (iivernment started industrialisation in Afghanistan with the munitions (Afurhinc Khanah). match and military supplies factories cstitblished befisre $1.310(1931)$ [A II, p. 120]. It played a paternalistic role during the $13104(14.105)$ by approving projects and providing financial assistance. It was not until the late 1330s (1950s) that industrialisation by the public sector was decided upon:

lixpericnce has shown that private enterprise does not possess adequatc resnurces and experience for undertaking large-scale investment of the iype required for achieving apid rate of growth. [MIS, p. 37]
With this, the public sector industrial programme was expanded and creditextended at such a rate to this end that the private sector was even more scverely restricted in obtaining adequate resources to finance enterprise. Life was not made casy lor private enterprise [U20, pp. 6-7].

The results have not been successful. Protected from competition, isolated lrom market forces, stafled and run by civil servants. most public sector enterprises failed to contribute to development:

This is not surprising since, typicilly, public industrial enterprises operate at 311 11) 40 percent .If capacily. [N], n. S4]

Interestmgly, import substitution activities in Alghanistan had been strongly allincked by sirickland as far hack as I.311 (1932) [S19. Pp. 719-20). 1:llezam showed in some detail why specific import substitution industrics, e.g. matches and sugar, lailed and suggested that export promotion was the only viable stratcigy for forcign trade policy [E2, pp. [(1) 1(02]. Import substitution industries have also been criticised more recently [11; P1I; SII]. Agatin, Ihe fragmentation phenomenon is highlighled by the fact that great waste in these industries has been possible in an economy with so few resources.

The mid-1340s (1900)s) saw a reversal of the extatist policies of the previous decade. The 50 public enterprises had failed to contribute to economic development as had most other investment under the first two development plans. Thus, a decision was taken to promote privilte industry and in 1345 (1967) the Foreign and 20omestic Private Investment Law wats enacted to this end. This law and the underlying rationalo embodied the inport substitution philousphy. Firms established under the law ivere given tax and turill exemplions for their first five years and plans were made for the establishment of an Industrial Development Bank to provide low cost credit. The Bank was eventually established after a number of schiacks in 135/ (1973). 13y mid-1352 (1973) 84 firms had heon estathlished and were producing under the provisions of the law [C15, Iialik 1, p. 50]. Tlicy had, however, predictably created only 6,000 jobs since incentives were for capital rather than labour intensive methods of production:

In common with ollher countices in the tarly stages of econonic development, Afghanistan has protected import-saving industries using imported machinery and in some cases (rilyon weaving. for example) imported raw matcilals. The few henefits thit have come from these projects have rentiined largely in the hands of the owners of the enterprises and in some cases have found their way out of the country. [PII, p. 10] 
There hats throughout the post-war period been a neglec of small scale Lack of which could have contributed highest returns [FI8, p. 26].

The Firs Five Year benefits from ind:strialisation is no new complaint.

First Five Year Plan's commenting on industrial finallce says: In some cases the participation of banks have no other resull except leading
to its own profit. [M14, p. 273]

At the same time, indiscriminate participation is also crilicised $[\mathrm{M} / 4$, p. 27.5\%. Rather than condemning self-interest (c.g. [K2, p. 2]), the observed phenomenon might be explatined simply als an aspecl of ragnentilin. In other words, the multiplier effects of expendinure are low hecausc economic linkages are weak.

The lack of any multiplier process emanating from foreign aid expendilure is due particular consideration in this regard. Foreign aid whether it is actually used for investment expenditure or syphoned off into private consumptirn expenditure has no multiplier effect simply because in both cases imports increase by the amount of foreign aid with no parallel increase in exports. In the case of expenditure on capitis gouds the investment has no direct income generating effect within the country. There in, however. an indirect generating effect within the country. previuusly unemployed, is employed to install or that domlestic labour, On lle wher hand, lised 11 import luxury consumer goods. llic gencral applicabilitysumer goods. In any case, strong doubt is to cionom model to underdeveloned Tile diuspos expressed over two decales ago by Rao [R4].

As be allributed performance of botl private and public industry can market. As this is considered fragmented market, natmely, the capital Chapter VI, it is not discussed in relation to investment as a whole in general belief, stated here by Strauss, that: Perhaps there is no greater stimulus to industrial development than credit
a varilithility ... [SI8, p. 3]

(Mil mipltt go further than this to say that there is probably no greater stimulus lo efficion industrial and other types of econonic development than an ellicient, unilied capital market. It is clearly market imperfection which 111 the one hand results in miniscule institutional imperfection providel lior small scille, high yielding on cullural ector and the alequistiong on-farm investment in the agriIndustrial Development Bank when, on the other hand, capital night is thought to be substantial becalusc real returns on finincial assets in Alghomistan have been negative [(i.3. p. 4]. In Afghanistan, as in India:

The assumption that in an undedeseloped economy all savings nay te thought of as a "pool", which is related to the entire national product in somic nore or less dedined manner and may be readily drawn upon either by the $r$ hlic or tlie private sector, in searcely borne out by the facts [S1 : p. 184]

The salme point is made in a more larmal theoretical exposition by Khatkhate $|k 9|$

The modern privale industrial wedor then is anollier fragmented part of the Afighin economy. With the recent introduction of minimum wage legistation, there it, additional incentive for industrialists to withdraw into the urball enclave and build walls belween them and the rest of the conmunity.

In conclusion, neither public nuf proalle sccor approach w industrialisation has atlected the population at large either by oflering a large number of jobs or by providing cheiper products. In fact, as discussed in more detail in Chapler VI development strategy appears to have been one of deliberaltely bringing change and thereliore disruption to as small a number of people als pousible.

The comstruction sector, in which over-invalment hits occurred in so many unlerdeveloped countries, has grown apace in Afghanistan. As expected, inversment in this traditional outlet for urban satvings yields low reiurus. In a recent survey of finance in this sector, the point was made that the proor were much beller all renling than borrowing money (o build a humse because market interest ralles were so high and rents so low that the latter were less than one-cighth of the cost of borrowing the necessary funds to build [KI. pP. 13-14]. This is a dramatic illustration of a fragmented capital market, given the evidence that large amounts of money are funnelled into the construction sector in which even allowing for cilpulal appreciallun expected reluums are liar below the murket interest alle. (In the oller hilnd, the sitme study produced evidence (1) suggest that funds borrowed alt market rates to linance notor calr purchases fior use as laxis could be uned w productively as 11 enable repayncent within a few months $[K /, p .9]$

\section{iv. Geoperaphic Fras!manturion}

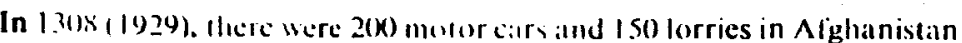
[G22, p. | $\mid 80]$. King Amanullah had himself driven a Rolls Royce from 
Tehrall "1) Kabul at the end of his European tour the previulls year [F9, p. 214|. Six months later it enabled him to escape to Kandahar from Bacha Saqao. Despite appalling road and weather conditions, he reached safety just ahead of the bandit's horsemen [F9, p. 218]. By 1333 (1954) there were 1,350 cars and 4,000 buses and lorries [W3, p. 250]. Internal air services were started in the second half of the 1330s (1950s) [M21, p. 126] But in 1335 (1956), transport facilities were still bad:

Trinsportation is a bottlenck. When northern karakul breeders complain aboul low returns for their lamb skins or when Qandahar consumers reseilt high prices for whent and barley shipned from the suuthwest they can blame the high cost of froight, due to terrible roads annuil freight was hauled by ani, due to terrible roads .... Half the tota [W3, pp. 247-48]

bridges were facilities were primitive. There were no paved roads, bridges were mainly temporary, air transport was practically non-existent and river transport was very limited. The gravel and dirt roads were renilered impassable by any heavy snow or rainfall even teiween majo centres of population. [M22, p. i]

The effects of poor transportation facilities on economic organisation are predictable:

Most of the industrial activities are on a modest scale and are not geared to supply a nationil market. Both the localization and the small scale are due to a lack of integration between various economic regions. of ten thi: 1 not one region may have surplus production ( $O r$ at least unused capacity) for which it has no outlet, while another may suffer from dire shorliges and be forced to import supplementary supplies from abroad. The economic organization of Afghanistan resembles a wide sea dotted with islands of economic activity, each one more or less limited to its own local market, primarily because of inadequate transportation. [W3, p. 162]

Road building in the southern regions of Afghanistan during the late 1330 s (1950s) met with considerable opposition and was one factor contributing to the Kandahar riot of 1339 (1960) [W6, p. 288]. The reasons appear to have been twofold:

The extension of the central government's power into the hitherto atutonomous tribal areas resulted in serious internal revolts. A revolt of Mango tribesmen in the Khost an tribesmen in the Khost was sparked by the government's roadbuilding efforts in the South. Such road construction thrialened the autonomy of the tribe and removed its local livelihood derived from carivan traffic. [R6, p. 160]

By 1352 (1973), caravan trade only flourished in the less accessible areas of Afghanistan such as the mountainous Hazarajat region of central Afghanistan [F3]. The improvements in transport and communication have in fict been motivated primallly by stategic necessities. As mentioned above, these improvements have not been particularly beneficial to the rural community.

The 2,500 kilometres of paved road constructed between 1355 (1956) and 1.351 (1972) have had a striking impact. There have been sharp reductions in transport costs which have had important repercussions on both fureign and domestic trade. Paved roads now connect Afghanistan with Ira.., Pakistan and the U.S.S.R., although ferries still have to be used to cross the Amu Darya (River Oxus). Eltezam calculated that Afghanistan's terms of trade had declined during the second half of the .1330 s (1950s) [E2, pp. 99-100]. H11wever, between 1338 (1959) and 1347 (1968) import prices lell by 40 pir cent. while export prices rose by is per cent. The resulting 80 per cent improvement in the commudity terms of trade was due in considerable part $w$ the fall in transport costs though these are still high (I), pp. 24 and 37). Hansen has estimated that the improvement in incunce terms of trade during the 1340. (1960s) added about one per cent annually to real National Income [U3, p. 38].

A study of the three land locked countries in the region covered by the United Niltions Economic Comnission for Asia and the Far East, Afghanistan, Laos and Nepal, pinpointed the inadequacies in transport. banking, and agricultural productivity as the critical constraints to economic development. In all three countries "rugged topography" is the main licctor inpeding the development of trassportation and the cause of high cast transport [U8. p. 183]. It is of interest to note that this study appeared long before the cross-country analysis of Adelman and Morris [A1; A 2].

The opening up of Aighanistan to the outside world has not only been a result of road improvements. As shown in Chapter VI, foreign aid has been solinued on a large scale over the past two decades which in part has been used to send Afghans abroad for training. Many have not returned It has also resulted in a large number of technical advisors and admin. istrators residing in Nithanistan. There has been a libcralising of the foreign Irade reginc, discussed in chapter VII, which has had an additional impict on exports as seen by the ligures in Tables 2.9 and 2.10.

The effects of improved transport on domestic trade has similarly been striking. The nortl, south and east are all connected by paved roads to Kabul, thus linking all major urbat centres by a day's drive. The impact has been so pervasive that one observer concluded in the mid-1340s (1960s): 
If any sinde sector of the conomy is to be named the mail lever of intensified conomic activity today, it is undoubtedly transport. lievelopment of roads in recent years has lowered cost of haulage. widened the market, made mining of coal and movement of labour easy and protitable, and has created an increacing demand for petroleum .... [(i21, p. 439] Seven years later, lowever, doubt was being voiced as to the unmitigated
henefits hrrught by improved transport because

main construction of feeder roads connecting production celllcrs: to the main trunklines to capitalize on the heavy tinancial outlays have so far neglected. [N3, p. 46]

The result has been to provide a competitive advantage to the movement of agricultural surplus to the major towns and an even greater dis idvantage to its movement into the hinterland where areas of wheal deficit have existed [B 4, p. 7; E2, p. 102]. Indeed, it has been suggested that Operation Help, launched in 1351 (1972) to bring wheat into the areas suffering acute distress after two years of drought, was necessary not because there was insufficient wheat in the country as a whole but rather because ther had been less and less economic incentive for the private sector to transport wheat in the directions [B $14, \mathrm{p}$. 7].

Differentials in wheat prices both on a geographical and temporal hasis indicate fragmentation between regions and over time. Part of the litler hils undoubledly been aggravated by the anti-hoarding legislation. Table 3.1 presents some wheat price data collected in eight provinces on a monthly basis over the past nine years. The interesting aspect of these data is that there has been no region of consistently high or luw prices. The ranking of the provinces on this basis changes from ycar to year. The coetlicients of variation have also lluctuated randomly. The latter is a cleis indication of a fragmented economy. However, in no year during the 1343-1351 (1964-1972) period was the coefficient of variation nearly as high as it was in 1303 (1924), also given in Table 3.3, or even in 1340 (1961):

The mountainous nature of the country has been a serious obstacle to

national economic integration, as indicated by the substantial differences

in prices as between various parts of the country. For instance, in 1961

wheat prices in the most expensive towns were 150 per cent higher than in

the cheapest towns. Thanks to the improvement in transport facilities.

the price differentials fell to about 30 per cent by 1966. [U3, p. 2-4]

Thus, although improved roads have resulted in some reduction in price differentials and have had an important effect in linking up the major urbin markets, there is much to be done before the fragmentary 
leatures still observed are eliminated. In particular, the construction and improvement of minor roads to join small villages to the major roads is vital. Even this will only achieve partial success unless $i t$ also acts as a catalyst to produce greater cohesion within the society.

It has been pointed out that although notionally a centralised Government, there is much local autonomy within each province. This has been a contributory factor in producing fragmentation. The army, however, ensured that secession of the tribal areas has not been a seriot. threat during most of the Musahiban period [G12, p. 2; R6, pp. 160-k6]. Some movement in the direction of political integration, compared to the heterogeneous tribal society of 1311 (1932) [T3, p. II], has taken place. Nevertheless, change in the opposite direction has also been detected:

Increased oducational opportunities and literacy, plus an improved infrastruc: ure (radio, telephone, telegraph, roads, internal airfields, airports) have nol, as many people predicted, furthered the creation of an Afghan nation-state, but have initially intensified regional and tribal schisms. [D9, p. 277]

Communication within the Government has been so pour as to have produced a fragmented Government:

As a result of missing information flow, each province applies its own techniques and procedures for tax collection .... Even within the precincts of one department or an euthority the communication is unsatisfactory

The consequence is administrative confusion. [!1, pp. 15-16]

Poor information channels have also been observed in the commercial field :

Market inforntation on prices and supplies reaches producers and consunters too late or in garbled form, if disseminated at all. But even if the interchange of commercial information were more efficient, 1 " e costly and slow means of transport would make it difficult for supply to adjust to conmercial intelligence. [W], p. 275]

In conclusion, all means of communications, whether it be in the form of transport, price reports or Government directives, are still so limited that the elfect is to maintain the archipelago-like structure of the economy. It was Adan. Smith who stressed the twin notions of division of labour and economies of scale. Market size, however, is the essential determinant of the benetits which can be reaped from their application. There is considerable room for expanding market size in Afghanistan. The transport factor is still therefore one of the critical constraints to economic growth in that it contributes to the low development potential for Aighanistan shown in the Adelman-Morris study [A2]. v. Genrrulisation and Explanation of Fragmentation

Fragnentation is not unique to the Afghan economy. Recently, a generalised description of this phenonenon has been put forward by McKinnon [M?]. The distance between economic units, which has been illustrated above in the case of Afghanistan, is viewed by McKinnon in terms of price differentials:

The economy is "fragmented" in the sense that firms and households are so isnlated that they face different eflective prices for land, labor, capital. and produced commodities and do not have access to the same technologis:s. [M7, p. S]

The effect of a wide scatter in prices of the same product is that any one of these has low probubility of being a real indicator of economic scarcity. Because some governments have pereeived this, they have often intervened to manipulate market prices in various ways in attempts to persuade the privite sector to take up what is assumed to be socially profitable investment opportunities. The result has been greater fragmentation:

Consequently, the market mechanism has become no better, and perhaps even 'orse, as an indicator of social advantage.

Modern fragmentation, therefore, has been largely the result of government policy and goes beyond the old distincition between the export enclave and the traditional subsistence sector. One manifestation is the often-noted existence of small houschold enterprises and large corporate firnis--ull producing similar products with different factor proportices and very different levels of technological efficiency. Continuing mechanias. tiun on fiums and in factories in the presence of heavy rural and urbas? utemployment is another. Excess plant and equipment with underutilized cannacity are commonly found in economies that are reputed to be short of capital and that do suffer from specitic bottlenecks .... While tangible land and capital are badly used, fragmentation in the growth and use of human capilal can be more serious and no less visible. [M], pI. $6-7]$

In M:Kinnons sheory, the critical aspect of fragmentation from the viewpuint of economic develupment lies in the fragmented capital market:

It is hypothesized here that fragmentation in the capital market-endemic in the underdeveloped environment without carefully considered public policy causes the misuse of labor and land, suppresses entrepreneurial development, and condemns important sectors of the economy to inferior technologies .... The resulting dispersion in real rates of return reflects the misallocation of existing capital and represses new accumulation. [M7, pp. 8 and II] 
Examples of these effects in Afghanistan are given in Chapter VI. McKinnon further suggests that the unification of the capital market is a prerequisite for the elimination of other forms of fragmentation [M7, p. 9].

The fragmented capital market which is again reflected in price $\cdot$. isparity, in this case taking the form of wide dispersion in the availability and cost of capital, facing different sections of the population misallocates investihle funds. Therefore, economic development is impeded not only by fragmented product markets but more seriously by fragmented capital markets. The correct prescription in all cases is the improvement rather than the circumvention of the market mechanism. Prices must be made to refiect economic scarcity and not dismissed or ignored because they d" not reflect true scarcity when markets are fragmented.

Having examined the fragmented $\mathrm{Af}_{\mathrm{g}}$ han economy from threc stind. points and put forward McKinnon's description and analysis of the phenomenon, a fundamental cause can now he suggested. It springs fron the lack or inadequate use of modern information systems in Afghanistun and other underdeveloped countries. It would seem that information channels in a traditional society are ill-suited and rarely uscd to convey economic information necessary for business decision making.

The rural population in Afghanistan shuns contact with the outside world hecause, in the past, most encounters have been unsatisfactory. This tends to perpetuate

.. the "inn'ard-looking" society, into which men and women are born into a set of answers. In the pluralistic ultmen men and women are born a man is born into a given question opens a questions, but he finds that the answer to any given question opens a Pandora's Box of other questions as the halftruths of tomorrow replace the half-truths of today.

Therefore, developing and developed societies have polar scales of values, attitudes and time, and these must be altered as well as technology, in order to bring about permanent changes in a socicty. For cxample woman dies because of a jinn (or the will of Allah) instead of childbed lever, the introduction of public health measures alone will help but litlle. If a tractor or a truck runs because of the will of Allah instead of preventive and corrective maintenance breakdown renders In all inward-looking cannot the tolerated. For any questions asked, subsistence level, dissidence cannors the answers are known and parroted from generation to peneration. [DII, pp. 17-18]

This would also seem to be the case in the political field:

There is relatively limited articulation of policy views by professional, occupational, sectoral, or aligned economic interest groups since the mechanisms and channels for articulation frequently follow tribal lines, or other lines where the more obvious economic group interests are sub- sumcd by other interests. The poor articulation stems from a lack of adequate comprehension and cohesion of class interest within the more numerous classes, its well as from a lack of discussion processes from which leaders and spokesmen can emerge. There has been little or no tendency io encourage such articulition through the encouragement of social intercourse. [N3, pp. 3-4]

Given that change itself in, for example, the lack of social, political and economic mobility [DII], is alien to traditional societies, information is not sought on matters relating to ilternative uses of scarce resources. Nor are the information channels suitable for conveying such data:

Afuhinistan's stratilualion has teen based almost solely on the ascriptive nowlel . . This creales a lach of willingness to act on independent judgnocnt. Hae right questions are not ashed and the right answers are not ohtinimed. (N.I. D. 5]

This would explain the random narure of wheat price differentials even betwe'll markels with g'ond transportation links. The latter are not used because infirmation han not been received or acted upon which would indicate profitable haulage activitics.

The what price data which exist have heen collected by branch employew of Da Alghanistan Bank. One might hazard a guess that the procedure was instituted because either a foreign advisor or an Afghan returning from abroad recommended it. In any case, little use has been made of them and there is no demand for such information from private husinessumen. Given that over 90 per cent of the population cannot read or writc. printed market information can of necessity reach only a few. Furthermurc, the existence of threc major language groups divided into some ten sub-fimilies and further into dialects in different regions of the country in an obvious constraint to information flow.

In the critical capitil market, the sitme information problem exists. McKinnun makes the general statement that:

Rciishle information on any one contimplated loan or investment may be costly, relative to its size, for outsiders to obtain. Repayment records are not well established, and miany units operate with little liquidity. The fear of bankruptcy or default --which hardly enters at all into conventional uncertainty theory-pervades the underdeveloped economy. [M7, p. 18]

But this does not go far enough. Banking practices in many underdeveloped countries are typitied by the absence of any attempts at obtaining information to make rational loan decisions. These are more often made on the basis of non-economic criteria such as the social stat us of the potential borruwer and his personial relationship to the banker. Information 
necessary for loan appraisals on economic criteria does not exist in Afghanistan because not only is it expensive to provide but also there has been little demand for it.

Accepting the Adelman-Morris finding that finanrial development is one of five critical determinants of development potential and McKinnon's explanation of why this is so leads to the recommendation that considerable development effort should be directed towards improving the capital market as well as the road network. An improved capital market is a necessary condition for widespread improvement in agricultural productivity. Financial development, in turn, has to start hy changing the traditional information system and teaching borrowers and lenders how to use newly provided information for business decision making. It is not sufficient in a country like Afghanistan simply to remove the constraints which may in part have been imposed hy the Government. This is necessary but not sufficient. In addition, non-traditional information systems must be created and their use encouraged through education. Where the former is provided but not the latter, the whealt price example above has shown that it will not necessarily be used. The important aspects of a programme of financial development for Afgh inistan and direct benefits which can be expected therefrom are outlined in Chapter VIII below. Here, it has simply been the aim to describe and explain the underlying cause of this particular critical constraint to development hy placing it in the context of the wider phenomenon of a frigmented economy.

\section{Bazuar Finance}

\section{APpendix}

With the exception of responder.ts in Lashkar Gah, almost all respondents in the survey described in the body of this chapter indicated that credit was more difficult to obtain and was more expensive in 1351 (1972) than it had been ten years previously. The reasons given for this phenomenon varied but increased demand for funds, reduced supply of idle money, decline in trustworthiness and abandonment of religion were the more popular explanations. Lashkar Gah is in the centre of the Helmand Valley and many private pockets have been well lined with funds allocited wi) the Heimand project. Thus, it is not surprising to find credit conditions there easier than elsewhere.

Rising interest rates are a normal concomitant to conditions of economic boom [L5, p. 505]. This finding is therefore consistent with the conclusion that business conditions in the bazaar have generally improved over the piast decade. The reported rates of interest, however, varied widely hol so much as a function of region but of credit worthiness of the borrower. Well-t $\mathrm{n}$-do businessmed all over the country mentioned rates between one and two per cent per month, whereas small artisans, tena farmers and shopkecpers were reported to pay up to 30 per cent per mon: the most comnonly quoted figure however being five per cent. Almost the respondents had no expectations of increasing prices in the futu Hence, the rise in reported interist rites does appear to represent increase in real as opposed simply to nominal rates.

At the top of the scale a slight regional disparity may exist, wa businessmen in kiabul able to obtiin finds somewhat cheaper than the. counterparts in the provinces. ('redit sectmed most expensive in Faizab: the tuwn furthest from both the asphatt road and (by time and $c$. Kubul sinch regionul disparity is predictuble given a banking sy which chatnnels all its funds into the head oflices [L7].

Infirmation on credit conditions tin years ago cannot be expected to be as reliable as infirmation on the present situation. Nevertheless, appeats that the prime rate win probiably only a few percentage poin lower in 1.341 (1962) than it was in 1.351 (1972): bank rates have remained constant. However, when respondents stated that the rate of interest now was $l(k)$ per cent per annum they usually reported a rate of 50 per cent for ten ycars ago. Rattes above 100 per cent per a nnun were considerably less than half their present level then. This differential effect is also a predictible concomitant to a period of tight money. A differentially greatter increase in the cost of "low-salety-factor" loans occurs because the expected profitability of the project being financed is reduced, the stability of the expected rate of profit is lower and leverage tends to be higher on these projects during such cyclical phases [G23, p. 836].

The credit squeeze which existed in Afghanistan in 1351 (1972) suggests that a new business outlook has been developing throughout the country. Respondents frequently explained the increase in interest rates by the fact that people no longer held idle cish ballances to the extent they did ten years atgo. Insteid, it was reported, money is now re-invested in stocks or new business ventures or otherwise employed. Since the differential between bank and nom-bank interest rates has widened, it can be assumed that the allocation of resources amongst different uses has become less rather than more eflicient.

In response to questions on the number of professional moneylenders in the respondent's town and province, answers indicated that most towns contained 50 to 100 , with about ten times that number in each 
province. Quite predictably, the larger the town, the larger the $n$ i mber of moneylenders estimated by respondents. Many, however, admitted that they did not know how many such individuals lived in their town and/or province. Some of the more religious respondents denied the existence of this occupation in Afghanistan.

In the abeence of a customary bank chequing system, the only way of transferrinc money between one town and another through the banks has been by telegraphic transfer which is expensive, complicated and not totally reliable. It is not surprising, therefore, to discover that a traditional financial instrument, the hawala, is commonly used in licu of a cheque drawn on a bank account, to transfer funds between towns as an alternitive to carrying cash. The hawala is a simple draft requesting a trading associate in another locality to pay the bearer a specified sum of money. A facsimile of a typical hawala is shown in Figure 3.1 with a translation underneath. Hawalas are used by many medium and large scale traders and shopkeepers to settle dobts in other towns between regular trading partners. Small scale traders and others can buy hawalas when they do not want to carry large amounts of money when travelling to purchase stock, etc.

ERONT

BACK

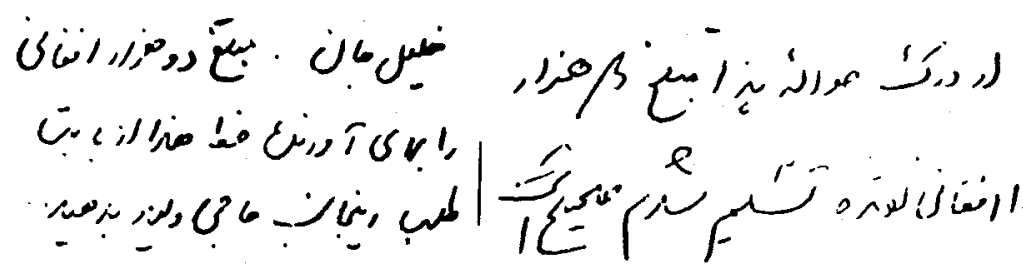

$|r o| / \Lambda / \wedge$
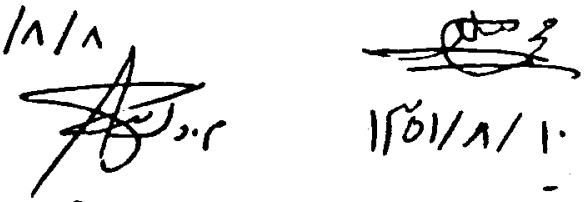

Dear Khalil,

Give the sum of Afs 2,000 to the

bearer of this letter from my account.

Haji Walid

8.8.1351 (Signature)
Through this hawala,

I have received Afs 2,000 in cash. It is correct.

(Signature)

10.8.1351

Hawalas and their counterpart in India and Pakistan, hundis, are commonly used in foreign trade, particularly with India, Iran and Pakistan. Thice is a slight difference in the form of hundis used in AfghanIndian trade, since the transfer of funds in this way is illegal in India. To avoid detection such hundis make use of code names in the form of fruits and vegetables to denote currencies and quantities. In all other respects they rescinble the haviala illustrated in Figure 3. :

Hassalas and hundis have the same disadvantage as that of bilateral trade in that balance must ultimately be achieved between each pair of traders drawing drafts on one another. A bank cheque system has the advantige of multilateral trade in that only an overall balance is required.

Fiz. 3.I. A Typtcal Hawala (Endorsed) 


\section{CHAPTER FOUR}

\section{RESOURCE MOBILISATION UNDER THI} DEVELOPMENT PLANS

\section{i. Financial, Fiscal and Foreign Sectors in Resource Mobilisation}

Development expenditure can be financed from domestic resource mobilisation through the financial sector and/or the fiscal syste: as well as from a deficit on current account in international trade. The cxtent to which domestic resource mobilisation is used in preference to foreign aid is important for two reasons. First, growth in the real volume of domestic credit is an indicator of financial development, one of the critical factors determining development potential. Thus, a rapidly expanding ieal volume of domestic credit will, ceteris parihu, not only provide resources for development expenditure but will also indicate high prospect development potential. Second, domestic resource mobilisation through the fiscal system too will be an indicator of development potential as well as provide funds for investment expenditure. This alcts as an indicutor because it suggests not only that there is a real commitment hy a country's leadership to economic development but also, under a great variety of political systems, an acceptance of higher taxes by the population at large as a necessary sacrifice for development.

Thus, the effectiveness of a country's development programme will be determined not only by the magnitude of investment in relation to Gross National Product (GNP) but also by the method in which it is financed. A priori, one can conclude that a development programme, no matter how large, which is predominantly financed by foreign aid will not result in a high rate of growth. This is because low levels of domestic resource mobilisation, irrespective of per capita income, indicate low development potential.

Heavy reliance on foreign aid when this indicates lack of commitment to and acceptance of development has several disadvantages from the recipient's point of view [G16; Ll; M7, Chapter 11]. First, the low development potential which beavy retiance indicates results in small if not negligible return from development expenditure leading eventually to a debt problem to the extent that aid received has been provided in loan form. The debt problem occurs despite concessionary terms whenever returns to foreign aid financed projects fail to exceed the interest rate on the loan to come significant degree. But it is precisely when foreign aid is used to a predominant extent indicating low development potential that returns will be low.

The second disadvantage to the recipient in using foreign aid as a substitute for domestic resource mobilisation lies in the fact that foreign aid inflows which sustain higher imports than exports actually penalise the tradible goods sector of the economy consisting both of export and import substitution enterprise [M], p. 160]. Under such cir?umstances, the provision of extra foreign exchange ensures that the domestic currency is over-valued in comparison to its equilibrium market rate in the absence wl foreign exchange supplying foreign aid. This, in turn, reduces earnings in domestic currency from exports and makes inports cheaper, thereby lowering prices of import substilutes. The importance of export promotion for development is discussed in Chapter VII. Cohen has shown empirically that extra exports are a more important determinant of economic growth than foreign aid [(') 7$]$. To the extent that the latter depresise the level of the former growth is, therefore, retarded. As suggestid in Chapter III. the tride imbalance created by foreign aid inflow produces a leat in the circular how of income of the same magnitude as lile injection. There is, therefire, no multiplier effect from foreign aid finalnced investment.

Finally, excessive reliance on foreign aid may shorten the period over which assistance will be forthcoming. Nut only will donors be disillusioned by the linw rate of growth their perhaps sizable contributions have produced, hut they may also become reluctant to allow the recipient country's leverage to exceed a given multiple of net worth. This can best be viewed from the traditional halance sheet analysis used by a bank contemplating a loan to a business tirm. When net worth remains constant, i.e. domestic or internal savings are zero, and borrowing conlinues, leverage increases as do risks to creditors. They then become reluctinl to offer new luans which wi!l increase their own risk even further. It can, of course, be argued that aid should not be looked at in banking terms.

Afghinistan has received one of the highest levels of technical assistance on a per capita hasis of any country in the world [B31, p. 158]. Indeed, the competition in the provision of aid between the U.S.A. and the U.S.S.R. during the lalle 1330s (1950s) has led Dupree to use the phrase "an economic Korea" to describe the situation in Afghanistan at that lime [D 10, Chapter 23]. The difference in the effects of foreign aid in these two countries could not, of course, have been greater. Afghanistan has 
relied heavily on foreign aid for financing the post-war development programme. The result of this has been all the disadvantages enumerated above. The remainder of this chapter examines the Afghan development programme since the First Plan of 1335 (1956)

\section{ii. The Five Year Development Plans}

Afghanistan has a relatively long history of development planning dating back to Abdul Majid Zabuli's plan for economic recovery which he prepared in three months in 1308 (1930) [B7].

The seven-yeat Over-all Economic Development Plan (1932.31-19.38/34) reformed the currency, introduced corporate business organimation. encouraged private investment in textiles, sugar and leather-goods manufacture. but did little for transport or power. [US, p. 58]

The first plan which fits, though imperfectly, the present day conception of an economic development plan was that prepared in 1328 (1949). It was not however formally adopted by the Government [U5, p. 58]. It is with the four five year plans starting with the First Plan of $1335(1956)$ that this

Table 4.1

Planned Financing of Development Expenditure 1335-1355 (Millions of Afghanis)

\begin{tabular}{|c|c|c|c|c|}
\hline & $\begin{array}{l}\text { First Plan } \\
\text { (335-1339 } \\
\text { (13334 Prices) }\end{array}$ & $\begin{array}{l}\text { Second Plan } \\
\text { (1.341-1345 } \\
\text { (1341) Prices) }\end{array}$ & $\begin{array}{l}\text { Third Plan } \\
\text { 1346-1350 } \\
\text { (1345 Prices) }\end{array}$ & $\begin{array}{l}\text { Fourth Plan } \\
\text { 1.351-1355 } \\
\text { (1.351) Prices) }\end{array}$ \\
\hline $\begin{array}{l}\text { Development Expenditure } \\
\text { Public Sector } \\
\text { Privale Sictor }\end{array}$ & $\begin{array}{r}10,499 \\
10,499 \\
0\end{array}$ & $\begin{array}{r}39,369 \\
19,100 \\
269\end{array}$ & $\begin{array}{r}13,000 \\
31,000 \\
2,000\end{array}$ & $\begin{array}{r}30,930 \\
27,730 \\
3,200\end{array}$ \\
\hline $\begin{array}{l}\text { Pinance of Public Sector } \\
\text { Budget current }\end{array}$ & $10,499$. & 39.100 & 31,000 & 27,730 \\
\hline $\begin{array}{l}\text { Account Surplus } \\
\text { Borrowing from }\end{array}$ & 2,750 & 3,000 & 6.600 & 6,570 \\
\hline $\begin{array}{l}\text { Da Afghanielan Bank } \\
\text { Commodity Aacistance } \\
\text { Foreign Project Aid }\end{array}$ & $\begin{array}{r}241 \\
7.508\end{array}$ & $\begin{array}{r}3,583 \\
5,818 \\
26,699\end{array}$ & $\begin{array}{r}1,200 \\
4,200 \\
19,000\end{array}$ & $\begin{array}{r}1.720 \\
0,100 \\
13,340\end{array}$ \\
\hline
\end{tabular}

Note: All foreign exchange expenditure and receipts have been converted throughout at Afs $45=-\$ 1$.

Source: Ministry of Planning. First Five Year Plan 1956/57-1961/62 (Kabul: Ministry of Planning. mimeo, 1956), pp. 312-20; Ministry of Planning. Sertond ive-Year Plan 1341-45 (Kabul: Ministry of Planning, 1342), pp. 11 and 13; Ministry of Planning The Third Five Year Ecomomic and Social Plan of A/ghanistan 1967-1971 (Kabul: Ministry of Planning. 1967), pp. 21 and 48; Ministry of Planning, Draft Fourth Five Year National Development Plan for Aghonistan 135/-1355 (Kabul: United Nations Development Programme, mimeo, July 1973), p. 45. 
chapter is concerned. The scope, however, is restricted to a survey of resource mobilisation in macroconomic terms under these plans. For details on all other aspects of the plans, the interested reader is referred to [J1; M14; M15; M16; M17; M18; N3; S4].

Planned development expenditure and its sources of finance are shown in Tables 4.1 and 4.2. The outcome of the first three plans is given in Table 4.3. Comparing figures in Table 4.2 and 4.3, a number of interesting points emerge. The First Plan saw more than the planned level of investment as a result of a greater forejen aid inflow than had been anticipated. However, liscall sivings contributed less than half the planned level of investible lubds and delicit finalle: was nearly six times that which had been plathred, highlighting the absence of any lialancial planning.

The second Plan, far more ambitious than the first Plan, reabised only 55 per ent of planned investment with shortfalls in all sources finance. particularly in the expected level of Commodity Assistance. Public sectur savings only reached t2 per cent of the planned level.

The Third Plan experienced the same shortfall in realised over planned investnent as had the Second Plan, despite its more modest scope. Fureign project aid obtained was less than half the planned level. Public sector silvings reached only half the level of the Second Plan and less than one-third of the planned level. This was offsct temporarily, as in the First Plan, by deficit finance of over 21 tines the level planned.

The thrce five year plans saw realisation of less than two-thirds of tre planned level of investment matched hy the same shortfall in foreign a: Public sectur savings failed to reach even half the planned amount th leading tlie Government to use delicit finance at a level greater thin planned aind to an excessive extent from the macroeconomic and longe? term viewpoints.

The planning period can be analysed not only through an examination of diverpences of actual from planned silvings and investment but also Ihrough comparisons of the latter with Gross National Product (GNP) magniludes. This is shown in Table 4.4. The weak fiscill effort, discussed at length in Chapter VI, is particularly apparent irom these figures. Public sector savings averaged less than wne per cent of GNP during the planning period and financed only 8.6 per cent of total investment. There was a noticeable decline in even this small level of savings in the Third Plan.

Privilfe sectur savings took the form almost entirely of forced financial savings resulting from the increase in the stock of money. The inllation tax which produced forced savings averaged 4.6 per cent 


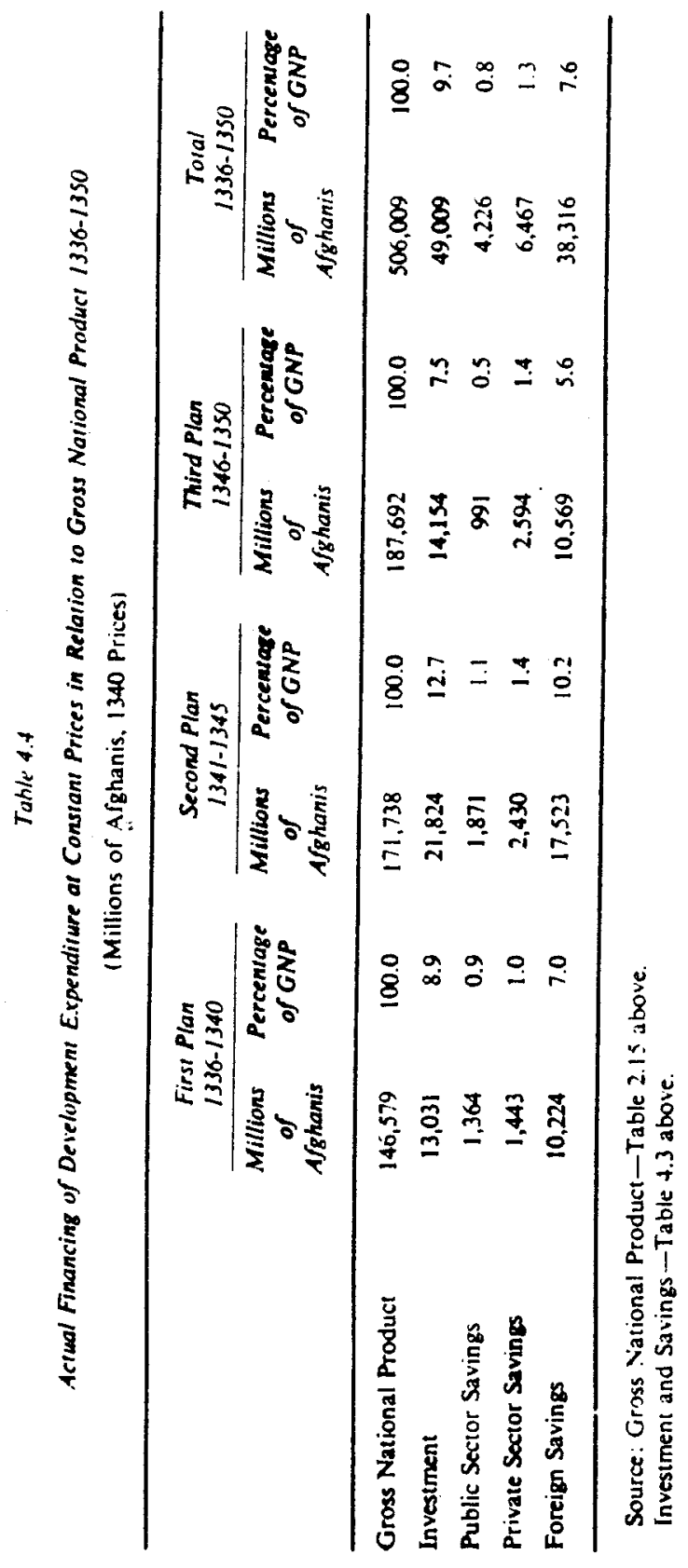

annually between 1336 (14.57) and 1.350 (1971). Over the three five year plans, thi liax on money-holding averaiged -...3.4, 13.2 and 4.8 per cent annually, tespectively. Because no tinancial development occurred partly attributahle to an annual average rate of intlation over the decade $1340-1350(1961-1971)$ or 8.9 per cent considerably above the tine deposit rate of 6 per cent, thus giving all types of money holding negative returns. this source of funds has not been large, averaging only 1.3 per cent of GNP over the period of the three tive year plans.

The interdependence between tinancial and fiscal savings has been stressed hy Shaw:

Strong comphasis is Jue to the interdependence of fiscal and monetary policy A weak fiscal effort duritig 1341-1350)(1962-1971) forced Afghanpolicy. A weak fiscal effort durimg $1341-1350$ (1) istan in the weak tiscal effort level inflation. The taxaton of meade. Algharistan teetered on the edge weiter still. By the end of this decade. Alghanistan teetered on the edge of a process that would close the flow from both iscal a copment. Solirices of

It has been foreign savings in the firm of commodity and project assistance that provided the largest srurce of funds lor investment expenditure over this period. For various reasons, this source began to decline during the Second Plan and not much hope can be held out for any sizatie increase in the future without a much higher proportion of investible funds coming from domestic resource mobilisation. As Shaw points ...t1:

Several lacturs may account for the decline in foreign savings. One factor muss be that Afghanistan's own tiscal and financial efforts were lax. If, acestis in the country's own estimation. its development did not deserve a substantial input of domestic savings. why should savers elsewhere take up the slack? Another factor must be the accelerating rise in Arghanistion's forciun Jebts for accruing interest and amortization on the national balatice sheet, debt to the outside world has been rising relative to the n:titinal cquity, and that is always the warning signal that makes creditors bach ilwily from new commitments. [S/I, p. 9]

Thus, interdependence exists nol only hetween private sector financial avings and public sector total hivings hut also between both these channel, of domestic resource mobilisittion and foreign sivings. That the decline in public sector savings has heen accompanied by a decrease in forced private sector tinancial silvings over the Third Plan was predictable. Neither caln it be a surprise to lind that foreign savings have fallen too. In sim: 
Processes of drawing savings to investment in Afghanistan appeared to three that have been discureed here the and of 1350 (1972). Fach of the weih meas in any one is contagious for the have been regressing. and savings give a signal ior contagious for the others. Declining real fiscal are give a signal tor more inflation in the financial process, and both are deterrents to savings inflow from abroad. [S11, p. 10]

iii. Investment and Growth during the Three Five Year Development Plans

An attempt can be made to analyse the macroeconomic impact of the development pians through the simple Harrod-Domar growth model (c.g. [A 19. pp. 197-206]). Aesuming an elastic supply of libour, the production .unction or the multiplier-accelerator version can be used to express the rate of growth in GNP as a function of the incremental capital, (utput ratio (ICOR) and the proportion of investment in GNP.

$$
\frac{1}{Y} \cdot \begin{array}{ll}
d Y & i \\
d t & i
\end{array}
$$

where $Y$ is GNP measured at constant prices, $i$ the proportion of investment in GNP, and $v$ the ICOR.

Despite deficiencies in the investment and savings data presented in Titble 4.5, five year average annual ICORs have been calculated for the period 1331-1351 (1952-1972) and are given in Table 4.6. For the three plans. average annual growth rates were $3.3,3.6$ and 0.9 per cent, respectively. The percentages of investment in GNP for the same three periuds were II . , 16.0 and 10.8 per cent. The resulting ICORs follow: $3.4,4.5$ and 11.5. respectively. If a lag of a year between investment outlay and initial productivity is assumed, the relevant ICORs are 2.6, 4.6 and 12.6 . The growth rate ruse only marginally during the Second Plin despite considerable increase in the proportion of investment in (iNP beciuse the ICOR was much higher. The lowest growth rate which occurred during the Third Plan was caused by the lowest investment ratio and the highest II OR. The latter has been considerably more volatile thin the former.

The ICOR is meaśured as a residual and simply incorporatcs all influences on the growth rate other than the proportion of investment in GNP. It does not therefore exclusively measure investment efficiency. Nevertheless, when ICOR accelerates to the extent it has in Afghanistan over the period of the three fivo year plans, an assumption of economic mismanilgement must be made. In Chapter VI, further evidence is introduced to support the conclusion that much investment during this period

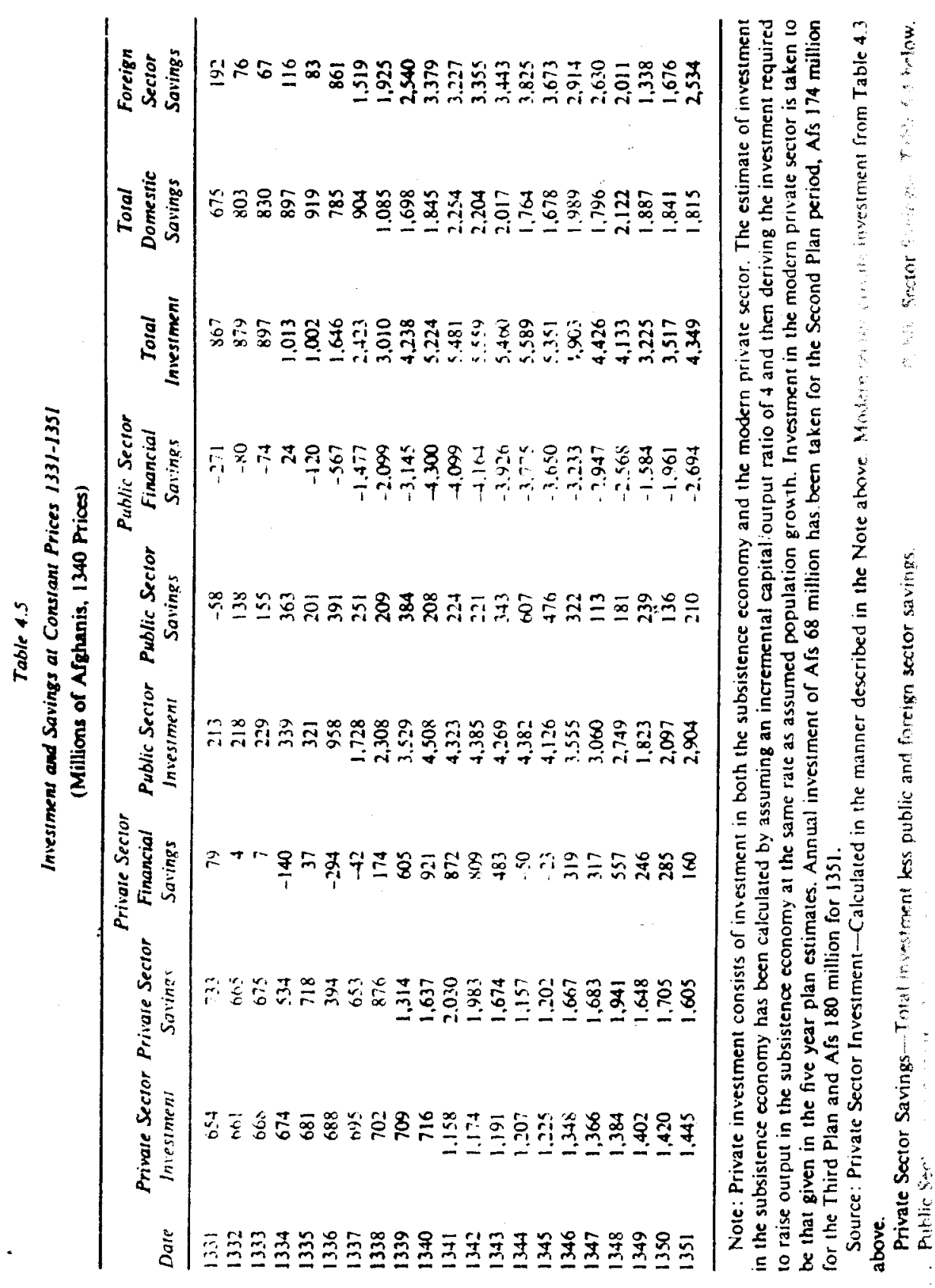


has yiclued neither significant direct nor indirect returns. Below, an examinition of the planning process leads to the conclusion that if investment was inefficient, part of the blame lies with the increasingly inadequate planning process.

Table 4.6

Fivi Year Aterage Annual Incremental Capitul/Output Ratios 1331-135I

\begin{tabular}{|c|c|c|c|c|c|c|}
\hline Dase & $\begin{array}{l}\text { Five Year } \\
\text { Total GNP } \\
\text { (Millions of } \\
\text { Afghanis) }\end{array}$ & $\begin{array}{c}\text { Fiie Year } \\
\text { Total } \\
\text { Investment } \\
\text { ( Milllions } \\
\text { of Afghanis) }\end{array}$ & $\begin{array}{l}\text { Five Year } \\
\text { Aiverage } \\
\text { Percentage } \\
\text { Invesiment } \\
\text { in GNP }\end{array}$ & $\begin{array}{l}\text { Five Year } \\
\text { Average } \\
\text { Percentage } \\
\text { Graw'th } \\
\text { in GNP }\end{array}$ & $\mathrm{ICOR}_{t}$ & $\left.I C O R_{t}\right)$ \\
\hline $1331-35$ & 124,680 & 4,658 & 3.74 & 2.61 & 1.43 & - \\
\hline $1332 \cdot 36$ & $128,67.5$ & 5,437 & 4.23 & 3.14 & 1.35 & 1.19 \\
\hline 13.13.17 & 131.674 & 6.481 & 5.30 & 2.32 & 2.28 & 1.82 \\
\hline 1.334 .38 & 136,236 & 9,094 & 6.68 & 3.50 & 1.91 & 1.51 \\
\hline $1335-39$ & 141,867 & 12,319 & 8.68 & 4.09 & 2.12 & 1.63 \\
\hline $13.36-40$ & 146.574 & 16.541 & 11.28 & 3.34 & 3.38 & 2.60 \\
\hline$|3.17-4|$ & 149.205 & 20,376 & 13.66 & 1.82 & 7.51 & 6. 20 \\
\hline $1.318-42$ & 155,550 & 23.512 & 15.12 & 4.21 & $\therefore 54$ & 3.24 \\
\hline $1.334-43$ & 161,355 & 25,962 & 16.09 & 3.73 & 4.31 & 4.05 \\
\hline $1340-44$ & 165,762 & 27,313 & 16.48 & 2.69 & 6.13 & 5.98 \\
\hline $1.341-45$ & 171.738 & 27,440 & 15.98 & 3.58 & 4.46 & 4.60 \\
\hline $1342-46$ & 178,820 & 26.862 & 15.02 & 4.26 & 3.53 & 3.75 \\
\hline $1343-47$ & 181,888 & 25.729 & 14.15 & 1.74 & 8.13 & 8.63 \\
\hline I 344-48 & 184.287 & 24,402 & 13.24 & 1.35 & 9.81 & 10.48 \\
\hline $1.345-49$ & 185,920 & 22,038 & 11.85 & 0.91 & 13.02 & 14.55 \\
\hline I 346-50 & 187,692 & 20,204 & 10.76 & 0.94 & 11.45 & 12.61 \\
\hline 1.147 .51 & 190.759 & 19,650 & 10.30 & 1.58 & 6.52 & 6.81 \\
\hline
\end{tabular}

Note: IC OR, has been calculated by dividing the five year average percentaco invest:ment in GNP by the five year average annual percentage growth in GNP (annually complounded). ICOR, has been calculated by dividing growth in GNP (anfor one perind by the growth rate fimure for the following period. Thus, investment ligure of 3.74 has been divided by following period. Thus, the 1331-35 3.14 to give 1.19. 3.74 has been divided by the growth rate figure for 1332.36 of 14 to give 1

Source: Ciross National Product-Table 2.15 above.

Invesimini -Table 4.5 above.

The general picture presented above is similar to that given in a recent United Nations' survey conducted by Hansen. During the 1.340 s (1960s) he estimates that the ICOR was over 6 , compared to a ratio of uver 3 for the 13.30s (1950s) [U3, p. 26]. His explanation for the doubling of the ICOR is as follows:

The app: rent reasons for this high capital-output ratio are the building of the infrastructure and the large-scale irrigation projects, in particular the Helmand River Valiey Project, which yielded much less than originally envisated. The develupment projects undertaken during the 1960s consisted II a large extent of modern paved highways connecting the country with the USSR and Pakistan. While the highways linked the major regions of the country, they were not planned entirely on economic grounds and, in any cisc. they cannot yield their full potential until further developments in the economy have taken place. Similarly, the commodity production projects and the electric power generation stations are producing far below full capacity utilization. [U], p. 26)]

On the itssumption that a sustainable incremental ICOR of about 3 could be achieved through a relatively ellicient investment programme, investment in relation to GNP would have to reach 15 per cent for a nodest atunual rate of growth of 5 per cent. Although this investment ratio was reached towards the end of the First and beginning of the Second I'lan, it declined thereafter and ICOR rose rapidly. In the future, a return 1 , the 15 per cent investment ratio is unlikely without a considerably grealcr contribution from domestic savings.

iv. The ('ommirme'nt to and Process of Plunning

The litst Plan was prepared by a planning unit within the Ministry of Finance | N3. p. 9]. The plan was prepared without foreign alsistance

.... alter a series of studies and investigations which have taken into considcration the lack of statistical jata and experience in planning. Withum this data and experience but with the help of God Almighty this plan hils been formulated. [MI4, p. 2]

Although $i$.eign assistance was used in the preparation of subsequent plans, deficiencies in statistical data were as serious a constraint to the Fuurth Plian preparation as they had been to the First Plan.

Deficicncies in planning have arisen not only as a result of over-reliance on forcign aid and insulficient mobilisation of domestic resources, but also as a result of the planning process itself. The absence of cost-benefit analysis, project evaluation and continuous assessment. and project supervision have also been responsible for the poor performance. The results of these lailures have been dexcribed recently as follows:

Some projects were poorly conceived or designed, such as the Kandahar Airnort (U.S.) and the Mahipar power generation project (German), and may never be productive. Others were uverly costly, such as the Balkh textile ntill (French) or involve outdated technology, such as the $\mathrm{Ma}$ zar fertilizer plant (U.S.S.R.), which is still not completed. Most of the factories built in the public sector are operating far below capacity or have sased operations kecause of inadequate availability of raw mattrials (cotton ginning, textile, vegetable oil and sugar mills) and very poor administration and management. [N], p. 47] 
The live year plans have appeared to be more lists of projects for which foreign ass'stance was to be solicited than attempts to lay foundations for overall economic policies. But donors have become disillusioned with such an approach:

Unlike the First and Second Plan pariods, foreign assistance in the Third Plan was primarily in the form of loans. There seemed to be il hardening of lender attitudes and terms during the Third Plan, brought on in part by the lack of economic performance in earlier periods. disappointment in the Afghan revenue effort, lack of sound feasible projects and deep concern over the general abeence of progress and of convincing evidence that improved administration and better performance would be forthcoming. [N3, pp. 100-101]

Despiti strong statements to the contrary in the Fourth Plan [M18. pp. 12-17], probably written by foreign advisors in any case, perliumance does nol indicate that Afghanistan has yet like

.... one country after another come to perceive that the principal sources of rapid growih and development are to be found within its own structure of production, institutions, technology and ways of idaption and functioning. [S1 2, p. 181]

The Ministry of Planning was established in 1335 (19.56) with the Prime Minister holding the portfolio [N3, p. 9]. However, partly as a result of personnel deficiencies, the Ministry never played more than a courdinating role. It has not conducted any project eviluations nor required other ministries and agencies to do so. The administrative constraint was stressed at various times by the Nathan Team which advised the Ministry of Planning throughout the 1340s (1960s):

Afghanistan was and still is one of the most traditional of the less developed countries. Over the years it became increasingly apparent that, if the available domestic and foreign resources were to yield significant results the highest priority and greatest concentration of efforts in Afghanistan had to be focused on the implementation of modern principles of ad. ministration and management and the building of development institutions. [N]. p. 1I]

With this, the German Economic Advisory Group also altached to the Ministry of Planning strongly agrees.

Since the mid-1340s (1960s) the Ministry of Planning appears to have lost authurity and respect, partly because the Prime Minister no longer acted as Minister of Planning and partly because the planning process did not improve:
Ouring the period covering the first thric plans, there appeared to be either stcilly deterioration or no perceptitle improvement in the degree of attention given to plan preparation athd plan execution, in the sorting out and establishment of priorities at high policy levels, in the preparation of more carcefuliy conceived and detailed annual budgets, in the formulation and cooldination of sectoral programs in the operating Ministries and agencies, in project preparation, allu perhaps even more importantly, in the formulation and execution of policy and in the vigor and tirmness with which the nation's development etfort was pursued. [N3, p. 22]

Thus, the question is raised as to the real extent of the commitment to planned cconomic development. Three liactors suggest that it has not been great. First. lla low level of domestic resource mobilisation to finance development expenditure points to low priority to such efforts as does the low achievement ratios of planned investment, a result primarily of low fiscial eflunt. Second, there with heavy reliance not only on fireign aid fo linance planned investmetll hut on foreign advisors to draw up the plans:

Particulatly in the first two plans, ther, was a tendency on the part of Afghans 11 relinquish much of the responsibility for development by permitting the donors considerable latitude in identifying and rinancing projects. This was the result of less than appropriate efforts by Afghan to do their ow'n platnning with the help of advisors .... With the exception of the First Plan, foreigners were depended upon to prepare the first drafts of each plan. [N], pp. 29-30]

There is the serious danger that such dependence has produced a deepening expectation among Afghan politicians, oflicia's and-to a lesser extentordinily citizens that the etfort and expenditure for development is the business of the donors: that development does not require sacrifice or the willingncss to modify the ways and allitudes of the Afghans themselves. [N4. p. 171)

Third has been the declining prestige of the Ministry of Planning, the failure 10 establish the required data collecting procedures and to train capable planners, and the disintegration of the planning process by the end of the Third Plan. The

.... tendency to take the plans less seriously as the years went by .... [N], p. $2 \pi$

combined with the other factors mentioned above, suggests that there has been weitk. it any, commitment to planned economic development. This, in turn, has been a critical constraint to development since it has contributed with the other four Auelman-Murris factors to an extremely limited pusential for development in Afghanistan. 


\section{CHAPTER FIVE}

\section{THE FINANCIAL SECTOR}

\section{i. Introduction}

In 1295 (1916) an American working in Afghanistan noted:

No Afghan would trust his money in a bank, nor would he take paper moncy-except, of course, a merchant who uses and is faniliar with the Indian paper money. Moet of them have Russian notea (whilit with the got for a wong in Kabul during the last ycars of the war). Barats are issued on the treasury for money, and the mirzas pay all salaries in rupees; no Afghan ever receives his pay without the mirza getting i percentuge.
[B/9, p. 285]

Rupees were hauled up from India on donkeys for paly day and hatuled down again to buy commodities on the Indian market. The route through the Khyber Pass was particularly hazardous for these convoys.

The situation which existed only 50 years ago must be borne in mind when examining the developments of the financial system since then. The complete absence of foreign banks (and indeed of any foreigners working in the domestic banks until very recently), the strong religious ant gonism towards the business of banking, the lack of social prerequisites such as a code of business ethics, attitudes favouring cooperative endeavours, mutual trust, etc., and a legal system ill-suited to the task of supporting modern business transactions and enforcing contracts have combined to produce an environment which could hardly have been less conducive to financial de'elopment. Nevertheless, Afghanistan produced one man who not only tried but succeeded in laying the foundations of the present financial system.

The history of banking in Afghan:stan is intimately related to the activities of Abdul Majid Zabuli who founded the first joint-stock company in Afghanistan in 1303 (1924) together with other associates from Herat to engage in trade with Russia. Between 1304 (1925) and 1308 (1929) Zabuli lived in Moscow as the company's representative. The political riots in 1307 (1928) against Amanullah's reforms and the brief reign of the bandit, Bacha Saqao, 1307-1308 (1929), resulted in severe economic disruption and almost complete cessation of foreign trade [G 15, pp. 263-75; G21, p. 424]
The political upheaval and military contlict that took place in $1929 \mathrm{lod}$ to a flight of capital from the country inustly in the form of yold and silver coins that constituted the only form of money at that time. [M21, p. 182]

Four weeks after Bacha Saqao was overthrown, Zabuli returned to Kabul [B7]. On arrival, he was summoned before the new king, Nadir Shah, and asked to prepare a plan for economic recovery. According to Zabuli, the king told him:

Today we see in our own country export, import, transportation, brokerage and everything else are all done by foreigners; only shopkeeping is left for our neople. This situation is intolerable and we must have our own nationals engilled in all these aclivities throughout the country. We must find a way to cill ofl the hands at llac forcigicers. [B7]

Zabuli stayed in Kabul for three months to prepare an economic plan which included a scheme to establish a bank. To this proposal, the Minister of Justice. Who had been directed to enforce Islamic law, strongly objected [H7; (j15, p. 295]. Nadir Shah, who was well aware of the religious opposition to a similar plan of Amanullah, also opposed the scheme, although he supported the rest of Zabuli's plan [B7]. The plan was completed by the end of $1308(1930)$ and Zabuli left Afghanistan to run the Berlin witice of his trading company. Meanwhile, the Shirkat-iSahami-i-Atghan had been established as a trading company rather than as the bank Zabuli had proposed. Permission to establish the joint-stock company, Shirkat-i-Sahami-i-Afghan, (1) regulate foreign trade and develop the donestic economy was granted by Nadir Shah in 1309 (1930) to the group of merchants from Herat led by $A$ bdul Majid Zabuli. As part of the arrangement, they were given the monopoly for sugar, petrol and motor velicic imports and cotton, karakul and wool exports $[B 7 ; C 9$, p. 411; M27, p. 1]. The Shirkat-i-Silhani-i-Afghan was founded with a capital of Afs 2.5 million, of which Afs 1.7 million was subscribed by the Government [M21, p. 182]. The company opened for business in the following yea. [G15, p. 316].

In 1310 (1931) after Zabuli's economic plan had run into difficulties, he was asked (1) return to Afghanistan. His prescription was once again the foundation of a bank and investment in the northern part of the country. As part uf his conditions for remaining in Afghanistan, he required Government support for his schene to establish the bank. Zabuli returned to Afgharistan lowards the end of 1310 (1931) and directed his first efforts to reviving his and Amanullah's stheme to liound a bank which could issue paper currency, provide credit and, above all, form the nucleus for the development of intrepreneurial and managerial talent in the country. The 
vehicle used was the Shirkat-i-Sahami-i-Afghan. Reorganisation took place in 1311 ( 1932) in which the name of the company was changed. "In Saur 1312 (April/May 1933), Bank Millie was established with capital invested by the (iovernment as well as founders of the Bank" [B6, p. 6]. This reorganisition involvod raising the capital to Afs 7.1 million. By 1316 (1937), this figure had been increased by stages through Afs 35 million to Afs 60 million [M21, p. 182]. Thereafter, the Bank's capital was progressively raised to Afs 500 million by 1329 (1950) [C10, p. 39]. There has been $n o$ increase in capital since then and total capital and reserves have risen slowly from Afs 519 million in 1330 (1952) to Afs 839 million in 1350 (1972). al cunsiderathle decline in real terms [B5; BK].

Banh Millie wass something of a hybrid in that its founder had ubtained hoth support and finance from the Government. As in other areas of (iovernulent interest or intervention since 1311 (1932), the relationship was infirmal. The Government appeared to show enthusiasm for economic develupment but no clear views on how this should be achieved. Assisting Bank Millie was just one of several ad hoc measures in this direction.

One of the main difficulties encountered at the beginning was the religious prohibition against interest. The opposition was led by the Minister of Justice. However, an ingenious solution was fnund whereby loans could be made interest free but the borrower obliged to buy a stamp. pule riket (money ticket), to be attached to each repayment receipt thus providing the bank with profit rather than interest, the former not in violation of Islamic law. The term, though not the stamps, is still used.

For the first six years, the success of Bank Millie was dramatic, pirticularly when viewed against the backcloth of the Great Depression.

When people were introduced to the idea of pooling their resources and interests, when representattve money and large-scale commercial credit were introduced and the first resuits obtained, the effect was amazing. During the first six years the Afghan National Bank [English translation of Bank Miltie Afghan] increased its capital one hundredfold. [( 9, p. 4II]

During the 1310s (1930s), Bank Millie's operations expanded rapidly with Government help. The latter consisted of the accedence to requests from the Bank for monopoly concessions and the control uver $f$ 'reign exchange dealings as well as finencial support. In 1314 (1935) Afghanistan adopted a fixed exchange rate and foreign exchange transactions were supervised by Bank Millie [B6, p. 7]. Due, to a deteriorating balance of payments situation thereafter, the Bank recommended tighter exchange control regulatturns. In 1.317 (1936) cilrnings from katrakul exports had to be surrendered to the Baink and importers were obliged to export an equal value of commodities before placing their import orders [O4, pp. 123-33]. Bank Millie was instrumental in an attempt to disband the Kabul money bazaar and did take over at large part of Afghanistan's foreign trade from bazaar dealers. In part, this followed a deliberate policy to break the domination of foreign trade by ethnic minorities (Hindus and Jews) [B7].

The fixed exchange rate system adopted in 1314 (1935) was designed in part to climinate seasonal fluctuations in the rates. Bank Millie agresd (1) huy lixl kupees for Afs 396 and to sell fior Afs 400 ). As a result or a continuous debasenent of the currency, this rate soon overvalued the Afghani and necessitated increasingly stringent exchange contro Responsithe by this time for the country's exchange rate system, the llank supptied all Government requiremients of foreign exchange at the tixed rate frum 1.314 (1935) onwards [M21, p. 182]. A preferential exchange rate for the (iovernment was a feature of the exchange system until 1352 (1973).

Bank Millie assisted the Government with the issue of Treasury currency notes which started in 1.315 (1936). The paper currency was convertible into silver Afghanis at the Bank; initially, soldiers and civil servants who received payment in currency notes immediately converted them into coins. However, after the tirst year silver coins began to be accumulated by the Bank. Within threc years Afs 60 million of Afghan and Iranian coins had been collected. Gold was also used to back the paper currency [B7]. By 1352 (1973), Afghanistan's international liquidity consisted in most part of gold, thus presenting the Government with a sizable windtall profit on the abandonment of the two tier gold system in that year.

Despite problems of trade imbalance in the pre-war period, considerable growth in the volume of both imports and exports took place. The expansion of Alghanistan's loreign trade and level of economic activity during - the Great Depression can to a large extent be attributed to the dynamic and unfettered development of Bank Millic [N5, pp. 60-62]. Activities were wide ranging, though largely dependent on the success of its banking business:

Along with these fundamental measures, the Banke Milli diverted special attencion lowards organizing banking aftairs. It afforded facilities in carrying out financial transactions and executing drafts in the shortest possible time. It of Tered prompt and satisfactory service to customers. The 
Bank also offered facilities in granting loans to traders. II introduced checulues as well as exchange and transfer drafts. All this attracted customers in a wonderful way, enabling fixed deposits and current and deposi accounts to increase considerably within a short period. [B6, Pp. 8-9]

The most important activity of Bank Millie in these years was its involvement and participation in industry. Joint-stock companies were established to engage in trade (cotton, karakul and wool exporting), cotton ginning. oil extracting, sugar refining and textile manuficturing [B6. pp. 9-30]. Between 1311 (1932) and 1313 (1934), 30 joint-stock companies were organised under the auspices of Bank Millie [ $i$ i s. p. 315]. 13y 1317 (1939), the total capital of these subsidiary compinies had reached Afs 292 nillion [04, pp. 123-33]. By 1325 (1947), Baınk Millie held interests in 50 trading and industrial companies :

The same important merchants who held shares in the bank were the majority stockholders of these companies. In addition to a virtual mono poly in the major commodities of the Afghan export-import trade, the Bank-i-Milli and its president, Abdul Majid Zabuli, gained control of most of the industry of the kingdom, both the well-estahlished stateowned enterprises and the budding new firms. [GI5, p. 36.3]

Hank Millie also extended credit, granting loans of all kinds at 12 per cent interest: For example, after it had received the monopoly over motor vehicle imports it exterided credit to purchasers:

The first vehicte owners were people from the Jaji tribe. Vichicles were sold for Afs 12,000 on instalments over 18 months. The Jajis did a great joh and took over the transportation business from the Indians. [B7]

There was, of course, no insurance on the vehicles. appalling roatd conditions and unskilled drivers. Bank Millie contended with the latter problem by establishing a spocial driving school.

The relationship tretween the Bank and the Government during these eitrly years has been described as follows:

It took a government franchice for the establishment of the first successful joint stock company (shirkat) with limited liability for the contributors. This company, Shirkat-i-Ashami, promoted the Bank Melli Afghan ... It not only assumed the position of the government's banker and handled its note issuc, but also promoted the establishment and participated in the linancing of at least 125 ahirkats. In each case, the government would approve the new company and thercby protect the investncint of the Hank Melli. [W3, p. 186]

In 1318(1939), Da Afghanistan Bank, the central bank. was established with a calpital of Afs 120 million, of which 93 per cent was subscribed ry the Governınent. Bank Millie apparently cooperated with the Government in this. Exactly what lay behind the move cannot be ascertained. However, Bank Millie took the opportunity to repay the Government's equity interest in the Bank and in this way contributed to the financing of the new institution [B7]. As the only trained bankers in the country, Bank Millie employees were provided to staff the new central bank. The issue of possible conflict of interest was never raised. By the end of the 1320s (1940s). there was no distinction between the interests of Bank Millie, Da Alghanistan Bank and the Guvernment:

The upcrations of Bank Melli becance so all-embracing that it was only natural that at the end of World War 11 the president of the Bank. Abdul Majid Zabuli, beciame the Minister of National Economy and also Governor of the State Bank. [W], p. 187]

The interlocking ownership and control still existing within the financial sector is discussed below.

Reports vuggest that relations between Bank Millie and the Government had, however, begun to deterioratte by 1317 (1938) [C9, pp. 412-13; Gis, pp. 307-68]:

During its first years of existence relations were good, but in 1938, when it became obvious that the new venture was developing well and its leaders were pocketing handsome profits which weic not all shown in the books of their compinies, the Government took away most monopolies from the Bank and ordered a first investigation into the group's activities. The official ratson given was a shortage of foreign exchange. "Invisible" exports of foreign exchange, in which the Bank was involved, were discovered and a leading personality of the group was sentenced to six years of imprisimment for too skilful disposal of karakul skins .... The Government ofrened a bank of its own and put it in charge of foreign exchange contrul ..., [C9, pp. 412-13]

Tlis dispute of 1317 (1938), whether ur not it led to the establishment of Da Afghinistan Bank as a retaliatory gesture, was soon resolved. Abdul Majid Zahuli Was appointed Minister of National Economy in the following year [W $3, p .239$ ] but left Afghanistan immediately to spend the War years in Switzerland [C9, p. 413]. The imprisoned member of the Bank Millie hierarchy was released and appointed president of one of the Bank's manufacturing companies [ $\%, p .+13]$.

The Secind World War so disrupted the Afghan economy that it is not surprising to find Bank Millie and the Government working in harmony to salvage whatever possible of the pre-war industries and trading concerms. Iurther, because Afghanistan had accumulated foreign 
exchange during the War, this was no longer a critical issue. With Zabuli as Minister of National Economy and Governor of Da Afghanistan Bank, peaceful co-existence prevailed during the $1320 \mathrm{~s}$ (1940)s).

It was once again Bank Millie's success which drew the Government's ire. For all private enterprise, this has been a threat of varying severity throughout the post-war period. Too much private sector expansion appears to have been anathema to most Governments. Profit has been considered undesirable and excessive profit immoral. Government assistance during attempts at recovery was replaced in the 13.30s (1950s) hy strong opposition:

A hre-and-let-live policy provailed under H. R. H. Shah M:tmoud, who succeceded his brother H. R. H. Hashim Khan as Prime Minister in 1946. As part of this policy, the sovernment allocated practically all the foreign exchinge needed by the industrial group and maintained a spevial exchange rate (the "industrial" rate) at a level between the official and the free rates. But the underlying economic rivalry between the Banke Millic group and the government (which had political overtones because of the absence of tribal and dynastic ties with Abdul Majid's industrial-mercantile group) broke out into the open when he left the Cabinet in 1950 over a controversial exchange allocation. The break was completed in September 1953, when Shah Mahmoud's recignation ended the line of the King's uncles serving as Prime Ministers. Under his successor, H. R. H. Mohammed Daoud Khan, cousin of the King and a former Minister of War and Ambassador to France, and the Deputy Prime Minister, H. R. H. Mohammed Naim Khan, aleo a cousin and a former Minister of Public Works and Ambassador to the U.S., a new oconomic policy of more stringent government control of business took hold. The cousins had not been so closely associated with the Bante Millie group as the uncles and were less impressed with the merits of a free enterprise system within the framicwork of an underdoveloped economy than they were.

The new approach to economic planning is perhaps best represented by the nolicies of Abdul Malik, the new Minister of Finance ( since the by ginning of 1955 also Minister of National Economy) who, perhaps under the influence of his previous experience as Quartermaster General of the Army. has been inspired by Turkey"s "étatiam," with which he had becoure familiar. He found the policies of Banke Millie no longer suited to the country's best interests.

Within the first years of his regime the following curbs on llanke Millie were put through:

(a) The government forced Banke Millie to sell 63 percent of the stock in the Northern Cotton company to the Ministry of Finance, which it turn engaged private merchants to enforce a new cotton buying policy.

(b) The government continued to control textile selling prices and the protit rate of the Banke Millie-owned Textile Co.

(c) The government set domestic minimum prices to be paid the breeders for karithul shins which left too narrow a margin for processing, handling. and selling in New York.

(d) The government forced Banke Millie to seil it st percent of the stock in the (ieneral t:lectric Co. (which is building the new Sarobie nower plant) and issumed control over that construction.

(e) The government took over the Cement Co. (which long had made plaus lor the first plant) and negotiated the construction cont raet involving machinery and a \$ 5-million credit from Czechoslovakia.

(f) The government charged Banke Millie with tax evasion in connection with cupital gain derived from the sale of stock and land.

(g) The government extended exchange control to all procoeds from karahul. wool, and cotton, but raised the buying rate from 16.8 afghanis to betucen 21 and 26 afghanis to the dhillar. This permitted the government to broisten its control uver new plint investment, since proxeeds from collull and wowl exports could no longer be used to make foreign purchase's without government approval. At the same time, by making avaitable what exchange it wanted at il lowet than the free market rate, the government cheapened foreign investment goods.

The impict on husiness volume and putlic opinion was such that Banke Millie shares, once scarce at $I,(x)$ afghanis, were now available at 500 afghanis. Moreover, the Bank could no longer obtain ready cash from its shareholders to defray the local cust of the Gulbahar textile plant, thus delaying the plant's completion. The hilnk's dívidends were reduced to 3 perceint in 1954, and prospocts for 1955 scem dark. [F 17, pp. 47-49]

Share pricis had only climbed back to Afs 1,0000 , their par value, by i352 (1973).

Measured i- 1340 (1961) prices. Bank Millie's capital and reserves have declined from Afs 669 million in 1330 (1952) to Afs 358 million by the end of 1350 (1972). It is not surprising that Bank Millie has felt disinclined (1) invest adtitional resources to any significant extent in the Afghan conomy sifice the 1330s (1950s). The "cuntrolled economy" programme announced in 1333 (1954) seemed designed to curtail the Bank's activities as did the threatened appointment of Ciovernment supervisors to the board of each private company to restrict cutrepreneurial initiative.

Part of the cause of these phases of hostility appears to have sprung from the Bank's concentration of its investment in the north [F19, p. 318]. Thic Pushtun majority in the Government from the south wanted investment in its area. This pressure eventually resulted in the Helmand Valley project, a sciseme opposed by Zabuli on economic grounds from its conception [P14, p. 7].

Perhaps Da Afghanistan Bank was established to allay some of the fears of a Bank Millie take-over of the country. In any event, the name is Pushtu rather than Dari thus tending to support the racial interpretation 
of Bank Millie/Government disputes. Da Afghanistan Bank was given responsibilities of acting as the fiscal agent of the Ministry of Finance, controlling the currency issue, regulating bank credit, controlling foreign exchange dealings and promoting investment in the national interest [DI]. In 1319 (1940), Da Afghanistan Bank started to issue bal.ıknotes [A.3, p. 9K] and by mid-1 327 (October 1948) had an outstanding issue of Afs 800 million [F15, p. 436]. The foreign exchange business was transferred from Bank Millic in 1322 (194.3) [B6, p. 7].

One of the early bones of contention between Bank Millie and the Government had been over foreign exchange transactions. When one of Bank Millic's ex-directors was Governor of Da Afghanistan Bank, another enquiry into the use of Bank Millie's foreign exchange earnings. was initialed. Such was the storm which blew up between the Governor and Zilhuli that the former resigned. Within a few months he had returned to Bank Millie. In 1334 (1955) the Government again accused Bank Millie of ulegal expropriation of foreign exchange earnings from cotton, karakul and wool sales. To eliminate further possibilities of such misdeeds, [): Afgh:ınistan Bank opened branches in London and New York to supervise the surrender of foreign exchange proceeds itself.

During the Daoud administration, 1332-1341 (1953-1963), a banking hoom lowk placé in Afghanistan. Each Government ministry wanted a bank. The Ministry of Public Works already had the Mortgage and Construction Bank established in 1326 (1948). The Ministry of Commerce set up Pisshtany Tejaraty Bank in 1333 (1954) and the Ministry of Agriculture liormed the Agriculture and Coltage Industries Bank in the same year. The Ministry of Mines and Industries under its Minister, Dr. Yousuf, apparently asked Bank Millie to become its industrial bank. Although willing to participate in the establishment of such an instit.tion, Bank Millie was quite naturally uninterested in the original proposition. Thus, the Industrial Development Fund set up in 1336 (1957) was the last in the lield.

In a deciade, one commercial (Pashtany Tejaraty Bank) and three specialised banks had opened their doors alongside Bank Millie and the central bank. Da Afghanistan Bank. By 1336 (1957), however, the fortunes of this infint financial sector were already on the decline. The currency/money ratio, an indicator of the stage of financial development. hid reiched its lowest point, i.e. highest level of financial development, in 1.334 (1955) at 0.64 ; thereafter it rose to 0.81 in 1341 (1962), only falling 100.75 by 1.351 (1972) as can be seen from Table 2.12. A serious bout of inllation hit the economy in 1333 (1954) continuing until 1337
(1958), which in part both explains and is explained by the trend in the currency/money ratio.

In an inllationary situation, never conducive to financial de:elopment, and with a rising currency/money ratio, it is not surprising to discover that the new financial institutions were not performing as well as had been hoped. Political interference, weak manigement and legal impediments to securing loans in addition to unconducive económic conditions resulted in a high rate of attrition. The Agriculture and Cottage Industries Bank ceased its lending activities in 13.37 (1958), the Industrial Credit Fund hadl virtually exhausted its resources hy the end of its first year of operation, the Mortgage and Construction Bank gradually contracted its business until it was only providing smatl. medium term loans to Government employees, and Pashtany Tejaraty Bank appears to have maintained only a tenuous existence for many years which any significant net deposit withdrawals would seriously jeopardisc. Indeed, even a year after its establishment, the observation was made that "it is hard to see how it can earn enungh to pay dividends" [W., p. 1 155 ].

Foreign aid to the financial sector in the form of technical assistance started in 1.349 (1970) after the establishment of the Agricultural Development Bank (AgBank) in 1.348 (1970) under German manatgement tinanced by a grant from the United Nations. The AgBank has also received a loan from the World Bank. The AgBank replaced the defunct Agriculture and Cottage Industries Bank. Similarly, the Industrial Development Bank was finally incorporated in 1351 (1973). years after plans had been drawn up to replate the Industrial Credit Fund by a new institution to provide finance to the industrial sector. This sector has seen some axpansion since the enactment of the Foreign and Domestic Private Investment Law of 1.345 (1967) but lack of credit his inhibited development at a faster pace. The new Industrial Development Bank is a World Bank project.

Although the banks dominate the limited linancial sector in Afghanistan, all historical sketch would not be complete without reference to the insurance companies, the Pension Fund. the sredit cooperatives in Baghlatn and Kolldaman and, most inportant, the money bazaars of Kabul and Kandahar. Prior to the formation of the Afghan Insurance Company in $1342(1963)$ there were three very small insurance agencies in Kabul, one representing the Sterling Insurance Company of New Delhi, one for the Northern Insurance Company, the third for Ingosstrakh, the overseas branch of the Soviet Insurance Trust. Most matrine insurance, which constituled virtually the only type of insurance in Afghanistan, was placed 
on the foreign insurance markets [W7, p. I: Z3, pp. 28-33]. These three agencies are still in operation, although the Northern Insurance Company was taken over by the Commercial Union in 1348 (1969) [T5, p. 40]. The insurance market in Afghanintan is still minute. Nevertheiess, all the institutions have fared well, pertaps as a result of strong links with parent companies abroad which have provided ex-patriate management from the start.

The Pension Fund was established in 1323 (1944). Its total assets at the end of I.351 (1973) were Afs 169 million. As contributions are not sufficient to linance all Government pensions, an additional Afs $I(X)$ inillion was provided by the Government in both 1350 (1971) and 1351 (1972).

The Project on Agricultural Credit and Related Services through Cooperatives in Arghanistan (PACCA), a joint venture of the Food and Agriculture Organisation of the United Nations and the Swedish International Development Authority began in 1347 (1968). By 1351 (1972) the Kohdaman cooperative had $\mathbf{8 1 2}$ members and capital and reserves of Afs 253.797 and the Baghlan cooperative which began in 1350 (1971) had 354 mernhers in 1351 (1972), although it has still not raised any equity or become a fully-fledged cooperative [B27, pp. 4-8].

Information on the money bazaars of Kabul and Kandahar with respect to the relative size of their assets is unavailable. Their operations are described in Chapter VII. A non-institutional credit network of considerable magnitude exists in Afghanistan. However, nothing resembling rotating credit associations or the like has been found. V: rious studies have presented information on the mechanics of these non-insitutional networks [N2: N8]. Because bazalar interest rates are higher than those of the financial institutions. it is thought that over hilf the total Io: nable funds is supplied by money lenders in the bazaar [S13. p. 315], who offer "nearly the same services as the commercial banks" $[Z 3$, p. 71]. In fact, the situal on in Afghanistan is similar to that in Iran over a decade ago:

Iranians have observed that the main distinction between the bazaar and modern Perian commercial banks is tha impressive buildings housing the latter. To an important extent, this statement is true. [B21, p. 65]

In both countries, the situation resulted from the absence of modern banking practices.

This bricf historical sketch of the financial sector has described two periods of apparent expansion during the decades of the 1310s and 1330s (19.30s and 1950s) and two of contraction during the 1320s and 1340s (1940s and 19(10s). Bank Millie grew rapidly during its first years but met with increasing opposition later. The Government sponsored developments in the 1330 s (1950s), which were shorter lived because collection rates renained well below the survival threshold. There are several reasons for these appirent fluctuations. Tlie first is there was in reality only one period of growth-the dynamic early years of Bank Millie. The second is that all banks established after Bank Millie until 1348 (1970) were Government banks closely linked to parent ministries and staffed by ill-trained, badly paid civil servallts. Given that the environment itself was unconducive to financial development, these additional internal handicaps made survival virtually impossible.

Afghanistan has embarked on the second round in the institution betding process within the financial sector. Internal conditions of the AgBank and thc Industrial Development Bank are a vast improvement over those of the Agriculture and Cottage Industries Bank and Indusiral Credit Fund. ... a result of both ex-patriate management and a reasonable degree of autonomy from the Government ministries. Nevertheless, collectiou rates on $A g$ Bank loans. now a reflection only of the external environment, are still too low for complacency. The problems of lending, i.e. the

$$
\text { Tuble } 5.1
$$

Financial Instimutions of Afghumistan

\begin{tabular}{|c|c|}
\hline Instit inen & $\begin{array}{c}\text { Date of } \\
\text { Establishment }\end{array}$ \\
\hline \multicolumn{2}{|l|}{ Bunks } \\
\hline \multicolumn{2}{|l|}{ Pivate } \\
\hline Bank Millie & $1311(1932)$ \\
\hline \multicolumn{2}{|l|}{ Ciovernment } \\
\hline Da Alghanistan Bank & 1318 (1939) \\
\hline Mortgage and Construction Bank & $-1326(1448)$ \\
\hline Pashtany Tejaraty Bank & 1333 (1954) \\
\hline Agricultural Development Bank & $1348(1970)$ \\
\hline \multicolumn{2}{|l|}{ Other Financial Institutions } \\
\hline Privale & 134206031 \\
\hline $\begin{array}{l}\text { Afghan Insurance Company } \\
\text { ThreE Insur:ance Agencies }\end{array}$ & \\
\hline Kohdathuall Credit Cooperature & $1348(1969)$ \\
\hline Bayhl.un Credit Cooperative & $1350(1971)$ \\
\hline Kabul Money Bazuar & \\
\hline Kandithar Money Bazaar & \\
\hline $\begin{array}{l}\text { Giovernilent } \\
\text { Pension Fund }\end{array}$ & $1323(1944)$ \\
\hline
\end{tabular}




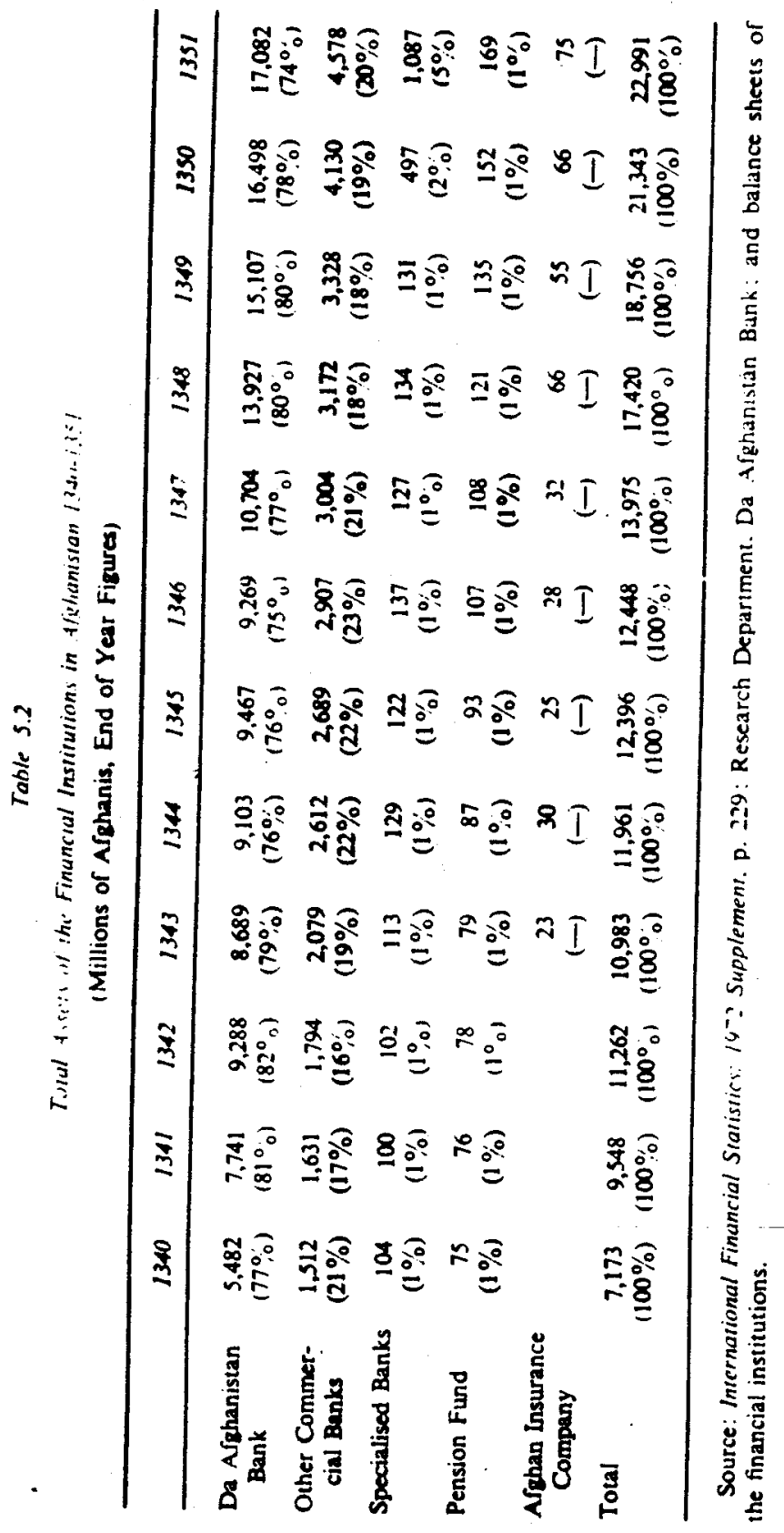

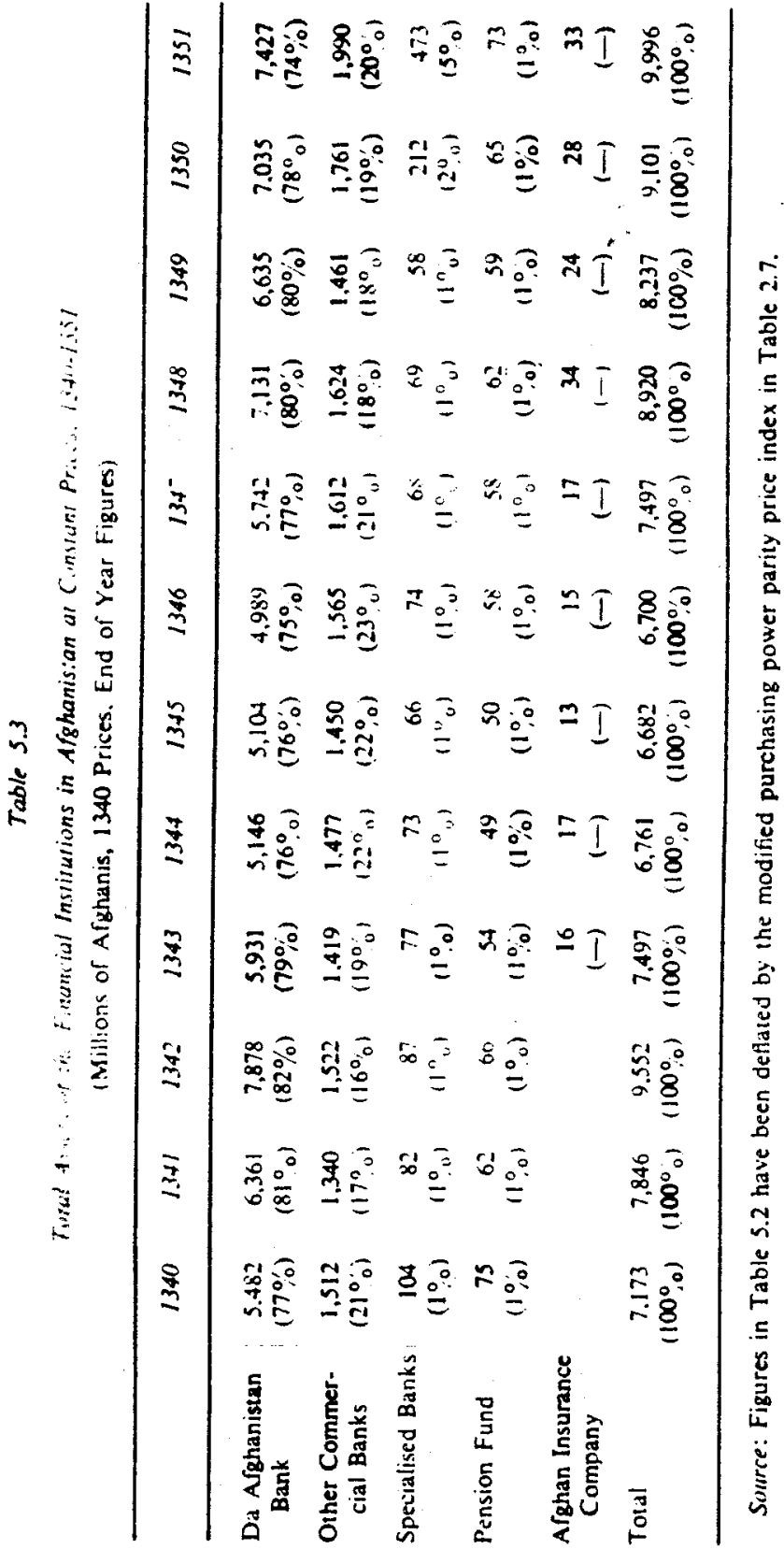


external environment, are discussed below. A major improventent in this environment could be achieved by the enactment of banking laws which would include both a Negotiable Instruments and a Security Interest Act.

\section{ii. Ovirull Vien' of the Financial System}

The existing financial system is dominated by the three commercial banks, Bank Millie, Da Afghanistan Bank and Pashtany Tejaraty Bank, and by the Kabul money bezaar. Table 5.1 gives a list of Afghanistan's financial institutions. Omitting the money bazaars for which data are unavailable. Tables 5.2 and 5.3 provide a rough quantitative comparison at current and constant prices, respectively, of the financial institutions, and Table 5.4 shows the numbers of people working in them.

It can be seen that the three commercial banks hold virtually all the atssets of the financial astem. Da Afghanistan Bank, which combines certain central banking functions such as the issue of banknotes with commercial banking activities, alone holds over three-quarters of the total assets of the financial system.

\section{Table 5.4}

Numiner of Persuns Working in the Financial Institustons at the lind of 1315 (Excluding Servants)

\begin{tabular}{|c|c|c|}
\hline Instirution & Number & $\begin{array}{l}\text { (of which } \\
\text { Forcikners) }\end{array}$ \\
\hline Da Afghanistan Bank & 1,803 & 6 \\
\hline Other Commercial Banks & 615 & -- \\
\hline Specialised Banks & 237 & 10 \\
\hline Cred,i Cooperatives & 92 & 5 \\
\hline Money Bazadrs & $110^{\mathrm{m}}$ & $\cdots$ \\
\hline Pension Fund & 38 & $\cdots$ \\
\hline $\begin{array}{l}\text { Alghan Insurance Company } \\
\text { l:ast rance }\end{array}$ & 24 & 3 \\
\hline & 10 & 2 \\
\hline Fiotal & 2,949 & 26 \\
\hline
\end{tabular}

- Approximate.

Source: Information provided by the financial institutions themselves.

In 1900), the banking system in the U.S.A. accounted for 6.3 per cent of total assets of the financial institutions. By 1963 this had fallen to 38 per cent [G13. Table 1-3. pp. 24-25]. A comparative picture of the percentage of assets of central and commercial banks in a selection of eountries is provided in Table 5.5. The high proportion of total assets held hy the banks in Afghanistan reflects both the low stage of economic evolution and the even lower level of financial development. The expectation of a declining share of banks' assets in the total of the financial system as economic and financial development proceeds has been elaborately reasoned in the works of Gurley and Shaw [G25; G26].

\section{Table 5.5}

Percentage of Total Assels of the finumcial Institurions Held hy Central and Commercial Banks in in Countries in 1963

\begin{tabular}{|c|c|}
\hline Couniry & Percentage \\
\hline Alghanistan" & 97 \\
\hline Israel & 53 \\
\hline Januaica & 66 \\
\hline Japan & 49 \\
\hline Mexico & 35 \\
\hline Pakistan & 78 \\
\hline Philippines & 67 \\
\hline Puerio Rico & 58 \\
\hline Khodesias & 40 \\
\hline Spidin & 65 \\
\hline Sweden & 35 \\
\hline Thailand & 88 \\
\hline Trimidad & 77 \\
\hline lurkey" & 71 \\
\hline I!S.A. & 38 \\
\hline Ventzuela & 56 \\
\hline
\end{tabular}

\section{$1350(1972$}

1968.

Source: Afghinistan-Table 5.2 above.

Turkey--M. J. Fry. Fimunce and Develupment Planning in Turkey (Leiden: Brill, 1972), Table 1, p. 38.

All other cuuntries- R. W. Goldsmith, Financial Structure and Development (New Haven and I.ondon: Yale Univeraity Press. I)(iy), Appendix IV.

Over the period 1340-1351 (1962-1973) thare has been an increase in the proportion of total domestic credit allocated to the public sector from 53 per cent at the end of 1340 (March 1962) to 68 per cent at the end of 1351 ( $\mathrm{March}$ 1973) as can be seen from the figures in Table S.6. Indeed domestic credit in real terms extended $t o$ the private sector has fallea from Ali 2,162 million at the end of 1340) (March 1962) to Afs 1.710 million al the end of 1351 (March 1973) in 1340 (1961) prices, as shown in Table 5.7

Table 5.8 provides a broad picture of the volume of domestic credit in Afghanisian aver the past twenty years. In Table 5.9 these figures have been deflated by the mudified purchasing power parity price index in Table 2.710 produce cstimates of donestic credit expressed in constant 
Domosilc Credit, 1330-1331

Torlik s.y

Domessic Credit at Consiant Prices, 1330-1351

\begin{tabular}{lccc} 
Date & $\begin{array}{c}\text { Clalme on } \\
\text { Government } \\
\text { (Net) }\end{array}$ & $\begin{array}{c}\text { Claims on } \\
\text { Privase } \\
\text { Sector }\end{array}$ & Total \\
\hline 1330 & & & 1,126 \\
1331 & & & 1,209 \\
1332 & & 996 \\
1333 & & & 1,510 \\
1334 & & 1,816 \\
1335 & & & 2,084 \\
1336 & 832, & 1,527 & 2,014 \\
1337 & 421 & 2,037 & 2,354 \\
1338 & 1,063 & 2,244 & 2,458 \\
1334 & 2,411 & 2,162 & 4,307 \\
1340 & 3,312 & 2,114 & 5,573 \\
1341 & 4,376 & 1,707 & 6,083 \\
1342 & 4,009 & 1,955 & 5,964 \\
1343 & 4,063 & 2,198 & 6,261 \\
1344 & 3,745 & 2,289 & 6,034 \\
1345 & 4,449 & 2,349 & 6,798 \\
1346 & 4,013 & 2,760 & 6,773 \\
1347 & 6,058 & 2,863 & 8,921 \\
1348 & 6,605 & 2,772 & 9,377 \\
1349 & 7,142 & 3,529 & 10,671 \\
1350 & 8,177 & 3,933 & 12,110 \\
1351 & & & \\
\hline
\end{tabular}

Source: 1330-1336 from J. R. Brooks, Recummendastons for a Bank for Industrial Develupment of Afghanlstan (Washington, D.C.: International Cooperation Administration, Office of Private Enterprise, mimeo, 1960), p. 8.

and Iniernutlomal Financlal Statlstics: 1972 Suptics, 26 (10), October 197.3. np. 40-41 . 228-29.

prices. To the extent that the deflator is accurate, an indication of movements in the real volume of credit is given; it appears to have increased from 1330 to 1342 (1952 to 1964), downward fluctuations have increased but a rapid increase in 1351 (1972) however leaves a final figure for the end of 1351 (1973) virtually the same as that for 1342 (1964).

The proportion of domestic credit absorbed by public and private the perind for which sectoral data arer the years 1337-1351 (1959-1973), public sector received 35 sectoral data are available. In 1337 (1959) the the proportion had risen to 68 of total domestic credit. By 1351 (1973), found in any non-socialist country. (Millions of Afghanis, 1340 Prices, End of Year Figures)

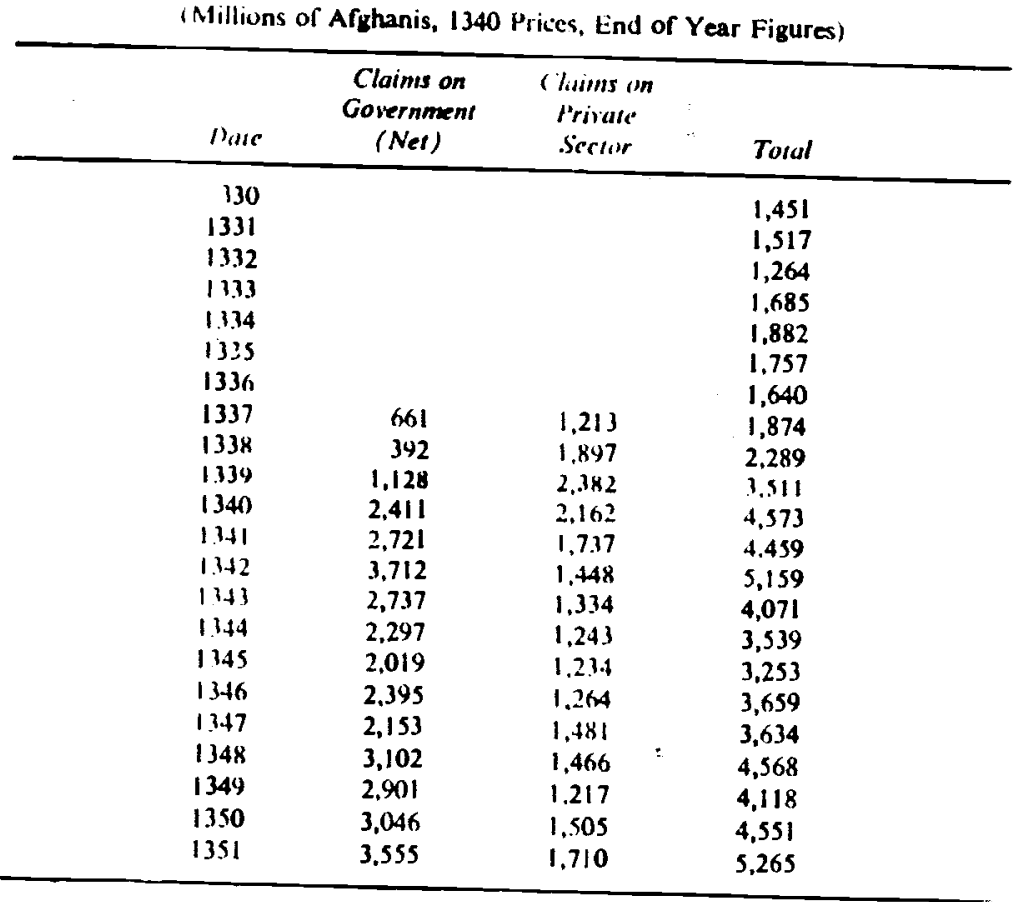

Source: Figures in Table 5.8 have been deflited by the modified purchasing power parity price index in Table 2.7 .

The result of the shift in the proportion of domestic credit allocated to public and private sectors between $1340(1962)$ and $1350(1972)$, a 50 per cent increase in the real volume of credit for the public sector and a 30 per cent derease for the private sector, was noted in a recent Survey of Progress:

The full hrunt of credit restriction is placed on the private sector, the result of which is that private enterprises which need short-term credit must either do without or borrow fron other sources at unnecessary high rates.
[M30, p. 18]

The ellects of the contraction in the real volume of institutional credit to the privale sector on economic growth have also received attention:

Some of the near-failures could have been avoided if the companies concerned had been able to obtain additional working capital to finance inventorics and to carry initial operating losses. The underlying projects 
were basically sound and could have been salvaged if normal commercial banking facilities had boen available. [R3, p. 3]

The scarcity of domestic financial resources was a major factor behind the slow rate of growth during the Third Plan. [M18, p. 14]

Some of the reasons for the decline in private sector credit are considered in more detail in Section vii below.

Rates of interest offered on deposits in and levied on loans from the financial institutions have remained virtually unchanged over the past two decades. Interest is not offered on demand deposits. but a tax iree return of " per cent is paid on savings deposits in all the hanks. Time deposits opened hy husiness firms with Bank Millie carry a taxable return of between 3 and 6 per cent. On the loan side, the Government and Government in'ustries pay 2 to 6 per cent on loans from Da Afghanistan Bank and the private sector numinally pays 8 to 10 per cent, although additional charges raise the rates by about one per cent in most cases.

In the bazaar economy, on the other hand, rates have apparently been rising sharply over the past decade. The great dispersion in interest rates, as seen in Chapter III, indicates a fragmented capital market. Perhaps nowhere has this phenomenon had a more deleterious effect than in the agricultural sector. High rural interest rates have been a strong deterrent to any move from subsistence to cash crop farming. This problem has been recognised for many years and one of the objectives of the bank expinsion in the 1330s (1950s) was the reduction in interest rates [W3, p. 190]. Unfortunately, the attempt failed because institutional rates were sel too low to attract the necessary funds with which to expand lending activities. The result was further fragmentation.

Despite relatively low and unchanged institutional interest rates, nun-price credit rationing does not appear to have been prevalent. There is little, if any, excess effective demand for loans from the tinancial institutions, primarily because there are few borrowers who can meet minimum requirements of credit sorthiness. This in turn springs from legal inadcquacies connected with the securing of loans and expropriation of collateral on default. The unfavourable external environment is exacerbated by the institutions' own inadequacies in terms of untrained personnel, poor pay and absence of incentives to improve the situation.

Despite the unfavourable environment within which banks have to operate. changes have occurred which make the stagnant financial sector, partly reflected in unchanged interest rates, an increasingly

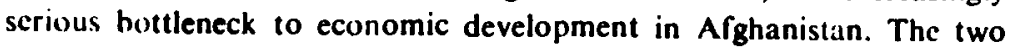
most important are the absorption of larger and larger proportions of the limited supply of domestic credit by the public sector and the developments within the embryonic industrial sector since the Foreign and Domestic Private Investment Law of 1345 (1967) and the boom in the baza:ır econo...y. Since the differential between bank and non-institutional interest rates has widened, it can be assumed that the allocation of resources amongst diliterent uses has become less rather than more efficient.

Table S.11)

lich on Guvernment Bonds in 22 Countries

\begin{tabular}{|c|c|c|c|}
\hline linumery & 1950 & 1960 & 1970 \\
\hline U.S.A. & 2.12 & 4.02 & 6.58 \\
\hline U.K. & $3 .(n)$ & 5.77 & 9.22 \\
\hline |kelgium & 4.42 & 5.48 & 7.81 \\
\hline I hennark & 4.53 & 5.76 & 10.57 \\
\hline France & 6.52 & 5.15 & 8.06 \\
\hline Germany & - & 6.40 & 8.30 \\
\hline Haly & 5.73 & 5.01 & 9.01 \\
\hline Netherlands & 3.28 & 4.20 & 7.76 \\
\hline Norway & 2.58 & 4.58 & 6.29 \\
\hline Sweden & 3.11 & $5.1^{n}$ & 7.39 \\
\hline Switzerlund & 2.6 .7 & 3.09 & 5.82 \\
\hline Canada & 2.78 & 5.26 & 9.82 \\
\hline Ireland & - & 5.45 & 9.56 \\
\hline Portugal & 3.92 & 3.46 & 5.27 \\
\hline Australia & 3.14 & 4.99 & 6.75 \\
\hline New Zealand & 3.07 & 4.83 & 5.51 \\
\hline South Africa & 3.63 & 5.29 & 7.15 \\
\hline Uruguay & 5.64 & 8.50 & - \\
\hline Jamaica & 1.50 & 3.80 & 4.03 \\
\hline Ceylon & 3.04 & 2.90 & 7.57 \\
\hline India & 3.11 & 4.07 & 5.00 \\
\hline Pakistan & 2.99 & 3.50 & 5.50 \\
\hline \multicolumn{4}{|l|}{ Unweighted } \\
\hline Average & 3.55 & 4.85 & 7.28 \\
\hline
\end{tabular}

Source: Imtirnational Finautriat Statisfics: 1972 Supplement.

Over the mist two decades, interest rates throughout the world have risen. An indication of this is provided in Tables 5.10 and 5.11 in which government bond yields in 22 countries and discount rates in an additional 19 countries are presented. On averigge both the yields on government bonds and discount rates have doubled. Interest rates in the Afghan bazaar have followed a similar course. Institutional interest rates in Afghanistan. however, have remained unchanged.

- The rise in nominal interest rates througho'st the world is in large 
Table 5.11

Discomu Rave in 19 Countries

\begin{tabular}{lccc}
\hline Country & 1950 & 1960 & 1970 \\
\hline Turkey & 4.00 & 9.00 & 9.00 \\
Brazil & 6.00 & 8.00 & 20.00 \\
Chile & 4.50 & 16.55 & 20.00 \\
Colombia & 4.00 & 5.00 & 14.00 \\
Costa Rica & 4.00 & 5.00 & 5.00 \\
Ecuador & 8.00 & 5.00 & 8.00 \\
El Salvador & 3.00 & 5.50 & 6.10 \\
Honduras & - & 2.00 & 4.00 \\
Nicaragua & 4.00 & 6.00 & 6.00 \\
Peru & 6.00 & 9.50 & 9.50 \\
Venezuela & 2.00 & 4.50 & 5.00 \\
Esypt & 3.00 & 3.00 & 5.00 \\
Iran & 4.00 & 6.00 & 8.00 \\
Syria & - & 3.50 & 5.00 \\
S. Korea & 5.84 & 10.22 & 19.00 \\
Philippines & 2.00 & 5.00 & 10.00 \\
Thailand & 7.00 & 5.00 & 5.00 \\
Ghana & - & 4.00 & 5.50 \\
Tunisial & - & 3.00 & 5.00 \\
Unweighted & & & \\
Average & 4.49 & 6.09 & 8.90 \\
\hline
\end{tabular}

Source: International Fimancial Siatistics: 1972 Supplement. Part a reflection of the rise in the expected rate of inflation [F8, Chapter
19; G9]. Using the very simple model

$$
i_{t}=b_{0}+b_{1}\left[\left(\frac{\Delta M}{M}\right)_{t}-\left(\begin{array}{c}
\Delta M \\
M
\end{array}\right)_{t-1}^{0}\right]+b_{2}\left(\frac{\Delta P}{P}\right)_{t}
$$

where $i_{t}$ is the noninal rate of interest, $M$ is the money stock, P the price p. 588]. Carr and Smith find value, and $b_{0}, b_{1}$ and $b_{2}$ are constants [C5, $(\Delta P)^{\bullet}$ $\left(\begin{array}{c}\Delta P \\ P\end{array}\right)_{t}^{0}$. has a significant positive effect on $i_{t}$, the nominal ratc of interest [C5, p. 590].

With an average expected rate of inflation over 9 per cent in Afghanis tan, together with its high standard deviation shown in Table 2.13 which increases the risk of real loss from holding money, a nominal rate of 6 per cent on savings accounts implies a negative real rate of interest from the slandard Fisher equation

$$
r_{t}=i_{t}-\left(\frac{\Delta P}{P}\right)_{t}^{e}
$$

where $r$ is the reasl rate of interest and i the nominal rate. Furthermore, it has been a highly risky negative return with the standard deviation over 8 .

In a recent survey of studies on the determinants of savings in underdeveloped countries, the conclusions were reached that:

A. Me:lsured savings are responsive luchanges in the real rate of interest [M10, p. 19].

B. The rate of interest is more important in determining the channels into which savings will flow, however, than in altering the propensity to save itself [M/0, p. 17]].

Hence, the real rate of interest is the hey factor in financial development Naturally, the negative real rate has not promoted financial development in Afghanistan.

Institutional interest rates in Afghanistall are low for two main reasons First, the eflective demand for loans is small because of the legal inade quacies which make loans difficult to secure. Thus, lending is not such an attractive proposition as it could be. I egal reform to secure loans and enforce collection might produce a strong incentive to expand banking operations.

The second basic reason why interest rates are low lies in the nature of the market structure of Afghanistan's tinancial sector. The interlocking ownership and control throughout the financial system is worth docu. menting. As of the beginuing of $1.352(197.3)$, the Supreme Council of Da Afghanistan Bank consisted of the Minister of Finance (Chairman), the Minister of Mines and Industries. the Minister of Planning, the Acting Minister of Commerce, the President of the Industrial Development Bank, a representative of the Prime Minister's Office, the Governor, Deputy Givvernor and the two Vice Presidents of Da Afghanistan Bank. The Board of Directors of Pashtany Tejaraty Bank included the Minister of Finallec. the Acting Minister of Commerce, the President of the Pension liund, the Governor of Da Afghanistan Bank, the President of the Agriculuural Development Bank, the President of Bank Millie, a member of Bank Millie's Board and four other traders. The members of the Board of Directors of Bank Millic naturally did not include any representative of the Government hut three members of its Board also sat on the Boirds of other banks. The members of the Supreme Council of the Agricultural Development Bank were the Minister of Finance, the Minister of Planning, the Acting Minister of Commerce, the Minister of Agriculturc and Irrigation, the Governor of Da Alghanistan Bank, the 
Vice Chiurman of the Board of Directors of Bank Millie, the President and General Manager of the Agricultural Development Bank and three other elected nembers. The Board of Directors of the Industrial Development Bank consisted of the President of Pushtany Tejaraty Bank (Chairman), the President of Bank Millie, the President and General Manager of the Industrial Development Bank, representatives of Chase, National Westminster and the World Bank and two industrialists. The Supreme Council of the Mortgage and Construction Bank consisted of the Minister of Finance, the Minister of Public Works, the Governor of Da Afghianistan Bank and four elected members. The Board of 1) , ectors of the Alghan Insurance Company included the President of Pashtany Tejaraty Bank (Chairman), the Vice Chairman of the Board of Directors of Bank Millie and a representative of the Guardian Assurance Company. The Pension Fund has invested funds in the form of equity participation in the Alghan Insurance Company, the Mortgage and Construction Bank and Pushtany Tejaraty Bank, and has a loan from Da Afghanistan Bank. Shires of the Mortgage and Construction Bank are held by Da Afghanivain Bank.

This lather lengthy documentation of inter-locking directorships and equity participation simply indicates that not one financial institution in Afghanistin is independent from the others. There have, furtlicrmore, heen inturmal links between the institutions including. apparently, representation of Bank Millie's views on the Supreme Council of Da Afghanistin Bank. One can, therefore, assume that there has been no conipetition between the financial institutions. Hence, interest rates have remained low and stable, advertising is negligible and there is no search whalsuercer for business. Bankers wait for customers, who on the loan side halve had to meet increasingly stringent collateral requirements. and do not contconplate any innovations or other action which might disturb the market waire balance. So far, the equilibrium has been preserved from any external disruptions, the most serious of which would be competition inside Afghanistan from a foreign bank. The banking fraternity has to date ensured that no serious threat of this kind has materialised.

The result has been financial stagnation over the past two decades. The eirly years of Bank Millie have long been forgotten as bankers have setlled down to a stable, low level, non-competitive equilibrium. This has been facilitated not only by inter-locking ownership and control within the financial institutions but also by complacency on the part of the $M$ inistry of finance and the conspicuous lack of indigenous credit arrangements such als rotating credit associations, pawnbrokerage, and simple 
financial instruments such as promissory notes, etc. This is not to imfly that non-institutional credit is unimportant but that there are no sophistications $t$ " hasic lending operations such as an indigenous negotiable instrument, elementary cooperative groups, etc. In fact, the only traditional tinancial instruments are essentially non-negotiable. They include the hawala, a simple draft, the harat a bill of exchange. the mijat, a promissury note and the sanad, a receipt. These are only known to a small pruportion of urban traders. The majority of the population has never even heard the words.

The lack of even simple indigenous tinancial instruments and instituIirns highlights one of the major obstacles faced by the embryonic mudern financial system should an attempt at expansion be made. nitmely, the lotial lick of understanding by the vast majority of the population of basic cuncepts of credit. As the Agrirultural Development Bank has discovered, when the distinction between a loan and a grant is unclear even an aggressive. German-managed financial institution is still in a precarius position when it attempts to expand rapidly its lending activities.

7 wo malters of significance in analysing Afghanistan's financial syste in hive recived much attention in the literature of recent yeirs. The first concern cionomies of scale in banking, the second competition. Table 5.12 provides a comparative picture of Afghanistan's banking system with thrse of the neighbouring countries of Iran, Pakistan and Turkey. Tirtal ansets and total deposits of the banking system are extremely small iil : iny criterion. At the end of 1967, for example, Kaufman lists 171 banks in the world with total assets over $\$ 1$ billion. Of the 151 banks for which further ditti were available, assets per bank averaged $\$ 3,2.39$ nullion and assets per branch \$8.626 million [K6, Table 2, pp. 104-109].

Populillum per bank branch was 4,618 in Iran in 1350 (1972), 53,039 in Pithistin in 1967 and 14,957 in Turkey in 1967. Using the oflicial populatiun estimite of 17.5 million for Afghanistan gives 188.172 people per hranch. The population estimate of 10 million gives 107,527-still considerathly greater than even Pakistan.

Benst $(1,1$ recently estimated a cost elasticity for banking of 0.93 indicating that a 10 per cent increase in deposits resulted on average in at 9.3 per cent increase in costs [B22]. He explained the economies of scale hy the fact that litrge banks were able to use a larger proportion of lower skilled lithour, needed fewer processing and administrative officers and could shift to technology only economical for large scale operations [B22. p. 339]. In another recent publication. Baltensperger showed that the custence of uncertinty also produced economies of scale:
.... if it is true that uncertainty is a linijor source of economies of scalc in banking, then, since the degree al uncertainty involved in different types of banking activities varies widely, the extent of these economies should be considerably dillerent for ditlerent lypes of banking servires. Thi again, it seems, should show up in the relative degrees of concentratio of different types of services. We should expect that in the long run thos services with relatively large scale economies become much nore cor: centratce in the hands of a few large banks than those having only it signiticint economies. [144, p. 475 ]

In an empirical analysis of the Swiss hanking system, Haltensperger ${ }^{\circ}$ Mt support hir his hypothesis. He comcluded

... Ihe liact that the high-risk seivices all more concentrated in $1 / x$ of the largest firms than the lou-risk services implies that, on awd relatively large pail of a large bath : busmess takes place in the hig: departukent, and a relatively large fiart of a small bank's business ir low-risk department. [B4, pp. 484-85]

From the work of Baltensperger and Benston, it could be expected even if Alghanistan's financial system were competitive and efficis: banking would he relatively high cost and prone to greater rish aversis. than other tillancial systems simply beciase of its small size.

The fact that Alghanistan's financial system is not competitive suggest a priori, that it is unlikely to be efficient and furthermore has remaine much snaller than a competitive system would have done. This alor suggests atwitntages from competition might accrue. Recent work o American and British banking suggests that the absence of competitic has produced high social costs [G17:G15: G19: R8]. In both countite regulation and restraints on competition are in the process of beir removed since ahe recognition of the fitcls that the dangers of competitio are much less serious than the banking communities try to make out ame that the benetits of competition are considerably greater. Alghanista could well titke note of this move lowards competitive banking in at attempt at thiancial development.

\section{iii. The (intral Bank}

Da Alghanistan Bank, founded in 1.318 (1939), is the central bank o: Afghanistan in that it "has the monopoly and privilege of issuin bank-notes throughout Aighanistan" [DI. Article 1, p. I] and acts banker to "The Government, Municipalities and all other Governme: Departments in Afighanistan as well as abroild" [DI, Article 11 (b), p. . However, the Bank has no powers to control in any wily other tinanci institutions. In the absence of standird central and commercial ban 
legislation. llicre is in lact no special control uver other financial institutions. This is unnecessary at present fir monetary policy purposes for two reasons. First, there is essentially no money multiplier process, i.e. multiplied relationship between high powered money and the money supply, since three-quarters of the money supply, broadly defined to include time deposits, is currency. Furthermore, 31 per cent of the deposit component of the money supply is held at Da Afghanistan Bank; Table 5.13 presents balance sheet data for 1340-1351 (1962-1973). Second, in the abscnce of borrowing possibilities for the public sector outside the linancial system, monetiry policy is determined almost exclusively by liscal policy.

Da Afghanistan Bank opened its first branch ollice in 1321 (1942) in Kandahar and establislied five more during the 1320s (1940s). During the 1330 s (1950s), 14 branches were started and 35 in the 1340s (1960s). At present in 1352 (1973), there are eight bratluches in Kabul, 51 provincial branches together with the Trading Comprany of Afghanistan. Incorporated, establisued in 1.3.33 (1954) in New Yurh and the Trading Company of Afghanıstan, 1 imited, established in 13.34 (1955) in London.

Despite the steinly increase in branches, the facilities normally offered by a branch network are absent. No branch makes any loans, only a dozen accept savings accounts and there is no cheque clearing system. By and large, the branches of Dal Alghanistan Bank serve almost exclusively as the Ministry of Finance's cashier. During the first six months of 1351 (1972), there were 930 transactions lutalling Afs 1,763 million between the head ollice and the branches and 747 transactions totalling Afs 1,359 million between the branches and the head office. There was an average of 43 chequing accounts, cight fiduciary, i.e. lemporary non-chequing, noninterest bearing accounts, and 27 savings atceunts per branch at the end of 1351 (March 1973). While 17,222 savings accounts were held at the head office, only 1,600 were held in the branches. In certain other respects, including the salary scales of its cimployees, Da Aighanistan Bank is treated as an argatn of the Ministry. The prollems created by less than subsistencic salaries which the Bank is obliged to paly are no different from these in all (iovernment offices.

One of the internal constraints to expansion and greater autonomy lies in the quality of the Bank's persunnel. Generilly, the staff have had inadequate education before joining the Bank and little methodical on-the-job training after recruitment. Hence, there is general recognition that to inprove the efliciency of operations on-the-job training must be given to almost the entire staff. Statf at the very top have generally 
received considerable training abrond but are thwarted in any elforts 0 apply their high level training by the eternal stream of mundane tasks which they are obliged to perform, including for example writing simple business letters and deciding which damaged banknotes are exchangeathle. It is therefore doubly important to initiate training at lower and middle levels not only to increase the Bank's operational efficiency but alsw to free senior staff to devote more of their time to policy issues, efc.

Da Aighanistan Bank plays a relatively important role in loreign trade with oflices in London and New York established primarily (1) facilitate and supervise the karakul trade. As shown in Table 7.12, Dil Afghanistan Hank accounts for 28 per cent of the total annual turnover of foreign exchange, excluding clearing currencies. In addition to the $\$ 71$ million foreign currency exchanged in 1351 (1972) there was business in clearing currencies amounting to over $\$ 50$ million. Da Afghanistın Bank not only has a monopoly in clearing currency accounts but also in $\$ 36$ million of foreign exchange bought and sold at the official rate.

In its foreign exchange operations and in its private sector credit policy. Da Afghanistan Bank is surprisingly unfettered. Although obliged to provide all funds required by the Government subject only to the physical constraint of banknote availability, foreign exchange reserve policy ind private sector credit are matters entirely within the Bank's responsibility. Efforts seem to have been made to counteritct the more violent swings in Government funding through compensating changes in reserves and private sector credit supply. This is taken up again in the subsequent section.

iv. Mom'y Supply.

The Afghani was introduced as the monetary unit of Afghanistan in a law passed on 23 Hoot 1304 (14 March 1925) [B29, p. 427]. II ivas a silver coin weighing 10 grams and replaced the Kabuli Rupee at an exchange rate of Il Kabuli Rupees to 10 Afghanis. Under the same law, two gold coins, the Amani and half Amani weighing 6 and 3 grams respectively were prescribed and valued at Afs 20 and Afs 10 [B29, p. 427]. With the decline in the price of silver shortly afterwards these coins went out of circulation.

The tirst batch of Afghani coins contained silver of the same fineness (0.99) as the old Kabuli Rupees, thus equating intrinsic values with the oflicial rate of exchange [G22, p. 173]. In subsequent mintings, less silver was used:
.... on the face of it, no material prolit could have been derived from recoining eleven old coins into ten new ones. The percentage of the alloy in the old coin is, however, exceedingly sinall, especially in the older "raw" rupoes, whereas in the afghani the alloy, though probably not exceeding the limit considered as legal. is an unknown quantity and is certainly comparatively high. [829, p. 433]

That further debasements took place wats suggested in Chapter II on the evidence of implicit exchange rate calculations. At this time, Indian and Iranian gold and silver coins also circulatted in Afghanistan.

The Law on Banknoles in Circulation in Alghanistan, enacted 4 Aqrab 1314 (26 () twber 19.35), authorised the issue of currency notes. The Latw enabled the Ministry of Finance to issue paper notes itself or through lbank Millic. The arrangement actually reatehed between Bank Millic anc the Ministry resulted in an issue of Treasury notes in 1315 (1936) which iccording (" Article 6 of the Law could be converted "..... into Afghan coins in all guvernment Ireasuries and in Bank Millic with no difficulty:" A previous altempt in the 1300 s (1920) 10 introduce paper currency has been unsuccessful. A contemporary account provides an interesting description:

There txing no bank in Afghanistan, no bank-notes or treasury-notes are issued and the eurreticy is limited to the silver and copper coins above descritued. That state of things is very trying when larger sums are involved in somc transaction. The usual method of avoiding that drawback is by having recourse to some foreign eurreney (English gold and treasurynotes, Indian currency notes, and the like) or to cheques on some bank in India, the amount being calculated in accordance with the rate o: exchange of the day.

A tinid attempt at introducing suh rosa some kind of currency-note into cireulation was, however, made sone time ago. A kind of promissory note was issued by the Treasury of Daru-I-Aman (the new capital of Afghanistan. still under construction, some ten miles to the South of Kabul). These notes were to serve for the payment of the workmen employed on its construetion, but not being accepted as money in the bazar of Kabul (or anywhere else), these notes very soon died a quiet, natural death. [B29, pp. 425-26]

Notes issued by the end of 1315 (1937) equalled Afs 20 million. By the end of 1318 (1940) Treasury notes totilled Afs 180 million. In this year Da Afghanistan Bank was founded with the right to issue banknotes. Article 19 ,f its Statutes states:

The 13ank, in order to cover its short-lerm liabilities, shall be in possession of at kiast $30 \%$ of their face-value in the form of gold, silver, free foreign currencies, commereial bills payable within 15 days and bank-notes delivered by the "Committee of Bank-note Reserves" in accordance with clause 63 of these Statutes. [DI, p. 6] 
Section $H$ of the Statutes also contains provisions on note issue and cover:

\section{H. THE COMMITTEE OF BANK-NOTE RESERVES}

62. In urder to control the reserve of Bank-notes a special Committee composed of seven members in to be formed at the Bank as under:

Two members of Purliament

A member of the Cabinet

The President of tho Supreme Court

The Governor of the Da Afghanistan Bank

The Chief Treasurer

The Government Auditor at the Bank

\section{Term of Service}

The term of office of the Government delegates and representalives is two years. Their appointment shall take place every year in the month of Hamal (March/April) at the occasion of the first session of Parliament and of the Cabinet. If Parliament does not sit at the aforesaid time, their nomination shall be postponed till the frut session of the House is held.

63. This Committeo has the following duties and powers:

(a) Inspocting and receiving the Bank-notes newly printed.

(b) Safe-keeping the Bank-notes and effecting their delivery to the Bank after examining the Lepal Reserves and ascertaining that it is in propcr ratio to the notes printed. The delivery of the Bank-notes to the Bank denorm, with regard to their cover, that such notes are considered to be in circulation.

(c) Receiving the Bank-note withdrawn from circulation as well as the worn and defaced Bank-notes; keeping the respective accounts for the sane and proceeding to their incineration with all necessary precautions. At the time of incinerating Bank-notes a protocol with full particulars of the procedure must be made in a special book. A copy of the protocol shall be forwarded to the Finance Minister.

(d) Controlling the account regarding the cover for the Bank-notes in accordance with the Rules and Regulations concerned. This Control Committe shall prepare a report at least once a month on the total value of notes in circulation and the coins, gold and silver bullions kent as cover for the ame. This report shall be submitted to the Government which in its turn publishes it for the information of the public.

[DI, nn. 15-16]

Incineration of worn banknotes has taken place at regular intervals with sonie ceremony in the gardens of Da Afghanistan Bank. On one such occision, a wind sprang up during the proceedings and notes swept up from the garden rained down outside on lucky by-standers in Pusheunistan Square, the Piccadilly Circus of Kabul.
When Dit Alghanistan Bank started issuing notes, it had them printed in Kabul an machinery imported from Gicrmany and operated with the help of technical assistance from German experts. The product was of high quality and considerable beauty. When the Germans were forced to leave Afghinistan during the Second Wortl War, the machinery fell into disrepair. Notes are now printed by De La Rue in Newcastle. The antique machinery for minting coins has also broken down and the Mint, although still cmploying quite a number ol people, is now unproductive.

By the end of 1.319 (1941) Afs 60 million of Da Afghanistan Bank notes were circulating alongside the Treasury notes. The latter had become the liability of 1 i Afghiulistin Bank. They were virtually all withdrawn from circulation by the and of 1327 (1949) by which time there were nearly Afs 700 miltion of l Ma Alghanistan Balnk nutes in circulation.

In $1317(19.38)$, the Alghan currency mole lost its convertibility:

.... the National Assembly authorized the Ministry of Finance to hold gold, viver. and foreign exchange as a reserve equivalent to half the value of the notes in circulation. [F $15, p .436]$

Nevertheless, there was clearly a strong disire for currency backing to prevent irresponsible recourse to the printing presses. The 1343 (1964) Constitution of Afghanistan follow's up this concern with monetary stability. Article 04 provides that "the authorization to issue money ..... are within the competence of the Shura (Parliament)." By then, however, the note cover had been reduced to 20 per cent [M22, p. 77].

Valued ilt ciltier official or free market exchange rates, there has always been ample excess cover. In fact, the official exchange rate is used and mainten:the :f the prescribed cover was the predominant factor behind the devaluatuon of this rate in 1342 (196.3). Gold and silver reserves had previously he'in revilued at the official rate introduced in 1328 (1949) during 1332 (1954) for the same purpose [W3, p. 194]. Between 1341 $(1963)$ and $1349(1971)$, the gold and foreign exchange backing of currency in circulation averaged 45 per cent [M25, 1'ible 6, p. 81; M32, Table 94, p. 156].

Although the depreciating Afghini/Dolliar exchange rate suggests that domestic inllallion has been generally grealter than inflation in the U.S.A., the average ammual rate of inflation has, in fact, only been 5.6 per cent between 1.329 (1950) and 1351 (1972). This can be compared with 3.1 per cent in Iran, 1951-1970, 2.9 per cent in Pak istun, 1950-1970, and 7.2 per cent in Turkey, 195(1)-1970 [F26, Table 19.3, p. 377]. Many underdeveloped countries have sullered considerably higher rates of inflation over this period. 
Unfortunately, the relatively modest average rate of inflation during the past two decades has been accompanied by high variance. The standard deviation of the annual rates of inflation between 1329 (1950) and $135 /$ (1972) is 10.6 . High variance produces uncertainty as to future directions of change and so makes money an extremely risky asset. As already pointed out, if inflation per se has not been a major deterrent to money holding, the variance in it certainly has. As the critical objective in any programme of financial development is to increase the demand for money in real terms, efforts must in the future be directed at reducing not only the level of inflation but, more important in the Afghan context. also the variance.

For this task it is essential to understind the factors which have contributed to this high variance. The major exogenous factor against which it is diflicult, though certainly not impossible, to take counteracting measures is fluctuations in agricultural output. Indeed, this is particularly well illustrated at the present (1973) when, for example, the price of wheat flour is 28.5 per cent lower than it was a year ago and the price of mutton 46.4 per cent higher [C8]. Although the stabilisation of meat prices is a long and complicated process, grain prices which are much more important in the cost-of-living index can be stabilised to al considerable extent through repeal of the Anti-Hoarding Law of 1346 (1967) and the implementation of a Government reserve stock programme.

Agricultural fluctuations and seasonalities are probably the major cause of short run (up to 18 months) price fluctuations. However, it is significint that a calculated series of expected inflation rates which uses a weighted average of inflation over four year periods yields a standard deviation of 6.0 [F31, pp. 13-15]. Thus, even if agricultural fluctuations contribute a maximum of 4.6 to the standard deviation of annual inflation rates the major cause is still to be discovered. This is, in fact, undoubtedly changes in the money supply. Between 1331 (1952) and 1350 (1971), the average throe year increase in the money stock was $38.7 \mathrm{pcr}$ cent; the stindard deviation of the 18 observations is 26.9 .

Regression of the simple relationship

$$
\dot{\mathbf{P}}_{\mathbf{t}}=\mathrm{a}+\mathrm{b} \dot{\mathbf{M}}_{\mathrm{t}-1}
$$

where $P_{t}$ is the three year percentage rate of inflation over period $t$ and $M_{t-1}$ is the three year percentage change in the money stock over period 1- -1, yieids the following results for the period 1331-1351 (1952-1972):

$$
\dot{\mathrm{P}}_{\mathrm{l}}=-8.88+0.77 \dot{\mathrm{M}}_{1-1}
$$

which, with $R^{2}=0.76$ and $t=6.9$, is a highly signiticant relationship, well over the 99.9 per cent confidence level. Thus, over three-quarters of the change in the price level during a three year period is accounted for by changes in the money stock. The data used in this analysis are presented in Table 5.14. There are high standard deviations for both changes in the money stock and changes in the price level. Table 5.15 presents a solnewhat longer series for currency and money stock on an annual basis. For an average annual increase in currency in circulation since $131 \times(1949)$ of 12.7 per cent, the stindard deviation is 9.6 , while for ill average imnual increase in the money unply over the same period of 11.9 per cent the stindard deviation is 110.3 . Both standard deviations are extremely hight. Tiable 5.17 provides a compririson with Iran, Pakistan and Turkey.

Differences between the size of clanges in the money supply and changes in demand for money in real lerms will influence not only the

$$
\text { Table' 5.14 }
$$

Thre'e Year Moring Average Percenusu Chungas in the Money Stock and

\begin{tabular}{|c|c|c|c|}
\hline & Dime & Money Studk & $\begin{array}{l}\text { Purchasing Power } \\
\text { Parity Price Index }\end{array}$ \\
\hline \multirow{20}{*}{ 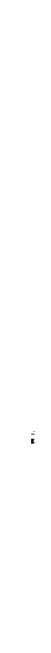 } & $1331-34$ & 64.6 & \\
\hline & $1332-35$ & 84.7 & 50.51 \\
\hline & $1333-36$ & 55.7 & 37.05 \\
\hline & $1334-37$ & 13.9 & 30.47 \\
\hline & $1335-38$ & 4.6 & -9.44 \\
\hline & $13.36-39$ & 10.0 & -23.29 \\
\hline & $13137-40$ & 24.8 & -20.57 \\
\hline & $1338-4 \mid$ & 37.8 & 13.31 \\
\hline & $1,3,39-42$ & 61.5 & 25.16 \\
\hline & 13.40 .43 & 80.9 & 46.50 \\
\hline & $13.41-44$ & 72.8 & 45.36 \\
\hline & $1342-45$ & 44.3 & 57.34 \\
\hline & $1343-46$ & 16.6 & 26.83 \\
\hline & $1344-47$ & 6.1 & 5.37 \\
\hline & $1345-48$ & 15.5 & 5.28 \\
\hline & $.146-49$ & 30.1 & 22.55 \\
\hline & $1.347-50$ & 34.0 & 25.80 \\
\hline & $\mid 348-51$ & & 17.77 \\
\hline & & $3 \times .70$ & 20.94 \\
\hline & Stamtard I)eviation & 26.87 & 23.76 \\
\hline
\end{tabular}
ifudifud P'urchasing Power Purity Price Inclex, 1331-1351 (Percentagts)

Source: Moncy Slock --Table 5.15.

Purchasing Power P'arity Price Index--Table 2.7. 
Table 3.1.5

Table 5.16

Currency and Money Srock 1310-1351

(Millions of Afahanis, End of Year Figures)

\begin{tabular}{|c|c|c|c|c|}
\hline Dale & $\begin{array}{l}\text { Currency in } \\
\text { Circulation }\end{array}$ & $\begin{array}{c}\text { Money Srock } \\
(M 2)\end{array}$ & $\begin{array}{l}\text { Percentage } \\
\text { Change in } \\
\text { Currency }\end{array}$ & $\begin{array}{c}\text { Percemage } \\
\text { Chunge in } \\
\text { Money Stock }\end{array}$ \\
\hline 1310 & & 165 & & \\
\hline 1311 & & 177 & & 7.1 \\
\hline 1312 & & 189 & & 6.8 \\
\hline 1313 & & 202 & & h.) \\
\hline 1314 & & 216 & & (1.) \\
\hline 1319 & & .31 & & 0.9 \\
\hline 1.116 & & 248 & & 7.4 \\
\hline 1317 & & 265 & & h.9 \\
\hline 1318 & 180 & 284 & & 7.2 \\
\hline 1319 & 240 & 300 & 33.3 & 5.6 \\
\hline 1,320 & 300 & 375 & 25.0 & 25.0 \\
\hline 1.321 & 372 & 465 & 24.0 & 24.0 \\
\hline 1322 & 430 & 538 & 15.6 & 15.7 \\
\hline 1.323 & 500 & 625 & 16.3 & 16.2 \\
\hline 1324 & 594 & 743 & 18.8 & 18.9 \\
\hline 1.325 & 680 & 850 & 14.5 & 14.4 \\
\hline 1.326 & 680 & 850 & 0.0 & 0.0 \\
\hline 1327 & 687 & 859 & 1.0 & 1.1 \\
\hline 1328 & 764 & 955 & 11.2 & 11.2 \\
\hline 1329 & 900 & 1.125 & 17.8 & 17.8 \\
\hline 1330 & 940 & 1.210 & 4.4 & 0.8 \\
\hline 1331 & 978 & 1,338 & 4.0 & 101.6 \\
\hline 1332 & 989 & 1,339 & 1.1 & 0.1 \\
\hline 1333 & 1.193 & 1,848 & 20.6 & $3 \times 0$ \\
\hline 1334 & 1.474 & 2,345 & 23.6 & 26.9 \\
\hline 1335 & 1.760 & 2.601 & 19.4 & 10.9 \\
\hline 13.36 & 1.889 & 2,360 & 7.3 & 9.3 \\
\hline 1337 & 1,849 & 2,473 & -2.1 & 4.8 \\
\hline 1338 & 1,881 & 2,700 & 1.7 & 9.2 \\
\hline 1339 & 2,155 & 2,756 & 14.6 & 2.1 \\
\hline 1.340 & 2,607 & 3,205 & 21.0 & 16.3 \\
\hline 1.341 & 3.158 & 3,924 & 21.1 & 22.4 \\
\hline 1,342 & 3,884 & 4,886 & 23.0 & 24.5 \\
\hline 1.343 & 4,722 & 5,900 & 21.6 & 20.8 \\
\hline 1.344 & 4.644 & 6,419 & -1.7 & 8.8 \\
\hline 1.345 & 4,624 & 6.290 & -0.4 & 2.0 \\
\hline 1,346 & 4,804 & 6,288 & 3.9 & 0.0 \\
\hline 1.347 & 5,238 & 6,788 & 9.0 & 8.0 \\
\hline $1.34 k$ & 6,144 & 7,893 & 17.3 & 16.3 \\
\hline 1349 & 6,532 & 8,468 & 6.3 & 7.3 \\
\hline 1.350 & 6,785 & 9,049 & 3.9 & 6.4 \\
\hline 1.351 & 8,180 & 10,858 & 20.6 & 20.0 \\
\hline $\begin{array}{l}\text { Average } \\
\text { Standard }\end{array}$ & Deviation & & $\begin{array}{r}12.7 \\
9.6\end{array}$ & $\begin{array}{r}11.0 \\
9.4\end{array}$ \\
\hline
\end{tabular}

('urringry' and Momey Stock at ('unstant Prices 1310-135/

i Mtillions of Afyluanis, 1340 Prices, lind of Year Figures)

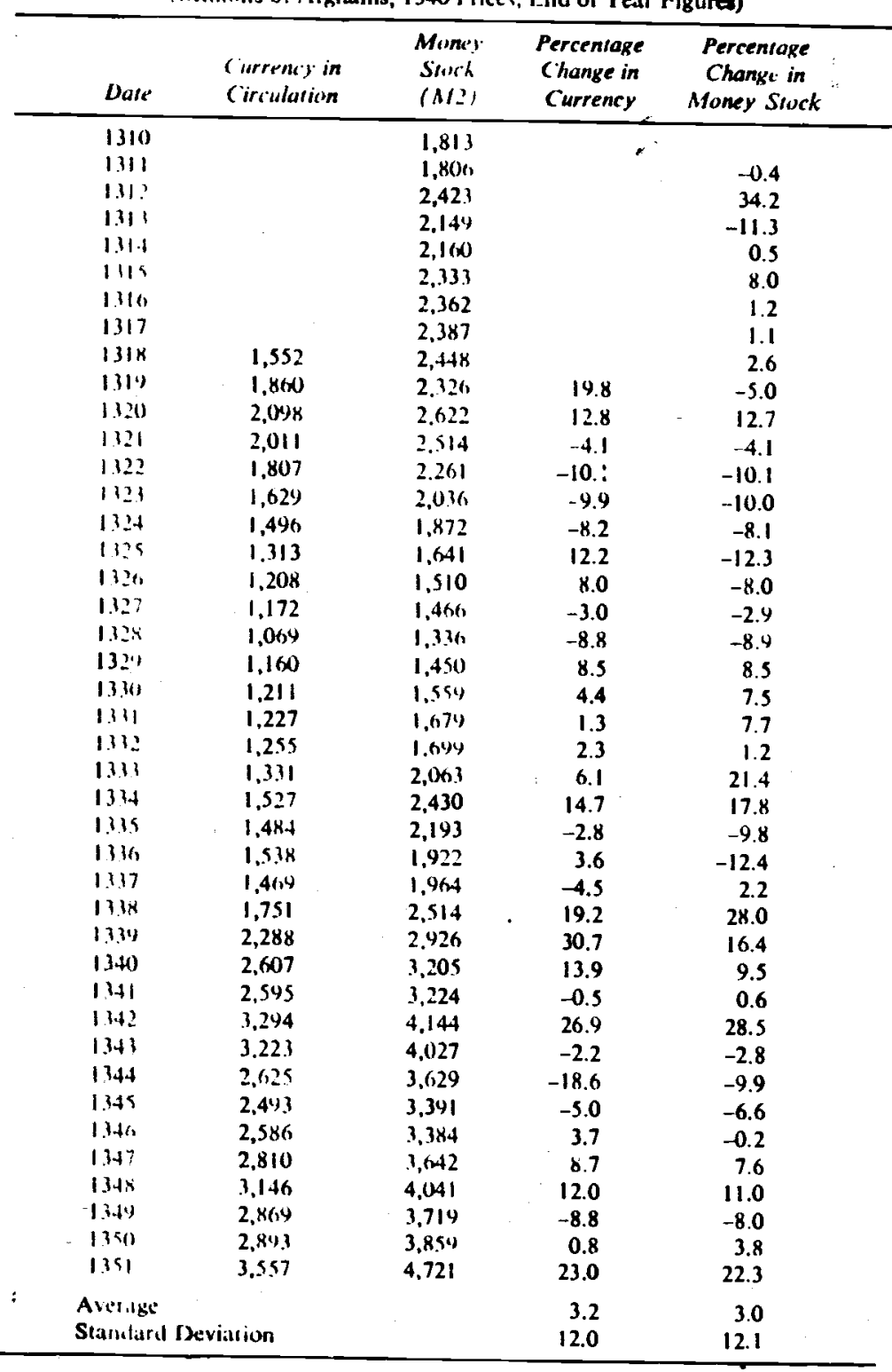

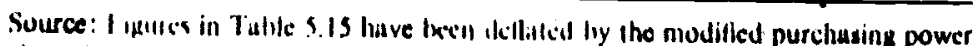
Nollc bice Nole in Table 2.9. Currency figures for $1318-1329$ include viluil cash. I wil be. wined thal this was very small during these yean. parity pricc inter in Table 2.7 
general level of prices but also the demand for money itself. Hence, the double importance of regulating the money supply. Reasoniable price stability is a necessary condition for increasing demand for money in real terms. Depositors desire security not only in the form of the certainty that they will always be able to get their money back but also in the form of the certainty that the money which is eventually withdrawn will be worth at least the same in real terms as it was when deposited. The latter condition is also required by currency holders. Thus, the paramount importance of

the crucial contribution that central banks can make to cionomic development by achieving-and maintaining-reasonable stability in domestic prices and equilibrium in the balance of payments. $\wedge$ central bank that uses its powers to discharge effectively these traditional central banking responsibilities makes a fundamental contribution to development because these are contributions that encourage and sustain economic growth. [B32, p. 781]

In all central banking activities designed to promote financial development, i.e. increase the real demand for money, the same two prerequisites appear, namely, the need to ensure security and the need to provide

Table 5.17

Aierage Annual Percentage Changes and Standard Devialitins in Money and Prices in Ashonistan, Iran, Pakistan and Turkey (Percentages)

\begin{tabular}{|c|c|c|c|c|c|}
\hline & & \multicolumn{2}{|c|}{ Money Stock (M2) } & \multicolumn{2}{|c|}{ Price Level } \\
\hline & & $\begin{array}{l}\text { Average } \\
\text { Annual } \\
\text { Percentage } \\
\text { Change }\end{array}$ & $\begin{array}{l}\text { Sulundard } \\
\text { Deviarion }\end{array}$ & $\begin{array}{l}\text { Average } \\
\text { Annual } \\
\text { Percentage } \\
\text { Change }\end{array}$ & $\begin{array}{l}\text { Situmdaril } \\
\text { De'viation }\end{array}$ \\
\hline \multirow[t]{2}{*}{ Arghanistan } & $1331-1.340$ & 11.0 & 13.6 & 3.1 & 11.1 \\
\hline & $1341 \cdot 1.351$ & 12.1 & .9 .2 & 8.3 & 10.4 \\
\hline \multirow[t]{2}{*}{ Iran } & $1950-1460$ & 14.0 & 7.3 & 4.5 & 9.7 \\
\hline & $1961-1971$ & 16.3 & 5.3 & 1.9 & 2.1 \\
\hline \multirow[t]{2}{*}{ Pakislan } & $1950-1960$ & 8.6 & 5.1 & 2.7 & 15.1 \\
\hline & $1961-1971$ & 11.2 & 5.5 & 3.9 & 4.8 \\
\hline \multirow[t]{2}{*}{ Turkey } & $1950-1960$ & 18.4 & 5.1 & 8.5 & $\delta .8$ \\
\hline & $1961-1971$ & 16.3 & 4.9 & 6.2 & 4.1 \\
\hline
\end{tabular}

Source: Afghanistan-Tables 2.7 and 5.15 .

Iran, Pakistan and Turkey-Internatlonol Financial Statistics: 1972 Supplement: Pah istan Mfonthly Statistical Bulletin, 12 (1), January 1964 (Pakistan Central Statistical Office): Pakistan Institute of Development Economics, A Measure of Inftation in Pakistan. 1951-K0 (Karachi: Pakistan Institute of Development Econonics. MonoPakistan. 1951-40 (Kar
graph No. 4, 1961). attractive caruings in real terms to moncy holders. Regulating the money supply must he designed, therefiore, (1) ensure that supply does not deviate from real demand, i.e. that the money supply is increased so that any increase in demand is satistied or decreased to compensate for any decrease in demand. It must not be increased faster than any increase in demand or decreased slower than any decrease in demand, both of which would cause inflation which in turn would produce uncertainty and negative relurns to money holding.

Given llic importance of regulating the money supply, the next step is to examine the way in which a central hank can do this. Work on money supply functions has followed two distimit patlis in recent years. The first approatch, lillowed among others by Molter [M8] and Cagan [C2]. separales three direct determinants if $1 / 10$ moncy supply, namely, high powered moncy. the currency/money rallw and the reserve/deposit ratio. and analyses their movements. High puwered money or the cash base is defined here as currency in circulalion and valult cash of the commercial banks. "This totil is called "high-poincred money' because one dollar of such moncy held as bank reserves mity give rise to the creation of several dollars of diposits" [F24, p. 50]. The second method, followed by Bell and Berman $[B \mid \gamma]$, concentrates on an .lccounting framework through which the (jurernment's financial deficit can be linked to changes in the moncy supply. These two approaches are hy no means mutually exclusive. The Governnent's financial deficit may well be, and in Afghanistan certainiy hia been, the major contributor to increases in high powered inoney.

The threc determinants approach, as the first method of analysis refired to above will hereafter be called, starts with an equation giving the moncy supply expressed in ternis wi the three determinants:

$$
\begin{aligned}
& H \\
& \text { ( } R \quad(R \\
& \mathrm{M}^{+} \mathrm{D} \text { MI) }
\end{aligned}
$$

where $M$ is Ho money supply, H high puwered money. $C$ currency in circulation. $R$ holdings of reserves by the hanking system, and $D$ deposits included in the definition of moncy. Contributions of each factor to changes it dice moncy supply can be computed after a minor transformation of the abuve equation has been made. It may then be possible to study the dicrminants of the determinants. i.e. of the two ratios and high powered moln'v. The relationship between the Government's delicit and increases in high powered money has alreatdy teen mentioned. 
In the process of econonic development, the currency/money ratio can be expected to follow a secular downward path. However, certitin factors maly accelerate or retard this trend, which may or may not move smoothly. Confidence both in the economic and political stability of the country will he in important factor. Other factors may include the geographical spread of bank branches, the interest paid on deposits. lottery prize inducements, bank advertising, and general measures associated with financial development.

The reserve/deposit ratio may also depend on the same variables as the currency money ratio, but will also be influenced by any changes in legal minimum reserve requirements. Where legal minimum reserve reyuirements exist, reserves can be separated into those which are required and those in excess of this requirement, i.e. usable reserves. A seculir downward trend in the latter might be expected during times of economic and politicil stability. Evidence from the U.S.A. suggests that changes in these two ratios have tended to be small and, when they did occur, to move in the opposite direction [C2, pp. 19-20].

In Afghanistan. changes in high powered money or the cash base are cilused hy the borrowing of the Governınent from Da Afghanistan Bank. the Bank $:$ lending to the private sector and changes in its foreign exchange holdings. When Da Afghanistan Bank assumes the role of banker to the commercial banks and discontinues its own commercial banking operatiuns, lending to the private soctor will only occur through its extension of credit io the commercial banks. By controlling the provision of credit to the public sector and the commercial banks and either accurately forecasting or controlling its foreign exchange position, Da Afghanistan Bank could determine overall changes in high powered money.

In the industrial countries of the west, there has been a generally accepted view until recently that changes in high powered money affect the money supply in a multiplier fashion through fractional reserve hanking practices. Elementary textbooks on money and banking invariably prowide examples of this process (e.g. [N6, Chapter 2]). In a country such as Afghanistan. where the liquidity position of the commercial bianks is known to be both high and variable, no such mechanistic relationship call he assumed. Nevertheless, it is frequently found in empirical investigations that, because of the greater importance of high powered nunncy in inoney supply as a whole, the relationship between changes in the latter "1) changes in the former is actually closer in underdeveloped countries than is the case in countries possessing highly sophisticated linincial systems.
Eventually. when bank deposits do become the dominant element of the money supply in Afghanistan, fluctuations in the currency/money and reserve/dupusit ratios will be potentially much more important determinants of changes in the money supply than they are now; at present, deposits cepresent only a small fraction of the money supply. Then, it will be important for Da Afghanistan Bank 11 pursue a rediscount policy which buth creates a strong dependence of the commercial banks on it and produces such confidence that reserves are Keld around the legal minimum requirement. In this situation. changes in credit extended to the commercial banks by Da Afghanistan Bank will have a predictable, multiplier allect on the level of their depusm. As Dorrance points out:

.... this instrument of monetary control is likely to be most powerful in the developing countries. It is likcly to be effective in that the depositmoncy hanks will probably respond wo any easing of central bank policy. while llke central bank retains the initlative to restrict its operations if such a policy is anpropriate at any timc. $I t$ is an instrument that is consistent with the institutional situation in most developing countries. It need not lead (1) countervaiting speculative reititions by the communily. Finally, it is by itself. independent of the fiscial and other requirements of a developirt: (u)untry. [1)7. p. 278]

In the brict discussion of a moncy vupply function presented earlier, the public sector deticit approach was incorporated into the more general three detcrminants approach as one of the factors influencing the quantity of high powered moncy. It may well be that high powered money is the most important determinant of the money supply and that the public sector deficit is the most significint fitctor producing changes in high powered money. Nevertheless, it is useful to keep the more general approach in mind as it does indicalte all possible sources of fluctuations in the nuncy supply, some of which, although not important in the past. might become so in the future. Furthermore, the three elements are controlled hy three different economic sectors, the currency/money ratio by the privilte. mon-bink sector, the reserve/deposit ratio by the binking sector and high powered money by the central bank and/or public sector. The reations of these three groups may differ from one another and yet be predictible. The importance of each determinant and the precise effects of cach of their own determinants hecomes crucial in an assessment of the extent to which the money supply is a policy variable of the central hank.

To csimtac the contribution of: the threc elements, high powered money. llic currency/money and reserve/deposit ratios, Equation 5.5 
requires some modification before it can be applied. A number of alternatives are possible, the one chosen here being to convert it to a log differential form:

$$
\begin{aligned}
\frac{d \log M}{d t} & =\frac{d \log H}{d t}+\frac{M}{H}\left(1-\frac{R}{D}\right) \frac{d(-C / M)}{d t} \\
& +\frac{M}{H}\left(1-\frac{C}{M}\right) \frac{d(-R / D)}{d t}
\end{aligned}
$$

and to approxinute this continuous function by annual averages. Thus, d ling $M$

dt is ipproximated by $\left(\log M_{t}--\log M_{t}\right)$ and similar adjusiments arc made for all the differential terms. The ratios $\frac{M}{H}\left(1-\begin{array}{r}R \\ D\end{array}\right)$ and $M$
$H$$\left(\begin{array}{c}1 \\ -\end{array}\right)$ are calculated by averaging their beginning and end of year values. For the entire period, the averages of all the annual rates of change have been used.

Table 5.18

Sirurces of the Roles of (hange in Afghanistan's Mtoney Stock 1.138-1351

\begin{tabular}{|c|c|c|c|c|}
\hline \multirow[b]{2}{*}{ Dar' } & \multirow[b]{2}{*}{$\begin{array}{l}\text { Tolal Percentage } \\
\text { Chanke in the } \\
\text { Money Stock }\end{array}$} & \multicolumn{3}{|c|}{ Percenrage Rares of Change Contrituted hy" } \\
\hline & & $\begin{array}{c}\text { High Puscred } \\
\text { Money }\end{array}$ & $\begin{array}{c}\text { Currency/ } \\
\text { Money Ratio }\end{array}$ & $\begin{array}{c}\text { Resuriel } \\
\text { Depos.l } \\
\text { Ratio }\end{array}$ \\
\hline $13.1 \times$ & 8.78 & 1.66 & 5.42 & 1.72 \\
\hline 1,1314 & 2.05 & 12.47 & 8.94 & 1.53 \\
\hline 1.3411 & 15.04 & 21.64 & .2 .65 & .1 .42 \\
\hline 1.141 & 20.24 & 20.21 & 0.61 & 0.57 \\
\hline 1342 & 21.93 & 21.92 & 0.66 & 0.66 \\
\hline 1.34 & 18.86 & 14.13 & -0.43 & 5.16 \\
\hline 1344 & 8.43 & -0.65 & 7.84 & 1.27 \\
\hline 1.145 & 2.01 & -1.31 & -1.27 & 0.56 \\
\hline 1346. & -0.05 & 6.83 & $-\mathbf{2 . 8 7}$ & 4.03 \\
\hline $134 ?$ & 7.65 & 4.12 & -0.76 & 4.29 \\
\hline $134 x$ & 15.08 & 20.51 & -0.65 & -4.78 \\
\hline 1349 & 7.03 & 8.22 & 0.55 & 1.74 \\
\hline 1.350 & 6.64 & 0.88 & 1.84 & 3.93 \\
\hline 1351 & 18.22 & 14.38 & -0.38 & 4.22 \\
\hline
\end{tabular}
(Percentages)

Notc: All ligures given in this tablo are the annual percentage rates of change. Not all lines allt up to the lotal because of rounding and approximation errors. Source: Iniernational Financial Statistics. 26 (10), October 1973, pp. 40-41; and Internuriumul Fimancial Stallstirs: 1972 Supplement, pp. 228-29.
Over the period 1338-1351 (1959-1972), the money supply increased at an annual wcrage rate of 10.57 per cent. Annual average contributions from changes in high powered moncy, the currency/money and reserve/ deposit ratios were 10.36 per cent, -0.07 per cent and 0.28 per cent. respectively. In other words, over the entire period changes in the money supply were the result of changes in high powered money. There were virtually no sffects from changes in the currency/money or reserve/ deposit ratios.

Table 5.10

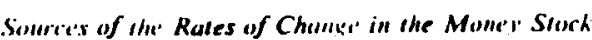

\begin{tabular}{|c|c|c|c|c|}
\hline Durs' & $\begin{array}{l}\text { liond l'erces- } \\
\text { rage ( hange } \\
\text { in the Money' } \\
\text { Siock }\end{array}$ & $\begin{array}{l}\text { Pircentase } \\
\text { High Powired } \\
\text { Money }\end{array}$ & $\begin{array}{c}\text { lates of Change } \\
\text { Currencyl } \\
\text { Money Ratio }\end{array}$ & $\begin{array}{c}\text { Contributed hy } \\
\text { Reserve / Dapossil } \\
\text { Ralio }\end{array}$ \\
\hline 19622 & 12.8 & 13.1 & 2.2 & -2.5 \\
\hline 196.3 & 17.0 & 100 & 1.0 & 6.0 \\
\hline $190+4$ & 16.6 & 4.4 & 3.1 & 4.1 \\
\hline 196,5 & 13.1 & 15.1 & 2.6 & 4.6 \\
\hline 1966 & 13.1 & 50 & 3.8 & 4,3 \\
\hline 1967 & 15.5 & 12.4 & 2.4 & 0.7 \\
\hline $196 . x$ & 18.2 & 13.7 & 2.9 & 1.5 \\
\hline 190.4 & 17.3 & 17.6 & 3.2 & -3.5 \\
\hline 1970 & 15.5 & 15.2 & 1.6 & -1.3 \\
\hline $1962 \cdot 70$ & 15.5 & 12.4 & 2.5 & 0.5 \\
\hline
\end{tabular}
in Irain. Pakistan and laiker. 196/-IV7I)

\begin{tabular}{|c|c|c|c|c|}
\hline \multirow[b]{2}{*}{ Dafo } & \multirow{2}{*}{$\begin{array}{c}\text { Toral Percen- } \\
\text { taxe (hanxe } \\
\text { in the Honey } \\
\text { Siock }\end{array}$} & \multicolumn{3}{|c|}{ Percentuke Rates of Change Contrihuled hy. } \\
\hline & & $\begin{array}{c}\text { Hixh Punered } \\
\text { Monney }\end{array}$ & $\begin{array}{c}\text { Currencyl } \\
\text { Money Ratio }\end{array}$ & $\begin{array}{c}\text { Rescric/Deposit } \\
\text { Ratios }\end{array}$ \\
\hline 190,1 & 4.7 & 2.7 & 2.0 & 0.1 \\
\hline 1962 & 6.3 & 1.3 & 5.2 & -0.3 \\
\hline 1963 & 13.6 & 8.1 & 6.1 & -0.6 \\
\hline $19 \mathrm{HH}$ & 16.6 & 12.9 & 4.5 & -0.7 \\
\hline 1965 & 12.4 & 7.9 & 4.8 & -0.3 \\
\hline 19rat & 14.2 & 13.0 & $0.7 \cdots$ & 0.6 \\
\hline 1967 & 9.0 & 4.2 & 6.4 & -1.7 \\
\hline $196 k$ & 9.0 & 3.3 & 4.4 & 1.3 \\
\hline 1964) & 10.5 & 11.3 & -1.0 & 0.2 \\
\hline 1970 & 9.6 & 7.5 & 2.1 & -0.1 \\
\hline 1961.70 & 10.6 & 7.2 & 3.5 & -0.1 \\
\hline
\end{tabular}


Table 5.19 (Continued)

TURKEY

\begin{tabular}{|c|c|c|c|c|}
\hline \multirow[b]{2}{*}{ Den. } & \multirow{2}{*}{$\begin{array}{c}\text { Total Percen- } \\
\text { rage Chanke } \\
\text { in the Mone.' } \\
\text { Shock }\end{array}$} & \multicolumn{3}{|c|}{ Percentage Rates of Change Comirilutled hi. } \\
\hline & & $\begin{array}{c}\text { H/gh Powered } \\
\text { Money }\end{array}$ & $\begin{array}{c}\text { Currency/ } \\
\text { Mones Ratio }\end{array}$ & $\begin{array}{c}\text { Reserw/Deposis } \\
\text { Runio }\end{array}$ \\
\hline 1461 & 7.7 & 9.3 & -1.4 & 0.2 \\
\hline 1462 & 11.6 & 10.2 & 2.0 & 0.5 \\
\hline 1963 & 8.8 & 8.5 & 1.2 & 0.8 \\
\hline 1464 & 11.8 & 14.0 & 1.5 & 0.7 \\
\hline 1465 & 17.9 & 16.0 & 3.4 & 1.4 \\
\hline IWN & $\mid$ |M.| & 14.7 & 4.7 & 1.1 \\
\hline 1467 & 19.4 & 15.1 & 2.5 & 1.7 \\
\hline $190, x$ & 14.4 & 12.6 & 3.8 & 2.0 \\
\hline 1969 & 19.8 & 13.2 & 4.0 & 1.1 \\
\hline 1970 & 13.5 & 13.1 & 0.0 & 114 \\
\hline $1961-70$ & 13.6 & 12.7 & 1.9 & -1.0 \\
\hline
\end{tabular}

Note: All tigures given in this table are the annual percentage rales of change. Not all lines add up to the total because of rounding and approximation errors.

Source: Bunk Morkwai Iran Bulletins, 3-10, 1962-1971; Pakistan Momthly. Statisticul Bullerins. 14r12-1971: Tiirkiye Cimhuriyeti Merkez Bankist Aylik Bülteni. 1962.1471.

The sane picture, however, does not emerge when the changes in the individual years are analysed. The figures presented in Table 5.18 above indicate that the short run influence of high powered money on the money supply is much less predictable than the long run influence. Both currency/ money and reserve/deposit ratios are much more volatile in the short run and from inspection do not appear easily explicable. Detailed work by the author on Turkish monetary statistics suggested that a lag between an increase in high powered money and the corresponding increase in the money supply of about five months existed [F25, p. 89]. Unfortunitely. the lack of data makes a similar test on the Afghan monelury system impossible. Table 5.19 provides comparative figures for Iran, Pat istin and Turkey. Declining currency/money ratios in all three countries have provided positive contributions to changes in the money supply. There is no noticeable trend in the Afghan currency/money ratio, an indication of the absence of financial development in Afghanistan. This is brought out more clearly from the ligures given in T:ables 2.11 and 2.12 above.

The question which must now be answered is :

Does control over the monetary base and other instruments provide the central bank with sufficient powers to fit the behavior of the money stock into at given program? [F2, p. 221]
Regressing the annual changes in the money supply against changes in high powered money produces a cireflicient of determination of 0.56 , indicating that 56 per cerit of the variance in the money supply is accounted for by changes in high powered money. Litgging the relationship by onc year, i.e. hypothesising that chlanges in high powered money affect the muncy supply a year later, gives a coellicient of determination of 0.39 , somewhat worse than that resulting from the unlagged analysis. In a similar exercise on Turkish monetary statistics, the author found that without taking account of any lagged adjustment changes in high powered money explained 70 per cent of the fluctuations in the rate of change in llic money supply. With a live month lag, 88 per cent of the variance was alccounted for by changes in high powered money [F25, pp. 89-90]. In I ratice, another study found that less than 50 per cent of the variance wals explained in this way [M8. p. 28.3]. II should be mentioned, however, that these results were for quarlerly rather than annual differencis.

Taking the arpalysis to have provided an alfirmative answer to the question poned abote. i.e. concluding that the largest part of the fluccuattions in clanges in the money supply are determined by changes in high powered money in Afghanistan. Iwo further questions require examination: ( an Da Afghanistan Bank comrol the stock of money on a month-to-munth or a quarter-to-quarter balsis? Does Da Aighanistan Bank, or at least the central Government authorities as a whole. hold control aver the volume of high powered money?

A glarue at Afghanistan's monthly and quarterly monetary data suggests that short run control over the money supply is considerably more diflicult than long run control. Evidence from the U.S.A. has also shown that vitsonal forces severely reduce the authorities ability to control the fuatntity of inoney in the short run [A25; F2, p. 225]. In Afghanistan, the inportance of agriculture accentuates this short run disability in that seasonal fluctuations calmot be accurately predicted; counteracting measures to maintain a target ligure for the money supply cannot therefire be taken in advance. Any agricultural price support programme will compound this difficulty. Thus, a negative answer to the first question $m$ : $d$ above is reached.

The second question produces a considerable statistical problem to which only a partial and liar from perfect solution exists. It arises from the fact that the annual public sector deficits produced using monetary data are by no means consistent with those derived from the Government accounts. The reasons for the difference spring from the fact that there 
is a sericus time lag in the compilation of Government accounts, these accounts are not strictly on a cash basis and further do not include Government enterprises. The discrepancy appears to find its waty into "other items" in the monetary surveys. Therefore, if changes in the Government position vis-d-vis the financial system are required, a more realistic figure may be obtained by including "other items" with "Claims on Government (net)." This procedure is followed here. Table 5.20 presents absolute as well as percentage changes in both high powered money and the public sector debt calculated by the method described i: hove. It is clear that little relationship exists. Changes in public sector debt have been much more volatile than changes in high powered money. lluctuations in the latter being to some extent ironed out by compensating changes in credit extended by $\mathrm{Da} A$ Aghanistan Bank to the private sector, Over the entire period, public debt increased by Afs 9,169 million, whereas high powered money only increased by Afs 6,452 million. Rejuctions in foreign exchange holdings enabled this to occur. Furthermore, private sector credit increased only very modestly and in real terms actually
declined.

Tabie 5.20

Annual Changes in High Powered Money and Public Sector Deht 1.138-1351

\begin{tabular}{|c|c|c|c|c|}
\hline \multirow[b]{2}{*}{ Dutse } & \multicolumn{2}{|c|}{ High Powered Money } & \multicolumn{2}{|c|}{ Public Sector Debt } \\
\hline & $\begin{array}{l}\text { Chunge in } \\
\text { Millions } \\
\text { of t/ghanis }\end{array}$ & $\begin{array}{l}\text { Perceniage } \\
\text { Change }\end{array}$ & $\begin{array}{l}\text { Change in } \\
\text { Millions } \\
\text { of Afghanis }\end{array}$ & $\begin{array}{c}\text { Percinuagi' } \\
\text { Change }\end{array}$ \\
\hline I.18 & 33 & 1.7 & -11 & 1.3 \\
\hline 1334 & 267 & 13.3 & $6+42$ & 76.2 \\
\hline 13.40 & 550 & 24.2 & $\$ 67$ & 38.8 \\
\hline 1341 & 633 & 22.4 & 1.351 & 36.1 \\
\hline 1342 & 848 & 24.5 & 2.144 & 42.3 \\
\hline 1.43 & 654 & 15.2 & $-1,011$ & 14.0 \\
\hline 14.4 & 32 & -0.6 & -355 & 5.7 \\
\hline 1345 & 64 & -1.3 & -717 & -12.1 \\
\hline $1.34 h$ & 344 & 7.1 & 1,185 & 23.1 \\
\hline 1.147 & 219 & 4.2 & 919 & 14.5 \\
\hline 1348 & 1.236 & 22.8 & 3.074 & 56.9 \\
\hline 1344 & 571 & 8.6 & 424 & 5.0 \\
\hline 1350 & 64 & 0.9 & 2,078 & 23.4 \\
\hline 1.351 & 1,129 & 15.5 & 717 & 6.5 \\
\hline \multirow{2}{*}{$\begin{array}{l}\text { Average } \\
\text { Standard }\end{array}$} & & 11.3 & & 18.8 \\
\hline & Deviation & 9.6 & & $2 x .8$ \\
\hline
\end{tabular}

Source: Imiernational Financial Statissics, 26 (10), October 1973, mp. $+0-11$ : anc International Financial Stat/stics: 1972 Supplememt, pp. 228.29.
Changes in high powered money have not moved in mechanistic response to changes in the public sector deht. Hence, even if Da Afghanistan Bank could control the latter this would not automatically ensure control over high powered money and through this the money supply. The absence of any mechanistic relationship between public sector deficits and changes in high powered money does not, fortunately. imply a negative answer to the second question. It simply means that the other determinants of changes in high powered money, namely, changes in $\mathrm{Da}$ Afghanistan Bank's lending to the private sector and changes in its foreign exchange holdings. must either be cuntrolled or predicted so that compensilting changes in public sector iredit can be arranged. In fact, the public sector deficit at present takes precedence and compensations in terms of changes in credit exteruded to the privalle sector and oflicial foreign exchange holdings are made. Idcally, the forcign exchange situation should be predictable or planned and a policy to make necessary changes in public and private sector credit extended by Da Afghanistan Bank so that high powered money chinged in the appropriate way worked out in advarice. This is where fircecist monetary surveys can play such a useful role in monetary policy.

Where Givernment borrowing requirements are neither planned nor nredictable, as is shown to have been the case in the following chapter, monetary policy of the type discussed ahove is doomed so long as the Government horrows solely from the central bank and the central bank is powerless to refuse. When such a situation is foreseeable. the only alternative which can allow monetary policy to be planned and implemented elliciently to promote financial dev slopment both by maintaining stable prices and avoiding violent and unexpected contractions of credit to the privalle sector is for the Government to raise loans through a free auction of treasury bills. Agreement can be reached in advance on the ammual acyuitition of bills by the central bank and on some expected interest rate or these bills. In this way. the independence of monetary policy is ensured and any variation in interest rate on the bills from that expected will occur only when the Government sells more than the central bink bas agreed to buy. Such variation will not only deter the Government from increasing its borrowing beyond the amount which the central bank has agreed to finance, but ensure that such extra borrowing is non-inflationary and furthermore force the Government to bid competitively for the economy's scarce resources.

The ullimatc aim of moncy supply regulation is the maintenance of stable prices, lull employment and an econonic climate conducive to 
development. It is therefore essential for effective implementation of monetary policy that the relationship between the money supply and the level of Gross National Product at current prices be examined. From projections of the real growth rate, an optimal money supply policy can then be calculated. The framework for such analysis has been presented in Chapter 11. Here, it is simply assumed that in general control of the money supply over the long run is the most important weapon for the maintenance of relative price stability.

The question which now arises is: Who was responsible for the erratic helaiviour in the money stock? It has been shown that the greiter part "f the fllucluations in the money supply are determined by chianges in high powered inoney. Furthermore, changes in public sector deht were found to have been even more volatile than changes in high powered noncy, as cin be scen in Table 5.20. Over the period 1338-1351 (1959-1972) the average annual increase in high powered money was 11.3 per cent with a standard deviation of 9.6. Over the same period the average annual increase in public sector domestic debt was 18.8 per cent with a standard deviation of 28.8. The greater variability of changes in public sector domestic debt than in high powered money is due to the fact llat Da Afghanistan Bank made compensating changes in the credit it extended to the private sector and in its foreign exchange reserves. Nict reductions in foreign exchange reserves enabled public sector domestic debt to increase at a considerably faster rate than high powered money.

Given that the Government's financial requirements have alwilys taken precedence over all other considerations, it would appear that the extraordinarily high annual variations in public sector domestic borrowing has been ultimately responsible for the variability in the inoney supply. with Da Arghanistan Bank attempting to and partially succeeding in dampening these fluctuations through private sector credit and reserve policies. The causes of the volatile public sector domestic horrowing rec; iurements are analysed in the following chapter,

Iligh virriance in the rate of inflation, caused by the extreme volatility of public sector domestic borrowing, has been one factor contributing to financial stagnation. In addition, the rate of inflation itself, which can also be attributed to excessive public sector demestic borrowing, has suppressed financial development. Such borrowing can be regarded as a ta $x$ on money holdings since the inflation it has created reduced the real vilue of money held. The consequences of this tax on one of the most important products of the financial sector have been succinctly analysed by Shaw in the followirg extract:

Real money balances can be regarded not merely as wealth from the standpoint of the money-holder but as social wealth, deserving a place on the social balance sheet with wealth in machines, inventories, structures, natural resource endowments and humin skills. A fully monetized economic system cill exıract the highest yield from its productive capacities. Incomplcte monetization constrains productivity. Afghanistan is among the least monetized of economics, yet it was public policy to tax money more severely than other forms of weilth. P'ut another way, it seems that policies were pursued to ensure that Afyhanistan would renain a barter society. [SI], p. 8]

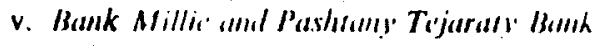

Of the llice $n$ m-s specialised banks, Bank Millic is gencrally regarded as the most ellicient, P'alitany the least. Bank Mrillic is the only private bank, yet in several ways it resembles a Government agency. For example, its personnel policy hears similaritics with the Government's in that great emphasis is placed on security and litule on paynent according to merit. Silary scales themselves are not much above the Government's and again senior staff bemoan the lack of trained statt at the lower and middle levels. Not surprisingly, Bank Millie s lending policy is now the most conservative of the lhree bauks.

Pashtany Fejaraty Bank sulliers from Government civil service personnet policies and Goverument intervention simce it is a Government bank, yet lacks nute issuing powers and/or rediscount facilities with Da Afghanistan Bank to ensture the maintenance of liquidity. This is likely to create a major problem at some future date.

Tables 5.21 and 5.22 provide some balance sheet data and banking ratios for these 'wo institutions. The former generally indicates the small size of the two banks. Of interest in the latter has been the steady increase in thre deposit/atsset ratio, the wildly fluctuating reserve/deposit ratio and the apparent decline in the credit/asset ratio until 1349 (1971). The latter is not too informative in that a large proportion of Bank Millie's loans go io firms in whic! it has major equity interests.

There atr o uny similarities between Bank Millie, Pashtany Tejaraty Bank and D: Alghamistan Bank. Lending is concentrated in the foreign trade sector, hanches are no more than deposit and collection agencies, elliciency is low and, in certain Government banks, corruption has been reported. In fencral, the commercial hallks present a sorry picture of stagnation.

The provinces have sultered from Nighanistan's highly centralised banking system. No loans have been grancel by the branches without the 
Tuble 5.2

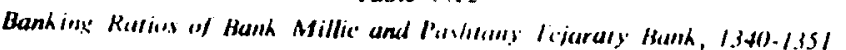
(Percent.tgk)

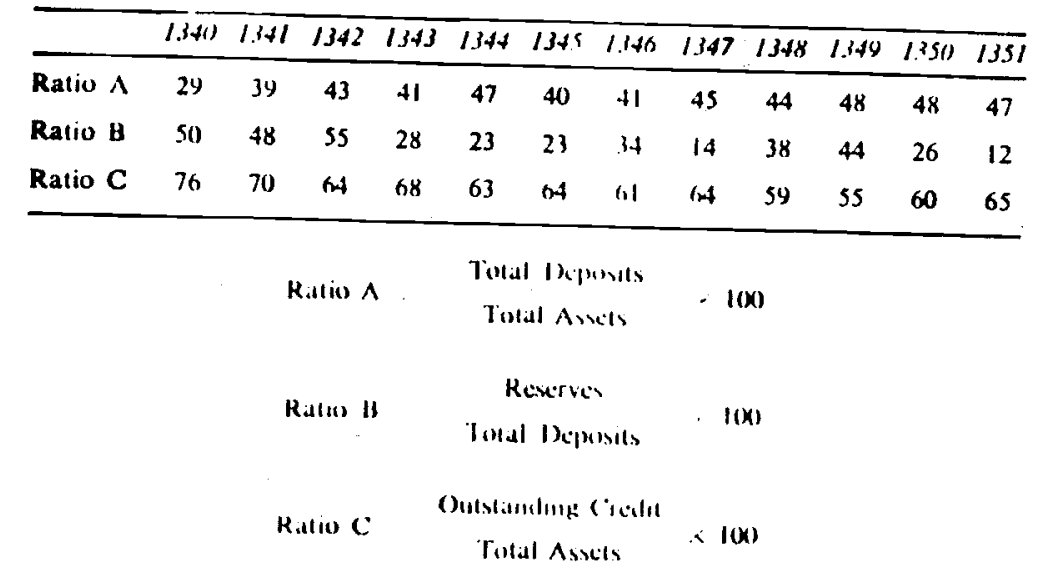

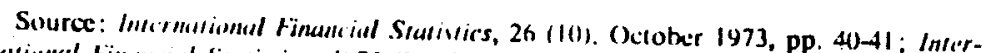

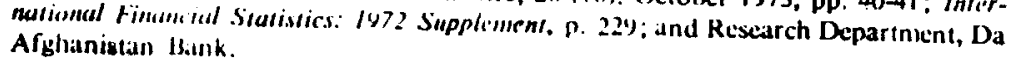

decision being tirst taken in Kabul. Most hranches of Da Afghanistan Bank have nol even accepted loan applications. A further deprivation in the proviness $w$ ' respect to banking facilitics springs from the lack of a bank clearing system. Thus, cheques cannot, in general, either be cashed or even paid into an account in any brancli other than that on which the clicques are drawn. An exception appears to be Bank Millie's head office branch which has accepted cheques from other branches and other banks for payment into an account after they have been cleared.

This stron' detcrent to the use of banking facilitics in the provinces has resulted in the possession of bank accounts by only a very limited number of people, c.g. wealthy fireign Iraders, and joint stock companies. Virtually no one else uscis the banks. lindeed, when asked whether they would like to borrow from a bank. scveral respondents in the survey mentioned in Chapter 111 replied that they already had enough trouble with the Cinsermment and indebtedness to it would be disastrous. The association of Dit Afghanistan Bank with the Government is not surprising given the fact that the smaller branclics undertake almost no besiness apart from the collection and disbursement of public funds. Information collected thus suggests that the banking system has done litule to facilitite the transfer of funds inroughout the country and has 
firiled (1) administer the payments mechanism. Improved trinsport between the major towns has made it easier to transfer cirsil. This has apparently actually retarded the growth of bank deposits.

Mixed feelings were expressed by respondents on the desirability of the estahlishment of foreign bank branches in Afghanistan. At one extrems. nationalistic sentiments were exhibited and the view lliat alt prolitalllc ventures should be in Afghan hands was propounded. At the other extreme, however, there wis a frequently expressed hope that forcign hanks would be more willing than domestic banks 10 lend money and so would be a considerable asset. This sentiment wlien took the form if a feeling that Moslem banks were generally unhelpliul. There were, of course, a number of respondents who viewed the establishment of liurcign banks in Afghanistan quite neutrally, stating that as long as there were more banks willing to lend, it did not matter whether they were domestic or foreign.

\section{vi. Sincinulised Bunk.s}

The history of specialised banking in Afylianistan has been less that sillisfactory. A new period, however, started in 1348 (1970) with the reconstitution of the former Agriculture and Cottage Industries Bank Hllo the new Agricultural Development Bank (AgBank) with help from the Inited Nations and the World Bank. There are severial striking dillerences between the alctivities of the AgBank and the cimmercial banks. Dupite the lact that it is a Government institution, the $\wedge_{\mathrm{gBank}}$ hats been operating under new personnel policies, which take some major departures from the eivil service procedures previcusly followed. since the heginning of 1352 (March 1973). Pay scales have heen considerably riaised. Hac civil service promotion system and titles abolishel ad an incentive scheme introduced.

The AgBank also differs from the commercial banks in that it is expanding ripidly as can be seen from the dala in Table 5.23. Thesc tigures can he compared to those of the Mortgage and Construction Bank given in Table 5.24. Recently, the AgBank solicited the problematic job of dist ibuting credit for leruliser purchases and has devised new ways and mcans of increasing the probability of prompt collection. Due to the lack of market intelligence, the former did not meet expectations in 1352 (197.3) hecause eflective demand for such credit was considerably lower than fincecast, again illustrating the endemic communications problem discussed in Chapter III.

The accounting procedures used by the AgBank dilfer from thone of the commercial hanks and the Mortgage and Construction Bank not only in the fact that they are much more accurate and are audited by external auditors of international repute, but also in the important fact that bad debts are written off. No debt in any of the other banks hals ever been written oft. This alone results in such distortions as to make the balance sheets and profit and loss statcments extremely misteiding.

The Montgage and Construction Bank has so reduced the scope of its activities that it is virtually defunct. $A$ few small loans to Government employees are all that are now made.

The Industri.l Development Bank ol Aighanistan (JDBA) established after many yours of planuing and negulations in 1.351 (1973) has just stitrted operations and hopes to make ws lirst loans in 1352 (1973). Like the $\mathrm{AgBank}$, the IDBA is managed hy a foreign management team lunded by lle UNDP with the World Bink as executing agency. Unlike the AgBank. the IDBA is a private corporation with 40 per cent foreign participation. Bank Millic. Pashtany Tejaraty Bank and the Chamber of (ommerci hold another 40 per cent of the equity. In relation to the equity capital of $\mathrm{Al}$, 240 million. the IDBA is 11 receive an enormous subsidy from the (iolcrumcit in the form of an $A$ is 560 million loan at 2 per cent interest with repalyment over 25 years. which includes a 10 year grace period, Irwm Da Aighanistan Bank. The World Bank, through IDA, has

$$
\text { Tals: } 5.33
$$

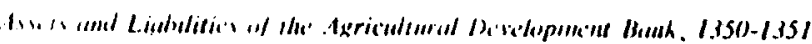
(Millious of Alghanis, Lind of Year Figures)

\begin{tabular}{|c|c|c|}
\hline & 1350 & 1351 \\
\hline \multicolumn{3}{|l|}{ ASSF 1s } \\
\hline Cash and Deposits & 118 & 229 \\
\hline Claims Aloroad & 24 & 49 \\
\hline Donmcitic loans & 91 & 384 \\
\hline Participiations & 16 & 16 \\
\hline \multirow{2}{*}{$\begin{array}{l}\text { Invenfouics and Cionds in Transit } \\
\text { Other Asscts }\end{array}$} & 65 & 56 \\
\hline & 8 & 13 \\
\hline ASSEIS LIABILITIIS & 322 & 747 \\
\hline \multicolumn{3}{|l|}{ LIAIIIIITIES } \\
\hline Deponis & 15 & 156 \\
\hline \multirow{2}{*}{ 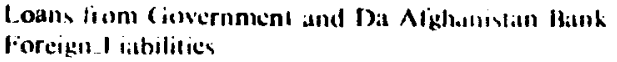 } & 6 & 142 \\
\hline & 53 & 18 \\
\hline Other lidulilitics & 32 & 13 \\
\hline Paid-un Capital & 215 & 395 \\
\hline Reserves and Undismbuled Protits & 1 & 23 \\
\hline
\end{tabular}

Source: Accounts Bepartulent, Agricullural Deselopment Hank. 
provided a $\$ 2$ million loan to the Civverument with a 50 year term, 10 year grace period, at a service charge only of three-quarters of a per cent on the amoumt outstanding. The ciovernment, in turn, is to extend foreign exchange to the IDBA at rates of $5 \mid$ and 71 per cent, the former for relending at 8 per cent to small scale firms, i.e. firms with less than $\$ 100,000$ worih of equipment, the latter at 10 per cent to other borrowers. The foreign exchange conversion risk is in both cases borne by the borrower. Lending policy is likely 11 be conservative. The expected return on IDBA capital in the short run is 12-18 per cent. The anomalous eflect of the spread of interest ratles and returns in terms of income distribution has been noled by Shaw:

$\ldots$ if the IIBBA achieves a portiolio eytial only to funds initially cominilted and earns upon them, after allowing for expenses, a return of 7 per cent, the yield to stockholders will exceed 18 per cent. That is hardly comparathle with the yichl to taxpayet of 2 per eent on the Government's loan, (hrough Da Afghanistan Batsh, to the IOBA. [S11, p. 20]

vii. Prohkims of Bank Le'nding

Not only has the volume of credit meatsured at constant prices which has been received by the private sectur declined considerably over the past decade, but the variety of loans has also contracted. Because of diflicultics experienced by the banks in collecting loans on maturity, the types of collateral which are now acceptable against secured loans have been reduced. The difliculties in collecting debts have been mentioned in several publications:

... the hallnks are reluctant to widen therr range of borrowers or to extend credit ficitities 10 industry and agriculture, owing to inadequate protection under existing laws. [U12, p. 106]

Since the rights, dulies and obligations of both borrower and lender are not cleally detined by law, neither connnercial bankers as lenders nor the privatc vector ins borrowers can be expected to fully mobilize the credit resources of the country to accelerate econtomic development. [M30, p. 19]

The lack of suilable laws as for example a civil code, credit security laws, a general banking law and the inexperienced administrative staff of the banks is well as that of the different commercial courts makes it difficult

... the banking institutions have not been successful in distributing and collecting loans.... The failure of the bainking systen in the distribution and collection of loans is mosily dice to poor management, untrustworthiness of borrowers and the use of bank credit for consumption and non-productive purposes. [M]1, p. 19] 
The three recurring problems which emerge from reports and interviews with the managers of credit departments in all the banks :Ire:
A. L.cgal
B. Management
C. Political

The legal problems appear to arise from the influence owncrs continuc (11) hold wer the disposal of their collateral, slow and inclicient court procedures, the political and social influence of the borrower, incompetent curert cillicials and corruption. Management problems arise from inidcyuatc training in audit and inspection procedures for bank cmployecs, nepotism in promotion and incompetence in buth branch and head ollices. Similar defects in the borrowing institutions themselves and in the customs houses compound these difficulties. Political influence has been exerted on state owned financial institutions to extend specilic loans.

The histories of the specialised Government owned banks well illustrate the prowlems of institutional lending in Afghanistan. One of the major problems has been postponement of interest and instalment payments. The Industrial Eredit Fund was established at the beginning of 1336 (1457) with a capital of Afs 205 million. By the end of its first year it had lent out almost all its funds and thereafter "ceased to uperilte to all intents and purposes" [B34, p. 15]. The Fund was later wound up when tt became "ident that loans would never be repaid. The salme fale hals bet:allen all the other specialised banks. The Agriculture and roltage Industries lank established in 1333 (1954) had exhausted its lunds by 1337 (195x):

The Agricultural Bank continued giving loans till the end of 1337 , but as many of these loans were not utilized in productive enterprises and is the hank could not recover the major part of its loans and interest of six percent, at last it decided to close the chapter of giving loans. [M23, p. 12]

The peculiar problem faced by the Agricultural Bank in taking land tilles as security is illustrated in the following passage on lending by nomads:

In most cases the ordinary nomad today owns no land, but on the other hand often takes it on the so-called gerawi terms. This means that. against a once-for-all payment in the shape of a loan, the nonlad takes a detinite area of land as security. All rights to the land belong to the tender. and as he neither can nor will cultivate it, this is left to an Hatrara on orditilry tenant conditions. If Islamic law is followed, the burrower (former owner of the ground) must not be employed as tenant. [1:3, p. 133]
Thus, land can only be given as mortgage if it is then farmed by someone other than llie uwner.

The $A_{g} B$ ink and the Mortgage and Construction Bank have turned to the Government to support collection. Until recently, the $\Lambda \mathrm{gBank}$ lending activities were conlined to tractor and water pump loans to large farmers, It is, luwever, attlempting fo exlend activitics. It tried with only limited succen to distribute credit 10 groups of farmers for fertiliser purchases in 1.352 (1973) and is planning (1) lend to sinall farmers under a system of supervised credit in the neur litturce. In this, it is sceking assislance for supervisun from (iovernment entomion services, PACCA, the

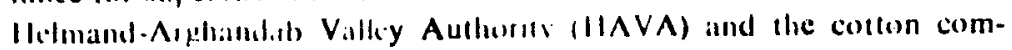
palnies.

The main problems faced by the AytB:anh in its lending activities are hest gleatled lirom twe repurts of the AgBink itself:

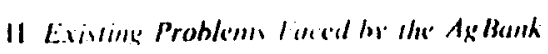

A Prollams Related w the Distriburm of Crodit

The ApBank in following general principles of banking and its own regulations does not extend luans (o) borrowers who cannot meet certain requirements. As security, the Aglsink has aceepted the following items: immow.the property (land, shops. houses, etc.); movable pronerty such as ilgricullural products, including anmal products, merchandise and houk : aul guarantes from tinancial institutions and auro-business firms. To bilipuard its losils. the Agbank has generally required immovable propkes is security for mediun and long-tern loans.

The mowision of such security is still hased on Governnent regulations concinning guarantees which were prepared by the Ministry of Finanic and latltisd by it: (abinet. To mortgage land, the owner swears in the preseme of iwo wimesses in a court of law (mahkama-e-wasayeq) that he is placing a particular piece of his land under mortgage against the loan which is being provided by the Bank. On default, the Bank has the right in sill the mortgaged property witheut recourse to further judicial procidurc.

In praclic. a number of defects in this system does not encourage banks to aceiple such security (wasiqa) for the following reasons:

I since the cadastral survey has not been sompleted, the actual size and nillure of the security is uncertain.

2 Incouret land registration results in uncertainty as to whether the posemore of the title is in fact the owsen of the land.

3 The biricty of customary rights in difterent parts of the country over witler use (haqaba) which is a mitiw lidctor in determining the value ot the property adds to the uncertainty of the security.

4 Various stindards of measurement llish hum raiz, paikal, quiba, etc.) lurbles add to the problem. 
5 Finally, legal promissory notes do not conform to the Bank's requirements. Unclear handuriting of court officials can easily prevent the document from being officially accepted.

B Inifhiulties in Sethling Lran Contracts

I I oans are extended in accordance with the conditions laid out in the contract which after the provision of adequate security is signed by both parties. The contract sets out the rights and duties of both sides. The Conimencial Law establishes that disputes arising from such contracts should be taken to the commercial courts. However. as a result of various problems such as the non-atlendance of borrowers of the bank atturney, contracts have not been registered in the courl. This, of course, creates additional problems.

2 The absence of commercial courts in many parts of the coluntly in any cilse makes registration of contracts impossible. 1 Registration departments (wasayeq) create obstacles preventing speedy
registration.

C C (allection Problems

Although the borrower vests the right to sell his security with the binh and his neighbours promise to buy the land in the case of default. the $h$. .lk is often unable to sell the security bucause: I The inhabitants of the district refuse to buy the land through fiar or
compassion.

2 The immediate neighbours are not in a position financially to buy the land or they also want to help the borrower.

3 The judicial authorities will not transfer the sccurity to the bank without the consultt of the borrower. Even if it is transferred to the bilnk. the bank will not be able to manage the properly: the establishment of management team is too costly.

4 Loan collection is another area in which the bank does not possess any atthority and at present this is undertaken by Governnteut agencies. This has crealed many additional problems.

\section{1) Horronucrs: Difficulies}

In the absence of cooperatives, land tilles and other securities. a large number of farmers are deprived of receiving agricultural loans. liven farmers with land titles who want to borrow are faced with severe diffcullics arising from the costs of legal promissory notes and psychological
fitetors.

\section{Prohlcms: Rexurding Security for Medium-Term Lumis.}

Medium-term loans are generally given to farmers to help them huy immediate needs such as improved seeds, fertiliser, chemicals to combat insects, small tools, animals and to help them improve their marketing. In these cases, immovable property is held as security.
In this instance, the AgBank faces the following difficulties:

I Preparation and distribution of eredit for individual farmers possibly exceeding a nillion in number is a najor problem.

2 Granting loans to farmers agaitsst their aglicuitural and animal products is not problem-free, both hecause the coomerative system is not common and also because the marketing system has not been developed, except for a few items such as sugar bect and cotton. Otherwise the sale of agricultural products is not contrulled and the collection of loans is difticult.

3 Preparation of promissory notes fir moitgages for short-term loans and alsu repistration of the contracts related to these loans in the commercial courts crealte some problems in that they make the distribution of loans. whish all incicalsing diay by day. impussible. In particular, fertiliser will the niciled by over half a million farmers in the next scason. Although the Alghan Fertiliser (ompany has been established to satisfy the needs of limmers. there are not enuugh slorchouses throughout the country and therefure fertiliser canmot be destributed to all the farmers. [A10, n. 3-12]

3.2 Serminios

At pexem, the only utilized form of security is mortgage on land. Land security is estahlished through a legal act unilertaken in the courts. A mortgige on land can be given only by a landowner. The Bank also accepts land mortgage of a person other that the borrower. The procedure involved in getting a land mortgage contirmed by the court is timeconsuming and troublesome. From the security document finally issued by the comit on the basis of the "Qithala". which does not show the actual status of ownership. AgBank cannot be certain that the land mortgage olutianed will be a valid guarantec, from which prosecution can be stasted without any dilliculty.

It is the desire of Agliank that steps should be taken to simplify the legal documtents and procedures involved in order to give further encourage. ment' ' the farmers and to enable Aglzank to expand its loan activities. If the former does not pay the loan when it falls due the Bank's only remedy is the possibility of selling the nurtgaged land. Under the present security system the sale of land not only involves legal problems but also problems in the practical aspects of the salc. Since the security is based on the signlitures of neighbouring landwiners. who have to state that they would the willing to purchase the land in the case of prosecution, this normtally results in the ncighbours' refusing to comply, claiming they have no civtl available. that they maintain a good relationship with the present landew $m$ and therefore do not want to take away his land, and that in cases where a neighbour signed the mortgage and has since died, his heirs are nul willing to fulfill the obligations anreed to by the deceased. If it actuatly comes to a sale it is also very jiflicult for an outsider to buy the land as he will face difliculties in the future with the neighbours. The AgBink's taking over the land under the present system would add more problems to the already existing oncs 
For these reasons many Bank loans have been long ovcrduc. There are many cases available in the Bank as proof.

Giencrally, besides land, farmers do not have anything else --such ats shares in companies, governmental bonds, warehouse receipts for goods placed in government warehouses, guarantees obtained from other banks, or wher movable property--of great enough value to serve as sccurity for $A g$ Bank. In addition to the difficulties arising from the legal procedures in obtaining land securities, the actual number of landowners in a position (1) obtilin these securitics on land is very limited, the reason being that only a minority of landowners has the land actually registered in that names and therefore can produce land titles. In many cases, the land hetongs to several members of a family who have inherited the land from their father, grandfather, etc. In such cases, it would take the content of all the family to put the land under mortgage. As experience has shown, this is also very difficult.

3.3 collertion

3.11 Short-term I.oans

The cullection rate of short-term credits dishursed to cotton companics, the PACCA (ioperative. and to agro-business enterprises with rates between 90 and 100 per eent is satisfactory. The collection rates for credits extended for fertiliser, however, are not at all satisfactory. For the disbursements of 1350, which were due on Mizan I, 1351, up to Hool 29, 1351, the average rate of collection was 63 per cent in the whole country, with, varialions from 28 per cent in Kabul Province to 100 per cent in Bamyan. The , eason for this poor result is the fact that not enough efforts to collect have Iren made and more pressure should come from the RGA [Royal (ivvernment of Afghanistan)

\subsection{Medium- and Long-term Loans}

The collection rates of AgBank of individual loans are also not siltisfactory. In the lirst nine months of 1351 , for instance, the recovery rate if mediumicrm loans fallen due in that period was only 76 per cent. The loans not cillected when they fell due are iransferred to the category of " iverdue" where the collection ratc is even lower. The category of "loans is having with the system of securitics as lower. The difficulties AgBank h nouing exactly that prosecution on as described above resull in farmers les for less for AgBank. Additionally, it is widely known that the (iovernous does not take a strong position in the collection of fertiliser eredit. This haturally has side-effects on AgBank's eollections.

[AY. pD. 6-8]

The Murtgage and Construction Bank, established as the Coustruction Bauk in 1.326 (1947) and renamed the Mortgage and Construction 13ank in 13.33 (1954), enjoyed the longest period of activity anongst the * 4 specialised banks. However, operations hive been severely comtracted froili a wide range of medium and long term lending operations for private housing, hotels, eincmas, elc.. and pirticipation in the construction business to a snall volume of loans to Government employees only for a period of five years at al rate of interest of five per cent. It is probable that bad debis will be recognised in the neiı future and the Bank reorganised on the siame lines as the AgBank wals in 1.348 (1.970).

Various allei.nts at debt collection have been made by the Mortgage and Construction Bank but so far without success. The Bank received little help from the Ministry of the Interior which merely issucd summonses on defauller but did not facilitite the sille ol the property. The result wils that borrwwers did not bother to repily their debts. In 1348 (1969), the Supremce (inuncil of the Bank detcrmined to take action by writing to all the defaullers demanding repayment within a month. Non-compliance would result in seizurc and sale of their property by the Law Department of Kabul Province. Furthermore, the Council decided to hire a lawyer for a specific period. Defaulting borrowers were informed of these

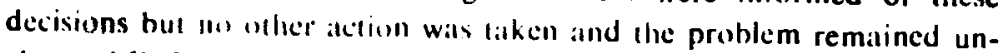
changed [M]o]

In the Amual Report of 1349 (1971), the problem of defiulting borrowers wats agalin brought to the attention of the shareholders. The compounded interest on many loans had reaclied a level at which the dibt excected the value of the mortgaged property. When sales had been attempted thurd partics claimed an interest in the property and so prevented $1 / 16$ ates. A further problem was created in 1349 (1970) when the Cabinct alpproved a mution prohibiting the Bank from holding the titles (qahula) of mortgaged property. Furthermore, the Bank had not insisted on imburance being taken out on mortgaged property. When unimiured murtgaged property had been destroyed, borrowers tended to assume that dicir obligattions to repay were thereby dissolved [M37].

Aguin in (he Annual Reporl of 1.351 (1972) considerable altention is paid to collection problens. The Parliamentary Committee on Public Works and communications had comsidered the Bank's problems and had directed it to firce the sale of muriginged property immediately. Two representalives from the Bank were assigned to work with the Collection Department af the Ministry of the Interior. The latter had been instructed to collect the Bank's outstanding loans by (abinet Decree 962 which received the Ruyal Assent in Jauza 1.345 (Mily/June 1966). It had made no steps to carry out these instructions and some ambiguity as to the intention of the Decree with regard to the responsibility for sale appeared to exist. The Parliamentary Conmittec a gain directed the Bank to make the approprate sales itself. The Bank applalled to the Ministo:t of Finance 
and there the matter rested with no one wishing to assume responsibility for deht collection [M38].

The commercial banks have also suffered from excessive loaln defaults. In particular, Pashtany Tejaraty Bank has virtually exhiusted its resources, faces a serious liquidity problem and is recognised to be in a difficult position as a result of the large number of loan deiaults. The one private hank, Bank Millie, pursues very cautious lending policies and has not expanded its activities by any significant amount over the past twenty years. Apart from some foreign trade finance, most of its funds are used to finance its own companies. The choice of lending policies, as seen hy the banking fraternity, appears to lie between ultra-conscrvitism and bankruptcy.

In the course of collecting a number of case histories of problematic luans. a pattern emerged of which the main elements are outlined below.

A. A loan is granted against collateral consisting of shares in a few specified joint stock companies, jewellery or real estite mortgage. IInsecured loans are also extended in a few cases. Most loans made by Da Afghanistan Bank are extended as a result of Cabinet decrees. This bank also discounts bills of exchange for exporters. In these cases, export licences can be withdrawn if bills are not honoured.

13. The loan is not repaid on the due date. After negotiation. an extension is usually agreed.

C. The bank finally decides to act upon the security. In the case of import finance, this should cause no difficulties in thit documents necied for customs clearance of all bank financed imports should go lirectly to the bank concerned. Unfortunately, customs clearance without the necessary documents has been possible on occasions through the judicious distribution of relatively small sums of haksheesh. Where goods are held up at customs houses, there is the problem that no fixed period is specified in any law or regulation aficr which they become the property of the bank. No specific regulations exist concerning loans for exports.

In the case of other secured loans, the borrower still appears to retain control over the disposal of his collateral. Thus, he may insist thall a minimum price be realised from and even on the timing of a silc. Partly for this reason, Bank Millie has discontinued its former prictice of lending against gold and jewellery. Where shares form the collateral. written authorisation indicating the name of the new owner must be obtained from the shareholder before a bank can divest itself of them in the ecint of default. Land titles are often non-existent but where they do exist, and can form the basis for a mortgage loan, land valuation by the courts for the fazmeen, which is the legal document required for land mortgage, is arbitrary and can be inlluenced by the landowner to the disadvantage of the bank. In any event expropriation of land and resale is almost impossible in practice. Potential buyers of expropriated land, if they exist, can quite easily be dissuaded.

In the case of unsecured loans, no precise reguiations exist for loan repayment in instances of bankruptcy of the borrower. There are apparently no clear provisions for scifure of property or expropriation of collateral on the delialt al a borrower.

D. In the few instances where a cisc reached the courts, decisions have agian been influenced through the use of baksheesh, social pressure or political influence. The banks have generally not received satisfaction from the courts.

It cannot, liowever, he concluded that all the problems of banking arise from bad laws and legal practices. The banks themselves suffer from inadequallely trained staff and faulty loan agreements. Thus, for example, in the casc of mortgage loans the borrower is not required to insure his property: lick of expertise often results in finance being provided unknowingly fiur higher risk foreign trade, etc. Political interference in the lending aclivities of the Agriculture and Cottage Industries Bank, the Industrial ('redit Fund and Pashtiny Tejaraty Bank has also thwarted any pursuit of sound banking practices.

Bankers in Aighanistan are unanimous in the need for legal protection in their lending uperations. The following specific legal requirements have been mentioned:

A. Law for securing bank loans

B. Registration Office for legal registration of all bank loans

C. Special court for enforcing repayment of bank loans

D. Legall provisions for chattel mortgatge

li. Legal provisions for lien on crops

1. Legal pruvisions for loans against letters of credit

G. Cadistial survey

11. Legil provisions for all financial instruments

1. Detailed regulations concerning the absolute rights over and automatic transfer of ownership of collateral 
J. Detailed regulations concerning expropriation of property on default

$K$. Legal provisions for real estate mortgage

L. Specification of responsibilities of customs officials to reliase imports under bank security only against all necessary documents and a time period after which goods become the properiy of the bank

M. Specification of how loans for barter imports should be secured

N. Detailed regulations concerning repayment of loans for exports

o. Detailed reguiations concerning loan repayment in cisses of binkruptcy

P. Wctinled regulations obliging courts to seize property in tuses of delitult

The present Commercial Law enacted in 1334 (1955) contains provisions on negotiable instruments, security interests, etc. The Law itself is defective in a number of important respects. For example, the use of cheques has not developed because there are no penalties specified for writing a cheque against insufficient funds. However, the basic provisions for negotiability exist, yet no negotiable instruments circulate in Afghanistan. The reasion for this is simply that virtually no one knows the Conmercial L.aw-certainly no one working in and with the commercial courts. There, cilses are decided on elementary principles of fairness, Shariat law and the whims of the judge. No one in the Government, the judiciary or the legal proliession understands, for example, that the key to negotiability lies in the provision that a transferee of an instrument can receive better rights than his transferor. In illustration of this, the Ministry of Finance reciently decided to take a foreign exchange dealer to court in a case of dispuled payment. The dealer was involved solely because lie cished an endoried cheque by which the payment was made. This also illusirates llic point that more than just a change in the law is required.

\section{viii. N'om-Bank Finuncial Institutions}

Little space need be devoted to Afghanistan's non-bank financial institutions since the size of their operations is insignificant. It is surprising. however, to find both insurance and cooperative activities so alien in a trading and agriculturally based economy. Gross insurance premiums totalling under Afs 150 million in 1351 (1972), as can be scen in Table 5.25, are small in comparison to a money stock of Afs 9.954 million and an estimated Grose National Product (GNP) of Afis 9.3.554 million for the same year. The ratio of insurance premiums to GNP of under 0.2 per cent can be compared with ratios for 14 developed countries shown in Tat: 5.26 below. Insurance business, like bank business, is not eolicited in Afghanistan.

In terms of investible funds, insurance supplies almost nothing. None of the agencies makes any investments in Afghanistan and the Afghan Insurance Company holds most of its funds abroad. It has, however, an equity interest of about Afs 1 million in the CAM (Coca Cola) Company of Afghanistan and a nominal holding in the Inter-Continental Hotel. The main problem of investing in Afghanistin is again the lack of security. For example, the Afghan linsurance Company had a major task in persuading the CAM Company to take out lire insurance on its plant.

\begin{tabular}{|c|c|c|c|c|c|c|c|c|c|}
\hline & Girms & $\begin{array}{l}\text { asuran } \\
\text { (Millis }\end{array}$ & $\begin{array}{l}\text { able } 5 \\
\text { Pren } \\
\text { ns of }\end{array}$ & $\begin{array}{l}25 \\
\text { ium, } \\
\text { reham }\end{array}$ & $\begin{array}{l}.343-1.3 \\
51\end{array}$ & & & & \\
\hline Institution & 1.343 & 1344 & 1345 & 1346 & 1.247 & 1348 & 1344 & 1350 & $|35|$ \\
\hline A.ghan Insurance & & & & & & & & & \\
\hline Company - & 13 & 24 & 19 & 25 & 34 & so & 69 & 107 & 86 \\
\hline Commercial Union & $-\ldots$ & $\cdots$ & -- & 5 & 5 & 8 & 9 & 10 & 10 \\
\hline Sterling General & $\ldots$ & - & 6 & 7 & 8 & 7 & 8 & 10 & 12 \\
\hline Ingosstrakh & n.a. & n.a. & n.a. & n.a. & n.a. & ค.a. & n.a. & n.a. & n.a. \\
\hline
\end{tabular}

Siurce: Infurmation provided by each invurance institution.

$$
\text { Table } 5.26
$$

Insuranre Premiums as a Percemage of Cruss Nurimal Promlurt in 14 Developedd Countrie's, 1971 (Percentages)

\begin{tabular}{ll}
\hline United States & \\
\hline Austlusliat & 7.1 \\
New /cialiand & 5.5 \\
Britain & 5.4 \\
Ilollaud & 5.0 \\
Switzerland & 5.0 \\
Canada & 4.9 \\
S. Africa & 4.8 \\
Germany & 4.6 \\
Japan & 4.5 \\
Irelausd & 4.2 \\
Denmark & 4.2 \\
Sweden & 3.6 \\
France & 3.4 \\
\hline
\end{tabular}

Source: The F.conomist, "Cinderella of the City: Insurance 1973 ...A Survey," The Econumist, 9 lune 1973, 1.. 28. 
The lick of interest in and understanding of insurance is almost pitholugical in Afghanistan. Property, whether owner occupied or rented out, is virtually all uninsured and few vehicle owners take out any cover. $I I$ is surprising to find entrepreneurs, sophisticated in many other aspects of business, totally uninformed when it comes to insurance. Marine insurance, which accounts for by far the largest proportion, is taken out grudgingly at the banks' insistence before export or import loans ian be received. One reason for the lack of awareness concerning insurance stems again frum lack of competition. As Trosper concludes:

If there is adequate competition among the insurors in a particular community or country, the inmurance companies will hire and liain salesmen who themselves will do the job of educating the potential insurance buyer. [T5. n. 6.]

There are no insurance salesmen in Afghanistin.

The Pension Fund receives about 43 per cent of its annual income from pilyments made by civil servants in the form of 3 per cent of their silaries, the first month's salary increment after promotion and any deductions from salaries for absence, etc. The remaining 57 per cent comes in the form of an annual allocition by the Government. Given that investment policy is non-profit seeking, e.g. it has equity holdings in the Afghan Insurance Company, the Mortgage and Construction Bank, Pashtany Tejaraty Bank and other Government enterprises, it caln hardly be considered an attractive savings outlet to civil servants, even with the 57 per cent direct Government contribution. The return of perhaps 6 per cent in the inflationary environment of the past two decades implies that the return to civil servants is low in real ternıs despite the Governnent's contribution.

The Baghlan and Kohdaman cooperatives are small pilot projects (covering just over 1,000 farmers at present) designed to be models, if sticcessfiul, for Government agricultural cooperative projects at a later datc. What success the experiment has had so far has been due to the fict that it takes the form of an "integrated operation supplying credit, technical assistance and marketing advice" [N8, p. iv]. Crecii for a sizable part of the necessary investment has been supplied hy the AgBank at an interest rate of 10 per cent.

Despitc favourable results, the possible extension of an agricultural cooperative movement is probably rather a long way off. PACCA has encountered serious impediments in working both with the farmers and the Government. The introduction of cooperatives throughout Aighanis- tan will require nol waly a liar greater commitment than previous Govern. ments have slown in this ficld bul also a build-up of well trained and highly motivaled extension agents befirc any programme of this kind could be launched. Hopefully, this will be all area of particular concern to the new Republican Government, since intensive eflorts throughout the country to reach the farmer with demonstration projects, technical assistance, marketing advice and credil, whether by means of cooperative development or not, are essential if agricultural productivity is to be increased. The importance of the latter, hecause it determines in part development pulential, was stressed in chapter III.

ix. Conclusion

The picture of Afghanistan's financial amstitutions presentcd above is not one which can be viewed with coniplacency. Three forces have combined to prevent the development of : sound, efficient linancial sector, namely, the external environilent, the Government and the bankers themselves. The external envirunment has been unfavourable to financial development beciuse of the absence of commercial laws, business ethics, weallh. elc., and the existence of a strong religious antagonism 10 interest. The Givernncml has created an unfavourable environment by its inflationary and highly variable demands on the financial sector in the liorm of public sector domestic borrowing requirements. The banhers have done litlle 10 develop an efficient banking system through training programmes, etc., but have sustained instead uncompetitive market conditions by means of an interlocking network of ownership and comtrol.

Towards the end of 1351 (1973). a Financial Development Committee was established in the Ministry of Finance. It was given a wide brief to prepare and implement a programme of tinancial development and reform. The must urgent measures were pinpointed; thay included banking legislation and revision of the commercial law, training middle and lower level hank employees, and laying the foundations for a strong. independent central bank. It was recognised that the latter required a substantial training programme as well as central banking legislation. None of these me:tsures has heen implemented: their importance remains.

Recently. Hac rate of interest received sime attention by Da Afghanistan Bank and a priposal to raise deposil rates in order to altract more funds was bruught before its Supreme council. Hopes were raised that at long last sume competition might be generated to awaken the dormant financial imstlutions. Two reports supporting the Bank's initiative 
appeared urging it to take additional measures in conjunction with the deposit rate increase [F31; S9]. Hopefully this initiative will he revived under the aegis of the new Republican Government along wit. other vital compunents of the Financial Development Programme. These are oullined in Chapter VIII.

It has been shown that the extent to which financial development has been occurring is the most important economic variable determining a country's development potential [A2]. Afghanistan's low development potential can, therefore, be attributed in part to its stagnant financial system. Hence, the absence of financial development has acted as a critical constraint to economic development. This chapter has explored some of the causes and effects of the lagging financial sector.

The more developed the financial system, the more efliciently can it perform the function of channelling savings into the most productive investment opportunities. Given that past Governments and foreign aid donors have been singularly unsuccessful in this latter task, as shown in the following chapter, it is all the more imperative that it now be undertaken by Afghanistan's financial system. The importance of financial development in the Afghan context cannot be exaggerated. The metamorphosis of the financial system from a lagging to a leading sector is a necessiry condition for economic development. Without this, Afghanistan's development potential will remain low.
CHAPTER SIX

\section{PUBLIC FINANCE}

\section{i. Introduction}

On the accessiun of Nadir Shah in 1.308 $(1929)$, a contemporary report states:

It was mabably the first case of a nationial exchequer being athsolutely bankrupt, unlincel with even a silver coin:... It was literally the case of a musarch ruling at Kabul without possessing so much as even the price of at meal for himself. $[A \mid 5, p .167]$

Forty-four years later, on the proclamation ol the Republic and deposal of Zahir, Nadir's son and successor, bank ruptcy, albeit figurative, was again declared [D2, p. 1; D., p. 2]. It is with the developments in public finance between these lwo years that this chapter is concerned.

Although dalta are almost non-existent for the earlier years, perhaps beciase of an unclear distinction between accounts of king and country, a series of revenue and expenditure figures for the entire period have been estimated and are presented in Table 6.1. For analytical purposes, the figures shown in Table 6.2 are of grcater interest. These are domestic revenue and sxpenditure at constant prices.

In the lirst lew years of the period, a small surplus was realised which Was "utilided to build up a currency reserve" [A II, p. 75; M33, p. 866]. Although a smooth increase has been assumed together with a balanced budget from 1.31.5 (19.36) 10 1.318 (19.39), the Statesman's Yearbook for 1934 salys:

The revenue of Afghanistan is subject to considerable fluctuations. The Covernment share of the produce recoverable is said to vary from onetifth to one-tenth, according to the auvamalges of irrigation. The total revenue is estimated at about one hundred and fifty million (Afghani) rupees, a considerable portion of which is found from customs. [S17, p. 654]

In 1318(19.39). Bank Millie returned most of the Government's original share capital in the Bank and at the same time provided an additional Afs 16 million hion for the establishment of the central bank. Dit Afghanistan Bank. There is doubt as to whether this loan was ever intended to be repaid since it is included in the sum mentioned by the President of Bank Millie when he stated that "the (iovernment therefore obtained 21,1 
Table o. 1

Government Dinnestic Revenue and Expentiture 1311-1.152 (Millions of Afghanis)

\begin{tabular}{lccc}
\hline & $\begin{array}{c}\text { Domesic } \\
\text { Revenue }\end{array}$ & Expendirurc & Oicrall \\
Bullance
\end{tabular}

Note: Puhlic finance dala prior to 1328 (1949) are almost non-existent. The Statesman's Yeitrook gives a rough extimate of revenue for 1313 (1934) and the United
Nations Edhatlewal, Scientitic and Cultural Organisation nrovides another benchmark revenue ligure lur 1318 (1939). The only other data source for the pre-1327 (1948) period is Da Afghanistan Bank Econumic Bulletin which provides gross borrowing by the Government for 1319-1326 (1940-1447). It appears that the Budget showed a surplus in the early 1310 (1930s) so a sniall positive balance is recorded. Revenues have been extrapolited between benchmark years and the overall balance for 1319-1326 (1940-1947) was assunled to equal gross (jovernncellt borrowing from Da Afghanistan Bank. Domeste revenue excludes (on)mudily Assisiance. Expenditure excludes foreign rid expenditure. Throushout this chapere the 1350 and 1351 (1971 and 1472) and afler 13 a 1961$)$ hiscal years have teit the sanke as the Afghan Shmomsi (sellar) calendar years. In 1336 (1957)

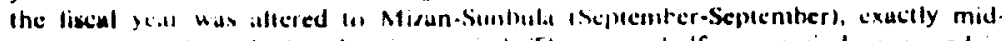
year 10 combule will the planming persod. Thus. two half-year periods cecisured in 13.36 (1957) .m1 $13.40(1961)$.

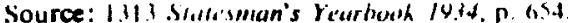

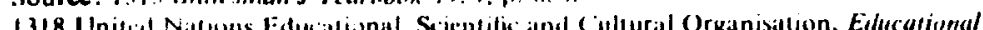

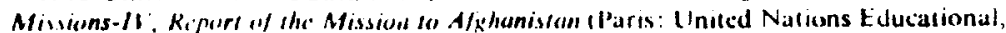
Scientific and (ullenal Organisation. 1952). p. 65 .

1319-1326 Overall balance from Da Afxhanisfan Barth Eiomomic Bullecin, (in Dari), 5 (1). August $\left|y t_{2}\right|$, Tahle $\gamma-A$

1327.1330 D V. Wither (I:d), Afghumiuan iNew Haven: Human Relations Area Files, 1956), Table 6, n. 177

1331-1352 Same as Tables 6.5 and 6.1 3 helow

million atghanis net protit from the bank" [C9. pp. 412.13; 19]. For purposes of constructing Table $(.1$, , it hats heen treated as revenue. Thus, until $1319(1940)$ a halanced or surplus Budget has been recorded.

The Budgetary position throughout the 1.310s (1930s) accompanied by the increate in the world price of silver after 1311 (1932) ensured that the domestic price kivel did not rise appreciably. Debasement of the currency, on the other hand, ofiset any tendency for prices to decline [B29, p. 433; G22, p. 1731

Fiscal problems really began with the decision in 1317 (1938) to suspend convertibility of currency notes inco silver coins [F15, p. 436], previously guatranteed by the 1314 (1935) Law on Banknotes in Afghanistan, and to horrow heavily from the newly established central bank which started activiries in 1319 (1940). Between it: establishment and 1326 (1948), loitns latalling Afs 218 million were authorised by the National Assembly, predecessor of Parliament [FIS, p. 437]. The inflationary impact of this can be gauged roughly through comparison with the size of the muncy stock. An estimate for 131K (1939) of Afs 275 million is given in Table 2.9. By 1.326 (1947) it had more than tripled to reach Afs 850 million.

The rapid inflation caused by deficit linance. a balance of payments surplus and wartince sarcities, played havoc with the fiscal system. 
Table 6.2

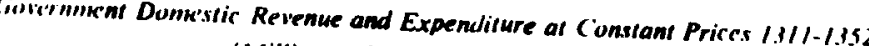
(Millions of Afghanis 1340 Prices)

\begin{tabular}{|c|c|c|c|}
\hline Mare & $\begin{array}{l}\text { Domestic } \\
\text { Revenue }\end{array}$ & Expenditure & $\begin{array}{l}\text { Overall } \\
\text { Balance }\end{array}$ \\
\hline 1311 & 1,428 & 1,408 & 120 \\
\hline 1.312 & 1,859 & 1,833 & +26 \\
\hline 1,113 & 1,596 & 1,575 & +21 \\
\hline 1114 & 1,600 & 1,580 & 120 \\
\hline 1115 & 1,768 & $1.76 \mathrm{H}$ & 0 \\
\hline 1116 & 1,810 & 1,810 & 0 \\
\hline 1317 & 1,892 & 1.892 & 0 \\
\hline $131 k$ & 2.129 & 2,129 & 0 \\
\hline 1114 & 1.938 & 2.566 & 628 \\
\hline 1130 & 1.818 & 1.944 & 126 \\
\hline 1121 & 1,459 & 1.751 & $2 \% !$ \\
\hline 1322 & 1,176 & 1,248 & -72 \\
\hline 1323 & 945 & 824 & 1121 \\
\hline 1.124 & 756 & 731 & +25 \\
\hline 1.325 & 398 & 606 & 8 \\
\hline 1326 & 560 & 769 & -204 \\
\hline 1327 & 544 & 682 & -138 \\
\hline 1328 & 541 & 645 & 104 \\
\hline 1129 & 610 & 862 & 252 \\
\hline 13,30 & 706 & 917 & 211 \\
\hline 1331 & 770 & 1,041 & 271 \\
\hline 13,32 & 983 & 1,063 & 80 \\
\hline 1333 & 1,076 & 1,150 & -74 \\
\hline 1.3 .4 & 1,330 & 1,306 & 124 \\
\hline 1335 & 969 & 1,089 & 120 \\
\hline 1316 (first half) & 681 & 603 & 178 \\
\hline $1,3.16 / 37$ & 1.098 & 1,125 & 27 \\
\hline $13.37 / 38$ & 1,218 & 1.328 & 110 \\
\hline $1338 / 39$ & 1,491 & 1.954 & 46.3 \\
\hline $1.3 .34 / 40$ & 2,228 & 3,299 & $-1,071$ \\
\hline 1.340 (second half) & 721 & 1,398 & -677 \\
\hline 1.341 & 1,744 & 2,708 & 964 \\
\hline 1.42 & 2,270 & 3,601 & -1.331 \\
\hline 1.34 & 2.089 & $2,8.3$ & 764 \\
\hline 1.34 & 2,248 & 2.613 & 165 \\
\hline 1.345 & 2,310 & 2,766 & 456 \\
\hline 11.46 & 2,266 & 2,863 & 597 \\
\hline 1347 & 2,395 & 3,258 & -863 \\
\hline $11.4 \%$ & 2,604 & 3,406 & -802 \\
\hline 1349 & 2,504 & 3,025 & -521 \\
\hline 1.350 & 2,483 & 3,164 & -681 \\
\hline 1,351 & 2,683 & 3,386 & $-? 03$ \\
\hline 1352 (B) & 3,060 & 3,949 & -889 \\
\hline
\end{tabular}

Source: I igures in Table 6.1 have been deflated by the modified purchasing power
Revenue increased modestly between 1318 (19.39) and 1327 (1948) fron Afs 247 million 10 Afs 319 million as can be seen in Table 6.1. In reat terms, however. Table 0.2 shows thal revenue was reduced to just over one-quarter of its pre-war level, which was not in fact exceeded until 1339 (1960). Domestic revenue in 1351 (1972) was only 26 per cent higher in real terms lhan in 1318 (1939).

The wartince experience highlights the major deficiency of the revenue system, namely, specific rather than ad balor'm tax rates on land, livestock and a facto on most imports, together with excessive reliance on foreign trade laxation. In 3305 (1926) sown after Amanullah had substituted cash payment for taxes in kind. land and livestock taxes contributed 62 ? ner cent or Ats 30 million tw the total revenue of ats 48 million [G22, p. 173. In 1.327 (19.48) taxes (3) land and livestock totalling Afs 83 million reprexented 26 per cent [1117. p. 6.5]. By 1.351 (1972) the contribution had declined 10 I per cent of totill dumestic revenue. Despite the fact What land tax rates had been doubled in 1344 (1965), revenue from land and livestock taxes actually fell to Als 78 million in 1351 (1972), partly as a result of the abolition of the livestock tax in 1345 (1966).

A law following the 1310 (1931) Constitution made it illegal for new taxes to be imposid or radical changes made without the consent of the Lova Jirgai (Great Council), which had to be convened at least once every three years [G15, p. 305]. Prior to 1343 (1964), the Budget was presented w ihe Shura (National Assembly). The 1343 (1964) Constitution also gave this power to the Shura (both houses of Parliament) [C18, Article 75!. Since the Great Council, National Assembly and Parliament were componed predominantly of landlords who were not permitted to form any political parties. it is not su surprising that by 1352 (1973) the agriculcural sector was paying virtually no direct taxes.

The reason for the powerful position of the landowners lies in the fact that it was tribal support which brought Nadir Shah to power. To maintain thin iupport for the critical years during which the army was rapidly heing strengthened, various cuncessions were made. Six serious trihal revolts since 1309 (19.30) attest to the polential threat posed by the Iribes to a central authority in Kabul [W.3. p. 103]. The fiscal concession was zealously guarded by Parliament until its disbandment by the Republicitn Government in 1352 (1973).

Modernising the army was a continuous objective of those in power during the Musahiban period [HII, p. 121: R6, pp. 160-86; SIS, p. 11]. In pursuing it, a number of changes of a developmental nature, e.g. in the areas of communicitions, education and transport, occurred. With 
Soviel holp. military capability was strengthened under the Dioud administration [F18, p. 6: G12, p. 2] to a point where by 1344 (1965):

With its long sought goal to modernize the military accomplished. the royill timily faced the continuing imperative that it preserve and strengthen the layalty and allegiance to the regime of an officers' corps which had been educated to operate a modern military organization and which, in the process, had also acquired modernizing perspectives and roles. In effect. those Afghan leaders who in the future would be able to secure the allegiance and control of the military establishment would he the individuils upon whom would devolve the power and authorily to detine the policies and goals of Afghanistan's modernization and in puicle its destiny as a nation. [R6. p. 197]

The establishment of the Republic in 1352 (1973) lends credence to this anilysis.

Budgel expenditures were not divided between ordinary and development outlays until 1331 (1952). Since then, a somewhat arbitrary, though cunvistenl, distinction has been made. However, the informallon on education, health and road construction presented in Chapter II indicates that development expenditure during the 1310s (1930s) was not insignificant. Since the First Plan, inaugurated in 1335 (1956), development expenditure has increased rapidly. Whether the vastly increased outlays of the 1340s (1960s) achieved much greater results than those of the $1310 \mathrm{~s}$ (1930s) is debatable. What certainly differed were the methods of linance.

Balanced budgets were the norm in the 1310 s (1930s) and few loreign loans were sought in the pre-war period. Afghanistan's first forcign debts were incurred during $\wedge$ manullah's reign. He ordered a substantial yuantity of military and other commodities on credit during his European tour in 1.306 and 1.307 (1927 and 1928), In 1311 (1932), the debt 10 Germiny which had still been outstanding in 1308 (1929) was being repaid in eight annual instalments [A II, p. 116]. A few relatively small loans were obtained in the pre-war period from Britain, Czechoslovakial and Germany. By 1328 (1949), however, there only remained a small fraction of the British loan outstanding [F14, pp. 312-13]. In 1328 (1949), Afghanistan's position and prospects for future foreign aid looked good:

In all these credit arrangements, as in the commodity barter agrements with other countries, including the Soviet Union, the Afghan Ciovernnent displayed a strictly businesslike attitude and loday oflers al tield for investment free from internatiunal mortgages and commitments. [F14, n. 313]

By 1.350 (1971) Afghanistan felt it necessary to request some rescheduling of its loreign debt, despite the fact that a considerable pirt of the credit still a vailable had not been used [U14. p. 94]. A nother request was submitted in 1.351 (1973). Without further agreements in this respect, the cost of debe servicing could reach SDR +5.3 million by 1355 (1976) or, at the $1351(1472)$ rate of exchange, Afs 3.597 million, a figure approaching so per cent of total exports in $1351(1972)$ and well over 50 per cent of total donestic revenue in that yeatr.

ii. The Fiscal insem

Tables 6. 3 and 6.4 present the hasic structure of the Government's budgetary position since 1331 (19.52), liour years prior to the First Plan. Domestic revenue and urdinary expendilure have increased steadily over the period, the latter at a slughtly fauter rate than the former. In real terms, there has alow been an upward trend except during and inmediately after the $1 w$. periods of relatively high rates of inflation, 1333-1335 (1954-1956) and 1.343-1.344 (1964-1965). The much more dramatic effect of wartime inllation on real revenuc and expenditure was discussed in the previous section.

The current account balance, which for 1332-1334 (1953-1955) represented 20 per cent of domestic revenue, has lluctuated considerably on an annual hisis mer this period. By 1.349-1.351 (1970-1972) it had actually declined in real terms and represented only 71 per cent of domestic revenue. (Juc inpect of the fiscal system, apart from the need to obtain legislative approval for the Budget, which hat tedevilled the Government, is the greatef price elasticity of ordinary expenditure than of domestic ronue $1 \mathrm{hm}$ fealure of the system has produced self-perpetuating initationary pressure requiring constant vigilance to stop it getting out of hand. Section $v$ helow considers this problem in more detail in relation 10 deficit linance.

A substantial increase in development expenditure, in both real and nominal terms, took placc between 133 | (1952) and 1344 (1965), a result of rapidly expanding domestic expenditure and loreign aid inflows. Given the failure of the current account balince to increase in real terms, domestic development expenditure had to be financed to an increasing cxtent from Commodity Assistance and even more so from domestic borrowing. Since most project assistance has been received only after the local currency component has been allocited, it is not surprising to find project awistance increasing in parallel with domestic development expendiume until 1344 (1965). In reall terms, the latter reached a peak in 1342 (196, . ). Two years later, project assistance peaked and by 1349 (1970) was only anc-third its 1.344 (1965) level. In real terms, domestic develop- 
ment expenditure was by 1349 (1970) less than half its 1342 (1963) level. During the 1350 s (1970s) some recovery has been achieved.

Between 1336/37 (1957) and 1351 (1972) project assistance contributed over 70 per cent of total development expenditure at constant prices and one-third of domestic development expenditure was financed through Commudity Assistance. Despite the substantial foreign aid input which in total cuntributed over 80 per cent of the development budget, raising funds for the remainder of the local currency component of the development budget has been a continual problem. The fiscal system has not been moklified by anything like the extent neceseary to allow sullicient current account surpluses to be achieved. In the short run, the problem wals solved by recourse to excessive domestic borrowing from Da Aighanistin Bank. Efforts to curb the ensuing inflationary impact resulted in cilt balch, in planned development expenditure. This pattern is well excmplified by events during the 1340s (1960s).

Table 6.3

Bulderary Position /33/-/352 (Millions of Afghanis)

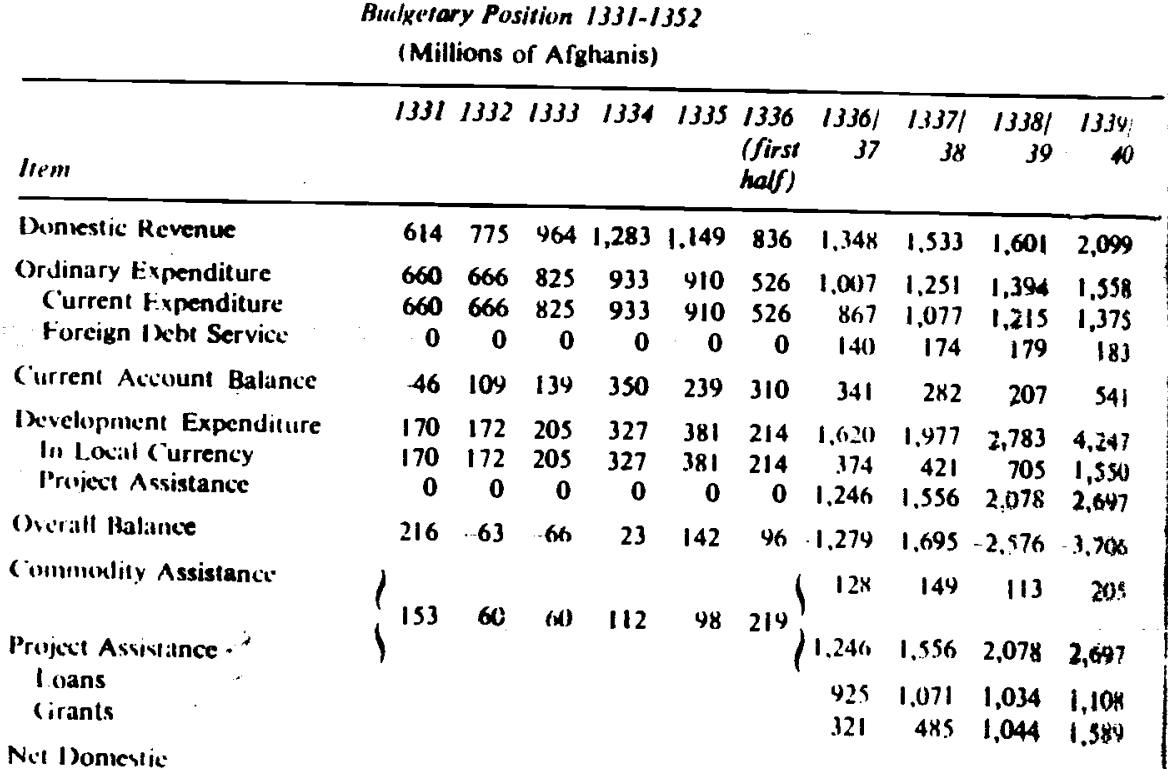

Burrowing (Residual) $\begin{array}{llllllllll}63 & 3 & 6 & -135 & 44 & -315 & .45 & .10 & 385 & 504\end{array}$
Declining forcign aid since $1344(196,5)$ can in small part be attributed to the inability of the Government to meet local currency financing requirements of projects for which the foreign exchange component had already been provided. The reduction in foreign aid since 1344 (1965) can also be attributed to donors' disillusionment with Afghanistan's overall development achievements, the inability of the Government to mobilise domestic resources through either the Budget or the financial sector, the increasing debt/equity ratio of the Guvernment, the end of the Cold War aid race, and the completion of some major infrastructure projects. By far the most inumortant factor, however, bis been the failure on the Governments part in prepare projects.

The summary budgetary position shown in rables 6.3 and 6.4 indicates a rapid increase in the negative overall balance. A more useful way of analysing this is to reduce it by the gramt component of foreign aid. Intil the late 1340s (1960) , most Commodity Assistance was obtained in

Table 6.3

Budvelary Pavision 1331-1352 (Millions of Afghanis)

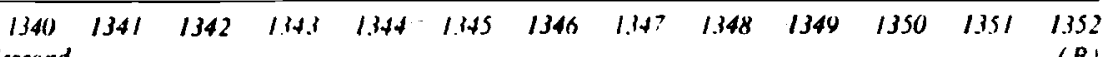

isecond

$\begin{array}{lllllllllllll}721 & 2,123 & 2,677 & 1,061 & 3.976 & 4.285 & 4,211 & 4.465 & 5.085 & 5,702 & 5,823 & 6,172 & 7,037\end{array}$

$\begin{array}{lllllllllllll}878 & 1,850 & 2,416 & 2,558 & 2,902 & 3,403 & 3,613 & 4.254 & 4,732 & 5,158 & 5.504 & 5,684 & 6,538\end{array}$

$\begin{array}{llllllllllllll}745 & 1.542 & 1.873 & 2.174 & 2.646 & 2.929 & 2.948 & 3.653 & 3.865 & 4.144 & 4.364 & 4.634 & 5.067\end{array}$

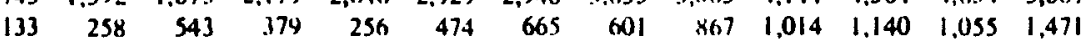

$\begin{array}{lllllllllllll}157 & 273 & 261 & 503 & 1.074 & 8 \times 2 & 598 & 211 & 153 & 544 & 319 & 483 & 494\end{array}$

$\begin{array}{llllllllllllll}2,343 & 4.590 & 4,663 & 4,790 & 5,205 & 5.101 & 4,496 & 4.079 & 3,910 & 2,972 & 3,460 & 4,609 & 4,7 \times 0\end{array}$

$\begin{array}{llllllllllllll}520 & 1,446 & 1,830 & 1.622 & 1.720 & 1,72 \times & 1,707 & 1.820 & 1.420 & 1,731 & 1,916 & 2,100 & 2,544\end{array}$

$\begin{array}{llllllllllllll}1,823 & 3,144 & 2,833 & 3,168 & 3,485 & 3,373 & 2.789 & 2.254 & 1.940 & 1,241 & 1,544 & 2,509 & 2,236\end{array}$

$\begin{array}{llllllllllllll}-2.510 & -4.317 & 4.402 & 4.287 & 4.131 & 4.219 & -3.898 & 3.668 & 3.557 & -2.428 & -3.141 & 4.126 & -4.281\end{array}$

$\begin{array}{lllllllllllll}104 & 112 & 615 & 411 & 7.14 & 8 \times 9 & 517 & 1.018 & 479 & 627 & 929 & 1,250 & 1.245\end{array}$

$\begin{array}{llllllllllllll}1,823 & 3,144 & 2,813 & 3,16 \times & 3,485 & 3,373 & 2,789 & 2,250 & 1,4 \times 0 & 1,241 & 1,544 & 2,509 & 2,236\end{array}$ $\begin{array}{lllllllllllll}\$ 943 & 1.556 & 1,1.50 & 1,854 & 2.539 & 2.918 & 2.477 & 1,854 & 1.552 & 924 & 1.339 & 1,842 & \text { n.a. }\end{array}$

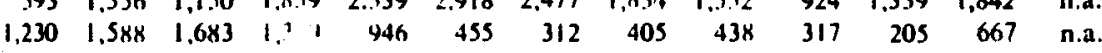

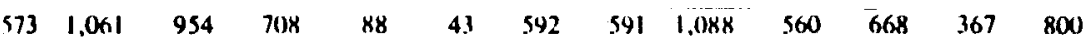

Note: Pruject assistance excludes most technical assistance. In |35| (1972), there were ahoul 2.300 foreign experts working on 300 projects in Afghanistan. The residual item. Net Domestic Borrowing, as explained in Chapter V, differs substantially

6.13

Source: Simme as rables 6.5 and 6.13 
Table 6.4

Bututetary Position at Constant Prices 1331.1352

(Millions of Afghanis, 1340 Prices)

Table a.d

Buclyetary Position at Combune Prices 1331-1.352

(Millions of Afuhinus, 1340 Prices)

\begin{tabular}{|c|c|c|c|c|c|c|c|c|c|c|c|c|c|c|c|c|c|c|c|c|c|c|c|c|}
\hline Item & & 1331 & 1332 & 133.1 & 1334 & 1335 & $\begin{array}{l}1336 \\
\text { (first } \\
\text { half) }\end{array}$ & $\begin{array}{r}1.3 .16 / \\
.17\end{array}$ & $\begin{array}{r}1.1371 \\
38\end{array}$ & $\begin{array}{r}13381 \\
39\end{array}$ & $\begin{array}{r}1339 i \\
40\end{array}$ & $\begin{array}{l}1340 \\
\text { (second } \\
\text { half) }\end{array}$ & 1341 & 1342 & $11+1$. & 1.344 & 1.345 & 1946 & 1.147 & 1.348 & 1349 & 1350 & $\mid .351$ & $\begin{array}{r}1352 \\
(B)\end{array}$ \\
\hline Domestic Revenue & & 770 & 983 & 1.076 & 1.330 & 969 & 681 & 1.098 & $\cdot 218$ & 1.491 & 2.228 & 721 & 1.744 & 2,270 & $2,0 \times 4$ & 2,248 & 2.310 & 2,206 & 2.345 & $2 .(x) 4$ & 2.504 & 2,483 & 2,683 & 3,060 \\
\hline $\begin{array}{l}\text { Ordinary Expenditure } \\
\text { Current Fxpenditure } \\
\text { loreiun Iebt Servict }\end{array}$ & & $\begin{array}{r}828 \\
828 \\
0\end{array}$ & $\begin{array}{r}845 \\
845 \\
0\end{array}$ & $\begin{array}{r}921 \\
921 \\
0\end{array}$ & $\begin{array}{r}967 \\
967 \\
0\end{array}$ & $\begin{array}{r}768 \\
768 \\
0\end{array}$ & $\begin{array}{r}429 \\
429 \\
0\end{array}$ & $\begin{array}{l}820 \\
7166 \\
114\end{array}$ & $\begin{array}{l}994 \\
856 \\
138\end{array}$ & $\begin{array}{r}1.298 \\
1,131 \\
167\end{array}$ & $\begin{array}{r}1,654 \\
1,460 \\
194\end{array}$ & $\begin{array}{l}878 \\
745 \\
133\end{array}$ & $\begin{array}{r}1,520 \\
1,308 \\
212\end{array}$ & $\begin{array}{r}2,049 \\
1.589 \\
460\end{array}$ & $\begin{array}{l}1.746 \\
1.4 \times 7 \\
2511\end{array}$ & $\begin{array}{r}1.641 \\
1.496 \\
1.45\end{array}$ & $\begin{array}{r}1.834 \\
1.579 \\
255\end{array}$ & $\begin{array}{r}1.944 \\
1.586 \\
35 \mathrm{H}\end{array}$ & $\begin{array}{r}2.2 \times 2 \\
1.4(x) \\
122\end{array}$ & $\begin{array}{r}2.423 \\
1.979 \\
444\end{array}$ & $\begin{array}{r}2.265 \\
1.820 \\
445\end{array}$ & $\begin{array}{r}2,347 \\
1,861 \\
486\end{array}$ & $\begin{array}{r}2.473 \\
2.015 \\
458\end{array}$ & $\begin{array}{r}2,843 \\
2.203 \\
640\end{array}$ \\
\hline C'urrent Account Balince & & -58 & 138 & 155 & 363 & 201 & 252 & 278 & 224 & 193 & 374 & -157 & 224 & 221 & 1.11 & $(x) 7$ & 476 & 322 & 111 & $|x|$ & 2.14 & 136 & 210 & 217 \\
\hline $\begin{array}{l}\text { Developinent Expendilure } \\
\text { In L.oxial C1.-rency } \\
\text { Project Assistance }\end{array}$ & & $\begin{array}{r}213 \\
213 \\
0\end{array}$ & $\begin{array}{r}218 \\
218 \\
0\end{array}$ & $\begin{array}{r}229 \\
229 \\
0\end{array}$ & $\begin{array}{r}339 \\
339 \\
0\end{array}$ & $\begin{array}{r}321 \\
321 \\
0\end{array}$ & $\begin{array}{r}174 \\
174 \\
0\end{array}$ & $\begin{array}{r}1,507 \\
305 \\
1,262\end{array}$ & $\begin{array}{r}1,888 \\
334 \\
1,554\end{array}$ & $\begin{array}{r}2.728 \\
656 \\
2.072\end{array}$ & $\begin{array}{l}4,331 \\
1,645 \\
2,686\end{array}$ & $\begin{array}{r}2,343 \\
520 \\
1.823\end{array}$ & $\begin{array}{l}4,323 \\
1,188 \\
3,135\end{array}$ & $\begin{array}{l}4,385 \\
1,552 \\
2,833\end{array}$ & $\begin{array}{l}4.2619 \\
1.107 \\
3.162\end{array}$ & $\begin{array}{r}4.182 \\
1772 \\
3,+10\end{array}$ & $\begin{array}{r}4,126 \\
4,32 \\
3,194\end{array}$ & $\begin{array}{r}3.555 \\
919 \\
2.636\end{array}$ & $\begin{array}{r}3 .(1)(A) \\
976 \\
2.0 \times 4\end{array}$ & $\begin{array}{r}2.740 \\
9 \times 3 \\
1.7616\end{array}$ & $\begin{array}{r}1,62.3 \\
760 \\
1,063\end{array}$ & $\begin{array}{r}2,097 \\
817 \\
1.280\end{array}$ & $\begin{array}{r}2.904 \\
913 \\
1.991\end{array}$ & $\begin{array}{l}2.881 \\
1,106 \\
1,775\end{array}$ \\
\hline Overall Raliance & & 271 & 80 & .74 & 24 & -120 & 78 & $1.28 \mathrm{y}$ & 1,664 & -2.535 & $-3,757$ & 2,500 & $-4,0494$ & -4.164 & 3.926 & 3.775 & 3,050 & $3,2.31$ & 2.147 & $2,56,8$ & 1,584 & 1.961 & 2.694 & $-2,664$ \\
\hline Commondity Assistance & 1 & 192 & 76 & 67 & 116 & 83 & 178 & 104 & 118 & 105 & 218 & 104 & 92 & 522 & $2 \times 1$ & 415 & 474 & 278 & 946 & $2-45$ & 275 & 396 & $\$ 43$ & $54 i$ \\
\hline $\begin{array}{l}\text { Project Assistance } \\
\text { Loans } \\
\text { Grants }\end{array}$ & 1 & & & & & & & $\begin{array}{r}1.262 \\
9.37 \\
125\end{array}$ & $\begin{array}{r}1.554 \\
1,070 \\
4 \times 4\end{array}$ & $\begin{array}{l}2.072 \\
1.031 \\
1.041\end{array}$ & $\begin{array}{l}2,686 \\
1,103 \\
1,583\end{array}$ & $\begin{array}{r}1.823 \\
543 \\
1.230\end{array}$ & $\begin{array}{l}3,135 \\
1,552 \\
1,58 .\end{array}$ & $\begin{array}{l}2,833 \\
1,150 \\
1.683\end{array}$ & $\begin{array}{l}3,1112 \\
1.855 \\
1,617\end{array}$ & $\begin{array}{r}3,410 \\
2,484 \\
420\end{array}$ & $\begin{array}{r}3,144 \\
2,763 \\
4,11\end{array}$ & $\begin{array}{r}2.0 .36 \\
2.341 \\
205\end{array}$ & $\begin{array}{r}2,1154 \\
1,730 \\
374\end{array}$ & $\begin{array}{r}1.766 \\
1.377 \\
3 \times 9\end{array}$ & $\begin{array}{r}1.063 \\
791 \\
272\end{array}$ & $\begin{array}{r}1.280 \\
1.110 \\
170\end{array}$ & $\begin{array}{r}1,491 \\
1,462 \\
529\end{array}$ & $\begin{array}{r}1,775 \\
\text { n.a. } \\
\text { n.a. }\end{array}$ \\
\hline $\begin{array}{l}\text { Net Dome'vic } \\
\text { Borrowing ( Residual) }\end{array}$ & & 79 & 4 & 7 & -140 & 37 & -256 & 77 & 8 & 358 & 853 & 573 & 872 & HOY & +3.3 & -50 & 21 & 319 & 317 & 557 & 246 & $2 \times 5$ & 160 & 348 \\
\hline
\end{tabular}

Note: Proicet assistance figures have hein deflated by the United States wholesale price inclev in Table 2.6. All uther figures have been deflated by the nodified purchasing power parily price index in Table 2.7.

grant form. Thus. adjusting the overall balance to show only that part for which debts were incurred shows a rapidly accelerating negative balance tuwards the end of the period. This, in turn, is a reflection of the considerable reduction in the grant component of project assistance since 1.342 (1963). Given that Commodity Assistance has also been offered on a loan rather than a grant basis in recent years, the acceleration in the alcumulation of debt has been somewhat understated. The request by Afghanistan for debt rescheduling negotiations in 1350 (1971) could not. therefore. have eorme as much of a surprise.

The Cinvernment's external debt is taken up again in Section vi, where a hrief review of project assistance is presented. Here, it is simply the intention to indicate the magnitude and source of what has now come to be regarded as a problem. The existence of a problem essentially lies in the fact that returns from projects for which debt has been incurred have been unsatisfactory. In anticipation of this, finance for a number of

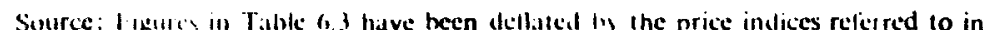
the Note ahwi.

projects whuld have only been accepled on a grant basis. Social rates of refurn appuar to have been low on many aid linanced projects and yield in the form of increased Government revenue nit. The latter state of affairs has been a result of the firm refusal of the landowning members of Parliament to pily jirect taxes and the failure of the Government to collect revenues irom the users of one of the largest and most profitable projects from the users' standpoint, namely, road huilding and improvement.

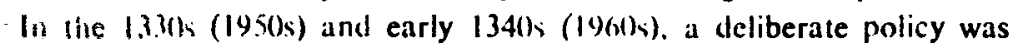
pursued to make transport as cheap as possible so that economic and social integrition would proceed rapidly. In the second half of the 1340s $(19(1) \mathrm{s})$, when attempts were made to ratise revenue from road users, the vehicle licenci proposal Hals rejected by Parliament. Furthermore, the roaki toll yystem has not yiclded even the modest revenue anticipated beciluse : implic baksheesh system has been substituted for the revenue raising toll liche. by road users and toll collectors to their mutual benefit. 
pintly because until 1351 reluctance to raise petrol prices to tax roid users, partly because until 1351 (1973) the Government believed that this needed Pirliamentary approval and did not want to annoy Parliament by submitting such a proposal, and partly because all price increases have been anal hema.

The bureaucracy and the Government appear to have had at strong preference for price stability, the former because it has always been penalised during periods of inflation in that salaries have not been adjusted commensurately, the latter because its revenue has been inelastic with respect to the price level. Purliament, in fuct, hus used intition to reduce real tax hurdens, although it has generally been opposed to inflationary deficit linance.

This uverview of the budgetary position ends with a brief cunment on the residual item, net donestic borrowing. Apart from the whe bond issue in 1.331 (1952) which raised Afs 6 million [F/6, pp. 41-42], all doniestic borrowing has been directly from Da Afghanistan Bank. Fxcessive recourse to central bank credit has been discussed in some detail in the previous chapter. There, consideration was particularly given to the eflects of the extreme volatility of public sector domestic borrowing requirements and the credit squeeze imposed on the private sector. The factors which caused these fluctuations are discussed in Section $v$ helow. Here, the macroeconomic impact of fiscal policy is considered.

Although the estimates of Gross National Product (GNP) are un reliable and may be misleading for long run comparisons, some attempt at analysing the effects of the fiscal situation on the general level of economic activity is warranted if only because of the variability in public sector net domestic borrowing which can be assumed to have had a destabilising influence. It must, however, be emphasised at the start that Government activities in relation to GNP are small. Domestic revenue and total local currency expenditure represented 3.2 and 3.6 per cent of GNP in 1331 (1952) and 6.6 and 8.3 per cent in 1351 (1972), respectively. Public sector savings represented only -0.2 and 0.5 per cent of GNP in 1331 (1952) and 1351 (1972), respectively, and the residual, net domestic borrowing, for the same years equalled 0.3 and $0.4 \mathrm{per}$ cent. Neverthelessing, fo: public sectur net domestic borrowing per cent. Nevertheless, beciluse been of significant magnitudes bearements in many years hat in itself has hid important impact comparison to the money stock, this on prices and he latter's rate of change atul hence Compiring

Comparing changes in the Goveriment's net domestic borrowing position with broad movements in GNP shown in Tables 2.14 and 2.15 , it can be seen that the period of negative net domestic borrowing in the mid-1330s (1950s) is associated with a stable level of GNP at curren prices. In real terms, however, growth was fairly rapid. The large increase in domestic borrowing at the beginning of the 1340s (1960s), although accompanicd by a rapid increase in GNP il current prices, has been widely blamed for the poor growth in real terms between 1339 (1960) and 1344 (1965). despite the filct that these were the years of largest foreign aid input. Fiscal stringency in the mid-1340s (1960s), however, has also been held responsible for the recession between 1346 (1967) and 1349 (1970). Most allalyses of these years have regurded the stabilisation programme or at least its outcome as an over-reaction to earlice fiscal irresponsibility. Indeed, by the time the first drafts of the Fourth Plan were being prepared in 1.351 (1972). a target of no deficit finance was being planned lor the secund year onwards ans if any positive level were undesirable. I:oreign advisors urged that positive levels should be planned for each year but should be laeld within al non-inflationary limit. However, by 1352 (197.3) the net domestic borrowing requirements hald ilgain reached high levels, although GNP in real terms was expanding so fast that prices ictually fell.

Excess deficit finance in the early 1.340s (1960) and excessive fiscal stringency in the mid-1340s (1960s) hatve both been held responsible for periods of recession. Evidence from international comparisons does support the view that both too little and too much inflation retards economic growth. Periods of rapidly atcelerating deficit finance followed by sharp over-reactions which have forced sizable reductions in planned development 4 , wenditure appear to have been damaging not only for this reason but also because erratic Government behaviour has increased uncestainty in the economic enviromment and added considerable variubility to the development effort.

Because public sector net domestic borrowing requirements have been met only by sintral bank lending largely in the form of an increase in the money stoch and because velocity is high in Aighanistan, relatively small fluctuations in these requirements in comparison to GNP have had important impact on the rate of inllation and hence the general level of economic activity.

There is atso another macroeconomic effect of changes in the budgetary position which might be anticipated. This is the effect of rapidly increasing development expenditure on the rate of economic growth. This expectation is, however, not fulfilled. Over the four five year periods since 1331 (1952), the averagc annual real rates of growth were $2.6,3.3,3.6$ and 0.9 
per cent, respectively, despite investment as percentages of (iNP over the same periods of 3.7, 11.3,16.0 and 10.8 per cent, as shown in Table 4.6. The summary cenclusion which seems to emerge is that the investment has not been s productive as might have been hoped. This is taken up again in some detail in Sections vi and vii below.

This section ends with a brief discussion of the administrative shortcomings of the fiscal system. Its economic defects from the macroecononic viewpoint have been covered ahove and in Chapter IV. I'rom a microeconomic standpoint, they will be dealt with in subsequent sections of this chapter. Since administrative shortcomings can be held responsible for the erratic fiscill impact of the past and must in large part determine the feasible set of alternative recomnendations for fiscal reform. it is doubly appropriate to touch upon some of the problems in this area at llis point.

Despite considerable :echnical assistance from the Public Administraliun Service since 1.336 (1957) and the Robert Nathan Team between 1340) (1961) and 1351 (1972), both financed by the United States Agency for International Development, fiscal administration and policy in Afghanistin is still weak. There have been some improvements, e.g. more accurate and speedier accounting, and improved budgeting procedures. Tax collection procedures are now being standardised and a training programme for provincial revenue collectors has been initiated. However, by 1.352 (1973) the results had been limited. Standardisation, a prerequisite for an equitable system, had not been achieved:

With the excention of taxes paid by aliens and foreign firms operating in Afghanistan, the entire non-customs revenue area is decentralized to the provincial level. Each of the 28 provinces has its own out-dated system for the enforcement and collection of revenues. The system is based on past practices and custom without regard to present day needs and existing legislation. Knowledge of the provisions of law is practically non-existent. This applies equally to land, income or business taxes. [U18, $p j$, , 6-7]

A lack of proper knowledge about the tax laws and decrees on the part of officials often causes decixions, taken at random, involving tax-liability. This arbitrary manner of fixing tax-liability results in special harassment of less well-off tax-payers .... A part of the landlords living in Kabul successfully refused to pay taxes. This problem must be solved in a manner that all tax-payers are forced to pay their tax-liabilities irrespective of their-sucial position. [I], pp. 16-17]

Revenuc-maximization and the principle of equity, the two common characteristics of any modern income tax are not realizable in the Afghan situation because of a lack of necessary technical preconditions involving both the tax asscincus and tax-bureatucracy. In addution, there persists a low level of tax morality on the part of tax-payers. who are unwilling to disclose details of their revenue. [11, p. 2]

Revenue from non-tariff tixes has filled to rise substantially, the number of assessments is low and delinquency rates are high; in 1352 (1973) it was estimated thill Ats I billion tax liabilities were outstanding [1, p. 17].

An example al the low level of administrative capability is the experience under the ncw income lax law enicted in 1344 (1965). Despite much assistance over the preceding live years from the two advisory teams in drating this law, revenue collected under it dismally failed to reach anticipaled levels. By 1347 (196is) income tax collected wals exalctly half the amount colketed prior lo enactument of the new law. Apparently, administrative capacity was well below that required to entorce the new and more conmplex law. Recenlly. this constranth has been given more explicit recognition and lhe simplest tax systems recomniended. It has also reccived more attontion in the general literature on public finance in underdeveloped commlrics. Thus, for example. Hart has urged that

.... the must important criterion of good tax policy in the next few years is whelicr a proposed tax measure helps towards the goals of mutual respect! where the taxplyyer and the tax ollicial will deal with each other on a fouring of respect for each other and of respect: for facts-] and of objective tax information. [H5, p. 872]

So severe is the constratint imposed upon liscial policy by administrative capability in most underdevcloped countries lhat objectives have to be modest :

The tradilional tactical goals of tiscal policy continuity of employment. tax equity, intcrual price stability. and a workable foreign-exchange situation are on a modest scale good things in themsclves; yet except as they are instruniental toward development, they might well be viewed as luxuries. [115, p. 871]

Wilh respect on the objective of equily, stallatardisation and uniform enforcement of assessment and appcal procedures would contributc far more than any changes in the tax structure in Afghanistan.

Mention hats already becn made of the substitution of bakshcesh for taxes in connccli, n with roid toll revenues. The same has applied to all other taxes; customs is an important cuse in point. When the author had occasion to visit the Kabul Custons House in 1351 (1972), baksheesh was required as stiundard payınent for various essential documents and signatures for customs clearance. The system operated quite openly on a fixed price hasis. Corruption apparently increased significantly during the 
1341) ( $19(x)$ s). This can in part be explained by declining salaries in real terms received by civil servants. In 1352 (1973), only a small minority of Government employees were paid salaries above the subsistence level cilculated in a recient cost-of-living study by the Agricultural Development Bank as a basis for its own salary structure. In this year, a report concludes:

Wide fuctuations in incomes from different sources of revenue can be superticially seen wholly as an outflow of economic trends but are, in fact. partly related to a widespread corruption. It is doubtful whether all cillcitvours ained at improvement of fiscal administration ean really sicciced if corruption is not curbed. [11, p. 18]

Fxplicil recognition of this problem has been given by the Public Administraliun Service which has advised against higher tax rates. These would unly create greater incentives for evasion and might actually lower revenue yields.

(irrtuption is not a problem unique to Afglatistan. It has apparently been increasing throughout South Asia in recent years and Myrdal suggests that "..... corrupt practices are highly detrimental from the puint of view of the value premises applied in the present study. namely, the inodirnization ideals" [M39. pp. 951-52]. In particular, corruption hats had the effect of slowing down administrative procedures, thus contributing to inertia and inefficiency within these societies [M]9. pp. 951-5.5]. Given the generally held view that corruption in Alghanistan increased substantially over the past decade, it is interesting to recall Myrdal's introductory comments on this subject:

The significance of corruption in Asia is highlighted by the fact that wherever a political regime has crumbled in Pakistan and Burma, for inslince. and, outside South Asia, in China-a major and often decisive cause has been the prevalence of official misconduct among politicians and administrators, and the concomitant spread of unlawful practices among businessmen and the general public. The problem is therefore of vital con tern to the governments in the region. Generally speithing, the habituill practice of bribery and dishonesty tends to pave the way for an althoritarian regime. whose disclosures of corrupt practices in the preced. ing government and whose punitive action against offenders provide a balsis for its initial acceptance by the articulate strata of the population. The (ommunists maintain that corruption is bred by capitalism, and with considerable justification pride themselves-on its eradication under a Communist regime. The elimination of corrupt practices has also been ads anced as the main justification for military takeovers. Should the new regime be unsuccessful in its attempts to eradicate corruption, its failure will prepare the ground for a new putsch of some sort. [M39, pp. 937-38]
Much of ulus amalysis is dorctly applicahlele to the coup in Afylamistan on 26 Saratan. 1352 (17 July, 1973). and the subsequent strategy of the Republican (iovernment. In his first address to the nation, the President statco:

... the regine and system became so corrupt that no hope or expectation for its reform existed. Consequently all pillriots, specially the patriotic armed forces of Afghanistan, decided 10 put an end to this rotten system and delwer the nation from their plight. [1 $2, n$. 1]

Dilily reports of uncovered corruption litve since appeared.

Apart from th: prevalence of corruption, incompetence and lack of motivation have alon played their pitrs in reducing administrative capabilly and capacity. As with bank comployee discussed in the previous chapter, sol lower allol middle level civil servants have received inadequate tratuning to carry out even simple, routine work. This has been recognised and the Public Administration Service has channelled a considerable part of its efforts into establishing what it is hoped will become a self-sustaining training programme. Also of critical importance among senior level civil servants is the rack of trained auditurs:

... the atuliting of enterprises" accounts is carried out by officials who possess very litlle knowledge of accountancy. This phenomenon. which has bad eticis on tax morality, arises mianly hecause of lack of training for the ofliciois. [11, p. 13)

A serious problem in this respect has been the capricious transfer of professionals between one type of job and another. Thus, under its present programme the Public Administration Service is to send five limes the number of tratiles required to the U.S.A. in the hope that one-fifth will be recoverad tio work in the field for which they will have specifically been trained. The reinaining four-fifths may never he called upon to use their expertise acquired during expensive two year courses.

back of muivation has been citused in pirt by inadequate salaries and a promotion system unrelated to merit. The importance of this was stressed in 13.31 (1952) by a United Nations expert in public finance who aralted a civil service law to provide for promotion on merit; he also recommendid the establishment of trining programmes [FI6, p. 39]. The problem has tor' vet heen tackled although the Public Administration Service has given attention to it and suggested various possible remedies [PI8].

In 1335 (1956). 1.344 (1965) and 1.351-1.352 (1972-1973) concerted efirorts were made to improve collection and reduce the proportion of tax delinquency. A Finance Committee established within the Economic Planning (inmmission in 13.34 (1955) proposed a major overhaul of the 
tax system. In particular, suggestions were put forward lior a more progressive income tax, higher corporate taxes, a progressive retail tax based on the rental villue of the retail outlet, a progressive livestock tax to replace the straight Afs 2 per animal. a progressive land tax and an increase in tariff rates [W3, pp. 171-77]. The National Assembly was not favourably disposed and combined with administrative constraints ensured thit no significant increase in revenue occurred. As cill be seen from Table 6.3, a considerable increase in domestic revenue was achieved in 1.34 (1965) and measures taken towirds the end of 1351 (1973) held high probibhility of achieving a substantial rise in revenue in 1.152 (1973). 7\%us, del-rmination on the Government's part has at times becll cllective in ralising buth taxes and collection ratcs. Whether a longer lirin ellort woruld have been elfective in producing a distinct upward trend in nontarill tax revenue is questionable. The evidently low admmistrative capishility. as witnessed in the income tax debacle, and the increased incentive to evasion which significantly higher effective tax rales would hive produced mighı have seriously limited the results of sustinined elforts in the directions sol fitr tried.

Within the new milicu created by the establishment of the Republic and the disbandment of Parliament, possibilities for the long run ale broidened. In particular, there may be a higher probability that agriculture and Iranyport sectors will be made to contribute directly to domestic revenue. The major constraint to revised land taxes in the past has been the absence of a cadastral survey. This again highlights administrative sluortconnings in that the survey was started in 1.337 (195X) on the recommendation and with the help of the newly arrived Public $A$ dninistralion Servic: By 1352 (1973), the survey haid been completed lior between one-yuarter and one-third of total agricultural land in the country but no firm plans had been prepared for using the data obtained. The seriousness of the administrative constraint has been stressed yet again in a recent repurt of the German Economic Advisory Group:

The eyperience with the first three development plans clearly shows that the rublic administration was unable. and still is so, to induce the social. cconomic, and technical progress of the country. Especially during the last ycars in incréasing decline in discipline can be noticed eve:ywhere. The hope that the public administration would be able to accelerite the develorment of the country further declined. In our opinion, the low efficiency of the public administration is the most momentous obstacle (1) The country's development. If the efficiency of the public administration is nill increased there will be no chance for a fundamental inırovement in llic country's performance. [G4, p. I]
Kildor's gencral assertion in this regard is totally applicable to the situation in Alghanistan:

It canmol the emphasized too strongly that the eflicacy of the tax system is not just il matter of appropriate tax laws but of the efficiency and integrity of tax administration .... Any additional cutlay incurred in improving the status and pay of the officials of the revenue department is likely to yield a very high return in ternss of increased revenue. [K 3, p. 189]

iii. Domessir Revemese

\section{A Sources}

Govermment revenue in componed of de nesstic revenue, Commodity Assistance and project atid. the last lwo lecing provided on a variely of terms and conditions by foreign gowernments and international agencies. Their relative mitgnitudes have been compatied in the previous section. Although project aid cannot be regirded as exugenously determined, it would be generally true (o) assume thatl its magnitude hats been only indirectly subject to Gurernment control. It has been essentially by improving domestic resource mobilisition and the overall effectiveness of the developnent eftort, of which project preparation has been the most critical elenent, that any desire to increise project assistance could be realised. It is for this reason that discussion of project aid is limited to an analysis of its elfectiveness in Sections vi and vii. However, because of its importitlice in the Government s budgetary position, Commodity Assistance as a source of revenue is discussid here.

A selective break down of Government revenue for the period 1331-1352 (1952-1973) is presented in Tables 6.5 and 6.6. As can be seen from these tables, by fir the inost important and rapidly expanding source of revenue hats been lurcign trade taxes. Fable 6.7 shows that considerably more reliance has bech placied on indirect taxes, particularly taxes on foreign trade, in Afghanistall than in other countries alt a similar stage of development.

Taxes (1) Aighinistan's lureign trade sector have taken the form of export and import duties. the requirement on exporters of cotton. karakul and wool 10 surrender their foreign exchange carnings at fixed rates below the lluclualting free market rate, fixed taxes on exports and imports, and special monopoly taxes on imports of itens such as cigarettes which were imporied prior to 1.348 (1969) by the Government Monopoly. Since then, i 10 per cent monopoly tax has been substituted for the monopoly privilege except for petrol products and sugar which are still imported solcly by the Government. More analysis of the tariff structure and other aspects of forcign trade regulation is presented in the next 
Tahle o.5

Giviernment Revenue' 1331-1.152

(Millions of Afghanis)

InM:

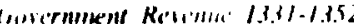

(Millions of Nighanis)

\begin{tabular}{|c|c|c|c|c|c|c|c|c|}
\hline וt'ו") & $1.3311332 \quad 1333$ & 1334 & 1335 & $\begin{array}{l}1336 \\
\text { (first } \\
\text { half) }\end{array}$ & $\begin{array}{r}13.361 \\
37\end{array}$ & $\begin{array}{r}13.17 \mid \\
.18\end{array}$ & $\begin{array}{r}13.38 / \\
39\end{array}$ & $\begin{array}{r}13391 \\
40\end{array}$ \\
\hline
\end{tabular}

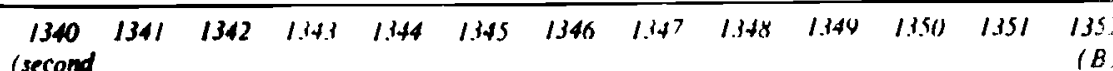
half)

Direct Taxes

Income Tax

Corporate Tax

Land Tax

livevlock Tax

Oilue:

\begin{tabular}{|c|c|c|c|c|c|c|c|c|c|}
\hline 192 & 208 & 216 & 215 & 225 & 158 & 287 & 267 & 242 & \\
\hline 81 & 99 & 98 & 98 & 153 & 109 & 192 & 161 & $\begin{array}{l}84 \\
51\end{array}$ & \\
\hline 77 & 77 & 77 & 77 & 3 & 2 & .35 & 4.3 & 40 & \\
\hline .34 & 32 & 41 & 40 & 41 & 48 & $(x)$ & 6.1 & 67 & \\
\hline 0 & 0 & $\mathbf{0}$ & 0 & 0 & 0 & 11 & 11 & 0 & \\
\hline 288 & 339 & 513 & $46 y$ & $(\boldsymbol{x}) \mathrm{x}$ & 314 & $7 k^{\circ}$ & $\times 7.4$ & 766 & \\
\hline 244 & 302 & 461 & 417 & 5.34 & 296 & 777 & $x 51$ & 732 & \\
\hline 44 & 37 & 52 & 52 & 74 & 18 & 12 & 23 & 34 & \\
\hline n.a. & n.a. & 22 & 26 & 26 & 18 & 17 & 101 & 74 & \\
\hline 0 & 0 & 0 & 0 & 0 & 0 & () & 11 & 0 & \\
\hline n.a. & n.a. & 22 & 26 & 26 & 18 & .37 & $|0|$ & 79 & \\
\hline 74 & 149 & 117 & 362 & 262 & 341 & 17.3 & $\therefore \cdot(1)$ & 198 & \\
\hline 0 & 0 & 0 & 0 & 0 & 0 & 0 & 0 & $\mathbf{0}$ & \\
\hline 74 & 149 & 117 & 362 & 262 & 341 & 173 & $2(x)$ & 198 & \\
\hline
\end{tabular}

lenluscul laxes

forengn Irade laxes

Other

Income fromil State Salcs

Naltural (ias

Oiher

Other Incomic

Reiad llace laxes and Tolls

Oher

$\begin{array}{lll}74 & 149 \quad 11\end{array}$

$362 \quad 262 \quad 34$

301
106
82
40
73
0
121
491
130
93
0
93
337
1
.36

Enterprise:

(x) $\begin{array}{lllllllll}79 & 96 & 211 & 28 & 5 & 62 & 1 & 316 & 247\end{array}$

L.ess: Commodity

Assistance included above

$\begin{array}{lllllllllll}\text { Tolal-Doniestic Revenue } & 614 & 775 & 964 & 1,283 & 1,149 & 836 & 1,348 & 1.533 & 1,601 & 2,099\end{array}$

\begin{tabular}{|c|c|c|c|c|c|c|c|c|c|c|c|c|}
\hline 81 & 313 & 376 & $+1 k$ & .575 & $(x) 3$ & 556 & .372 & 411 & 464 & $42 \mathrm{x}$ & 574 & $648^{\circ}$ \\
\hline 38 & 114 & 157 & 238 & 324 & 390 & 318 & 162 & 208 & 234 & 216 & 230 & 300 \\
\hline 6 & 77 & 79 & I & 81 & 123 & 145 & 120 & 118 & 138 & 138 & 165 & 200 \\
\hline 34 & 39 & so & 44 & X2 & Ky & 93 & 0 & $\times 3$ & 88 & 70 & 78 & 88 \\
\hline 3 & 83 & $(x)$ & Ka & $x x$ & 1 & 0 & 0 & 0 & 0 & 0 & 0 & 0 \\
\hline 0 & 0 & 0 & 11 & 0 & 0 & 0 & 0 & 2 & 4 & 4 & 101 & to. \\
\hline 317 & $1,1,31$ & 1,712 & 1,917 & 2.176 & 2.145 & $2,41 \%$ & ואום.2 & $\therefore 549$ & 2.806 & 2,974 & 2,942 & 3,267 \\
\hline 282 & 1,059 & 1,622 & 1.7111 & $2.0 \times 4.4$ & 2,5665 & $2,4\} ?$ & $2.01,2$ & 2.424 & $2.10 \times 4$ & 2,860 & 2.821 & 3,0 \\
\hline 35 & 72 & Y) & $19 x$ & 42 & xo & 6.1 & 51 & 125 & 117 & 114 & 121 & 23 \\
\hline 45 & 114 & 151 & $19 x$ & 245 & 279 & 214 & 651 & 721 & ' & $8 \times 6$ & 1,051 & 1,192 \\
\hline 0 & 0 & 0 & 0 & 0 & 0 & 60 & 424 & 45,3 & 714 & 589 & 726 & 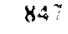 \\
\hline 45 & 114 & 151 & 198 & 245 & 274 & 154 & 222 & $26 x$ & 275 & 297 & 325 & $34 \%$ \\
\hline 115 & 236 & 300 & 320 & $3 \times 2$ & 180 & 3313 & 351 & $.10 x$ & 493 & 562 & 675 & 625 \\
\hline 1 & 2 & 2 & 0 & 0 & () & .11 & 33 & 36 & 54 & 59 & 63 & $\mathrm{kit}$ \\
\hline 114 & 234 & $29 x$ & 120 & $3 \times 2$ & $3 \times 6$ & 302 & $31 x$ & .372 & 434 & 503 & 612 & 545 \\
\hline 16.3 & 340 & 570 & 347 & $76 x$ & 178 & 613 & $1,(x) x$ & 996 & 950 & 973 & 930 & 1,310 \\
\hline
\end{tabular}

Nole: Foreign Trade Taxes include Duties (210), Export Duties (2201, Tax on Commercial Transactions (240), Fixed Taxes on Imports (260), Fixed Taxes on Exports (270) and Munomoly Taxes (250). The tax on commercial transactions is mainly profit on Da A fgh:ınislitn Bank's foreign exchange operations, i.e. from the differcince between free and official exchange rates. Revenue from Government enterprises $(610)$ is almost exclusively profit from the Government's petrol ana sugar monopolies. As these are essentially revenue raising activities, this revenue should really be treated as indirect ax. The monopoly taxes consist predominantly of a special tax on cipartle ind ind im.

So:urce: 1331-1332 Tudor Engincering Company, Repart on Develuy ica imurls. Valley (Washington. D. $(\because$ : Tudor Engineering Company, 1956), Table 9, p. 153: and Ministry of linance.

chapter. In broad terms, some of the economic disadvantages of heavy reliance un indirect taxation have been stressed by Hinrichs:

Concentration on indirect taxation has led to a system of built-in incentives that tend to depress production, trade. exports and, thus, the general growth of the economy .... This practice retards the growth of production of those commodities which are more heavily taxed and rewards the holding of land for speculative incresses in value. Hence, the incentive

1333-1336 uirse half) Ministry of Planning. Surner of Progress 1959 (Kabul: Ministis of Planning. 1459), Volunie IV. Table 54, nn. 226-31; and Ministry of Finance.

1336/37-1 310 (second half) Ministry of Plannirig, Survey of Progress /962-64 (Kabut Ministry il I'lan "1g. 19(t), Table A-1, p. 89.

1341-1.41 Menistry of Planning. Survel of Progress 1967-1968 (Kabul: Ministry of Planning. M(N), Tahles S-1 and S-2; and Ministry of Finance.

1344-1347 Alinistry of Planning Surrey of Progeress 1970-197/ (Kabul: Ministry of planning. 19711 . Tables $S-1$ and S-2: and Ministiy of Finance.

1348-1 34" Mlinistry of Plamning. Sirre't of Progerss 197/-1972 (Kaloul: Ministry Dianning, 1972). Tables $S-1$ and $S-2$; and Ministry of Finance.

1350-1352 M1mistries of Finance and Planning.

structure is contrary to good economic developnent strategy. The resulfs have followed logical expectations: widespread export smuggling (especiall? karakul and wool) and little or no growth in production of these commodities, while the valuc of land in favored locations has increased as muct as tenfild in the past livo decades. [119. pp. 12-13]

Hansen hits actually estimated the loss in output resulting from the discriminatury export taxes [U3, Table 19, p. 47]. 


\begin{tabular}{|c|c|c|c|c|c|c|c|c|c|c|}
\hline $\begin{array}{r}\text { Governimen } \\
\text { (Mi }\end{array}$ & $\begin{array}{l}\text { nt Reve } \\
\text { fillions }\end{array}$ & $\begin{array}{r}T a \\
\text { enue at } \\
\text { of } \mathrm{AI}\end{array}$ & Consta & $\begin{array}{l}\text { int Price } \\
1340 \mathrm{Pr}\end{array}$ & $\begin{array}{l}\text { res } 133 \\
\text { Prices) }\end{array}$ & $31-1352$ & & & & \\
\hline llem" & 1331 & 1332 & 1333 & 1334 & 1335 & $\begin{array}{l}1336 \\
\text { (first } \\
\text { half) }\end{array}$ & $\begin{array}{r}13361 \\
37\end{array}$ & $\begin{array}{r}13.37 \mid \\
38\end{array}$ & $\begin{array}{r}13381 \\
39\end{array}$ & $\begin{array}{r}13391 \\
40\end{array}$ \\
\hline $\begin{array}{l}\text { Direat Taxes } \\
\text { Income Tax } \\
\text { Corporale Tax } \\
\text { land Jas } \\
\text { liveslex.h Iax } \\
\text { Other }\end{array}$ & $\begin{array}{r}241 \\
102 \\
97 \\
42 \\
0\end{array}$ & $\begin{array}{r}264 \\
125 \\
98 \\
41 \\
0\end{array}$ & $\begin{array}{c}241 \\
109 \\
86 \\
46 \\
0\end{array}$ & $\begin{array}{r}223 \\
102 \\
80 \\
41 \\
0\end{array}$ & $\begin{array}{r}190 \\
129 \\
26 \\
35 \\
0\end{array}$ & $\begin{array}{r}129 \\
88 \\
2 \\
39 \\
0\end{array}$ & $\begin{array}{r}2.34 \\
1.56 \\
24 \\
44 \\
0\end{array}$ & $\begin{array}{c}212 \\
12 x \\
14 \\
011 \\
11\end{array}$ & $\begin{array}{r}225 \\
78 \\
48 \\
37 \\
62 \\
0\end{array}$ & $\begin{array}{r}319 \\
113 \\
87 \\
42 \\
77 \\
0\end{array}$ \\
\hline $\begin{array}{l}\text { Indired Tises } \\
\text { Foreign Tride Taxes } \\
\text { Other }\end{array}$ & $\begin{array}{r}361 \\
.06 \\
55\end{array}$ & $\begin{array}{r}430 \\
383 \\
47\end{array}$ & $\begin{array}{r}572 \\
514 \\
58\end{array}$ & $\begin{array}{r}486 \\
432 \\
54\end{array}$ & $\begin{array}{r}\$ 12 \\
450 \\
62\end{array}$ & $\begin{array}{r}256 \\
241 \\
15\end{array}$ & $\begin{array}{r}64.3 \\
633 \\
10\end{array}$ & $\begin{array}{l}694 \\
676 \\
18\end{array}$ & $\begin{array}{r}713 \\
681 \\
32\end{array}$ & $\begin{array}{r}1,190 \\
1,052 \\
138\end{array}$ \\
\hline $\begin{array}{l}\text { Incoumc from Sitate Sales } \\
\text { Natural (ials } \\
\text { Oher }\end{array}$ & $\begin{array}{r}\text { n.a. } \\
\text { no } \\
\text { n.a. }\end{array}$ & $\begin{array}{r}\text { n.a. } \\
\mathbf{0} \\
\text { n.a. }\end{array}$ & $\begin{array}{r}25 \\
0 \\
25\end{array}$ & $\begin{array}{r}27 \\
0 \\
27\end{array}$ & $\begin{array}{r}22 \\
0 \\
22\end{array}$ & $\begin{array}{r}15 \\
0 \\
15\end{array}$ & $\begin{array}{r}30 \\
0 \\
30\end{array}$ & $\begin{array}{r}80 \\
0 \\
80\end{array}$ & $\begin{array}{r}74 \\
0 \\
74\end{array}$ & $\begin{array}{r}94 \\
0 \\
49\end{array}$ \\
\hline $\begin{array}{l}\text { Oiher Income } \\
\text { Ruind l liser Iaxes and Tolls } \\
\text { (Hlier }\end{array}$ & $\begin{array}{r}93 \\
0 \\
93\end{array}$ & $\begin{array}{r}189 \\
0 \\
189\end{array}$ & $\begin{array}{r}131 \\
0 \\
131\end{array}$ & $\begin{array}{r}375 \\
0 \\
379\end{array}$ & $\begin{array}{r}221 \\
0 \\
221\end{array}$ & $\begin{array}{r}277 \\
0 \\
277\end{array}$ & $\begin{array}{r}141 \\
0 \\
141\end{array}$ & $\begin{array}{r}231 \\
0 \\
2.31\end{array}$ & $\begin{array}{r}185 \\
0 \\
18.5\end{array}$ & $\begin{array}{r}358 \\
1 \\
357\end{array}$ \\
\hline $\begin{array}{l}\text { Inciume frum ciovernment } \\
\text { Enterprises }\end{array}$ & 75 & 100 & 107 & 219 & 24 & 4 & 50 & 1 & 294 & 262 \\
\hline $\begin{array}{l}\text { Less: Comnksdity } \\
\text { Assistance included ahove } \\
\text { Total Donkslic Reventw }\end{array}$ & 770 & $\overrightarrow{983}$ & 1,076 & $1, \overline{330}$ & $\begin{array}{c}- \\
969\end{array}$ & 681 & 1,0098 & 1,216 & - & - \\
\hline
\end{tabular}

Tahli: 6.6

Givermmem Revenue at Cimstan Prices 1331-1352 (Millions of Afghanis. 1340 Prices)

\begin{tabular}{|lllllllllllll}
\hline $\begin{array}{c}1.340 \\
\text { (secund } \\
\text { half) }\end{array}$ & 1341 & 1342 & 1.14 .1 & 1344 & 1.345 & 1.346 & 1.347 & 1.348 & 1349 & 1.350 & 1.351 & $\begin{array}{c}1.152 \\
(B)\end{array}$ \\
\hline
\end{tabular}

\begin{tabular}{|c|c|c|c|c|c|c|c|c|c|c|c|c|}
\hline 81 & 257 & 319 & 3060 & .325 & 125 & $2 \%$ & $2(x)$ & 211 & 204 & $\mid 8$. & 250 & $2 \times 2$ \\
\hline 38 & 94 & 133 & 163 & 183 & 210 & 171 & 87 & 107 & 103 & 92 & 100 & 131 \\
\hline 6 & 63 & 67 & is & 46 & 66 & $7 x$ & 6.5 & $(x)$ & (x) & 59 & 72 & 87 \\
\hline 34 & 32 & 43 & 11) & 46 & $4 K$ & 50) & $4 x$ & 4.3 & 34 & 30 & 34 & 36 \\
\hline 3 & (1) & 76 & $5 x$ & 50 & 1 & 0 & 0 & 0 & 0 & 0 & 0 & 0 \\
\hline 0 & 0 & 0 & 0 & 0 & () & 11 & 0 & 1 & 2 & 2 & 44 & 26 \\
\hline 317 & 924 & 1.452 & $1.31 \mathrm{~K}$ & 1.2 .10 & 1.426 & 1,343 & 1.117 & 1.305 & 1.232 & 1.268 & 1.279 & $1,41 \mathrm{x}$ \\
\hline 282 & 870 & 1.376 & 1.171 & 1.178 & 1.383 & 1.309 & $(1,(x)$ & 1.241 & 1.181 & 1.220 & 1.226 & 1.322 \\
\hline 35 & 54 & 76 & 135 & 52 & 43 & 34 & 27 & 64 & 51 & 48 & 53 & 96 \\
\hline 45 & 94 & 128 & 1.35 & 139 & 1.50 & 115 & 344 & 360 & 434 & 378 & 457 & 518 \\
\hline 0 & 0 & 0 & 0 & 0 & 0 & 32 & 230 & 232 & 313 & 251 & 316 & $36 x$ \\
\hline 45 & 14 & $12 K$ & 135 & 139 & 150 & 81 & 119 & 1.37 & 121 & 127 & 141 & 150) \\
\hline 115 & 194 & 254 & 21.5 & 216 & 2015 & 179 & 188 & $2(k)$ & 217 & 239 & 293 & 272 \\
\hline 1 & 2 & 2 & 0 & 0 & 0 & 17 & 18 & IX & 24 & 25 & 27 & 35 \\
\hline 114 & 192 & 252 & $21 x$ & 216 & 205 & 162 & 170 & 191 & 193 & 214 & $2 t h$ & 237 \\
\hline
\end{tabular}

- $50 \quad 366 \quad 115 \quad 96 \quad \ldots \quad-$

$\begin{array}{lllllllllllll}721 & 1.744 & 2,270 & 2.6 \times 9 & 2.248 & 2.310 & 2.266 & 2,3195 & 2,604 & 2,504 & 2.483 & 2,6 \times 3 & 3,060\end{array}$

Source: Higures in Tahle 6.5 have been defiated by the modified purchasing power parity price index in Table 2.7 .

The mure than proportionate increase in non-tax domestic revenue belween $13.33(1954)$ and 1351 (1972) is partly illusory and parlly a result of gias sales. The illusory feature is the classification of revenue from monopoly sales of petrol and sugar as non-tax revenue. There has "ien virtually no revenue forthcoming from the other Government enterprises despite substantial investment over the period. The investments have not yielded any significant return. The proceeds from natural gas sales which have increased sharply since 1346 (1967) are used exclusively for debi repayment (1) the U.S.S.R., the purchaser of the gas.

Finally, Comanodity Assistance has become an increasingly imporlant support to the Budget. Given that its magnitude depends on agricultural conditions in the recipient country, it has been an unstable and unpredictable revenuc source. This in turn has been partly responsible for the high

degree al volitility in net domkvlic borrowing requirements. Good harvests in Alghanistan have reduced Commodity Assistance and so thrown the Government into unexpected and usually excessive reliance on domestic horrowing. Bad harvests have generally been a boon to the Budget. This particular problem could be solved by raising tax revenue from the agricultural sector. Then, a good harvest year, while resulting in a reduction in Commudity Assistance revenue, would show an offsetting increase in alericultural tixes provided that demand was kept elastic through sloke inanagement activities. The latler could be carried out by the privals setor were the $1346(1967)$ Anti-Hoarding Law, unjustifiable any way on coonomic grounds, repealed or through a Government wheat reserve programme. This, however, would absorb the additional revenue it was designed to raise. 
Table 6.7

Tax Revenue Sources in SI Underdeveloped Countries

\begin{tabular}{|c|c|c|c|}
\hline $\begin{array}{c}\text { Per ('apira GNP } \\
\text { (Dilllars) }\end{array}$ & $\begin{array}{l}\text { Number of } \\
\text { Countries }\end{array}$ & $\begin{array}{c}\text { Indirect Taxes } \\
\text { as Percentoge of } \\
\text { rolal Tax Revenue }\end{array}$ & $\begin{array}{l}\text { Forcign Trade Taxes } \\
\text { as Percentage uf } \\
\text { Total Tax Revrime }\end{array}$ \\
\hline 100 or less & 20 & 68 & 41 \\
\hline $101-200$ & 11 & 64 & 39 \\
\hline $201-500$ & 19 & 64 & 35 \\
\hline Afghanistan (1351) & 1 & 86 & 67 \\
\hline
\end{tabular}

Source: H 1. McKiunon, Money and Capiral in Eromomic Development (Washinkloul,

D. ' : The Brcokings Institution. 1973), Table 10-3. p. 140; and Table 6.5 above:

Neither tilxing the agricultural sector nor contriving demand elasticity for agricultur: I products are new ideas. The Nathan Team stresicd the importance of land tax [L4, p. 16] and in its final report stated

Whatever the incidence and equities and complexilies of a land tax, it must the a significunt source of revenue: in Afghanistan where agriculture is so overwhelmingly important a part of the total economy. The land lax scims the best means of tapping this sector for needed revenues. [N.]. p. 109]

Hansen also makes the saime recommendation [U3, pp. 49-50].

The isste of price stabilisation policies for agricultural products recived rellowed interest in 1352 (1973). The Government announced a support price of Afs $\mathbf{4 5}$ per seer for wheat at the beginning of the year and various reports on immediate and future problems and requirements of price support policies were prepared (e.g. [F30; KII]). The abandonment not unly af the price but more important of any substantial Governusent purchases litter in the year seriously exacerbated the problem of raising agricultural productivity, as mentioned above in Chapters II and III

B Elasticities

The concessions to the tribes which had rallied behind Nadir Shah in 1308 (1929) consisted in part of abrogation of power to increase taxes without their approval. Virtually no initiative since then has succeeded in persuading the legislature to raise land and livestock taxes. Neither the prohlem of declining tax revenue in real terms from the agricultural sector nor the power of the legislature to impede fiscal reform are unique to Afghanistan. On the former, Kaidor comments :

An anouil tax on land, expressed as a percentage of the value of the produce wer acre, is the most ancient form of taxation both in I:urope and in Asia. 110 to the beginning of this century the land tax still provided the principal colurce of revenue in the countries of the Middle East. in India and many wher areas .... Since that tims, lwwever, political pressures. combined with munetary changes, hive succeeded almost everywhere in 'eroding' (lice weight of this tax almost completely, and its rehabilitation new faces heavy political and administrative obstacles .... the low "coefficicill of utilization" of that [taxation] potential-due to had tax laws, bad tax administration, or both-which in turn is only partly to be explained by lack of knowledge, understanding or of administrative competenci... it is also the result of resistance by powerful pressure groups who block the waty to effective tax reform. [K3, pp. 171 and 178]

He also points out that

it is the taxation of the agricultural sector that has a vital role to play in accelcratlng economic development; t/1. disproportionate taxation of

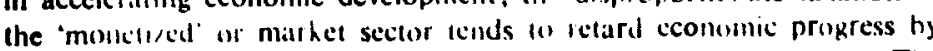
reducing herth the sources and the meentives to accunutation .... The importance for economic development of an efficient system of taxation of the agricultural or subsistence sector of the community cannot he overestimated. [K. pp. 176 and 180]

Nor hats its infurbant potential been ignored in Afghanistan.

On the scound problem, namely that of powerful legislatures. Hart suggests the fill, wwing solution:

the lin w vep toward reform in cases where legislatures have real autonomy should be to develon an indequate professional staff (largely. but not eclusively, of economists) for the legistilture .... (Without such a preconcattion] altempted substantive reforms will fail. [HS, pp. 874-75]

Indeed, one might suggest that the Nathan Team was preaching to the converted when

Throughust the contract period the team indeavored to create within the RCiA [Royal Government of Afuhanistail] an awareness of the need for and the cipability of developing a domestic revenue base sufficient to support sustained and increasing economic development. [N3, p. 89]

Redirected cllirts to convince the legislitture of this were what was needed.

The denixe of direct agricultural taxation together with administrative constritints, the rising ordinary expenditure, and yet a desire on the Govermmen! ' part, particularly during the Diloud era of 1332-1341 (1953-190,3), (o) sustain a development programme have combined to force the (ivvernment to resort to foreign Iride taxes and deficit finance as interim measures. Excessive recourse to both these sources of revenue which have been necessitated by these circumstanses have had unlortunate consequences in the longer run. 
Taxes on the foreign trade sector have distorted resource allocation through discrimination against the major traditional exports, with the cxception of carpets and fruit, in which comparative advantages have heen greatest. As mentioned earlier, Hansen has calculated the actual effects of the discriminatory export taxes on the level of output [U3, Table 19. p. 47]. The specific price system employed in Afghanistan has made forcign trade taxes price inelastic. Thus, in order to raise revenue the tax rites have had to be revised. This has not only acted as at deterrent to cxports, no matter whether taxes have been levied directly on exports or imports 11.2: M6: M7], but with incllicient administration hals increised snugghing. The allocative inefficiencics of the laller hnve recenlly received attention [B24; J3]. The additional distortions creatcd by titx exemptions have also heen reviewed:

The existing provision regarding the S-year exemption from customs has resulied in serious distortion of competiiive conditions without achieving a ritpid industrial growth .... Therefore, we recommend that the reniission of customs under the private investment law should the put off [II. pp. 8-9]

The problems Afghanistan will face in the future from continuled heavy reliance on foreign trade taxes as a source of revenuc are the same as those to be faced by Ethiopia:

Ohvinusly as Ethiopia matures and capital becomes available wor inJustritilization. these revenue tariffs of long standing become protective and call attract domestic resources into the manufacture of these same consumer "luxuries." (This was not a problem in the earlier. inore pristine state.) The government then loses revenue as the volume of inports of final consumer goods is rediced when domestic manufacture begins. The lax syutem has become inclastic to the rising incone that is issociated with industrialization. [M7, p. 141]

In ather words, although tariffs have heen price inelastic in the past, occasionill revaluations and rate changes together with an increasing volume of trade have enabled a substantial increase in revenue to take place. In the liture, income elasticity may become negative and the tax bise decline. Attempts simply to maintain revenue from this sottrce might then criate a vicious circle in which rate increases reduce the tax base and revenuc declines.

Inconic and price inelasticities are of particular concern in a country where changes in rates have had to be approved by the non-party, car driving nembers of Parliament, most of whom derived their income from land ownership. Dupree proffers the following analysis:
The elcitions [of 1344 (1965)] produced one paradox which plagues the centre. Many regionally strong, conservative religious leaders. gradually losing power in Kabul since 1953, became parliamentary deputies. Now they hive a narional platform on which thcy can stand and attempt to stymie reform programmes which threaten their economic, political and social mower. [D9, p. 275]

The unwillingness of the legislature to permit ligher taxation might not, however, hite heen due solcly to sclfish motives. Had Government expenditure provided more tangible benclits to a larger fraction of the population. nore cooperation might have been found in this quarter. But expendiure has not produced widespread benefits. The statement that "the keasantry .... gatined nothing by the enhanced revenues" made in 1.312 (193.3) [A15, pp. 10-11] st1ll applied in 1.352 (1973). Perhaps Gilhert's report reflects more alccuralely lle legislature's position in the following extract:

What was needed 15 or 20 years ago, at the inception of the program, was a wide diffusion of the benefits of developnent, to lay the basis for widespread suppurt of the development program and the willingness to make sacrifices. 10 pay taxes for it. What was required for the unification of the country wils a sense of universal benctit from which no area and no ethnic group wals excluded. linsted, the program and its benefits were highly concentrated. Even the road program, which was truly national in scope, had less than national visibility in the absence of feeder roads. On the other hitnd, the costs of the program, the pains of development were widely diffused. The inflation of food prices may be cited as an example. And the ritpid decline of aid in recent years with the decrease in construction and in employment flowing from it must have had a negative effect. On the iminal side it must be remenhered that the democratic process is a receml phenomenou. It was only in 1342 that the King promulgated the Comptitution which limited his pouess and sat the stage for a substantial enlargement of Jemocralic development. The members of the Jirga represent whint are still tribal and local inlluences. There are as yet no political partics with national outlook and responsible programs. The result, unfortunalcly, has been a near paralysis in the government. The members of the Jirga, seeing for the most part little benefit from development for the people they represent. and charging and seeing corruption and waste in government operations, have resivted and obstructed measures of self help. The government has not had the means to provide the kind of program with widely spread bencfits that coulc have appealed to the Jirga. [G10, n. 10].

The Nathan Tcam's final report says roughly the same thing:

... mest Afghans can rightfully sily that they are paying for the exclusive benelit of a privilegel ninority it privileged areas of the country. [N3, p. 56] 
Whether or not such altruistic motives can be attributed to Parliament, inelasticity of revenue sources to rising income and prices has been the must acute budgetary problem over the past two decades. Effort has been required just to prevent slippage, let alone move forward. Price inelasticity has been the result not only of the specific value system but also of lags in tax collection [H5, pp. 867-69]. Because rates have been rilised too little and too late, excessive deficit finance has been used which has simply exacerbated the problem in subsequent years. Necessary effort to avoid the vicious circle has been forthcoming. No energy has been left, huwever. 11) make the effort needed to move out of the low level trap. (iompared to many underdeveloped countries, inllation in Alghanistan hats not heen high during the post-war period. Yet, becillsc the fiscal system has been so adversely affected by any rise in prices it has been a coustant threat to the development effort.

The failure of domestic revenue to rise appreciably in real terms has been altributed by a number of observers to economic stagnation. It has already heen argued in Chapters II and III that this conclusion, reached by circulitr reasoning from analysis of the Government's budgetary pusilion. is erroneous. Here, it has been suggestcd that the Giverni.lent's dumestic revenue sources have been income and price inclastic and for this reasun have failed to increase substantially. Furtherınore. over the past decidde, the tax collection effort seems to have deteriorated. This has been parlicularly noticiable with respect to direct tax receipts.

\section{Incidence}

The two most obvious gaps in the tax structure appear, at first sight, to lic in the exemption of the agricultural and transport scctors from direct taxition. It has been taxes on these two sectors which have been most strongly resisted by the legislature. Indeed, this is well excmplified by the Parliamentary debate on the 1352 (1973) Budget. Finally approved (1n) 25 Saratan 1352 (16 July 1973), it was returned to the Government with the following amendments: Afs 112 million off the proposed land tix. Afs I(x) million off the livestock tax, and Afs 10 million of the vehicle registration tax. These cuts reduced the agricultural taxes to their 1351 (1972) levels, namely, Afs 88 million and nil, and halved the proposed vehicle licence tax. Given that agriculture and transport have received well over 50 per cent of the local currency development expenditure and a considerably higher proportion of foreign aid disbursements, the question ol equity is clearly raised.

The two sectors must be treated separately in this regard beciuse tax incidence and benclits diller. In the cisce of the agricultural sector, although true that no direct tax burden is borne, to the extent that exports are primarily agricultural products, foreign trade taxes are passed back to the agricultural sector to some extent. This has been particularly apparent in the case of cotton, karakul and wioul, the production of which has teen direclly deterred by the export laxes. Ilowiver, in that foreign tritde taxes have counteracted the depreciation of the exchange rate to some extent, fruit and nut producers have also been affected. One of the anomalies springing from an incidence-hencfit analysis is that the recipients of: Governmen expenditure, prinarily in the lfelmand-Arghandab Valley Region, have not in the main becn producing exportable commodities. The concentration of etrort by the Helmatnd-Arghandib Valley Authority has been on wheat production. However, on the benefit side results have been meagre even in this areal as will be shown in Sections vi and vii.

Transport presents a different picture in that benefits arising from the sharp decline in transport cosis hase been high and tax incidence, even indirectly. Ilegligible. The changes procluced by the extensive road building programme of the past four decildes were discussed at some length in Chapter III. Sections vi and vii deal with the high direct user benefits. Here it suffices to point out that these benefits have been provided vircuilly free.

Despite unique factors determining the revenue structure in Afghanistan, it is far irom atypical:

By one Jevice or another, including marketing boards, substantial revenues are collected from traditional exports. Fxeises on some items of luxury consumption and duties on imports of goods that compete with products of capital-intensive industry are other ranking revenue sources. Real property is taxed lightly, if at all: various tax concessions are arranged for the industrial enclive; and public enterprise supplies cheaply, or at loss, vartewn utilities that, like savings and foreign exchange, are rationed in some degree of compliance with it plan of industrialization. Total revenues tend to be inclastic to both intlation and growth in real nationat output. [S8, p. 13]

In Alghanistin, the industrial sector has been nurtured under the 1345 (1967) Foreigu and Domestic Private Investment Law which has provided a five year tax holiday and tarill exemptions.

\section{Regressivity}

Data do not exist for any firm statements un the regressivity or otherwise of the tax structure. Certain laxes are undoubtedly regressive-the 
tax on shopkeepers which takes the form of a poll tax and the tax based on the number of vehicles owned for transport companies are two obvious eximples. The applicability of the following comment made in 1333 (1954) still stands :

When the nature of the tax system is considered, officials of the present government have agreed that the tax revenue system has not served to work towards an equilibrium in the distribution of income among the different classes of the people. Moreover, because of many haphazard policics enacted in the past, the tax system as of 1954 has led to an unbalanced growth of the cconomy in that it encouraged capital investments in one area and discouraged them in others. In particular, there has been too much dependence on indirect taxes instead of on direct ones. The changeover to more reliance on the income tax, so encouragingly initiated in 1943 , failed to make much progreas after 1952. despite a grow/h in national inconc. Finally, the tax administration was poor, so that cvi, such relatively simple levies as customs tarifrs failed to rise in propurtion to the rise in prices and in the volume of production and tride. [W., p. 171]

The narrowness of the tax base and the political constraints have forced the Government to pursue on!y the one fundamental ubjective of preventing erosion. Equity considerations have had to take a low priority in the Gutrument's objective function.

Afghanistan's fiscal system exhibits many characteristics common amongst the underdeveloped countries. Inelasticity of reventic with respect $t$ ) both income and inflation is just one:

Tax bases have ways of eroding relative to income and wealth: without increases in rates of tax, revenues can fall absolutely or relatively .... First, the values of products subject to indirect taxation decline relative to total output because sources of supply are depleted, because demand is income-inelastic or hecause substitutes appear. In one scinse or anuther, cominonents of the base are inferior goods. Second, nuonctary values assessed for the tax base are not adjusted to inflation so that the real value of the base diminishes when the price level rises .... Inflation yields rcal revenues from a part of the financial base-the money supply, for example - but it reduces real revenues from parts of the fiscal base. When the fiscill hase is both income-inelastic and inflation-inelastic, the peakcilinluyment fiscal surplus becomes smaller as rates of growth in real inconic and the price level aro higher, especially if revenues from the inflation tax are counted in the surp'us. Such a fiscal base automatically consirains capital accumulation and is automatically destabilizing in the short run. [S8, pp. 171-72]

In reforming fiscal systems in underdeveloped countries, the traditional preference for direct over indirect taxation has been dropped. Part of the reason lies in the questionable usefulness of the distinction [P16], part in the high administrative costs af collecting and dilliculties of enforcing dircit taxation. Strong arguments have recently been presented in favour of the value added tax [115, 1). 884; M7, Chapter 10; S8, pp. 179-80). Despite its relative simplicity, idministrative capabilities will have to $h$ vastly improved before Afghanistan could administer such a tax suciessfully.

\section{iv. Fiscal thfort}

A rapidly growing body of literature hats been produced recently presenting the view that there is something called a country's fiscal or lax ellort and that his can be measured. That more fiscal effort is better than less springs from the premise satted fincefully by Kaldor that:

.... the importance of public revenuc from the point of view of accelerated cconomic development could hardly the exalggerated .... taxation provides the mosi appropriate instrument for increasing savings for capital formation. $[K$.$\} np. 170-71]$

On this assumption, two bases lor measuring liscal eflort suggest themselves. The tirst and more usual approach is to examine the ratio of a cruntry's tax revenue to GNP. The other is t" analyse public sector savings, atgain as a ratio to GNP. An important qualification to Kaldor's statement is essential in the Alghan context. Por se, strong fiscal effort is irrelevant. It is important only to the extent that this would signify a real interest in development on the part of the Government and a far better periormance an the expenditure side of the coin.

A lew years ago, the International Monctary Fund initiated studies on the lax eflort of underdeveloped countries; several articles reporting various resulls have now appeared. The lwo concerned with measuring tax efTort mathe comparisons between 49 countries [B1; B2]. 7he method used in the lirst article is to measure filxable capacity and then to compare this with achievements. In the enpirical worh taxable capacity is determined by the stage af development, the composition of National Income and the sise of the loreign trade sectur. The indicittors used are Ay, the percentage of agricultural income in (iNP. and Ny, the percentage share of the mining sector in GNP. Elaborate justiticallion for using these two variables is provided. The results of the regression analysis are as follows. For the 49 countries, taxible capacity is measured by the equation

$$
T_{y}=14.95-0.0742(A y)+0.2951(\mathrm{Ny})
$$

$$
\begin{array}{lll}
(9.682) \quad(2.074) \quad(3.678) & 0
\end{array}
$$


where Ty is taxable capacity as a percentuge of GNP. Figures in brackets are " $"$ " villues. The adjusted coefficient of determination, $R$ ", is 0.411 [BI. p. 592], giving a higher explained variance than previous studies of this kind

rax efliort. E, is measured by the ratio of actual to capacity lax revenues as percentiges of GNP :

$$
E=\begin{aligned}
& T y \\
& T y
\end{aligned}
$$

Irom I yuations 6.1 and 6.2 , the results shown in Table 6.8 were obsained. Aighanistan was not amongst the 49 countries included in this study. However. using Equation 6.1 and GNP data estimated by a team of economists from the World Bank, tax capacity and achievement cian be me:isured. With an estimated GNP for 1346 (1967) of Afs 62, 218 million, gross agricultural and mining sector income of Afs 30,214 million and Ats 284 million, respectively, and tax revenue of Afs 3,082 million, the taxithle cupacity, $\hat{T} y$, is 11.31 per cent of GNP and tax actually collected 4.95 per cent. This gives a tax effort. E, of 0.44 which would place Alghanistan last in the ranking given in Table 6.8 were it not for an even lower effiort of 0.32 recorded for Nepal.

The result implies that, given Afghanistan's low stage of economic development, unconducive composition of income from a taxability viewpoint and relatively small foreign trade sector, less than hilf the tixes which could be collected through an exertion of only average effort were in fact collected in 1.346 (1967). Some of the reasons for such a low score hitve been discussed in the previous section.

Table 6.8

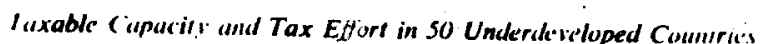

\begin{tabular}{lcc}
\hline Coumry & $\begin{array}{c}\text { Taxable Capacity } \\
\text { as a Percentage } \\
\text { of GNP }\end{array}$ & $\begin{array}{c}\text { Tax Effort } \\
\text { E }\end{array}$ \\
\hline Ivory Coast & 12.09 & 1.63 \\
Brazil & 13.50 & 1.53 \\
Chad & 9.86 & 1.39 \\
Zaire & 16.97 & 1.38 \\
Senegal & 13.24 & 1.37 \\
Euynt & 13.41 & 1.34 \\
Muli & 11.36 & 1.32 \\
Ceylon & 12.03 & 1.30 \\
Tunisia & 16.69 & 1.24 \\
Tanzania & 11.83 & 1.22 \\
\hline
\end{tabular}

Table 6.8 ( ( imtinued $d)$

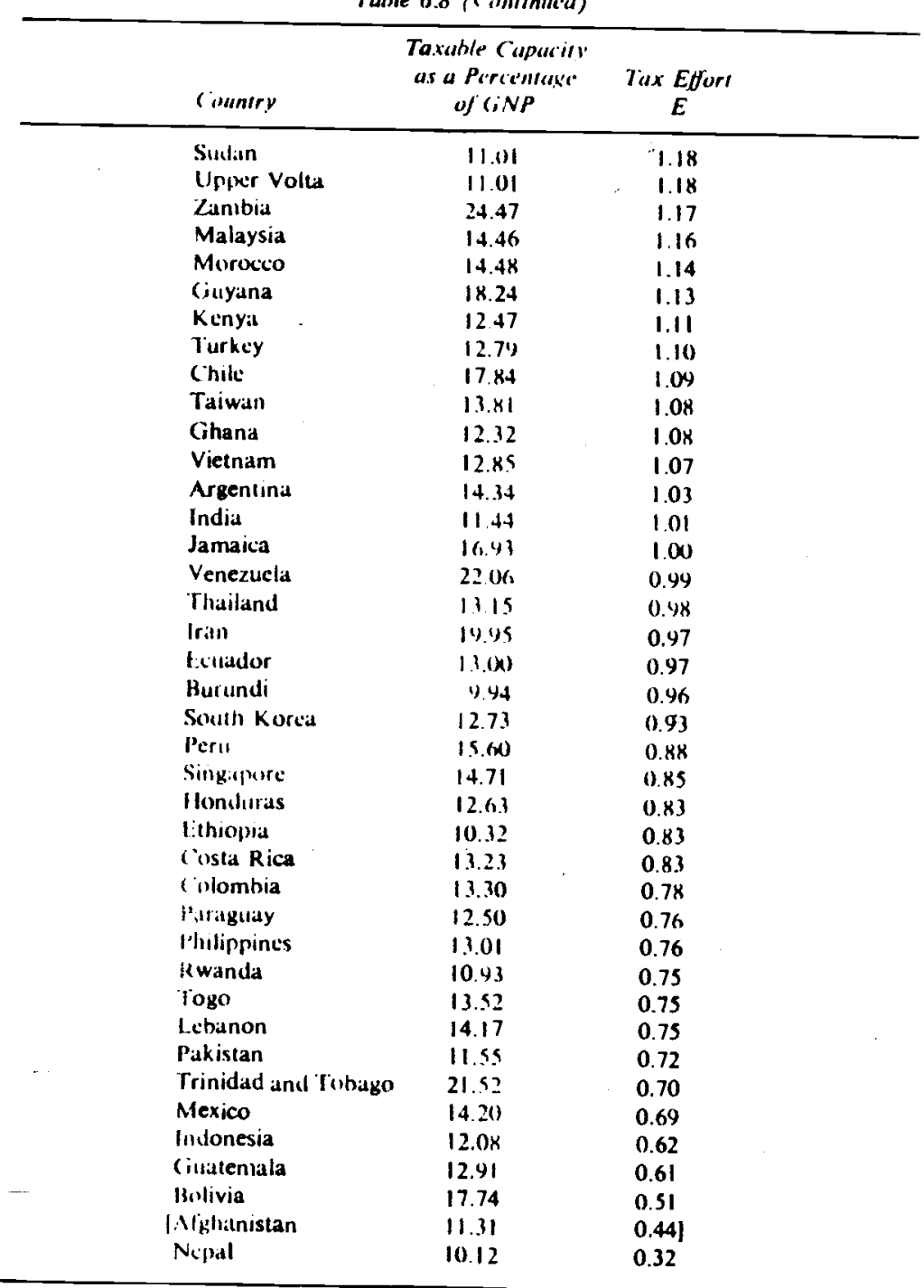

Note: Afghanistan was not included in the 49 coumlry comparative study in which tirabie capincity wits catculated. Measurement of tax effort is deviritiel in the text.

Sisurce: R. W. Bahl. "A Regression Apnroach lo Tiax Effort and Tax Ratio Analysis," International Monetarv liund Stulf Papers. Ix 1.3). November 1971. Table 2 p. 596. 
Oher measures of tax elfort have been used by various invesligallors. Sume of the equations which have been estimated are listed below:

$\hat{T}_{y} 10.48+0.0026(Y p)+0.0614(X y+M y)$

$\hat{T}_{y} 10.05+0.0031(\mathrm{Yp}-\mathrm{Xp})+0.3973(\mathrm{Ny})+0.0881(\mathrm{Xy}-\mathrm{Nxy})(6.4)$

$\hat{T} y \quad 15.9 x-0.1077($ Ay) $+0.0350(X y+M y)$

where $Y_{p}$ is per canita inconc, $X y$ exports as a percentage of incone, $M y$ impurts is a percentage of income, $X p$ per capita exports, Ny the shatic of (jross Dumlestic Product (GDP) generated in the mining sectur, Nxy mining comirts as a percentage of income, $\wedge y$ the share of GDP generated

Tuble 6.9

Data for C alcularing Afghumistun's Tax Etfort, 1346

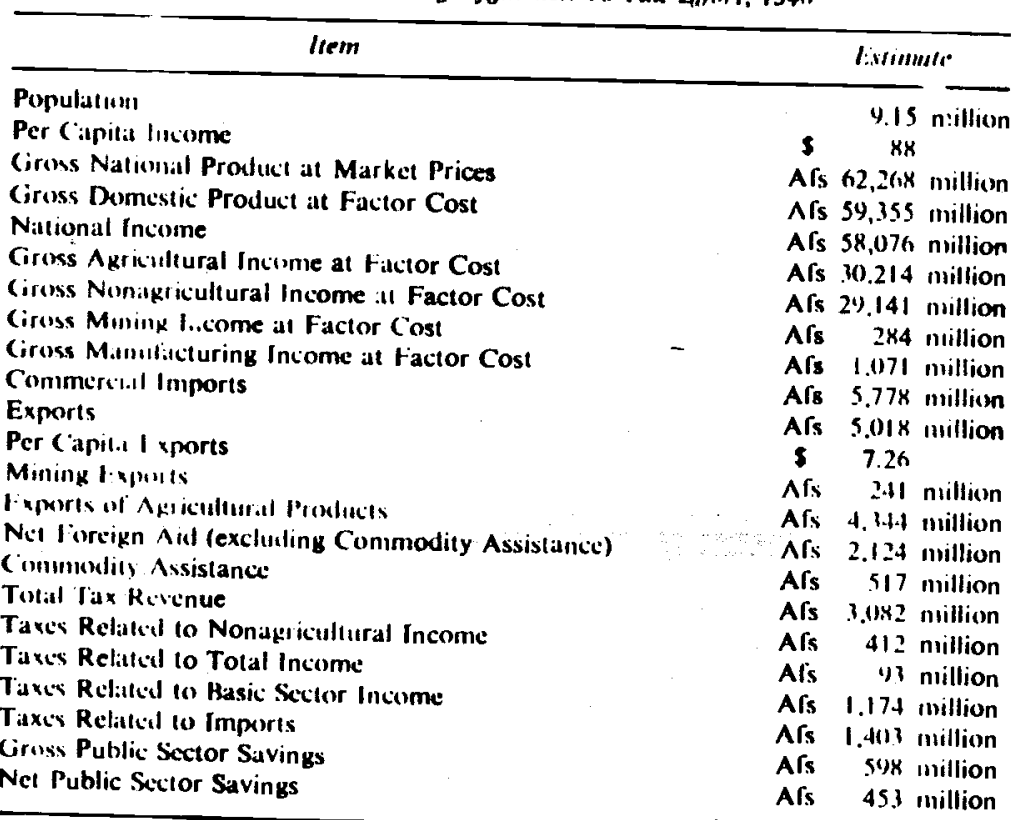

Sinurce: Ponulation Table 2.1 above.

Pur Canit.1 Income United Nations, Warld Ecommmic Survey, 196.4.1970. The Dewloping ('ountrles in the 19601s-The Problem of Appraising Progress INew York: United Nations, 1971). Table A.1,p. 177.

National fncome Data - World Bank estimates provided by the Ministry of Platuning. Foreign Trade Data-Ministry of Commerce, A Summary of Afghamistan's Iinreign

Trudk. 1.34,1-1.148 (Kabul: Ministry of Commerce, mimeo, December 1471).

Tax Datid Table 6.5 above. luhk o. 11

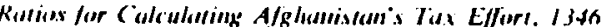

\begin{tabular}{|c|c|}
\hline$\left\|1 \prime^{\prime},\right\|$ & Perc"nlage \\
\hline Gross Agriculiural Income / Ciross Domestic Prodluct & 50.904 \\
\hline Gross Nonagriculturat Incone / Gross Donkstic Product & 49.046 \\
\hline Gross Mining lnconxc / Gross Domestic Product & 0.478 \\
\hline Gross Manulacturing Income / Gross Domestic Product & 1.804 \\
\hline Commercial Inluwis / Ciross National Product & 9.279 \\
\hline Exports / Cirons National Product & x.05y \\
\hline Exporls of Aplicultural Panducts / Ciross Nathould Product & 6.976 \\
\hline 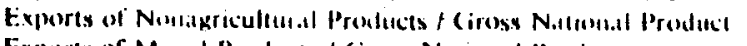 & $1.0 \times 2$ \\
\hline Exports of Mmacd Prodtacts / Cross Narional Producl & 0.355 \\
\hline Nel loreign Ald / Girm, National Product & 3.411 \\
\hline Commodity Assistince / Cross National Proslect & 0.830 \\
\hline 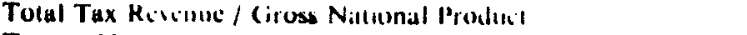 & 4.950 \\
\hline 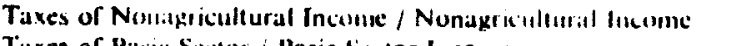 & 1.230 \\
\hline Tiuxes of Bussic Scctor / Basic Scctor Income & 20.600 \\
\hline Tiaxes of Inypenis / lanports & $24.2 \times 2$ \\
\hline Taxes of Tolal Imconec / Grom Nattional Prodacl & 0.141 \\
\hline
\end{tabular}

Note: Nonitgricultural income is incone generated outside the agricultural sector plas the vallue of agricullural cxports on which personal income tax, sales taxes, excistes and wher internal indirect taxes are levied. Taxes related to total income comprise properly. poll and personal, and unclassificd lax collections as a mercentage of CiNP. The bisic sector consists of nining and mamufiacturing sectors and agricul turat exports ont which conporate inconne tax and sxpen, laxes are levied.

Sisurve: Table ti.y above.

in the agricultural sector, and Ty taxible capacity is a percentage of income [B2, p. 109]. Taking the datis provided in Tables 6.9 and 6.10, the linluwing cisults are obtained for Alghtaustau:

$\begin{array}{lllll}\text { Equation 6.3 } & \hat{\mathrm{T} y} & 11.773 & \mathrm{~V} & 0.420 \\ \text { Equation } 6.4 & \hat{\mathrm{T}}_{y} & 11.168 & \mathrm{~V} & 0.443 \\ \text { Equation } 6.5 & \hat{\mathrm{T}}_{y} & 11.104 & \mathrm{E} & 0.446\end{array}$

These results support the conclusion that less than half the tax receipts which could have been collected by an average effort were actually collected in 1.346 (1967). This year is not alypical. It is not surprising to find that this poor tax ellort has been accompanied by low levels of public sector salving.

An alternattive way of meatsuring lax eflorl on the lax revenue criterion involves the use of the representative tax system approach. This method uses the arctage tax rate structure for all countries in the sample and 
compules line tax revenue which would be collected by each cisuntry had it applied these average or representative rates. A recent study employing this technique [B2] produced the following representative tax structure:

$$
\begin{array}{r}
\hat{T}-0.0869(Y-A+A x)+0.1430(N+I+A x)+0.1725(M) \\
+0.0132(Y)
\end{array}
$$

where $\hat{T}$ is the yield from the representative tax system, $Y$ is GNP, $A$ total income generated in the agricultural sector, $A \times$ total value of agricullural exports. $N$ lotal income generated in the mining sector, I folill incume generated in the manulacturing sector, and $\mathbf{M}$ the total value of imports [B2. p. 1(44]. Data required to compare Afghanistan's tax effort on this basis are given in Tables 6.9 and 6.10. The results are presented in Table 6.11 helow. In this case, the tax effort, $E$, is 0.556 , indicating that just over half the taxes which could be colleoted through applying the representalive tax structure were collected.

The representative lax approach enables a more detailed analysis of the tax elliort. In Afghanistan's case, as indicated in Table 6.11. of the 44.40 per cent shortfall in expected revenues, 45.06 per cent can be attributicd to below average personal income and internal indirect taxes and 13.15 per cent to below average property taxes. On the other hand, import taxes are higher than would have been the case had Afghanistan adipted the representative tax system. This offsets the 58.21 per cent shortfall contributed by the other tax groups by 7.33 per cent. The higher value of taxes collected on corporate and export taxes (mainly the latter) also iffsets the shortfall created by low internal tax collection by 6.48 per cent. These findings are consistent with the analysis presented in Section iii.

Unfirtunately, datia on public sector savings are not as easily a vailable as datil on tax revenues. However, a comparison of a small selection of countries lor which figures could be obtained is given in Table 0.12 below. From a glance at this table, the conclusion is again dritwn that Afghanistan's tax efrort based on the savings criterion has been extremely kow. In 1346 (1967), public sector net savings represented 0.8 per cent of National Income

An analysis of domestic savings rates has been attempted in a recent cross-country study [P1]. Based on 85 observations, the following result from regression analysis was obtained:

$$
S:=11.4-1.00(\mathrm{~A})+0.20(\mathrm{P})+1.50(\mathrm{E})
$$

$$
\text { (12.1) }(-7.1) \quad(5.4) \quad(7.0)
$$


Table 6.12

Irullic Sector Nict Sarings as a Percentage of Nutional Incounc in 1.5 Undercleveloped Couniries, (Yxis (Percentage)

\begin{tabular}{|c|c|c|}
\hline Conmeri & $\begin{array}{l}\text { Public Sector } \\
\text { Net Surings }\end{array}$ & Tax Ellurt \\
\hline Argentina & 2.7 & $(1.03)$ \\
\hline Brazil & 3.2 & $(1.53)$ \\
\hline Chile & 9.6 & (I. (1) \\
\hline Taiwin & 3.6 & (1.0K) \\
\hline Colombia & 5.8 & $(0.7 x)$ \\
\hline Invia & 1.9 & $(1,01)$ \\
\hline South Korea & 9.5 & $(0.9 .3)$ \\
\hline Philippines & 1.2 & $(0.76)$ \\
\hline Thailinnd & 3.2 & $(0.98)$ \\
\hline Tunisia & 3.8 & $(1.24)$ \\
\hline Venezuela & 7.8 & $(0.99)$ \\
\hline Iran & 4.1 & $(0.97)$ \\
\hline $\begin{array}{l}\text { Pakistian } \\
\text { Turkey }\end{array}$ & $\begin{array}{l}4.1 \\
9.5\end{array}$ & $\begin{array}{l}(0.72) \\
(1.10)\end{array}$ \\
\hline Afylimistain & 0.8 & $(0.44)$ \\
\hline
\end{tabular}

Note: 1 or lran, Pathistan and Turkey, gross public sector saving as a pet chltage of Cirows Natconal Product is used. For Afghanistan, public enterprises atre atssimed to yichl no net savings. Therefore, the Government current acount batauce of 398 nuillion lir $1346(1967)$ is taken as gross savings and Afs 145 deducled fior of Afs ciation. (iruss public sector savina as a percentave of Gioss deducled fior depre0.96 per cent for Afgilanistan. Tilx effort. E, from Table Gross Nalional Pridlucl is Source: Alghanistan-Table 6.3 above.

Iran. Pakistan and Turkey-M. J. Fry, Money. Exchange Control and Bumh Rexullafist in Irum. Runistan and Turhey (London: City University, mimeo, March ly72, Statistical Appendix.

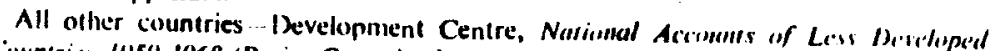
(iountrios 19.59-1968 (Paris: Organisation for Economic Co-operation and Development, 197()).

where $A$ is foreign aid, $P$ exports of primary products, and $t:$ ather exports, all expressed as percentages of GNP. Figures in brackets are " $t$ " values. The adjusted cuellicient of determination, $\bar{R}^{2}$, equalled 0.62 [P1. Table 5, p. 127]. Inserting values for $A$ fghanistan given in Table 6.9 into I:quation 6.7 gives $S$ - 9.67 which is a relatively low figure compared (1) domestic savings achieved in many of the underdeveloped countries. However, from figures in Tables 2.15 and 4.5 , it can be calculated that donıestic savings reaclied 5.29 per cent of GNP in 1346 (1967) but hald declined to 4.46 per cent, less than half the level predicted by Equation 6.7 . by 1.151 (1972). Equation 6.7 and additional results published by
Papanek [PI] lend support to the contention in Chapter IV that foreign aid is not so eflicitive as exports in stimulatirg growth. Equation 6.7 illustrates one reason, natnely that foreign aid acts as a substitute for domestic savings whereas exports generate it. Palpanek's results also show that foreign ail represses exports [PI. Table 6. p. 129]. It is interesting to note that on the hasis of the tax eflurt calculations $(E-0.44)$, had the tax effort in $1346(1967)$ been of average strength, i.e. E - I. and had all extra revenue been saved for development expenditure, public sector savings alone might have heen raised $10 \wedge f s, 521$ million or 7.3 per cent of GNP.

If Afghanistan is classitied as an underachiever in relation to some expected rate al economic growth, it might be grouped with a number of other countries "..... whose governments put a very low priority on economic performance ...." [P1, p. 124]. This was the conclusion reached in Chapter IV. That the Government has failed to raise revenue for development expenditure supports this contention. It is strengthened by analysis presented below in which imserment is examined in more delinl.

\section{v. Defirin Fïmmer}

Noticeable lor their ontission in hoth ths and the preceding chapter have been ritierences 10 monetary or liscal policy; in the Alghan context they would represent two sides of the sime coin. The omission springs from the fitct that no detiberate policies have been pursued. Domestic borrowing has been a balancing item and not a part of either monetary or fiscal policy. The uncertain outcome of the budgetiry position would in any case have made the preparalion of tiscal policy a sterile exercise. As for monctirry policy:

Unformately, in Afganistan it is difficult to formulate and make affective monetary policy. since the (jovernment has to rely solely on the Da Alyhanistitn Bank to linance its delicil since there is no private sector market from which the Government can borrow. [M30, p. 18]

It was suggested in Chapter $V$ that Da Afghanistan Bank had done what it cusuld to mitigate the effects of violent fluctuations in public sector net domestic horrowing requirements. Periods of excessive recourse to deficit thlince can easily be pinpointed from the money supply series presented in liable 2.9. 1.333-1.335 (19.54-19.56). 1340-1344 (1961-1965) and $1351-1352$ (1972-1973) are picked out in this way. Using monetary data. the public sector deficit lor the three years 1.333-1335 (19.54-1956) appears to have been $A f s 726$ millian or 26 per cent of total revenue. This dilfers 
greatly froin the residuals given in Table 6.3 since most of it consisted of loans (1) the new Government enterprises established at this time. From Table 5.8, it can be seen that during the five years 1340-1344 (1961. 196.5) net claims on the Government by the financial sector increased by Afs 3 billion or 21 per cent of total revenue. In 1351 (1972), net claims on the Government by the financial sector increased by Afs 1,035 million or 34 per cent of total revenue and the estimated outcome for 1.352 (1973) is likely 10 be of a similar order of magnitude and proportion. In relation to the initial money stock, the average annual deficits for the periods 1333. 1.335 (1954-1956) and 1340-1.344 (1961-1965) represented is and 19 per cent, resprectively. The 1351 (1972) deficit of Afs 1.035 million represented 11 per cent.

The balance between revenue and expenditure has been large enough in relation to the money stock to have had a strong effect in terms of increasing the latter. In the previous chapter, the relationship between changes in the money stock and changes in the price level was analysed. That at strong relationship appears to have existed and that domestic revenue hils been price inelastic suggest that any level of deficit finance which increases the money stock annually by more than 4 per cent leads to further inbalance in the future. Roughly, this implies that the deficit should he held within 4 per cent of the money stock.

Using Fyuation 5.4 from the previous chapter, the maximum noninflationary increase in the money stock over a three year period is 11.5 per cent. Thie average three year increase between 1331 (1952) and 1350 (1971) shown in Table 5.14 has, in fact, been 38.7 per cent; it has already been argued that increases in net claims on the Government by the financial sector have been the primary determinant of changes in the money stock.

Not all expenditures are price elastic. In particular, throughout the period civil servant salaries have been adjusted only very irregularly. Thus, for example, in 1328 (1949) a mission from the United Nations Educitional. Scientific and Cultural Organisation stated:

It seems clear from our study that in 1938 a family of four could live reasonahly well on 300 afghanis per month. At present the same family would need about 1,600 afghanis per month. [U17, p. 67]

Yet, the mission found that teachers were receiving between Afs 150 and Afs 712 per month, the latter being the salary of a university professor [U17, p. 68], and concluded:

The Mission is of the opinion that the tragic financial situation of the teaching profession is one of the principal reasons for the poor results achievel by Afghanistan in the sphere of education. [U 17, p. 68]
A similar situattion occurred in the $134(1)$ ( $(19(x) s)$, there having been no general increiase in salary scalles for civil servants between 1344 (1965) and 1352 (197.3). Most civil servints receive sillaries generally regarded as below the subsistence level.

For illustrattive purposes, one might perhaps reasonably assume that in the short run revenue price elasticity has been about 0.5 and expenditure price elasticity about 0.7. For the years 1339-1342 (1960-1963), the part of the (iovernment's deficit financed by the financial sector was Afs 3,313 million. Tutal revenue for those scius was Afs 7,061 million and totial expenditure Afs 10,49$)$ million. The money stock increased by Al 2,130 millmon, the diflerence being linimed in equal part by at reduction in domestic credit to the privalte sector and a depletion of international reserves $[13$, p. 229]. Despite countermovements which offset the effect of the increise in Government borruwing on the noney supply, the latter increased hy 61.5 per-cent. From Equation 5.4, this increase would have calused an increase in the price level of $3 \times .5$ per cent. The actuall increalue whown in Tiable 5.14 is 46.5 per cent

A $38.5 \mathrm{per}$ cent increase in the price level would, on the basis of the assumed price elasticities, increase revenue by Afs 1.359 million and expenditure by Afs 2,828 million and thus increase the deficit for the subsequent three year period by Afs 1,469 million. At the end of 1342 (1964), the moncy stock lotalled Afs $4,8 \times 6$ million. Hence, even the increase in the gap between expenditures and revenues created by price increases ahine over the 1339-1342 (1960-1963) period would have necessitated it 30 per cent increase in the money stock over the subsequent three year period 1342-1345(1963-1966), adding a further 23 per cent to the rise in the price level, had new revenue measures not been forthcoming to prevent the perpetuation of this vicious circic.

This example serves to illustrate the potentially self-generating nature of the inflationary process in Afghanistan. A strong pressure group which can hold its tixes to very modest increases, if any, in nominal terms, a revenue structure which is less price elastic than expenditures, despite civil service pay freezes, and a desire at certain times stronger than at others to promote economic development have combined to produce a circle of inflationary pressures which eventually have had to be cut by unpopular alction on the revenue side of the equation and growth retarding cuts on the expenditure side. That such actions have been too late and tou weak is evinced from the inllationary picture presented in Table 2.7.

Alghanistativ colst is nol unique: 
Becaluse government expenditures are clastic to income growth even if revenues are not, the problem of relieving financial repression is made much more difficult. Growth brings with it a tendency toward budgetary deficits. Public saving does not keep pace, and governments either allow more non-neutral small taxes to proliferate or turn to central banks for financing. given the absence of capital markets for absorbing long-term public debt. Excessive issue of nominal money can then cause inflation and a reduction in the real stock of money .... [M], p. 142]

Various other aspects of deficit finance, including its drawhacks, have heen discussed elsewhere by others, e.g. in [E6: R5: U4; VI].

An impurtant aspect of the deficit finance issue in Afghanist :n has hecn the extreme vatriability in the level of public sector domestic horruwing from one year to the other. The effects of this in terms of the variance af changes in the money stock and hence of the price level were covered in the last chapter. Here, an examination of the causes of the high variance in the Government's domestic horrowing requirements is due. Turning baci to Table 6.3 it can be seen that current account balances have not fluctuated to anything like the extent of the residual domestic horrowing requirements. Omitting the two half years, the cucllicient of variation of the current account balance in constant prices is 61 per cent over the period 1331-1351 (1952-1972), while over the same period the coefficient of variation of net domestic borrowing is 123 per cent. The causes of the high variability of net domestic borrowing would at first sight appear to lie in the capital account and in other financing items. Project assistance cancels out, thus leaving development expenditure in licial currency and Commodity Assistance. The former appears to have followed a fairly steady path (coeflicient of variation 56 per cent for $1.3 .11-1.351$ (1952-1972) omitting the two half years) which leaves (onmulodity Assistance. In fact, this item has not been particularly volatile (coeflicient of variation 54 per cent for 1336/37-1351 (1957-1972) omitting the one half year). But it has been unpredictable since it depends primarily on agricultural conditions for any particular year. Thus, it has heen impossible to budget accurately for this item and so take measures in advance " counteract its fluctuations. Apart from unpredict:able Comnodity Assistance, the fact that net domestic borrowing requirements is a residual further contributes to its own variability. Small movements in opposite directions of the major revenue and expenditure itens have a relatively large percentage effect on the small residual. That such movements hate not been anticipated has heen a result of the primitive hudgeting procedures, lack of implementation checks, and uther aspects of the weak administrative system which impinges on the Government revenue and exnenditure outcome.

A need fur some systen of controls on levels of deficit finance in Afghanistan has been recognised. A report by the German Economic Advisory Group suggesis:

$\ldots$ there should at least exist regulations for all credit relations between Government and Central Bank. Suci regulations should fix limits, purpose. : procedure, term structure, repayment. interest rates for government debt to the central Bank.

Da Afghanistan Bank too fecls that such regulations are unavoidable, if uncontrolled monetary expansion by government deficit spending should be prevented (see I)a Afghanistan Bank's reply to the Ministry of Planning's enquiry of 29.2.1350). During the last four years the Government has neither paid loan instalments nor interest on loans. [G], p. 3]

Regulaliums of this type would be unnceissary were fiscal and monetary policies rationally formulated and then accurately implemented. Such a situation has not existed in Afghanistan. where instead immediate financing reyuirements halse driven the Government to the only available source. An appreciation of the idea that even this source should not be used when the longer run consequences are likely to be detrimental was clearly recinguised by the Guvernment and Da Afghanistan Bank in 1352 (1973). A ( abinet policy statement on banking legislation stated:

Loans by the central bank to the Government will be limited by law to a maximuit percentage of the Budget. Each year, consultation will take place buween the central bank and the Government on the optimum level of deficit tmance within this limit for that particular year. [CI, p. 3]

This was incorporatcd into the laws which were then draftcd by the Financial bevelopment committee with assistance from the International Monetary $I$ und and the United States Agency for International Development, The draft legislation awats further consideration by the new Republican (iovernment.

vi. Expentuturc

As can bie seen from the figures in Tables 6.13 and 6.14, ordinary expenditure hats increased steadily over the past two decades in both nominal ind ral terms. In 1349 (1970) personnel, debt servicing and defence aciunted for 78 per cent of ordinary expenditure. The only new and accelerialing component has heen debt service. This has clearly had a strong negiitive eflect on the Government's current account balance. However, it wals its predicted effect on the balance of international payments that wats in fact used as primary justification in the request to 
Table 6.13

Government Expenditure 1331-1352

(Millions of Afghanis)

\begin{tabular}{|c|c|c|c|c|c|c|c|c|c|c|}
\hline$h t^{\prime \prime \prime \prime}$ & 1331 & 1332 & 1333 & 1334 & 1335 & $\begin{array}{l}1336 \\
\text { (first } \\
\text { half) }\end{array}$ & $\begin{array}{r}13.361 \\
.37\end{array}$ & $\begin{array}{r}13.371 \\
38\end{array}$ & $\begin{array}{r}13381 \\
39\end{array}$ & $\begin{array}{r}13391 \\
40\end{array}$ \\
\hline $\begin{array}{l}\text { Ordinary frmenditure } \\
\text { National I Refence and }\end{array}$ & 660 & 666 & 825 & 933 & 910 & 526 & 1,007 & 1.251 & 1,394 & 1.558 \\
\hline Security & 244 & 281 & 211 & 294 & 259 & 181 & 420 & $\$ 10$ & 522 & 640 \\
\hline Ihebl Service & 0 & 0 & 0 & 0 & $\mathbf{0}$ & 0 & 141 & 174 & 179 & 183 \\
\hline Ollker & 411 & 385 & 614 & 639 & 6.51 & .345 & 4.47 & 51,7 & 69.3 & 735 \\
\hline Developmient Expenditure & 170 & 172 & 205 & 327 & 381 & 214 & 374 & 421 & 705 & 1,550 \\
\hline Education & 26 & 28 & 19 & 22 & 28 & 20 & 44 & 35 & 47 & 154 \\
\hline Health & n.a. & n.a. & 7 & 7 & y & 6 & 10 & 3 & IX & the \\
\hline Transport and & & & & & & & & & & \\
\hline Communications & n.a. & n.a. & 49 & 71 & 133 & 82 & 16,7 & 2.3 .3 & 434 & 949 \\
\hline Agriculture & n.a. & n.a. & 10 & 8 & 15 & 8 & 99 & 85 & 91 & 114 \\
\hline Industry and Mines & n.a. & n.a. & 0 & 15 & 11 & 5 & 43 & +7 & 11.1 & 18.3 \\
\hline (Wher & 144 & 144 & 120 & 204 & 185 & 93 & 11 & Ix & 2 & $\$ 4$ \\
\hline
\end{tabular}

Table 6.1 .1

Goiernment Expenditure 1.131-1152

(Millions of Aighanis)

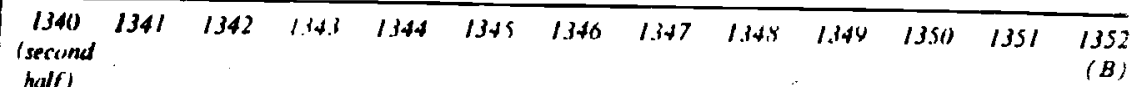

in Foreign (urrency

(Projecl Assistance)

Total

- $\quad$ - $\quad-\quad 1,246 \quad 1,556 \quad 2,078 \quad 2,697$

$\begin{array}{llllllllll}830 & 838 & 1,030 & 1,260 & 1,291 & 740 & 2,627 & 3,22 \times & 4,177 & 5,805\end{array}$

Note: ( lassifications follow Ministry of Finance procedures and are in some cases arbitritry. Thus, for example, higher figures might well be assigned to cduciation and health development expenditures. In 1336/37, only 33.5 per cent of totul culucution expenditure and 23.2 per cent of health expenditure were classified as deveh For transportation and communications, agriculture, and mines and industren. propurtions of total expenditure claseifed as develop print 74.7 . and $79.7 \mathrm{mit}$ cent, respectively. As no distinction between ordinary and development expenditilic was made prior to 1336/37, these proportions were assumed for the period 133-13.h (lirst half) and expenditures of the appropriate ministries and agenor partitioncl ilccordingly. The resulting eatimates agree reasonably well with ligures Tudor Engincering Company, Report on Delchupment of Helmand Valley (Wasting in

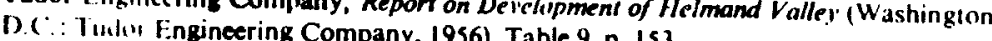

Througlwul. project assistance has been converted into Afghanis at Afs 45 th the tiuted Silltes Dollar

1- Jucation includes Ministry of Education, Kabul University and the Fidulty of Medicine.

Ilealth includes Public'Health and Health Institutions.

Transport and Communications includes Communications, Public Works, Civil Aviation and Transport.

donors for debt rescheduling made in 1350 (1971). The II.S.S.R.. the largest creditor, agreed. The U.S.A. felt that the request was unjustiliable because the appreciation of the Afghani since 1349 (1970) and Afghanistan's ample foreign exchange reserves did not suggest an imminent

\begin{tabular}{|c|c|c|c|c|c|c|c|c|c|c|c|c|}
\hline 878 & 1,850 & 2.416 & 2.958 & $2 .(x) 2$ & $3,+103$ & 3,613 & 4.254 & 4.7 .32 & 5.158 & 5,504 & 5,684 & 6.538 \\
\hline 297 & 693 & 759 & Y25 & 1.044 & $1,2 \times 5$ & 1.370 & 1.501 & 1.577 & 1,651 & 1,637 & 1,657 & 1,785 \\
\hline 133 & 258 & 543 & 174 & 256 & 474 & 665 & $(x) 1$ & $x 67$ & 1.014 & 1,140 & 1,055 & 1.471 \\
\hline $4.4 x$ & 894 & 1,114 & 1.29 .1 & 1. $(x) 2$ & 1.1 .64 & 1.578 & 2.192 & $2,2 \mathrm{kx}$ & $2,49,3$ & 2,727 & 2,477 & $3,2 \times 2$ \\
\hline 520 & 1,446 & 1,830 & 1.622 & 1.720 & $1,72 x$ & 1,707 & 1.820 & 1.920 & 1.731 & 1.916 & 2,100 & 2.544 \\
\hline 34 & 81 & 117 & 51 & $\mathrm{kz}$ & 125 & 127 & 1.30 & 128 & 96 & 57 & 82 & 108 \\
\hline 21 & 18 & 21 & 14 & 15 & 21 & 11 & 33 & .14 & 57 & 49 & 82 & 112 \\
\hline $30 x$ & 844 & 938 & $87 x$ & $4(1) 3$ & 362 & 314 & 338 & 386 & 410 & 390 & 316 & 345 \\
\hline 50 & 117 & 173 & 16 & +37 & $\ln 7$ & 681 & $6 \times 1$ & $k+2$ & 711 & 927 & 953 & 1,113 \\
\hline או & 367 & 442 & 1.45 & inds & $5 \times 1$ & 428 & $36 x$ & $32 x$ & $32 \mathrm{x}$ & 334 & 340 & 367 \\
\hline " & 14 & 134 & $9 x$ & 1,36 & 16.7 & 146 & 270 & 2012 & 129 & 159 & 327 & \\
\hline
\end{tabular}

$\begin{array}{lllllllllllll}1.823 & 3,144 & 2,833 & 3,16 \times & 1,4 \times 5 & 3,373 & 2,784 & 2,294 & 1,400 & 1,241 & 1,544 & 2,509 & 2,236\end{array}$ $\begin{array}{llllllllllllll}3.221 & 6,440 & 7,079 & 7.31 \times & 8,107 & 8,504 & 8,109 & 8,3.33 & 6,642 & 8,130 & 8,964 & 10,298 & 11,318\end{array}$

Agriculuuc indudes Agriculture, lfelntand Valley Authority, Rural Development, Water and soml, Nangarhar, Patklia, and Land Reclamation and Settlenkent. Industry and Mines includes only the Ministry.

Source: $1111-1332$ Tudor Engineering Company, Report on Development of Helmand V'alley (Waslungton, D.C.: Tudor Engineering Conpany, 1956), Table 9, p. 153; and Ministry of I mance.

1333-1336 1tirst half) Ministry of Planning. Survey of Progress 1959 (Kabul: Ministry of Planning. $\mid(5)$ ). Volume IV. Table S6, pp. 242-44; and Ministry of Finance. 1336/37-1340 (second half) Ministry of Planning, Survey of Progress 1962-64 (Kabul: Ministry of Platining. 1964), Table A-2, p. 91 and Table A-4, pp. 94-95.

1.341.1343 Mutustry of Planning. Survej of Progress 1967-1968 (Kabul: Ministry of Planning, 1\%(x). Tables $S-2, S-3$ and $S-4$.

1344-1347 Ministry of Planning. Surve' of Prograws 1970-197/ (Kabul: Ministry of Planning. $\mid \cdots 71$, Tiables S-2, S-3 and S-4.

1348-1349 M iuntry of Planning. Survery of Proxerss 197/-1472 (Kabul: Ministry of Planning. 19721, Iables S-2, S-3 and S-1.

1350-1352 Ministricis of Finance and Plaming.

balance of pityments crisis. The United States balance of payments situation, on the other hand, was not one under which the request could be viewed sympathetically.

Part of the reason behind the request lay in the composition of the 
Table 6.14

Government Expenditure at Constant Prices 133/-1352 (Millions of Arghanis, 1340 Prices)

\begin{tabular}{|c|c|c|c|c|c|c|c|c|c|c|}
\hline liem & 1331 & 1332 & 1333 & 1334 & 1335 & $\begin{array}{l}1336 \\
\text { (first } \\
\text { half) }\end{array}$ & $\begin{array}{r}1336 \mid \\
37\end{array}$ & $\begin{array}{r}13.37 / \\
38\end{array}$ & $\begin{array}{r}13381 \\
39\end{array}$ & $\begin{array}{r}13391 \\
40\end{array}$ \\
\hline \multirow{4}{*}{$\begin{array}{l}\text { Ordinary Expenditure } \\
\text { National Delunce } \\
\text { and Security } \\
\text { Debt Service } \\
\text { Other }\end{array}$} & 828 & 845 & 921 & 967 & 768 & 429 & 820 & 994 & 1.298 & 1,654 \\
\hline & 312 & 356 & 236 & 305 & 219 & 148 & 342 & 405 & 486 & 690 \\
\hline & 0 & o & 0 & 0 & 0 & 0 & 114 & $13 k$ & 167 & 194 \\
\hline & 516 & 489 & 685 & $0 x, 2$ & 549. & 281 & $3(x)$ & 451 & 645 & 780 \\
\hline \multirow{7}{*}{$\begin{array}{l}\text { Developmelt lexpenditure } \\
\text { Idluciationt } \\
\text { Ileallh } \\
\text { Transport and } \\
\text { ('immmunications } \\
\text { Agriculture } \\
\text { Industry and Mines } \\
\text { Other }\end{array}$} & c 213 & 218 & 229 & 339 & 321 & 174 & 305 & 314 & 656 & 1.645 \\
\hline & 33 & 39 & 21 & 23 & 24 & 16 & in & $2 K$ & 44 & 164 \\
\hline & n.a. & ก.2. & 8 & 7 & 7 & 5 & $x$ & 2 & 17 & 70 \\
\hline & n.a. & n.a. & & & & & & & & \\
\hline & $\begin{array}{l}\text { n.d. } \\
\text { n.a. }\end{array}$ & n.a. & 55 & 74 & 112 & 67 & 136 & 185 & 404 & 1.007 \\
\hline & n... & ก... & $\begin{array}{l}11 \\
0\end{array}$ & 8 & 13 & 6 & 81 & $6 x$ & 84 & 121 \\
\hline & $\begin{array}{l}\text { n.2. } \\
180\end{array}$ & 183 & 0 & 16 & 9 & 4 & 35 & 37 & 105 & 194 \\
\hline \multirow{2}{*}{\multicolumn{11}{|c|}{$\begin{array}{l}\text { Development Expenditure } \\
\text { in Foreign Currency } \\
\text { (Proje:t Assistance) }\end{array}$}} \\
\hline & & & & & & & & & & \\
\hline (2) & - & & & - & - & - & 1,262 & 1.554 & 2,072 & 2.686 \\
\hline & 1.041 & 1,063 & 1,150 & 1,306 & 1,089 & 603 & 2,387 & 2,882 & 4,026 & 5.985 \\
\hline
\end{tabular}

Note: Devclopment expenditures in forcign currency, i.e. projoct assistance, have been deflated hy the United States whoteale price index in Table 2.6. All other figures have been deflated by the moxlified purchasing power parity price index in Table 2.7.

foreign exchange reserves, over 70 per cent of which was in the form of gold. The Government was naturally loath to use gold, which it would have li:ld to have sold at well under half the world price following the rules of the two tier system, to support the Afghani. The abandonment of the two ticr gold system in 1352 (1973) justified this reluctance.

Agarwal has recently measured the optimal monetary reserves for seven Asian countries [A4]. The model used is inapplicable (1) Afghanistan because the countries in Agarwal's study operated on fixed exchange rate systems in contrast to Afghanistan's floating rate. However, there is little doubt that Afghanistan's international reserves exceed the optimum level. Hopefully, the abandonment of the two tier gold system will provide the necessary incentive for Afghanistan to convert some of these unproductive reserves into productive investment goods.

For the future, the so-called debt problem looms large. The existence of a problem or a potential problem lies essentially in the fact that returns to the Government and in most cases to the country as a whole from
Table 6.14

(iindirmene'nt Expenditure at Coulvant Price's 133/-1352 (Miltions of Afghanis. 1340 Prices)

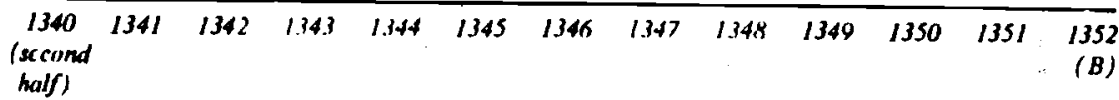

\begin{tabular}{|c|c|c|c|c|c|c|c|c|c|c|c|c|}
\hline 878 & 1.520 & 2,049 & 1.746 & 1.64t & $1,8.14$ & 1.944 & 2,282 & 2.463 & 2,265 & 2,347 & 2,473 & 2,8 \\
\hline 17 & 5604 & 644 & 6.31 & 540 & (64) 3 & 737 & yos & 807 & 725 & 698 & 720 & \\
\hline 33 & 212 & $4(x)$ & 250 & 149 & 255 & $35 \mathrm{~K}$ & 322 & $4+4$ & 445 & 486 & 458 & \\
\hline 48 & $7.1 \%$ & 945 & K56 & xk & $K K 6$ & 849 & 1,155 & 1.172 & 1,095 & 1,163 & 1,295 & \\
\hline 520 & $1.1 \times k$ & 1.592 & 1.1017 & 472 & 9.12 & 919 & 476 & $9 \times 3$ & 760 & 817 & ग3 & \\
\hline .34 & tht & y4 & 15 & 40 & $6 K$ & 68 & 70 & th & 42 & 24 & 36 & \\
\hline 21 & 1.5 & IK & $y$ & K & 11 & 6 & IK & 17 & 25 & 21 & 36 & \\
\hline $0 x$ & $6 y 1$ & 745 & Siny & 228 & 14 & 16 & $|x|$ & 198 & 180 & 166 & 137 & \\
\hline 50 & 96 & 147 & 43 & 247 & 252 & 367 & 365 & 431 & 312 & 395 & 414 & \\
\hline $9 k$ & 302 & 375 & 3144 & 365 & .116 & 230 & 197 & 168 & 144 & 143 & 148 & \\
\hline$y$ & 16 & 118 & 67 & 78 & (x) & 79 & 145 & 10.3 & 57 & 68 & 142 & \\
\hline
\end{tabular}

$\begin{array}{lllllllllllll}1.823 & 3.135 & 2,833 & 1.162 & 3,410 & 3,194 & 2,636 & 2.064 & 1,766 & 1,063 & 1,280 & 1,991 & 1,775\end{array}$ $\begin{array}{llllllllllllll}3.221 & 5.841 & 6.434 & 6.6115 & 6,023 & 5.460 & 5.499 & 5.342 & 5,172 & 4.088 & 4.444 & 5.377 & 5.724\end{array}$

Sensce: figures in Table 6.13 have teen deflated by the price indices referred to in the Note atures.

foreign aid linanced projects have failed to produce yields sufficient even to cover the concessional interest rates charged on the loans, let alone reached levis anywhere near approximating those actually anticipated by the dumurs themselves. Given the admitted lack of expertise within the Afghan hurciucracy and the Government's reliance on the donors for project suggestions and appraisals, a somewhat more forceful argument for debt rexchejuling or even some debt moratorium might have been based on allaching somc responsibility lor the unsatisfactory outcome of donor projects on the donors themselves. Their feasibility studies for patential lian financed projects have consistently produced wildly overoplimistic estimates of expected returns. A striking example of an overoptimistic cytim:ate of returns made recently is the following:

From the research and practical on-farm work done, results show it is possible for wheat farmers in Afghanistan to receive up to 1,000 Afs for each $100 \mathrm{Af}$ pent for fertilizer if they use improved seed and recommended production practices. [K II, p. 13] 
Defence and national security expenditures under the new Republic and, in the absence of successful debt rescheduling negotiations, debt service as well, are likely to increase sharply. Direct assistance for the former may be obtained from the U.S.S.R. Even so prospects for ordinary expenditure appear expansionary.

The distinction between ordinary and development expenditure has already been given some attention. The arbitrariness of some classifications throws doubt on the meaningfulness of comparisons within the development expenditure category. For example, the development proportion of expenditure on education and health is much lower than that on agriculture and transport. Nevertheless, the emphasis on infrastructure and particularly road building during the First Plan and the carly years of the Second Plan stands out. Another major problem of analysing the sectoral breakdown of development expenditure arises from the fict that project assistance expenditure is not broken down in the (jovernment accounts. Partly because accountability for project issistince expenditure does not rest with the Government and partly heciluse such expenditure is for specific donor projects there seems to hive been something approaching abrogation of responsibility for donor projects on the Covernment's part. As far back as 1328 (1949). the Afghan Delegation to the United Nations which had submitted a request for aid in 17 projects "left to the UN the task of selecting the most desirable projects" [F16, p. 15]. The same still appeared to be the cise in 1352 (1973). as shown in Chapter IV.

Neither the Government nor the donors have been too concerned with ex-post rites of return analyses, despite the fact that benefits from both continuous project appraisil and post mortems would have heen high. On the part of the Government this neglect seems to have been deliberate. Because most projects were of a long term nature, returns have not been expected in the short run. Thus, there appeared to be no urgency for relating expenditures to performance and no experience and expertise have been acquired for such analysis. Furthermore, there has been little incentive 10 complete projects which, while still uncompleted, have provided channèls for siphoning off foreign aid funds into private poihets [1313, pp. 33-35].

In Chanter IV. macroeconomic analysis suggested that development expenditure as a whole had yielded low and declining returns, i.c. that the incremental capital/output ratio had been high and rising over the period since 1335 (1956) when the First Plan was started. Although an analysis of development expenditure at the microeconomic level is essen- tial to all ullderstanding of what hat ponc wrong, the mammoth task which a comprehensive study of this type would require has been beyond the resources allocited to the present enquiry. However, one example can be examined to illustrate some of the problems to which developmen projects in Afghanistan have been subject. Given the importance and longevity of the Helmand Valley project, it makes a natural case study. Since its inception in 1325 (1946), many reports have been prepared on this project. Of particular significance is that while most of them admit to the failuic of the project to yield a satisfactory return to date, optimism has been shuwn f. ir the future.

A brief historical skctch of the llclmand-Arghandab Valley projects call serve to produce specilic examples of the most pervasive developmer: problems in Afghanistan. A more detailed history can be found in Dupree's brik [D10, Chapters 22-24]. Forry per cent of the country's total water resources flows through the Valley, which is situated in the southwest of Afghanistan and has many attributes conducive to highly productive africulture [B|0, p. 2]. However,

"hat was once supposedly the "bread basket" of Central Asia was by the 20 th century vast barren or scantily vegetated lands affected to varying dierces by salts, alkaline, ground water and erosion. [B10, p. 7]

Development elliorts started in 1289 (1910) when part of the vast network of old irrigition canals was reconstructed. Foreign technical assistance was first introduced in the 1310 s (1930s) when new canals were built with German and Jilpanese help [D10, pp. 478-81].

The Second World War brought not only the Helmand project to a stundstill but all other devclopment activities in the country because of a British-Sovict ultimatum on the Afghan Government to expel all German, Italian and Japanese personnel. The $W$ ar also hit private industry by preventing tic importation of essential supplies. Standards of living in the urhinn areas declined substantially [F/4, p. 295; U17, p. 67-68; W3, p. 2C7].

In 1325 (1946). . In American tirm, Morrison-Knudsen, arrived in Atghanistan under contract with the Govermment to build two diversion danis, enlarge an irrigation canal and construct roads in the Valley. A loan was oblained from the Export-Import Bank in 1328 (1949) after rapid depletion of Afghanistan's foreign exchange reserves built up during the $W^{\prime} a r$ on the first Morrison-Knudsen contract [D10, pp. 482-84]. Under a reoind contract, Morrison-Knudsen built the Arghandab and Kajakai I Hati, on the Arghandab and Helnatnd Rivers, respectively. The dims were cumpleted by 1331 (1952). 
The United Nations Preparatory Mission to Afghanistan recommended in its 1329 (1950) report that the United Nations should provide assistance to the Helmand Valley project [F16, p. 36]. However,

I $N$ headquarters entertained doubts about the economic soundness of the projects proposed and the Government's administrative capacity to complete them. Moreover, the economist of the first operational mission reported opposition from officials of the Afghan Department of Agriculture. whose advice was not sought by those blueprinting the development of the Valley. It also seemed to him that the officials assuming resnomsibility for the undertaking attached too much weight to engineering feitsibility and too little to economic and social usefulness. [1 16. p. .16]

The United Nations economist suggested that on cost-benelit criteria irrigation projects in the north of the country along the Amu Darya (River Oxus) were far more promising. However, later studies were considerably less enthusiastic about this alternative. Interestingly, he also noted as long ago as 1329 (1950) that investment was seriously unbalanced, there heing too high a proportion allocated to the irrigation works and too little to ancillary investment. This criticism can be applied to many other foreign aid projects in Afghanistan, perhaps most tellingly to the roid building programme. Part of the reason for this has been the donors. belice that the necessary ancillary investment should and/or would be undertaken by the Government.

An important criticism in this early appraisal wis that the Heimand proiect as it stood "would be too expensive to pay for itself in ternis of fureign exchange" [F/6, p. 37]. The same criticism has been made against other large projects. Another United Nations expert expressed the view in 1.331 (1952) that the foreign exchange spent on the Helmand project should instead have been spent on small scale agricultural schemes. He further noted that Afghan officials failed to supervise and monitor the contratcors, Morrison-Knudsen, and that technical assistance should be provided to the Government to increase its supervisory capacity:

Only in this way, he implied, could the contractor be prevented from dotting the Afghan countryside with dams on every site that looked pronising 10 its engineers. [F16, p. 37]

The United Nations was not the only critic of the Helmand project even in the eitrly stages. Indeed. Abdul Majid Zabuli. Minister of National Fconomy until his dismissal in 1329 (1950), stated that he opposed the scheme on economic grounds from its inception [P|4, p. 7]. This admission is somewhat ironical in that his dismissal was based in part on the extra- vagant use af loreign exchange used lo pay Morrison-Knudien for its work on the Helmand project under its lirst contract [F16, p. 17; F18, p. 39].

One teatture of decisions relating wh the Helmand project which has been apparent in other projects has been the importance attached to expenditure already made rather than an acceptance of the only economically justifiathle approilch to past expenditure of "bygones are bygones." To save liace or simply on an erroncous understanding of economic principles, projucts such at the Helmand hatve been continued despite adinission of the low relurns expected on luture outlays. In the case of the Helmand projecl, such a pattern has been followed right from the first loan granted by the Export-Import Bink in 1328 (1949) which was designed 11 salvage something from elforts already expended. After a second loan trom the Export-Import Bank in 1332 (1953) for more capital intensive irrigattion work, the U.S.A. alssumed tacit responsibility for a Satisfactory outcome of the Helmand project

It became obvious to the U.S. government in mid-1953 that the project. without help from experienced extension workers and other experts, was headul fir the worst. Since that time. U.S. technical assistance has been essential 10 the project's success. [F17. pp. 44-45].

Unfortunittly, the two agricultural extension advisors provided under the Point IV Assistance Program were too late and too few

The Murrisun-Knudien period ended in 1.338 (1959) with recriminations on buth sides:

The Afyians hlanied M-K [Morrison-Kuudsen] publicly for the failures: privatei). M-K blamed the Afyhans ....

Afghamistan's shortconings in handling the projects can be attributed to the weakness tharacterizing underdeveloped government-lack of proper planning and :tdministrative machinery. The latter depended on the agricultural planning which had run into snags. In addition to problems of settlement. insuflicient tention had been given to that of reimbursing the government for land, water, and services. Production and settler income were low and squatters settled on nonirrigable land while thousands of applicants waited. All these inadequacies made the government turn to $M-K$ for help above and beyond actual engineering

M-K's initial objective had becn to build specified engineering works in the yuickest and most effective way. Thanks to many inprovised solutions to novel situations, the company lived un to its reputation as a fast. dependable consiruction firn. But gradually $M-K$ had to assume additional responsibilities hecause of the governnicnt's unexpected lack of preparation. the uncertainty surrounding the physical and engincering features of the structures, and the considerable doubts developing over the economic 
merits of the reclamation and settlement program. These factors did not seem 10 be sufficiently allowed for in the company's agro-economic cstimales--particularly projections and computations of cost-benefit ratios with resultant deficiencies of resource allocation. in the face of he deficiencies of resource allocation. To protect itself in the face of the Afghan government's desire for only perfunctory surveys. $M-K$ had a clause in the contract which spared it legal consequences; but this clause could not protect it from public blame .... M-K could hardly escape the assumption of some responsibility. [F18, pp, 37-38]

The vaml: allocation of responsibility is also made by Duprec [D/O, pp. S(x)- $5(11) 1$.

At this point, a team from the United States Bureau of Reclamation $u$ :1s browght in to help on the second stage-preparation of lands $t)$ be irrigated. New villagers were settled and given a 20 year loan for equipment and seed by the Government. By the early 1340s (1960)s) even marginal lind, reportedly only suitable for pasture [T6, Chapter 3], had been reclitimed. None of the Government loans to settlers hils yet been repaid, an illustration of another major problem in Afghanistin, namely the fitilure on the part of the Government to collect payments from the forlunill minority which has benefited from developmental expentiture. This has heen the case with electricity, in which even enough to cover upcrating costs has not been collected, roads, telephone ficilities and almost all public enterprises whose pricing policies combined with low cipacity utilisation of plant and inefficient management has resulted in a negligible return on capital estimated roughly at $A$ fs 15 hillion [F/3. pp. $x-9 ;$ (ic. r. 2].

()ne example of the acceptance of low returns even at the feasibility stage in Alghanistan. Where capital is so scarce that as a general rule of thumb a 2) per cent return should be regarded as minimal, is the feasibility study of the Girishk and Kandahar electricity plants [B|7]. The desired returns hatied on alternative capital structures vary between 5.25 and 6.25 per cont. Projected returns from both plants were expected to rise to 4.18 and 4.95 per cent, respectively, in $1349(1970)$ and to 6.73 and 7.24 per cont in 1354 (1975) [B 17, Volume I. Table II M1.2].

Between 1341 (1962) and 1349 (1970), total public sector investment in agriculture has been estimated at Afs 22 billion. The increase in . Ilue added in llis sector by 1.349 (1970) was supposedly Afs 4-4! billuon higher thatn in 1341 (1962). The incremental capital/output ration of betueen 5 and 51 , high on any criterion, allows a maximum gruss return of 311 per cent on capital had no additicnal labour been used in whtaining the increascel output.
Complatcency ever low yiclding investment inight not have been so serious hild at reasonable proportion of totil development expenditure been spent on small, high yielding projects. But the Helmand again exemplities in one project the overall picture-overemphasis on large scale, slow maturing, capital intensive infratstructure. The Nathan Team criticised agricultural development expenditure in general during the 1340s (196() along the same lines:

[Analysis] .... does not support the claim that the pursuit of improved agricultural productivity has been a dominant goal of the government. The most eflictive means available are not heing employed. Instead in 1350 (1971-147: and in the Third Plan nearly seventy percent of the expend tures in the agriculture and related sectors went to large-scalc irrigation projects, the construction of the Mazar urea plant. and rural roads and bridges. [N2. ( hapter 2. p. 2]

Although the central thrust of the Agricultural Plan was said to be the direct support of the farmer and increase of productivity, only one-tenth of the agiciculiural development budget was earmarked for that purpose. The RCiA [Royal Government of Afghanistan] allocated Afs 221 million for agricultural development and Afs 2.1 billion for construction of dams and camals. [N3, p. 15]

The fertiliser plant in Mazar-i-Sharif, mentioned in the quotation above, was generally recognised to be obsolete exen before its completion until the dramatic rise in the world price of fertiliser in 1.3.52 (1973) gave it a positive valuc.

Part of the explanation for this contradictory emphasis between intention and husfet allucation lies in the high proportion of uncompleted projects in tot:al tevelopment expenditure. By the Fourth Plan, carry-over projects accounled for $6 x$ per cent of total planned development expenditure [M1X, Tible 14. pp. 266-67]. For this. the Government cannot be held solely responsible. The first two requests for loans from the ExportImport Banh in the early 1.330 s (19.50s) were pitrtially rejected. In particular, finance for the ancillary investments was refused $[B 10$, p. $22 ; \mathrm{F} 18$. pp. 39-41). In any calse, the underestimates of the costs of canal construction due $111 \mathrm{l}: \mathrm{s}$ : absence of engineering surveys beforehand "left insufficient funds for the irrigation and drainage systems which were to serve it" [FIS. p. 4.3] Amother part of the explanation lies in social fragmentation: it is casier hi work on projects not directly involving or affecting people. Thus, local apposition is unlikely to he encountered 10 a dam building project. There can naturally he considerable reluctance to disturbing a traditional wersus quo through land levelling. minor irrigation projects and onpliarm assiutance programmes: 
1.xpectations for action and innovation among civil servants are low, and condentned if the actions infringe on or are likely to disrupt local and indigenous semi-autonomous systems of power and influence .... Major changes in the directions of land reform or water control under government ituthority are a clear threat to the Khans [feudal superiors] and the established system of order. These, along with other similar issues, are problem areas government officials would prefer to leave alone. [B10. p. 10.3]

Where development projects occasionally encroach,

Officials can claim ignorance of the plan which is stated to be the work of the forcigner. [810, p. 104]

The lack of communication, already discussed in Chapter III as the underlying cause of fragmentation, also plagues development projects:

contunterparts have frequently and consistently resisted any sort of major public information scheme. stating that they understand their own people hetter than foreigners can and that they must use traditional methods to inform and gain local support for their actions. Their method "is delined. by U.S. technical personnel, as being low-key gradual but thorough. acceptable within our frame of reference. [B10. p. 44]

But.

1.ew literate Alghans, particularly government officials, really understand their peasant villagers or tribal nomads. [D10, p. 501]

A result al this lack of understanding has been lack of communicatiun. In 1351 (1972), a survey of farmers living in the Helmand was conducled by at sociologist with much experience in the area. He told the author:

Io the man, I found no one who wanted the project as it involies land leveling. There are numerous reasons for this position, the most basic being the lack of understanding of the usefulness of the leveling for them as firniers. There has been no systematic attempt to explain to farmers the technical advantages of the proposed system, nor have individual farmers heen told how the scheme would affect their holdings.

Neverthetess. after 25 years there are indications that change has hegun in some parts of the Helmand area. The availability of modern agricultural inputs, credit and technical advice has resulted in rapid increases in productivity. A signilicant number of farmers in the region have stirted double cropping and cish crop production. A popular cash crop his 'seen opiun poppy. Some have engaged in land levelling. But as yet, these men are few in number and the acreage affected small. However, the past three years have witnessed a beginning of a process which could well acceleratc. If this were to happen, the cffect on the general level of agricultural productivity would be substantial.

The communications problem has not been contined to that between Afghan bureillirat and Afghan farmer. It has been a serious problem in most technicial assistance programmes. In the Helmand, Americans have not in the main bothered to learn the language even if they have expected to remain in the country for a considerable period of time. However. technical advisors from all donor agencies have not generally remained long in Afghanistan. Distance has been further increased by the great gulf in living standards between advisurs and their counterparts:

The stindard of living of American technicians living in Afghanistan had to be at a relatively high level in order to altract them ... . The depressing result hals been the creation of a myth, which U.S. exhibits of fancy consumer pidclgets have not helped to correct. It has created a barrier to close contacis, a liuly artificial one. but nevertheless effective in the minds of the Alghiws who otherwise might be scriously interested in establishing or maintining contact with American institutions and ways of life. [F/8. p. 48]

Alter comparing diflerences in living standards between American and Russian advisors in $1339(1960)$, the same author continues:

The average Afghin does not note the fact that the upkeep of the Americans of ICA projects is paid out of ICA grant funds while all Soviet aid is paid for out of credit, repayable by the Afghan government (as is the cost of $M-K$ 's employees). The most sensitive ouservers are higher government officials and intellectuals who see in this great difference between cost and ways of living a cultural gap, if not an unbridgeable barrier which they expect to last as long as Afghanistan Joes not have the resources to afford the Anerican way. [F/8, p. 6.3]

Thus, once agil.. inadequate communication and information systems lie at the rout of development problems in Afghanistan.

That high yiclding alternative investment opportunities do exist in Afghanistan are suggested by direct and indirect evidence. Detailed plans for road improvement and inaintenance prepared by an advisory firm, Kampsax, estimated the lollowing returns from improving roads to the next grade: overall return to all proposed work, 33 per cent; improvement from 132 to 131 roads 41 per cont, from $C$ to $B 2$ roads 31 per cent and from 1) to ('roads 33 per cent. On a geographic breakdown, highest returns were expected in the eastern region $[K 4$, p. 6/02]. One proposed improvement was expected to yield an internal rate of return of 73 per cent [K4, Table 602 ]. For the initial selection of roads, a discount rate for future direct user benefits of 20 per cent was used. This rate was chosen because Minintry of Public Works' projects generally yielded a return of 
this maknitude and funds allocated were known to be insulficient to cover all improvements yielding more than 20 per cent.

Some of the public enterprises themseives need not be written off as inherent lailures. Indeed, in the early 1340s (1960s) the Afghan Cement (iompany declared dividends of 25 per cent [R3, p. 10]. However, a major constraint has been inefficient management whose shortcomings are compounded by the fact that performance is not a criterion on which loans from Dil Alghanistan Bank are made. These have generally been determined as a matter of Government policy with little regard to commercial ficlors. In fact, on a number of investments made by $D a$ Algh. aistan Hank. the Bank has not even obtained basic information such as the tolal capital of the enterprise.

Not all development expenditure in agriculture has produced poor results. The Project on Agricultural Credit and Related Services thruugi Cooperatives in Afghanistan (PACCA) has already been mentioned in the previous shapter. A return of 33 per cent on its investment in improving yuelds on vines has been achieved. The Paktia project which has als concentrated on direct on-farm efforts also appears to have yielded satisfictury returns $[\mathrm{B} / 2$, p. 2]. Potential social returns from cotton are evidently high and rising.

P'rivite small scale agricultural investments of extraordinarily high yiclds have heen recorded. In one set of case studies, returns from 75 to 200) per cent were found [N7: N8; N9; N10; N11]. Although returns in private industry are difficult 10 ascertain because accounts are misleitding rates in the order of 30 per cent have been estimated. Transport also appeirs 1 offer high returns if judged on the basis of the results of one case study [N7] and a recent survey of transport finance which suggests that protits are high enough to enable loan repayments firr vehicle purcliase within six to twelve months [KI, p. 9]

Scasonil price fiuctuations suggest high time preference reflected in high markit interest rates. Thus, for example, it is found in the ixt chapter that the average annual returns from foreign currency speculation between seasonal lows and highs resulting from the seasonal nature of the export trade have been 22, 27 and 24 per cent on holding Dollars, Indian and Pakislani Rupees, respectively, over the period 1332-1351 (14531972). Conımodity holding, in general, has yielded roughly similar returns.

Thus, this section concludes in agreement with a paragraph from the Natlian Team Final Report:

If a fraction of the money and effort spent over the years on large, expensive. poorly implemented, and slow-yielding irrigation and land development projects and on Government farms in the poorest and most sparsely populatid agricultural areas of the country had been devoted to assuring farmers in the best irrigated agricultural ateas a larger and growing supply of fertilier, improved seeds, pesticides, tractors; pumps, small self-help surface irrigation improvements, and technical assistance in crops and liveslock practices, Afghanistan would Ioday be self-sufficient in food grain production. [N]. p. 131]

To this list should also be added cooperative development, for sven with the PACC A demonstration projects resistance to enacting cooperative legislation and promoting cooperative activity has been strong. This project, in fact, illustrates one of the main problems of the United Nations programme in Afghanistian:

In general. UN tcanis were successiul in using pilot operations to demonstrate the economic potential of new lechnology or of improvements grafted upon old ones .... It renlained for Afghan private or public enternrise (o) exploit and enlarge the experiments. UN experts seldom stayed long enough to aid and complete that process. [F18, p. 52]

In many instances, it still remains for Afghan initiative to exploit successfully demonstralled opportunities. Agatin. this can be interpreted as yet another problem in communications and information as well as of economic fragmentation, as shown in Chapter III. It also illustrates the reluctance on $t^{1 \cdots}$ : part of Governments in the past to change existing institutions and ystems. Had Governments been keener on instigating social and conomic changes for development and less interested in obtaining liurcign aid for lirge scale projects which were not a threat to the traditionlal social order, Afghanistin could not only have become self-sufticiont in lood grain production, but also acquired fewer foreign debts and have produced much more for export to pay for those debts which would still have been incurred for justifiable foreign aid projects. Of perhaps greatest signiticance in the long run, the alternative paltern of development expenditure would not have been so regressive in effect. As it is, there is ample evidence to suggest that the limited effects of the development programme to date have made the rich richer and the poor poorer, as shown in Clatpter III.

Given the lesuns learnt and partially recorded from the past. does it lowk as thrugh this accumulated experience will be used in the design of new proficts in the future? The short answer is: No. Part of the explanation for this lies in the high turnover rate of locall als well as foreign experls. As the Deputy Chief of the United States Mission to Alghanistin wrote towards the end of 1.351 (1973) about the 1335 (1956) 
Tudor Engineering Company report [T6] to which he had been referred by the Economic Counsellor because it had predicted in detail many of the problems which had occurred since then:

A good report from all appearances. But probably hasn't been looked at in last 10 years. Good example of our lack of any institutional memory. [L3]

Another part of the explanation again lies in the high proportion of future expenditure which will go to finance carry-over projects. Finilly, a briel glance through the proposed list of development projects of the Ministry "if Agriculture and Irrigation for the Fourth Plan clearly indicates that dam building is still favoured [M|8, Table 16, pp. 269-73]. Inder new projects are listed three new dams, naturally absorbing almost all the lunds allocited to new projects [M/8, Table 16, p. 271]. In other sectors, large scale infrastructure projects also predominate. Despite only 40 per cent use of existing capacity [N3, p. 47], Afs $2 t$ billion or $7 \mathrm{f}$ per cent of total development expenditure has been allocated to investments in electricity over the period of the Fourth Plan [M18, Table 20, pp. 282-84]. This can be compared with the road building and maintenance budget for the period of only Afs 1 billion of which nearly one-half was to be spent under the Kampsax improvement and maintenance programme on which an average return of 33 per cent was forecast. The Fourth Plan also illustrates the observation made in Chapter IV that a critical constraint in the planning process lies in the absence of expertise in project preparation. Unfortunately, as several observers have suggested, economic planning has deterioritted.

\section{vii. Varianle' in Rates of Return 10 Inverstment}

A glance at proposed investment expenditure for the Fourth Plan suggests that the variance in the expected returns from the different projects livted therein must be high. Why is it that funds for ancillary investment in such things as minor road improvement and maintenance are short when there is planned investment of considerable magnitude in electricity which is likely to yield low returns? The simple answer is that rate of return was not the sole criterion used for allocating development expenditure in Afghanistan. One must suspect that this criterion has in fact been given negligible weight in the decision making process despite verbal clatims that investment is to be directed to high yielding pi ,jects. No cost-benefit analysis has ever been carried out by the Government, nor has reference to expected returns from projects listed in the plans been baised on realistic analysis. Indeed, donors themselves seem to give low weighting lo economic return when preparing and execuling new projects (e.g. [BII, pp. 5-7]). The importance of the rates of return on investment was stressed by Edward Shaw during a visit to Afghanistan in 1352 (1973). He pointed out that part of a project to promote industrialisation through a protective tariff structure wis misdirected in that it would not result in efficient resource allocation and high returns to investment. He suggestid that efficient industrialisation might be fostered through the establishnicint of a Productivity Centre, reform of the commercial law and rapid financial development.

A simplistic interpretation of the low weight attached to the expected rate of return on like donors' part might run as follows. In the early years of the post-war period, Afghanistan wats so poor and so obviously shurt of capital that it was inconceivable that any assistance would not be of greal vatue. Twenty-five years litter, the pendulum had swung to the extremc pessinustic view: Afghanistan is still so poor and has so little potential for development that ficw projects can be expected to be successful. Nevertheless, the unequal struggle must continue for humanitarian andior. litical reasons. The latter view seems to have been responsible, in part, for the relatively high proportion of grant to loin funds still available to Afghanistan from the United States Agency for International Development. Few projects with expected returns high enough to justify loan tinance have been forthcoming. Thus, the majority of project, have been grant financed on the implicit admission that returns are !ikely to be low.

It would appear that the economic lessons expensively learnt over the past quarter of a century throughout the Third World have been lost on Afghanistatr. Lack of expertise anongst donors and the Government is onc explatiation. It is surprising that the donor agencies themselves have had such stitul or non-existent economic intelligence staffs. The lack of library facilities and the lack of interest in their provision have been another impedinemt to benefiting from mistakes of other countries. This is particularly unfortunate in a country like Afghanistan which because of its position still at the early stages of the course has most other countries as examples unt in front. However, in one of the most important respects, namicly in the pursuit of policies which increase rather than reduce fragmentation. Afghanistan appeirs to have gone down the same path as so many other countries and seems likely to continue down it. The following passage is an apt description:

.... the strategy of interventionison with fixed nominal prices and rationiag on some critical markets seems to be a deliterate choice. "Market forces" 
are mistrusted on the grounds that elasticities of response to butive prices are thought to be too high or too low for desired outcomes, that mirkets are vulnerable to exploitation or that "this country is different." Although markets are mistrusted, there is faith in the captry is different." service --especially if it includes a plapit establish the coconmission- -10 identify and establish the econoniy's appropriate growth path. [S8, p. 14]

The introduction of price lists drawn up by the Government, minimum wage legislation, and the promise of exchange controls unjer the new Republicinl Regime is one more illustration of this phenomenon.

linderlying the lack of concern for the rate of return on investment is an information system so designed that it provides planners with the message that capital is not scarce, that therefore returns do not mitter. Interest charges on both foreign and domestic institutional credit are low in Aghinistan and domestic rates have remained static. This is not atypicial of capital-scarce underdeveloped countries :

Despitc this revealed scarcity and productivity of unsophisticitted rural investment, the standard nominal lending rate to protected manufacturing "ctivily, and real estate promotion (such as hotel building) is 8 or 9 percen in Fthiopia's few urban areas. Importers borrow at rates closer to 6 percent. Together with the government, these borrowers absorb virtually all of the banks' lending resources. The legal interest rate ceiling on bank loans is 12 percent, although little lending takes place at that rate; and the maximum interest rate on two-year time deposits is 7 percent a year, the average nominal interest rate on deposits being much lower than ihis. These huge interest differentials between organized banking and informal "rural" credit in Ethiopia are not unusually great relative to those in other (.1)('s [Less Developed Countries]. Inflation is moderate, and thus Ithiopian interest rates are at least significantly positive in real terms unlike the rates in many Latin American disparity between rates charged in areas- the latter containing 80 to in urban enclaves and those in rural if not uncommon. [M7, p. 71]
in percent of the population-is startling

Statute. custom, and moral law against interest rates that rise "too high" are willespread in the lagging oconomies-and elsewhere, too. [S8, p. 93]

In Afghanistan this is nowhere truer than in rates of interest charged to the public sector an its two-thirds share of domestic credit and $m$ its oflicial loans from abroad. The distortion in the price of capital has inevitably resulted not only in capital intensive development expenditure but, given cilpital's low cost, a lack of roncern over the degree of capital utilisition. $1 t$ is therefore predictable that a situation in which shift work is almost non-existent, University classrooms are used for an average of five hours a day for only nine months of the year and excess capacity exists in the malurity of larger industrial plants can be found.

: Since thic start of the First Plan in 1.3.35 (1956) the public sector has increased its share of institutional domestic credit from one-third to two-thirds of the total. This has created a credit squecze in the bazalar economy and the modern private sector. High yielding small scale investments haw 11, been undertaken becausc of lack of relatively small amounts "f credit. This situation, again far from atypical, has become increasingly urious in Afghanistan as possibilities for the Green Revolution are opened up. The poor farmer tinds it virtually impossible to finance frum his current sitvings the whole of the balanced investment needed to adopt the now technology. Access to external financial resources is likely to be mecessary over the one or (wo years when the change take piace. Without this access, the constraint of self-finance sharply takes mivestancul inalegy loward Ilatimal variations within sharply biases lechereleges: [M7, [. 1.3]

The porthtial gain from almost every agricultural innovation recommended $b$ the army of advisors in Afghanistan is qualified to the extent that the fimber adopts "recommended practices." That the Afghan farmer is copable of making changes and following rational economic incentive $1:$ bir longer disputed:

The majoi problems of Afyhan agriculture do not lie in the psyches of the indivitius farmers, but in simple practical problems of the physical environiticnt. of supplies, credit and markets. [B/0. p. 97]

And yer, the Agricultural Development Bank (AgBank), itself only established in 1348 (1970), had domestic loans outstanding at the end of 1 ist (Macti 1973) of Afs 384 nillion. Most of this tiny sum has been ken for trit:or purchatses. The median expected return on these investments.ass a whole calculated by the author from AgBank loan records lies in the rames $30-70$ per cent. With a down-pityment of 25 per cent and an $\&$ per cent interest rate charged by the Bank, the return on the farmer's own outlay is three times the return on the investment as a whole. Yet. because of the absence of an adequatc commercial law, default rates on these loans are critically high.

The criticiom of low interest rates leading to inefficient investment in the public sector is supported by Johnson:

Governments now often enjoy the privilege of paying a rate of interest of 2 or 3 per cent; this encourages them to think, and to plan, as if capital were cusily available. There seems no reison why Governments should 
enjoy low rates of interest when capital is scarce; on the contrary, it promotes wasteful investment and also, for reasons explained below, tends in the long run to promote inequality of income distribution .... It may be preferable to stimulate private saving by offering high interest rates, rather than by forcing savines into the hands of the state by taxation or inflation. One argument amingt a policy of low interest racs a saving is that it may in the long run contribute to the ins rates and forced distribution. The reason is that re contribute to the inequality of income distribution. The reason is that the poor or small savers are mainly confined to low-yielding fixed-interest investments, directly or indirectly in Govern. ment Jebt, because these are safe and easily available, whereas the larger savers can invest their money in higher-yielding stocks and shares or direct$y$ in profitable enterprises. There is, therefore, an apportes or direct(ii)vermment both to stimulate saving for development and to improve the distribution of income. [J2, pp. 160-61]

The eflects of the increase in low cost public sector burrowing in Afghanistan combined with an average annual rate of inflation of about 5 per cent since the start of the First Plan has been twofold. First, linancial savings have remained low as witnessed by the apparent abserice of anv reduction in velocity. Second, this has compounded the effects of heavy public sector borrowing and its rapid increase in total domestic cre it in creating a credit squeeze in the private sector. The resulting higher noninstitutional interest rates in the private sector increase the misallocation effects of low interest rates to the public sector.

Deposit rates are low in part because of low public sector interest rates. Uncertain real deposit rates fluctuating around zero are a deterrent to finincial sa.ing. This leads to socially wasteful hoarding. McKinnon illustrates this as follows:

If the real return on holding money is low or negative, a significant propurtion of the physical capital of the economy will be embodied in in ventories of finished and for production or consus semi-finished goods that are not used directly rice inventories as consumption. A small farmer may keep unduly large he inventories as the embodiment of his savings--a portion of which the rats eat every year. Alternatively, a wealthy member of some urban enclave may build an unusually elatorate house, which he hopes will also maintain its value under inflation. A businessman might deliberately "overinvest" in plant capacity or in certait stocks of raw materials, "overto his current operating needs. [M7, p. 63]

The few examples of returns to small scale investments in the privite sector have served to illustrate the effects of the absorption of" a slowly expanding supply of domestic credit by the public sector and highlight the great variance of returns to investment in Afghanistan. McKinnon suggests. in lact, that development can be viewed as a process of reducing this variance and by so doing raising the average return to capital:

The accumulation of ciapital per se means little in the underdeveloped economy, where rates of return on some physical and financial assets are negative while extremely remunerative investment opportunities are forgone. ( nne farmer may save by hourding rice inventories, part of which is eaten by mice so that the return on his saving is negative. Another may foresee an annual return of over 60 percent in drilling a new tube well for irrigation, hut the local moneylender wants 100 percent interest on any loan he provides. The operator of a small domestic machine shop may find it impissibl. (1) get bank credit to finiuce his inventories of finished goods and petitive machinc. parts whereas an sidized rate of o percentias easy access 10 foreign trade credit at a subsidized rate of " percent.

In the lace of great discrepancies in raltes of return, it is a serious mistake to corsider development as simply the accumulation of homogeneous capilal of uniform productivity. This simplistic view has been held explicitly by economic growth theorists and econometricians who incorporate nomogeneous capital of uniform productivity into production functions. It is heli inplicitly by policy-makers in less developed countries (LCDs), who all two often have followed a strategy of maximizing short-run gross investunc: ${ }^{i}$ in virtually uny form. It has been abetted by official international "agencies that calculate the "need" for forcign aid on the assumption that cutput-capital ratios in recipient countries are fixed.

It seems importun' to develop a distinct alternative view of the role of capital. To focus the analysis still more narrowly, let us define "economic developmicit" as the reduction of the great dispersion in social rates of return "' existing and new investments under domestic entrepreneurial control. "i he capital maiket in a "developef" economy successfully moniturs the efficiency with which the existing capital stock is deployed hy pushitigz returns on physical and financial assets toward equality, thereby signiticatily increasing the average return. Economic develop, thereby defined is necessary and sufficient to generate high rates of saving and investment (accurately reflecting social and private time preference), the adoptioni of best-practice technologies, and learning-by-doing. [M],
pp. 8-4]

This prosess has not yet begun in Aighanistan.

viii. Com: $(u$ ian

Domestic bullece mobilisation through lle fiscal system has exhibited as poor a recurd as mobilisation through the financial sector. The former has exacerbilled the latter situation beciatse deficit finance has been inflationary. Not only has this adversely alliected the budgetary position but has aloo repressed financial development. Inflation has weakened the budgetary prosition as a result of lower revenue than expenditure price 
-liwlicity. It has repressed financial development by making llic real relurn on the liabilities of the financial institutions negative. This in turn his depressed the demand for money. A further undesirable elfect of excessive deficit linance on the financial system has heen the rapid increase in the proportion of domestic credit allocated to the public seclor. This has caused a serious credit squeeze in the private sector.

The fiscal systen barely able to meet ordinary expenditure has heen inadequate as the vehicle for underwriting development programmes. Inadequacies spring from a tax struclure which has placed far too much relaallec un foreign trade taxes, has failed to crente an internal tix basc and has been inefliciently administered. Despite considerithle technical assistance 10 remedy the latter problem and much advice on the subject of tax reform, particularly in relation to the land tax, changes have heen minimal. Again, a parallel between the fiscal system and the linincial eclor can he drawn. Actions necessary to mobilise domestic resulurces through bolh channels have generally been understond but halce not been implemented.

Donesic resource mobilisation has not held grealt attractions becalue henefits irom development expenditure have been small. roo little emplasis has been attached to the expected rate of return criterion, too much on completing nrojects at any cost. Where feasibility sludies conducted by the donor agencies have indicated high rates of return. these were in the main based on over-optimistic assumptions. Incertainty in mally areas is so high in Afghanistan that such studics cinnot be expecled I" provide clear guidelines to decision makers. It is also evident. however, that projects have generally not been well conceived and outcomes liar less satisfactory than could have been achieved even given many of the urkenducive attributes of the environment.

The conclusion is reached that reform, if it is to take place. must be directed simultaneously along two fronts. Both revenue and expenditure need to be encompassed in such a programme. The formor should concentralle on raising revenue from sources other than the lincign Irade seclor, the latter on improving the planning process, in gencral, and project preparation and impiementation, in particular. Without increasing the effectiveness of development expenditure, its expansion cannot be justilied. Without tax reform the finance for vital ancillary invesiment will not he available and an over-reliance on foreign aid and delicit finallce will again occur. Neither source is a satisfactory substitule for increased lax revenue from greater tax effirt.

The nuterial provided in this chapter amply attests to the proposition put forwath in (hapter IV that the mude of development linance in Af ghanistan will heilvy reliance on foreign aid suggests the existence of two of the Adelman-M forris critical constraints. Buth the weak tax effort and the nature of the development programme have indicated a lack of commit. ment on the pirt of leadership to economic development and the absence of general support for development efforts. Both have seriously limited Afghanistan's capacity for development. 
CHAPTER SEVEN

\section{THE FOREIGN TRADE SECTOR}

\section{i. Introdirction}

The removal of the critical constraints to economic development discussed in the previous chapters will raise Afghanistan's development polential The realisation of this greater potential must be achieved in lare part through the rapid expansion of exports. Therefore, this chapter dexriber the foreign trade and exchange systems that have existed io date and an:aly ses the determinants of exchange rate movements.

The importance of foreign trade not only over the past forly years but also as the sole viable path to economic growth in the future has been recognixal for some time:

trade provided the earliest access road to the riches of the world without which no Afghan King or private investor could hope to increase the country's productive capacity. Because Irade has been the trafitional and most natural way of adding to the meager resources, it has assuined increasing importance as development efforts have become nore intensive. Henelits from trade preceded any direct forms of international assistance frum advanced countries. [F 18, p. 16]

Only by intensive efforts to increase the production of exportabie law nuaterials and by solving the problems related to marketing agricultural products can it high rate of growth in econed to marketing agricultural moducts can a high rate of growth in economic development of the couniry be maintained. [PI0, p. 5]

I xchange control measures introduced immediately after the eslablishment of the Republic, presumably desig.led to prevent capitill tlight, threw the fircign trade sector into confusion. Although it is still not clear what the position is at the time of writing. mid-1352 (December 197.3), exchange coutrols have been relaxed and traders seem more optimistic that they were sonic months ago. Their previous concern and uncertainty resulted in postponement of import orders in the hope that the situation would hecome clearer. The effect of this was an appreciation of the Afghani which in IIIrn deterred exporters. What is referred to below as the present position is generally that which existed prior to the coup. A gradual return to that situation in the loosening of the exchange controls imposed informally immediately after the coup seems to have been occurring. The possibility of drastic changes in the foreign exchange and trade system in the future cannot, however, be discounted.
Tahis 7.1

Afyhanistan's Foreign Trath' 1309-1351 (Millions of Dollars)

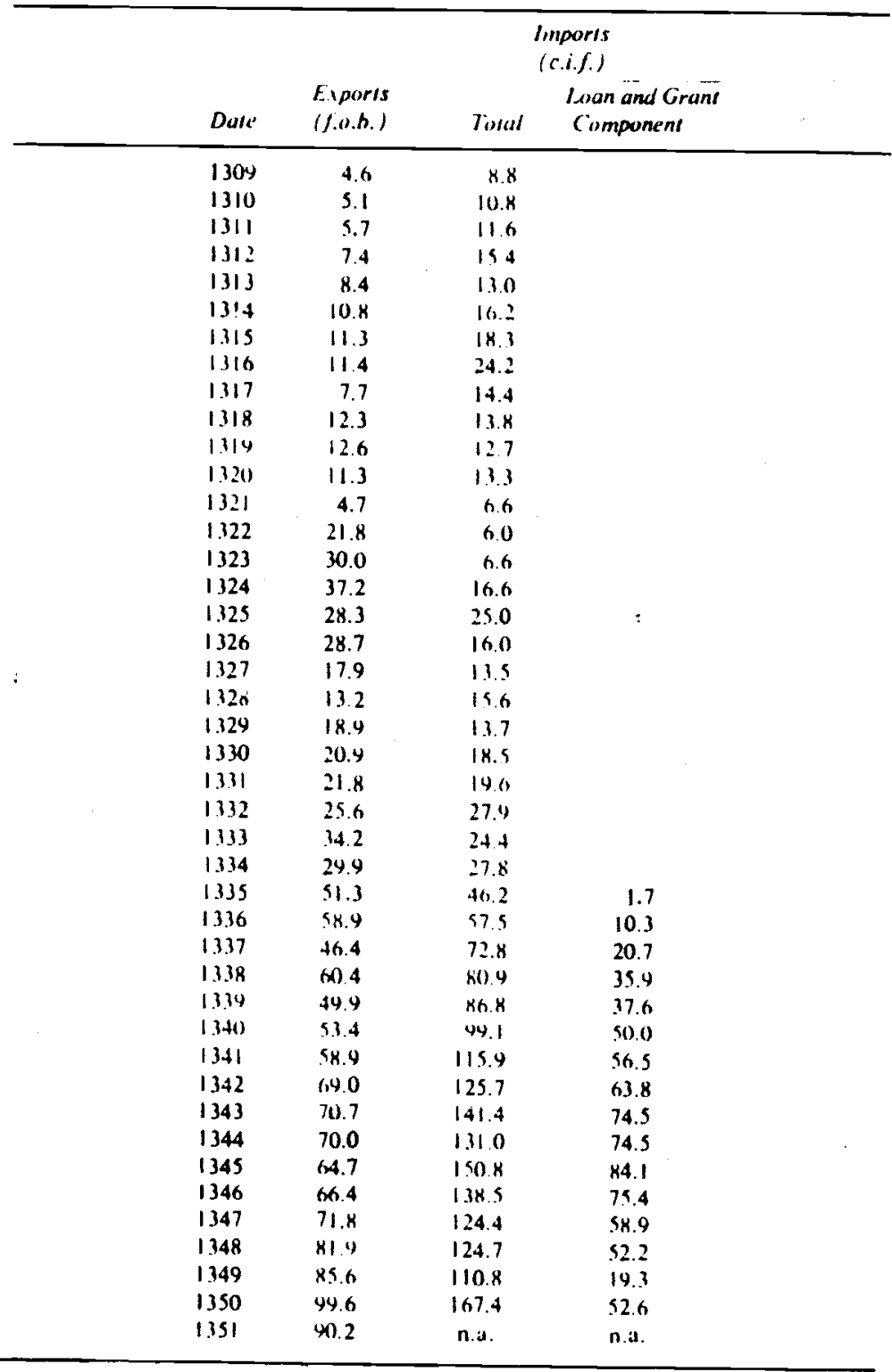



Sulurce: $13(109-1334$ from Da Afghanistan Bank Economic Bullerin. (in Dari). 9 (1).
Aligust 1961 . Table 18 .

1134.1 .142 from Ministry of Commerce, A/ghanistan's Fureign Trade 1.115 throuk I.14? (Kahul: Ministry of (ommerce, 1343). Table 1, p. I.

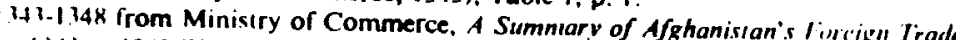
from 1.141 1" 1.148 (Kahul: Ministry of Commerce. Qaus 1350).

1349-1 190 from Ministry of Commerce. Exports of Merchandise from $4 / \mathrm{k} / \mathrm{hm}$ istan. $1.34 \mathrm{mml} / 1.56$ (Kabul: Ministry of Commerce, 1352), Table I and Ministry of Com necre, Imports of Merchandise into Afghanistan, 1349 and 1350 (Kabul: Ministry of Commerce. 1352), Table

1391 from International Financial Statistics, 26 (10), October 1973, p. 41)

\section{i. Forricul Trade}

\section{A ()uantitative View of Foreign Trade Developments}

Nighantian's foreign trade sector has never been large. llowever, will a Hoilting exchange rate and no quota system, foreign irade has gencrilly grown at a faster rate than Ciross National Product (GNP) under what has been essentially a liberal foreign trade policy. Although the aflicial statistics seriously understate the volume of trade, these arc presented in Table 7.1. Table 7.2 provides a rough GNP series fir compatrative purposes. From this it can be seen that recorded exports have never excecded 10 per cent of GNP, a relatively low percentage for: small coumlry.

The peith in imports ats a percentage of GNP in the lirst half of the 1.340s $(1 \varphi(n) s)$ rellects the heyday of competitive foreign aid donations. The Irough in exports as a percentage of GNP in 1.345 (1966) coincides with the highest export taxes over the period an karakul which in turn was a result of ripid depreciation over the preceding two years, thus widening the galp between the fixed surrender rilte and the free market exchange ratc. The depreciating free market exchange rate was caused by domestic inllation. Two studies on the determinants of karakul exports indicate a strong negative relationship between the value of exports and the effective tax rate $[(i x: K 7]$

Tables 7.3 and 7.4 provide a somewhat more disaggregaled picture of the direction of Afghanistan's foreign trade and composition of exports for the perind 1331 ta.1350 (1952-1971).

Fluctuations in the proportion of exports to "other countries" is closely correlated w karakul exports which go solely to convertible currency countries. Afghanistan auctions its karakul on the l.ondon matket where the main buyers have been from Germany. The irends in lotal expurts have shown a slight increase to the harter countries. reflecturg increises in citton, nittural gas and wool exports to the (I.S.S.R. fucturtiom in trade with India and Pakistan, an effect of politicil
Tah/e 7.2

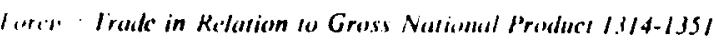
(Millions of Afghions)

\begin{tabular}{|c|c|c|c|c|c|}
\hline$b_{t \prime \prime \prime}$ & $\begin{array}{c}\text { Griss National } \\
\text { Pruedurt } \\
\text { ( }(\text { iNP })\end{array}$ & $\begin{array}{l}\text { Exports } \\
\text { (f.o.h.) }\end{array}$ & 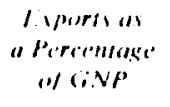 & $\begin{array}{l}\text { Impors } \\
\text { (riff) }\end{array}$ & $\begin{array}{l}\text { Impurts as } \\
\text { " Percentuge } \\
\text { of GNP }\end{array}$ \\
\hline 1314 & 2.44 .3 & 108 & 4.3 & 162 & 0.5 \\
\hline 1115 & $2.55 x$ & 110 & +3 & $17 k$ & 7.0 \\
\hline $111 \mathrm{~h}$ & 2.740 & 111 & 4.1 & 235 & $x .6$ \\
\hline 1117 & $2 .(x) 4$ & 87 & 10 & 162 & 5.6 \\
\hline 1318 & $30 \times 4$ & $14 k$ & $+x$ & 166 & 54 \\
\hline 1314 & 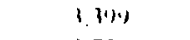 & 16.5 & +11 & Ithe & 4.4 \\
\hline 1.120 & 1720 & $14 x$ & +11 & 174 & 4.7 \\
\hline 1321 & $\ln \sin 3$ & hl & 1.3 & $x_{6}$ & 1.8 \\
\hline 1322 & $13,113 k$ & $2 \times 5$ & 4.7 & $7 x$ & 1.3 \\
\hline 1321 & $l, 1,54$ & 341 & 5.1 & K6 & 11 \\
\hline $13 \geq 1$ & 1.5190 & $4 \times 6$ & 5.1 & 216 & 2.3 \\
\hline 1135 & 12,135 & 188 & 3.2 & .142 & 2.8 \\
\hline 1326 & 13.412 & 4194 & 3.7 & 275 & 2.0 \\
\hline 1227 & $13,14,1$ & $4 \times 2$ & 3.5 & 3104 & 2.6 \\
\hline 1328 & $16 .(3.141$ & 416 & 2.7 & 415 & 3.2 \\
\hline 1324 & 17,3166 & 739 & 4.3 & 5.3 & 3.1 \\
\hline 1.130 & $|x, 0| 5$ & 731 & 4.1 & $\operatorname{tr} 46$ & 3.6 \\
\hline 1.331 & $\{1, .05\}$ & $K\left(2, b_{1}\right.$ & +2 & 727 & 3.8 \\
\hline 1.332 & $19.4+41$ & ")ร1) & 11 & 1,036 & 5.3 \\
\hline $1,3,33$ & $21.77 \%$ & 1.440 & 0.6 & 1,027 & 4.7 \\
\hline 13.34 & 24.441 & 1,352 & 55 & 1.255 & 5.1 \\
\hline 13135 & 11.120 & 2.775 & $\times 4$ & 2.501 & $\times .0$ \\
\hline 1.336 & 44.2612 & 3.156 & 19.2 & $3,0 \times 2$ & $\begin{array}{l}9.0 \\
0\end{array}$ \\
\hline 1337 & $3.4 \times 56$ & $2.4 \times 6$ & 7.1 & $3.69 k$ & 11.2 \\
\hline 338 & $(10.4(1) 4)$ & 2.732 & $x \times$ & $3,6,50$ & 11.8 \\
\hline 1334 & $\because 211$ & 1.1950 & 0.7 & 3.392 & 11.6 \\
\hline 1,340 & 11.120 & 2.223 & 7.1 & 4.124 & 13.3 \\
\hline 1341 & 37.151 & $2.96 k$ & X.1) & 5.841 & 15.7 \\
\hline 1342 & 111.121 & 3.459 & K.6 & 6,303 & 19.7 \\
\hline 134.3 & $90.7 \times 4$ & 4.152 & K.2 & $x . ?(1) 4$ & 16.3 \\
\hline 344 & 62.652 & 5,025 & 80 & 9.407 & 15.0 \\
\hline 345 & $6, K, X 14$ & 4.8 .35 & 7.0 & 11,271 & 164 \\
\hline 346 & 611.877 & $5.01 x$ & 7.2 & 10,454 & 15.0 \\
\hline 1.47 & 64.151 & $5.14 k$ & 7.7 & 9.267 & 13.4 \\
\hline $34 k$ & $72 . .301$ & $6,180)$ & $\times .5$ & 4.410 & 13.0 \\
\hline 1349 & $x-1,3,3.3$ & 7.160 & K.S & 9.271 & 11.0 \\
\hline 350 & 11,146 & $x .427$ & 9.2 & 14.155 & 15.5 \\
\hline 351 & 91.554 & 7,162 & 7.7 & n.a. & n.al. \\
\hline
\end{tabular}

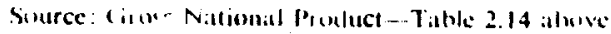

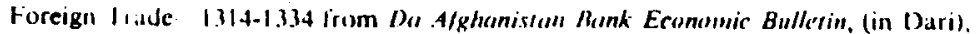
5(1). Aupun 1961. Table 16 : $1335-1,342$ from Ministry of Commerce, Afghanistan's

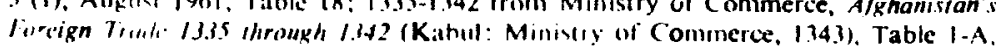

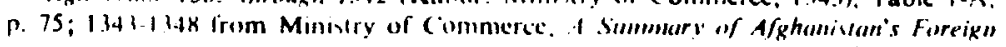


Trueld from 1.143 10 1.34X (Kabul: Miniatry of Commerce, Qaus 1350): 1.144-1.350 fron Ministry of Commerce, Exports of Merchandise from Afghanistan, 1.144 and 1.350 (Kabul: Ministry of Commerce, 1352), Table I and Minisiry of Commerce. InIpiris of Merchandise into Afzhanissan, 1349 and 1350 (Kabul: Ministry of Commerce. 1352), Table 1: 1351 from International Financial Siatistics, 26 (10), October 1973. p. 40.

Table 7.3

Direcrion of Trade, 1331-1350

(Percentages)

\begin{tabular}{|c|c|c|c|c|c|c|}
\hline \multirow[b]{2}{*}{ Dotu } & \multicolumn{3}{|c|}{ EXPORTS } & \multicolumn{3}{|c|}{$\begin{array}{c}\text { IMPORTS } \\
\text { (Exc/udlink Loan umd Giruml I .purts) }\end{array}$} \\
\hline & $\begin{array}{l}\text { Barter } \\
\text { Countries } \\
\end{array}$ & $\begin{array}{l}\text { India and } \\
\text { Pakislan }\end{array}$ & $\begin{array}{c}\text { Other } \\
\text { Couniries }\end{array}$ & $\begin{array}{c}\text { Barter } \\
\text { Countries }\end{array}$ & $\begin{array}{l}\text { India und } \\
\text { Pakistun }\end{array}$ & $\begin{array}{l}\text { Other } \\
\text { Comusries }\end{array}$ \\
\hline 1331 & 3.9 & 26.3 & 41.8 & n.a. & n.a. & n.at. \\
\hline 1332 & 12.6 & 39.1 & $48 . .3$ & n.a. & n.a. & n.a. \\
\hline 1333 & 18.8 & 36.7 & 44.5 & 25.2 & 41.4 & 3.4 \\
\hline 1.334 & 13.7 & 40.6 & 45.5 & 29.2 & 42.2 & $2 \times .6$ \\
\hline 13115 & 34.9 & 24.4 & 40.7 & 36.6 & 35.2 & 28.2 \\
\hline 1.36 & 39.8 & 24.2 & 40.0 & 30.6 & 25.8 & 4.1 .6 \\
\hline 1337 & 28.8 & 29.4 & 41.3 & 32.5 & 20.4 & 47.1 \\
\hline 1338 & 30.0 & 24.3 & 45.7 & 37.9 & 23.1 & 19.0 \\
\hline 1334 & 28.0 & 23.3 & 48.7 & 33.9 & 24.0 & 42.1 \\
\hline 1340 & 36.1 & 12.3 & 51.6 & 42.6 & 20.6 & 36.8 \\
\hline 1.341 & 44.5 & 13.5 & 42.0 & 45.8 & 15.1 & 39.1 \\
\hline 1342 & 40.8 & $18 . x$ & 40.4 & 35.3 & 19.9 & 44.8 \\
\hline 1343 & 37.9 & 25.0 & 37.1 & 35.1 & 19.4 & 45.5 \\
\hline 1144 & 27.5 & 20.4 & 51.7 & 42.0 & 15.9 & 42.1 \\
\hline 1349 & 38.3 & 21.4 & 40.3 & 42.0 & 17.0 & 410 \\
\hline $1.34 h$ & 37.4 & 24.6 & 38.0 & 34.7 & 15.2 & 50.1 \\
\hline 1.347 & 39.3 & 29.9 & 30.4 & 26.3 & 21.8 & 51.9 \\
\hline $1.34 x$ & 40.2 & 26.1 & 33.7 & 21.7 & 20.5 & 57.8 \\
\hline 1.34 & 410 & 23.0 & 36.0 & 31.4 & 17.7 & 50.4 \\
\hline 1150 & 41.1 & 10.0 & 48.9 & 23.2 & 13.0 & 63.6 \\
\hline
\end{tabular}

Simurce: 1331-1334 from P. G. Franck. The Ecunomics of Conpcitive Cuexiveruc: Afrhunistrm Bitureen Easi curl West Washington iation. $\mid y(x)\}$. Tables II-4 and II-6, pp. 19-20.

1.335 .1350 Sillue as Tables 7.1 and 7.2

disputes with Pakistan, but a slight increase over the period, resulting from increatsed exports of dried and fresh fruits and nuts.

On the import side, there has been a significant increase in the proportion of commercial imports from "other countries," created by a large increase in manufactured imports from them, particularly from Japan, and a decrease in textile imports from the other two groups of countries. Additionally. sugar and tea imports have not risen as rapidly as total imports. In general, the barter countries. India and Pakistan have lost

Tuble $7+4$

Cumpersition of Liyorts, 1.131-1350

(Percenlages)

\begin{tabular}{|c|c|c|c|c|c|}
\hline Date & Corton & Narakul & Wool & $\begin{array}{c}\text { Nurural } \\
\text { Gas }\end{array}$ & Orher \\
\hline 13,11 & 29.0 & 15.9 & 18.0 & 0 & 37.1 \\
\hline 1,332 & 17.8 & 17.5 & 15.7 & 0 & 49.0 \\
\hline 1.33$\}$ & 17.2 & 21.4 & 13.0 & 0 & 48.4 \\
\hline 1.334 & 10.4 & 21.6 & 10.9 & 0 & 57.1 \\
\hline 13199 & 17.1 & 27.6 & 14.3 & 0 & 41.0 \\
\hline $111 \%$ & 21.5 & 26.1 & 12.6 & 0 & 39.8 \\
\hline 1.317 & 12.4 & 26.8 & 15.2 & 0 & 45.6 \\
\hline $133 x$ & 12.7 & 28.8 & 16.1 & 0 & 42.4 \\
\hline 18.14 & 9.7 & 27.8 & 14.1 & 0 & 48.4 \\
\hline 13.40 & 19.6 & 28.6 & 11.4 & 0 & 44.4 \\
\hline 1.141 & 14.3 & 20.3 & 12.4 & 0 & 52.5 \\
\hline 1342 & 18.3 & 24.4 & 10.7 & 0 & 46.6 \\
\hline 1343 & 21.1 & 17.6 & 8.7 & 0 & 52.6 \\
\hline 1.344 & 15.4 & 23.0 & 2.8 & 0 & 58.3 \\
\hline 1145 & 18.4 & 18.1 & 7.7 & 0 & 55.8 \\
\hline 1346 & 11.8 & 21.2 & 7.1 & 4.4 & 55.3 \\
\hline 1347 & 8.2 & 11.6 & 4.7 & 12.6 & 57.9 \\
\hline 1348 & 6.8 & 15.9 & 8.2 & 14.8: & 54.3 \\
\hline 1349 & 9.9 & 11.8 & X.X & 16.9 & 52.6 \\
\hline 1.350 & 12.5 & 17.3 & $\times .0$ & 14.6 & 47.6 \\
\hline
\end{tabular}

Source: Sitlle as Tables $7.1,7.2$ and 7.3

ground beciuse their exports (apart from petrol from Russia) have tended fo he lluse with low income clasticities, whereas manufactured goods from the West have high income elasticities of demand.

Two allempts have been made to decompose imports into capital

$$
\text { Tisble } 7.5
$$

Compessition of linports, 1.147.1348 (Percentatges)

\begin{tabular}{|c|c|c|c|c|}
\hline & \multicolumn{2}{|c|}{1.147} & \multicolumn{2}{|c|}{1348} \\
\hline & $\begin{array}{c}\text { All } \\
\text { Imports }\end{array}$ & $\begin{array}{l}\text { Commorcial } \\
\text { limports only. }\end{array}$ & $\begin{array}{c}\text { All } \\
\text { lomports }\end{array}$ & $\begin{array}{l}\text { Commercial } \\
\text { lomports onl! }\end{array}$ \\
\hline Consumer cionits & 144 & 01.9 & 55.7 & 77.4 \\
\hline Iritermediate cinesds & 27.3 & 22.7 & 20.6 & 15.6 \\
\hline Capital Gouds & 18.4 & 15.4 & 23.7 & 7.0 \\
\hline
\end{tabular}

Soutce: 1347 From United Nations. Staristical Yrarthesk for Asiu and the Far Eost 1970 (Bangkoh: United Nations, 1971), p. 15

$134 \mathrm{~K}$ prenartid by R. Manly for this study from Ministry of Comnerce, Imports of Merchandise litw (Kabul: Ministry of Commerce, 134), 
gouds, rall materials and consumer goods. Unfortunatcly, these are frustrated by the fact that no details on the composition of loan and grant imports arc available. On the assumption, however, that two-thiids of these unspecified imports are capital goods and one-third consists of rat materials the estimates in Table 7.5 have been derived. It should be stressed that the estimates are not comparable since arbitrary definitions were used

Table 7.6

I:xmrt Distribution of Ten Selected Cimmodities, 1345-1348 (Thousands of Dollars)

\begin{tabular}{|c|c|c|c|c|c|c|c|c|c|}
\hline 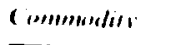 & & 134 & & 1.14 & 146 & 134 & & 1.14 .4 & \\
\hline $\begin{array}{l}\text { Dricd Iruil } \\
\text { and Nul, }\end{array}$ & $\begin{array}{l}M \\
\mathbf{H} \\
\mathbf{C}\end{array}$ & $\begin{array}{l}1.746 \\
7.869 \\
5.597\end{array}$ & $\begin{array}{l}10 ; \\
(12) \\
(51) \\
(37)\end{array}$ & $\begin{array}{l}2,709 \\
7,422 \\
7,378\end{array}$ & $\begin{array}{ll} & " 1 " \\
y & (15) \\
2 & (44) \\
& (41)\end{array}$ & $\begin{array}{r}4,336 \\
3,707 \\
10,917\end{array}$ & $\begin{array}{l}11 \\
(23) \\
(20) \\
(57)\end{array}$ & $\begin{array}{r}1, \% 1,7 \\
6.742 \\
10.6147\end{array}$ & $\begin{array}{l}" 11 \\
1101 \\
131 \\
1551\end{array}$ \\
\hline $\begin{array}{l}\text { Katrithul } \\
\text { Shiul }\end{array}$ & $\begin{array}{l}M \\
B \\
C\end{array}$ & $\begin{array}{c}11.713 \\
\ldots \\
\ldots\end{array}$ & $3(100)$ & $14.05 x$ & $x(100)$ & $\begin{array}{r}8.123 \\
4\end{array}$ & $\begin{array}{r}(100) \\
(1)\end{array}$ & 13, & $(I(x))$ \\
\hline $\begin{array}{c}\text { Nutulual } \\
\text { (i.1) }\end{array}$ & $\begin{array}{l}M \\
H \\
C\end{array}$ & - & & 2.428 & $(f(x))$ & $4,0,34$ & $(100)$ & 12,14211 & $(I(k))$ \\
\hline $\begin{array}{l}\text { Frenh } \\
\text { linil }\end{array}$ & $\begin{array}{l}M \\
B \\
C\end{array}$ & $\begin{array}{c}- \\
16 \\
0.537\end{array}$ & $(100)$ & $\begin{array}{r}52 \\
8,097\end{array}$ & $\begin{array}{r}2 \quad(1) \\
(49)\end{array}$ & $\begin{array}{r}26 \\
153 \\
7, \times 14\end{array}$ & $\begin{array}{r}(-) \\
(2) \\
(98)\end{array}$ & $\begin{array}{r}7 \\
220 \\
\times, 704\end{array}$ & $\begin{array}{l}(1) \\
(2) \\
(4 \times)\end{array}$ \\
\hline Woul & $\begin{array}{l}M \\
B \\
C\end{array}$ & $\begin{array}{r}346 \\
4.630 \\
1\end{array}$ & $\begin{array}{r}(7) \\
(93) \\
11\end{array}$ & $\begin{array}{r}573 \\
4.243 \\
42\end{array}$ & $\begin{array}{r}(12) \\
(87) \\
(1)\end{array}$ & $\begin{array}{r}580 \\
6,408 \\
1\end{array}$ & $\begin{array}{r}(8) \\
(92) \\
(-)\end{array}$ & $\begin{array}{r}507 \\
0.215 \\
\end{array}$ & $\begin{array}{l}\text { (8) } \\
\text { (1)2) }\end{array}$ \\
\hline $\begin{array}{l}\text { arpusuiml } \\
\text { Ruys }\end{array}$ & $\begin{array}{l}M \\
B \\
C\end{array}$ & $\begin{array}{c}7,996 \\
\cdots \\
\cdots\end{array}$ & $(1(0))$ & $\begin{array}{r}5,173 \\
1\end{array}$ & $\begin{array}{r}(100) \\
11\end{array}$ & 4,522 & $(100)$ & $0.23 \times 1$ & $(f(x))$ \\
\hline conton & $\begin{array}{l}\mathrm{M} \\
\mathrm{B} \\
\mathrm{C}\end{array}$ & $\begin{array}{r}990 \\
10.410\end{array}$ & $\begin{array}{l}(x) \\
(y 2)\end{array}$ & $\begin{array}{r}7.857 \\
3\end{array}$ & $\begin{array}{r}(10(0)) \\
(1)\end{array}$ & $5,8 \times 21$ & $(100)$ & $\begin{array}{r}1844 \\
4,023\end{array}$ & $\begin{array}{l}(1 x) \\
(x 2)\end{array}$ \\
\hline siced & $\begin{array}{l}M \\
B \\
C\end{array}$ & $\begin{array}{r}20 \\
+110 \\
10.3\end{array}$ & $\begin{array}{l}(2) \\
(39) \\
(54)\end{array}$ & $\begin{array}{r}68 \\
505 \\
326\end{array}$ & $\begin{array}{r}(x) \\
(56) \\
(36)\end{array}$ & $\begin{array}{r}344 \\
1.66 .3 \\
7.38\end{array}$ & $\begin{array}{l}(14) \\
(60) \\
(26)\end{array}$ & $\begin{array}{r}\times 12 \\
1.570 \\
174\end{array}$ & $\begin{array}{l}(32) \\
(61) \\
(7)\end{array}$ \\
\hline $\begin{array}{l}\text { ider and } \\
\text { Shins }\end{array}$ & $\begin{array}{l}\mathrm{M} \\
\mathrm{B} \\
\mathrm{C}\end{array}$ & $\begin{array}{r}1.457 \\
908 \\
-13 \\
-\quad\end{array}$ & $\begin{array}{r}(61) \\
(38) \\
(1)\end{array}$ & $\begin{array}{r}1,198 \\
1,179 \\
5\end{array}$ & $\begin{array}{r}(50) \\
(50) \\
(-1\end{array}$ & $\begin{array}{r}1,001 \\
1,206 \\
61\end{array}$ & $\begin{array}{r}(44) \\
(53) \\
(3)\end{array}$ & $\begin{array}{l}1.6(x) \\
1.316\end{array}$ & $\begin{array}{l}(55) \\
(45)\end{array}$ \\
\hline WIInks & $\begin{array}{l}M \\
13 \\
C\end{array}$ & $\begin{array}{c}1.412 \\
40 \\
-\end{array}$ & $\begin{array}{l}\text { (47) } \\
\text { (3) }\end{array}$ & $\begin{array}{r}1.232 \\
48 \\
-\end{array}$ & $\begin{array}{l}(9(1) \\
(4)\end{array}$ & $\begin{array}{r}1.0125 \\
82 \\
\ldots\end{array}$ & $\begin{array}{l}(9.3) \\
(7)\end{array}$ & $\begin{array}{r}932 \\
46\end{array}$ & $\begin{array}{l}(95) \\
15)^{\prime}\end{array}$ \\
\hline
\end{tabular}

Nole: $M$ Multilateral: B-Barter; $C$-India and Pakistan. 1341 " lit, 1 kathul: Ministry of Commerce, Qaus 1350 .

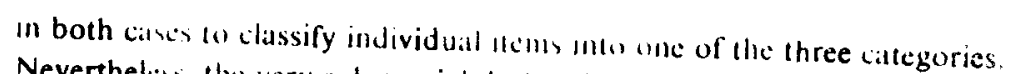
Nevertheles, the very substantial dectule in foreign aid financed imports between 1347 and $1348(1968$ and $19(99)$ does support the direction of change in the composition of imports over these years indicating : tion a clatal goods and raw nuterial imports. Classification inconsistencies, however, probably account for a sizable part of the

$$
\text { Tabse } 7.7
$$

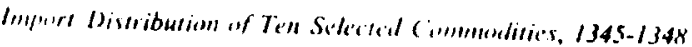
$1]$ housands of Dollows

\begin{tabular}{|c|c|c|c|c|c|c|c|c|c|}
\hline Cimnorits. & & 1.4 & & 114 & & $|34\rangle$ & & 1348 & \\
\hline Wha:d & $\begin{array}{l}M \\
\text { II } \\
\text { ( }\end{array}$ & $\begin{array}{c}1.3 .124 \\
\ldots\end{array}$ & $" 1100)$ & $\begin{array}{l}8,652 \\
5.490\end{array}$ & $\begin{array}{l}n " \\
(12) \\
(i x)\end{array}$ & 3,400 & $\begin{array}{l}\dddot{0} \\
(1) \\
(f(x))\end{array}$ & $\begin{array}{c}0,7101 \\
- \\
-\end{array}$ & $\begin{array}{c}\% \\
(100)\end{array}$ \\
\hline Sugar & $\begin{array}{l}M \\
11 \\
6\end{array}$ & $\begin{array}{r}4 \\
x, 81 \% \\
26\end{array}$ & $\begin{array}{r}(1) \\
(1(x)) \\
11\end{array}$ & S.11\% & $\begin{array}{r}1 \\
1 /(x)) \\
11\end{array}$ & $\begin{array}{r}16 \\
924 \\
-\end{array}$ & $\begin{array}{l}(2) \\
(1) x)\end{array}$ & $\begin{array}{r}23 \\
3 . \times 34 \\
-\end{array}$ & $\begin{array}{l}\text { (1) } \\
(y 4)\end{array}$ \\
\hline$T(a)$ & $\begin{array}{l}M \\
\text { II } \\
1\end{array}$ & $\begin{array}{r}128 \\
2.155 \\
1.744\end{array}$ & $\begin{array}{l}(2) \\
(15) \\
(n) 1)\end{array}$ & $\begin{array}{r}51 \\
115 \\
3,864\end{array}$ & $\begin{array}{l}(1) \\
(11) \\
(x 1)\end{array}$ & $\begin{array}{r}24 \\
\times 69 \\
\times .565\end{array}$ & $\begin{array}{l}(1) \\
(y) \\
(y 1)\end{array}$ & $\begin{array}{r}210 \\
1,04.5 \\
x, 091\end{array}$ & $\begin{array}{l}\text { (2) } \\
\text { (11) } \\
\text { (87) }\end{array}$ \\
\hline $\begin{array}{l}\text { Petrolicum } \\
\text { Pioducts }\end{array}$ & $\begin{array}{l}\mathrm{N} \\
11 \\
1\end{array}$ & $\begin{array}{r}682 \\
4,77.1 \\
85\end{array}$ & $\begin{array}{l}(12) \\
(x 6) \\
(2)\end{array}$ & $\begin{array}{r}554 \\
4,654 \\
140\end{array}$ & $\begin{array}{l}(10) \\
\mid 87) \\
111\end{array}$ & $\begin{array}{r}1,290 \\
4,773 \\
344\end{array}$ & $\begin{array}{l}(20) \\
(75) \\
(5)\end{array}$ & $\begin{array}{r}969 \\
6.113 \\
3 \times 7\end{array}$ & $\begin{array}{r}(13) \\
(82) \\
(5)\end{array}$ \\
\hline $\begin{array}{l}\text { Pharma- } \\
\text { ceutical } \\
\text { Products }\end{array}$ & $\begin{array}{l}M \\
B \\
1\end{array}$ & $\begin{array}{r}2,258 \\
26 \\
2\end{array}$ & $\begin{array}{l}(49) \\
(1) \\
(-1)\end{array}$ & $\begin{array}{r}2,504 \\
316 \\
1\end{array}$ & $\begin{array}{l}(30) \\
111 \\
11\end{array}$ & $\begin{array}{r}2,462 \\
37 \\
2\end{array}$ & $\begin{array}{l}(98) \\
(2) \\
11\end{array}$ & $\begin{array}{r}3,+23 \\
33 \\
1\end{array}$ & $\begin{array}{l}(y 4) \\
(1) \\
(1)\end{array}$ \\
\hline $\begin{array}{l}\text { Rubber Tyres } \\
\text { and Tuhe: }\end{array}$ & $\begin{array}{l}M \\
11 \\
1\end{array}$ & $\begin{array}{r}2,78.5 \\
20.1 \\
51\end{array}$ & $\begin{array}{l}(41) \\
(7) \\
121\end{array}$ & $\begin{array}{r}1.601 \\
20.3 \\
14\end{array}$ & $\begin{array}{l}(4+1) \\
\text { (5) } \\
\text { (1) }\end{array}$ & $\begin{array}{r}2,623 \\
208 \\
5\end{array}$ & $\begin{array}{l}(43) \\
(7) \\
(1)\end{array}$ & $\begin{array}{r}2,735 \\
260 \\
57\end{array}$ & $\begin{array}{r}(40) \\
(8) \\
(2)\end{array}$ \\
\hline $\begin{array}{l}\text { rexule } \\
\text { Fabrics }\end{array}$ & $\begin{array}{l}M \\
11 \\
1\end{array}$ & $\begin{array}{l}4,246 \\
1,714 \\
2,792\end{array}$ & $\begin{array}{l}(4 \times) \\
(20) \\
(32)\end{array}$ & $\begin{array}{l}4,599 \\
1,904 \\
2,16.1\end{array}$ & $\begin{array}{l}(5.1) \\
1221 \\
(25)\end{array}$ & $\begin{array}{l}5,340 \\
2,163 \\
1,684\end{array}$ & $\begin{array}{l}(58) \\
(24) \\
(18)\end{array}$ & $\begin{array}{l}4,934 \\
2,515 \\
1,929\end{array}$ & $\begin{array}{l}(53) \\
(27) \\
(20)\end{array}$ \\
\hline Aachincey & 1 & $\begin{array}{r}3,114 \\
525 \\
211\end{array}$ & $\begin{array}{l}|8| 1 \\
(1+1 \\
(5)\end{array}$ & $\begin{array}{r}3.012 \\
311 \\
156\end{array}$ & $\begin{array}{l}\text { (x7) } \\
\text { (1) } \\
\text { (4) }\end{array}$ & $\begin{array}{r}3,148 \\
339 \\
341\end{array}$ & $\begin{array}{l}(83) \\
(8) \\
(y)\end{array}$ & $\begin{array}{r}3.405 \\
330 \\
442\end{array}$ & $\begin{array}{r}\text { (81) } \\
\text { (8) } \\
\text { (11) }\end{array}$ \\
\hline $\begin{array}{l}\text { Jotor } \\
\text { Vehicles }\end{array}$ & $\begin{array}{l}\mathrm{A}_{1} \\
\mathrm{~B} \\
\mathrm{l}\end{array}$ & $\begin{array}{l}1.919 \\
1.151\end{array}$ & $\begin{array}{l}(6,3) \\
(37)\end{array}$ & $\begin{array}{l}1.117 \\
1.401\end{array}$ & $\begin{array}{l}\text { (44) } \\
\text { (is) }\end{array}$ & $\begin{array}{r}362 \\
1,727 \\
8\end{array}$ & $\begin{array}{c}(17) \\
(83) \\
(1)\end{array}$ & $\begin{array}{l}2.135 \\
1.24 x\end{array}$ & $\begin{array}{l}\text { (63) } \\
\text { (37) }\end{array}$ \\
\hline $\begin{array}{l}\text { llier } \\
\text { Manillatclused } \\
\text { Goods }\end{array}$ & $\begin{array}{l}M \\
11 \\
1\end{array}$ & $\begin{array}{l}3.735 \\
1 . x \times 6 \\
912\end{array}$ & $\begin{array}{l}(57) \\
(24) \\
(1+1)\end{array}$ & $\begin{array}{r}4.217 \\
1.461 \\
801\end{array}$ & $\begin{array}{l}(1+1) \\
(2 x) \\
(12)\end{array}$ & $\begin{array}{r}5,562 \\
2.451 \\
946\end{array}$ & $\begin{array}{l}(1.2) \\
127) \\
(11)\end{array}$ & $\begin{array}{l}9,721 \\
3.072 \\
1,34 .\end{array}$ & $\begin{array}{l}(69) \\
(22) \\
(4)\end{array}$ \\
\hline
\end{tabular}

Source: Siune di Table B- Harter; C Malia and Pikisian. 
reduction in the share of capital goods imports in commercial imports. A more detailed picture of composition and direction of tradc for the period 1.345-1348 (1966-1969) is provided by the figures given in iables 7.6 and 7.7 .

The amount of smuggling obviously cannot be estimated with any accuracy. However, it is known that many items are officially imported into Afghanistan for unofficial re-export to Pakistan. In return. wheat has been smuggled into Afghanistan from Pakistan. From the west of the country. large numbers of sheep have been smuggled into Iran. The vilue of smuggled goods has been estimated at about one-filth of the value of total commercial trade [R9, p. 95; S13. pp. 328-29]. As shown later, this is probathly an underestimate.

\section{B The Fureign Trade System}

The hasis of Afghanistan's foreign trade system is a noilling exchange rate for nost items and a fixed rate for a small group of commodities. There have been a number of transfers of items between one group and the other, the most important being itt 1342 (1963) and 1344 (1965) when items were transferred from the fixed exchange rate group to the foating rate group. In 1345 (1966), the Government Monopoly and public and

\section{Table 7.8}

Official Intermational Reserves, 1335-1351 (Millions of Dollars)

\begin{tabular}{lll}
\hline & 1335 & 59.0 \\
1336 & 65.0 \\
1337 & 60.0 \\
1338 & 55.0 \\
1339 & 50.0 \\
1340 & 42.3 \\
1341 & 40.5 \\
1342 & 45.5 \\
1343 & 44.5 \\
1344 & 45.3 \\
1345 & 46.9 \\
1346 & 38.3 \\
1347 & 39.1 \\
1348 & 41.2 \\
1349 & 45.7 \\
1350 & 60.6 \\
1351 & 56.2 \\
\hline
\end{tabular}

Source: International Financial Statistics, 26 (10), October 1973, p. 40 ; Im/ernational rimuncial Statistics: 1972 Supplement, pp. 228-29. private industry were no longer able to obtitin foreign exchange at the fixed official rate. The reverse process had been taking place for several years prior $t(1342(1963)$. As an attempt to limit the extent of depreciation caused by inflationary levels of deficit finance in the 1330s (195Cs) large losses of official foreign exchange reserves occurred, a list of prohibited imports was drawn up and a number of exports transferred to the fixed exchange group, whose earnings have to be surrendered to Da Afghanistan Bank, with the objective of providing cheaper foreign exclunge for essential and Government imports. The fixed rates have always been below the houting rate except firt a short time towards the end of $1351(1973)$ when the fixed ratte for katrakut remained at Afs 70 to the Dollar for a few wecks after the devaluation of the Dollar; the A ighani apprecitted to Ais of to the Dollar at that time.

Table 7.8 above presents estimates of onlicial international reserves. The drain in reserves helween 1345 (1966) and 1346 (1967) is noticeable, although in relation to the value of forcign trade they have always been ample. In fact, in the previous chapter it was suggested that they have considerably exceeded the level which might he regarded as optimal.

$$
\text { Tatsle } 7.4
$$

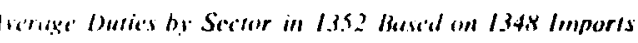
(Percentages)

\begin{tabular}{|c|c|c|c|}
\hline & $\begin{array}{l}\text { All alutiahli } \\
\text { xosods }\end{array}$ & $\begin{array}{l}\text { Goods for which there } \\
\text { are no local producers }\end{array}$ & $\begin{array}{l}\text { Guods for withich there } \\
\text { are local producers }\end{array}$ \\
\hline All Dulable (ionds & 37.0 & $3 \times 9$ & 14.1 \\
\hline Canital ciovds & 22.4 & 18.5 & .45 .3 \\
\hline Intermediale (jowhis & .13 .1 & 15.3 & 20.5 \\
\hline Consumer cionels & 39.2 & +3.0 & 34.9 \\
\hline Fsential & $(38-4)$ & $(51.7)$ & $(24.2)$ \\
\hline Less Exxhlial & $(40.1)$ & $(33.8)$ & $(47.4)$ \\
\hline
\end{tabular}

Source: R. Manly, Afxhumisan: Report and Tabl's to Accompany Recummended Revistal Cussoms Turiff Bursd im SITC Codes (Kabul: Checchi and Company, mimeo. April lingl). Tathle III. p. $2 x$

The par value of Afs 4510 the SDR was agreed with the International Monctary find in 1341 (196.3). Prior to then, there had been two official rates, one alt $\lambda$ is 20 to the Dollar, the other at Afs 28 to the Dollar, since I335 (1956) [1,3, pp. 22x-29]. The second rate wals known as the industrial rate.

Tariffs range from zero to 100 per cent. The average import duty rate on all dutiable imports in 1352 (1973) wals 37 per cent. A recent 
detaled study on the tarifr structure brings to light severil anomalies: a high average duty on essential goods for which there is no locill production [M.3, pp. 27-28], and a bias against local industry:

Private in 'ustry pays the same average duty $(35.3 \%)$ on imported intermediile goods and where such industry produces essential personal goods. it must compete with traders who pay only a 24.2 percent average duty on such goods. In this case, there is an unfavourable spread of minus if perceit on the imports involved. [M], p. 32]

This phenomenon can be clearly seen from the figures in Table 7.9. For a detalued analysis of the tariff structure the interested reader is redered (1) tilis study [M3]. At present, in 1352 (197.3) twenty unimportint items (sce Appendix C) are banned from importation. These include wond firnilure. "soft" dyes and certain items prohibiled for religiuns reinons.

Table 7.111

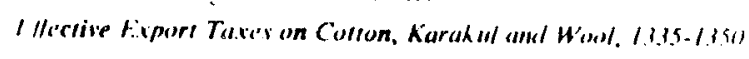
(Percentages)

\begin{tabular}{lccc}
\hline Dale & Corron & Awrakul & $W_{(n)}$ \\
\hline 1335 & & 55.0 & \\
1336 & & 55.2 & \\
1337 & & 48.3 & \\
1338 & & 41.2 & \\
1339 & & 41.8 & \\
1340 & & 48.3 & \\
1341 & & 50.4 & \\
1342 & & 40.5 & \\
1343 & & 57.8 & \\
1344 & 51.8 & 43.4 & 50.9 \\
1345 & 53.2 & 41.9 & 51.0 \\
1346 & 45.5 & 40.6 & 44.4 \\
1347 & 15.4 & 27.3 & 38.0 \\
1348 & 13.5 & 12.1 & 25.7 \\
1349 & 13.7 & 19.9 & 32.2 \\
1350 & 14.8 & 25.6 & 37.0 \\
\hline
\end{tabular}

Sunce: 135-1343 from A. H. Kayoumy, "Monopoly Pricing of Afghall Karakill

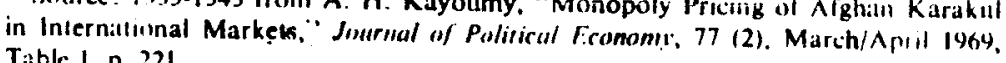
Tahle I, p. 221

1.34-1.150) fr. m Research Department, Da Afghanistan Hank.

Eirnings from the export of cotton, karakul and wool must be surrendered to Da Afghanistan Bank. Prior to 1352 (1973), the surrender was made at fixed rates. The effective tax which this requirement has levied on exports to convertible currency eountries is shown in Table 7.11) above. In 1352 (1973), the system was modified so that the surrender of earnings on coltun and karakul Wats made at the free market rate unless that ratce rose above Ats 70 and $\Lambda f s 75$ to the Dollar, respectively. in which ciase these fixed rates would apply. Wool was still to be surrendered at Mts 6.5 to the Dollar. Cotton and wool are also exported to the harter commlrics alt at lixed surrender ralle of $A$ is 60 to the clearing Dollar. Since data on the bazaar rates for clearing currencies are unavailable, elfective export tax rates camnot be calculated. However, virtually all wool and a large proportion of cotton has in lla past been exported to the barter colntrics. suggesting that eflecllve expout duties have not been so high here. Indecel during the balance al payments crisis in the first half of the $1340,(196(1))$ expurlers of collon were actually required 6 export at least 20 per cont of their cotton to convertible currency countries. This restriction was hifted in $1.36(1967)$.

Much advice has heen given to the Guvernment by forcign advisory

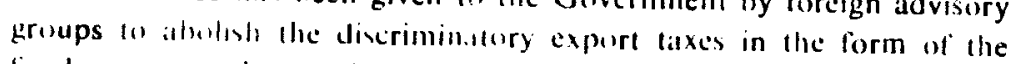
liced rat: surrenler requirements. However, this did not lake place until $1352(197.3)$ vince alternative revenue surces copld not be found. The Cimernmenl has also bein advised to athandon the non-discriminatory export taxes hut less has been heard on this since the equivalence of nondiscrimi. lory import and export taxation, discovered so long ago [L2] and restiated forcefully more recently [M6: M7, pp. 133-34], was broughe (1) the attention to those divpensing advice on such matters.

Privale cilpual transiers are in principle controlled since exporters are obligea by litw wo sell their foreign exchange carnings to Da Afghanistan Bank or one of its authorised agents (i.c. Bank Millie or Pashtany Tejmary Bawh) or to use it to import an cyuivalcnt value of goods. In fact. expurters are even required to sign an undertaking to this effect when gonds are brought to the customs house. However, in practice there has been nucontrol over capital movements. It is known that considerable capital has icti Afghanistan for Europe and North America.

The bank, have been unlavourably affected by the foreign exchange controls. Since 1343 (1964) payments for imports through the banking sysiem could inly be made under letters of eredit for which $f(x)$ per cent prepiaymem in Afghanis had to be made. As the exchange controls were relaved bint. began providing loans against these letters of credit. They nuw treels wll cheques and make payments by telegraphic transfers, as do lie forcign exchange dealers. However, they are not permitted to aceept billo hior collection.

Liberalisation has also taken place with a reduction in the Government's dircet involvement in foreign trade. Intil 1348 (1969) the Mono- 
poly Department was responsible for a wide range of imports. In this year. however, it was split into three drpartments, namely, petrol, sugar and liquidation. The monopoly privileges are now sold for a 10 per cent licence fec for all but petrol and sugar imports which are the only items still imported by the Monopoly.

So far, the major elements of the foreign trade system have been covered. To complete this general picture, a short description of the particular systems of trade with the barter countries and India and Pakistan is necessary.

Hy far the most important barter trading partuer is the U.S.S.R. ( hina and (cchoslovakia follow with Bulgaria, Hungary, Poland and Yugoslavia as minor trading partners. Annual protocols are negotiated with each barter country in which the quantities of the goods to be bartered are set out. Prices of cotton, wool and various other commoditics are also established. Trade is initiated in the main by private enterprise in Afghanistan. Traders negotiate export/import packages within the prolucol agresment with the Soviet Trade Mission in Afghanistan. Letters of credit for Afghan exports are opened through the Bank for Foreign Trade of the U.S.S.R. and the trader's clearing account (denominated in Sterling for China, Dollars for all the other barter countries) with Da Aighanistan Bank is credited. Theoretically, the trader then imports an equivalent value under similar financial arrangements and his balance is debited. In the case of cotton and wool exports the trader receives an Atghani sum converted at the particular fixed rate existing at the time for the commodity and the clearing currency is made available for Government iniports of petrol, sugar and other items actually required by the public sector. The main use to which this exchange is put, however, is debt service.

Swing balances have been created with each barter trading partner. These enable excess export or import within the maximum set by the swing to take place without any interest charges. For example, the swing balance with the U.S.S.R. enables Afghanistan to have imported up (1) \$CI million more than she has exported without penalty and vice versa. Net imports in excess of this are subject to a 2 per cent overdraft charge on the outstanding balance. The other barter countries charge 3 per cent on the excess. The bilateral trade balances are presented in Table 7.11.

In 1349 (1970) the swing balance with the U.S.S.R. fell from $\$ C 0.48$ million to - $\$$ C4.37 million. This was tlie result of a fairly complicated set of circumstances. There was an unforeseen shortfall in cotton exports. Government purchases from the U.S.S.R. had already been made before

$$
\text { Trahlis. } 7.11
$$

Biluteral Trade Bishunces, 1.335-1350

(Millions of Clearins Dolldrs, End of Year Figures)

\begin{tabular}{|c|c|c|c|c|c|}
\hline Date & G..S.S.R. & $\begin{array}{l}\text { Carcho- } \\
\text { showakia }\end{array}$ & Polumd & China & Toral \\
\hline 1.335 & 2.87 & 0.42 & $\cdots$ & - & -3.29 \\
\hline 1336 & $10.7\}$ & 2.30 & 10.08 & -- & -1.49 \\
\hline 1337 & 0.36 & -1.54 & +0.02 & $\cdots$ & -1.88 \\
\hline 1338 & 0.07 & -2.35 & 10.16 & +0.14 & -2.12 \\
\hline 1339 & 3.53 & -3.11 & 10.04 & +0.07 & -6.53 \\
\hline 1340 & $12 n$ & 198 & 10.10 & 10.20 & 7.94 \\
\hline $1.3+1$ & 1\%? & 3.05 & 10.02 & 0.12 & 7.82 \\
\hline 1.342 & 1.61 & 0.86 & 10.54 & $\{0.13$ & 2.04 \\
\hline 1343 & 21.4 & 11.25 & $1-0.62$ & +0.05 & -0.42 \\
\hline 1.344 & $11 \times 4$ & & 10.50 & 0.05 & +2.34 \\
\hline 1.345 & 11.13 & 040 & +0.31 & -0.06 & +1.20 \\
\hline 1.346 & $|x|$ & +0.61 & -0.02 & +0.07 & -1.18 \\
\hline 1.347 & 10.14 & 10.43 & -0.31 & -0.10 & 10.18 \\
\hline $1.34 \times$ & $10+k$ & 10.72 & -0.43 & +0.40 & +1.04 \\
\hline 1.343 & 4.37 & 10.35 & -0.51 & -0.12 & 4.79 \\
\hline 1350 & 5.74 & 10.75 & -0.11 & +0.23 & 5.11 \\
\hline
\end{tabular}

Source: Research Deparımint, Da Afghanistan Bank. :

it was realised that revenue from cotton sales would not be forthcoming to pay for them. Government enterprises increased their imports from the U.S.S.R. in this particular year and certain non-trade items moved uniavourably.

Trade with the U.S.S.R. has been generally more attractive to Afghan traders than trade with the convertible currency countries [FI8, pp. 26-27]. Indeed, in Jiuza 1352 (June 1973), the clearing Dollar sold for Afs 72 per Dollar in thic money bazaar compared to Afs 61 for the United States Daliar. In the latest agreement, the price established for cotton was $\$ C 800$ per ton at an official exchange rate of $\wedge$ fs 70 to the clearing Dollar, with the world price lying around $\$ 600$ per ton at that time. The world price has subscyuently risen to over $\$ 2,000$ per ton. Wool was sold to the U.S.S.R. if $\$ C I, 300$ per ton; the quality is so poor that there was not much of a market for it in the West. However, the price was raised substantially recently as world prices rose and wool began to be smuggled out of Afghanistan to the West towards the end of 1351 (1973). Whether the price paid for natural gas is generous has been subject to considerable dispute. It hats been suggested that the projects for which the gas earnings are paying have been so unsatisfactory that the barga in is a very poor one.

On the import side, prices are generally favourable. The average price 
for sugil aver the past four years has been $\$ C 95$ per ton compitred with a "wirld price of $\$ 135$ to $\$ 200$ per ton. But recently supplies hitve been reduced because of the high world market price. Green tea, velhicles, books and petrol have also been imported at below world prices.

were Afs 70 to the barter countries Were Ais 70 to the clearing Dollar with the U.S.S.R., Afs 220 to the (he clearing Dollar with the other harter countries in 1352 (197.3). These rates form lhe hatuis for the effective export tax on the export of cotton and wool to thene countries lirough alce fixed lalle surrender requirements. Allhough changed several timcs, the re rates have also indicated Da Afghitnistan Hanh's buying ralks since 11 began dealing in clearing currencies in 1343 (1964). 1/owever. bazalar ifles are also quoled for each clearing currency which have often diflered cunsiderably from Da Afghanistan Bank's fixed rates. The sules of clearing currencies in the money bazaars are mainly limited to the procech of consumer loan funds from China and the U.S.S.R.

Trade with India and Pakistan is conducted in inconvertible Rupces. In 1.3 .36 (1957) India began restricting its imports from Afghinistan threc melhods of pilyment were instigated in 1344 (1965), namely, pilymint in inconvertible Rupees, payment through a special self-ba' :ncing account maintained by $D_{\text {il }}$ Afghanistan Bank with the State Batuk of India and payment through letters of credit in convertible Dullars or Sterling. The second method is used for proceeds from Afghanistan's exports of hides and skins and Indial s exports of a range of specified commodities. The third method is used for exports of Afghin collon and wanl and Intian capititl and durable consumer goods. In 1.347 (1968) value limitu previously set by India were abandoned in favour of y riantity controls. The majority of Irade with India and Pakistan is conducled in Rupecs. the export and inport of which are theoretically prohilited. Neverthcless, large values of Rupees are traded daily on the money halialrs of Kabul and Kandahar.

Inder the latest agreement exports of fresh and dried fruits and nuts are valued at Indian customs houses. This agreement also sets a limit to Afghan indian trade with a maximum percentage of this being set aside for teit inports into Afghanistan. This limit is designed to prevent te: re-sport 10 Pakistion. In tact. lower quality tea has to he patid for in convertible currency since this is the type most commonly re-expurted

Oflicial tride with Pakistin has become freer since the introduction of self-balancing accounts in 1)al Afghanistan Bank and the Statc Bank of
Pakistan (1:10, p. 10 .
A discusion of Afglianistan's foreign trade would be incomplexe without rilicencic to the problems of transit trade arising from the fact that Afghanut.m is a land loched country. $\wedge$ litrge part of the trade has taken place through Pakistan, which the continuing dispute over Pushtunistan hats at timls scriously jeopardised. Both Dupree and Fletcher provide excellent histuries of the Pushtunistitn issue (DI0. Chapters 22-24; F9, (hapter 171 . The dispute has resulted in the disruption of Iransit trade or horder clomati in 1.326 (1947). 1330 (1951). 1334 (1955) and 1340-1342 (1961-196.1)/1)10. (hilpters 22-24: Fi). Pl. 275-76: F18, p. 24). Because o: this, trade llwugh the U.S.S.R. has expanded. For hoth roules, however. costs are high and the tinc taken for hipment long and unpredictabies. With overcrowding in the port of Kalticlis becoming increasingly serious the agreement over lamsit trade through laan to the Persian (julf reache in 1353 (1174) bocks well. For rapid expamion of foreign trade, improvement an transit trade ficilities by one me:ins or another is essential.

\section{iii. Financings Forsign Tradic}

Since thcir establishment, a major function of Rank Millie, Da Afghanistan Bank and Pashtany Tejaralty Bank has been export finance. Indeed, the absence af security and efficient court procedures discussed in Chapter $V$ sirongly duters these banks from lending for oher purposes. All three banks competc to furnish loans lor karakul exports. Because of the exchange surrender requirements and karakul valuation and grading conducted by the kirakul listitute. lhese export loans are the silfest.

Cotton lains consist of money actually provided by Da Afghanistan Bank but dwtributed by Pashtany Tejaraty Bank' on its behalf. Export loans are alye made for carpets and dried lruit and nuts. The hanks have been aided by the Carpet Institute with respect to cirpet valuation although l'anhtany Tejaraty Bank still uses its own stall with apparently unfortunate conseyuences. L.oans several times the value of the carpets have been given, thus providing no incentive on the part of the exporter to raalise a sile. Pashtany Tejaraty Bank has apparently been faced with many defitults on the excuse that the carpet market has slumped and sales cannot be made. Since the establishment of the Institute, this has not been llac experience of the other hanks. Nevertheless, non-sale of exports provides llie main risk to the lending institution.

Export loans against exports to barter countries are generally quite sale since carnings have to pass through Dat Afghanistan Bank. However, "ciasional moblems arise when the exports are not sold immediately and 
pityments pass through the Bank in instalınents. Administrative inellicien(i) can then lead to a failure to inform the lending institution of the repatriation of funds.

Da Afghanistan Bank theoretically accepts bills of exchange for discount to finance exports but the relevant department in the Bank is now morihund. Security was provided by the fact that the Bank could ensure that the trader lost his licence, thus preventing him from making any more exports, in the event of default. The only major risk here lay in the possibility of bankruptcy. Bills were generally discounted for three (1) six months at an annual interest rate of $7 f$ per cent and could be extended lior additional periuds at double that rate.

$k$ il rakul is sold at auctions and thus requires financing until the time of attuiun. ("arpets are also exported for direct sale abroad. Silles of most wher cxports, however, are negotiated before shipment. In these cases, paymeut is normally made at the time goods pass through customs. Thus, cyurt finance is generally only required for hocal procurement and processing prior to shipment. Cotton companies receive credit from Da Afganistan Bank for this purpose and the AgBank has made loans to a 4 ro-business by lending against letters of credit placed with them hy foreign companies in advance of delivery.

On the import side, the variety of financing methods is considerably grealter. The banks do extend import loans but finance is also provided by foreign exchange dealers, trade agencies and the suppliers themselves. Payments are made through letters of credit, telegraphic transfers and cheques to the convertible currency countries, letters of credit to the barter countries and cash, cheques, letters of credit and humdis to India and Pakistan.

The banks generally prefer to extend import loans against letters of credit opened by them. In the case of barter countries, all letters of credit are opened by Da Afghanistan Bank. After communication with the Bank to confirm the existence of the letters of credit, the other banks will make loans against them. Letters of credit are relatively expensive in that a one per cent commission is charged and an annual interest rate of 10 per cent is levied on any credit extended against the letter. Furthermore. the foreign exchange often costs Afs I to Afs 1.50 per Dollar more in the bank than in the bazaar.

Import credit from the money bazaars generally takes the form of lians against hawalas or hundis. These are simple drafts drawn on corresponding traders in India, Iran and Pakistan by Afghan traders and foreign exchange deilers. This is the usual method of making payments hetween these countries. The hanking system is hardly used at all for Rupee transactions. The purchatse of such a draft normally includes a one par cent comrnission. Deferred payment naturally includes an interest charg: which ranges from one per cent a month for first class risk borrowers through rates of two or three per cent to much higher figures for small scale operaltors. Foreign exchange dealers often have facilities for opening letters of credit and some have sufficiently good credit standing that their foreign bankers will open letters against a 30 per cent deposit. This is important for trade with Japan as Japanese suppliers insist on full payment in advance. Thus, credit is sometimes obtilined from foreign banks to linance imports.

There are a number of trade agencics in kabul acting on behalf of supplier irom their own country. Since 1.34t (1965), foreign trade agencies have anly been permitted w import from their own country. a special exteption being made in the calse "ll Indamer which is permitted to import Lamdroters from Britain. Alghan trade agencies, on the other hitnd, are fromilled 10 import lrom any country. The foreign trade agencies generally play an important role in the financing of imports from their country and do provide certain banking services. The demand for these arises from the prohibition on banks from accepting bills for collection. The eredit standing of the foreign trade agency usually allows it to obtin supplier credit on a 25 per cent down payment with the balance on receipt, or three months after shipment, basis. Similarly, the Afghan-International Trade Agency recently obtained a guarantee from its Swiss bank which enables it to import on these terms. Thus, trade agencies import on commission for other traders who cannot obtain such fitrourabie finalleing arrangenents, becatuse of the banks' inability to aceept bills fir collection. Indeed, the intention of this prohibition was precisely to prevent traders obtaining supplier credit. Trade agencies tend to prefer making payment hy cheque since this is cheaper and more flexible than payment through letters of credit.

Trade agencies acting un commission are. of course. completely secured in that full payment is always insisted upon before the imported gonds are actually released to the trader. Since the agencies also act on their own accounts, few problems are created in the rare event of a trader int producing the balance for his consignment. As most trade agencies expurt ats well as import. they generally accept payments for imports on commission in domestic currency converted at the prevailing free market rate. Interesi.ogly. trade agencies will not act on commission for the public sector without full payment in advance. The public sector has a 
nolormuls bad record for settling accounts both with the trade ilfencies and forcign suppliers.

Capital imports sometimes receive medium term supplier credit. However. Afghanistan does not rank as a sufficiently importint market 11 generale much competition in this respect. Nevertheless. goul terms art reported for capital imports from China and the U.S.S.R. There are no" "mixed credit" arrangements [H7] although, of course, a considerable volume of capital imports is financed by forcign aid.

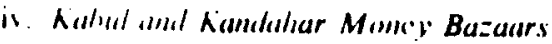

The hustury of forcign exchange dealing in Alghanistan call he traced hath many centuries to the time when the greill overland irate antes passed Ihrough the country. Despitc steady dectine since then, it has been only withun the past fifty years that a series of events seriously disrupted the forcenn exchange markets to a point of ncilr extinction. In the past sesen years. however, the markets of Kibul and Kandahar have (xperienced a is iod of rapid development and had regained the dominatnt pouitun they held in foreign trade finance prior to 1309 (19.30) by 1.352 (1973):

Prio, 10 1930. there were no banks in the country. All foreign exchange transictions were handled by private exchange dealers set up in the inirket plices (hazaars) of Kahul and Qandahar. It is estimated that in 1930 there "se about 30 10 40 such dealers in Kabul and from about 10 10 15 in ():1n. l.thin I ven the Government's requirements were bought from the deaken. |M21, r. [82\}

With the establishment of the Shirkat-i-Sahami-i-Afghan. the predecersur of Bink Millic, in 1.309 (1930) cime repression. Nol only was a large part of Afghanistan's foreign trade immediately acyuired hy this compally. hul three years later when reorganisation produced Bank Mille it was granted a monopoly over all foreign exchange dealings \{ $115 . \mathrm{pp}$. 314-15\}. Initially, the number of forcign exchange dealers was simply reduced [M21, p. 182]. However, in 1314 (1935) a fixed exchange rate system was adopted, free market dealings were prohibited and Bank Millic exercised its honopoly rights in foreign exchange [B6, p. 7: M21, p. $|82|$. It opened exchange departments in Kabul and Kandahar (o) replace the foreign exchange bazaars [M21, p. 182].

Thall the repression of the inoney bazaitrs was not altogether successtul is wmeed by the litet that by 1317 (19.38) Bank Millie wits lorced to recognise and even place its own dealers in the bazaars [M21, p. 182]. This. houces, wals lo be a short lived respite; alter the assumption of its fureign exchange responsibilities in 1.322 (1943), Da Alghanistan Bank which had heen established in $131 \times(1934)$ instigated new measures of exchange couterol:

The transfer was in recognition of the exigencies of the war and the desire of the ciovernment to exercise complete control over trade and payments through its central bank. The new system of euntralised control over all exchange reccipts remained in ellect until 1947 when new rules were introlucied [P-121, p. [8.]]

It is clear lhat "centralised control" again linled to be elfective since free market exchange rates have heen recurded throughout this per:

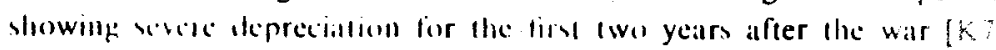

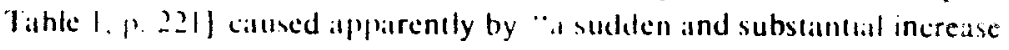
in impors .... (1) moct unsattisfied scmand during the war" [M21, p. 1821. The changes in 1.326 (1947) were in effect a return to the system established in $1317(193 \%)$. Da Afghanistan Bank presumably recongnising. as Bank Nhllic had betire it, that the frec market system could not be climinaled [M21. p. [8.3].

: The fireign exchange system now theoretically aperates under Decree No. 26.32 promulgalled in $1.329(1951)$ which is presented in Appendix A. It represent a colditication of the system introduced in 1326 (1947) [M21, p. 183]. which wats a return to the 1317 (1938) system [14].

That loreign exchange regulations have not changed since 1329 (1951) does not myly that the foreign exchange system has not undergone any changes and the past 20 years. Rather, the fact is that the Decree hats been a lestal letter most of the lime. The basic requirement for the surrender af forcign exchange earnings al below frec market rates from expurts af collum, killatul and woil has remained throughout this period. kespate a continual stream of advice from loreign advisors to the Governukm to abandon it. The surrender requirement formed the basis lior the multiple exchange rate system which has also survived with modificillums.

The cumplexity of the system increased until 1.342 (1963), when the majority of multiple exchange rate practices were eliminated. However, the watershed in recent foreign exchange history came in 1344 (1965) when Bat Afghanistan Bank, under a stand-by agreement with the International Monetary fund. started its present policy of maintaining its free rate within Als 2 of that yuoled in the Kabul money bazaar. At the same time, the scope af the official rate was reducid, sonre export itens removed from the exchange surrender list, export laxes lowered and import control filcratised. The details of the exchange system existing before the 
estitblishment of the Republic are presented in Appendix B. No formal chianges hive been made since then.

The heginning of 1344 (1965) also marks the beginning of the renaissance of the money bazaars. Prior to that date foreign exchange deilers had been almust entirely Hindus and Jews. The position of the.Jews, however. hald been deteriorating since 1240 (1861) and "the fiercely competitive Hindu merchants gradually ousted the Jews from money-changing ....." [G15. pp. 64-65]. The Arab-israeli conflict of 1346 (1967) resulted in the withholding of trade licences from Jews; the last Jewish foreign exchange deiler comgrated a few years ago.

Although banking has not flourished in Afghanistan over the past decide, the money hazaars have undergone a period of rapid growth. The volumic of business has increased substantiafly, specialisation has occurred and technical improvements such as the widespread installation of electronic calculators have taken place.

The present foreign exchange market in Kabul is situated near the river in Puli-Kheshri in a large courtyard known as Saray Sho/da. Before this silrity was constructed the moriey market was locilted in Saray Mohimmsiad Qumi which lies behind tlie present market. The Saray Mohaunmad Qumi helonged to Shahzada Abdul Aziz but wals demolished some twenty years ago for the site of the Puli-Kheshti mosque. Shahzada Ahdul Aziz then bought the existing site and completed a Iwo-storey courtyard in 1336 (1957). Eight years later a third storey was added.

When lioreign exchange dealers moved into Saray Shozda there were apparently only three or four dealers, all Jews, who set up business. However. Hindus soon followed and by 1339 (1960) there were ithout fifteen dealers established in the courtyard. Religious scruples were finally avercome quite recently when the first Afghan Mosienss set up business in Saray Shozda.

Dealers in the Kabul money bazaar appear to have accepted cheques drawn on foreign banks some time ago but this practice may have stopped during the Second World War, since present dealers believe thit the first cheque wis accepted in 1325 (1946) by a prominent dealer, Ibrahim Aranov. Ile emigrated to the U.S.A. ten years ago and there established a tratling business. That cheques were accepted in the pre-war period is documented in the following extract from the British Legation's Otlice Manuial of 1312 (19,33):

Purchaw' of Afxhanis-When the balance of Afyhanis in hand is less than Rs. $3,(x)$ the Accountant will inform the Counsellor who will ascertain through the Oriental Secretary or Accountant the official rate of exchange quoted for the day by the Shirkat Ashami Company, or the lowest exchange rate prevailing in the Kabul hazatir on that day. After approval of the rate hy lle (iunsellor a checpue will be prepared on the Imperial Bank of India at Peshawar for an anıumt in Indian rupees equivalent to the sum required in Alghanis. The Accountant will then proceed to the bazaar accompanied by a Legation orderly and. after counting the money received from the banker. witl bring it to the Legation in a suitable conveyance. The Accountant should obtain from the banker a statement in writing on the bank's official paper shewing the rate at which the exchange was effected. The money will immediately be brought to account in the cash book. In order to check the quotations made by the Shirkat Ashami Company or other Katul Bankers, the Accountant will inform the Counsellur of the ollicial rate quoted in the daily "Islah" newspaper for the daly a11 which the purchase was made. [13.3., p. 12]

In $1352(1973)$ there were about 35 principal dealers together with 50 to 60 partiners or agents operating on small commissions. Each principal rents one of the small shops in the courtyard, instals desk, safe, telephone and calculating machine and opens for bustness. He closes again if his turnover is insuflicient, rattes turn against currencies he is holding or personal or travellers' cheques which he has accepted are not honoured. Competition is keen and survival generally depends on cultivating business from large traders, specialisation and trading on one's own account.

Although foreign exchange transatctions take place throughout the country, Kindiahar is the only city hesides $K$ itbul in which there exists a physical marketplice for forreign exchange dealling. In Herat, for example, scattered tourist shops and traders act as forcign exchange dealers as a side line but there is no centralised lucation. The same situation exists in Jalalabald, Kunduz and Mazar-i-Sharif. In Kandahar, a courtyard similar to Situay Shozda exists in the Bizzalar-e-Shekarpoor called Tara Singh in which fureign exchange transactions have reportedly been taking place for al leint the past 70 years.

Most furcan" exchange transactions in Kandahar were apparently conducted on the street until $1342(1963)$ when three dealers opened shops in the newly re-built Saray Tara Singh. In 1348 (1969) another foreign excluange dealer moved inte this courtyard and the complement of tive found there in 1352 (1973) was completed in 1349 (1970). There are. however, scucral retailers in Kandahar who also engage in foreign exchange tainsactions as well as a dozen or more partners or agents operating it th. entrance to Saray Tarat Singh in the same way as they do in Saray Shurda.

Dealers in Kabul and Kandahar maintain close links with one another 
alld with the foreign exchange markets in Beirut. Humbay. Delli, Karalchi, london, New York. Peshilwar, Tehran. Zurich, eft. The Pakinial, Rupce appeared 10 be the most important currency in Kandahar, while Dullars and Indian and Pakistani Rupees were the most common currencies in Kahul.

Despitc the fact that Da Afghanistan Bank, as well as the wher banks, has followed the exchange rates set in Saray Shozda in determining its own free mi. iket rate, the legality of these operations is still in some doubt. Indeed. the foreign exchange regulations reproduced as Appendix A hardly appear amhiguous on this matter. Furthermore. Bank Nillic was itcll not allowed to engage in any foreign exchange transatctions between 1322 (1943), when Da Afghanistan Bank took over stoh alclivilies from B.11k Mlllic, and $1.346(1967)$ when it was recugnised as an allthorised dealer atier submitting numerous applications to the Government on this matter. Prior to that date the only other authorised dealer apart from Dat Alghanistan Bank had been Pashtany Tejaraty Bank

In 1.347 (1969), following several incidents of hirassment, it police raid on Saray Shozda took place and dealers were marched off in the police station. Alter questioning. each dealer was obliged 10 show his tride permit. identity curd and military service certificates, and (1) produce three phofugraphs and a guarantee. It is also reported that hakslicesh fines were imposed. For a while after this event, dealers discontinued their exchange operations and the Afghani depreciated substintially. At the samc time, reports of a number of earlier incidents of police harass mient came to light [FI2]. However, after this report carricd in Caravan Neu ypaper, no further incidents took place for some time. In 1351 (1972) lhere were rumours of dealers" mail being delayed and opened ipparent1). lurblier repressive mealsures were feared. Under the new Revublician Ciuvernment, mail was again opened and dealers becanie reluctant to deal on allything other than a cash basis.

The minn problem created by this dubious legal position concerning the activly of foreign exchange dealing lies in the fict that it prevents dealers from registering as businesses. Plans were in fact malc hy the Ministry of Finance several years ago to register dealers but were shelved betore attion was taken. This situation naturally greatly increases the dillicultic of data collection. For exanple, no dealer will openly admit I1 the pussesion of foreign bank accounts to anyone who might be a Government ofticial.

The incriase in efficiency and scope of activities of both money bilzatars over the pilst decade has been dramatic. Only ten years ago cross rates were repustal to be incomsistent, lurmoser fow, the spread hecween buyir and selling t.lles high and fluctultions excessive [W5. p. 258]. Clearins: currencies were nol quoted and the markel was miniscule. Ten years lats foreign missions were reporting that the market operated efficiently line margins betwesn buying and selling rates. The fuctuations ars longer as violent as they used to be as call be seen from Figure 7.1 bs...

The incriace in efficiency springs from increased competition, pis: larly over the past five years. This, in turn, has led to specialisation whin the bazatu. (hne indication of increasing competition is the movers the rate of interest in the foreign trade sector over this periog: interest rate have gellesally doubled ower the past decade tivi. Afghanivial. the rates in the bitzaitr lor foreign trade finance apparently declated. This can be attributed to increased competition loreign trille it velf which in turn has redaced profits. Thus, the opportt ity cost of ciputal in this pirticular sector of the economy has declined brought down interest rates from alround 30 to around 20 per within five years. The possibility of declining rates in one sector a rosing interes rales elsewhere is another illustration of econonic fr: mentation discilssed in Chapter III.

Foreign exchange dealers can be divided into three groups of specialis namely, those dealing in convertible currellues, those dealing in clearing currencis, and those dealling in Rupees, In fact. specialisation is not watlertiglit and the first and third groups can only be distinguished ir: terms of their maln emplasis. Thus, most dealers in convertible currencie ciln supply small quantities of Rupees and rice versa. although their own trading aclivalies and main exchange business will be confined to : particular currency lype.

concertible currency dealers keep themselves informed by teiepha: of rate movements in the major international markets on a daily bas For sum in excess of 5,5000 it is usually worth shopping around the Delhi. Bumbay. Beirut and Tehran markets for prices. Kandahis dealers keep in close lonch with the Kahul market making several telephonc calls a day. When Dollars are bought abroad the correspondent celegraphs New York to transfer funds and Afghanis are deposited in Kabul account.

The clearing periond is used for short term finance. Cheques for w: outside the U.S.A., in particular Japan, can be sold 14 days or so pria to their reathing the U.S.A. Twelve days later the Dollars are bough: and the Iranster telegraplied to Neu Yurk. Thus, the clearing period provides 12 days tinanci. Transactions can normally be conducted by 
cheque, telegraphic transfer or cash through a network of deposits. Most livoured centres for accounts are Hamburg. London and New York.

In 1.351 (1972), a representative of one of the big American merchant halnks visited Afghanistan to entertain traders from Kandahar who held large deposits with his institution and to solicit more accounts. Although : "wholesale" bank, this bank was keen to keep such personal alciounts because its Afghan clients appear to have been content to hold demand deposits in excess of $\$ 100,000$ each with few demands for services apart from eisily undertaken credit standing enquiries. A charge of $\$ 3$ per Irilnicition is miade to discourage sinall traders from opening alciounts. It would seen, therelore, that dealers in the Kandathar bazaar also finance a substantial volume of trade from convertible currency countries.

In trade transactions, dealers operate on cash and credit and can also make use of their own credit standing to obtain supplier credit for customers in the same way as the trade agencies.

Four or five dealers in Kabul act as brokers in the markct for clearing currencies. There are no clearing currency dealers in Kandahar. The ntirkct for clearing currencies is by no means as developed as that for convertible currencies; the margin fluctuates between Afs 1-5 per clearing Dollar. whereas it stays fairly uniformly at 50 Puls per United States Dollar. N/though Afghan exporters to Russia negotiate an import list at the timc of export, this can usually be modified or rencigotiated by inother trader who has bought clearing currency. The ability to modify or rencyutiate an import list seems to depend on the individual trider's standing: there are first, second and third class traders. First class traders are almost entirely free to alter import lists whereas third class traders will be obliged to import a substantial proportion of the or ;inal list. Exporters can either use their clearing Dollars to pay for imports or can vell clearing currency from their clearing accounts to the brokers in the bilzaliar.

Dealers in Kupees have close links with India and Pakistan. The niain method of payment is through the hundi or hawala which is a draft drawn (3) a tridi.. g associate. About fifteen large traders with rakistin and ten with Indiat possess first class credit standing with respect to the atceptance of turndis. There is usually a one per cent commission charged on the accept:ance of a hundi. Smaller traders find it more expensive to sell their Rupec cirnings in the form of hundis, but may nevertheless sti" tind it provides a more attractive rate than selling cash. Because currency export from India and Pakistan is illegal, there is a considerable differen- 


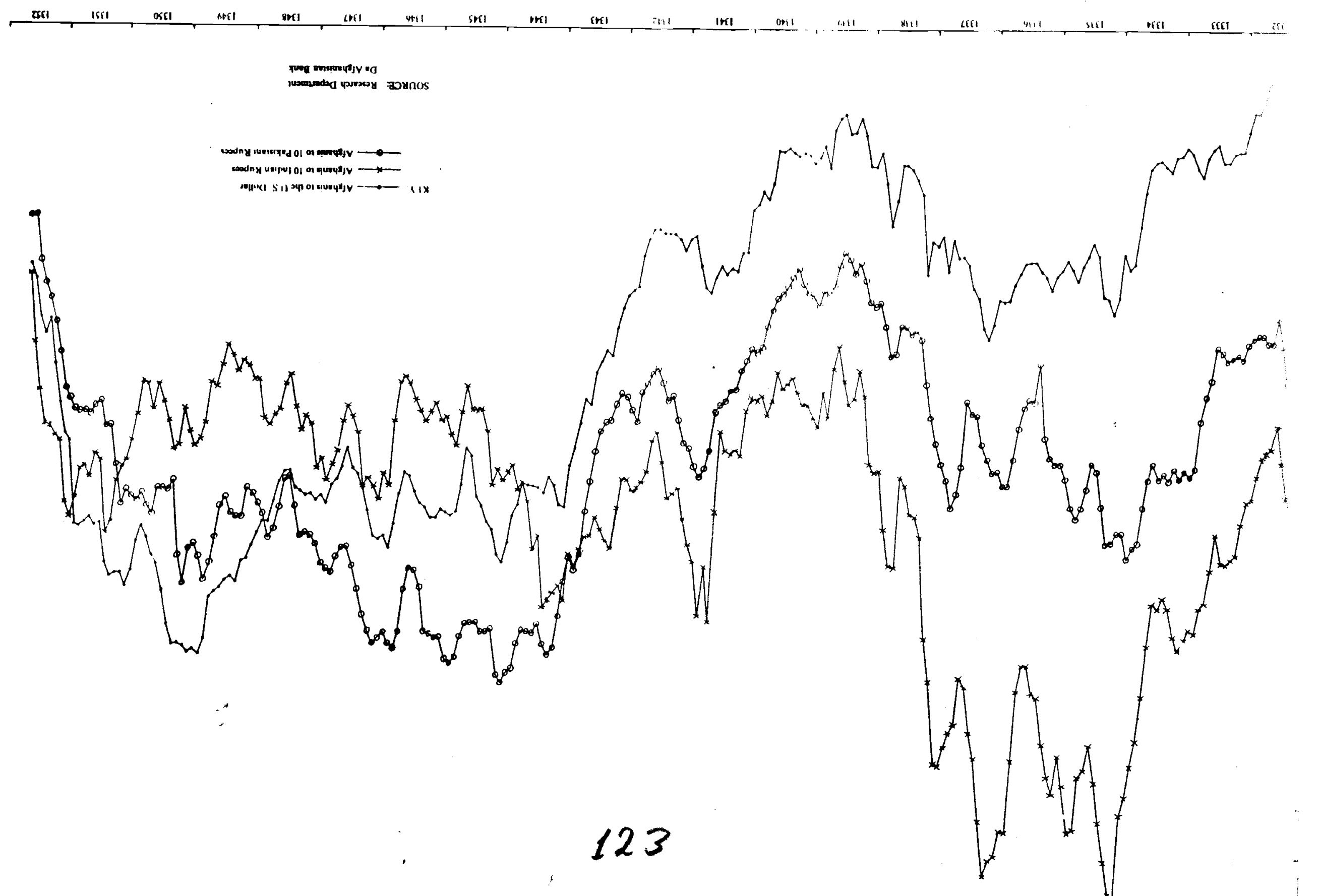


tial between currency and hmoli exchange rates. Hawalas are also used extensively in trade with Iran as well as in domestic trade.

The existence of forcign exchange controls in both India and Pakistan mealns that all Rupees in Alghanistan have been taken out of India and Pakistan illegilly. (jiven that exchange controls have naturally resulted in overvalued curfencies at the official exchange rate, Rupees sell at a discount in Mlghanistan as elsewhere. Beciluse of the exchange controls, lundis and ielegraphic transfers make use of code names for currencies and values.

There is riporiedly a considerable trade in Ruubles and gold. A Rouble rate and rasce fur gold coins are quoled in the bazalar. Apparently, Roubles :are in greatest supply in Herat, ic. neitr the section of the Afghan-U.S.S.R. border not on the Anu I) irya (River Oxus). It is across this section of the border that sizable smuggling operations are reported to take place. However, Roubles also cross the river and can be found in Mazar-i-Sharrit and Sherkhan Bandar, the largest river port.

Roubles linding their way into Afghanistan follow well established routes thrugh Iran, Lebanon, Kuwail and Switzerland, where they are sold at about a 20 per cent profit balck to the U.S.S.R. It can be assumed that they reach $A$ fghanistan in payment for goods from the West smuggled into the USS.S.R. and are eventually repatriated in return for gold or convertible currencies sinuggled out of the U.S.S.R.

Gold in Aghamistan is generally in transit to India and Pakistan. There is little evidence of a large demand for gold in Afghanistan itself.

This briel survey provides an inadequate picture of the bazaar ac.ivities. The extra-kegal position of the foreign exchange dealers makes them very refuctant (1) talk about their operations.

v. Imporfance of the Money Bazads is Forgign Trade

It is impomible to make any accurate estimates of either balance sheet or tumover figures in the money bazatars. This difficulty is doubly compounded lirit by the questionable legal status of foreign exchange dealings allal second by the high proportion of smuggled trade in totil foreign tratc. A number of observers [S।3, p. 315; Z3. p. 71] have concurred with Wither that "half of the lendable funds for the bazaar traders emanates froun the bazalar moneylenders" [W3, p. 258].

A study in lleral and $K$ andahar found the relative importance of noninstitution:l finance signilicantly greater in the provinces than in Kabul for the simnte reason that bank loans are extended only from the banks' head oflices in Kabul. In Herat, a small survey at a meeting of the 
(hamber of Commerce produced estimates that 50 per cent of agricultural production expenses, 40 to 50 per cent of trade and 30 per cent of construction investment was financed by non-institutional credit at annual interest rittes of between 20 and 40 per cent [O2]. It wis also reported in this study that interest rates had risen in recent years.

There is no doubt that in foreign trade the Kabul money bazalar is the dominamt institution. Dal Afghanistan Bank and the other two commercial banks not only keep closely in touch with activities in the batzitar but aho hase their own agents operating there. Da Afghanistan Bank is, limwever. the largest operator and has acted as a price setter while still kecping ils own rates aligned to those in the bazalar.

Estimalles of nine of the 35 or so dealers in the Kabul money hazaar for the lotal daily turnover in foreign exchange were collected by the author in 1352 (1973). Part of the high variance in these estimattes is doubless due to the increased use of cheques and telegraphic transfer for which value estimaltes would naturally be more difficult thin for cash Iransicturns. The main currencies dealt in the Kabul money hilziar were D.,llars. 1)eutsche Mark, Sterling. Iranian Rials, and Indian and Pakistani Rupees.

There is a sizable business in clearing currencies, i.e. clearing Dollars for Czechoslovakia, Poland and Russia and clearing pounds Sterling for China. These transactions take the form of transfers of owncrship of clearing accounts held by traders with the barter countries at Dit Alghanistan Binh. There exist small quantities of many other currencics in the Saray Shusda primarily generated by tourists. The spread between buying and selling rates on thesc currencies is naturally greater than on commonly trided currencies. This results in certain discrepancies in cross rates.

The five dealers in the Saray Tara Singh in Kandahar provided estinates of their wwn average daily turnover. Apart from the evident diflerence in sice between the two foreign exchange markets, only six currencies were Iraded in Kandahar, whereas a large number of currencies were Iraded in Kibul. In Kandahar there were only five brokers while in Kabul there ucre about 35. The Pakistani Rupee was the most important currency in the Kandiliar milsket, the Dollar in Kabul. However, both baizairs operalled in currency. hundis, cheques and telegraphic transfers.

One wi the largest dealers in Kabul estimates that about 50 per cent of Alghamistin's foreign trade is financed through the bazaar. Foreign cconomic missions have also quoted this figure. Other estimates are even higher. A rough attempt has been made to provide some indication of the relatice importance of the bazaar in Table 7.12. Averages for each
Tiable 7.12

Anmol Turmiser of Fircign Exrhange'. 1.149-1351 (Milliows of l)ollars)

\begin{tabular}{|c|c|c|c|c|}
\hline \multirow[t]{2}{*}{ Inviturimn } & \multirow[t]{2}{*}{$13+4$} & \multirow[t]{2}{*}{1.350} & \multicolumn{2}{|c|}{1351} \\
\hline & & & & Percentake \\
\hline Kilbul Moncy Bazatar & n.i. & n.it. & 152 & $(60.3)$ \\
\hline Kithulaholr Moncy Holdatr & n.a. & nid. & 3 & $(1.2)$ \\
\hline Dat Nikhanistan Banh & $4 y$ & 75 & 71 & $(28.2)$ \\
\hline Binh Millie & $y$ & 16 & 17 & (6.7) \\
\hline Pawhing Telaraly Banh & $y$ & ") & na. & $(3.6)$ \\
\hline & & & 12521 & $(100)$ \\
\hline
\end{tabular}

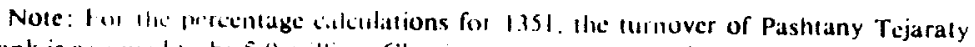
Hank is asulused to be $\$ 9$ million. (learing currency transactions are excluded.

Source: 13.1.1 neovided by mone foregen exchange dealers in Kabul and five in Kandabar and ha the three banks

currency wace calculated, added to ligures obtained from the Kandahar dealers. cimverted al the average free market exchange rates for 1351 (1472) m1. Dollars and multiplied by 300 to obtain an annual estimate. Compared with a ligure of $\$ 146$ million for total foreign trade in 1350 (1971), cxcluding loreign aid tinanced imports and barter trade, the ligures in Table 7.12 suggest an upper limit 11 sinuggling of $\$ 106$ million or 40 per cent of total recorded trade. This can be compared with estimates of 20 per cent produced by other observers [R9, p. 95; S13, pp. 328-29].

Virtually m. payment connected wilh trade with India and Pakistan is transacted llarugh the banks, much to the annoyance of the Indian authoritis, whe innually attempt 6 include such a requirement in the trade agrcoment with Afghanistan. This was a major point in the 1349 (1970) negoliations. India obtained one tiny concession in this connection last year when it was agreed that, als an experiment, payment for Afghan export of atwhelida would be made through banks. Otherwise almost all trade pityments are made using humdis.

Table 7.1 .3 presconts the "bazaar rate" for the Dollar and Rupees. This is the average daily rate for drafts and cheques (buying rates for Dollars. selling ritles fir Rupees) in Saray Shozdal obtained by the Research Department of Da Afghanistan Bank each day from a number of dealers. Figure 7.1 imilarly presents monthly average rates of daily exchange rates for the B.ll.n. Indian and Pakistani Rupec, respectively.

The ligurs in rable 7.13 show a general trend in which the Afghani has depricialed agatinst the Dollar. However, the extent of depreciation has been cilatively modest in comparison to currency depreciation in 
Table 7.1.1

Fric' Market Dullar and Rupee Exchange Rares "Bazaar Rares" 1329-1.151 (Annual Average of Daily Rates for Drafts and Cheques. Buying Rates for United States Dollars, Selling Rates for Rupecs.)

\begin{tabular}{|c|c|c|c|}
\hline Dare & $\begin{array}{l}\text { Afghanis to } \\
\text { the Dollar }\end{array}$ & $\begin{array}{l}\text { Afghanis to } \\
10 \text { Indian Rupees }\end{array}$ & $\begin{array}{c}\text { Aghanis "I" } \\
\text { 10 Pakistani Rupe'ss }\end{array}$ \\
\hline 1.329 & 39.0 & 73.2 & 78.4 \\
\hline 1330 & 35.0 & 68.1 & 71.8 \\
\hline 1331 & 37.0 & 71.2 & 70.2 \\
\hline 1332 & 37.1 & 72.6 & 62.1 \\
\hline 1333 & 42.1 & 82.2 & 64.3 \\
\hline 13134 & 45.2 & 91.3 & 75.0 \\
\hline 1335 & 51.8 & 106.0 & 76.2 \\
\hline 1336 & 54.1 & 98.7 & 69.5 \\
\hline 1337 & 54.7 & 101.5 & 71.3 \\
\hline 1338 & 46.6 & 81.5 & 61.4 \\
\hline 1339 & 40.8 & 66.1 & 54.6 \\
\hline 1340 & 43.5 & 65.5 & 56.6 \\
\hline 1341 & 52.8 & 74.9 & 67.0 \\
\hline 134 & 51.3 & 74.0 & 66.3 \\
\hline 1.143 & 63.6 & 78.3 & 72.3 \\
\hline 1344 & 75.3 & 79.5 & 88.8 \\
\hline 1.345 & 76.4 & 69.1 & 89.5 \\
\hline 1.346 & 76.4 & 67.5 & 87.0 \\
\hline 1347 & 74.8 & 71.4 & 84.0 \\
\hline 1348 & 75.4 & 67.3 & 77.3 \\
\hline 1349 & 84.8 & 64.7 & 78.3 \\
\hline 1350 & 84.6 & 67.5 & 76.9 \\
\hline 1351 & 79.4 & 74.2 & 69.0 \\
\hline
\end{tabular}

Sulce: Research IRepartment, Da Afghanistan Bank.

nany underdeveloped countries. As ir all cases, the exchange rate is prinurily determined by relative prices which in turn are largely dependent on changes in the money stock.

Rates vis-d-vis the Indian and Pakistani Rupee are of some interest, particularly since 1344 (1965). The Afghani has appreciated substantially against both currencies. The modified purchasing power parily index for Afghanistan gives a 32.6 per cent price rise compared to 44.2 per cent in India and 34.2 per cent in Pakistan. Afghanistan's terms of trade have also improved substantially over this period. Furthermore, price controls in Indiat and Pakistan have doubtless had a depressing effect on their indices.

$A$ detililed investigation into the lagged response of the exchange rate to changes in the money stock has been conducted using the following relationships:

$$
\begin{aligned}
& \Delta \log E R_{1}=a_{0}+a_{1} \Delta \log N_{1} \ldots n \\
& \Delta \operatorname{logER} R_{t}=a, \Delta \log M_{1} \ldots n \\
& \Delta \log E R_{1}=a_{0}+\text { at } \Delta \log M_{1-n}+a_{2} \Delta \log L_{t-n} \\
& \operatorname{Jlog} E R_{1} \quad \text { an } \Delta \log M_{1} \text { on }+ \text { ia: } \Delta \log L_{1-n} \\
& J \log E R_{1}=a_{n}+a_{i} \Delta \log B C_{1} n \\
& \left.\Delta \log I: R_{1} \quad \text { an } \operatorname{slog} 1\right) ; \text {; }
\end{aligned}
$$

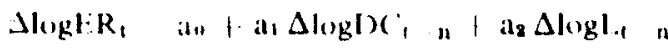

$$
\begin{aligned}
& \Delta \log E R_{\mathfrak{l}}: \text { at } \Delta \log D C_{1} \text { " }+a_{2} \Delta \log L_{t-n}
\end{aligned}
$$

where ER is the Aighani/Dollar exchange rate. $M$ the money stock, $L$ international liyuidity and DC domestic credit. " $t$ " represents the date and " $n$ " the number of nunths lag. The lagged response was tested for each month between 0 and 23. M, L and DC are mid-year estimates calculated by taking the average beginning and end of year figures. The exchange rate is the average over twelve month periods of the monthly averages of ditily bazilar rates given in Appendix D. By taking the 12 alternative annuil periods and a one year shift in the annual data, 24 possible lags were tested. Only Equations 7.1 and 7.2 gave good results. Domestic credit and international liquidity did not produce satisfactory results. Quite predictiably, good results were not found using the Rupee rates in the same cuuations.

The average lag between changes in the moncy stock and changes in the Afghani/Dollar exchange rate has been investigated in some detail. Results of the regression analysis are presented in Tables 7.14 and 7.15. It can be seen that for one. two and three ycar moving averages the lag which produces the highest adjusted coefficient of determination, $\bar{R}^{2}$, is seven months, whether or not a constiant is included in the regression. As the " $t$ " valuc win the constant term was significant, its suppression in the equation used in Table 7.15 constrains the regression estimate. Theoretically this mitkes the coefticient of determination meaningless. However. as the value or the constant is so close to zero, no great dimage is done in interpreting the results in the usual wily. The omission of the constant is justified on thenretical grounds in thit its inclusion in a regression of 
Tahls: 7.14

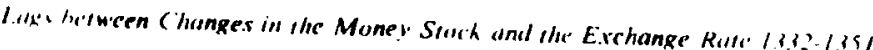
$\perp \operatorname{logER}_{\mathrm{t}}=a_{n}+a_{1} d \log M_{t}$

\begin{tabular}{|c|c|c|c|c|c|c|c|c|c|}
\hline \multirow{2}{*}{$\begin{array}{l}\text { lack in } \\
\text { lonths }\end{array}$} & \multicolumn{3}{|c|}{ Annusal Averagi" } & \multicolumn{3}{|c|}{$\begin{array}{l}\text { Two Veror Moving } \\
\text { Aleruge }\end{array}$} & \multicolumn{3}{|c|}{$\begin{array}{c}\text { Thete liour Mturing } \\
\text { ferage' }\end{array}$} \\
\hline & $a_{0}$ & $\mathbf{a}_{1}$ & $\mathbf{R}^{2}$ & $a_{n}$ & $a_{1}$ & $R^{2}$ & $a_{n}$ & $a_{1}$ & $R^{2}$ \\
\hline 0 & 0.03 & 0.66 & 0.23 & -0.03 & 0.73 & 0.41 & -0.04 & 0.88 & 0.58 \\
\hline 1 & 0.03 & 0.70 & 0.27 & -0.03 & 0.77 & 0.46 & -0.05 & 0.91 & 0.63 \\
\hline 2 & 0.03 & 0.73 & 0.31 & -0.04 & 0.79 & 0.50 & 0.05 & 0.43 & 0.68 \\
\hline 3 & 0.04 & 0.76 & 0.34 & 0.04 & 0.83 & $0 . \$ 4$ & 0.05 & $0 . \%$ & 0.71 \\
\hline 4 & 0.04 & $0.7 \mathrm{~K}$ & 0.14 & 0.04 & $0 \times 5$ & תצ ו) & $0.0 \%$ & 0.137 & 0.75 \\
\hline 5 & 0.04 & 0181 & 0.42 & 0.05 & 0.87 & 0.61 & 0.06 & 'איא & $0.7 k$ \\
\hline 6 & 0.05 & 0.63 & 0.43 & 0.05 & $0.8 x$ & 0.64 & 0.061 & $0.9 x$ & 0.80 \\
\hline 7 & 0.0 .5 & 0.84 & 0.44 & -0.05 & 0.89 & 0.65 & -0.06 & 0.48 & $0.8 \% 1$ \\
\hline 8 & 0.05 & 0.84 & 0.4 .3 & -0.05 & 0.89 & 0.65 & 0.06 & 0.47 & 0.80 \\
\hline " & 0.05 & 0.84 & 0.40 & 0.05 & 0.89 & 0.63 & 0.06 & 0.97 & 0.74 \\
\hline 10 & 0.05 & 0.82 & 0.37 & -0.05 & 0.88 & 0.61 & -0.06 & 0.46 & 0.78 \\
\hline 11 & 0.05 & 0.81 & 0.36 & -0.05 & 0.87 & 0.59 & $0.0 h$ & 0105 & 0.77 \\
\hline 12 & 0.03 & 0.72 & 0.20 & -0.04 & 0.85 & $0.5 k$ & $-0.0 \mathrm{G}$ & (1) & 0.77 \\
\hline 11 & 0.03 & 0.71 & 0.29 & -0.04 & 0.14 & 0.57 & -0.06 & 10.44 & 0.75 \\
\hline 14 & 0.03 & 0.70 & 0.24 & -0.04 & 0.8 .3 & 0.55 & -0.05 & 0.42 & 0.73 \\
\hline 15 & 0.03 & 0.70 & 0.24 & -0.04 & 0.81 & 0.52 & -0.05 & 0.01 & 10.70 \\
\hline 16 & 0.03 & 0.68 & 0.29 & -0.04 & 0.79 & $0.50)$ & 0.05 & 0.67 & 0. 66 \\
\hline 17 & 0.03 & 0.66 & 0.27 & -0.04 & 0.76 & 0.46 & 0.05 & 0.84 & 0.62 \\
\hline 1.8 & 0.03 & 0.65 & 0.25 & -0.03 & 0.74 & 0.42 & -0.04 & 0.80 & 0.57 \\
\hline 14 & 0.83 & 0.63 & 0.23 & -0.03 & 0.71 & 0.34 & 0.04 & 0.77 & 0.52 \\
\hline 20 & 0.02 & 0.61 & 0.20 & -0.03 & $0.6 k$ & 0.34 & 0.04 & 0.73 & 0.16 \\
\hline 21 & 0.02 & 0.60 & 0.18 & -0.03 & 0.65 & 0.31 & -0.03 & 0.64 & 0.42 \\
\hline 22 & 0.02 & 0.58 & 0.15 & -0.02 & 0.62 & 0.26 & -0.03 & 0.66 & 0.37 \\
\hline 23 & 0.62 & 0.55 & 0.13 & -0.02 & 0.58 & 0.22 & -0.03 & 0.62 & 0.31 \\
\hline
\end{tabular}

first diflerences is the equivalent of inserting a time trend variable in the equation relating the absolute levels of the same variables. Exclusion of such a lime trend variable enables a better test of the particular behavioural relationship postulated. For forecisting purposes, its inclusiom is iustilical if better results are thereby obtained.

The revults indicate a highly significant relationship. For time seric: allilysis conducted in central differences of the logarithmic values of the virrables. the coeflicients of determination, are relatively high for all cises using the seven month lag. Predictably, results are improved by taking twa and three year moving averages thus dampening the eflects of randiom fictors such as burder elosures, agricultural fluctuation. etc. ratc by cxplanation of the variation in the rate of change of the cxchange ratc by changes in the money stock rises from 44 to 80 per cent by taking threc year moving averages instead of simple annual data.
Tuble : Is

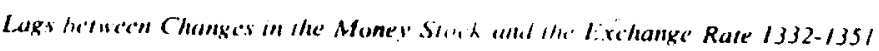
JlogER :- in, Jloggh, "

\begin{tabular}{|c|c|c|c|c|c|c|c|}
\hline \multirow{2}{*}{$\begin{array}{l}\text { l.cus in } \\
\text {. Womths }\end{array}$} & \multirow{2}{*}{$\begin{array}{c}\text { Immonl } \\
i_{1}\end{array}$} & \multirow{2}{*}{$\begin{array}{c}\text { Herake } \\
\mathrm{R}^{2}\end{array}$} & \multicolumn{2}{|c|}{ 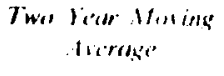 } & & \multicolumn{2}{|c|}{$\begin{array}{c}\text { Three Year Moving } \\
\text { Alerage }\end{array}$} \\
\hline & & & $a_{1}$ & $R^{2}$ & & $\mathbf{a}_{\mathbf{1}}$ & $\mathrm{R}^{2}$ \\
\hline 0 & 052 & 0.26 & 0.54 & 0.40 & & 0.56 & 0.49 \\
\hline 1 & 0.53 & $0.2 x$ & 0.55 & 0.43 & & 0.56 & 0.52 \\
\hline 2 & 0.54 & 0.31 & 0.55 & 0.46 & & 0.56 & 0.54 \\
\hline 3 & (1) 44 & 0.33 & 050 & $0.4 x$ & & 0.56 & 0.56 \\
\hline 4 & 11.25 & 0.36 & 11: i7 & 1151 & & 0.56 & 0.58 \\
\hline 5 & 0.56 & 0.38 & 0.57 & 0.53 & . & 0.56 & $0.60)$ \\
\hline 6 & 0,56 & 0.34 & $11.5 x$ & 11.54 & & 0.56 & 0.60 \\
\hline 7 & 1).56 & 11.34 & 11.57 & 0.54 & & 0.56 & 1.60 \\
\hline$x$ & 0.55 & 0.37 & 0.57 & 0.54 & & 0.55 & 0.60 \\
\hline 4 & 0.54 & 0.35 & 0.50 & 10.52 & & 0.54 & 0.59 \\
\hline 10 & 0.53 & 0.32 & 0.55 & 1.50 & & 0.54 & 0.58 \\
\hline 11 & $0 \leqslant 2$ & 0.32 & 0.54 & 11.48 & & 0.53 & 0.57 \\
\hline 12 & 0.55 & 0.30 & $0 \leq 7$ & $0<1$ & & 0.56 & $c_{60}$ \\
\hline 1.3 & 0.94 & 0.30 & 0.56 & 0.50 & & 0.55 & 0.59 \\
\hline 14 & 053 & 0.30 & 0.56 & 0.45 & & 0.54 & 0.57 \\
\hline 15 & 1153 & 0.30 & 0.55 & 0.47 & & 0.53 & 0.55 \\
\hline 16 & 1152 & 0.30 & 0.54 & 0.45 & & 0.52 & 0.53 \\
\hline 17 & 0.51 & $0.2 x$ & 0.53 & 0.42 & & 0.51 & 0.51 \\
\hline 14 & 0.44 & 0.26 & 0.52 & 040 & & 0.50 & 0.48 \\
\hline 14 & 0.46 & 0.25 & 0.51 & 0.37 & $\because$ & 0.48 & 0.45 \\
\hline 20 & 0.47 & 0.23 & 0.44 & 0.34 & & 0.47 & 0.41 \\
\hline 21 & 0.46 & 0.21 & 0.48 & 0.31 & & 0.45 & 0.38 \\
\hline$\because 2$ & 0.44 & 0.19 & 0.46 & $0.2 x$ & & 0.44 & 0.35 \\
\hline 23 & 0.4 .1 & 0.17 & 0.44 & 0.25 & & 0.42 & 0.31 \\
\hline
\end{tabular}

The results obtained from the three year moving average regression analysis warant more attention. Therefore, the complete set of results from the revil month lag equation is shown below:

$$
\begin{aligned}
& \Delta \text { log! I } R_{1} \quad-0.0579 \text {;- } 0.9805 \Delta \log M_{1} ; \quad \bar{R}^{2} \cdot 0.8031 \\
& \text { “" } \quad(-4.021 .4)(7.8 \times 04) \quad \text { SEL }=0.0009 \\
& \text { is } \quad 0 \quad 8.3253 \quad \text { DW }=1.0076
\end{aligned}
$$

where $\bar{R}^{2}$ W the coellicient of determination, SEE the standard crror of the estimat: $B W$ the Durbin-Watson statistic and $\beta$ the beta coefficient. The eorellicien! w determination gives a " 1 " vilue of 7.5575 which is significant well over the 449 per cent confidence level

Eutation 7 indicates that in the absence of any change in the money slock the exhatige rate would appreciate by 5.79 per cent annually. An 
increalse in the money stock of 10 per cent depreciates the exchange rate hy 9.8 per cent. To have maintained a stable Afghani/Dollar exchange rate wer the period 1332-1351 (1953-1972), the money stock would have had (1) have been increased annuaily by 5.91 per cent. This would. of cuurse, still have produced inflation roughly similar to that experienced hy the $I$ I.S.A.

Alghinisian's terms of trade improved dramatically during the 1340 s $(1960)$. I Iansen has calculated that the income terms of trade improved hy ahout 85 per cent between 1338 (1959) and 1347 (1968) [U3. p. 37] 11 is ligures are reproduced in Table 7.16 below.

Table 7.16

Cimmundity and Income Terms of Track 1338-1347

\begin{tabular}{ccc}
\hline Dase & $\begin{array}{c}\text { Commodity Terms } \\
\text { of Tradc }\end{array}$ & $\begin{array}{c}\text { Income Terms } \\
\text { of Traik }\end{array}$ \\
\hline 1338 & 94.1 & 10.3 .8 \\
1339 & 112.2 & 98.0 \\
1340 & 100.0 & 100.0 \\
1341 & 107.8 & 112.2 \\
1342 & 116.6 & 137.0 \\
1343 & 118.6 & 146.1 \\
1.44 & 143.0 & 166.4 \\
1.345 & 118.0 & 15.3 \\
1346 & 165.2 & 177.1 \\
1.147 & 169.1 & 191.8 \\
\hline
\end{tabular}

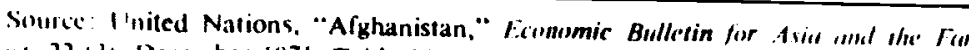
Iinl. 2213 . December 1971. Table 14, p. 37.

If the clasticity of demand for imports were assumed to be 0.8 [114, p. 189]. an improvement in the terms of trade, which makes inports cheaper rilative to exports, would result in currency apprcitition. In pitrticular. an 85 per cent improvement in the income terms of trade would increase the demand for imports by 68 per cent. To equalle demand and supply of foreign exchange, the Afghani would have to appreciate by 11 per cent. This is equivalent to an annual rate of appreciation of 1.2 per cent. This in part explains why the money stock could have been expanded at a considerably faster rate than the real growth rate without deprecialting the Afghani over this period.

llie hroid trends in the exchange rate seem convincingly cuplained by macments in the money stock. However, a number of ohscrvers have anilysed shorter run movements in the light of a number of other ficurs. Ior example. the depreciation from Aqrab 1334 (1955) to Jauza
1335 (195(1) has been explained both with reference to an excessive monetary expansion in 1333 (1954) and an embargo on trade through Pakistan in 1334 (1955). When this was lifted there was a rush to import.

A major fluctuation took place in the second half of 1341 (1962) when the Afghani appreciated from Afs 56 to $A f s 46$ to the Dollar. This was apparently the esult of an expectation thitt an official devaluation would take place combined with an attempt to calluse an appreciation of the bazalar rate to narrow the gap. The appreciation was calused by a temporary capital inflow [H1, p. V1-32]. The second measure was not taken and even before the devaluation from Afs 20 to Afis 45 to the Dollat in 1342 $(1963)$ the bilatilr rate had again depreciated to $\mathrm{Al}$ is 55 to the Doilar.

During :he last quarter of 1344 (1966) the Afghani again underwent a considerable lluctuation. The depreciation of the Afghani from Afs 74 to Afs 82 (1) he Dollar was reportedly due to a large capital outflow to India. Thi, outllow resulted from the National Defence Remittance Scheme af November 196,5 which was designed to attract convertible currency held by Indians ahroad. The Scheme was abolished in May 1906 and the capital flow was reversed. This contributed to the appreciation of the Alghini in 1345 (1966)

The deprecitition in the second half of 1346 (1967) seems to have been the resul, at several factors, namety, poor karakul and rug earnings, large pux hases of foreign exchange by Bank Millie and the provision of import ficibtic by Da Afghanistan Bank [PR].

Da Afghanistan Bank has at tines played an important role in the exchange market. The Bank has followed the widely held belief that currency depreciation or devaluation is bad and should be avoided. The Bank supported the exchange rate by selling forcign exchange extensively during llac period $133 \times-1,340$ (1959-1961) and continued to do so thereafter, Ilwaer, suce 1344 (1965). Da Afghanistan Bank has maintained its rate whin $\mathrm{Al}$ lis 2 of the bazaar rate. although as the largest dealer it can inlluence substantially the bazaar rate. Attempts to even out seasonal fluctuillons were started in $1348(1969)$ hut a limit on reserve losses has been estabished.

Table 717 shows the differentual hetween the selling rates for Dollars in the Salny Shorda and Da Alghamistan Bank for the last Tuesday of each mumlly for the period 1.34-1.350 (190.5-1971). Da Afghanistan Bank appers wo have followed the hatatr rate with a slight lag. Hence. positive dillerentials are greatesl when the Afghani is depreciating. negative differentials greatest when the Afghani is appreciating. If Da Afghanistan Bank ucre prepared $W$ buy and sell unlimited quantities of foreign 
Whange (which, in fact, it is not) at its yuoted rates, arbitrage would generally be profitable when the positive differential exceeded 50 Puls. When the rate is fluctuating erratically, the differential between buying and selling rates in the bazaar rises from the normal spread of 50 Puls to Atis I. At these times, arbitrage would only be profitable when the positive dillerential exceeded $A f s$.

Tahk 7.17

Ditfersmical between Dollar Cash Selling Rates in the Kabul Mone.' Bazusur und Da Afrenanistun Bank for the Last Tuesda, of Each Month. $1344-1.391)$ (Afuhanis Positive figure implies hazaar rale is higher than Da Afghanistin Bank rate)

\begin{tabular}{|c|c|c|c|c|c|c|c|}
\hline 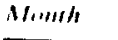 & 1344 & 1345 & 1346 & 1.147 & 1348 & 1.144 & 1350 \\
\hline $\mid$ |:1111,1| & $(1.0)$ & 1.75 & 1.00 & 0.75 & 0.75 & 0.45 & 1.80 \\
\hline Situin & 3.50 & 0.75 & 1.00 & 0.25 & 0.25 & 1.50 & 1.50 \\
\hline J.111/.1 & 2.00 & 1.13 & 1.00 & 0.25 & 0.25 & 0.50 & 2.00 \\
\hline S:11.11.11) & 1.75 & 1.20 & 1.30 & 0.25 & 0.25 & $i(0)$ & 2.00 \\
\hline Asitl & 0.50 & 1.80 & -0.50 & 0.25 & -0.75 & 0.25 & 1.00 \\
\hline Siunbula & 1.25 & 2.00 & -0.50 & 1.00 & 1.50 & 0.50 & 0.50 \\
\hline $\mathrm{Ml} / \mathrm{sn}$ & 2.00 & 3.00 & -1.50 & 0.70 & 0 & 0.50 & $2 .(x)$ \\
\hline Aulal & 2.00 & 2.0 .5 & 1.00 & 1.00 & 0 & 0.50 & 040 \\
\hline Q:alus & 2.00 & 1.30 & 0 & 0.75 & 0. .50 & 1.50 & 0.50 \\
\hline Jali & 2.50 & 1.75 & 1.50 & 0.25 & 0.75 & 2.50 & 1.50 \\
\hline Dalust & 3.50 & 2.00 & 0 & 0.75 & 0 & 3.00 & 1.00 \\
\hline Howet & 1.75 & 1.25 & 1.25 & 0.25 & 0.50 & 2.00 & -1.50 \\
\hline
\end{tabular}

Siurce: Ressarch Department, Da Afghanistan Bank.

1)a Alghanistan Bank always maintains a differential of 50 Puls. Therefore, arbitrage would always be profitable when a negative differential cuceded 50 Puk. From Table 7.17 it can be seen that buying lureign exchinge from Da Afghanistan Bank to sell in the bazatar is morc ircquently prolitable than vice versa. However, since foreign exchange is not freely sold by Dat Afghanistan Bank the more interesting case is when a negative diflerential implies that Da Afghanistan Bank is a buyer from the bizalar. Thus it in in the middic of the year when from Figure 7.1 it can be seen that the Alghani is usually at its most appreciated.

Having explained over three-quarters of the fluctuations in the annual average exchange raites by changes in the money supply, monthly fluctuations now require some attention. It generally appears that the Afghani is terongest in the third quarter of the year and weakest in the first, as is shown clearly in Figure 7.I.

The explanation for the seasonal fluctuations lies primarily in the seasonal pattern of exports. As an agriculturally based economy,
Mghanistan exponts naturally vary 11 accordance with the seasons. Ruad conditions are also important in this respect. However. this is partially dampened by the surrender requirements on foreign exchange carnings from itton, karakul and wool. With the exception of carpets and gas. all major exports are agricultural products. Monthly export figures for 1.344-1350 (1965-1971) are shown in Table 7.18 below. Their relationship with seasonal movements in the exchange rate is shown in Figure 7.2. Although monthly exports vary quite erratically a scasonal pattern niirroring the seasonal exchange rate movement can be detecied.

liwh 7.1 .1

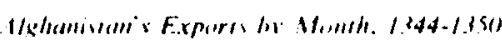
(Thousind of I Jullars)

\begin{tabular}{|c|c|c|c|c|c|c|c|}
\hline Mtonth & 1.144 & 1.145 & 1.340 & 1.167 & $1.14 x$ & 1.349 & 1350 \\
\hline Ilamal & 5.170 & 3.287 & $3.1 \% 0$ & $3.9 ! 4$ & 2.020 & 4.449 & 7,447 \\
\hline Saur & $5.34\}$ & 4,624 & 2.254 & 1.945 & 2.683 & 1.601 & 4.811 \\
\hline Jauza & $3 x+7$ & 5,434 & $1,6.37$ & 2.506 & 2.358 & 2.527 & 5.248 \\
\hline Saratan & 2.066 & 2,842 & 1.623 & 2.203 & $4.10 x$ & 3,850 & 6.906 \\
\hline Asad & 2.635 & 5.907 & 5.074 & $4,4(4)$ & 9.826 & $8.24 K$ & 10,565 \\
\hline Sunbula & 4.394 & 7.034 & 7.066 & 4.354 & $8.1 \mathrm{k.7}$ & 6,256 & 8.785 \\
\hline M:zan & 7,233 & $x .1 \% 6$ & 10.422 & 12,856 & 13.529 & 10,441 & 10,278 \\
\hline Aqrab & 10,445 & 6.177 & 13.063 & 5,428 & 10.321 & 6.170 & 6,410 \\
\hline (Qiuus & 11,547 & $5.2 \times 3$ & 6,815 & 3,442 & 6,788 & 5,254 & 5.777 \\
\hline dadi & 0,774 & +.612 & $3 .(11 \%)$ & 3,814 & 3.163 & 10.574 & 6.047 \\
\hline D:alwa & 4,310 & 5,587 & $7.14 \times$ & $5,40.1$ & 3.025 & 6.517 & 2,695 \\
\hline Hind & $(3.200)$ & 4,399 & $2 . \times 012$ & $2.6 \mathrm{hk}$ & 4.019 & 5.241 & 3,335 \\
\hline Tutal & 64.974 & (H.687 & 63,440 & $5 \times .575$ & 64,957 & $71,1 \times 3$ & $78,35.4$ \\
\hline
\end{tabular}

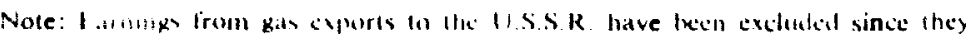
were recorded an the last nombli ul the year

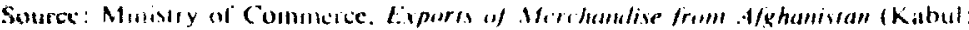

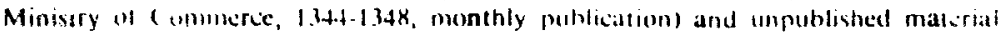
irom the Mlunsty of Commetce.

For chetring Dollars, there is also a seatsonal swing caused by the fact that consumer loan funds are generally in largest supply at the beginning of the yeitr. At that time the Afghani appreciates. Towards the end of 1351 (Match 1973) the clearing Dollar ratc for Russian trade stood at Alis 82 to the clearing Dollar. In the third month of 1.352 (May 1973) it had appreciated to Afs 72 to the clearing Dollatr.

The sciuonal nature of Afghanistan's exports and the resulting effect (n) the exchange ralle has been given some consideration by those who 


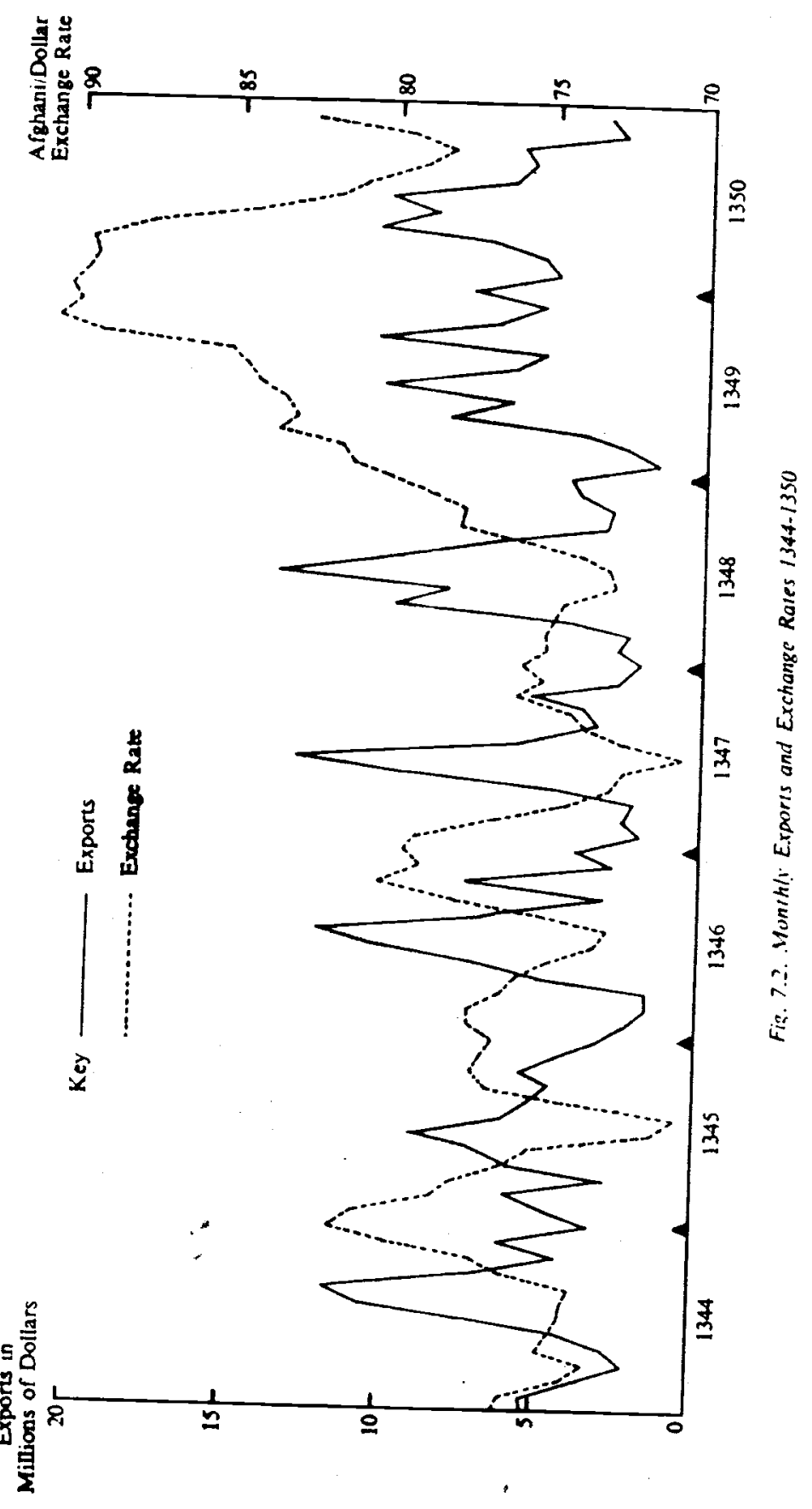

would prefer a tixed exchange rate system which would hold the rate down at export lime and up at other limes of the year, thus favouring exporters:

... transfer possibilities for amounts resulting from selling in Pakistan are made on the basis of at kind of liberalised barter. The grapes are paid for in the wholesale market of Pahistan with Pakistan Rupees. The Rupees are bought hy Afghan importers in Kabul from the grape exporter. During the tible plape season the offers "if Pakistan Rupees are considerable, because the grape export is very high compared with other produce exports ind concentrated in S.pumber October. These high offers in Rupecis caluse tow exchange rates for Afyhanis. During February/March, exchange rattes for Rupees Afghanis alc generally $25^{\prime}$; higher and it is thus wou thwhile to sell the Rupees during l ebruary/March. The competing middlemen are taking advantage of this possibility and the cooperative should also have the possibility of credit is get the same advantages for the exports of its nembers. [PI], p. 42]

Table 7.19 presents the results of calculations of the return to holding foreign exchunge over a four month period of each year during which seasonal depreciation is generally most pronounced. The average equivalene ellective annual return ranges from 22 to 27 per cent depending on which currency is held over the period. It should be noted, however, that speculation of this kind is subject to considerable risk as shown by the relatively ligh standard deviations. Thus, these returns cannot be used as a proxy firr the pure rate of interest or at a measure of social time preference. As mentioncd atove, returns from trade and interest rates for fureign trituc linance appear to be considerably lower than these speculative return. Nevertheless, a case can be made for intervention by Da Afghanistin Bank to smuoth out seasonal fluctuations. If it is assumed that society's time preference is lower than individuals' time preference, intervention which effectively reduced returns from seasonal foreign exchange speculation to a level reflecting the society's time preference would be justified. Given the high risk elenent, however, this might only imply reduing fluctuations to provide an average effective annual return of arrund 15 per cent or so.

\section{vi. Conclusion}

The matterial presented in this chapter suggests that the foreign exchange dealers in the Kabul and Kandahar money bazaars have played an important role in Afghanistan's foreign trade. Although foreign exchange surrender requirements provide Da Afghanistan Bank with a monopoly over export earnings of about $\$ 40$ million a year, as do the barter 
Rerurns frum Seasumul Foreign Exchunce Speculatiun, 13.32-1.151

iPercentage Returns from Holding Foreign Exchange from Mi

Year, i.e. Returns over a hiur Mo from Mizan to Dalwa of Each

\begin{tabular}{|c|c|c|c|c|}
\hline murc & Dolllar & Indian Ruper & Pukissuni Rupere & \\
\hline 1112 & 8.57 & 7.18 & 2.76 & \\
\hline 113 & 6.10 & 12.07 & 19.11 & \\
\hline 1334 & 23.36 & 18.41 & 11.27 & \\
\hline 1335 & 5.12 & 8.70 & 5.84 & \\
\hline 1116 & 7.0 .3 & 17.87 & 12.79 & \\
\hline 1137 & 1.12 & 6.21 & 1151 & \\
\hline $113 x$ & $4+11$ & 5.67 & 0.17 & \\
\hline 14114 & 8.12 & 1.50 & 0,95 & \\
\hline 14.41 & 4.55 & 1.08 & 8.90 & \\
\hline $\mid 141$ & 0.00 & 25.98 & 10.56 & \\
\hline 142 & 11.29 & 7.8 .3 & $8.2 x$ & \\
\hline 11.11 & 11.37 & 6.22 & 16.22 & \\
\hline 11: & 311 & 10.20 & 3.71 & \\
\hline 11.15 & 7.48 & 3.59 & 4.4 & \\
\hline 1346 & 9.55 & 15.37 & $x \times 7$ & \\
\hline 13.47 & 7.65 & 10.98 & 2.74 & \\
\hline $114 x$ & 6.44 & 4.95 & 4.45 & \\
\hline 11.61 & 7.54 & 11.31 & 65 & \\
\hline $13: 1$ & 2.80 & 4.81 & 1.6 .1 & \\
\hline 1.151 & 0.1 .1 & 5.84 & 0.45 & \\
\hline Arerilgs: & & & & \\
\hline $\begin{array}{l}\text { Retwen } \\
\text { Standind }\end{array}$ & 6.12 & 8.27 & 7.14 & \\
\hline 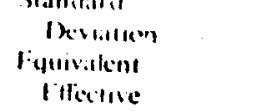 & 5.49 & 7.59 & 517 & \\
\hline $\begin{array}{l}\text { Iffechlse } \\
\text { Ammual Return }\end{array}$ & 21.89 & 26.93 & $23.6^{\prime \prime}$ & \\
\hline
\end{tabular}

arrangemints over a further $\$ 68$ million, healthy competition his existed between banks and bazaar for all other foreign trade transactions. The liberalisaltion of foreign trade over the past seven years has increased this competition and reduced profits. This, in turn, has provided a small

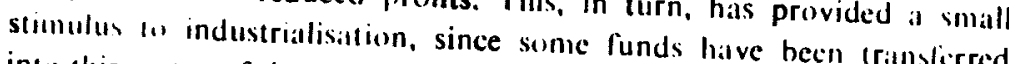
into this sector of the economy from trade.

An appriciating currency and indications of a number of new export possibilitien (in particular cotton fabric and wheat) provide an ideal opportumily to perniti banks to engage in all forms of foreign exchange transiletions and to establish clearly the legal position of the fureign exchinge dealers. In fact, the recent Cabinet policy statement on the bat exlaw, cirrical in the Kabul Times, 6 June policy statement on the hanking 6 June 1973, made provision for both [CI]. This, logether with tariff reform and direct export promotion measures such as the provision of a market intelligence service, demonstration of yuality control, standardisation and packaging techniques, are the essential ingredients of an export promotion programme which will be required if any increase in Afghanistan's development potential is to be realisul

Appindix -1

Foreign Evahunge Reguiations in Afghanistan Decree No. 26.32

$$
1.329(1951)
$$

In ordes lo regitlate and hillance the exports and imports of the country and wa the rate of alghani agaims lorcign currencies, the following rules are approued:

Aricicle |

Buying allu! xelling of foreign currencies, ramsior of lurcign currencies 11) ather comntries, logether with all transitctions related thereto, are striclly prohibited in Afghanistan except in accordance with the following rules and rivilations.

Arricle?

All foremg currencies carned through the export of goods shall be surrendered after deducting all expenses to Da Afghanistan Bank and sold against alghanis according to the fillowing rules.

a. The council of Ministers shall fix, according to proposals made by the Supreme Council of Da Afghanistan Bank, the percentage of all foreign currencies carned through the export of merchandise to be surrendered w the Bank.

b. Fixing and altering the afghani rates for buying and selling of foreign currencies is the prerogative of the Council of Ministers which shall act according 1 , the country coonomic and monetary needs. Arivile 3

The forelgn excliange needed by the jovernment, according to the budget, prepiared hy the Ministry of Finance and approved by the council of Ministers and other litwiul bodies, shall be provided by Dat Afghanistan Bank.

Ariinl' 4

Economic projects needing foreign exchange proposed by national institutions of Ciovernment departments shill tirst be submitted to the 
Ministry of National Economy (functions of this Ministry were assumed in 19.56 by the Ministries of Planning and Commerce) and then to the Currency Commission for investigation. The Currency Commission shall be constituted according to Article 6 below. Proposals shall then be subnitted, after approval by the Foreign Currency Commission and the Supreme Council of Da Afghanistan Bank, to the Council of Ministers fior linal jecision.

Note: Government budgetary needs hall have first priority claim over the coullty's foreign exchange holdings. The next priority shall be for project under appruved development plans.

\section{Irrick .5}

The foreign exchange needs of productive institutions shall be referred lirst to the Ministry of National Economy. After approval of the Foreign Currency Commission and the Supreme Council of Da Alghanistan Bank. the sums assigned shall be paid to the designated institutions.

Voff: The foreign exchange needs of projects approved before this Act shall be payable after the consent of the Currency Commission and of the Supreme Council of Da Afghanistan Bank have been obtained.

Article' 6

The foreign Currency Commission shall be composed of five members, three of whom shall be appointed by the Finance Ministry, the Ministry of Nillional Economy and the Bank Milli respectively and the other two by Dal Afghanistan Bank. The rank of the representatives of the Ministries shall not be less than Deputy Minister and that of the Banks not less than Asistant President.

\section{Arricle 7}

Any surplus or deficit in foreign currencies referred to in Article 2 , both the total at the end of the year and amounts for individual projects, shall he reported by Da Afghanistan Bank to the Ministry of National Economy. The said Ministry shall be empowered to investigate the matter through the authorities concerned.

$$
\text { Arricle } 8
$$

The bilance between the foreign exchange earned through the export of merchandise and amounts surrendered to the Bank shall bc put freely used for merchants and firms earning it. Such balances shitl be used for importing needed goods into the country. In this case a guatrantee

shall be given (1) Da Aighimistan Banh that goods equal in value to the balance shall be impurted.

Note: The manner in which these guarintees shall be given, the mode of transfer and the waty in which the accounting shall be made shall be set out in detailid regulations prepared specitically lor the purpose by $\mathrm{Da}$ Afghanistan Bank.

Article 9

Every exporter shall be required either 10 import goods equal in value to a lixed perentage of the exported merchandice or to sell any excess foreign currellcy alt a specified rate to Dit Alghanistan Bank.

The percentage shall be lixed in accurdance with Article 2 of this Decree after deducting real business exponses from the sale price of the merchandis:.

Artidite 10

Each merchant's sale prices of exported merchandise and purchase prices of imported merchandise shall be calculated after deducting the real business expenses incurred.

Bills and invoices for exported and inported merchandise shall be subject lo invesigation by Da Afghanistall Bank. They shall be certified by the Bank's representatives according to the currency regulations in force.

\section{Arigle'll}

Merchanu or other individuals carning foreign exchange in ways other that through evorts shall be free to import goods to the amount of the exchunge callacl or sell it to the Bank or merchants guarantecing to import goods wo the sime anount.

\section{Aritive 12}

Persons wh: tratid to foreign countries for recreational, medical or oher necisary purposes shall be permitted to export goods to the value of uthe thuswand affhanis without glatrantecing to import goods for that amount.

Article 13

Fxport of $z^{2+a l}$ and silver shall be strictly prohibited without the written consent of thic Council of Ministers issued to the Customs through the Ministry of National Economy and subject to the formalities of the Customs. 
Tratvellers to or from Afghanistan shall be permitted to take out or bring in not more than five hundred afghanis in bank-notes.

Noll: Notes permitted to be taken out or brought in (up to the five t:undred afghanis allowed) shall be in (wo and five afghani bank-notes unly.

\section{Ariick 1.5}

Foreign subjects entering Afghanistan shall declare the foreign currency in their pussession to the ("ustoms Otlicers at the Alghan horder ...ul such aminunt hall he certilied in their passports. Foreigners wishillg to leave Aghanistan shall approach Da Afghanistan Bank to authorise deduction of the amount they have spent (according to their mode of living). They shall be allowed to take the rest of the above-mentioned currency out of the country with written permission.

Note: Those living in Afghanistan as guests or earning their living expense is the country shall be allowed to take with then the lotal they had imported.

Arriclic 16

1-oreigncrs having come to Afghanistan as employees shall he required (1) exchange at least $30 \%$ of their foreign currency income into afghanis at the fixed rate of exchange in Da Afghanistan Bank.

\section{Article 17}

Afghan uationals having to go to foreign countries for medical treatment shatl be permitted to buy foreign currency needed in conformity with approved regulations provided the necessity for their treatment abroidd is advised by the Ministry of Health.

\section{Arlisl: $/ 8$}

Dit Alghinistan Bank shall sell foreign currency at the Bank ralle when such currency is required for Afghan students studying abroad all their own or millional institutions' expense, provided such expenses shall be certified by the Ministry of fiducation and provided that such expenses shall not exced the expenses incurred hy government students abroid.

\section{Article 19}

Dit Afghanistan Bank shall sell foreign currency as needed to the Pilgrims of Haj and other Holy places after the approval of the Ministry

of Interior. HW. Ministry of National foonomy and the Currency Commission.

Note: Ihe (urrency Commission shall determine the amounts of foreign exchange needed for each pilgrim.

Article 20

Da Afghanistan Banh shall sell forcign eurrency at a fixed rate of exchlange 10 those buying professional and scientific books or magazines, with the comsent of the Currency Commission.

\section{Artic/l 21}

As an cecplun wh the foregoing artictes Dat Afghanistan Bank shall be empowered lacxport in bank-noles any lureign currency to be credited to its accounts abroid through any of its furcign dealers.

Travellers shall be permitted to export their foreign currency require-

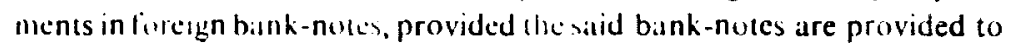
them by Dat Nghanistan Bank according to its rules and regulations.

\section{Irtick: $: 2$}

The publication of these rules shall autumatically render all previous rules and regulations regarding exchange invalid and abrogated.

Arricle 23

Da Afghinistan Bank shall be hercby authorised to apply these rules and made responsible for their application.

Da Afghtunistan Bank shall formulate its own internal regulations to carry out these rules and put them intu force.

$$
\text { Appomalix } B
$$

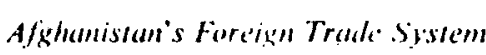

Itrom International Monetary Fund, 23rd Annual Report int Exhohnge Restricuions 1972. pp. 21-22]

\section{A. Exchatige Ratte System}

The par value is $0.0197+62 \mathrm{gram}$ of linc guld per Afghani. The Afghanistan Bank (the ceatral bank) charges commissions ranging from to of I per cent to ! of I per cent on exchange transactions. The Bank's whicial buyim: and selling rates for the U.S. dollar are Af 44.70 and Af 45.30. repuavely. The official sclling rate applies to certain foreign exchange paymuts by the Central (iowernment. The official buying rate applies to the priseceds of exports of karakul (which is exported only to the convertible currency area), wool (except cishmere wool exported to the convertible currency area), cotton, and natural gas (which is exported 
"Inly w the U.S.S.R.); to 30 per cent of the foreign currency viluries of linreign :mployees of the Government, government entcrprises, and domestic companies; and to purchases of bilateral agreement currencies lirr mamlenance in Afghanistan of embassies and state arading organizalions by the respective bilateral partner countries. Exchange subsidies are applied to the olficial buying rate as follows: Af 3 per USSI for export proceds irom cotton when payment is received under a bilateral payments agrement: Af 10 per USSI for proceeds in convertible currencies from exports of wool: Af 25 per US $\$ 1$ for proceeds in convertible currencies Irom exports of collon; and Af 20 per US\$I for proceeds from exports wharakul.

All wher transactions take place at free market rates through either the bank s or the bazaar; proceeds from the export of walnuts received over hilaltoral payments accounts are subject to an exchange tax of 9.5 per ‥th. The Afghanistan Bank maintains its operational free market selling rate for the U.S. dollar within Af 2.0 per US $\$ 1$ of the daily free narket rale quuled in the hazaar. On December 30, 1971, the free market rate of the Alghanistan Bank was Af 78.00 buying. and Af 78.50 selling, per I $S$ il. and the free market rate in the bazaar was Af 77.45 huying, and Af 77.95 selling. per US\$1. The Afghanistan Bank also posts iree market rates for deutsche mark. French francs, pounds sterling, and Swiss irancs, which rellect their relative values to the U.S. dollar in international markets, and free market rates for the Indian rupee and Pahistan rupee that are determined by demand and supply for the currencies comcerned. The Alghanistan Bank from time to time buys and sells in the frec market bilateral agreement dollars and bilateral agreement sterling resulting partly from loans for consumer goods under certain of Aighanistian's hilileral payments agreements; most of this exchange sold by the Bink is purchascd by government commercial and industrial enterprixcs for their imports liom the countries concerned. The selling rate for U.S.S.R. clearing dullars was $A f 6() .50$ per US\$I un December 30,1971 , and that for mainland China clearing sterling was Af $206.20 \mathrm{per}$ fstg.1. On the same datc, the selling rate for clearing dollars under the payments agreements with Bulgaria, Czechoslovakia, Poland and Yugoslavia was Af 55.50 per US\$:

\section{B. Administration of Control}

Forcign exchange is controlled by the Goverminent through the Afghanistan Bank. The control is facilitated by the existence of relatively large companies, some of them government owned or government controlled. specializing in the export of such commodities as karakul. cotton, Howl. athd carpets. However, these companies do not exercise at monopoly wer the export of such commenlities.

\section{(C. Presiripuinn of Currency}

Settlemcol, with countries with which Afghanistall has bilateral payments agreements (Bulgaria. matinland China. Czechoslovakia. Poland. II.S.S.R. and Yugoslavia. There is also at bilateral payments arrangentent with Indiat under which the bulk of trade is settled through it special account maintained in inconvertible Indian rupecs with the Reserve llawk of India.) must be mide in the loreign currencies specified in the agrecments. The proceeds from exports of karakul, wool and collon to ullec countries must be ohtained in convertible currencies. There are no wher prescription of currency requirements.

\section{1). Imports and lmport l'ayments}

Imports are not subject to license. Imports of a few items (e.g. some dratgs, liỵur, arms, and ammunition) are prohibited on public policy grounds ar lor security reasoms; in some instances, however, special permissinn an import these goods may be granted. The importation of certain oflicr goods (e.g. a lew textiles and selceted non-essential consumer gouds) alw in prohibited. There are nu quantilative restrictions on other imports. Ma.t bilateral agrecments. however, specify quotas (and sometares prices) lor commodities to be Iraded, and the Government facilitates the fulfillmeal of the commitments undertaten in the agreements. On the whole, trade wilh bilitcral agreement countries is carried out on a compensation basis and usually both imports and exports are arranged by the same llat' $r$; imports against exports of cotton and wool are carried but by the ciovermment and government agencies, or the proceeds of cxports are allocated for the Government's extcrnal debt servicing.

Exchange i provided at the oflicial rate tior imports by the Government. Payments for imports through the banking systen may be made only under letters of credit, against which a deposit of 100 per cent of the value of the imports in alghanis calculated at the prevaling free market rate, or in forcign exchange, is reyuired upon establishment of the letter of credit. Such depwils may he used as collateral w whtain loans from commercial banks. The dighanistan Bank is authoried to refuse to sell foreign exchange for the importition of a group of consumer goods that are regarded is non-essential. However, excltange for these items may be purchased ciller from the commercial banks or in the bazaar. 


\section{E. Payments for Invisibles}

(entral government payments for foreign debt service and other invisibles are malce at the ufficial rate. All other payments are seltled at free marhel rates. Travelers leaving Afghanistan may take out no more than $A f$ s $(x)$ in Afghau banknotes.

\section{F. Exports ind Export Proceeds}

lixports are not subject to license. Exports of a few commoditics (e.g upiun and muscum pieces) are prohibited. Otherwisc, control is exercised only ate exports to hilatcral agrecment countrics (sec section on luiports and Impurt Payments, above). However, exporters of colton ale required (1) well al ieast 20 per cent of their total exports to countries from which payments will be received in convertible currencies. Karakul is not exported to payments agreement countrics.

lixchange receipts from exports of karakul, wool. and collun must be surrendered at the oflicial rate. irrespective of destination. The net proced of all expurts other than karakul, wool and cotton. irrespective 11) the currency in which they accruc, must either be sold at free mirket ritles to a domestic bank or be used by the exporter or a third patrly w pay fire impurts.

Ixport receipts from colton are subject to an exchange subsidy at the rate of A 25 per USSI for convertible currency receipts and $A f 3$ per US if for exports settled under bilateral payments agreements. Collvertible currency reccipts from wool exports are paid an exchange subsidy at the ratle of $\mathrm{Al} 10 \mathrm{per}$ US\$I and those from karakul exports arc paid an cxchinge subsidy of Af 20 per US $\$ 1$.

Procects from the export of walnuts received over bilateral palyments accounts are subject to an exchange tax of 9.5 per cent.

\section{(i. Proceeds from Invisibles}

Thirly per cent of the forcign currency salaries of foreign employecs of the Alghall public and private sectors must be converted into alghanis at the official rate, but the remaining 70 per cent may be remitted abroad or exchanged at the ffec market rate. Except in the case of India, receipts wer bilateral payments agreement accounts from the embassics and statc trading organizations of the countries concerned for their local expenses in Afghanistan are converted at the oflicial ratc. NII other receipt from invisibles are sold at free market rates through cither the banks "r the bazalar. Travelers entering. Afghanistan maly bring in Aighan hanknotes not exceeding Af 500 .

\section{Capitit}

Forcign investment in Afghanistan requires prior approval and is administered, as is domestic private investment, by an Investment Committe componcd of five cabinet ministers. The Foreign and Domestic Private Investment Law (February 10, 1967) provides for a number of benefits, which include ( 1 ) income tax exempt on for five years, beginning from the datc of the first sales of products resulting from the new investment: (2) exemption from import duties on essential imports for tive consecutive years after approval of the investment; (3) exemption from taxes on dividends for five years after the tirst distribution of dividend: but not more than eight years affer the approval of the investment; (4) exemption from personal income tax and corporale tax on interest on foreign loams which constitute part of all approved investment; (5) exemption from export duties for len years after the approval of the investment; and (6) mandalory purchatses by government agencies and departments of their requirements from enterprises established under the law where such products are substantially competitive with imports in price and ylatily. The law also estiblishes that an investment approved by the Incilment (ommitlee shall require no further license to operate in Afghanivian.

Principil and interest installments on loans from abroald may be remitted freely 10 the extent of the legall othigation involved. Profits may he repatrialed freely, and capital may be repitriated after five years at an annual ratc bot exceeding 25 per cent of the total registered capital. Al! the foregoing trinsters are made through the free market. Joint ventures of foreign and $A$ lighan capital are cncouraged, but no specific percentages of domestic participation are prescribed and 100 per cent forcign-owned investmenls are nol precluded by law.

1. Gold

Resikena maly fredy import and purchase, hold, and sell domestically goild in any form. Exports of gold and silver in any form other than jewelry reyuire licenses issued by the Council of Ministers; such licenses are not mirmally granted except for exports by or on behalf of the monetary authuritics and industrial users. (immercial exports of gold and if fver jew. Iry and of other articles containing minor quantities of gold or silver do nol require a license and may be made frecly. Customs duties are payable on imports and exports of silver in any form, unless the inport or export is made hy or an behalf of the monctary authorities. The import duty on gold is I per cent. 


\section{Appondir C. Prohibited Trake}

Impors

Seditious or pornographic material

Poisons and drugs except by authorised pharmacists. etc

Firearms and weapons of war

Television

Castor-aiil

Iranian rugs and carpets

Silk turbilns and cotton clothes

Sesime and other oil secds

Silh cocouns excluding silk worms

Building wones

Various ‘kins, e.g. marten

Various hlankets and sheets made of cotton and rayon excludling woullen blankels

Various rugs, pillows, sheets (woollen or cotton pieces and prilyer rugs)

Alcoholic heverages except under special licence by representatives of
Metal furmulute excluding safes and drawers

Spring-netal beds rubber coated excluding rubber foilm which is used for car sealls

1)ried peis

Siraw products

Floor coscring made of cotton

Stone utensils (marble)

Wonden furniture

ciloured rilyon

Burliıp

(intorn thusidel

Lisports

Gold and sher

Alghanis 11 excess of $A l i s(x)$ per individual

Opium

Antique allake

Livestock

(irain

Appendix D. Fre' Market Doll:u :ut Rupee livhang' Rules

"Mazaar Rates' 13.12-1352

Tahle 7.211

Irre Afurke" Dollor Exchange Rates "Buzaar Rales" (13:2-135)

IMonthly Averalges of Daily Buying Rales for Drafts and ( heutues)

\begin{tabular}{|c|c|c|c|c|c|c|c|c|c|c|c|c|c|c|c|c|c|c|c|c|c|}
\hline Afrumbl & $1.3 ?$ & 133.1 & 1334 & 1.335 & 1.336 & 1.337 & 1.3 .38 & 1.1 .14 & 1340 & 1.141 & 1.14 .2 & 1.14 .1 & 1348 & 1.14 .5 & 1.346 & 1347 & 114.5 & 1349 & 1350 & 1.351 & 1352 \\
\hline Il:mbal & $m o$ & 39.8 & 41.3 & 51.8 & 53.3 & 56.2 & 51.1 & .13 .4 & 43.1 & 47.7 & s & 56.0 & 76.2 & 81.6 & 76.9 & 79.5 & 75.7 & 80.0 & 90.4 & $k+1$ & 69.5 \\
\hline Saur & $\ln 0$ & $41 . x$ & 42.2 & 56.0 & 53.4 & 58.6 & 50.6 & +3.3 & 42.2 & 51.8 & 51.11 & 57.2 & 70,0 & 80.9 & 77.3 & 79.1 & 75.0 & 81.3 & 89.9 & $k 2.9$ & 66. 6 \\
\hline Jawrat & $m 1$ & 41.8 & 42.4 & 57.6 & 55.3 & $(0) .0$ & 5.3 .9 & 40.1 & 42.0 & $5: .8$ & 90.6 & (9) 0 & 7.11 & $7 x .4$ & $77 . .1$ & 76.6 & 75.1 & 81.6 & 89.6 & $k 2.9$ & 62.8 \\
\hline Saratan & 4010 & 42.0 & 43.8 & 56.2 & 54.0 & 58.9 & 46.0 & $3 \times 6$ & 42.3 & 53.6 & 50.1 & 61.7 & 713 & 77.7 & 76.3 & 74.5 & 74.8 & 83.7 & 89.7 & 83.2 & 38.5 \\
\hline Asintil & $3 \times 0$ & 42.9 & 4.3 .2 & 55.9 & 53.5 & 56.1 & 44.6 & 40.0 & +2.0 & $\therefore 3.3$ & 50.0 & 61.2 & $74 \%$ & 76.2 & 75.4 & 73.0 & 74.5 & 83.2 & 87.8 & $k 1 . x$ & 60.0 \\
\hline Sunhula & 37.0 & 42.9 & 42.6 & 52.0 & 52.6 & 55.2 & 43.7 & 40.1 & 41.5 & 53.9 & 50.0 & 62.2 & 741 & 75.3 & 74.8 & 72.5 & $72 . k$ & K.3.5 & 84.6 & 77.9 & 58.4 \\
\hline Mirinl & 35.0 & 41.0 & 42.8 & 50.8 & 52.6 & 52.9 & 43.2 & 38.2 & 41.9 & 53.1 & 49.6 & 61,3 & 742 & 71.4 & 73.3 & 70.6 & 73.0 & 84.3 & 82.0 & 78.2 & 54.5 \\
\hline Ayrith & .35 .0 & 41.5 & 43.9 & 52.0 & 52.7 & 52.1 & 43.1 & 38.6 & 41.8 & 54.1 & 49.6 & 661.4 & 7.11 & 706 & 72.9 & 72.5 & 71.4 & 84.7 & 81.1 & 77.4 & 53.3 \\
\hline Qans & 39.11 & $42: 1$ & 45.8 & 53.0 & 53.7 & 52.2 & 46.7 & 39.7 & 45.1 & 55.7 & 506 & 65.8 & 71.9 & 742 & 75.0 & 73.7 & 75.8 & K5. 2 & 79.3 & 77.9 & 57.4 \\
\hline Jadi & 370 & 44.1 & 49.1 & 34.5 & $54, K$ & 50.5 & 49.2 & 435 & 46.6 & 55.2 & 52.2 & $6 \times .1$ & 76.1 & 76.7 & 77.9 & 74.2 & 77.8 & $s^{\prime}, 2$ & 78.3 & 78.3 & 59.9 \\
\hline Dalu: & $1 \times 10$ & 43.5 & 52.8 & 53.4 & 56.3 & 53.6 & 45.1 & +1.3 & +5.9 & 53.1 & 55.2 & 70.5 & 77.1 & 77.1 & 80.3 & 76.0 & 77.7 & 10.7 & 79.7 & $7 \times .1$ & 63.6 \\
\hline Honel & $.8 \times .0$ & 41.9 & 53.3 & 52.5 & $\$ 6.4$ & 50.1 & 41.9 & 42.5 & 47.2 & 50.2 & 55.5 & 72.2 & 34.4 & 76.18 & 79.10 & 75.1 & $7 \times .8$ & $x 1.1$ & $\times 2.7$ & 70.1 & 59.8 \\
\hline $\begin{array}{l}\text { Annual } \\
\text { Average }\end{array}$ & 37.1 & .42 .1 & 45.2 & 53.8 & 54.1 & 54.7 & 46.6 & 40.8 & 43.5 & 52.8 & 114 & $6 \times 6$ & 79.1 & 76.4 & 76.4 & 74.1 & 79.4 & $K 4 . K$ & 84.6 & 79.4 & 60.4 \\
\hline
\end{tabular}

Table ?.21"

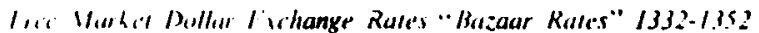
Monihly Averages of Datily Buying Rales for Draf(s and Cheques)

Source: Research Department, Da Arghanistan Bank. 
Table 7.21

Table 7.21

Free Market Indian Rupee Exchange Rales "Bazaur Ral's" 1,3,12-1352

Irec Murhi' Indian Ruper' Exchange Rascs "Buzaar Rater" 1332-1352 (Monthly Averages of Daily Selling Rates for 100 Rupces in Drafts and Cheques) (Monthly Averitges of Daily Selling Rates for 100 Rupees in Drafts and Cheques)

\begin{tabular}{|c|c|c|c|c|c|c|c|c|c|c|c|c|c|c|c|c|c|c|c|c|c|}
\hline Munih & 1.132 & 1333 & 1334 & 1335 & 1336 & 1337 & 1338 & 1334 & 1340 & 1341 & 1342 & 1343 & 1344 & 1345 & 1346 & 1347 & 1348 & 1349 & 1350 & 1351 & 1352 \\
\hline llamal & 717 & 755 & 888 & 1,058 & 1,000 & 1,099 & 1,009 & 728 & 673 & 657 & 799 & 735 & 853 & 738 & 680 & 756 & 727 & 642 & 692 & 720 & 760 \\
\hline Siaur & 720 & 777 & 898 & 1.138 & 1.037 & 1,102 & 929 & 720 & 663 & 669 & 773 & 735 & 834 & 726 & 663 & 74.3 & 683 & $62 \mathrm{~K}$ & 669 & 725 & 701 \\
\hline Jaura & 752 & $80 x$ & 885 & 1,135 & 1.020 & 1.119 & 889 & 655 & 663 & 713 & 743 & $7 \hbar 3$ & 846 & 742 & 672 & 735 & 675 & 624 & 706 & 740 & 697 \\
\hline Saratan & $7(x)$ & 811 & 858 & 1,103 & 988 & 1.064 & 790 & 630 & 650 & 707 & 749 & 803 & 853 & $6 \times 0$ & 681 & 744 & 690 & 634 & 710 & 778 & 687 \\
\hline Asid & 751 & 816 & 848 & 1,065 & 944 & 1,002 & 770 & 658 & 637 & 711 & 753 & 795 & 860 & 6.69 & 671 & 692 & 667 & 619 & 681 & 790 & 685 \\
\hline Sunbula & $71 x$ & 815 & 858 & 1.025 & 440 & 478 & 768 & 66.3 & 64.3 & $70 k$ & 719 & $7 k .4$ & 790 & 670 & 660 & 676 & 6.16 & 609 & 664 & 720 & 653 \\
\hline Mirian & GK2 2 & 787 & 853 & 989 & 112 & 9.14 & 741 & (1040) & 648 & 6*4 & $6 \times 0$ & 772 & 804 & $\operatorname{sing}$ & $1+4$ & (xhs & cotis & 628 & T45 & 713 & 608 \\
\hline Aurals & 7015 & 822 & 844 & 1.013 & 1113 & 925 & 732 & $6 N_{1}$ & 6.32 & 7 the & 649 & 790 & 757 & +47 & 638 & 681 & 670 & 1049 & 671 & 736 & $54:$ \\
\hline Gaus & 708 & 893 & 942 & 1,020 & 4.37 & 970 & 820 & $62 x$ & $6 x 0$ & $87 !$ & 728 & 791 & 739 & 672 & 644 & 709 & 675 & 644 & 645 & 725 & \\
\hline Jadi & 713 & 858 & 985 & 1,073 & 1,005 & 978 & 819 & 675 & 674 & 820 & 738 & 804 & 746 & 704 & 680 & 722 & 685 & 68.3 & 644 & 728 & \\
\hline Dalual & 7.31 & 882 & 1,010 & 1,075 & 1.075 & 992 & 783 & 650 & 655 & $86 x$ & 744 & 820 & $72 ?$ & 643 & 743 & 738 & 678 & 699 & 676 & 755 & \\
\hline Howt & 792 & 878 & 1,040 & 1,028 & 1,074 & 1.011 & 727 & 684 & 659 & 819 & 747 & 807 & 729 & 676 & 731 & 716 & $6+1$ & 706 & 701 & 775 & \\
\hline $\begin{array}{l}\text { Annual } \\
\text { Averilke }\end{array}$ & 726 & 822 & 91.3 & 1,060 & 487 & 1,015 & 815 & 6.61 & hss & 749 & 740 & 783 & 749 & (19) 1 & 6,75 & 714 & 673 & 647 & 675 & 742 & \\
\hline
\end{tabular}

Source: Rescarch Department. De Afghanistan Bank.

Table 7.22

lirce Marhel Pakistani Rupee Exchange Rales "Bazaar Rules" 1332-1352 (Monthly Averages of Daily Selling Rates for 100 Rupces in Drafts andl (heques)

\begin{tabular}{|c|c|c|c|c|c|c|c|c|c|c|}
\hline Mfunth & 1.112 & 1.3 .33 & 1.334 & 1335 & 1.336 & 13.37 & 1338 & 1.1 .34 & 1340 & 1341 \\
\hline Halmal & $(N, 2$ & 604 & 726 & 786 & 720 & 727 & 700 & 570 & 560 & 610 \\
\hline Saur & 645 & 618 & 733 & 786 & 720 & 728 & 674 & 565 & 557 & 621 \\
\hline Jauza & 6.6 .3 & 614 & 724 & 795 & 714 & 716 & 643 & 545 & 548 & 631 \\
\hline Saratan & 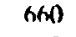 & 617 & 735 & 797 & 695 & 701 & 601 & 528 & 534 & 649 \\
\hline Asad & (240 & 620 & 728 & 760 & 622 & 673 & 591 & 538 & 542 & 650 \\
\hline Sunbula & (n)6 & 612 & 733 & 727 & 660 & 671 & 596 & 525 & 551 & 660 \\
\hline Miran & 580 & 607 & 719 & 719 & 657 & 659 & 589 & 518 & 558 & 663 \\
\hline Aqrah & $(x) 3$ & 6.38 & 734 & 743 & 665 & 722 & 588 & 530 & 562 & 671 \\
\hline Qaus & (x) 3 & 654 & 761 & 761 & 685 & 748 & 614 & 550 & 573 & 708 \\
\hline Jadi & $5 \%$ & 677 & 796 & 772 & 715 & 762 & 616 & 558 & 588 & 725 \\
\hline Dalwia & 546 & 723 & 800 & 761 & .741 & 735 & 588 & $\$ \$ 4$ & 608 & 733 \\
\hline Hoot & אצx & 731 & 811 & 733 & 741 & 720 & 565 & 568 & 613 & 723 \\
\hline $\begin{array}{l}\text { Annual } \\
\text { Average }\end{array}$ & 621 & $643^{\prime}$ & 750 & 762 & 695 & 713 & 614 & 546 & 566 & 670 \\
\hline
\end{tabular}

Table 7.22

Liw' Marhi's Pakistani Rupue Exchange Rates "Bazuar Rates" 1332-1352 (Monthiy Averagi": of Daily Selling Rates for 100 Rupees in Drafts and Cheques)

\begin{tabular}{|c|c|c|c|c|c|c|c|c|c|c|}
\hline 1.142 & 1.34 & 1344 & 1.345 & 1346 & 1347 & 1.148 & 1344 & 1.350 & 1351 & 1352 \\
\hline 706 & $65 \%$ & 835 & 432 & 889 & 891 & 744 & 750 & 805 & 748 & 652 \\
\hline 701 & 653 & $8 n s$ & '/24 & 890 & 896 & 791 & 745 & 839 & 762 & 6,37 \\
\hline 678 & 663 & $89 \%$ & K81 & 887 & 883 & 788 & 773 & 812 & 724 & 58 \\
\hline 6.55 & 678 & $y 06$ & 884 & 884 & 868 & 791 & 773 & 738 & 685 & 560 \\
\hline$h+0$ & 681 & Ken & 883 & 842 & $84 !$ & 76.3 & 770 & 748 & 687 & 551 \\
\hline 643 & 689 & $87 \mathrm{~h}$ & 874 & 820 & 821 & 734 & 754 & 746 & 662 & 530 \\
\hline 628 & 709 & 885 & 875 & 82.3 & 802 & 737 & 763 & 746 & 667 & 485 \\
\hline 634 & 738 & 883 & 876 & 843 & 803 & 764 & 793 & 772 & 675 & 487 \\
\hline 644 & 767 & $8 \times 2$ & 888 & $K 84$ & 812 & 785 & 819 & 763 & 672 & \\
\hline 652 & $80 \mathrm{~s}$ & 844 & 908 & $x(y)$ & 827 & 794 & 836 & 751 & 673 & \\
\hline 680 & 324 & $91 x$ & 913 & $\left.k^{1}\right) 6$ & 824 & 770 & 813 & 758 & 670 & \\
\hline 669 & $31 ?$ & 312 & 910 & 885 & 818 & 760 & 800 & 754 & $6 \in 0$ & \\
\hline 663 & 722 & $k K \dot{x}$ & 845 & 870 & 840 & 773 & 783 & 769 & 690 & \\
\hline
\end{tabular}

Somirce: Rescarch Department. Da Afghanistan Bank. 


\section{CHAPTER EIGHT}

\section{FINANCIAL AND FISCAL REFORM}

\section{i. Introduction}

The five critical constraints to economic development in Afghanistan have been analysed in some detail in the previous chapters. In the final chapter, some essential elements in a programme of financial reform are discussed. An hypothetical exercise is then presented to shuw what might hitve been achieved during the fourth Plan period in terns of domestic resource mobilisation had an aggressive programme of tinancial and fiscal reform been initiated at the outset, i.e. in 1351 (1972).

The inter-dependence of the two channels through which domestic resources can be mobilised, namely the financial sector and the fiscal system, was stressed in Chapter IV. The inadequacies of both were con sidered in Chapters $V$ and VI. Because of the linkages between the two, any efforts at reform must take place simultaneously on both fronts $[M 7: S 8]$. The concentration in this chapter on financial development should nol, therefore, be interpreted to imply that fiscal reform is less important. It only reflects the facts that numerous recommendations for the latter already exist and that the important constituents of a programme of fiscial reform are relatively simple, as shown in Chapter VI. Furthermore, the tratining requirements for this are virtually identical with those oullined in the programme of financial development.

Avililable empirical evidence, in addition to the Adelman-Morris results presented in Chapter I [A2], suggests that financial developinent hals hat werwhelming effects on the pace of economic growth in the countries where it has taken place. Germany and Japan since 1953. Taiwan and Iran since 1960, and South Korea since 1965 have all exhibited extraordinary real expansion in their banking sectors. These have also been countries in which the rate of economic growth has been spectacular. Sine basic data on these five countries are provided in Table 8.1. Here the rate of decrease in velocity of circulation is used to measure the rate financial development. Velocity is a useful indicator of the relative size of the tinancial sector in countries lacking sophisticated capital markets, particularly when the broad definition of money, M2, is used. The lower velocity. the higher the ratio of money to Gross National Producl (GNP) and ience, crereris parihus, the larger the supply of domestic credit and the relative size of the financial system.
Conversely, cases of declining financial sectors, i.e. rising velocitie: and declining rates of economic growth have also been recorded. For example, industrial growth in Brazil declined from 9.8 per cent per annum in the 1950s to 3 per cent over the period 1963-1966. The real money supply contracted as a result of the increased inflation which had occurred between these two periods and the real volume of bank credit fell. The latter severely retarded industrial expansion [M34, p. 184]. Incidentally, Brazil reversed this trend and has provided another example of successful development over the past five years [12, pp. 66-68].

Tuble .x.l

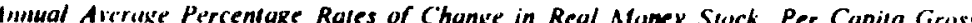
Vurlional Product and Velocitics of Circulation in Six Cauniries (Percentages)

\begin{tabular}{|c|c|c|c|}
\hline Couniry & $\begin{array}{c}\text { Aleraye Annwal } \\
\text { Growith in Real } \\
\text { Money Slock } \\
(M 2 / P)\end{array}$ & $\begin{array}{l}\text { Average Annual } \\
\text { Gransth in Real } \\
\text { Per Copira GNP }\end{array}$ & $\begin{array}{c}\text { Arerage Animal } \\
\text { Change in } \\
\text { Velocity of } \\
\text { Circulation } \\
\text { (GNP/M2) }\end{array}$ \\
\hline Afghanistan 1340-1350 & 2.3 & 0.7 & 0.0 \\
\hline Germany $1953-1970$ & 13.5 & 5.0 & -4.3 \\
\hline Iran $1961-1970$ & 15.0 & 6.2 & -5.5 \\
\hline Japan 1954-1970 & 17.4 & 9.2 & -3.0 \\
\hline South Kores 196.5-1970 & 46.1 & 9.6 & -20.1 \\
\hline Taiwan $1960-1970$ & 20.7 & 6.6 & -7.9 \\
\hline
\end{tabular}

Note: Money supply data are centred annual averages. except in the case of Iran where centred monthly averages are used. Money supply for Germany includes bank bonds. Growith raies are annually compounded.

Source: Intirmuianal Financial Statistic. 25 (9). September 1972; Internatiunal Financial Situistics: 1971 Supplenent: United Natiuns Stativital Yearbisik 1971: United Natiuns l'eartwok of Natiunal Accusunts Situtistics 1966: United Nations Monthly Bulletin of Stotrisrics, 26 (3), March 1972: Bank Markazi Iran. Annual Report and Balance Sheet 1350 (Tehran: Bank Markaji Iran. 1972): Bank Mark asi Iran Bulletins, $1-10,1960-1471$

The importance of linancial development has been stressed by a number of emi.,ent economists. Friedman recently concluded :

.... in developing countries a major source of future development is an improved tinancial structure. In every country which is developed the financial institutions have played a major role in assuring a wide distribution of capital funds, in assuring the efficient utilization of capital, in assuring the availability of capital to people who do not themselves have the wealth. [F22, p. 709] 
Fhe ino men who pioneered the theoreticall work in this branch of economic. Gurley and Shaw, have produced a mass of material to support their contention that:

1)erdopiment involves tinance as welt as goods. [G25, p. 515]

lsing the Gurley-Shaw theoretical framework. Patrick has extended this approach:

There are three major ways in which the tinancial system cian inlluence the cunital stock for growth purposes. First, financial institutions can cncourage a more efficient allocation of a given total anount of tangible wealth (capital in a broad sense), by bringing about changes in its users and in th conmosition. through intermediation among various types of asset-holders. Second, linancial institutions can encourage a more eflicient allocation of new investment-additions to capital stock - from relatively less 11 relatively more productive uses. by intermediation betweelatively and entrepreneurial investors. Third. they can induce an increase in the ritce of accunulation of capital. by providing increased incentives to inc. Invest and work. [PY. p. 177]

I rom this, pulicy implications are derived:

the basic objectives of financial policy for economic growth are to encouldge savers (asset-holders) to hold their savings (assets) in the forn of tinancial rather than unproductive tangible assets; to ensure that investment (capital stock) is allocated efficiently to the socially most productive uses: and to provide incentives to increase saving. investment and production. To achieve these objectives, policy-makers must encourage the proper foundation and expansion of financial institutions. [129. p. [86]

McKinmun has recently developed a theory of money and capital in economic development, again based on the Gurley-Shaw approikch, in which financial development plays a crucial role. The impetus fir his work was provided by "the remarkable financial transformation that accurred in 196,5-(16 in Korea-.-where Shaw was an influential advisor" [M], P. 2] McKinnon's main propositions were outlined in Chapter VI.

Mckinnun tests his theory extensively on a selection of both sllccessf $t: 1$ and unsucessful underdeveloped countries. In every casc, linancial develupment is strongly correlated with the rate of economic growith and the causal redationship runs from financial development to economic growih. the key policy variable in each case being relatively high real rates of interest to attract time and savings deposits.

Al, $[A|4|$. Brimmer [B32], Chandavarkar [CII], Emery [E4] and many other monctary and development economists have produced evidence attesting (1) the importance of financial development in the process of economic growth. Perhaps one of the most significant collections of
Material is Ilaat of Brown [B35]. Gurlcy. Pattrick and Shat [(j24], Kanesa Thasan $[K 5]$ and McKinnon [M7] an the Korean experience. This wat undoubledly a unique cisse. Of particular importance is the fact the both financial and liscil reform took place simultaneously there $1 \mathrm{hH}$ p. 107].

On the cusential role of the fiscial system in domestic resource mot sation, matterial from Hart [HS] and Kaldor [K3]. among others, is cited in Chapter VI. The discussion in Chapter IV also led to the concis sion that a successful development strategy had to be based on dosas resource mobiluallow to a lar higher degrec than has to date been th:

in Afghanistall.

Many repurts have siressed the need fir both financial and reform. On the latter, most recommendations agrec that the two prirr largets should be administration and agricultural taxation. Administrat shartcommen wereconsidered in Chapter VI and lle basic prerequisites? improvement suggested. The need for higher agricultural taxation w. alsu stresicol. It should be added here, however, that such taxes shot: be mon-discrminatory and should not deter production. Virious fors. of land tal can be found which meet both criteria. Applicd elsewhere they have been generally simple to administer. a third essential criterio for taxatwon in Afghanistan. One hopes that administrative reform wilhin the Ministry of Finance and the introduction of a new land tax are high on the lis of priorities of the new Republican Government

ii. Outlime of a Programme of Finame ial Development

A Legislation and Legal Practices

Before linancial development can take place in Afghanistan, legislation and improved legal practices are needed. It appears that this prerequisite hats already been recognised by the Government. Three fundamental legislative measures have been generally recognised: lending and borrowing legislatwon providing for legal negotiable instruments, morigage expropriation of collateral on default, specdy debt collection procedures, credit stinding enquiries, penalties for isstuing cheques against insufficient lunds, etc.; legislation for the establishment and operations of financic! intermediarues such as commercial and development banks, insurance companies, credit eooperatives and any other institutions which transfe: funds trom sit.ers $t 1$ investors by the atets of alcepting deposi's and lending; central banking legislation establishing control mechanisms for the normal operation of monetary policy and the supervision of the financial sector. 
By litr the most urgent requirement consists of measures under the general leading of lending and borrowing. Although the sime quu non for the rapul expansion of banking activities, relatively little attention has w far hech focused on this particular legislative requirement.

The (wo other groups of legislative measures are simpler. Many draft central and commercial banking laws have already been prepared, the best heing those prepared by the Financial Development Committe with the assistance of a team from the International Monctary Fund in 1.352 (197.3). As well as central and commercial banking laws. the ('ommillece also drafted a Deposit Insurance Act.

Ihere is a critical need lor improved legal practices along will new legivlation. As mentioned in Chapter $V$. there is little knowledge af the existing connmercial Law and court procedures have not bech adequate for the protection of banks as lenders. The Government must also show willingness to protect the banks in their lending activities by providing support firr debt collection, etc.

\section{I) Revitalising the Existing Financial Institutions}

Before the estiblishment of any new institutions, the existing financial institutions, with the possible exception of the Agricultural Development Hank. require help and support in increasing their efficiency and expanding
their operations. It would seem that a programme of technical assistance in the form of experts in central, commercial and specialised banking is an esemtial concomitant to the inplementation of the proposed legislalion and improved legal practices. One cannot, for example. expect Da Afghanistan Bank to become a full central bank overnight simply by enaclung a central bank law.

II conjunction with the provision of tachnical assistance a Iratining progranme is needed. In fact, the existing banks all have their own small programmes and one of their legitimate fears of competition from new "I lureign banks is the loss of expensively trained staff. Civen that the leakages ol bank personnel who have been trained might be cunsiderable it wuld he reasonable to assume that the social benefits irom training batıkers are greater than the private benefits. From this, econonic analysis suggests that the existing provision of training is socially suboptimal and a clear calse exists for state subsidy of such activities. Serious considerattion might be given to the establishment of either a Bankers' Cullege or a Banking Faculty within the Kabul Commercial college.

As well as techaical assistance, the existing institutions, pilrticularly Dat Alghanistan Bank, are in considerable need of modern cyuipment such as electronic calculatting machines. Here it is a matter of providing not labour saving devices but machines which eliminate the element of human error. The latter is in such abundance at present that even the accuracy of aggregate monetary statistics is seriously jeopardised. Inaccurate howk kecping is a strong deterrent to potential depositors.

The unfivourible external environment faced by the banks was discussed in Chapter $V$. The enactment of banking and commercial legislation logether with steps to ensure prompt and eflicient court action should do much to improve this.

Although trituing is the critical reyuirement for improving the internal environment in which Afghanistan's tinancial institutions operate, there are two prerequisites $t$ the success of large scille training eflorts witlin the financial sector. The first is competent management to use trained personnel efliectively, the second an elficient set of procedures in which to train.

The existing training needs can be separated into six distinct groups which can be tllustrated as follows:

livisting Training Re'quirt'me'nts

$$
\text { New Intrants }
$$

Existing Staff

High Level or Administrative Grade

Medium Level or Executive Grade

Elementary Level or Clerical Grade

Within the high level or administrative grade, it is generally recognised that the tritining of personnel already working in the banking system can only aim at the improvement of the exceution of existing functions. Indeed, this is benerally the case with all those presently working in the financial securr. Hence, the need here is solely for on-the-job training at all he vels or griades for existing stalt.

On the other hand, within the next live years it might be hoped that all banks, particularly Da Afghanistan Bank, will expand their range of activities and for this will recruit new staff at all levels. In Da Afghanistan Bank, new research, inspection and audit, and credit departments should be esablishad for which personnel must be recruited. At the high level or administrative grade perhaps 10 to 15 new graduates a year might be hired by Da Alghanistan Bank for the evintual stalting of these departments. These graduates might be given one "Ir two ycars' training in the form of both on the-jobinstruction and acidemic courses in Kabul and then be sent abroid for one or two years' alditional training. Those intending to enter research departments would receive acadenic training abroad in 
subjects wich as monetary and international economics, while those planning (1) work in the fields of inspection, aludit and credit would be scilt to wiork in foreign commercial and central banks and actount be firms for vocational training and accountancy experienced employecs drawn and on-the-job instruction. Although such departments at dre outset, the aing would naturally head young men and women who aim should be to produce well trained assume managerial wo who would soon gain sufficient experience to

It the second lave departments.

Irain the cuisting persed the main thrust should be to Wilhin thiv callegory fall directors and out their duties more ellicicntly. in more junior positions who possess the carectors and those at present higher musitions when vac.anc possess the calpacily to gain promotion to banking swtem is unlikely to occur. Given that rapid expansion of the a smitl number of new ro take place within the next few years, only accepted hanh, it should be possible offering suitable training facilitics for all the in banking procedures. .

Within the medium level or executive grade there exist $1(0)$ to 150 people within Afghanistan's banking system, most of whom could benefit from on-the-job training programmes. For example, there is in urgent need to train people at this level to write business letters in Dari short periof $A t$ the clementary (six months) of additional on-the-job training in Iratn.

pluyces within the banking system who grade, there are over $1,000 \mathrm{em}$ follow the hinks' procedures with acce require training to enible them to of linke required to acedures with accuracy and efficiency. The length fundanental prerequisite that modest aim is fairly short, provided the and efficient is met.

met.

On-the-job training basically consists of part time classroon instruction (wo ) $i$ three hours a day) combined with supervision of the trainces" work during the training period by managerial and teaching still. Agilin medium the relatively modest aim of the training programmes at the in Dari rillerementary levels, it is essential that all instruction be given there is a need for a nuglish. Neverticless, for teaching the teachers be used for dirct teaching of foreign advisors. The latter would also A schomatic picture of the at the high level or administrative grade. belouv.
Training Viects and Sial/ing

\begin{tabular}{|c|c|c|c|c|}
\hline \multirow{2}{*}{ Levit } & \multirow[b]{2}{*}{ Nen tentrums, } & \multirow[b]{2}{*}{ Existing Sratf } & \multicolumn{2}{|c|}{ Teaching Stos. } \\
\hline & & & A/ikhan & Fore: \\
\hline $\begin{array}{l}\text { High or Almumishative } \\
\text { Medium of Peculive }\end{array}$ & 10-15 a ycitr & $\cdots$ & 1 & 2 \\
\hline flementary of (lerical & $\begin{array}{l}20.30 \text { a ycal } \\
.30-50 \text { a year }\end{array}$ & $\begin{array}{l}100-150 \\
1000\end{array}$ & $\begin{array}{l}2-3 \\
8-10\end{array}$ & $1-2$ \\
\hline & & & $n-10$ & $1-2$ \\
\hline
\end{tabular}

Funds will be required for the provision of forcign experts and scholarships to send new recruits (o) the high level or administ rative grade abroad. In conjunction with this, however, is a futher need for onc or two foreign experts to wirk directly in the rescitrch departments and assist management in virious walys in all three ballks.

The llnutcd Nitlons recently anmounced that it is providing an addi. tional gramt of $\$ 2$ million to Afghanistan. It might be suggested that one.

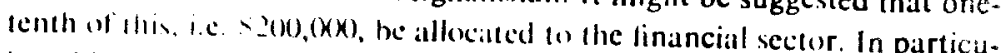
lar, this culd hinance the redrafting of procedures manuals, the first few years at lik drining programme and the provision of some equipment. It would seim thitt other sources of finince might be needed for the managenem assistance and organisational restructuring.

\section{Rapid I ymanvion in Real Volume of Domestic Credit}

Concemratiu, on the primary goal of financial development, namely : rapid expamwan in the real volume of domestic credit, can be seen as the essetitial clement of the next stage, after legal and educational problens have been tiakled. Thought should then be given to the possibility of channelling more loan aid through the linancial sector. Donors have not so fir been moed fir their ability to find and support productive projects. The neccsill y concentration on small scale investments, on-farm assistance. etc., la ralixe agricullurat productivity in particular, requires a much larger field witl for evaluating and supervising profitable invesinent opportunitio lla:an the donor agencies can provide themselves. A modern, efficient finamial sector should provide such a staff and administer these loans, as the Agricultural and Industrial Development Banks do at present with World Bank funds. The increased volume of domestic credit in real terms which tinancial development would generate should be directed primirily into the agricultural sector for small scale on-farm investments. It is difficult to envisage any viable alternative for raising agricultural pronductivity, seen in Chapter I to be one of the critical constraints to conomic development at present. 
Iwo clements in the programme of financial development outlined above require more detailed consideration. The first is the crucial role which a central bank must play in developing the financial sector. The second is the interest rate policy it pursues, since as pointed out above it is the interest rate, that most pervasive of prices, which is the key to both elfective anc efficient domestic resource mobilisation.

\section{iii. Contral Banking for Development}

The primary function of a central bank is traditionally "to regulate the llow of muncy and credit in the economy" [L5, p. 556] through its role as banker to commercial banks and the government, the objective being the maintenance of full employment without inflation. In the main, this is achicved hy the central bank's control over the supply of credit to its customers. During the past decade, however, several centrall binks have hecomc involved in specific problems of economic development almost as much a in this tratitional lunction of central banking.

lhere are many examples of ineasures taken by central ballhs which directly ". indirechly have contributed to economic development. On the "ther hitul, there are a number of measures designed for the salme purpose which hate invariahly failed to make any such contribution. This section ulutines some of the central banking activities which have been successful, as well as some which have not, in promoting economic growth.

The hisic aim of financial development is to mobilise domestic savings into prodlutive investment. This involves, on the one hand, increasing buth the livel of savings and the proportion of savings held in the form of finincial assets. In a country like Afghanistan, the latter consists almust entirely of currency and bank deposits. On the other hand, it involves ensuring that the financial sector channels funds into the most prolitible investment opportunities. Thus, in an underdeveloped country lacking a capital market the basic objectives are:

A. To increase the demand for money at every level of GNP;

B. To ficilitate lending by the financial institutions to those who can use the resources in the most productive investments.

Central banking activities should therefore be analysed with these fundanental aims in view. If the demand for money can be shifted at every level of income as illustrated in Figure 8.1, the money supply can be expanded by that magnitude without causing inflationary pressures. Increasing the dentand for money implies persuading the private sector to free voluntarily resources for use by those who provide the counterpart claims

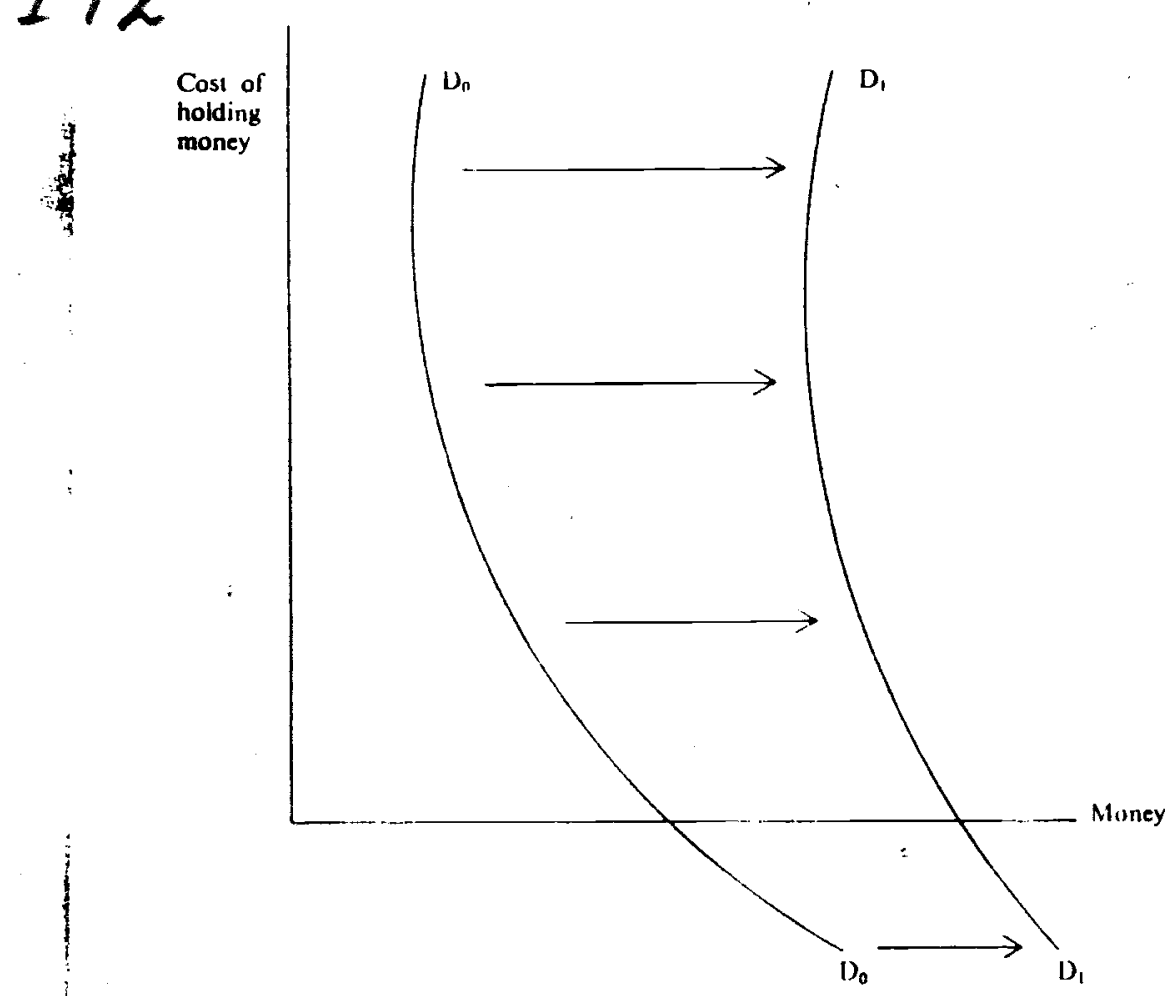

Fig. 8.1. Shifring Denumd for Money

to the increalse in the money supply. In other words, an incrcase in the demand for money enables, ceteris parihus, an equal non-inllationary expansion it the level of domestic credit. The importance of this has been expressed clearly by Mckinnon:

Whether atthorities decided to nourish and expand the "real" stock of money that is, the stoch of money measured by its value in relation to the prices of goods and scrvices) or allowed it to remain shrunken and heavily taxed. has critically affected the relation between saving and income and the efliciency of investment in a number of countries .... [M], p. 3]

Muney is a commodity supplied by the central bank in the form of currency and by the commercial banks in the form of deposits. Increasing the demand for money involves the same factors as increasing the demand for "ny other commodities, the two most important being price competitiveness and milrketing.

The price competitiveness of Afghanistitn's money supply can be 
measured by two inter-related variables, namely, the price of an Afghani in terms of the commodities for which it can be exchanged and the price of an Afghani in terms of foreign currencies. More precisely, price competitivenes, of the Afghani is determined by the level of inflation (the change in the rate at which commodities can be exchanged for Afghanis) and the speed of depreciation (the change in the rate at which forcign currencies can be exchanged for Afghanis). The lower the level ol inflation and the speed of depreciation, the greater the price competitiveness of Alghanistan's moncy and hence, ceferis parihus, the greater the demand line it. I. the savings depusit component of the money stoch, the rate of inlerest is a third variable determining price competitiveness.

When :m individual increases his stock of money in an ecomomy such as Afghanistan's where virtually no other financial assets exist, he automalically perlorms an act of silving. By increasing his money stock he abstains from spending. Where on halance people in a country are adding more to their stuks of money than they are drawing upon them, finincial saving aceurs in the economy. This saving can be mohilised, i.e. channelled, into productive investments hy the institutions providing the additional money, An increased demand for currency, for example. enables the cential bank 11) increase its lending in the form of new currency without creating inllaton. The new currency put into circulation in this process is voluniari1) added to currency holdings. The increased spending by those who recive new loans in this form from the central bank is matched by the increased saving of those wanting to hold the new currency which has been issued. Similarly. an increased demand for hank deponits enables inireased lending to the same extent hy commercial hanks. the new spending being matched hy new saving. This process is agalln noninflationary, provided that the demand for currency has not concomitantIy decreased. Thus, stimulating denand for money and allowing financial imstitutions to increase their loans for investment purposes without causing inllation is the most important objective of central binking for development.

The predominant factors involved in stimulating demand for money are wurity and eturu. When there is rapid inflation no one witnts to hold III) ney hecause the return is negative. The longer the money is held the les it is worth. Friedman has shown that with realistic demand for money parameters and a pasitive rate of economic growth, the level of domestic credit expansion in real terms is maximised in the long run when prices are lialling [!:23]. This result springs from the generally estimalcd high cost chasticitic of demand for money. Hence, when even the return un liolding currency is actually positive, as is the case when the price level is falling, the demand fir money increases and so enables a larger level of domestic credit expansion. In practice, deflation has disadvantages; an optimal policy might. therefore, be to aim for a stable price level, thus gaining demand for domestic currency both from those who previously preferred to hold tangible assets whose prices were rising and from those who previously held foreign currency. In holh cilses the substitution frees resources for investment.

The holders of loreign currency free resources for use by the country which supples the currency, the holders of an incrcatsed supply of domestic currency free resources for domestic investment. The simplest way of making domestic currency more attrattive is to cause it to appreciate vis-a-vis foreign currencies. $A$ minimum condition for this is holding the rate of domestic inflation below that of the rest of the world. It has already been argued that this would also increase the demand for money by those who previously held tangihle assets. Furthermore, it would stimulate savings from those who previously had not saved and increase savings of thome vho, were already savers by providing positive returns to deposit holding.

The aim of linaticial development is to persuade people both (o increase their saving and to hold their assets in financial claims rather than in unproductive ti!ngible assets, such as gold and jewellery. Resources are thereby freed w lin.snce expenditure by those whose liabilitics corstitute the alsets of the linancial system.

One of the striking visual differences between the cities of $A$ fghanistan and those of meighbouring Iran, Pakistan and Turkey is the total absence of bank adverlisements in the former. The Afginan financial system is completely pissive in outlook; there is no active competition whatsoever amongst the hanks for deposits. Perhaps the must important device open to Da Afghamistan Bank for increasing demand for money is the instigation of a posituve policy for the encouragement of banking and the banking habit. This must involve furthering conpetition within the financial sertor.

Another ispect of the security attribute of money is the protection of depusitors firm the risks of bank failure. The central bank is therefore usually given the responsibility for maimtaining the "soundness" of the banking syst:m. As controls for this purpose have a different objective from controh w regulate the total volume of credit for monetary policy, there is an a wantage in keeping the lwo sets of regulatory devices distinct and separate fiom one another. Furthermore, regulation to ensure 
"sound" hanking may well be linked to a deposit insurance scheme. The rationatle behind this is twofold: first. the insurer, i.e. the central bank, can insist that certain conditions be met before it will issue a policy to a hank: sccond, the central bank will generally be obliged in any event to rescue banks which find themselves in difficulties in order that contidence in the bisking system be maintained. Therefore, it might as weil collect insurance premiums and run the operation on something approximating an actuarial basis. All commercial banks would be required to insure their deposits and the insurance department of the central bank would prescribe the conditions, like any other insurance agency, which had to be met heliore policies would be issued. Such conditions would be those of "round" hanking. The insurance department must be empowered to inspecl hillks to ensure that the conditions of the insurance, c.g. minimum ciprlal, inganisational strueture, minimum liquid reserve reguirements, acceptatile lending practices, etc., were being observed. Such a department could also ensure that any monetary policy.directives, c.g. special deposits. overall limitation of credit expansion, etc., were also being oloserved. In this waty, the second element of security so importaint to noney holders is provided.

The insurance premiums might form the basic source of funds for upcial central bank lending operations to help, where necessary, the estiblishment and activities of new financial institutions. This can take the furm of subscriptions to part of the initial capital or special loans during the first few years of a new institution's operations.

Setting aside non-inflationary sources of funds to be used to help the development of financial institutions in the country is not a new idea. A, Patrich states:

The nonetary authnrities have an important institution-building roie ir, encouraging the establishment of a wide array of financial markets (and linincial institutions to operate in these markets) which allocate saving competitively to the most productive investors. One important : approach is i1 encourage the private development of the financial system, in response to the demand for its services, by clearing away impeding institutional and orher obstacles of a legal or customary nature. The financial authorities can creatc an environment which is conducive to growth both of the real economy and of the financial system .... [P9, p. 186]

It has :Ilready been suggested that a special fund based on deposit insurance premiums might be established to assist new institutions in the financial sector. Where this has been done, Tamagna found successful restults:
In various cases their special funds have provided the capital, organization and techniques for autonomous institutions, which eould enter the financial system on the basis of their own experience, complementing other institutions and without requiring any furiher special support and assistance from the central bank. [T1, p. 80]

One set al finincial institutions which needs special consideration in this regard are the development banks. Frequently, such institutions remain too imall for fully effective operation because of lack of funds. Where deposits are not accepted these institutions must rely on other ways of raising funds most of which are diflicult in underdeveloped countries lacking developed capital markets. The central bank can play a role here by providing capital in the first instance, but much more important. purchasing their bonds as they expand and in this way help to

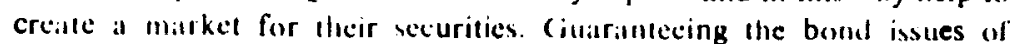
devilopment banks can also be a valuable central hanking service to these institutions [13.32, pp. 784-86]. As suggested above. credit to the agricultural seclor through the Agricultural Development Bank must be expanued as rapidly as possible to increase agricultural productivity. Da Afghanislan Bank can help here in the way described above.

The encoturagement of new financial institutions and assets can be important in increasing financial saving:

... the expansion of the banking system and noubank financial institutions and a change in people's preference from money to other types of liquid asiets. in addition to broadening the domain of monetary policy, wiil exert it downward pressure on interest rates and will increase the a vailability of eredit throughout the economy. The central banks can also play an important role in mobilising savings by helping to develop a biarket al kuvernment securities. [R2, p. 144]

Of equal importance is the encouragement of the regional spread of branches inlo the provinces. It maly well be unprofitable for a bank to open a brauch in a new location outside the matin urban centres, as the banking halvit takes time to develop. Nevertheless, it may be socially both productive and desirable from the income cquality vicwpoint. The central bank ian encourage the spread of branches through positive incentives such is grants. tax reductions related to number of branches, etc.

Where privalte enterprise is seriously lacking for the establishment of a banking network, state banks may be founded. Not only can they be used to establish a network of branches throughout the country but they may ilso be indirectly beneficial in providing credit to sectors, 
particularly the agricultural sector, traditionally starved of institutional finance. The policy of spreading bank branches throughout the provinces will he accompanied, provided the branch managers have the authority to dispense laans, by an increase in the provision of credit to those living in these areas. In fact. the eventual profitability of rural branches is likely only if every brancli grants loans. The provision of loans acts as the hest potential advertisement the banking systent can use: the wider the reach of the advertisement, the larger the number of depositors.

The main difficulties faced by banks in underdeveloped countries in giving branch managers authority to grant loans are first the lack of sulliciently well trained personnel and second the absencic of strong accounting systems. The latter is, of course, intimately connccted with the former. The central bank can play a major role in the provisjon of adequate management training and development programmes as well as direct assistance in the development of accounting systems. At the apex of the financial sector, the central bank is in the best possible position to assess educiltional requirements and provide technical assistance either from its own staft or by requesting it from foreign donor agercies. forcugn currespondent hanks are also often willing to provide snall traming prigrammes. Such links can be fostered and developed with the aid af cientral bank initiative.

The central bank can develop the financial sector in a number of ways. Through indirious use of a development fund, new institutions can be started. Various incentives can be provided for the spread of branch bank networks. Training and technical assistance can be made alvailable to enabls. these branches to carry out a full range of banking activities. Thi central biak should take on the responsibility for the development of its sector of the ceonomy. This sector is not traditionally considered in the simle light as, for example, the agricultural, industrial or transportation secto1. Development plans do not set targets for, or assess achievement in. the financial sector. Regulation rather than development is the usual emphasis. Becaluse the financial sector is not defined as a sector in this sense, there is no minister or ministry responsible for its development. In wence. th $\AA$ is why central bank initiative and responsibility for the financial sectors development is of such critical importance in almost ill anderdeveluped countries.

fin lindertiake the development role sketched in the preceding sections, it has impluitly hein assumed that the central bank possesses a well traned, competent stalf. Where this is not the casc, training and technical assistance must be channelled first into the central bank before it can carry out llice important roles in the develupment process for which it is so well placed. Fortunately, in most underdeveloped countries, this prerequisite is met. Thus, an additional role as government advisor can be played:

As a rule, the central biuh is likely to be a well-equipped institution, with respect lo stalf and fintmial resources, to undertake the research and analysis (1II which a well conceived development plan must rest. [B32, p. $79(0)$

The obvious lield of development planning in which the central bank is best eyuipped lo atdvise the government is the linancial side of the plat However. pulicies allecting the investment climate and private sector activities in gene al may also usefully be prepared by the central bank. It is, after all. in a position to know more about the private sector than most govermment ministries. In a general survey of the role of central banking in the planning process, Tamagna inakes the following comment:

It is in most cases the centrat hank that formulates the "linancial framework of the program" according to now of funds or relitted linancial arcounts at its disposal; such financial framework outlines the present and prospective sivings formation. the avalability of foreign citpital, both from private and public and international sources, and the domestic credit cxpansion that the central hilnks regard it consistent with monetary stability. [T1. [. 79]

The central bank can further estimate the maximun possible overall in restment larget and indicate the monetary and fiscal measures needed to athieve it.

In severil tunderdeveloped countries. celltril hanks have stacceded in esiablishing llamselves as important sources of advice and infirmation. In a survey of the role of eentral banks as guernment advisors, Brimmer inncludes:

In gencrit, where the central bank hats beell allowed to maintain a reasonable degree of detachment, its advice has tended to he objective and, even if not always received wilh enthusiasm, respected .... on the whole, the : evidence stggests that in many countries the centrat bank is a senior partner in the developnent enterprise. [B32. pp. 789-90]

It wouk the smolewhat unrealistic wasume that Da Afghanistan Bank is at present in a position to assume lac role of impartial, expert advisor to the Government. Part whe problem lies in the lack of expertise and the lowly role assigned (1) the Rescarch Department. Recruitment and training cind do much lo rectify this. However, a major part of the problem lies in the relatiunship between Da Aighanistan Bank and the 
Government. At present, a multitude of Cabinet decrees nrdering the Bank to make specific loans virtually eliminates the possibility of any independent policy design.

Da Afghanistan Bank is unlikely to develop into a prestigious institution attracting well qualified recruits so long as it remains in its present subservient position vis- $d$-vis the Government. It is therefore essential to discontinue the present practice of arbitrary interference in the Bank's activities w frequently engaged in by the Government. The obvious solution lic in the establishment of a Money and Credit Committee convisting al representatives from both the Government and Da Afghanistan Bank. as well as representatives of private sector interests, tu determine the hroad issues of monetary policy. This should then be the only source of (iovernment influence over the Bank's activities. Precise rules governing the nature of such influence through representation on this Committee need to be drawn up. Da Afghanistan Bank would then attain the attonomy so crucial for its own development.

The potential which a central bank possesses to perform various development activities can be considerable. The realisation of this potential. however, requires certain conditions, the most important being a clearly defined relationship between government and central bank, providing the latter with exclusive authority over the implementition of monetary polic; and sufficient autonomy to generate a useful position as external advisor to the former. Effective control over the supply of money and dynamic action in relation to all the other aspects of financial development discussed above require, on the one hand, that the government provides sufficient authority to the central bank and, on the other, that the ceniral bank accepts willingly its responsibilities. There are many other details which must be given careful attention but the essential prerequisites for effective central banking for development, the importance of which call hardly be over-emphasised, are the establishment of a conducive working relationship between government and central bank and the acceptance of development responsibilities by the latter.

iv. An Intere'sl Rasic'Policy

Interest rate policies have several dimensions. In the words of Chandavarkar:

. interest rates can be viewed as instruments for more effective mobilisation of savings (as deposit rates) through the offer of realistic rates on monetary savings, such as time and savings deposits, claims on financial institutions. and government securities. Similarly, interest rates can be viewed as a social rate of discount to Jeternine the optimum allocation of savings between consumption and investment and as a rationing device for efficient allocation among alternative forms of investment. [C1]. pp. $49 \cdot 50]$

Thus, with the interest rate performing not just one but three functions, any policy must take all into consideration. In fact, these three functions can be simultancously satisfied in a perfectly competitive economy without institutional constraints of any kind by allowing interest rates to find their own market levels at which supply eyuals demand. In most underdeveloped countric's there are a number of existing constraints which militate against this passive policy. Alghanistan provides striking examples of two such constraints, namely, the lack of bankable projects on which loam cian be mide and artiticially low interest rales to the public sector.

Interest rates on deposits are relatively low in a country such as Afghanistan, in which a priori one would expect high returns to savings and generally high rates of interest as a result of the scarcity of capital, because the eflective demand lor bank loans is small. The banks cannot lend as much as they would like to and even the small volume of deposits is, at present, sufficient for their operations. Thus, without additional measures, raising deposit rates would merely provide the banks with an excess supply all lunds under most conditions.

The paradox af low equilibrium interest rates of Afghanistan's tinancial institutions and capital scarcity is explained by the existence of legal and management cunstraints. Where de facto the only security is shares in the few reliable juint stock companies, the elliective demand for bank loans by the private vector is bound to be ninute. Furthermore, the lack of any managenicht expertise in project appraisal ensures that unsecured loans are not made on any economic criteria but only on the basis of personal acquaintance.

If it is accepted that relatively high interest rates should be a concomitant to capital scarcity, for which there is evidence in Afghanistan in the form of hoth non-institutional interest rates and returns on small scale investments, then effective demand for bank loans must be increased This cin be act: ved by legal reforms to increase the range of effective securities available to the banks in the form of chattel and real estate mortgages, liens, negotiable instruments, hire-purchases and guarantees, anc speedy facilities for expropriation on default, as well as improved legal practices discussed above. Management expertise can also be developed through technical assistance and training programmes. 
(Ince a central bank in an underdeveloped country has taken measures (1) lacilialle hanks' lending operations, interest rates will rise provided cuntruls are not imposed. In many countries, maximum rates have been established by the central bank or agreed upon in some cartel arrange ment hetween the commercial banks. The argument tends to be that loan rates must be kept down if investment is to be encouraged. Where such ceilings are effective, resources are misallocated. In fict, in the vast majority of countries where they exist they are not effective. It is in the interests "it hoth the banks and prospective clients who might olherwise not receive a loan at all to agree on a higher rate. This is most easily acomplished by an undertaking on the part of the horrower lo keep a secilied proportion of the loan in an account with the bank. In this way, the ellective interest rate is made intinitely variable. $\because$ or exiunple, a 25 per cent deposit agreement raises the effective interest ralte to the borrower hy one-third, a 50 per cent deposit doubles the rate and a 7.5 per cent deposit raises the efrective interest rate by a factor of four.

Accepling the undesirability of trying to enforce maximum in! .rest ratc for whatever misguided purpose, and assuming no such controls exist, the central bank's actions to facilitate bank lending will result in a rise in interest rates on loans. Demand increases, hence price. $i . c$. in this case the rite of interest, goes up. Provided the banking system is competitive, a rixe in loan rales will cause a rise in deposit rates, each hank now wantung more iunds for protitable lending operations and thus raising deposit ralles to attract more deposits. The desired result is achicved.

l'nfortullately, binking systems in botl developed and underdeveloped countries are notoriously uncompetitive (e.g. for Britain see [J4, Chapter IV]). (artclagreements, often with the approval of the central bank, purportedly tw cinsure a "sound" banking system, abound. Where fixed interest rates on deposits have been agreed upon to prevent cut throat eompetition, rising laan rates simply make banking more profitable. There are no other efticts. Given that this will often be the case, the central bank can be given the authority to establish minimum interest rates un deposits 10 considcrable advantage. Then, where cirtel arrangements are clearly resulting in nonopolistic profits, banks can be obliged to ratise their deposit rates. The minimum deposit interest rate requirement is, in fact, the only interest rate control which can be justified.

The final aspect of interest rate policies concerns the comnun practice of diflerential rates not reflecting differential risk and duration for activities in selected economic sectors. The almost universial calse is diflerential interest rates between public and private sectors. Afghanistan is no exception. with at rate of 2 per cent heing charged by Dat Afghinnistan Bank on Govenument loans while rates from lhe banks to the private sector range from $x$ (1) 11 per cent. In many countries economic sectors such as agriculture and industry are also provided with loans at lower rates. Various firms of incentive are provided to the commercial banks, such as differential rediscount facilities, lower reserve requirements for a more preferred purtfolio, etc., for this purpose.

Evidence suggest, that differential interest rate policies have not been successful [B.32. Pl. /86-89]. Furthermore, there is no economic justificittion for this pratice. Where particular economic sectors are to he encouraged, direst subsiuy hits considerable advantages. First. with a direct subsidy it is cissier to ensure that the benefit actlablly accrucs to the sector 10 be encuuraged. With differential inte:est rates, borrowers in the favoured sector can re-lend their loans to those outside the sector. There is much evidence that this practice occurs in Turkey where differential in:erest rate molicics have been pursued most unsuccessfully IF25, Chapter ol. More important, where a policy of this kind is stlccessfully enforced it resull. ill a greater subsidy to capital intensive than lo labour intensive methind, af production within the lavoured sectors. Given general capital scircity, the net result is over-capital intensive production in the favoured sectors and even greater capital scircity elsewhere. Illustrations of this were given in Chapter VI. By substituting an overall subsidy for differential interest rates. correct allocition of resturces between capital and labout can be maintaned. the subsidy can be ticd to the particular activilus for which it is neant. and a more effective boost given 10 solected nactors.

This argument is as equally applicable, of course, to subsidies la public versus private sector activities as it is (1) agricultural versus trade sectors. As Chandavarkar points out

The very enioynuent of monunsonist borrowing powers makes it all the more inctutintit on governments in the less developed countries to borrow at more completitive rates in kecping with the reit cost of capital in the economy, rabier than to combinue to borrow at attificially low ralles in the organied sectur. Neither the capacity of pevernments lo borrow at low rates nor llue existence of a captive mathet for privale savings can be regarded as a decisive arpunkent against more realistic interest rattes. To continue to chllie ullattractive interest ralles to anc class of savers. when eflective ralls in the rest al the economy are much higher. amounts to subsidizing unc ciltegory of horrowers (public sector) merely beciluse the lenders (privalte sector) have no alternative. But this argument is hatsed not mecicly on grounds of equily to the savers bul even more importantly on eriteria of comemic ellicacy in allocating sciace investible funds. which 
are clearly vitiated by permitting excessive diversion of funds to the public sector through the captive market. To the extent that these condition prevail. the oconomic rationale of low and stable rates on government horrowing in some of the leas developed countries is not well founded. since it disregards the opportunity cost of public borrowing and investment. This issue is of vital importance for developing countries, as the organized sector (public and private), although small in relation to the tot:ll economy, accounts for the major share of new investment under development plans. [CII. pp. 108-109]

Mckinnon argues in favour of high interest rates as follows :

Paradoxically. cheap credit in a populist sense may not benetit the little man al all. Quitc the contrary. It may effectively prevent him froin competing for long-term finance from the organized banking system, ard as \& result he is contined to getting month-to-month credit from the villaos storekeeper. [M7, p. 73]

In conclusion, therefore. the case has been presented for an interest rate policy which aims at equating supply and demand for funds in a competitive market environment. In Afghanistan this must start with action to facilitate bank lending and raise public sector interest rates. With all sectors of the economy competing on an equal basis for loans, the following benefits should accrue:

A. Scarce capital is allocited more efficiently;

B. Saviing is increased as is the proportion held in financial form:

( $\therefore$. Income is more equally distributed hecause small savers receive a positive return and small borrowers have a greater opportunity to borrow from financial institutions.

Two advantages of the higher interest rates expected from financial develupinent deserve consideration. The one relates to hoarding, the other to greiter equality of income distribution.

Not all hoarding is anti-social. People who hoard money actually allow a larger quantity of money to be issued without inflationary effects. This moncy can initially be lent by the central bank to finance investment which benelits everyone. People who hoard gold and silver can create additional employment opportunities and so raise wages of the workers, if by so doing gold and silver mining industries flourish. If there is no gold and silver to be mined then hoarding simply raises, or at least maintains. prices of such precious metals to no one's evident detriment. Only where such hoarding results in large inflows of precious metals into a country in return for exports is there a social loss to the inhabitants of the country. It would be much more benelicial if, instead of unproductive precious metils, productive machinery. etc., were imported. This is an acute problem in countries like India but fortunately is of little significance in Afghanistim, e: 'pt to the extent that official international reserves are held above the optimum level.

In the case of grain, hoarders buy at harvest time when prices are low and sell before the harvest when prices are high. The increased demand generated by the hoarders at harvest time actually keeps prices higher than they would be otherwise, thus giving farmers a better return. Converscly. th: increased supply before harvest keeps prices lower, to the benelit of the bread eatting public. It no one stured grain, there would be two inonths of gluttuny followed by ten months of starvation. Similarly, extral purchases in years of good harvest for sale in years of drought dampen price lluclualions to the benefit of both farmer and consumer.

When grain is hourded for long periods for non-commercial purposes, a phenomenon which certitinly exists in Afghanistan, it can be argued that there is no social benefit; prices are not evened out by the process and no one prolits. It can also be argued that were all unproductive assets such as gold, silver. grain stocks, etc., converted inco productive assets, such is machinery for a new factory, everyone, including the hoarder, would benefit.

Thus, it cill he conctucled that those lorms of hoarding which are anti-social are gencrally those which are also unprotitable. The question which must now be examined is: Why does anyone hoard if it is unprofitable? Having answered thatt, it maly then be possible to suggest a better remedy "1) Whis problem than the enactment of anti-hoarding legislation which hits at the symptoms ratlier than at the causes.

Anyone wamling lo save in a country like Afghanistan faces difficulties. In the industrial countries of the West, there are nyriads of savings outlets time deprosits, sivings and loans accounts, government bonds, equitics, ctc. In most arcas of Afghanistan there is not even a bank within easy reach, If'a siving account is eventually opened, the meagre 6 pe: cent interest is sown eroded through inflation. There are virtually no other forms of financial assets available here apart from a few shares in joint stock companic lor which no urganised market exists.

The result is that for most piople the only way of saving is to hold tangible assets such as gold, jewellery, grain, etc. Even if such assets yield no positive return, they do have the advantiges of easy procurentent and liquidity. i.e. llicy can also easily be sold. Furthermore, they may maintain their value better than moncy. Thus, rather then viewing the hoarder 
with disditin, his activities can better be understood as a natural reaction to the deliciencies of his environment. He, as well as society, loses by holding unproductive tangible assets.

S.lving is in fact critically important in the process of economic develupment. It needs to be encouraged as much as possible in Afghanistin. llwwever, it does no one much good if it is immediately invested in unproductive inventories of grain, etc. As important as savings, therefore, is their direction into productive investments. This is where at well developed linancial systen plays a crucial role.

1 conomic development can be achieved only from the nobilisation of resources into productive uses. In the present technological era, this often necessitales the concentration of capital into large units of production. In a mixed economy, the most important way in which this can be done is through the voluntary pouling of resources.

It is only through the financial system that this can be achieved. On the one laind. the business enterprise needs resources for five, ten, maybe fifty years 11 use in what at the outset will be an uncertain, risky venture. On the other hand, individuals generally wish to keep the majority of their salvings in liquid, risk free forms. By drawing together large numbers of salvers, who will not all want to withdraw their savings at the same time, and linancing large numbers of enterprises, thereby spreading and reducing risk. a developed financial system can meet not only business medium and long term financial needs but also depositors" requirements of liquidity and security.

Salvers all over the world are found to be highly susceptible to the real return. i.c. the rate of interest minus the expected rate of inflation. recived wn their sivings. Where financial assets such ats savings deposits yicld a fluctuating real return averaging zero, savers are not attracted. Instead. they prefer to hold tangible assets whose return, although zero, does nut tend to fluctuate. Hence, the answer to the problem of antisocial ho:arding lies in both the availability of and real return on financial assets. In conclusion, the remedy for eliminating anti-social hoarding lies not in legislation but in the rate of interest.

Raising interest "rates on deposits benefits the small saver to a greater extent than the lárge saver for the simple reason that the latter has a much wider range of opportunities open to him for using his savings priductively. On the other hand, the small saver is unable to invest in any indivisible investment which exceeds his savings and is usuilly less well informed and less sophisticated than the large saver in locating other assets in which to hold his savings. $A$ deposit is a simple financial

claim with Iwn atlributes particularly desirable to small savers, namely, liquidicy and cillvenience.

Small scalc hurness benefits from both higher deposit and, piradoxically, higher loill rattes. Higher deposit ratces which result in increased resources in the tinancial system mean that the sinall scale businessman is more likely 10 be able to borrow from the system. Similarly, higher loan rates curb the demand of big husiness, which normally receives priority, and rations credit on a price rather than a non-price basis. Non-price ratloning invariably climinates small borrowers first and simply rations credil whe large ones. The small businessman tlien has to borrow from non-institutional sources at far higher rates. Ilence, he actually benelits from higher institutionill rates provided that this enables him then to borrow from the linancial institutions.

Raising interest rates hits hardest those whose returns are lowest and disstaides them from borrowing, thus allowing scarce resources to flow into investments which are now on average yiclding higher returns. Furthermore, higher interest rates promote labuur as opposed to capital intensive invesments. It appears that Afghanistan may soon, if it does rot already, suttier from an unemploynent problem. Hence, there is an added urgency for producing more employment opportunitics through given amounts of investment. This higher interest rates should do.

Of equal importance is the fact that higher institutional interest rates will narrow the gall herween institutional and non-institutional rates. This in itself should increase the efliciency of resource allocition not only through it, ellect on the behaviour of existing institutional borrowers in terms of delerring low yiclding and capital intensive investments but also through allateling additional funds into the financial institutions which cin be lent to new borrowers with high yielding investment projects who previously were excluded from these sources of finance.

This happy picture will of course only be realised to the extent that new banking kgislation and improved legal practices enable such new borrowers to be brought into the orbit of the institutional system. In essence this is a matter of reducing costs and risks of lending to small scale businesses which in Aighanistan tend to be those with potentially very
high returns.

In the absence of exchange controls, for which there is sound economic justification fir ant imposing. Afghanistan's financial institutions must compete with lac international market for funds. It is well known that capital has lett Aighanistan and that considerable amounts are now investcd abroad. With intermational marhets offering 10 per cent and 
more on relatively short term, safe financial assets, there hats been increasing incentive to remove funds from Afghanistan to take advantage of this differential. Until two years ago, the depreciating domestic currency enhanced the incentive provided by this differential. $\wedge$ rise in deposit rates would realign institutional interest rates in Afghanistan with increased rates throughout the rest of the world.

There is always a delayed reaction to a change in the economic environment. People in Afghanistan are probably just now beginning to realise that the $A$ fghani is no longer depreciating. Hence, this is an ideal time to try : 1 attract capital back by offering competitive returns on short term, safe tinancial assets, which in the present context implies higher returns on deposits. At this time rates do not have to provide additional compensiltion for expected currency depreciation. However, this is still needed fir loss of convenience and will continue to be the case until the efficiency of Afghanistan's banking system in respect to international transactions is increased. The introduction of exchange controls would effectively ensure that no capital returned when tinancial development occurred and the investment climite improved.

The scupe for an interest rate policy in Afghanistan is linited by the absence of reserve requirements for commercial banks and a central bank to act as lender of last resort to these banks, the relatively small effective demand for bank loans, the excecdingly undeveloped nature of the financial sector and the small volume of deposits held and credit extended by it.

On the other hand, Da Afghanistan Bank does engage in commercial banking activities and so can act as a price leader in an oligopolistic market. By changing its own commercial interest rates on deposits and loans not unly would it affect directly a sizable portion of the market (31 per cent fur deposits, 24 per cent for loans to the private sector) but it would almum certainly force the other banks to change their rates in step.

lliwever, an important consideration here is: Why, when interesi ralles all around them have been rising, have Afghanistan's finincial institutioms not already raised their rates? The answer seems to be that there has been little desire to increase resources, since the opportunities for using likm profitably are so limited, and no desire whatsoever to foster competition. This being the case, raising deposit rates to attract a larger proportion of domestic savings into the financial system will not by itself produce the desired result of raising the average productivity of investment by allocating resources more efficiently. In fact, under existing conditions precisely the reverse might occur. Banks would attract more resoures which could only be used to finance the relatively inefficient large sciale private and public enterprises while leaving productive small scale business even more starved of funds.

Thus, the success of an interest rate policy designed to attract a larger proportion of dumestic savings into the finincial system, which under normal circumstinces could be expected $w$ increase the efficiency of resource allociation and the productivity of investment, is not guaranteed in Afghanistan. Additional measures are required in conjunction with stch a policy for the latter to achieve the desired results.

The key to a policy of raising interest rates within the financial institutions appears to lic with the ability of these institutions to increase rapidly their range and volume of lending. Given that there is ample evidence of many highly prolitable investment opportunities in Afghanistan, to be expected of course in a country in which capital is scarce, the necessary measures consist of those which can facilitale bank lending. These have already been outlined in Section ii above.

v. Domestic Risunrit Mobilisution

Velocity in lle ncighbouring countrics of Iran and Pakistan was 3.6 in 1970. Assuming an income elasticity of demand lor money of 2.0 , an initial velocity of 3.6 and an annual growth in real income of 4.4 per cent, the non-inflationary increase in the money supply and, on the assumption that foreign exchange reserves remain unchanged, domestic credit "ould be 2.44 per cont if GNP. The GNP estimate in Afghanistan for 1350 (1971) of Afs 91,146 million given in Table 2.14 would allow a "safe" expansion in domestic credit of Afs 2,228 million, a sum equal to 27 per cent of total investment in 1350) (1971) given in l'able 4.5 .

The example presentcd above is quite unrealistic in the actual circumstances now existing in Afghanistan. It simply illustrates the potential level of donestic credit expansion to which Aighanistan might aspire. Afghanistan's relucity lies around 10 which, even with an income elasticity of dumand of 2. Would allow a "silfe" anmual level of domestic credit expansion of $\mathrm{dl}$, 8012 million. There is, however, no evidence 10 suggest that income elatsticity is as high as 2 in Afghanistan, although elasticity in Iran, Pakistan and Turkey appears to lic within this range. If income elasticity in Afghanistan under the existing institutional constraints were more realistically estimated at 1.1. the "safe" annual level of domestic credit expansion falls still further to Afs 441 million, still assuming a 4.4 per cent rate of real cconomic growth.

Table 8.2 presents estimates of currency/deposit ratios and velocities of 
Tabic 8.2

Currency/Deposit Ratios and Velacities of (irculation in 4.5 Umlerdeveloped Countries. 1969

\begin{tabular}{|c|c|c|}
\hline Coumiry. & $\begin{array}{l}\text { (iurrency/Depessit Rurits } \\
\text { (Dimand and Time Deposits) }\end{array}$ & Felocity \\
\hline Alghanistan & 3.439 & 10.312 \\
\hline Aigentina & 0.446 & 3.442 \\
\hline Bolivia & 1.67 .3 & 0.807 \\
\hline$|B r, a / 1|$ & 0.201 & 46040 \\
\hline$(c) k m)$ & 0.649 & $426 x$ \\
\hline c link. & $0.27 x$ & 0.580 \\
\hline ( luma (Taiwan) & 0.190 & 2.47 .4 \\
\hline Columbia & 0.397 & 5010 \\
\hline Cista Rica & 0.361 & $4.40 \%$ \\
\hline Cinrus & 0.191 & 2.0066 \\
\hline Fcuador & 0.370 & 4.772 \\
\hline $\mathrm{F} x y \mathrm{pt}^{\prime}$ & 0.846 & 2.542 \\
\hline I Stalvador & 0.292 & 4.277 \\
\hline Fthiopia & 1.191 & 7.36 .6 \\
\hline Cirecce & 0.392 & $2.06 k_{2}$ \\
\hline Ciualemala & 0.397 & 5.3 .47 \\
\hline Ciuvina & 0.320 & 2.1155 \\
\hline Ilondluras & 0.357 & 5043 \\
\hline Inctiat & 0.7 .37 & $4.3 \times 1$ \\
\hline Imlonesia & 1.105 & $14.2 \times 2$ \\
\hline Iran & 0.220 & 3.970 \\
\hline Iriall & 1.407 & 3.754 \\
\hline |srial & 0.200 & 2.413 \\
\hline Jantaica & 0.129 & 2.976 \\
\hline Jordian & 1.453 & 2.034 \\
\hline Korea (South) & 0.217 & 3.780 \\
\hline Kuwail & 0.1 .34 & 2.581 \\
\hline I chanon & 0.311 & 1.270 \\
\hline libyal & 0.592 & $44 \times 7$ \\
\hline Malawi & 0.4 .33 & 5.945 \\
\hline Mialaysia & 0.343 & 3.255 \\
\hline Mauritius & 0.345 & 2.852 \\
\hline Murreco & 0.589 & 2.949 \\
\hline Niciaragua & 0.379 & 6.527 \\
\hline Pithistan & 0.618 & 4.07 .3 \\
\hline Paralpuay & 0.463 & $6.43 \mathrm{~A}$ \\
\hline Philinpines & 0.298 & 3.744 \\
\hline Portugal & 0.169 & $1.2 ! 4$ \\
\hline Saudi Arabia & 1.094 & $4.3<6$ \\
\hline Spiain & 0.166 & 1.246 \\
\hline Sultan & 0.986 & 5408 \\
\hline Surra & 4.371 & 3.570 \\
\hline Thailund & 0.392 & 2.999 \\
\hline Tunisia & 0.392 & $2.44 x$ \\
\hline Turkey & 0.333 & 3.786 \\
\hline
\end{tabular}

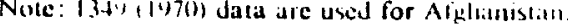

Source: Alghamistan-Tables 2.12 and 2.14 alwove.

All other coumtries..-In'ernational Finumeral Statistics. 25 (9), September 1972 and International Financial Statistica 1971 Supplemesu.

circulation lior 45 underdeveloped countries. Afghanistan has both the highest velucily, with the exception of Indonesia which experienced an increase in the level of prices of 27.510 per eent hetween 1343 (1964) and 1348 (1969) and the highest currency, deposit ratio, with the exception of Syrial.

In a recell 47 country comparative study [P12]. Perlman linund the following two relationshins:

$$
\begin{aligned}
& \operatorname{logM}=0.337+0.396 \log \gamma-0.923 \dot{\mathrm{P}} \\
& \mathrm{R}^{\prime} 0.53 \quad(0.045) \quad(0.272) \\
& \log (1 \mathrm{D} \quad 1.05-0.56 \log \gamma \\
& \mathrm{R}^{2} \quad 0.59 \quad(0.05)
\end{aligned}
$$

Where hen in the logarithn to base 10 (1) the money stock broadly delined ( $\mathrm{N}_{2}$ ) e pressed in terms of the number of weeks of income held, log $\gamma$ is the lugarithm to base 10 of per cilpita real income in Dollars, adjusted for distortions intruduced by fixed exchange rate systems, $\dot{p}$ is the expected rate of intlation expressed as a proportion, which is approximatted by the the of the logarithmic trend fitted to the cost-of-living index over preceding eight year periods, and $(/ D$ is the ratio of currency to bank demand and time deposits. Standard errors are given in brackets.

Taking a per capita income in Afghamistan of $\$ 8 x$ [U16, Table A.l. p. 177] and cupcected inflation of 5.75 per cent from Table 2.13, the velocity preilicted for Alghanistan from Eyuation 8.1 is 4.591 and the currency/deposit ratio from Equation 8.2, 0.914. In 1349 (1970), actual velocity was 10.312 and the currency/deposit ratio 3.439. These two figures are buth predicted by Perlman's equations if. instead of laking a per capita income of $\$ 88$, an income of $\$ 10$ is used. One might conclude, therefore, that measured velocity and clirrency/deposit ratios for Afghanistan are consistent with one another, and hence that money supply and GNP estimates are atso consistent, but that the linancial system is so undeveloped that it should only be found in an economy in which per capita incume was $\$ 10$. Since per cupita income in Afghanistan is at least eight times greatler, the linancial system lags behind ather parts of the economy to an alarmule degree. 
$A(x)$ per cent allocation of additional bank eredit to the public sector during the Fourth Plan might be accepted as a first approximation. $A$ total of $A$ fs 27.7 billion was to be spent by the public sector on economic development during this period [M18, Table 6, p. 256]. It will he suggested here that deficit finance could have covered 34 per cent of the planned public sector development expenditure under favourable conditions of active financial development. It is assumed that under a programme of financial reform. $A$ fghanistan could achieve a falling velocity such that the velocily predicted above for a country with a per capita income of $\$ 88$ woulal be achieved by the end of the Plan period. That other comneries have experienced rapidly falling velocities is illustrated by the figures provided in Tiable X.3.

Table 8.3

('hanges in Ciurency/Mons.' Ratiox and Vedocitic: of Circulasion in 10 Commlries, $1964-1960$

\begin{tabular}{|c|c|c|c|c|c|}
\hline & \multicolumn{2}{|c|}{ 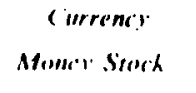 } & \multicolumn{2}{|c|}{$\begin{array}{c}\text { Gross National Product } \\
\text { Moner. Stock }\end{array}$} & \multirow{2}{*}{ 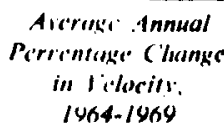 } \\
\hline & 1964 & 1964 & 1964 & 1969 & \\
\hline South Korea & 0.36 .5 & 0.178 & 11.771 & 3.780 & 20.32 \\
\hline Jordan & 0.428 & 0.592 & 3.161 & 2.034 & 8.44 \\
\hline Ilonduras & 0.365 & 0.26 .3 & 7.629 & 5.04 .3 & 7.95 \\
\hline Parrapulay & 0.421 & 0.316 & 9.050 & 6.434 & C. (x) \\
\hline Isritel & 0.205 & 0.166 & 3.326 & 2.41 .3 & 6.22 \\
\hline Taiwan & 0.180 & 0.160 & 3.936 & 2.974 & 5.45 \\
\hline Turke'y & 0.357 & 0.250 & 4.99 .3 & 3.786 & 5.16 \\
\hline Jatmaica & 0.141 & 0.114 & 3.920 & 2.976 & 5.16 \\
\hline Sulan & 0.492 & 0.496 & 7.059 & $5.40 x$ & 5.19 \\
\hline Thailand & 0.370 & 0.282 & 3.898 & 2.999 & $\$ .11$ \\
\hline
\end{tabular}

Nute: An annually compounded growth rate is used in the final column.

Source: Inernational Financial Statistics. 25 (9). Scptember 1972 and International Finuncial Simtistics: 1971 Supple'mernt.

The implications of these assumptions for "safe" levels of deticit linance for the period of Afghanistan's Fourth Plan can now he calculated. The results are presented in Table 8.4. Case $A$ uses the draft Plan figures for deficil linance and calculates the implied fuctuations in velocity. Case $B$ assumes no financial development but that the existing tinancial conditions are maintained, i.e. constant velocity. Case $C$ uses it 15 per cent annual liall in velocity which would bring it down to the predicted 4.591 by 1355(1976).

One of the simplifying assumptions which has been used is highly
Table x.t

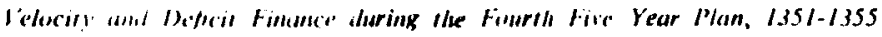
(Millions of Afghanis)

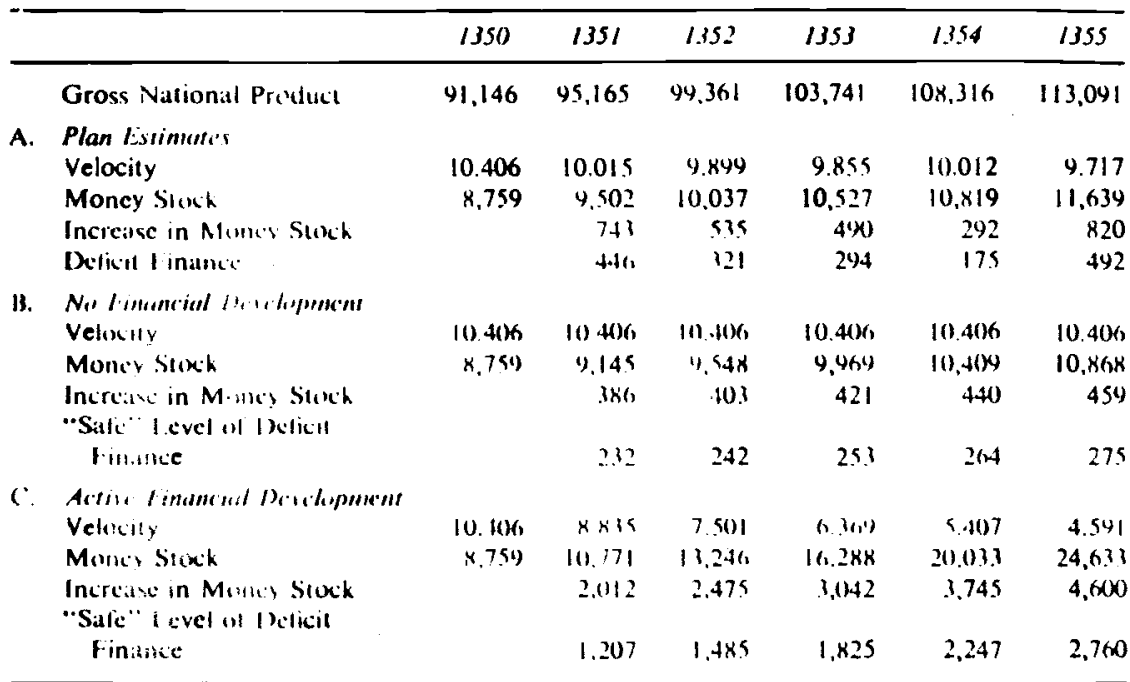

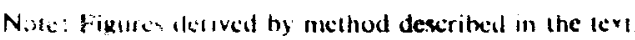

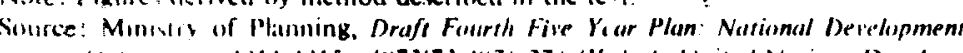

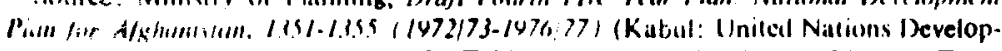
Inemi frokramukc, mumeo, July 1973). Table 1, p. 249 and Table 7, p. 257: and Table 2.14 aboves

misleading. It in that GNP will grow at the same rate regardless of the degree of linancial development. All the availathle empirical evidence refutes this and it can be expected that the achicvable growth rate under active inanciat development, where more resources are available for devekpment ; penditure. will be considerably higher than would be possible under $c$ ase $A$ or $B$ financial conditions. In fact, the 4.4 per cent anmail average growth target might be considered unrealistically optimistic under essting linancial conditions. II lhe incremental capital/ output ratio (ICOR) for the lourth Plan period were assumed to be 2.5 , a hiv tigure, the planned lotill investment of $A f$ s. 30.9 billion would achieve a growth rille of under 2.6 per cent per annuni. If the resources made available from aggressive financial development were aldued to those already allocited, the growth rate would increase under these assumptions to 3 .oppercent.

Another important assumption made was that Afghanistan is a closed economy, Batance af payments disequilibria disturb the results produced 
ahole. However, so long as there is no attempt to increase foreign exchange reserves, the "saie" levels of domestic credit expansion and deficil tinance will if anything be under rather than overestimated. Similarly with "other items" in the monetary survey accounts. a contintaltion of its trend uver the past five years would allow a greater "safe" level of delicit linance than estimated.

A deliberate policy of financial development in Afghanistan could be expected lo accelerate the rate of economic growth and provide much necded additional liunds for development expenditure. If linancial develupment slightly more than halved velocity of circutation, i.e. more than doubled the demand for money at every level of income, over the next live sears. and if the ratte of economic growth were partly thereby raised w the target of 4.4 per cent per annum, the "safe" annuall levels of deficil finance would be those given in Case $C$ in Table 8.4. Thus at total of Afs 15.874 million would be niade available over the period of llic Fourth Firc Year Plan which would finance over 50 per cent of plamned total investment. The "sate" level of deficit finance would provide finds for 34 per cent if planned public sector investment.

Some lorms of investment are likely to accelerate monetisation. i.e. increase demand for money. more rapidly than others. For eximple, the better communications are, the faster monetisation will occur. Investment in roads can be particularly effective in causing the demand for money to increase. To the extent that they cause an increase in the demand for money, such investments can be regarded as self-financing and, therefire, particularly attractive.

Without an active policy of financial development the tot:al "salfe" level af deficit finance would be $A$ fs 1,260 million on the assumptions used in calculating figures in Table 8.4. It could be argued that the growth rate $\left.u_{\text {oudd }} n_{1}\right)$ be the same in both cases and therefore that the difference in the "safi" levels of deficit finance under active financial develonment and miler the status quo would be considerably greater.

The polential for increased domestic resource mobilisation from grealler tiscal elfort can be examined in the same manner as that from finaticial declopment. Here, it is assumed that fiscal effort is to reich the averitge level, i.e. ${ }^{-E} \quad$ I. by 1355 (1976). It is also assumed that the Government s ordinary expenditure increases annually at the planned rate of 72 per cent [MI8. Table 1, p. 245], and that the approach to average fivial effort takes place gradually. Figures in Table 8.5 are derived on the hasis of these assumptions. For average fiscal effort, it has been assumed that domestic revenue would equal 11.31 per cent of CiNP
7 ahis $x .5$

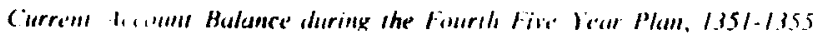
(Millions of Alghatuis)

\begin{tabular}{|c|c|c|c|c|c|c|c|}
\hline & & 1.350 & 1.151 & 1.352 & 1.3 .53 & 1.354 & 1355 \\
\hline & Ciross Nalional Powlact & 91.146 & 95,165 & 94,361 & $10.3,741$ & $10 \times .316$ & 113,041 \\
\hline \multirow[t]{4}{*}{ A. } & Plan Livimare: & & & & & & \\
\hline & Domestic Revenu: & 5.82 .3 & $6,2(x)$ & 7.170 & 7,957 & 9.191 & 9.837 \\
\hline & Ordinary Expcinduluc & $5,5(4)$ & $5,(x) \times$ & 6.218 & 6.721 & 7.134 & $7,8 \times 1$ \\
\hline & Current Account Balamic & 314 & (9)2 & 9.12 & 1,236 & 1.852 & 1,450 \\
\hline \multirow[t]{3}{*}{ II. } & No Increase in l woul tillurt & & & & & & \\
\hline & Doneslic Revelllis & 5.823 & $\begin{array}{l}6.080) \\
5(0,0)\end{array}$ & (1. 1.18 & $6,62 x$ & $\begin{array}{l}0.120 \\
73319\end{array}$ & 7.225 \\
\hline & $\begin{array}{l}\text { Grdinaly t-xpondelene } \\
\text { Courent Account Batiance }\end{array}$ & $\begin{array}{l}15(44 \\
114\end{array}$ & $\begin{array}{l}4.60 \\
+72\end{array}$ & 110 & 93 & 114 & $\begin{array}{l}1,305 \\
0.50\end{array}$ \\
\hline \multirow[t]{4}{*}{ c: } & 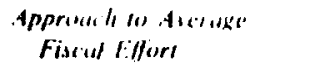 & & & & & & \\
\hline & Domestic Revillici & 4.82 .3 & 0.816 & 7.477 & $9,3.17$ & 10.428 & $\mid 2.791$ \\
\hline & Ordinary Expouditure & 5,504 & $5,(x) x$ & 1.2 .38 & 6.721 & 7313 & $7,8 \times 1$ \\
\hline & Current Account Bsilume & 319 & $1.211 \mathrm{k}$ & 1.7 .14 & 2.616 & 3.584 & 4.910 \\
\hline
\end{tabular}

Note: Figures dewall by method descrited in the cat.

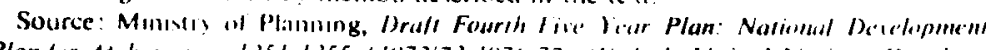

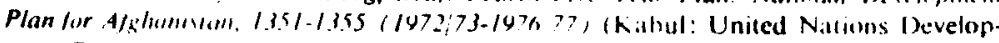

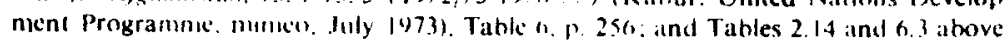

in $1.355(1976)$. The current account surplus produced by a gradual approach to a verige fiscall cllort equals $A$ fis 14,062 million or over 50 per cent of plamed public sector invesiment during the Fourlh Plan.

If the resurices from aggressive financial development and fiscal reform were added to those already allocilted. total development expenditure would tis in Als $\$ 1,069$ million which with an ICOR of 2.5 would enable a 4.1 fici coll average anmual growth ralle. However. if there were to be no increase in fiscal effort lotal resources for development expenditure would fill from the projected Afs 31.9 billion to Als 23.7 billion even if the donors contributions remained tinchanged. This would yield a growth rate al only 2.0 per cent, provided that the ICOR remained at 2.5 .

\section{vi. Conclusion"}

It has beell gued in this book that Alghinistan's development potential durng the post-uat period has been low. Two of the fictors contrihuting to this low pulential, namely the inadequate financial system and the apparent lack of cormmitment on the part ol the country's leaders to developinent, were analysed in detail. The lack of commitment was examined in respect to hoth the planning and budgetary processes in 
Chaplers IV and VI, respectively. The absence of financial development was discussed at length in Chapter $V$.

It wils suggested in Chapter III that the critical const raints to economic development have been closely related to economic fragmentation which in turn hits greatly inhibited the results of development efforts. Economic integration must be viewed as an intermediate objective in removing the five critical constraints to economic development presented in Chapter I Fintuncial development can be designed in the first instance 11 renove frafmenlallun in the capital market, feeler road construclion (o) reduce gecographic lragmentation. The latter would in turn do much to remove fragnentalion in product narkets. In pursuit of economic integration. much murc altention siould also be focused on effective agricultural credil, demunstration, extension and supplies programmes. For this and for the fecder road programme greater fiscal effort is imperative. This is also required for the much needed reform of civil service pay scilles and the introducion of financial incentives for improved performance.

A substantial improvement in the levels of domestic resource inobilisation Ihrough the financial sector and the fiscal system of the order illustrated in the hypothetical examples given in the previous section would do lar more than just double the growth rate. Such changes would be clear indications of a rapidly improving financial system and strong commitment to economic development on the part of the country's leadernip. The increased resources conld be used to maximum elfectiveness 11 improve agricultural productivity and the country's feeder road network. lior neither is foreign aid likely to be forthcoming in sullicient volumes $(1)$ make the necessiry impact.

Thus. lour of the Adelnuan-Morris [A2] indicalors of development potential could be directly manipulated by reform programmes in the financial and liscal areats. The result in the form of rapid economic growth through an aclive export promotion programme which an increase in Afghanistali s development potential would enible could he dramatic. Indeed. the widespread benefits which should accrue could well secure the support of a substantial proportion of the community for development ellork. This, it may be remembered, is the fifth deterninint of develupinent potential [A2].

\section{BIBLIOGRAPII)}

No reference huve been made in either the text or the bibliography to the excellent reports prepared regularly by the Asian Development Bank, the Internationil Bank for Reconstructien and Devetopment (World Binnh) and the International Monetary Fund, since their distribution and use are restricted. The interested reader will not, however, encouncer much dilficulty in consulting these ceperts.

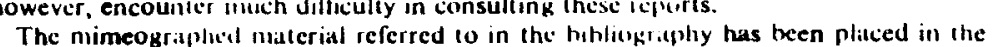

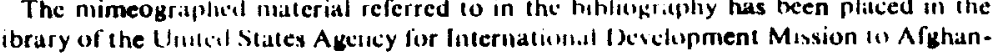
istan. Sets of $11 \mathrm{x}+11$ I inancial tevelopment (imfuntlee reports have been denosited as follows:

In Kabul Da Alghanistan Bank Library Kiahul Public Library Kabul University Library

Minisiry of Finance Library Munistly of Planning Library Keseitrch Departnent, Da Algh.uistian Hank Resident Representative of the International Monetary fund tinited Nations Developnlent Progl amme Library lluited States Agency for International Develonment Libraty

In Britain Deximnentation Centre, Middle East Contre, Universily of Durhan. !ishium

In U.S.A. Nighianstan Studies and Research Program," University of Nebyaska al Onlatha. Onlaha. Nebraska

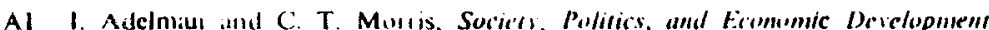

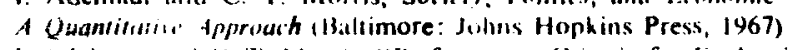

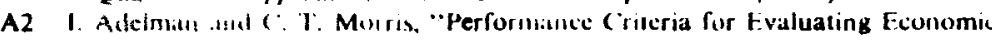
Developmem Potential: An Operational Approach," (Juarierly Jasurnal af Latsiomio, $\mathrm{x}:$ (2), Micy lyot8, pp. 260-80

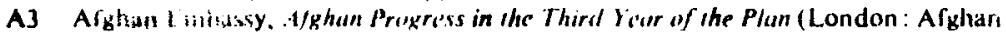
Einbassy seoutember 1954)

A4 J. P. Agitu, wi, "Optimal Monetary Reserves lor Developing Countries." Weltwirsschaylin in's Archiv. 107 (1), 1971, np. 76-91

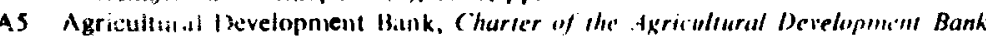
of s/ghuma:al: (Kabul: Agricultural Development Bank, 1970)

A6 Agricuitural levelopment Bank. Loan Rexuthetions (Kabul: Agricultural Dessioginin Bank. Oetober 1970)

A7 Agricilturitt Gevelopment Bank and Helmand-Alghandab Agricultural Finance

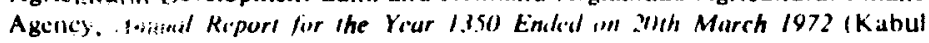
Agricul(n:d! ! Developnent Bank, 1972)

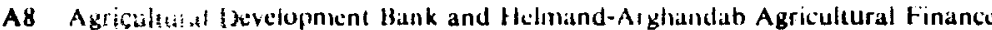

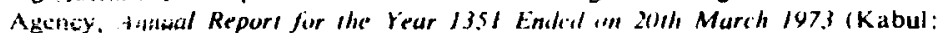
A A

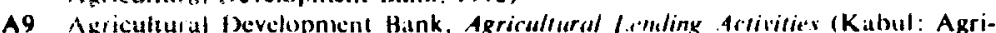
cultural Desctopnent Bank, mimeo, May 1973)

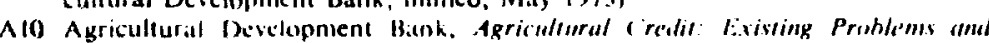


Rerminmented Solumions tKabul: Ministry of Finance. Financial Development (ommiltee, Report No. R/024, mimeo. 22 May 1973)

AII J-ud-I). Ahmad and M. A. Aziz, Afg/hanistan: A Brief Surver (Kabul: Dar-utralit. (313)

AI2 S. S. Alimady, A Glance an Afghanistan's Tracle (in Dari) (Kabul: Chamber of Commerce. Extra Publication of Iqtisad Journal for the $45 \mathrm{th}$ Anniversary of
Indenendence, 1343)

Al3 R. T. Akhramovich, Oulline Hislory of Alyhanislan afier the Secomd Wirlil War (Moscow: Nauka Publishing House, 1966)

Alt A. Ali. "Banking in the Middle East," International Monetary Find Situll Pupers, h (1). November 1957. pp. 51 -79

A1s M. All, Prugressive Afxhanisian (Lahore: Punjab Educational Flectric Press, 1933)

Al6 M. Al. Commere iul A/khumistan (Dethi: Mohammed Ali, 1946)

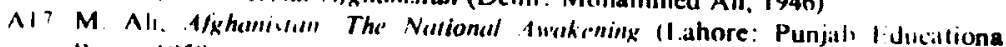
['riv. (9)

AIx M. All. t/ghoniston the Mohammedaui Period (Kabul: Mohamned Alı, 1959)

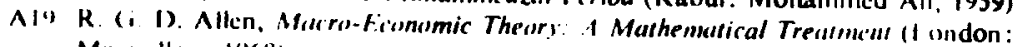
Macimilian. (1968)

A20) Amerkan Embassy. A/xhamistan: Ecomemic Trends Report (Kalbul: American Intiasuy. Septeniber 1972

A:1 Amerkicin International Investment Corporation. World Currency. (Jurrts 1970) ISan I Iancisco: American International Investment Corporation duc Iy70)

A: P. Ancialux, A. Forgeur and $Y$. Farjot, Advisory Mission on mus June 1970) in stghanisian linul Repurr (Two volumes) (Kabul and Brussels: Research and

A21 ( J. Anderson, \& Runking and Cratit Syser October 1971)

I/xhamulan (Washmington, D.C.: Robert R Nar the Ecomimic Derchopmerm of

A24 (1967) ( J. Anderson, A/khunistun: The Bank ing Act 1967, Preliminary Draft (Kabul: Rotuert R. Nathan Associales, mimco, 1967)

A25 1 ( Andersen. "N ederal Reserve Defensive Operations and Short-Run Courrol

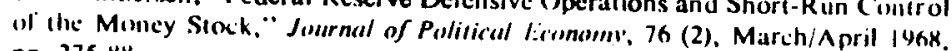
pp. 275-kx

A2" S vill Mta, "A Note on Usury Legislation in the Philippines." Philippine IComsinic Journal. 10 (1). First Semester 1971, pp. 4X-62

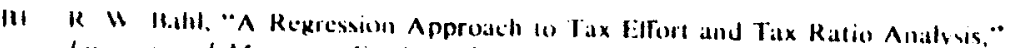

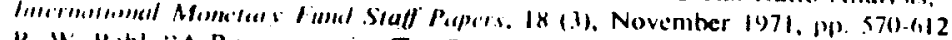

132 K W It.thl. "A Repiesentative Tax System Appoach to Measuring Tax liflore in Developing Countries." Internatiomal Monetary Iumb Siaft Papers 14 (1). Narch 1972, pp. $87-124$

B. (i B. Haldwin. Planning and Develuphencut in Irau (Ballimore: Johns Hlopkins Pien. 1967)

B4 F. Ballewperger. "Fconomies of Scale, Firm Size, and Concentration in Banking." Jinurnal of Money. Credit and Banking, 4 (3), August 1972, np. 467-88

BS Bank Millic. Repurı of Bank Millie's Activities in 13,30 (in Dari) (K. 467 . Bank Millic. (3fi)

Bh Hink Millie. Repwort of Ihe Buard of Directors and Balance Sher' for th' Year l.med 311h H(sul 1.136 (Kabul: Bank Millie, 1958)

B7 Bank Millie. Repurt of Bunk Millie's Artivities in 1344 (in Dari) (Kabul: Hank Miallie, 1345) BX Bank Millic. Repurt of Bunk Millie's Activitirs in 1350 (in Daril (Kabul: Hank
Millic. I1si)

By A P. lla nabas. Furmer Characteristics in the Baghlan Pilut Area lKabut: United

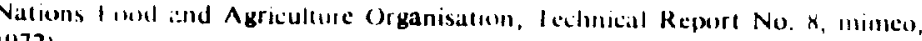

B10 L. Baron. Sictor Analysis: Holmand-Arghumdah Ville'y Region (Kabul: Uniled Stales Ageilcy lor Internatuanal Development. numeo, February 1973)

BI1 L. Baron. A (rivique of ihe Proposed Helmumi-Arghumlab Valley. Project (1971) (Montreal: Maciill Univershy, numeo, July 1973)

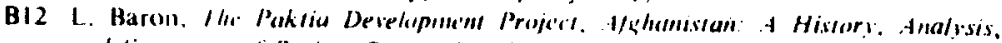
and Sirmmary af Project Proposals (Montreit: Meciill University, mimeo, July 197.31

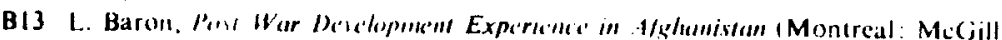
University, minteo. July (973)

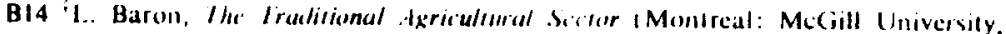
mimeo. lulv 1971,

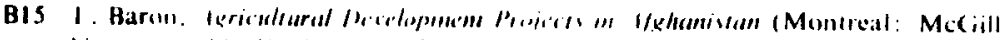

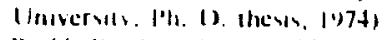

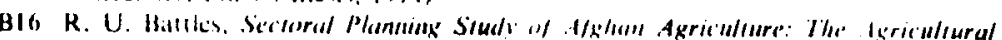

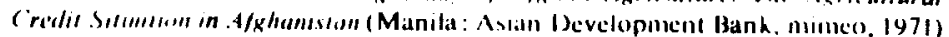

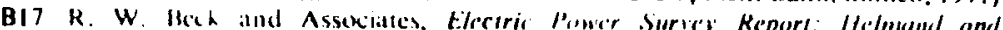

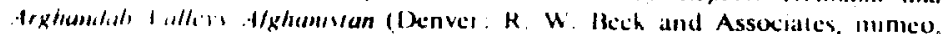
Noverniber fwoll

Bis (i. L. Bell and 1. S. Berman, "Changes in the Money Supply in the United

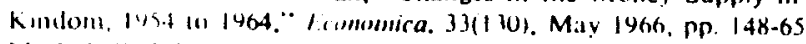

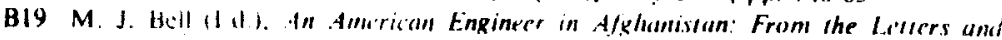
Nuses of t. C. Jewell (Munncapolis: Munnesola University Press, 1948)

B20 M. Heloft. The Rirrign Pulic. of Suvice Ruswia $14.39-1441$. Volume If 1936-1941 (London: (Balind University Press. 1944)

B21 R. E. Bencedich, Imlusirial Finunce in Iran (Cambridge: Mass.: Harvard Uni versity, Giadualle School of Business, 1964)

B22 G. J. Benston. "I conomics of Scale of Financial Institutions," Jomrnal of Afonev.

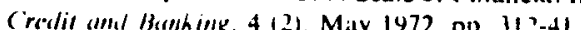

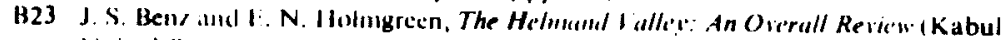
United Stalcs Agency lor Internationat Development, nimeo. Novensber 1962)

B24 J Bhagwali and if Itansen, "A Theoritical Analysis of Smuggling," Quarterly fournal of l. (1)

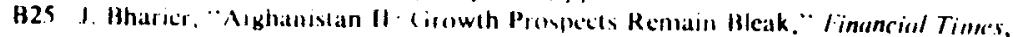
17 Augui 1971, 1.,

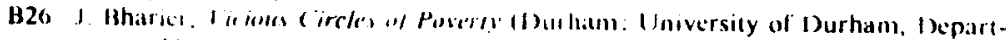
Illent of I comomes. typescript. 1972,

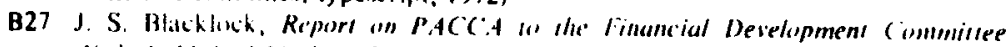
(Kabul: Uniled Nations Food and Agricullure Orgimisation, mimeo 4 March $(1973)$

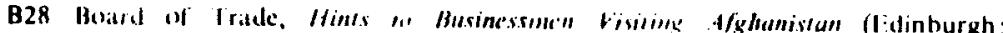
11. M. Stationery Otfice Press. 1969)

B29 L. Bogdanos. "The Afghan Weights and Measures." Journal of the Asiatic Siocicti of licengal. N.S., 24, 1928, pp. 419-35

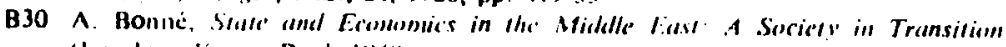
(London: Kexan Paul. 1948)

B31 M. R. Hrant, "Recent Fomomic Develonment in Afghanistan" in Afghanistan in the Sav'mliev edited by L. Dupree and 1 . Albert (New York: Praeger, 1974). in. 144-86

B32 A. F. Brimmer. "Central Bamking and Fomomic Devetopnent: The Record of

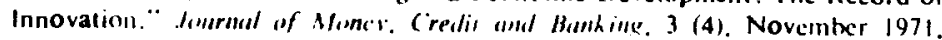
pp. 780-92 
H.14 British f.eqation, (1/fice Mumal (Kabul: British Legation, 1933)

B 34 J. R. Brooks, Recommendatiuns for a Bank for Indusirial Developmu'n in/ A/ghamistan (Wasthington, D.C.: International Cooperation Administration, (Ollice of Privitic tonterprise, mimeo, 1960)

B35 (i. I. Hrown. Eromumic Policy and Development: A Case Study of Kurea in the $140(s$, Washington, D.C.: Unitod States Agency for International Developnient, numeo, $19 ; 0)$

B36 K. Hiumer and A. H. Meltuer, "Predicting Velocity: Implications for Theory and Policy." Journal of Finunce, 18 (2), May 1963, pp. 319-54

C) "Gabinet Policy Statement on the Banking Law," Kabul Times, 16 Jaura 1352 (6 Junc 1973), p. 3

(2) D. (ayall. Deferminumts and Effects of Chamge's In the Slock of Monel. 1875-1960) (New Yurk: National Bureau of Economic Research and diatributed by ( olumbia University Press, 1965)

C) R. Cameron (Ed.), Banking and Economic Development: Some Lessums of Histur, (New York: Oxford University Press, 1972)

(4) C. 1). ('ampbell, "The Velocity of Money and the Rate of Inflation: Recient Expreriences in South Korea and Brazil" in Varieries "f Monelary Iixperisnces edited hy 1). Meiselman (Chicago: University of Chicago Press, 1970), p1). $31 \%-66$

('s J (ali ind L. H. Simith, "Money Supply, Interest Rates, and the Yicld ( Jourmal "f Afoney, Credit and Bankinx, 4 (3). August 1972, pp. 582-9.4

C6 1 Canpani and 1 . Cagnacei, Ashonistam: Crocervia Dell'Asios (Milian: AnIonio vallardi, 1951)

('7 ('entral Statistics Office, Re'vised National Price Indexes for Afghumistun fitr the Vi'uri 1.148-1350 (Kabul: (entral Statistics Office, nimeo, 1972)

CN Central Statistics Oifice, Weekly Prices: Ficuls (Kabul: Central Statistics oflice. Kepull (x)y.059, ninkeo, 18 Saratan 1352 (9 July 1973))

Cy $V$. Cirvon, "Probiems in the Integration of the Afghan Nation," Milklls. Fis.st .hisural, 6 (4), Autunun 1952, pp. 400-16

(11) V (Crvinka, Afkhanistan: Siructure Econtmique et Sociale: Commerce lix cirirur. (liausanne: Office Suisse d'Expansion Commerciale, (950)

CII A. (i. Chandavarkar, "Sonie Aspects of Interest Rate Policies in Less Developed Economics: The Experience of Selected Asian Countries," Intermational Mfonefary Iund Sicuff Papers, 18 (1), March 1971, pp. 48-110

C12 Checilit and Company, The Demand for Debe Finansing in Afshanistumi Prisare Indusirr. Scrior (Kabul: Checchi and Company, mimeo, September (971)

C1. (hecchi and Company, A Discussion of the Market Available to the Industrial Develifuisent Bank of Ajkhanistan (Kabul: Checchi and Company, mimeo. Noveruler (971)

Clt (hecihi and Company. Financial Projestions: Industrial Develupment Bumb of 1/khumivin (Kabul: Checchi and Company, minieo, January 19?2)

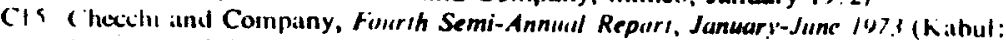
(hecith and Company, minco, Juse 1973)

CI6 11. H. (henery and A. Macliwan, "Optimal Patterns of Growth and Aid: the (ase of l'akistan." Pakissun Development Review, 6 (2). Summer 1966, pp. 204-42

$\mathrm{C} 17$ 13. I. ('when. "Relative Efrects of Foreign Capital and Exports on I Conomic 1)evelupment." Ri'view of Ectmomics and Statistics, 50 (2), May 1968. pp. $281-84$ CIX (unstiution of Afxhanistan, 9 Mizan 1343 (I October 1964)

(14 J S. Cinta. Tax Rerirnues Sources of the Roval Government of Afghaniviun (Kabul: United States Agency for International Development, mimeo, Octotur (Kabu)

C20 (i, H. Craig. Imlustrial Development Bank (Kabul: Robert R. Nathan Associates, iypescrint, Novemter 1965)

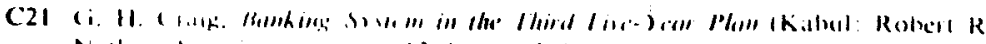

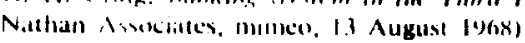

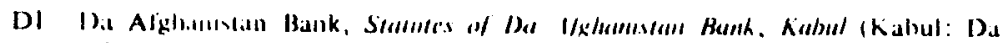
Mghanisl.11 Bank, 1942)

D2 M. Danotut, "Proclamation of the First Repullse of Afghanistan," Nulm/ Fimes, 27 Saration 1352 (18 July 1473), p. 1

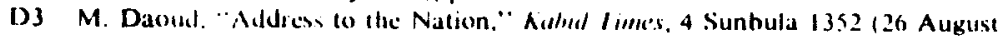
(4) 31, p). 1.4

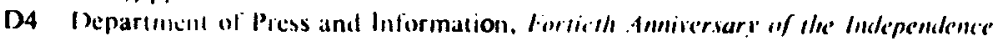

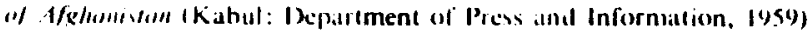

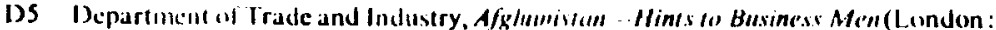
Departincilt of Holdete and ludestry, 1972)

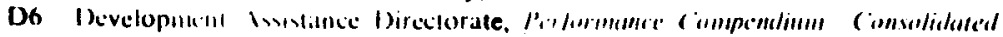

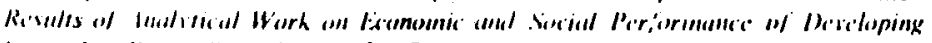

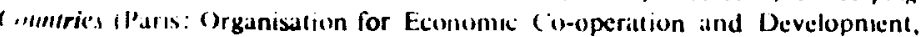
1).eclopnicit Nisistance Dircetorate. 197.1 ,

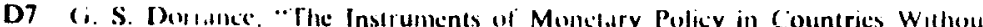

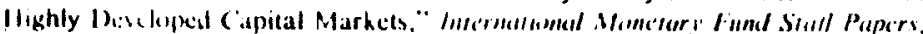
12(2). Juls 1\%os. pp. 272-70

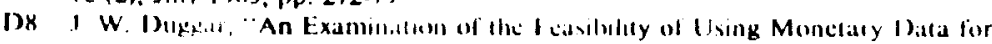

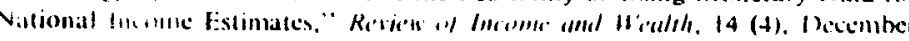
$146 x, 1,3) .311,11$

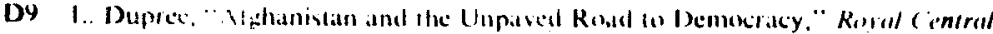

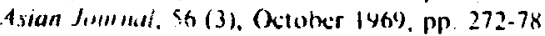

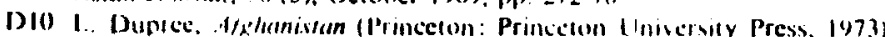

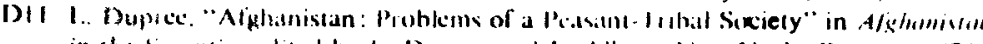

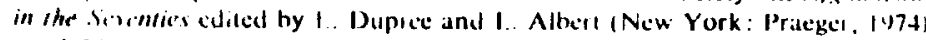
in. 1.2 .

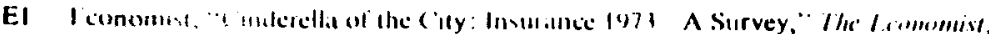
"Sine 167.3

E2 Z. A. Ettcram. "Afghanistan's Foreign Iratde." Hiddle East Journat, 20 (1). Winter 1'wh. Mr. 95-103

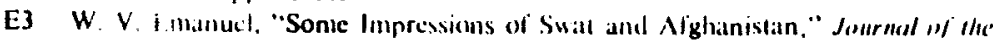

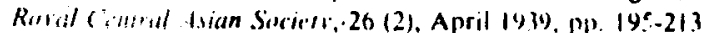

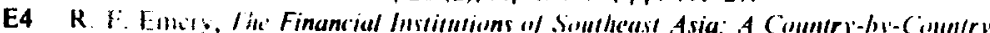
Sthdy INicw Youk: Praeger, 1970

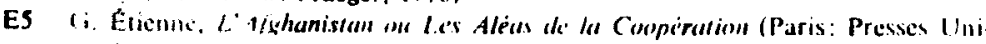
versitail a diance, 1972,

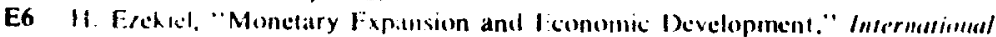

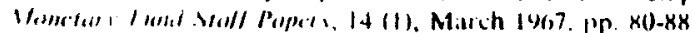

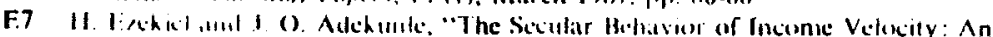

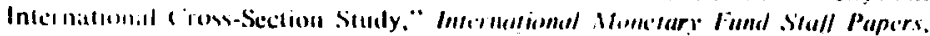
$16(2), .111,1 \%(1)$. pN. 224-37

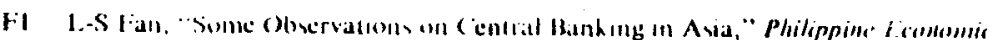
Jinumal, y (1). First Sonicster 1970, nn. 125-11

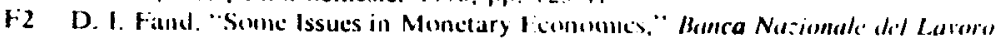
Quarter/1. Bull, t. (x), Seplember 1964. Mp. 215-47

F3 K. Ferdintend. "Nomad Lapansion and Commerce in Centrat Alighimistan A sketch of Somc Modern Trends," liglk (Copenhagen), 4, 1962. pp $12:-59$ 


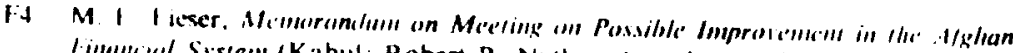

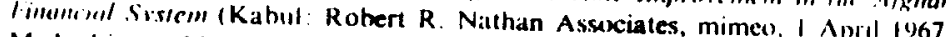

Is M t licer Roteil R. Nalhan Assiciates, mimeo, 14 May 1467)

10 M. I. licser, The Forstiales, mimeo, 14 May 1967)

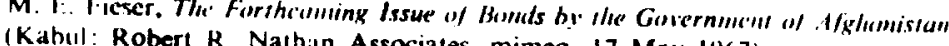

7 Finallil Times, 17 May 1967)

Finialcial Times. "Afghanistan: Financial Times Survey," Financial Times, 17 Alugust 1971

1.s I. Tinler. The Rale of Inicrest (New York: Macmillun. 1930)

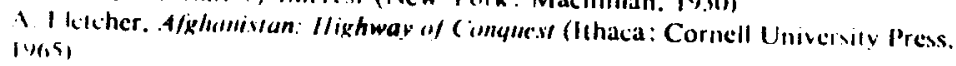

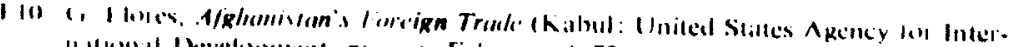

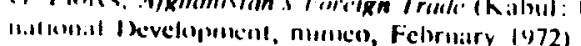

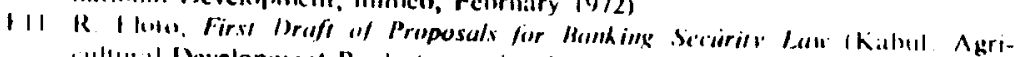
(11tult,al I Development Bank. typescript. November (1)70)

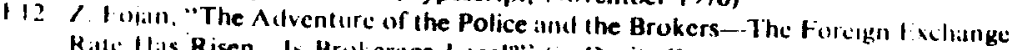

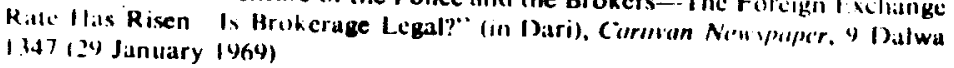

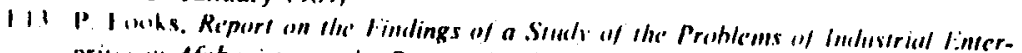

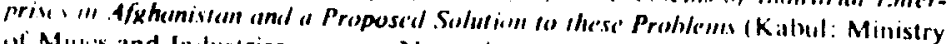
if Mllics and Industries. mimeo, Novemter 1972)

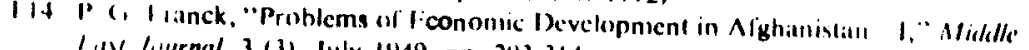
I iN . Airnal, 3 (3). July 1949, pp. 293-314

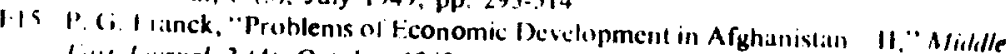
livi l, irrial, 3 (4), October 1949, pp. 421 -41)

1. It P. (i. I ianck. "Technical Assistance through the United Nations: The UN

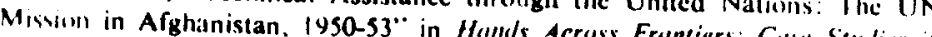

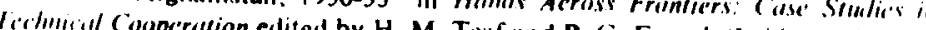

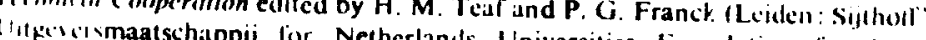
o.ttiobill Cooperation lys Netherlands Universities Foundalion for Inter-

11 11 (i lo (anck.

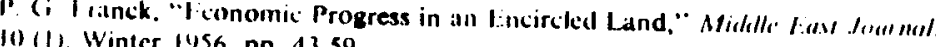
10 (1), Winter 1456, pp. 43-59

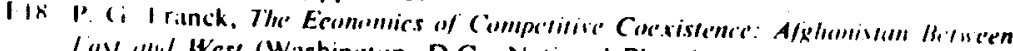

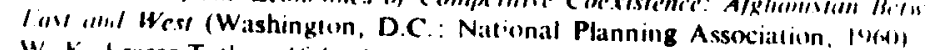

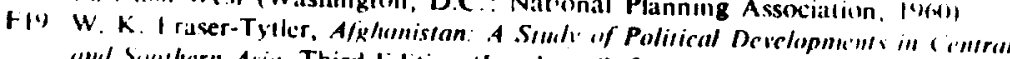

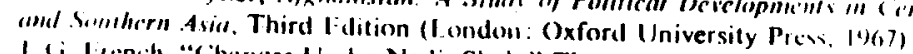
i' (i. Irench. "Changes Under Nadir Shah," The Times (London). II November

F21 M1 I riedman, "Monetary Data and National Income Estimales." Irommmic

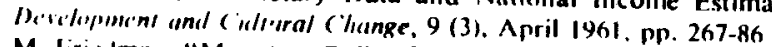

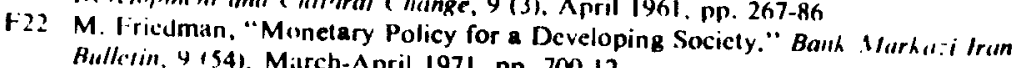

21 M. Friedman. "Ciovernment Revenue Thom M. Iriedman. "Ciovernment Revenue from Inflation," Jourmul of Pilitical

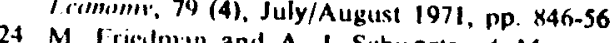

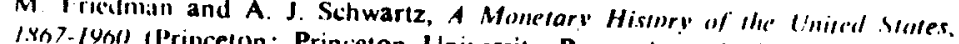
IYA $7-/ Y h(1)$ (Princelon: Princeton University Press. A study by the National Burcain of Econogyic Research. 1963)

F25 M I. Fry. Finutic and Develupment Plamming in Turkey (Leiden: Brill. 19721

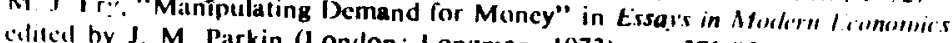
27 M. J. Jiy. Fim. Parkin (Londlon: Longman. 1973), pp. 371-85

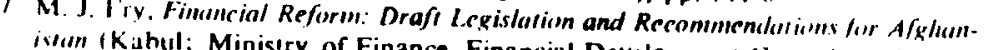

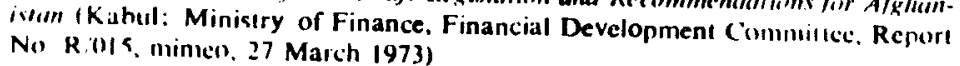

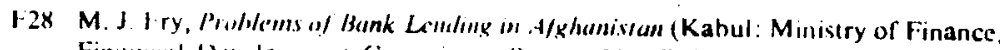
Finitucial Bevelopnent Conmitte. Report No. R/017, mimeo, 3 April 19?3)

129 M. J. I.ry, Gorernmem Bomds (Kabul: Minisiry of Finance, Financial Developmellt (immitlec, Report No. Rivis, ininico, 4 April 1973)

F.) M. J. Fry, Financing the Whear Price Support Programme (Kubul: Ministry of Finance, I inancial Develupment Committec. Repurt No. R/020, mimeo, y May 1973

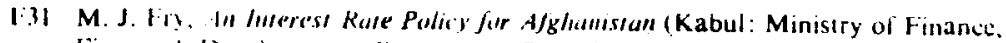
Finalscial Development Coninulfec. Report No. R/032, mimeo, I July l 973 ,

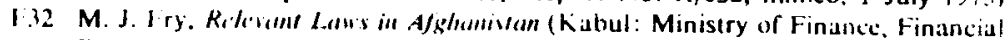
Develonment (ommintic, Report No. R,035, mumeo, 17 July 197.3)

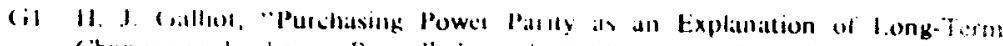

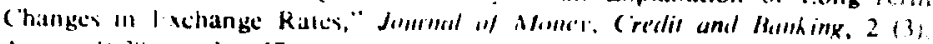

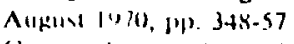

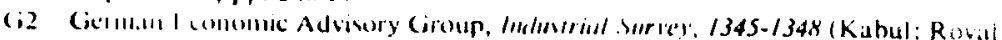

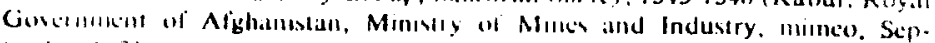
teniler 1971)

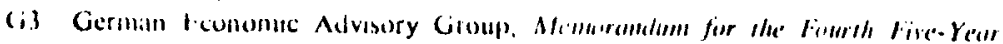

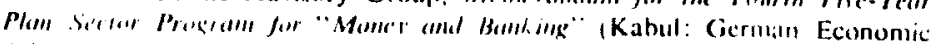

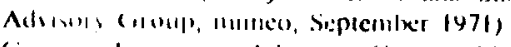

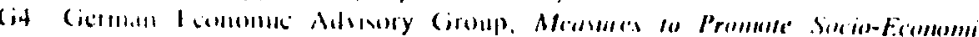
Progen" H/ghanistan (Kabul: German tcononic Advisory (iroup, nimeo. Matrcli 1972)

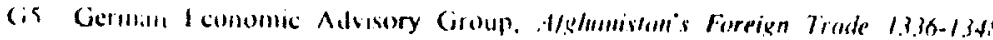

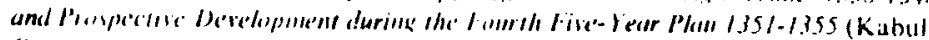
Ciermin I contmic Advisory Group. numleo, Hamal 1351 (April 1972)1

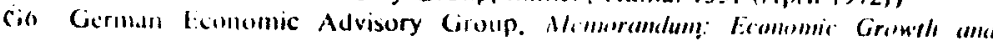

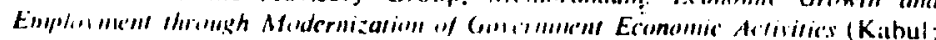

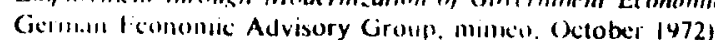

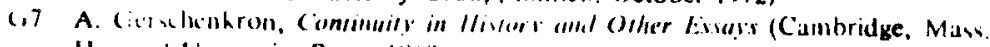
Harvillal thuversity Press, ligh8)

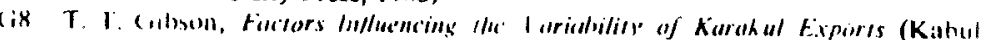

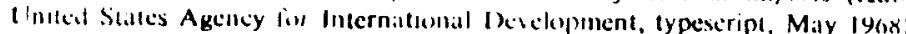

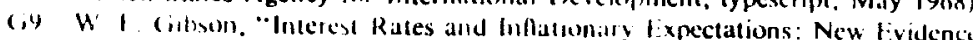

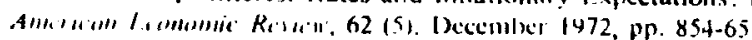

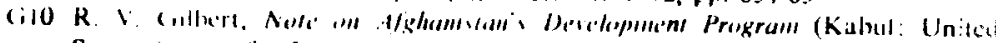

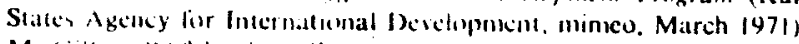

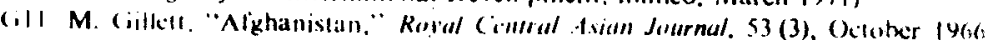
pp. $238-4$

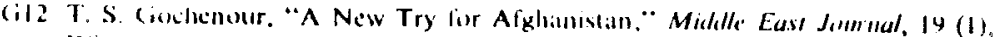
Winter 1\%t.5. Pl. 1-14

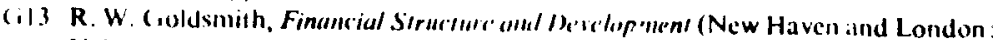
Yale (Iniverstly Press. 1969)

(i14 S. I ceconbuum and C. F. Hiaywowd, "Sccular Change in the Fintuncial Services

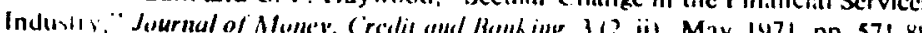

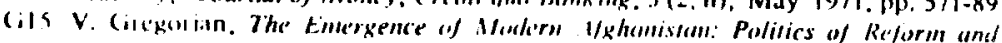

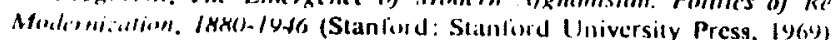

(ill K. Cirlliti Forcign Capital, Domestic Sinvings and ticonomic Development."

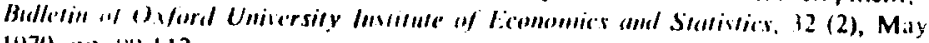
1970, 131. 194.112

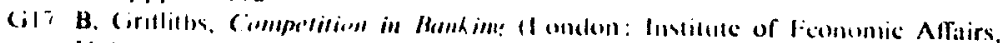
Hot..11 P.iplet 51,1470 
(iix B. Cirlfitls, "The Welfare Cost of the U.K. Clearing Banks" Cartel," Jumrmul af Moncu. C redit und Banking, 4 (2), May 1972, pp. 227-44

(ily B. Cirillihs. "Resuturce Efliciency, Monetary Poticy and the Reform of the U.K. Banking System," Journal of Afoney, Credit and Banking. 5 (1, i), February 197.3. inp. 61.77

G20 J. C. Cirilliths, Afkhmistan (New York: Pracger, 1967)

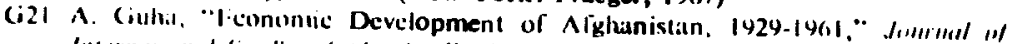

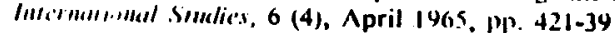

622 A. Ciuhl, "The Economy of Afghanistian during Antanullah's Reign, |4/4. $1929, \cdots$ Jinumal of Internationul Studies, 4 (2), Octuber 1967. 1p. $161-82$

G2. M. C. Ciunta, "Differential tillects of Tight Money: An Economic Rationate"

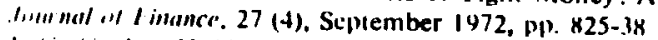

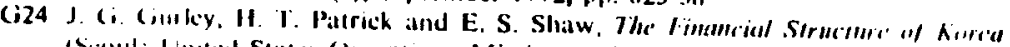

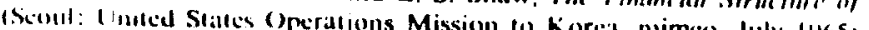

(i25 I li. (i)

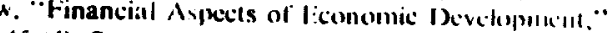

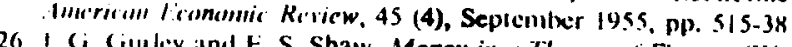

llic liswey and F. S. Shaw. Money in a Theory of Finance (Washington, D.S.: llic Bronthings Insticution, 19(x)

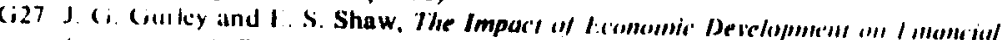

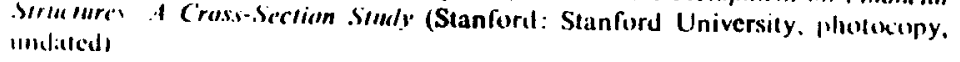

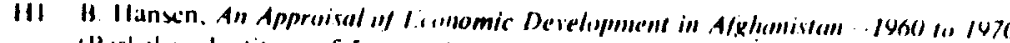
lBserkeles: Institute of International Studies at the University of Califormia al

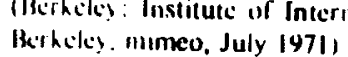

H2 II Hl.nx'll and K. Tourk, "Three Papers on Price and Trade Indices for Alghan-

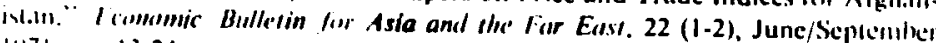
|47|. 10. 13-24

113 I. S Ilamon and R. C. Vogel, "Inflation and Monetary Velocity in I attin

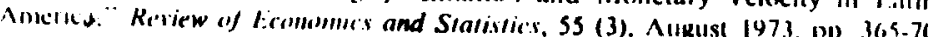

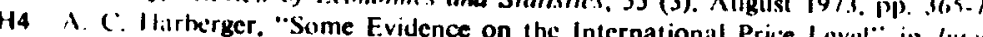
muriumul linumce: Selccled Reculings edited by R. N. Cooper (Harnondsworth: P'enguin Books. 1969). pp. 165-90

HS A. (i. Hall, "Fiscal Policy in Latin America," Journal of Pulitical Ricmumm!, is (4. ii). July August 1970). pp. 857-89

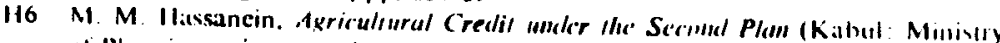
ot Plamoning. minese, undaled)

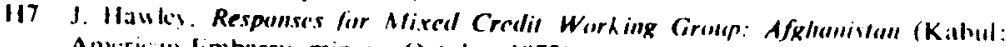
Amkriciol Imbassy, mincolo, (ktober 1972)

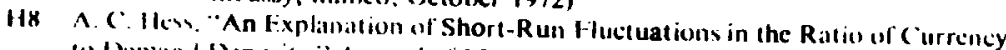

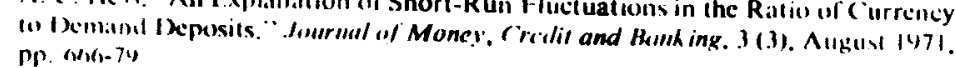

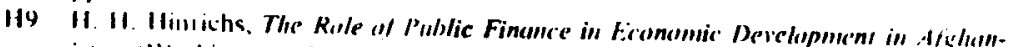

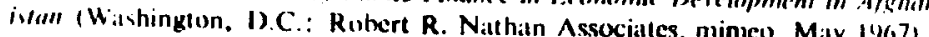

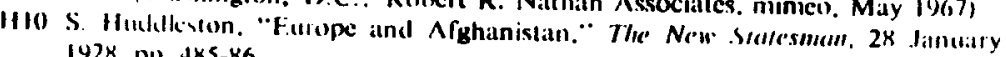
192x. P1). $4 \times 5-86$

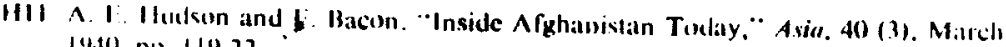
14.40. ro $119-22$

11 Institut fur Fntwichlungsforschung und Fntwicklungspolitik, Foposuls far.

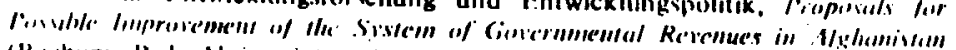
(likhouns: Ruhr Unicersitiat, nimeo, 1973)

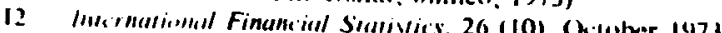

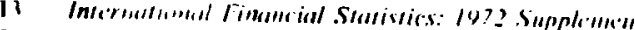

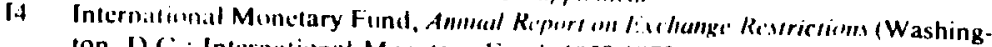
ton, D.C.: International Mfonetary fund 1950-1973)

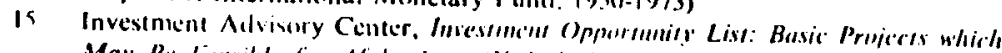

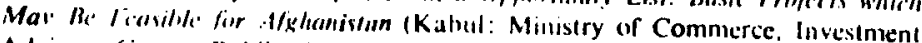
Advisury (íller. Publication No. 2.1972)

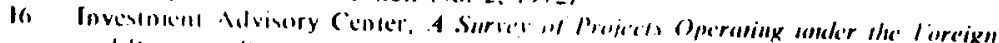

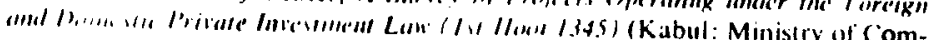

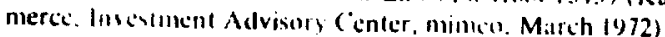

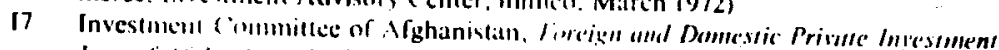

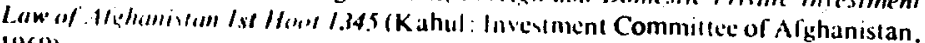

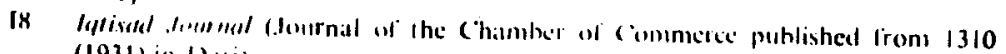
(1931) in (B.tri)

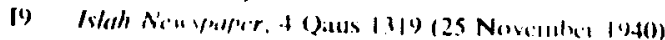

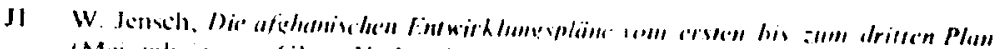

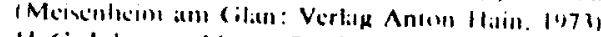

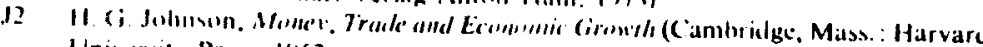
liniversily Press. 1962)

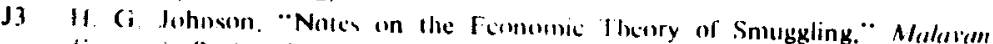

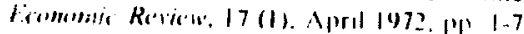

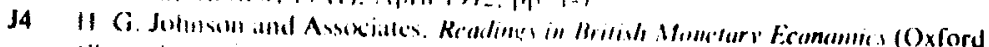
ciarenton Pacis. (1)72)

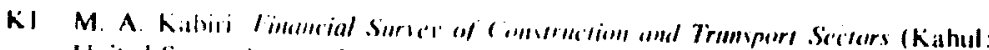
United Siats Agency for Liternattional Desclopment, mineo. Noventer 1973)

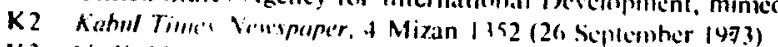

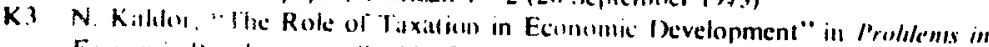

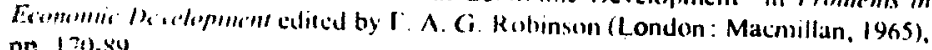

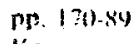

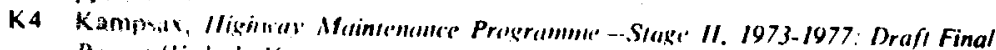
Rapuivf (Kithul Kanpsax. mimeo. August 1972)

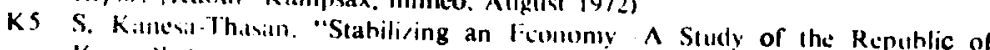

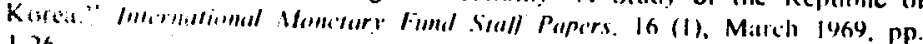
$1-2$

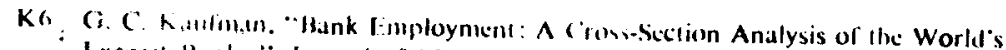

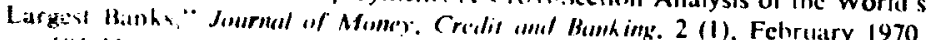
in. $\mid 0$ in-li

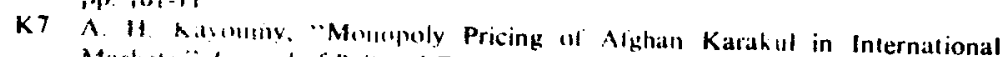

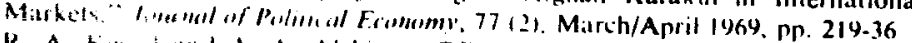

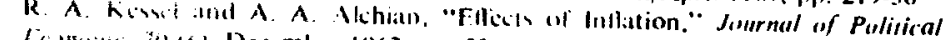

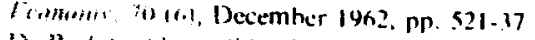

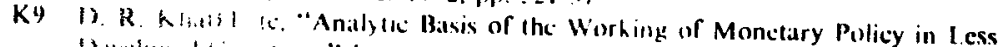

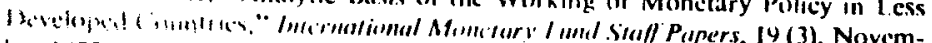

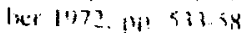

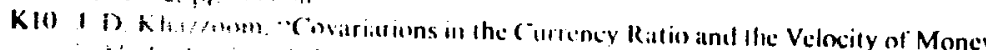

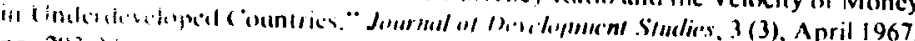
Tr. $24 \mathrm{i}$. $10 \mathrm{~m}$

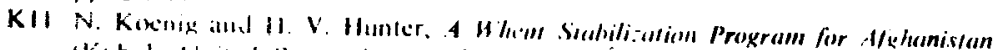

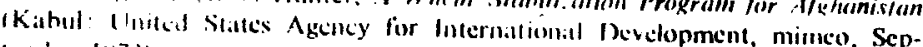
(entixer $(1, ?\})$

K12 I) and I. Kulm, Burderlams (New York: Knopd [962) 


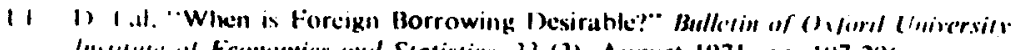

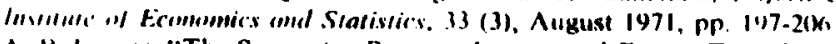

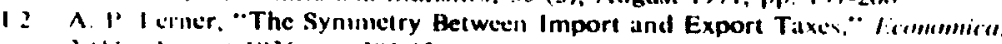
1111. Al1gusi 14.36. pr. 366-13

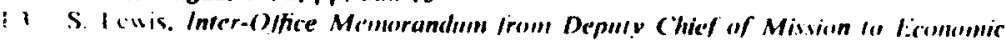
Ciasoll/tor (Kahul: American Emhassy, hatndwritten, Fehruary (1973)

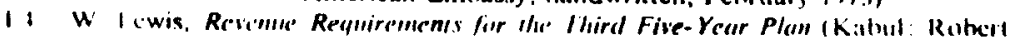
R. Nithan Associates, nimeo, April 1968)

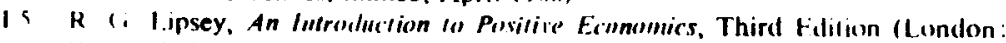
W(ilinfeld and Nicolson. 1971)

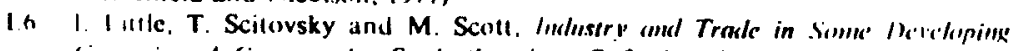

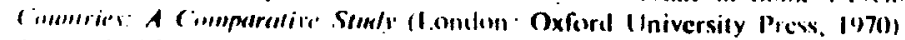

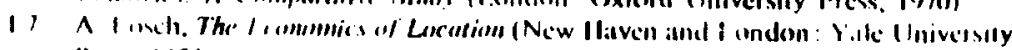
P(1) 1994)

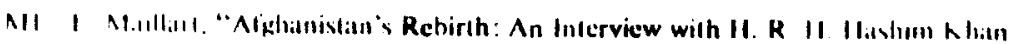

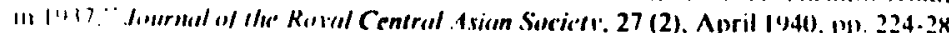

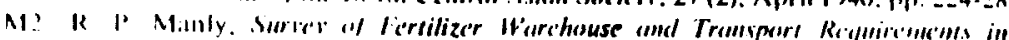

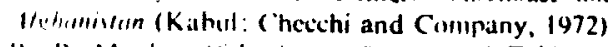

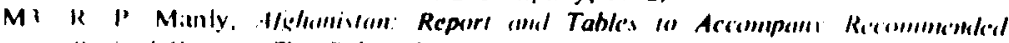

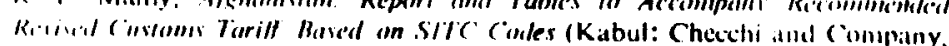
111161\%. April 197?)

M4 R II Marshall. "The IInderdeveloned tonnomy: Some Implicatiuns for ( Entrit

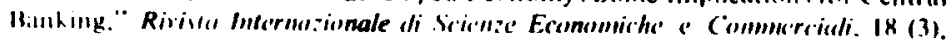
Milld 1971. pr. 269.77

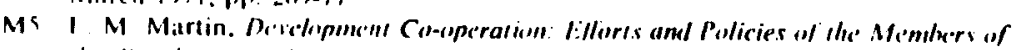

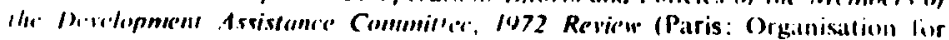
Iconnmic Co-operation and Developneine. Decemter (472)

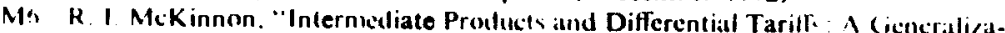

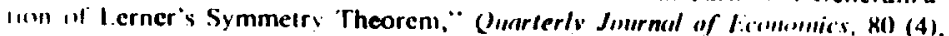
Nowininer 1966. pp. Sk4.hls

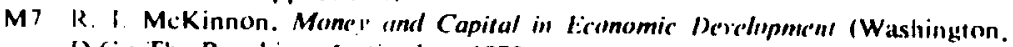
I). $:$ : The Brookings Institution, 1973)

MAX A. II Melizer. "The Behiviour of the French Money Supply: 19.14-54." Iturnol

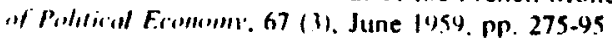

M") A. A Michel. "Ioreign Traule and Vorcign Policy in Alghinnistinn." Mislll' linvi?" Afairs. 12 (1), Jinnuary 1961. pp. 7-15

MIO R. I Mikesell :mal J. F. Zinser. "The Nature of the Saving, Funclion in 1). Whaping Countries: A Survey of the Thenrelical and Empirical l.ilcrature." fonurnal of Ecomomic lifirature. 11 (1). March 1973, pp. 1-26

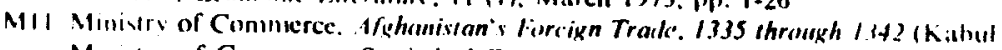
Mlinistry of Commerce, Statistical Department, nimeo, March 19)(15)

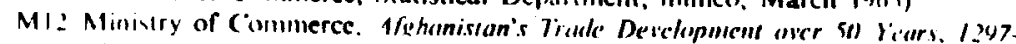
1.is: rin Dari) (Kabul: Ministry of Comnerce. Special Publication for the Pitticth Anniversary of Independence. 1,347)

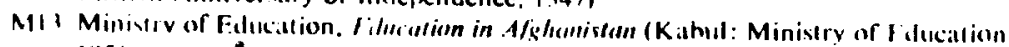
(1) $2(1,1)$

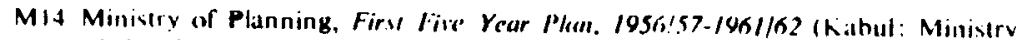
(1) Pl.moning. minues. (4956)

MIs Mlonivley of Planning. Secomel Five Your Plan, 1341-45 (Kahul: Miniverv of P'l:mining. (342)

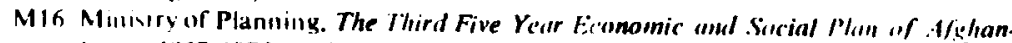
ivul', 1467-1971 (Kabul: Ministry of Planning, 1967)

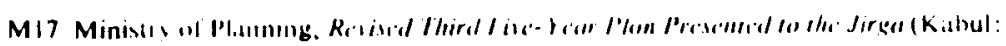
Minisly of Planning. mimeo, lyos

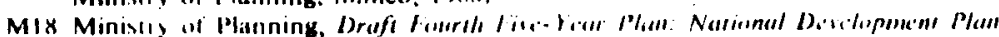

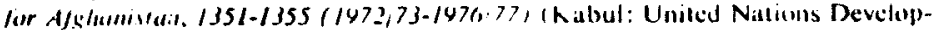
ment Programinus, mimco. July 19731

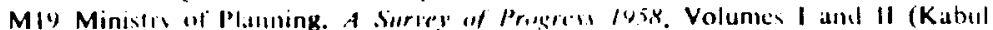
Minisul of Platuing. 195\$)

M20 Ministy al Planning. Sarrey af Progres 145\%. Volumes 1-1V (Kabul: Mimstry of Planning. 145\%)

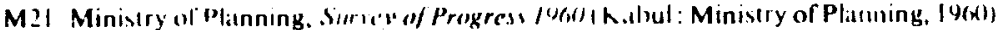

M22 Ministry of Planning, Surreey of Pregere's /96/.612 (Kahul: Ministry of Planning. 196,31

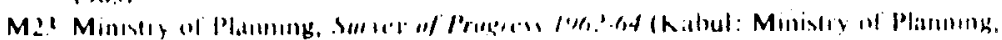
1964)

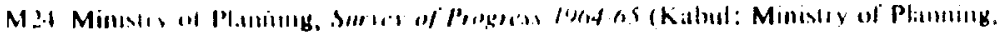
1965)

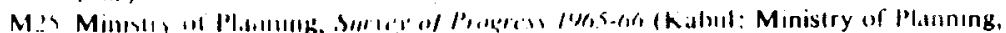
I)hon

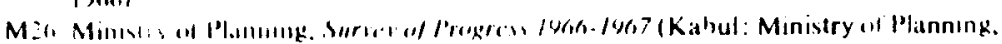
$|\%(3)|$

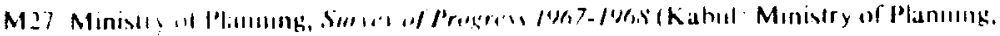
1968)

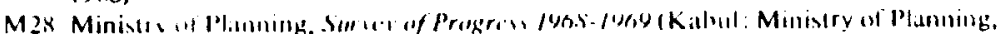
1969)

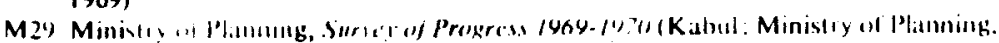
(4)70)

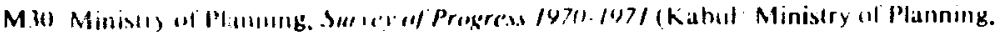
(971)

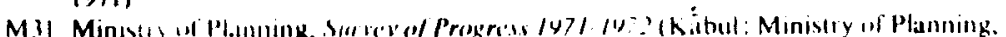
19721

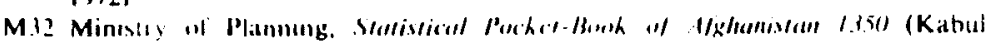
Ninistry of Planning. Dipaltment of Silatsics, 1972)

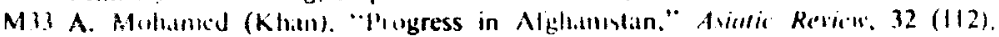

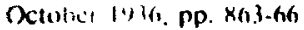

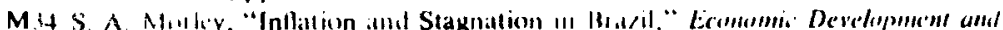

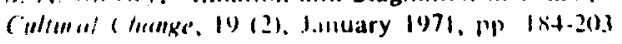

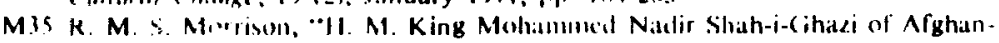

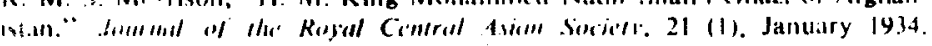
m.70.75

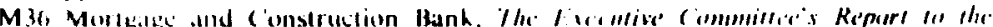

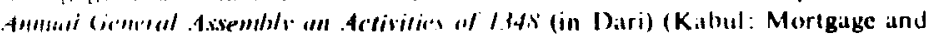
Comstrution liank, 1345)

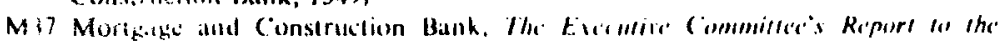

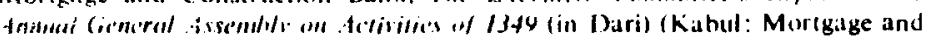
Constriktion Ballo. 1350)

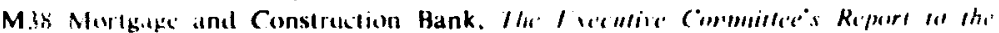

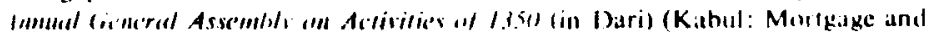
(Construction Bank, 1351)

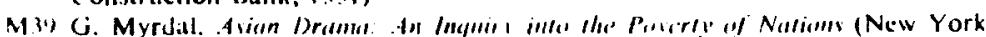
Pantheon. 146,

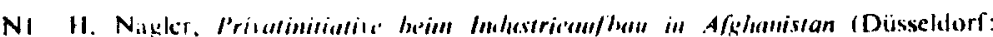
Verlag ba unpe Bertcisnlatın Gnıbll Berlelsmanı Universitätsverlag. 1971) 


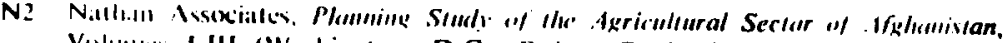
Volublev I-III (Washington. D.C.: Robert R. Nathan Associalls, nimen, Diciminer 1971)

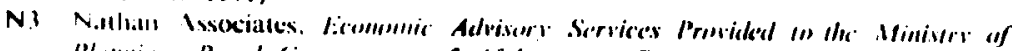

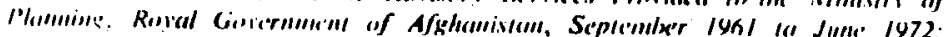

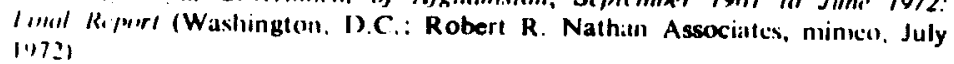

Nt R. S. Newill. "Nghianistiut: The Dangers of Cold War Gencrosity." Midhlle

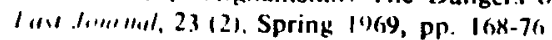

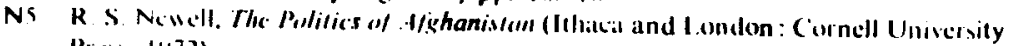
Prow. 11172)

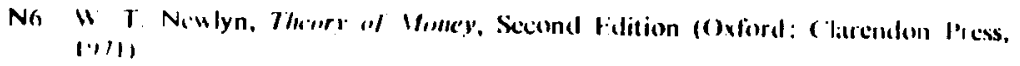

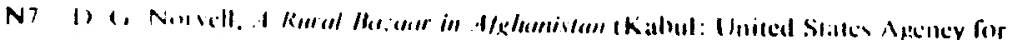

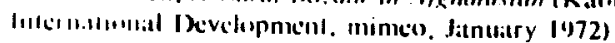

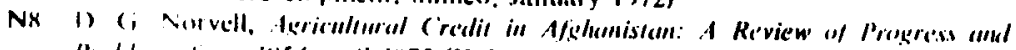

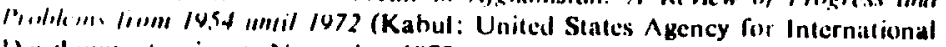
Benclupullent, mimeo, Novenber 1972)

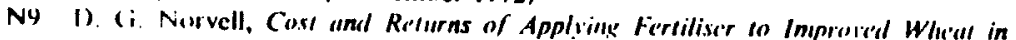
1/khumul (Kahul: United States Agency for International Developnicnt. mince. I chruary (973)

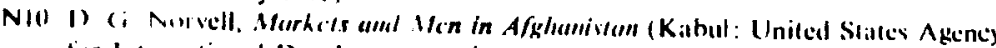
for lateriliational Developmeillt. mimeo, July 1973)

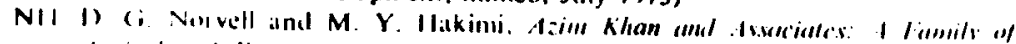

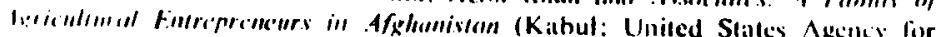

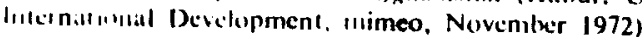

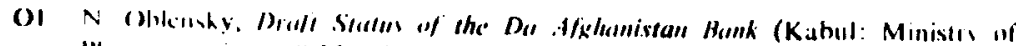

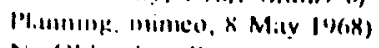

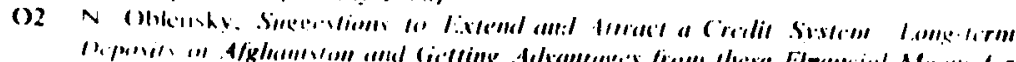

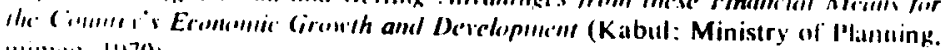

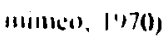

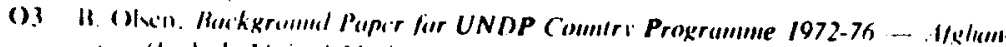

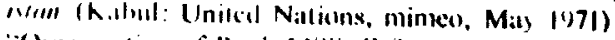

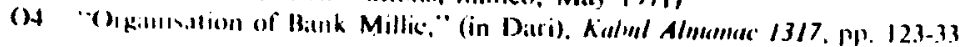

PI (i. 1. Paplanck. "Aid. Fureign Private Investment, Savings, ard Growth in I csi Deicloped Countries," Journal of Political Ecromomy, 81 11). Januaryl lichruary 1973, pp. 120-30

P2 Y C. l'alrk. "The Variahility of Velocity: An International Comparioun."

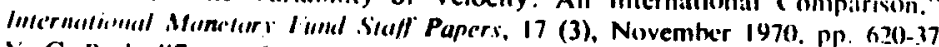

P) Y. C. P.uk. "Some (urrent Issues on the Transmission Process of Munetirs

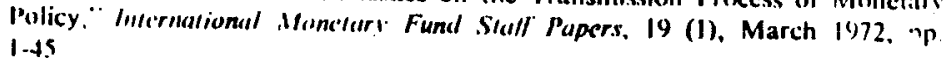

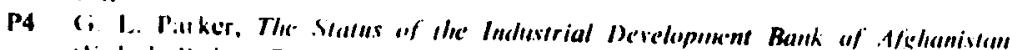
(Kisbul: Roluert R. Nithan Assuciales. lypescript, Richruary (966)

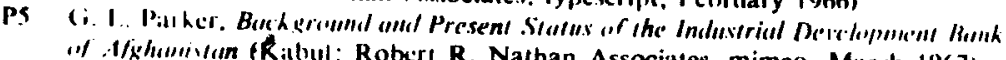

Ph (i. I. Paither. Centrol Br, lik Law Drafi (Rabul: Robert R. Nathan Associalles. inilleor. Jine 1967)

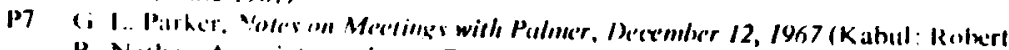
R. Nall hill Associalt's, mimeo, December 196,7)

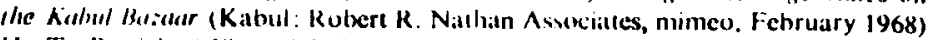

py H. T. P'atrick, "Financial Developnecul and I conomic Growth in Under-

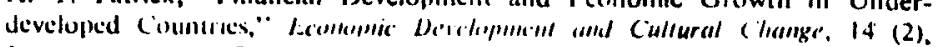
lanuary 14a.6. pp. 174-89

Plo A. Paul. "Rule ol Trade in Afghanistan's Development," Asia Fismelation Bregram bulleton, Decculler 1963, pp. 1-5

PII A. Pial, "Cimstratur on Alghianistan's I conumic Development and Prospects

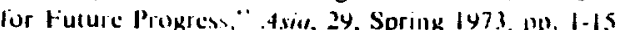

P12 M. Perimam, "International Differences in Liquid Asscts Portfolios" in varieties

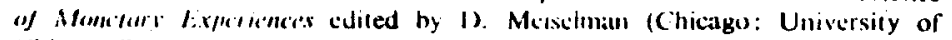

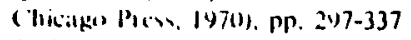

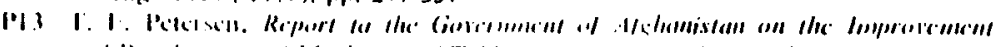

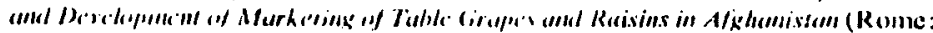

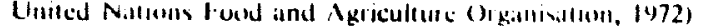

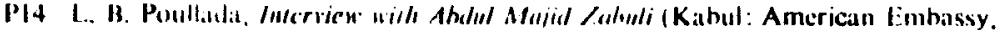
typescripl, 4 Siptenter $\mid y(s)$

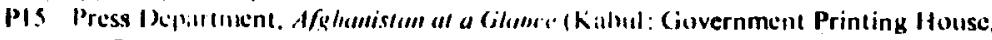
1957)

PI6 A. R. PIeve. "()n the Distinction hetween Direct and Indirect Taxation" in

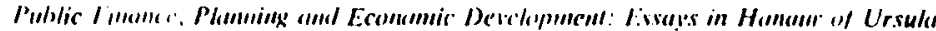
Ilicks cdracd loy W. L. Datrid (London: Macmillan, 1473), plo. 44-56

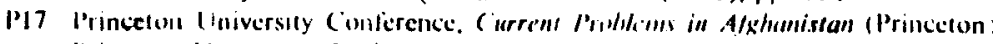
Princelon Linversily conlesence, 1901)

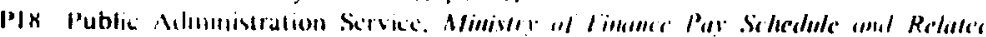

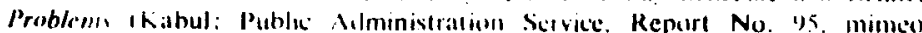
limuary l'm,

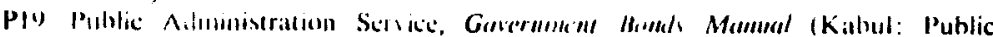

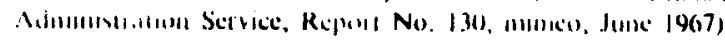

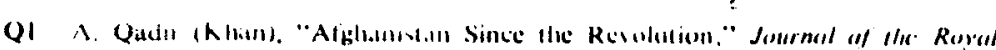

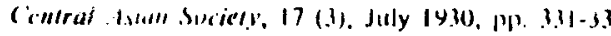

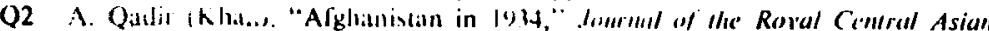
Socich. 2212\%, April 1935, po. 211-20

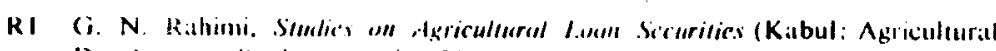
Developmient Bank. typescript. November 1470)

R2 it r. Kithmaltabadi. "Importance of the Central liank and State-(Owned Banks in the Cinduct of Monctary Policy" in (INTO Simposium on Central Banting.

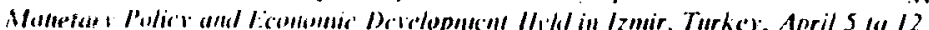

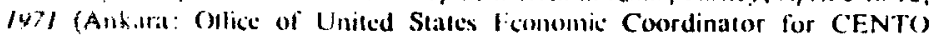
Ailairs. Jelu uary 1472), pp. 142-44

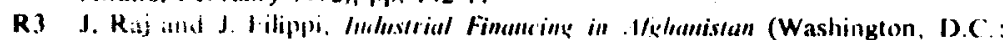

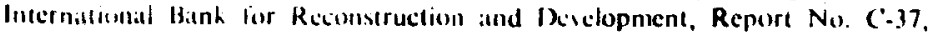
minteo. Nowenther $[963\}$

R4 V. K. R. V P'w, "Investmente. Income and the Multiplier in Underdeveloned

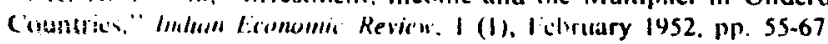

RS V. K. K. V. Ran. " Deli it I illancing fur Capilal lormation and Price Behaviour

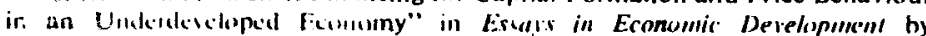
V. K. R. V. Ria (London: Asia Publishing Ilouse, 1964), pp. 105-41

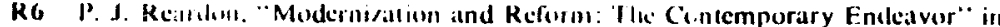

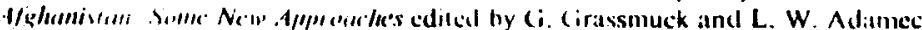

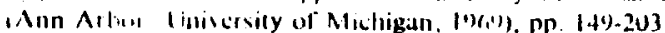


R7 Repional Cooperation for Development Secretariat. Regionul Corpurarim and

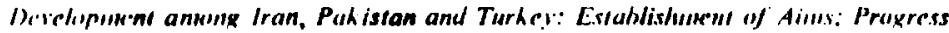
if Actirities (Tehran: Regional Cooperition for Development Secretiarlat, (1) A(,y)

RX Ripurt it the Prevident's Cilnmission un Financial Structure and Regulation, llunt Renort (Washington, D.C.: United States Government Printing Oflice, (1171)

Ry 1. Rheoll and A. G. Ghaussy, Die wirtschaftliche Entwick/ung Alghumivuns I.Y.YI-14\%5 (Biclefeld: C. W. L.eske Verlag Opladen, 1966)

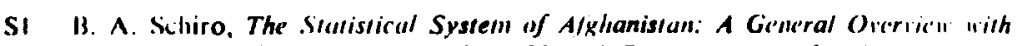

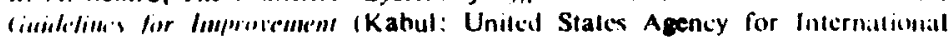

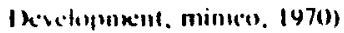

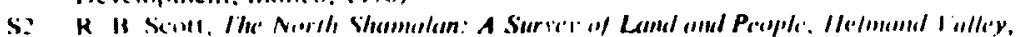

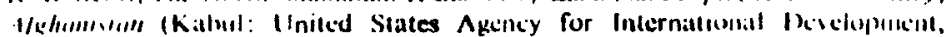

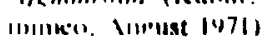

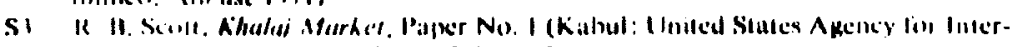

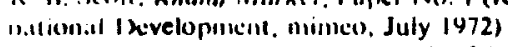

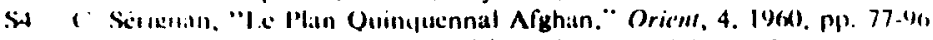

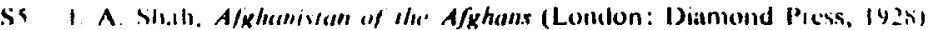

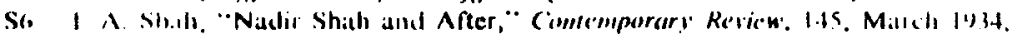
ili. $337-42$

S7 1 A. Slt.1!. Moukern Ajkhaniviun (London: Sumpson Low, 1934)

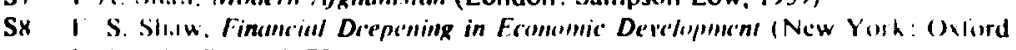
('niverity Press, 1973)

Sy I. S. Shaw, Interist-Rate Reform: Impact Effects. Indicoutors amd Simmonthing Iridmisms (Kabul: Ministry of Finance. Financial Developnent commiltes. Report No. R/036, minieo. 10 July 1973)

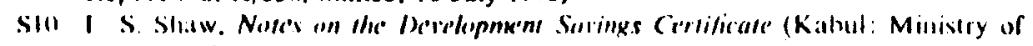
firsance. Pinancial Development Commitles, Report No. R/10.37. mimeo, 17 lilly 1471 ,

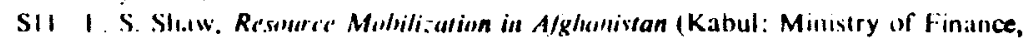
I inancial Development (ommittee, Report No. R/03R, minico, 31 July 1973)

s12 I Singlı, "Fnlanking the I:conomic Base for Donestic Savings". in lathlic

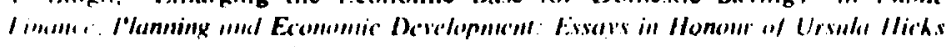

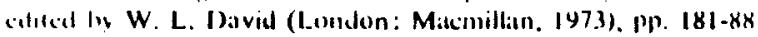

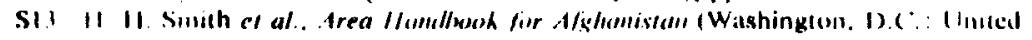
staltes covernment Printing Oflice, 1969)

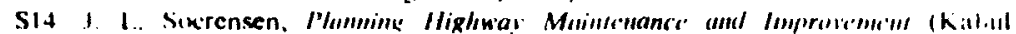
h.timp)is, mimen. (ktoter (972)

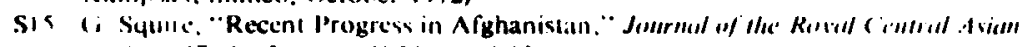
Siecicts, i7 (1), January 1950 , pp. 6-18

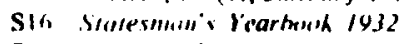

S17 Sirder.

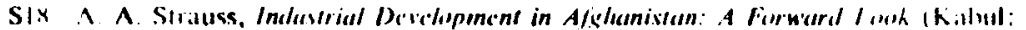
Rulxerl R. Nuthan Associalles, minico, September 1965)

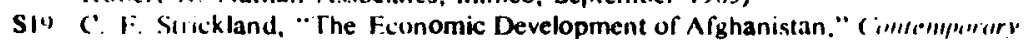
Resion. 143, June 1933, pp. 714-22

S20 I. Sykes. I Hithorl of A/ghanis/an (London: Macnillan. 1940)

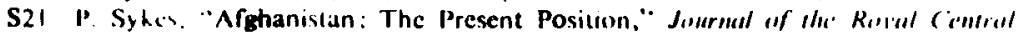
1 viou sia ict11. 27 (2). April 1440, pp. 141-71

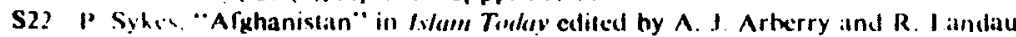
11 indion: I ilker and Faber. 1以53), pp. 178-47

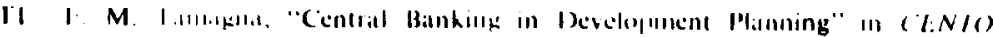

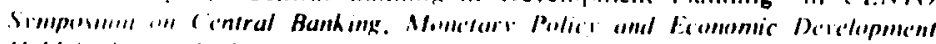

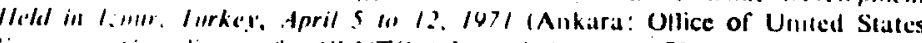

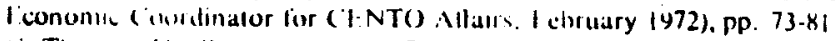

12 (i. Thawn, "Ille Hacaar as a ('ise Sludy of Religuon and Social Change" in Irut ficies the bromics edited by I:. Yar-Shater (Now York: Praeger, 1971), pp. $|x y-2| t$

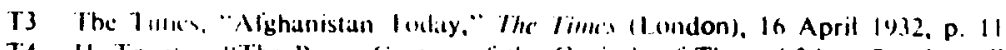
4 11. Tocpls, "The Basar centres of the Capilat of Three Afghan Provinces,"

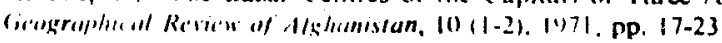

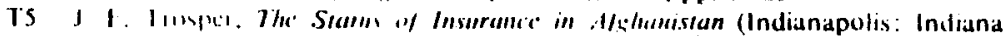

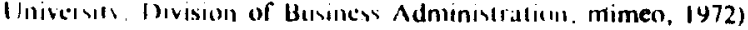

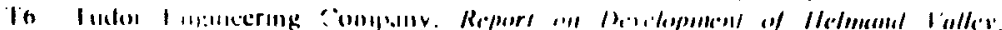

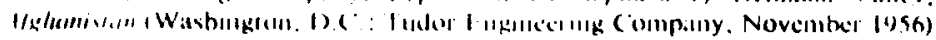

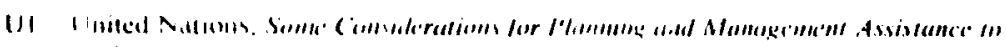

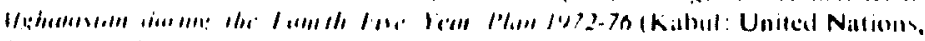

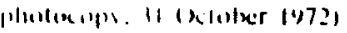

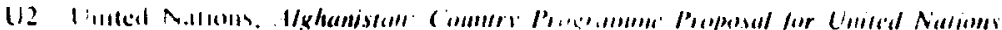

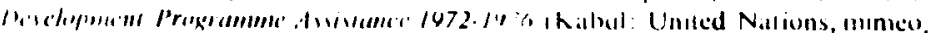
(Becomlex 19?3)

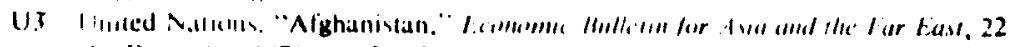
11. Deciolulye 1971. pp. $24-53$

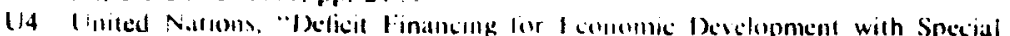

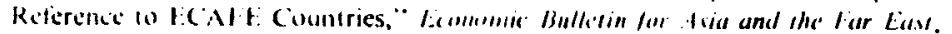
511) Nowinter 1054. pp. 1.18

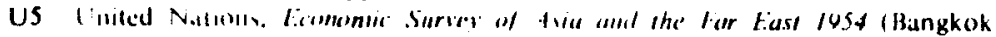

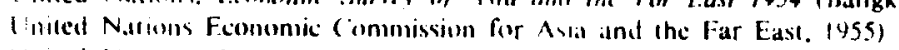

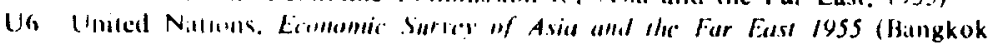

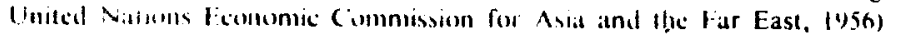

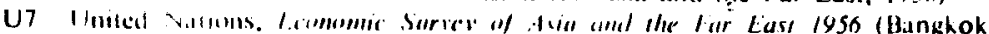

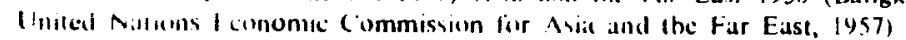

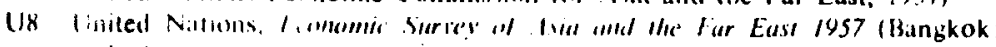

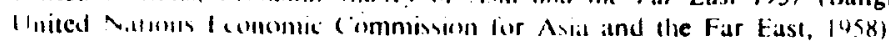

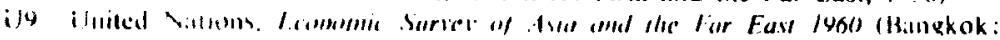

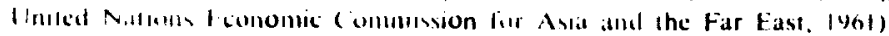

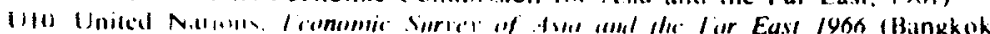

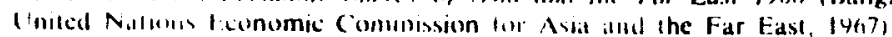

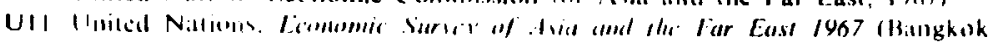

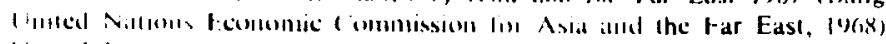

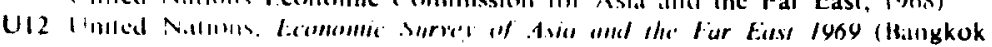
liniled Noluotis leconcimic (omminsion for Asid and the far East, 1970)

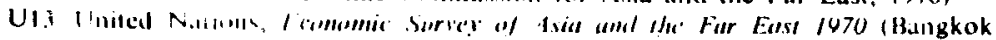

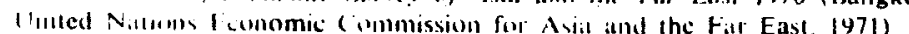

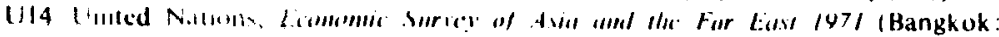
thred Nollom lcomonuc Conmission for Asiat and ihe Fat last. 1972)

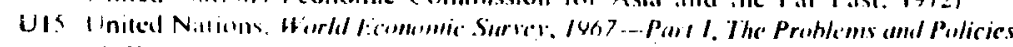

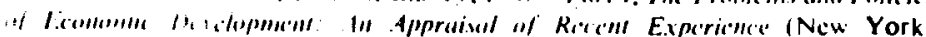

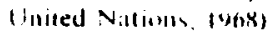

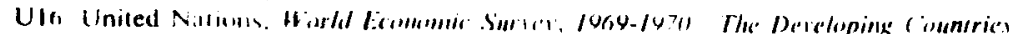

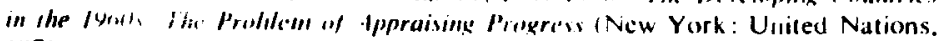
14711

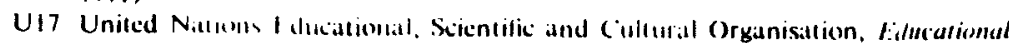




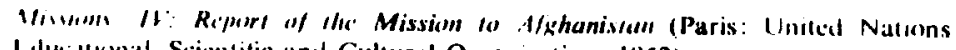
I dicillonal. Scientific and Cultural Organtsation. 1952)

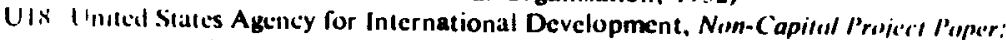

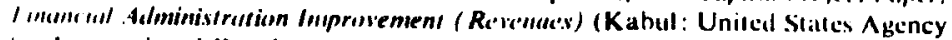
lor Inter hational Developnent, mimeo. September 1970)

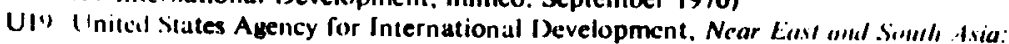

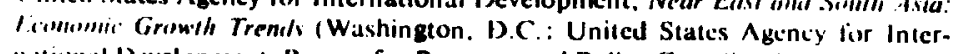

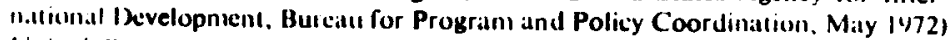

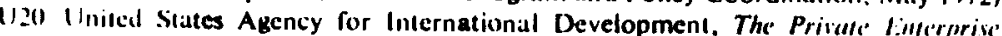
Proyram. Afghanistun (Kabul: United States Agency for Internutionall Development, mimeo. November 1972)

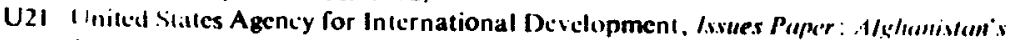

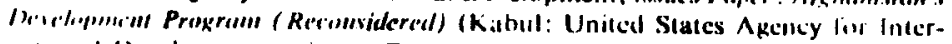
nottumill I devetopment, numeo, Deceniber 1972)

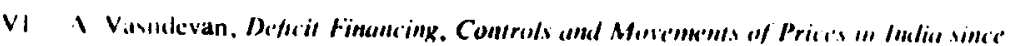
14.47 (liumbay: Allicd Publishers Privatc. 1967)

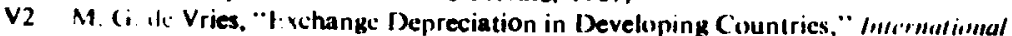
1/..1........ Fund Situll Papers, is (3). November 1968. pp. $560-77$

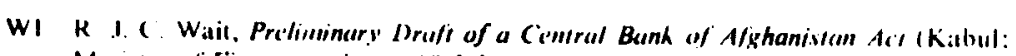
Mimistrs of Finance. mimen. 10 July (968)

W2 (. (. Whiling and R. B. Hughes, Th' A/ghan Farmer: Repert "If "Swid" 1Wishington, D.C.: Rothert R. Nathan Associates, mimeo, October |v7|)

W3 1). $N$ Wilber (Ed.). 1/khumisian (New Haven: Human Relations Area litles. $1125(1)$

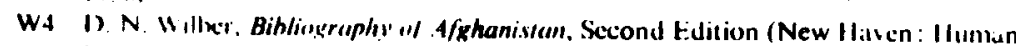
Recollom, Area Files, 1962)

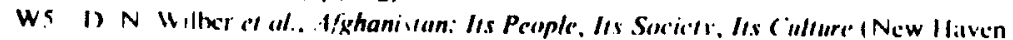
Ilumbin Retations Area Filcs, 1962)

Wh A. Wilum, "Inside Afghanistan-A Background to Recent Trombles," Roncel

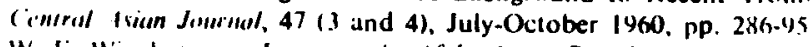

W7 W. F. W'inebrenner. Insurumse in Afghanis/an. Supplementary Reporl (Kiabul: Ministry of Commerce, mineo. April 1960)

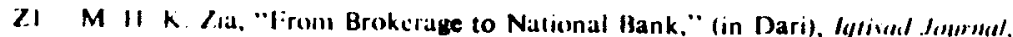
220. Sittiltan 1314, pp. $321-28$

Z2 (I) Amblag. Afkhan Lexisholion (Kabul : United States Agency for Intcriati ina Developunkent, nimkeo, April 1971)

23 ('. 11. Kondag. Prixule Indhstrial Iniestment in A/khanistan (Kabul: United States Akencs lor International Development, mimeo, 19711

INDEX

Compiled by Sheena E. Will, A.L.A. amal Leonard D. Will

Authors of 11 ems in the bibliography are inctuded in the index if the items are cited in the test: page numbers containing such citations are printed in italic type lems given only as sources in notces to tables are not indexed. The letter $t$ affer an index entry indicitles thall additional information on the subject appears in one or

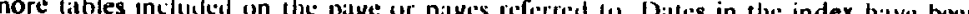
given in the Alghan. S/anmsi form: the relittionship of these to Giregorian dates is explituned in the "111le on plige [xii].

Adckunle, J. (): I chicl, H. and 3? Adelonan, I. and Merros, C. I

indicators of desclopment potential 1.5. 300

discriminant intialysis $7-8$

linancial desctoplowent $42,6 \mathrm{nt}, 150$. 268

llitnsport licior $\$ 7.00$

Administration we Hath and banking Civil service; Puhlic Administrattion Service; Traming

Advisurs, forcign w' foreign experts

Afghan Cement Company 206

Afghan Denugratphic Survey it

Afgha, limbansy, London $y_{1}$

Afghan fertiliser Cimpany 3

Afghan linsurance Company 91,147

148

assets $y d$, , 95 t

Board of Dircetsers

cmph.yers yin

Afghion Joint Stock Company so'

Shirkal-i-Sahamu-1-Nighan

Afghan Nationat bank see Bank Millic

Afghani (monetaly unit) [xi], 23, 112

(sce ats, Foretgn exchange ratis)

Afghamistan Ilialsh. 1):1 86 - $87,(14.112$

122-123, 127

(s'i' also Banhs and banking)

assels 94-46,1, 11(1)

bills of exchithe discounted 232

roreign exchange

controls wi, $112.235,260-261$

dialings $9.112 .235 .238,241-250$

(unnover $(134.1351) \quad 243$

liabifitics 1tal

loans lior development 70-73, 206

(1) exporters $231-232$

to Government 153, 162, 169, 193 paper currency issucd 9()$, 1 / 4$ personnct 961, 111-112, 273-274

Supremc Council 105

Agarwal, J. P. 196

Agliank sec Agricultural Development Bank

Agency for International Development ver Unticd States Agency for Internarional Developmen!

Akricultural Developnent Bink

(Agliank) 3, 93, 1,34-135. 275

ansets and habilitites 135

lending

10 conperatives 148

to farmers $2 \mathrm{Tl}$

problems 138-142

need for central bank credit $2 x$

perstomed policies 134, I6r

replated Agriculture and Contage Industries Bank 91, 93, 134

Supreme Council los

Agriculture

cash crop production 50-51

Helmind area 204

high inrerest rates deter 102

development projects unsuilable 206 207

Alucluations in output

inflation ind 116

moncy supply and 127

improvement of, as indicator of devel.

openent potential 2-3,8,52,300

predominimt position in economy 49

private insestnent 
cretil neceded 211, 275

high relurns on 206, 211

productivity 1,51

taxillion increases needed 155, 168,

173-174.178-179.271

Agriculture and Cottage Industrics Bank 40. 11,13

replaced hy Agricultural Development Bunh 91, 43, 134

Ahmad, J-utlis). and Aziz, H. A. 52 . $19 \% .156$

Ald we loncons and

Ais 11 andingert 50

Athramovicli. R. T. 40

Al. $\wedge$ : :71

Al1, A1 16, 12.27.151

Allen, $R$ (; 1) 76

Almon litg it

Allinill 112

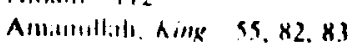

Amtelcall Intchattional Invesument Corperstum ?

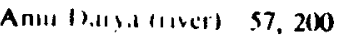

Andiosell. 1. (1: 127

Anti-Hoald ding Law see Hoarding

Army: modernisillion of 155.150

Azir. 11. A.: Ahmad, J-ud-D. and 52 . 151.156

Azi, S. A. 236

Bacom. H.: Hlulson. A. 1:, and 40, 159

Bushl..1 (redil Couperallive 92, 931, 148

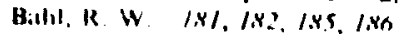

Bah whesesh a. Corruption!

Ballemyergel, 1. 104

Bandil rulc \%-10, 56, 82-83

Banth Millic $\therefore$, 71, 8.3-4), 131

antagenisoll to hazaar cconomy 5.44,

aswe and h.luil. ies $1.12 t$

bionhing rallios 133 t

Board of Dilcetors 105

canitill and reserves 49, 84, $\mathrm{k4}$

created from Shirkat-i-Sahani-i-

Afighan $8.3-84,86$

cencesuraged trade and industry 85-86

esport linance 231

forcign cxchiange

controls 22, 47, $84-15,96), 234,238$

lurnover 11.349-1.351) 243,

forms of name [xii]

illegallities atleged 90

personnel policies 13 paper currency issued through 85.1 .13 relations with Da Afghanistan Bank $86-87$
relations

relations with Government 45, \$4-90 subsidiary companies 86

Ba.ık notes sue Currency. paper

Balkss and banking 12.82-146, 149-150

(wee also specific bank.s)

assets 94-95,

hranches, assets and deposits in Afghatnistan. Iran. Pakistatn and Turkey 107,

credit for fireign taide 227-224. 231 2.32

deposits as fraction of numey unpply 123

economies of scale $10 x-1(x)$

fritction of countries tinanctial ancts

held hy hatuks 96-47,

growth of 82-96

as indicillor of devetopurent pulcontial 2, 5-6, 300

inter-relationships of instifutions 105 $10 x$

need for improved hranch network

$111,131,133,281-2 \times 2$

problems of lending 137-14t,

legal reforms needed 145-146, 271$272,28.5,291$

reserve/deposit ratio $121-126$

reserve refuirements 122,242

rote of a central bank 274-284

persomed policies 3-4, 272-275, 2182

Aglisink 134. I66

Ballk Millic 131

1)a Afghanistan Bank $|1|-1 \mid$

number of employeses 96,

possible competition 10\%, I(m), 1.34 144-150, 286

Barats 82. 108

Baron, L.

development projects

tinance $203,206,200$

Ilelmand Valley 194

lack of local support $14.8,2014$

problems in agricultural development 58,211

\section{Barter trade}

(sce' also Clearing currencies)

exports and inports 218,220 )

effective export dutics 227

micthods of paynent 22K, 232, 261 . 262 swing balances 224,

Bazaar cconorny

linance for forcign tuade 6, 234-254

foreign exchange dealings isee alsw

Foreign exchange

controls 22, 47. 85, 234-235

legal status $23 x, 241,254$

rates 2()$t .22$

lurnover (13 344-1351) 243t

in Iran $48, y 2$

intcrest lates 47, (44-65, 92, 102-10.1

for fincesen tride $239,2.12$

merventum by (ievernmeit and Bank

Mitlic $5.44,47,85,234-235,23 \mathrm{~K}$

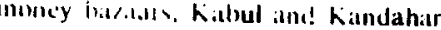

$2.4-3.4 .11$

fersols wollking in 96

legionallachls 47-48

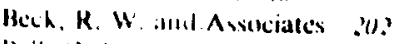

Bell, (i. L. ind Bermath, l.. s. 121

Bill, M. J. , 5 :

Henedick, $R$; W

ikenston, $(i$ i los

Berman, L. S Holl. (i. I. and I2I

Bhagwati, J. and Hansen, B. 176

Hharier, J. 5/

Bilsetsral pow unitus agrements we Barter irade

Bills, ereasuly 13"

Hiacklicik. J.S. 4:

Bogthase, L. 2, 1/2,1/3,193

Bonds sie liovernment bonds

Borroseng by Governancut we Deficit firsance: Pruthe unance

Hi,unt, M. R, r,y

Himmer, A. 1. 1211, 27", 2k1, 23, 2k7

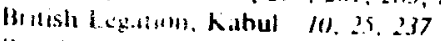

Browks, J. Ie. I B.Y

Brision, G. I . 27/

Brotiner, $K$. allal Molese s 11,30

Budget se' Puhtic finatuce

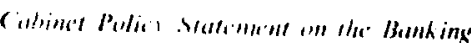
Loti: ly. . 54

Codastral :atroy 1.34.168

Cagin, P. $1: 1,2$

(apical

le'e alse Donnestic credit: Inlestment)

ciedit avalilahility 54, 64. 1112

mixht of $44-55,227,291.242$

market 54-5.5, 61-62

physical onerheid. as indicillor of

development pettential 2 .
IItlisation of 210-211, 269-270 bitiance of return on 213 Cillill.t goods imports $221-223$ t

supplicer credit for 234

Carpet exports 4x, 222t, 231, 232

Carpol institute 231

Carr. J. and Smith. L. B. 34

Cars 55-56

(wec also Motor vehicles)

('ash crop production 50-5

(encill production 16

(iillial hatenk sere Alghanistiun Bank, Dat clutal banking: role in development $271-284$

Contral Statistics Ollice 17.110

(ivill, V. 8.3.84, 87, 15.8

Chakcharan: business dectine $4 x$

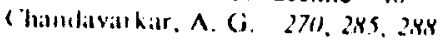

Clecclit and company 5.8

(heylus system 236-237

atrence of 60,133

ckelling period used fior short-term

fillince 239

no penallies for dishonotumg cheques

$$
\text { 146. } 271
$$

used by trade agencies 231 China

birler trate with $228,22 \%, 230$

credlit for cuípital imports 234

Civil service: personnel policics, im-

prorsensonts needed $3-4,131,166-167$

(kearing cur encies

vidiange ralles $2(x)$

in barler trate $22 x-230.261$

meney ba/atir dealers 240, 242-243

Cial production $\mathrm{log}$

(inlien, B. I. 69

Cormercial courts 146

(iommercial l.aw (1334) 146. 272

(inmmittee of Bank-note Reserves

(inmonodily Assistance

(we' alsw) Forcign aid)

as source of revenue 169-173,

colltribution to development expenditure $70-73$ t, 157-161t

eflect on wheti prices and production 49-50

fluctitations due (1) agricultural results 172-173, 192

('ommunications $15 t, 46,56,60,62-63$ 204

(sed also lufurmation how; Road sys(cin) 
Companies. Insurance ice Insurance: companices

Compinies, mint stock s'e Joint stock companies

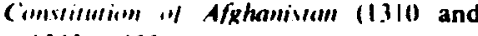
(.3.1) 155

Comstrants an development, critical to $5,3(10)$

Construtton liank sere Mortgatge and Comstructien Bank

Constretetion inclustry ss

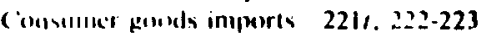

Cinsumer prescie inder 17, 18,

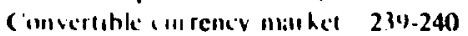

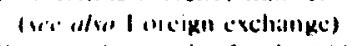

(onerelative $11,42,931,148-149$

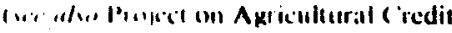

$$
1
$$

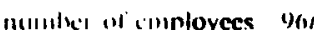

Contulution 161. 165-167

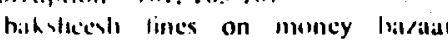
deilers $23 x$

Bianh Millu allegalities alleged

Cotton!

(ser atwe loreign exchannge: surrender

regutirentents)

exports 218. 2211, 222

hillter mices 229

sinrinder requirenkents 226r-2277, 210. 215

prodiction 50

Council on Ministers: forcign exchange

regulations 255-257

Credı a. illability sep Capital

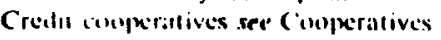

Currems

$(1318-1351) \quad \mid 18-114$

$(1331-1351) 33$

deolind $f_{(1)}+1$ 42, 277.274

Currency. forcisen se't lorreign exchange

Currency palper 12,113-115

Cimumillece of Bank-note Reserves

114

consertihility suspentled 153

issued hy 1). Afghanistan Banh 90 113

issikd hy Treasury lhrough laink Millic 85.113 .

L:IN on B:a11hinutes * 113, 153

Curremey commission 256. 259

Currency deponit ration 2044-205,

Cimanc imoney ration

$(131.1151) 31$ as determinant of moncy supply 121 126

cyclical fuctuations $41-42$

financial development and $(x)-4$ |

velocity and 32t, 33, 296t

Currency smuggling 241

Customs duty se's Foreign trade: tirxes on

Cachosiovakia: harter trade with 228 2241

Da Arghanistan Bank sere Aluhamivtan Banuk, Da

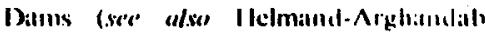
Valley proiect)

lonurth Plan propmosils 208

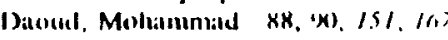

Datce: Shemesi and (irckorian [Ni]

Deht sier Lending

Defence expenditure $194-14 \$$

Deticit tinance 162-163, 184-191

(sce' aiso Donestic crestit. Public (inunce)

estimated safe future levels 293, 2\%6. 2981

growth retarded by excessive 41

Denand for money sie Moncy: dell .und for

Demography |3-14

Department af Press and Informaltion $2.5,85$

Deposits see Banks and hanking: Sir' ings, private

Development Assistance Difcitorate of OICCD 4

Divelopment hanks 28

(sere alse Agricultural Devetopinent Bank: Industrial Developunent (Biank)

Developnent plans 70.81

(vice adso Project assistance)

central bank as financial advisur 28.3 .

284

Exenditure see Public finance

Fuurth Plan proposals

estumated financial developullent 296-299t

lurge projects still favourcid 208

planned development expenditure 70-71،

returns neglected in choice of projects 206-209

Ciuvernnent resistance (o chatll ge 207 hindered hy lick of stativitics 70)
Over-all I connminc bevelophent Plan 70

popular suppint for

as indlcallor of development poten-

$$
\text { tial } 2,6,46,300
$$

lack of $41,-47,177,204$

74.81 207-208

role of foretgal idvisors 81

role of Minisiry of Plannme $\quad x(1-x \mid$

support of Nitalir Shah $2 x_{1} 8.3$

Developmeclut potcultal 1.5

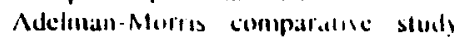
1.5. 7-x

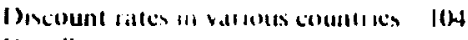

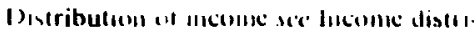
hution

1)ollars: uxc in Alghanistan 238 (we also f incigen exchangt rales)

Domestic credlit

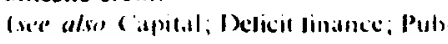

lic linatucis!

as indicator of simancial development of

cutimated silc fitture levels 293, 296$298 \%$

Itkonctaly stissev (1340)-1351) 98-941

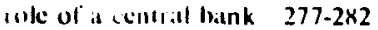

shift from private to pulblic sector 46 .

$$
\text { 17. } 1(x) \cdot 1031,211,212
$$

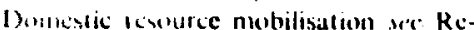
seruce nublisation

Domestic rencintic 12, 27, 28, |61\%-1x (vere also Puthe finance: Taxces

(1311-1341) 24t, 26t 152t, 154t

compalisems will (iNP changes 40\%, 41

vimalled siluwth (1.350-1.355) 20\%$24 y$

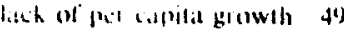
prisce inclatsicity of 176, 178, 191 sotrices 170-1731

liaxes in 51 contentries 174,

Donlance, (i. s. 122

Dogkar, J. M. 20

Dapuce. L.

disticultics in mondernising agsicullute $51,62,63,177,21) 4$

foretgn aid 69

Helmand projict 199, 20)?

ecgionat fritgnentation of

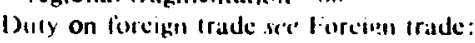

taxes on
1 comonnte indicators minctary 26-20" moll-monetary 13-17t

Fcomomic Planning Conmossion, $\mathrm{F}$ nance Committee: taxation changes sugested 167-168

licolomy

(iwernment, modern and bakatar seclars 44-44

liscrical review 9-12

Fillcillion 11, 12, 141

(vie ahe Truinumg

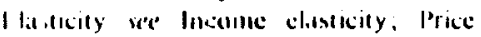
diosicity

dectilitily the

Hallts, veturn ou capital 202

I. Itc/anli. \%. A. 5.5, 57, 58

l:manuel, W. V. 10

I:nery, R. I: 270

Employment

cffect of interest rates $2 \%$

numbers in tinancial institutions 965

Lutuity participation in industry: government and private 45 ,

Ixchange ser forcign exchange

lixpansion sere (irowth

Expendieure, public see Public tinance

I:xport-Import lank

(oins for develupment piojects 203 llelmand project $\mid \%-20$

I:xports

(we' ahe Forcign irade)

(130y)-1351) 217,

$(\mid 31)-1351) \quad 24,261,27-28$

comprosition of 221,

destmittion of 220), 222t

ciononic growth and 216

finance for 2 ?

fraction of (iNP $21 y$,

growth aided hy Bank Millic 85

prohihited itens 262. 26.5

proniotion programme necded 254. 255

seatsenal vatriations and exchange ratte 251 , ( / / 252

fitxes on 161), 176, 179, 218, 226-227 (xec also forcign exchange: surrender iequirenents

Hehid. H1. 192

and Aclekunle, J. O. 32

Fatablad: Musiness decline 48 high interest rates to 
land. 1) 1. I,K. 127

(i) 12

Firmmeng at Agriculture

terdibiliti. $k$. $51,56.1 .38$

lertiliners? 3.203

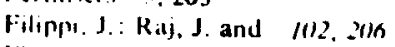

Finatucial devetopment

dircloponenr potential and 2

ccimbonic growth and 43, 2608-27)

thimincrid hy traditional altitudes 82

indsatlers of

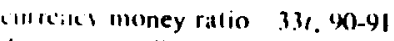

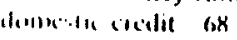

neleme 42. $26 x-2(10) 4$

miscol r.1les, real. and 43. 270

ccommisteded programme 271-276

role ol : I central basuk 276-284

lilluletial Development comnitte

la:llikung lirws drafted 272

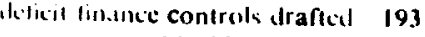

mentallmine 149-150)

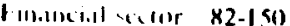

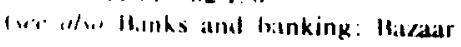
(a)menty)

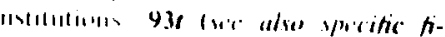

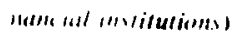

asscel, "1t-1)5t

issistimac fren a central bank 280$2 \times 2$

cillowineses 96

improviculent of. as indicator of develupment polential ? 5-6. 151) (ox)

lexislattion required 271

Findince committec of the foconomic Planning ( omnuittec 167-16x

First I ive Yiar Plian sic' Development plans

Fiscal effort $181-184$

polential ecovorce mobilisation 298 244 ,

Fix:al systion 157-169

(wor a/m I nes)

demestic resource mohilisations

21 3.21.4. . $711.296-2 \% 4$

poces admiometration 164-160

Pistoer. 1. lat.

Fletcher. A $111.11,50,0.11$

Flures, (; 2.m

Foj.1. $Z$. 238

Fond and A priculture Organisation 92

Fooks. '?. ?II?

Foreign ais frec alsw Commodity A wiol.diled ProJict ansistance)

as loans swe Lending

contributem to developuneme expenditure 70-74t, 150-16,1

llexline in 75-76

disadvantitges of relialnce on tis

for training abroud 57

no multiplier effect 54. (2). I 4 )

overvalues domestic currency (19)

Foreign and Domestic Privatc lnvest-

ment law 263

inclusirial sector expansion undele 12

$$
53.91,103.179
$$

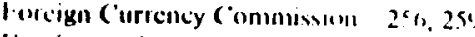

Forcign exthange

(rir also Bazaiar cconomu: ('katring currencics)

Bank Millic illegalitics allepecl (s)

convertible currency nutiket 23.'-240

currency smuggling 24

ciovernment controls

introduced by Renulule ?lo

ecgulations 235, 255.211

through Bank Millic $\because 2,47.4-85$ 234

through Dat Afghanistan Hituh 40 112. 235. 260-261

undesirabic 291-292

surrender requirements $85.8 \%$, Ih9.

26,2 (see also Exports: taxes on)

Imolition urged 227, 235

as a tax on exports 169, 226-227

leterrent to cash crop prodluction

regulations 255,256

(urnover (1349-1351) 243

Foreign exchainge rates

(1332-1352) (fig.) facing 240

Afghani vs. rupee $2441,248-250$

Afghani vs. US dollar 225, 26-26-265 $(1310-1.351) \quad 20 t$

backing for Afghini currency

itgreement with IMI: 235

ollicial reserves 115.196

bank and bazaar ralles dilledcutial

249-250t, 260

harter triale 229-230, 260

distortion by aid in foreign curicincy 69

fluctuations $6,239,246-250$

seasonal 206, 250-2.54t

speculative returns on $25.3-254 t$
IMF repurt 259-2(x)

industlinil rille 225

lagged icyounse to money supply

challger 244-247,

price competitiveness of Afghani 277 278

surrender lattes $89,224-225,226-227$ 262

used in colva... ling price index (1) compallsoll wille price of silver 22

$$
23 t
$$

Forvign experis

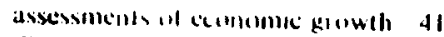

disparity in vimdard of liveng 205

il) bankmg 272, 27.4. 27.5

over-relliatlec on $x$

repurs ixnored 207.208

Poreign urade 6, 216-267

lece al... Barter trade; txporls; Imporm

11309-13511 217,

IMF repord $25 \%-205$

increase, 1311 60 1151 15

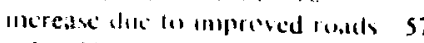

role of tillih, 231-232

Dis Alphimistan Bank $112,231-23$

wole of anthey butatars 6. 234-25.4

competilion lowers interest tales

$$
234
$$

percentige of llate tinanced $2+1$ -

$$
242
$$

wole of tiritie agencies 2.31-2.34

lixes on 16,4, 175-176, 179, 214, 218

$226-227$

$(1331-1352) \quad 170-17\}$

impout ditles 11352$) 234$

proporturn of total reventic 174,

tarit!? (IIII) |l

lerms of Iritede (1338-1347) 57, 248

use of hwolis $67,232,24$ )

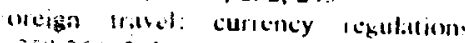
$238-259,262$

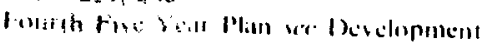
plims

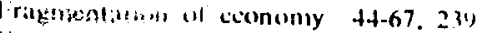

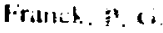

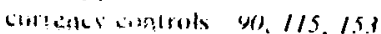

dedino in olindaru of living $/ 49$

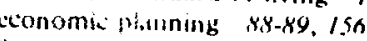

forcign and

dermompration projects $3(17$

donors clowese projects toy

Heiniand project $2(1)-3() !$ publicily poor 205 covernment bonds 162 shirhats 28

sulall-xale industry neglected 54 Marle $2 / 6,231$

with USSR th, 15h, 224

II.alling progratmines $\mid 67$

wheat imports iy

I reight 56-57

(.te' a/w Road system

French, I. G, 10

Irrieciniall, M. 29, 209, 27s

adod Sichwart A J LI

I Iy, M. J.

cultency/money ratios $33,136,127$

inllation 115,116

interest-rate nolicy 1.50 .237

wheat price support programme 174

(ialliot, 11. J. 19

(ias

crpant, $21 \%, 2211,222$

hatter prices 224

profiction 1 ot

salcs 172.170-173t

(icographic fragmentation $55-60$

Griani ko,uls 13x

Cicomatn Founomic Advisory (iroup

al vice to Minfstry of Planning 80

citpital market 5.5

credit controls needed 143

taselicicient public administrattion $16 \%$

177, 2112

indestrial statistics $/ 2$

lending legistation needed $\quad 1.37$

Ghatussy, A. (i.: Rhein, E. and 27, 224, 34

(ithem, T. T. 218

(iibson, W. E. 1114

(iNI)

Will coromonte indicator $24,261,27$ $2 x$

estintitt) $11314-1352) \quad 37-3 \%(1 / 40) 30$

issevirnent of vatliclity $36,40-42$

mellowd of estimation $29-36$

glowili rate in six countries $268-2691$

per caprila

wimlates 4

rale of clange $40 \%$

projections (1350)-1353) 297.294

suhsistence coniponent 30-31, 36,37

(iochenumir. T. S ot), 150

(ii)l 
Inited Nat ions 2ys

Iliticl Nations Development ProRrallulus: assistance it development hiluh, 1.34-135

Inilat valtions licononnc (ommission

for W.t. and the far last

forcull aid 7x-79. 156-1.57

(Be. all Fonomic Devolopment Plam

11.14le $57,24.4$

copent laxes 171,170

li.moviort and $57 \quad 5 \%$

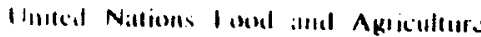

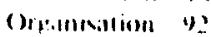

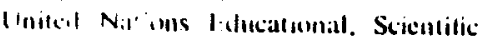

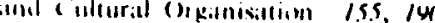
low,

linted Nattions Preparattorv Mission lo Niphimmetan $2(x)$

linteal States Agency lin International

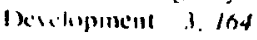

deficit untence controls arafted [y]

low icturns expected 2try

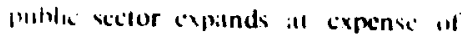
pris.lle 53

(ISis)

(tis) firmin 69

llchillated project $201-2112$

"hwelesile price inder 201

"wid in cadcull.ting Alphan price in$$
\text { i... } 19
$$

fisite

ind linen nes

credal tor cannital imports trom 234

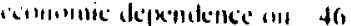

It.di wilh II, IN, \&!

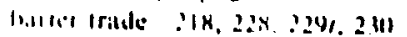

inguened robids 57 .

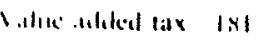

Sivide vin. A. 10!

Velecul of circulation

corrency/deposit ratios and in 45

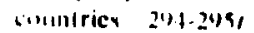

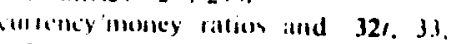
$2 m y$

ccimeninc growith and, ut sir countries $2\left(1, i-2()^{2}\right) 1$

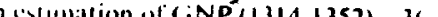
3it. 42

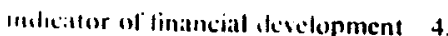

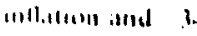

C.N1" muney unply and 24.32, 205
Iran and Pakislin ?213

vorel. R. C. Hiuluen, Is and

166

Wage rate.

us price :ndices is

minimum, Kegislatlun s

War sere World War I

Wheal

(xece alwe Hoardinge)

Commodity Assivinlus 40.5)

distribution sx

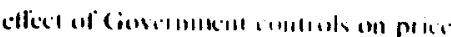
4")

prices

its at price itsdex 17. 1 6

renional diflerentials is. 59) 63

support propritume is 174

prodection ind importadion 4". 223, statislics lot

yicld 521

Wholesale price inder catcutaled from US villuc Iy

Willur. 1). N 17, 15, 10is 190, 100 biunhs and laanking st, s', $4 /, 211$ ?

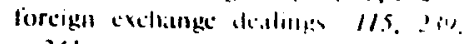
24

Iransport sho 60

Wilson. $A$. Sh

Wincbrener, W. 1 ,

Wool

exporss $218.2211, \ldots$

batrler prices 220

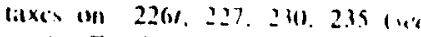

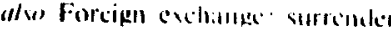
requitements

Wulld liatih

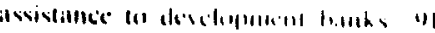
134.135

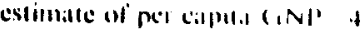

World War II

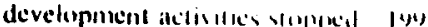

disruplion of ecomeminy $2 \times, 4(1,87,85$ distortion of price inclies it

inflition dese to 151.15

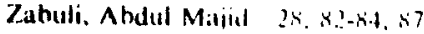
plan for economic eccencty 70

Helmand prosect critecised

7ahir Slath 3. 151

/inser. J. F.: Mikenell. R I , Ind Ios

Zonilike. ('. H. 0.241

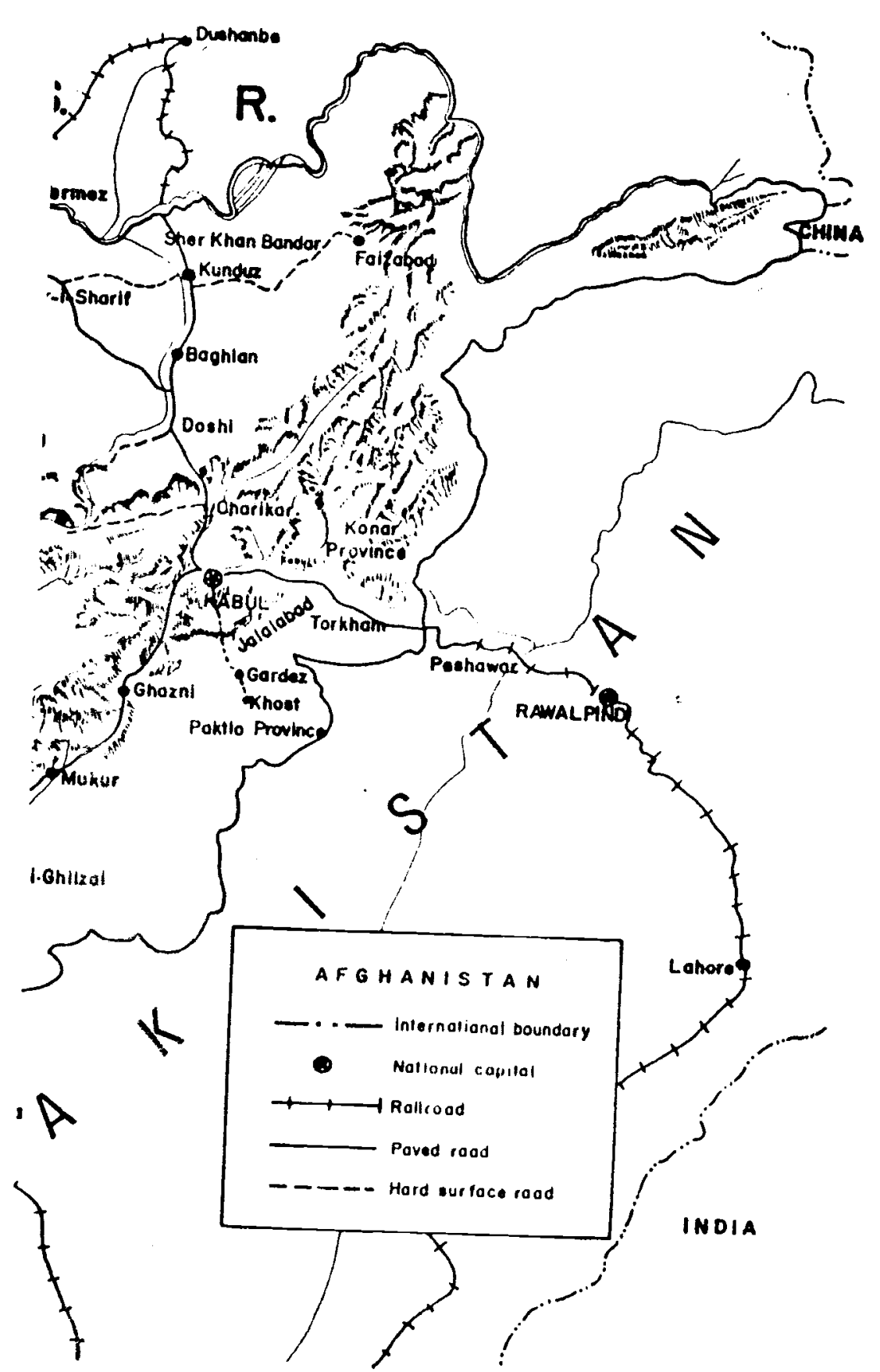


crpoul I cgulations 257, 26, (in) sille in money harad 241 cixcris 85, 115, 196, 224, dvitip leckl as $288-290$ collsmith, R. W. 96

(imeromkint

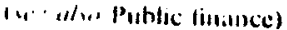

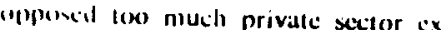
pialwene 88

vallicipdion in indlustry 45-46, 52 idinimuling with Bank Millie 45, 84

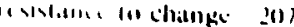

Carcellowe int londs

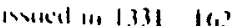

rehls ill vatrious comentries 10.3

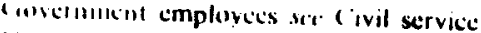

(owerimlent Monopuly l(1), 224, 228

(uvernmint revenue sec Donestic revchue

Grain wi. Wheat

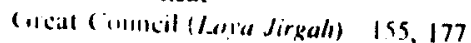

Geen revilution 211

(irigontiall, V. 4, 42, 155, 3, 36

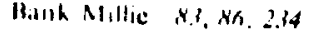

cillusllum $4.11,3,3$

(irllin. $k$ o,

cintlithen. 109

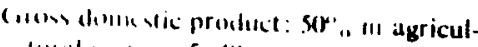

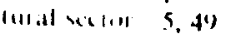

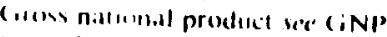

l.1.1, th

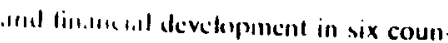

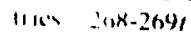

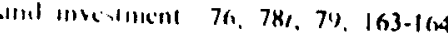
asinillenl by forcign experts 41

constlamb $1-5$

malcked (iNP 11350)-1355) 297-294) Irend $11310 \mathrm{~s}-1340,28$

(ail)aic a

Alinamillitis reforms $\$ 2,15.5$

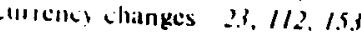

thitnspout 55, s8

"Cilided conomy" 45

(ituptit. 11 ( 65

Ciurlcy, I. Ci. and Shaw, E. S. 33, 97, Pallich, II T. and Shaw, IE S. 27I

llithilli. As Y.: Norvell, D. (i. and $26 \%$ Ilatmaticrath, decline $4 x$

Hamen, 11 78-74,38 and lourk. K. 17
Bhagwilli, J. and /7h

lansen-Tourk price indlex 17, 18,

Hanson, J. S. and Vogel, R. ('. so

I Jarberger, A. C. $24 x$

liarrod-Domar growth mudel 76

llart, A. G. 165, 175. 178, 19\%1, 271

IAVA ser Helmand-Arglatindial Valley

Authority

Ilawaless 66-67, 108, 232. 2410-241

llawley, J. 234

Hazarajat region is

llararas: Hade whth hombats s

llealth stittestics lot

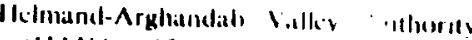

IIIAVA) 13\%, 17\%

Hiclmind-Arghandah Valley porsect

$$
\text { 199-202 }
$$

fiunds expropriated ont

low yields 78

pressed for by Pushtun nicn:bers a|

Government 84

Herat: business expansion $4 \mathrm{x}$

lless, A. C. 42

lligh powered noncy $121-130$

llindus: in money hazatid $x 9,2\}$

linrichs, 11. 11. 171

Hoarding

Anti-Hoirding Law so

consifuent flucteations in wheal prices 58,116

lled for repeal 17 .

as allernative to tinancial savme $2 x k$ 290

llousing: renting cheaper thisn huying

Hudilkeslon, s. o

Hlludion, A. H. and Baccon, 1: HII, IS5

Holiats lo8

Hlumlis 11, 67, 232, 240-241, 242, 243

Hunt Report (Rcport of the Peresters.

Commission an Finumcial Siruture and

Regulation (US)

Hunter, H. V.: Koenig, N. ind $1 /, 197$

IBRD see World Bink

ICOR w'e Increntential capitil/output rillio

II)BA sce Industrial Devedupment Bank of Arghanistan

Illitiracy 6.3

IMF see International Monclaty I und

Import substitution industric's 5 ?

Inports
(16) a/w I I)cign trats)

(1.314-1351) 217,

coill) (1)

fintilice for 2.12-234

linergon ad uned for $54,69,217$

frisction of (iNP $21 \%$

growdh indal by Bank Mallic $x$

origna ". 220

proluluted ilents 226, 261, 260t-26,

fiases on 169, 225,

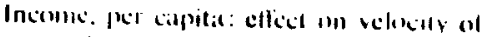

calculdalen 31-32

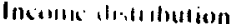

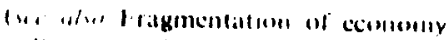

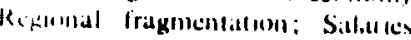

11 . nine rales)

merimalutles

ditc 10 low inleser bates 212

inucasing 48-4')

lax system does not lind to remor. Isi)

Incointe clasticily

of acmand for woncy $31-32.293$

af covernment revenue 178

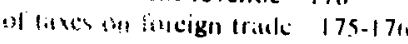

tacome tax

difficility of collecting |ta-16,5

[as (1) 344) 165

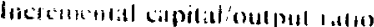

and ide of growsth of $($ iND 76,758 (19) 247.294

higli. fir sevelepment expendature

Inisiti:

(w) ahe Roures)

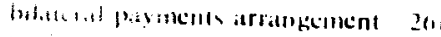

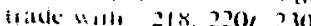

ux, of humhs, 67, 232, 240, 243

Industatil ciedit tund 91, 93, 1.3

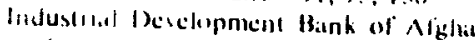

nistall (II) 13 A) 53, 135, 137, 275

Baillel of Inecclors 106

inderendentice of 93

fiduvtial Develupment Bank 9

Industilat Dciclopment fund

induslly 12, 45-461, 52-54, 74)

sources of finance 45 ,

Inflation

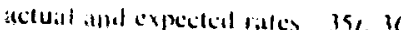

deniathi for money and 1/6. 277-27x

effect of ciowernnent borrowing 16 .

effect an interest rates tor eilect on velesily of circulation 31,14 exceeds tintc deposit rate 75

in tstimating GNP 37

valriance of rate 116

and chinges in moncy supply 116 117

threal to development eflore 178

lullation las 7.3, 75

lifformalion flow, incllicient s0, 62-6xt,

134, 204

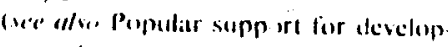

incill programmes

metweell Alghians and Americans 2015

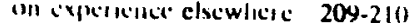

litstitul für tentwick/ungsforschung und

I: ntwichlungspolitik

import substitution undustrics 5.

political integration 60

tall collection 164, 165, 166, 167, 176

insurance 146-148

(iii also Alghan Insurance Conupany)

companics and agencies 91.92

number of employces 96

of bank deposits by a central batnk 279.280

il mortgaged propurty 14.3, 145

premiums 146, 1471

percentage of ( $i N P$ in various conntries 147

Intercit: retigious prohibition overcome 84

fillerest rates

dispiarities

horrower slattus os

low rates for Governnient 210.211

212

legional 6.5

sectoral 239

undesirable 286-2kx

tinancial develupment 43,270

recomniended policy $2 \times 4-293$

in bazalar economy $47,64-65,92,102$.

103

forcign tracte 239. 242

111 linancial institutions $102-103$

possible competition 149-150, 266

in valrious countrics

(iovernmens hond 1034

disconint rittes $104 \mathrm{t}$

incrusising

effect on demand for money $31-32$

elation to inflation and money slock 104 
tcivile ol incicilsed prosperity of ler tor |11.105. 212, 290-24.

Intern.tlunill liwh for Reconstullition and Dewelepmisent sece World Bank

Intermatisenal lomanciol Statisfics

deticit linithes $19 /, 225$

growth $\$ 1.230$

populaum 14

Internattumat Nonctary Fund

banking latu, irafted 272

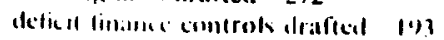

erchilnge ralle anteed 229. 2is

repmol an Afuhbinistan's firceign drade

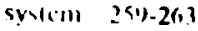

stalivical millers, advice on 27

Invertunent

(wer alwe l)evelonnent programmes:

larrign .mel Dommulc Privale In

cestment 1 aw: Publuc finance)

funded frum tiscal system $6 x$

incintives and at trol 26.3

inlerest rates rise would henedit 290

(1)?

relurns

nequatuc all financial ansets 55,130

131, 212

neglected in choice of project 208 .

2(r). 214

varusice off 213

voltumic

as percentige of (iNP 74

growth and 4, 76-70)

public and private (13.11-1391) 77,

vake af desclopnemt and 4

linventulent fintmitlec 263

Invivilies: exchanke rates for palyments and proceceds 262

ran

biubs. hromeless. arsed and deposits [11)?

bitritir conomeny $48, " 2$

currenev nomey ratios and velocities 321,13

determinillt of money supply 125

momey and ivices 120 ,

(ratue roule 97,231

use of howalles in trade wilh 67.232, 241

velocity and money supply 29 .

Islamic litw re'r Religious constrainis

Jalalubart: business expanston
Japall: inıports from $\quad 220,233$ Jensili. W. 73

Jews: in money bazaurs $\times 5,2.16$

Johnson. H. G. 176, 2/2

and Associales 286

Joint stixik companies (shirkm) 2X, 86,

$2 \times 9$

(sce alsw Shirkat-i-Sahami-i-Alghlual)

Nabul Tinkes 54

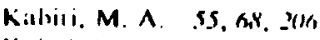

Kilhul: husincess expansion ax

Kalual moncy hazadar 234-243

(sce a/su Hit/aar economy)

Kabuli rupec 11,112

(w't also Exchange rates

Killilor, N. 169, 175, 181, 271

Kinnisiax 2015, 208

Kandiahar: business expansion is

Kandlahar money hazaar 2.34243 ,

(scr also Busair economy)

Kincesi-Thasitn. S. 271

Karakul

(ser w/so foreign exchange: suatender riyuirements)

aluclioned on l.ondon mathel 218

exports $\mid 61,2211,223$

hank loans for 23 !

taxes on 218, 226

minimum domestic prices sel $x$ - -84

role of Da Afyhanistan Bant 112

Kitrakul Institute 2.31

Kiafman, (i. (C) 108

Kayoumy, A. H. 2l.4. 2.15

Khatkhatte, D. R. S5

Khat.room, J. D). 33

Kocnik. N. attal Hunter, H. V. /1, 197

Kuhliaman credil Cooperatuve 12,93

$14 \mathrm{~K}$

Kuhn, 1), and 1: (1), 11

Lag

hetwecn high powered moncy itnd money supply $126-127$

belween inflation and interent ralle

between moncy supply and

currency $41-42$

exchange ralc 244-247,

GNP. 31-34

Land taxes 155, 174-175, 271

cinlastral survey 168

Linfuage barriers 63, 205
Latos: trallypuld as at constlatum al developnent $\$ 7$

Lashkar (iath: business boom 48,64

l.aw on Hinknoles in (ifculation in Aighanist.tn 11314) 113,153

Laws

Anti-Hordding Law (1340) 50, 58 , 116. 173

Commerclal Lati $(1334) \quad 146,272$

Foreign and Domestic Privale Investnicut 1 aw $(13.45) \quad 12,53,91,103$. 174. 20.3

Income Iar l.aw \&1.344) |6.5

law on It:anknotes in (itculation in Afphanistitu (13/4) 113,153

1 ciddership

commitment of as inclicutor of devel. opment petectilial 2-3, 6. K. 215,3(x)

l cast Develoged Country: Alghanistan, chassitied an a g

legislation 1ecommosuded 271-272

l.conding

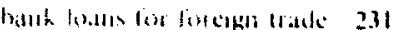

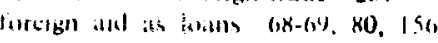
157

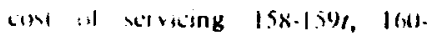
$\{1.11,19\}-10 \%\}$

a.wil line by harter tracle 228

ghowh in windicator of developmeill

pat?:nthit 2,0

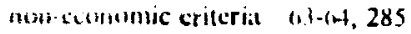

nesed to sncourage 278, 282, 291-243

eccurtiy indidequate $102,105,1.17$

$$
\text { i.sti, } 2 \text { ini }
$$

inkii demand for 102 in

laner i $P$, 176,297

I citers 151

linis, s. zim

Iesir. W 17t

lipkes, $k x, y$

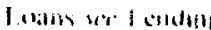

1 arritis

Hece "is: Nutue vetucles

lombl, $A$ it:

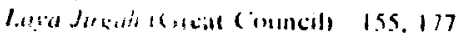

Nikinnon. R. I.

delicit lind anci: 14?

exports $64,17 \%, 227$

tinanciati development +2. 64, 268 capital in $2111-213,270,277,28$. fiagmented comomy 44,6/-6?

intormation, lack of 65
D.tuc adted tax $|8|$

Atullint $t$ to

N1.umbuna : business decline $4 \mathrm{x}$

Malaria: cradicated in 13.30, 11

Millik, Abdul: restrictions of Bink Millie 45. $88-84$

Manly, R. P. 226, 245

Map ol Alghamistan facing I

Martin, F. M. 16

Medicine sece Health

Mellici, A. 11. 121,127

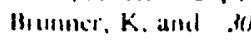

Mikesell. R. F. and Zinser, J. E. IIIS

Munistry af Agricultuie: established Agri-

culture and cottage Inclustries Bank

Minisery of commerce /I

estallislued Pashtany Tejaraly Bank

Mintistry ol Racation //

Ministry ol Hinatece

I intancial Derelopment Committee eslablished 149

1.14: Five Year Plan prepared 79

Minww! uf Mines and Industries: es-

lathlusled Industrial Development Fund

Ministry of National Economy: forcigu

exchange regulations 256, 257, 259

Ministry of Planning 12,17,56,83,115

bitnks and banking 8.3. 84, 85, 137 .

I.S. 189

development plans $7.1,80-81$

Iirst Plan 54,74

sicond Plan s?

Third Plan $10 \%$, 1/2

lourth Plan 20.1. 201., 296, 298

firtign exchange dealings $2.14,2.15$

Ministry of Public Works: eslablished

Martpalge and construction Bank $\%$

Minivity of the Interior: role in debt col-

lection 143

Mirzas 82

Modified purchasing power parily price

index 21. 22I

Mohitumed (Kitho), A. 15/

Mohanmmad Dasual Khan $8 \times, 90,151$

167

Monctary indicators 27-29

Monctisation 30, 298

Money

demand for

curremey/noney ratio and 
ligh cont elasticity 278

income elasticity 31-32, 293

inflation and Ilo

need for a central bank to stimulate 276-274

high punced

detineil 12

dieterminant of muney supply 121 . (3)

monetary survey (1 340-1351) 98-99,

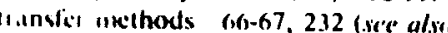

('heyere is stem)

Moncy haralars see bucalar economy

Money bitunomy component of GNP .16-171

Moncy sick we Moncy supply

Money supply |12-131

$(1311-1 ? 94)$ 24r, 26r, 27-2k

changes

due to agricultural fluctuations 127 due to Government borrowing 130 , $162.163,189.192$

lagged response of exchange ratte 244-247!

ligged response of GNP 31 currency and (1310-1.351) 118-1191 currency money ratios and 3.31 plowth

liatule entimated 24.7, 245-297, velocity and. in six countries 268 $20 * 1$

in estimation of GNP 34, 36, 37,

millatton and lln-lizl

interent rates and 104

income. velocity and 29-32,295

Itill. Pakistan and Turkey $120 \%$

regulation of, to meet demand 121

three detcrminants analysis 121,123 1241

Iran, Pikistan and Turkey 125-126 Moncy tickel (pule ikel) 84 Moncylenders 65-66

(ire a/w Bazaar economy)

Monopuly Department see Guvernment

Momopoly

Morler, S. A. 260

Murris, $C$ T. sce Adelman,

Morrison-kinudsen Company 199-202

Morigage and Construction Bank (for merly (onstruction Bank) $90,91,135$ assets and liabilities 136r

debt collection difficultien 14.1-14

Suprence Council 106
Motor vehicles 15t, 55-56, 86

Musahiban period 1, 60, 155

Myrdal, (i. 166

Nadir Shah 10, 28, 83, 151

Nathan Associates $47,174,175,177$

development plans 7.3

agriculture 203, 206-207

poor planning $58,74,80,8:, 208$

liscal administration 164

industrial development is, th, 53

National Assenibly (S/Imr'l): power to impose taxes 155

National Defence Remiltance Scheme 249

Nationalised industries 46, 52-5

Nalural gas sece Gas

Negotiable instruments 146, 27

(sce alsw Cheque system)

Nepal: transport as a constraint to development 57

Newell, R. S. 81,85

Newlyn, W. T: 122

Nomads: trade with 5

Norvell, D. (i. 92, 14x, 2 $1 / 1$

and Hakimi, M. Y. $2 i m$

Oblensky, N. 242

Operition Help 58

Organisation for Econonocic Cooperation

and Development (OECD) 4

Organisurion of Bank Millic so

Over-all Economic Develupnient IPlan 70

Oxus (river) 57,200

PACCA we Project on Agricultural Credit

Pakistan

bitnks, branches, assets and deposits 1071

currency/money ratios and velocities 321,33

determinants of money supply $125 t$ nioncy and prices 120

trade routes to and through 57, 79). 231

rade with $218,220 \% .230$

use of hundis $67,232,240-24$

velocity and money supply 293

Paktia project 20

Papunck, C. F. 186, 18\%, 184

Paper currency see Currency, paper
Park, Y. C. 29

Parker, G. L. 249

Pashtany Tejaraty Bank $90-91,131$

assets and liabilities 1.121

hanking ratios 133,

Board of Directors 105

export linance 231

forcign exchange dealings 238, 243,

loan defaults 144, 231

Patrick, H. T. 270, 280

Gurley, J. G.. Shaw, E S and 271

Paui, A. S., 2/6

P'ension I'und 92,148

assets 94t,95t

connections with uther institutions

$$
106,148
$$

employeces 96

Perlman, M. 32, 24.5

l'ersonnd policies see Banks and bamhing: Civil service

Petersen, T. F. 253

Physical overhead capital. improvement of

as irsticator of developnent potential

increass in ICOR due to 78-74

Plan Orkinimition staff, Iran 4

Plusning

as intiknur of develupment potential. 2, 5, il

lack of expertise $20 \mathrm{~s}$

Pians, Desclopment ree Develomment Plans

z'oint IV Aisistance Proyram 201

Foland: harter trade with 228, 224t

Popular support for development pro grammes

as indicator of development potentia $2,6,46,300$

lacking, because of pour publicity 46 47, 62-63, 177, 204

Population 13-14

Poullada. 1. B. 89,200

Bitscription of currency 261

ipress Depurtment (Depatriticent of (Bres and Information) 25, Y.5

Prest, A. R. 180

Price elisisicity of domestic revenuc 176 $178,|-x|-|>|$

Prices

(see also Inflation

differensials 61

wheat ix, 9y, indices $17-26$

intervention by Governthent 61,162 174

money stock and 120

Private sector

decreasing share of domestic credit $46,97,100-1031,211,212$

development expenditure 70-72,

high returns on investment 206

Project assistance (see also Developmen plians; Foreign aid)

is source of revenuc 169

contribution to development expenditure 70-72', 157-161/

responsibility left with donors 198 returns

expucted to be low 2049 not analysed 198-199, 214

Project on Agricultural Credit and Relat ed Services through Cooperatives in

Afghanistan (PACCA) 92,139,148 149

13"., return on investinent 206

denionstration projects 207

Provinces

cconomic variations $47-48,55-60$

local autonomy

Public Adninistration Service: advice on

liscal administration 164, 166, 167 168

Public enterprise 46, 52-53

Puhlic tinance 151-215

(sece also Deficit finance: Domestic credit; Domestic revenue; Taxes) hudget

$(1311-1352) \quad 1521,154$

$(1331-1352) \quad 158-1611$

current account balance 157

estimated growth (1350-1355) 298

290,

expenditure 193-208t

deficit, and high powered money 121 , $123,128-1.30 t$

development expenditure 70-74t,156|6il

Instinction from ordinary expenditure 198

estimated growth 299

poor return on 202-203

(iovernment borrowing

hond issue (1331) $\quad 162$

lluctuations 192

GNP and 162.10$\}$ 


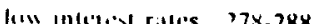
licisulry bill vingested 129

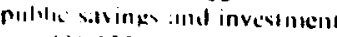
11111-1351, 77,

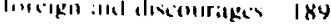

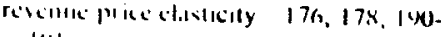
|⿰丨丨

untepsent.ulse of while comomy

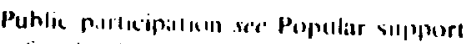

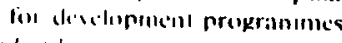

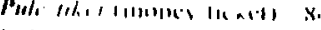

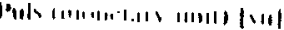

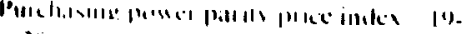
20,

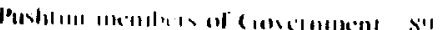

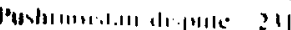

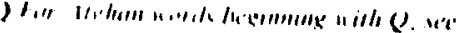

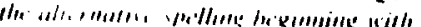

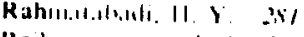

Railw.I, werem. lach of 2

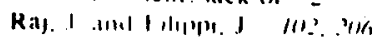

Kiw. I h K I S4, 10:

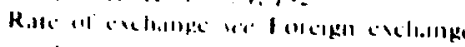

Rcilllon. P. J ₹r. 011. 159. 1.56

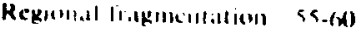

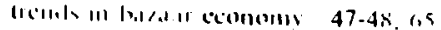

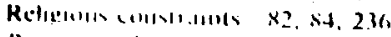

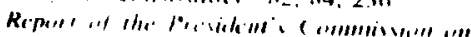

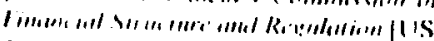

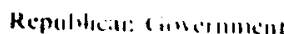

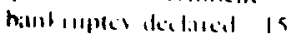

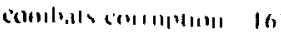

establested I

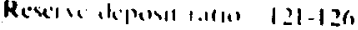

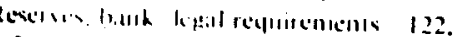
2y.

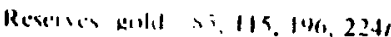

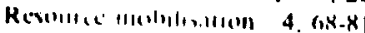

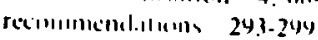

role if a centiol hatuk 27x-282

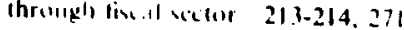

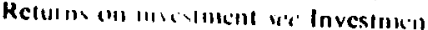

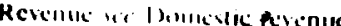

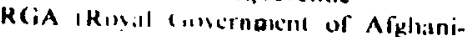

stant we cionstrment

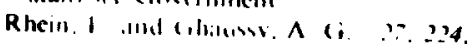

improvernent of $\$ .12,57.58$

ats indicator of development perenlial 2. 300

eflect on regional prosperily 17.4:$$
57.58
$$

increased demand for mone dere an 248

\section{increased ICOR dUe IO 70}

opposition Io 56,177

relurns on investment 206-307

poner comblition of $10.59-56$. (4)

vatistics las

lines $1 / 8.1 / 21$

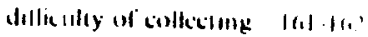

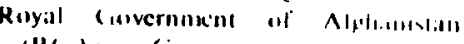

IRCos) we Cinvernmell

Rombles: Allekil tridte in 2.11

Rupres: use in Afghanislian $x$ ? 11

2.3. 2 ix. 2+0-241

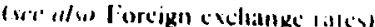

Keventic vil Donkestic revenus

Silarie:

increise necded for civil wares o I66. 16.7

price inctasticily $|(x)-(1)|$ Sathuses 10x

Sayio. Bacha 9. 56. 82.8.3

Saray Shoyda 22. 236, 238

(wer' ak, Bazatar conouny)

Sariny Tara Singh 2.37

frec alwe Baratar economw)

Silvings. Mrivale

$(1331-1351) 771$

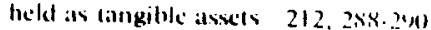

in bianhing "vstem. as incieillar at

development potential 2.6. 11

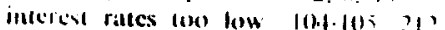

$2 \times 5.280,200,203$

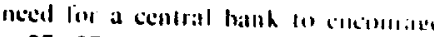
27(1-27)

used fior develapinent 74,

Savings. public aro Pablic timaune

Schools we Folucation

Schwary. A. J.: friedman. M. and $L$

Second live Yeir Plan sere Developpllicill

Second World War sere Worlal Wia 1

Seer (sveight) [xii]

Sirignan. C. 7,3

Shamni diales (xii)

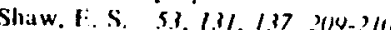

listal clliort 75.70. 174. AN 300 viduc addut as tist

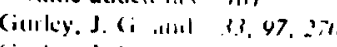

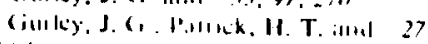

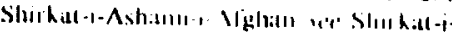
S.Ih.1III-i-N), H..11

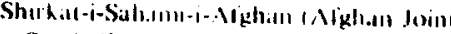
Sund Compratry [ vii]

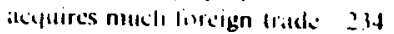

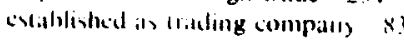
reorgitnised as Bank Millic 84. Kor

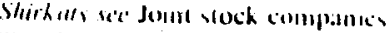

Slucida. Siltay 236. 2.16

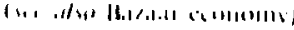

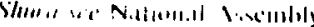

Silve

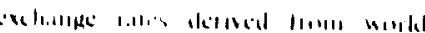
Inte $2 ?$ -

“)

and

Singht, 1. 5.5. . W

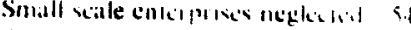

Similt. H. H

monestender. 12.241

smupgling $\therefore \therefore 4,243$

Simbl. 1. H. (.11. I and it

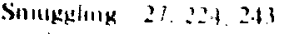

of loleign cillolicy 241

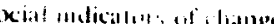

Syullo. (i. 511. I:

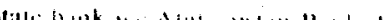

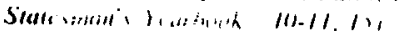

Strame 1 a is

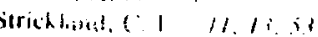

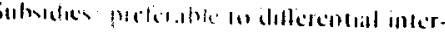
w bales 20:

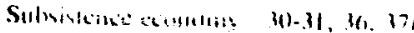

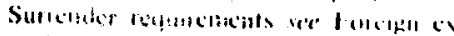

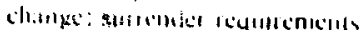

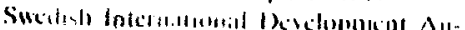
Ilisitly 42

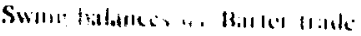

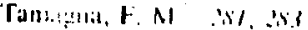

Tarit Singh. Sitı.4 237

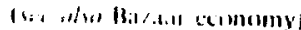

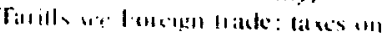

Tix glon $1 \times 1-1 \times 1)$

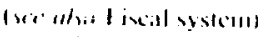

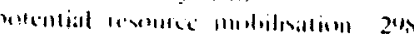
$2 m$

Tavible silpisal

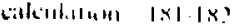

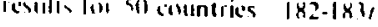

firses $1, x .157-174.214$

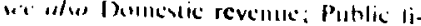

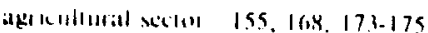

$17 x-179,271$

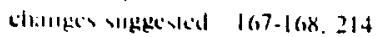

fincigen wade we forcign trade: taxes

ilicidencis $178-179$

IIIC111010 1.15 i64-16.5

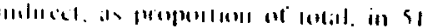

(1)1116116. $1 / 4$

IIIIl.111011 1.4, 11,25

a)

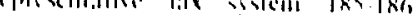

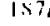

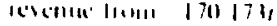

iniol l.1906 101.16.2

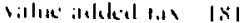

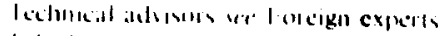

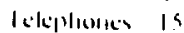

lirmo of ritde (1348-1.47) 248,

Hians. Ar dis

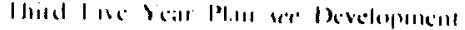
pinss

linuh, h Hilluser, H. alld it?

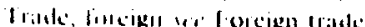

brade ingencies 231.234

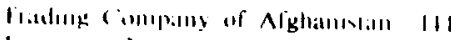

11.411119 1.4.111-112,167. 272-275. 262

dherid 97.167

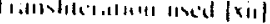

$1.111 \times 1 \times 11$

.111 in

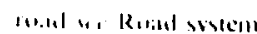

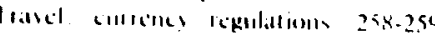
362

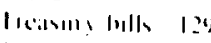

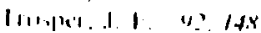

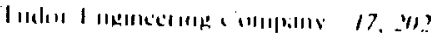

linkin

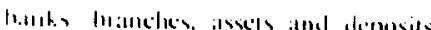
107

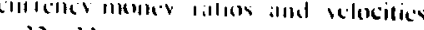
3.13

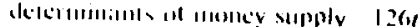

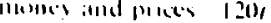

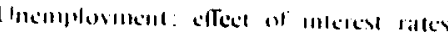




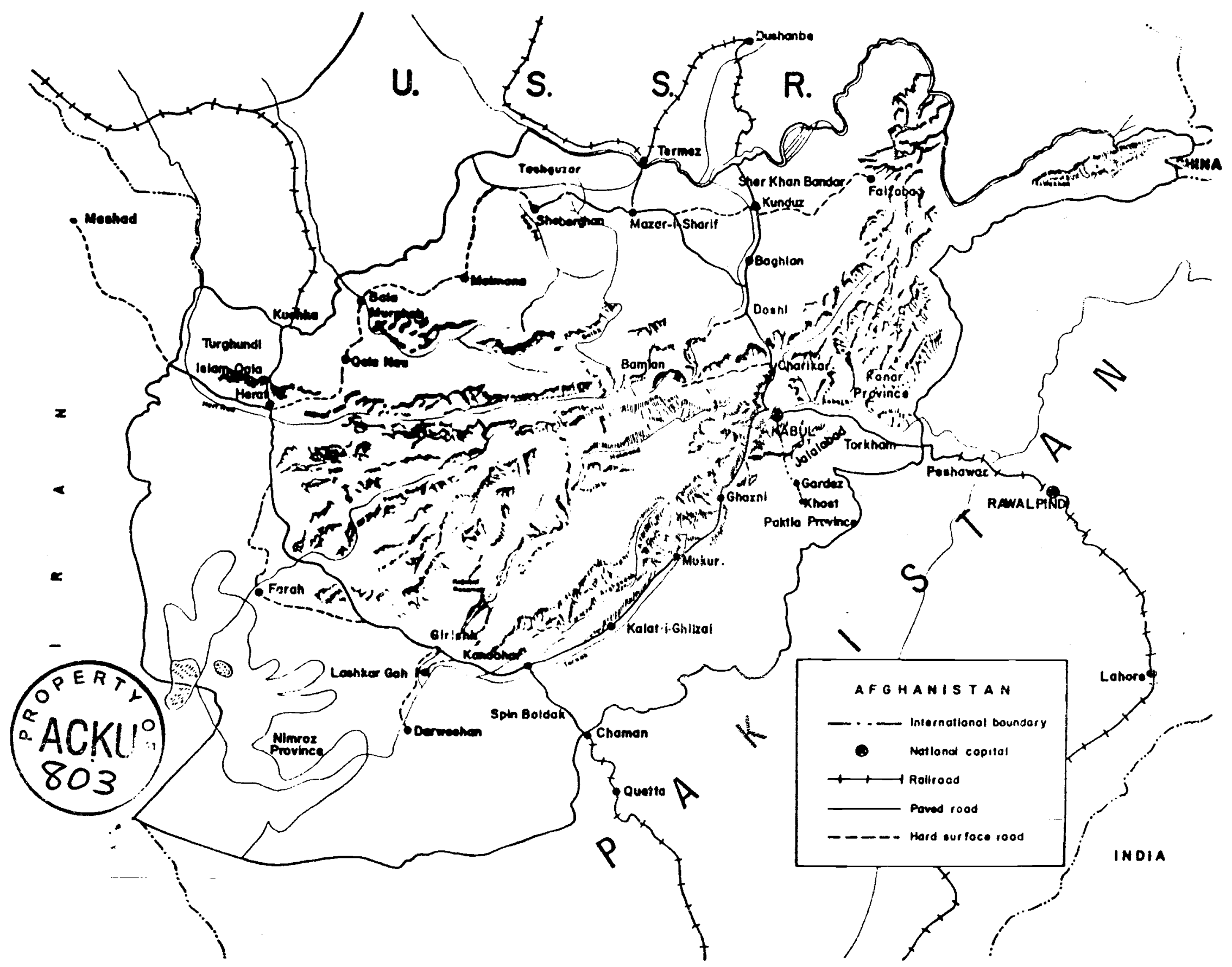

Wap of 1/shumburm 